$$
\text { UNIVERSIDADE DE SÃO PAULO }
$$

FACULDADE DE FILOSOFIA, LETRAS E CIÊNCIAS HUMANAS

\author{
Augusto da Silva
}

\title{
A IlHa de Santa Catarina e Sua Terra Firme Estudo sobre o governo de uma capitania subalterna (1738-1807)
}

São Paulo

2008 
UNIVERSIDADE DE SÃO PAULO

FACULDADE DE FILOSOFIA, LETRAS E CIÊNCIAS HUMANAS

\section{A Ilha de Santa Catarina e Sua Terra Firme Estudo sobre o governo de uma capitania subalterna (1738-1807)}

Augusto da Silva

Tese apresentada ao Programa de Pós-Graduação em História Econômica da Faculdade de Filosofia, Letras e Ciências Humanas da Universidade de São Paulo, para obtenção do título de Doutor em História.

Orientador: Professora Dra. Vera Lucia Amaral Ferlini

São Paulo

2007 


\section{Agradecimentos}

Ao longo desses anos, recebi apoio de muitas pessoas e instituições. Em primeiro lugar, quero agradecer à Professora Vera Ferlini, que acreditou nesta pesquisa e proporcionou, por meio de sua competente orientação, a elaboração do trabalho. À Professora Marianne Wiesebron, por ter-me motivado a ingressar no doutorado; Às pertinentes sugestões e críticas feitas pelos Professores Pedro Puntoni e João Paulo Garrido Pimenta, por ocasião do exame da Banca de Qualificação. Aos Professores Mafalda Soares da Cunha (Universidade de Évora) e Pedro Cardim (Universidade Nova de Lisboa), que aceitaram participar do I Workshop de pesquisa/2007, promovido pelo Projeto Temático/Cátedra Jaime Cortesão/USP e ofereceram, também, valiosas considerações a respeito de meu projeto de pesquisa; Ao Professor Warley Rosa pela revisão gramatical do texto. A José Evando Vieira de Melo, a Rosângela Leite, a Pablo Mont Serrath e a Maximiliano Menz, que leram partes do trabalho e fizeram preciosas considerações, muitas das quais, acolhidas por mim. A todos os colegas e amigos que, de uma forma ou de outra, chamando a atenção para um artigo, um livro ou um documento, muito colaboraram para o desenvolvimento deste estudo. Nesse sentido, agradeço também a Paulo Gonçalves, a Lucas Jannoni, a Rodrigo Ricupero e à Professora Iris Kantor.

Pude contar com alguns incentivos institucionais, sem os quais, as numerosas viagens de estudo seriam impraticáveis. Sou grato assim: ao $\mathrm{CNPq}$, pela bolsa concedida; à Cátedra Jaime Cortesão/USP e ao Instituto Camões/Portugal, que, mediante um convênio, facultaram-me um auxílio financeiro para a realização das pesquisas nos arquivos portugueses. Naquele país, devo agradecer ao Professor Nuno Gonçalo Monteiro, que aceitou ser meu co-orientador, acolhendo-me como investigador visitante no Instituto de Ciências Sociais da Universidade de Lisboa e possibilitando-me excelentes condições de trabalho e de pesquisa.

Às minhas colegas professoras e aos acadêmicos do Curso de História da Unochapecó-SC sou sensivelmente grato por facilitarem a flexibilização nos horários 
das disciplinas em decorrência de meus afastamentos. Com Juçara Nair Wollf pude manter proveitosa troca de idéias e informações sobre a elaboração dessa história. A ela eu devo as indicações de muitos livros e artigos utilizados na tese, além de algumas sugestões e análises que fez no texto e que foram por mim incorporadas.

Por fim, quero agradecer aos meus familiares, especialmente aos irmãos Maria Amália, Maria Lúcia, Eduardo, Vitor, Marcelo, Maria Isabel e João Paulo, que me deram todo apoio, carinho, e respeitaram meu enclausuramento quase obsessivo nestes dois últimos anos. À memória de minha mãe, que tanto queria ver concluído este projeto, mas nos deixou no inverno passado, eu dedico o trabalho.

Augusto da Silva

Porto Alegre, novembro de 2007. 
É que o "isolamento" é aqui uma verdade com o seu quê de relativismo. O mar só constitui um fator de isolamento maior que qualquer outro meio físico quando as ilhas estão fora dos grandes circuitos marítimos. Quando, pelo contrário, se encontram nesses circuitos, as ilhas tornamse (muitas vezes por fatores externos e de acaso) ativos elos de ligação, fortemente abertas ao mundo exterior (...).

Fernand Braudel, O Mediterrâneo..., 1983, vol. 1, p. 174. 


\section{Resumo}

Este trabalho tem por propósito compreender a constituição do governo subalterno da Ilha de Santa Catarina, entre 1738 e 1807, seu estatuto político-jurídico e suas dimensões, no contexto de consolidação do Império Português no sul da América Meridional. Procura-se verificar as trajetórias e os perfis sociais e militares dos indivíduos nomeados para governar a Ilha e avançar no entendimento das atribuições e limites de jurisdição do cargo de governador subalterno no sul do Brasil. Analisando aspectos da prática governativa pretende-se ainda perceber como que esses oficiais conduziram e equacionaram as determinações passadas pela Corte Portuguesa com as demandas e pressões da sociedade local.

Palavras-chave:

Ilha de Santa Catarina, governo subalterno, administração colonial, capitania 


\begin{abstract}
This work has as the purpose to understand the constitution of the subordinate government of Santa Catarina Island, from 1738 to 1807, its juridical-political statute and its dimentions, in the context of consolidation of the Portuguese Empire in the south of Southern America. It is also sought to verify the trajectory and the social and military profiles of the individuals named to govern the Island and to move forward in the understanding of the attributions and limits of jurisdiction of the subordinate governor's position in the south of Brazil. Analyzing the governamental practice aspects, it is still intended to notice how those oficials led and equationated the determinations passed through the Portuguese Court with the demands and pressures of the local society.
\end{abstract}

Keywords:

Santa Catarina Island, Subordinate government, colonial administration, captaincy 


\section{Sumário}

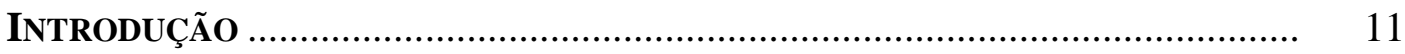

1. Da Ilha ao Continente: A Organização Política do EsPaÇo ......... 19

1.1. Mais que um Bon-port nos mares do Sul ............................................... 20

1.2. A valorização do espaço ........................................................................... $\quad 30$

1.3. De Praça Militar a Capitania .................................................................... 57

2. GOVERNADORES: OS HOMENS E SEUS OFÍCIOS …….................................. 92

2.1. As qualidades dos governadores ................................................................ 93

2.2. Seleção, nomeação e posse .................................................................... 139

2.3. As atribuições do cargo ........................................................................... 146

3. A GovernanÇa de uma Capitania Subalterna ................................... 162

3.1. O governo da praça militar ................................................................... 163

3.2. O governo das gentes: economia e sociedade ....................................... 171

3.3. Administração em tempo de guerra ......................................................... 211

3.4. A refundação da capitania .................................................................... 216

CONSIDERAÇÕES FINAIS ........................................................................ 239

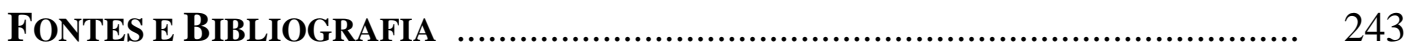

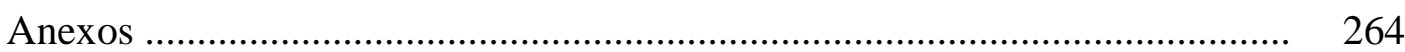




\section{Índice dos Mapas e Quadros}

Mapa 1.1 Carta particular da Ilha de Santa Catarina - Frezier (1712) .......

Mapa 1.2 Parte da América Meridional - século XVIII

Mapa 3.1 Plano Hidrográfico da Ilha de S. Catarina - Paulo Joze Miguel de Brito (1814)

Quadro 2.1 Governadores da Ilha de Santa Catarina (1738-1807)

Quadro 3.1 Relação de todos os casais e pessoas que têm vindo das Ilhas dos Açores e Madeira para esta de S. Catarina (1748-52)

Quadro 3.2 População da Capitania de Santa Catarina segundo Walter Piazza e Dauril Alden

Quadro 3.3 Levantamentos populacionais do governo da Ilha de Santa Catarina (1739-1806)

Quadro 3.4 Relação dos teares e dos tecidos produzidos na Ilha de Santa Catarina e freguesias da terra firme (1755)

Quadro 3.5 Rendimentos anuais dos dízimos na Provedoria da Ilha de Santa Catarina (1756-1802)

Quadro 3.6 Rendimento do contrato da pesca da baleia para a Ilha de Santa Catarina (1765-1801)

Quadro 3.7 Lista das Baleias que se pescaram por conta da Real Fazenda na repartição do Rio de Janeiro (1801) .....

Quadro 3.8 Jornais que se devem aos trabalhadores livres (1780)....

Quadro 3.9 Receitas principais da Provedoria da Real Fazenda da Ilha de Santa Catarina e dívida acumulada em mil réis (1774-1789) ...

Quadro 3.10 Mapa da quantidade de Gêneros e efeitos que se colhem e fabricam anualmente na Ilha de S. Catarina... (1796)

Quadro 3.11 Resumo do Número de teares que há nas seis Freguesias desta Ilha (1786)

Quadro 3.12 Qualidade e preços dos tecidos produzidos nas freguesias da Ilha (1786) 


\section{Abreviações}

ACL

Academia das Ciências de Lisboa

AHU

Arquivo Histórico Ultramarino, Lisboa

ABNRJ

Anais da Biblioteca Nacional do Rio de Janeiro

AESP

Arquivo do Estado de São Paulo

AHRS

ANRJ

Arquivo Histórico do Rio Grande do Sul

ANTT

Arquivo Nacional, Rio de Janeiro

APESC

Arquivo Nacional da Torre do Tombo, Lisboa

BCRGEH

Arquivo Público do Estado de Santa Catarina

BNL

Boletim do Centro Rio-Grandense de Estudos Históricos

BNRJ

Biblioteca Nacional, Lisboa

Col. Doc.

Biblioteca Nacional, Rio de Janeiro

\section{CEHB}

Coleção de documentos sobre o
RIHGRGS, no ${ }^{\circ} 109$ a 112, 1948

CNCDP

Catálogo da Exposição de História do Brasil

Comissão Nacional para as Comemorações dos Descobrimentos

Portugueses

Cód.

Códice

cx.

Caixa

$\mathrm{DH}$

Documentos Históricos, BNRJ

DI

Documentos Interessantes para a História e Costumes de S. Paulo

doc.

fl.

Documento

HGCB

Lv.

Folha

História Geral da Civilização Brasileira, vols. 1 e 2 (Época Colonial)

- Direção de Sérgio Buarque de Holanda

Mç.

Livro

mf.

Maço

Mss.

Microfilme

OMR-1797

Coleção de Manuscritos, BNRJ

$\begin{array}{ll}\text { OMR-1797 } & \text { Ofício do governador João Alberto de Miranda Ribeiro à Rainha D. } \\ & \text { Maria I, em 16.11.1797, transcrito no Anexo 1. } \\ \text { PAPN } & \text { Publicações do Arquivo Público Nacional do Rio de Janeiro } \\ \text { PBA } & \text { Coleção Pombalina, BNL } \\ \text { Pt. } & \text { Portugal } \\ \text { RIHGB } & \text { Revista do Instituto Histórico e Geográfico Brasileiro } \\ \text { RIHGRGS } & \text { Revista do Instituto Histórico e Geográfico do Rio Grande do Sul } \\ \text { RIHGSC } & \text { Revista do Instituto Histórico e Geográfico de Santa Catarina } \\ \text { RMR-1797 } & \text { Relatório do governador João Alberto de Miranda Ribeiro ao vice-rei } \\ & \text { Conde de Rezende, em 17.11.1797, publicado por Dante de Laytano } \\ & \text { in RIHGB, vol. 245, pp. 122-187, 1959. } \\ \text { RTIHGSC } & \text { Revista Trimestral do Instituto Histórico e Geográfico de Santa } \\ & \text { Catarina } \\ \text { v. } & \text { Verso }\end{array}$




\section{Pesos, medidas e moedas}

Pesos

quintal $=59,98$ quilos

arroba $=14,57$ quilos

Medidas de comprimento

légua $=$ entre 5.555 e 6.600 metros

braça $=2,20$ metros

vara $=1,10$ metros

Medidas de volume

alqueire $=36,27$ litros

pipa $=15$ almudes $=479,10$ litros

Moedas

1 real (plural: réis) $=$ unidade monetária

$\$ 100=$ cem réis $=1$ tostão

$\$ 400$ réis $=$ quatrocentos réis $=1$ cruzado (a moeda de prata comum)

$1 \$ 000=$ um mil réis

$1: 000 \$ 000=$ um conto de réis 


\section{INTRODUÇÃO}

Situada a meio caminho entre o Rio de Janeiro e o Rio da Prata, a Ilha de Santa Catarina constituiu-se desde o século XVI como porto privilegiado aos navegadores europeus que se dirigiam ao Prata, ou de lá voltavam, para abastecerem-se de alimentos frescos e de água, curarem os enfermos e repararem suas embarcações. A partir da terceira década do século XVIII, a Monarquia Portuguesa faria dela uma importante base estratégica e militar para a consolidação dos seus domínios naquele espaço marítimo e continental.

Este trabalho se propõe a analisar as características, as dimensões e os limites do governo da Ilha de Santa Catarina, de 1738 a 1807, como forma de melhor compreender a função que ele desempenhou nesse contexto de configuração territorial entre os impérios ibéricos no sul da América Meridional. Trata-se, portanto, de uma história que tem como foco principal e ponto de partida para a análise mais abrangente, o governo e as ações dos governadores nomeados para a sua administração.

Verificando os regimentos, instruções e ordens passadas a esses oficiais, assim como as ações efetivas realizadas por eles no exercício do cargo, pode-se perscrutar aspectos da estrutura e dinâmica da administração portuguesa nas colônias, assim como também da sociedade que governavam.

Dentre as autoridades fixadas nas capitanias, os governadores foram aqueles que mais personificaram o rei nas conquistas. Frente aos poderes regionais concorrentes como juízes ordinários, provedores, oficiais da Câmara, párocos, entre outros, constituíram-se como os principais agentes na condução das políticas monárquicas portuguesas. Todavia, no exercício do cargo, inseriam-se, querendo ou não, numa "rede relacional" complexa na sociedade que iam governar. ${ }^{1}$ Dependendo das conjunturas específicas e mesmo da atitude pessoal de cada um no exercício do cargo, estabeleciam com os indivíduos e grupos locais relações marcadas, ora por acordos e negociações -

\footnotetext{
${ }^{1}$ Ver, entre outros, Arno Wehling e Maria José Wehling. O Funcionário Colonial entre a Sociedade e o Rei, in Mary Del Priore (Org.) Revisão do Paraíso: os Brasileiros e o Estado em 500 Anos de História. Rio de Janeiro, Campus, 2000, p. 142; e Laura de Mello e Souza. O Sol e a Sombra: Política e Administração na América Portuguesa do século XVIII. São Paulo: Companhia das Letras, 2006, p. 168.
} 
até porque o novo meio e o próprio funcionamento da colônia exigia o apoio mútuo -, ora por enfrentamentos e conflitos. Há que se levar em conta ainda que os próprios governadores, mesmo que reinóis de nascimento, podiam estabelecer vínculos familiares e patrimoniais sólidos nos territórios para os quais eram destacados, o que os deixavam mais no interior da sociedade local.

A opção pelo estudo da administração fundamenta-se no pressuposto de que a dominação colonial não se reduz ao funcionamento do processo produtivo, mas que sua realização exige formas político-institucionais, que perpassam todas as relações sociais.

Da proposta original, que era de trabalhar com as capitanias do Rio Grande de São Pedro e de Santa Catarina, entre 1737 e 1822, optou-se por restringir o estudo a essa última por duas razões: a dificuldade em dar conta do universo documental dos trinta e quatro governadores envolvidos e o próprio desenvolvimento da pesquisa a suscitar questões sobre a função e o próprio estatuto jurídico-político da chamada "capitania subalterna de Santa Catarina". Além disso, a carência de estudos sobre essa colônia, seja da historiografia de escopo abrangente, preocupada com os espaços mais diretamente vinculados à dinâmica econômica do sistema colonial, seja da historiografia sobre as problemáticas específicas de Santa Catarina que, curiosamente, pouco tem se dedicado ao período colonial, justificava ainda mais a escolha do objeto. Espera-se, todavia, que a redução do campo temporal e espacial de análise não prejudique a compreensão dos contextos mais amplos em que ele se insere, até porque a condição social, política e militar dos governadores nomeados para a Ilha era muito semelhante à dos nomeados para o Rio Grande de São Pedro e Colônia do Sacramento.

Os marcos cronológicos redefinidos indicam o tempo em que o governo da Ilha de Santa Catarina esteve subalterno ao do Rio de Janeiro. Em 1738, uma Carta Régia dirigida ao governador desta capitania, Gomes Freire de Andrade, ordenava que se criasse um governo naquela Ilha separado da capitania de São Paulo e subordinado diretamente a ele. A medida fazia parte das políticas de Dom João V no sentido de reforçar a autoridade régia sobre esse extenso espaço situado entre a capitania de São Paulo e o Rio da Prata. Em 1807, oficialmente, a subordinação da Ilha passava do Rio de Janeiro para o Rio Grande de São Pedro que, naquele ano, fora elevado à condição de capitania geral pelo Príncipe Regente Dom João. Embora essa subordinação não se efetivasse de fato, a medida representava, no plano político, a consolidação territorial daquela fronteira-sul. 
As fontes utilizadas nesta pesquisa compõem-se principalmente: dos documentos produzidos pelo poder régio como leis, decretos, alvarás, provisões, cartas, regimentos e instruções; da documentação avulsa do Conselho Ultramarino, respectiva à capitania de Santa Catarina e disponível em forma digitalizada pelo Projeto Resgate; e de outras correspondências estabelecidas entre as diversas autoridades metropolitanas e coloniais, que têm o governo da Ilha de Santa Catarina como objeto em questão e foram transcritas em anais e revistas históricas.

Os fluxos dessa comunicação mais observados aqui ocorreram entre: governadores da Ilha $\leftrightarrow$ Gomes Freire de Andrade ou vice-reis; governadores da Ilha $\leftrightarrow$ Corte $^{2}$, Corte $\leftrightarrow$ Gomes Freire de Andrade ou vice-reis; e também oficiais da Câmara de Desterro $\leftrightarrow$ Corte.

Para análise do estatuto militar e social desses oficiais, fez-se uso da documentação existente nas chancelarias reais como cartas-patentes, licenças e provisões, assim como das Habilitações da Ordem de Cristo e dos Decretamentos de Serviços. Utilizou-se ainda dos relatos dos viajantes estrangeiros que passaram pela Ilha no século XVIII e, pelo menos um documento que se acredita seja inédito. Trata-se da Dissertação instrutiva sobre a escolha dos governadores das Conquistas... (1780) de Francisco de Almeida Silva, encontrada na Academia das Ciências de Lisboa. Os dezesseis volumes do importante Códice 106 - Correspondências dos vice-reis com os governadores da Ilha de Santa Catarina (1752-1807) - guardados no Arquivo Nacional do Rio de Janeiro, não parecem ter sido utilizados pela historiografia regional, ou, se foram, não constam referenciados nos trabalhos.

A análise das fontes foi feita com base em alguns pressupostos teóricos e conceituais que perpassam todo o trabalho. O primeiro deles refere-se à abordagem que se dá à colonização portuguesa. Percebe-se ela como um sistema complexo, o conjunto das relações entre as metrópoles e suas respectivas colônias, na Época Moderna, denominado por Fernando Novais como Antigo Sistema Colonial. $^{3}$

Nesta acepção, a grande produção mercantil de exportação, o tráfico negreiro, as economias de abastecimento interno, assim como também as formas de flexibilidade das instituições político-administrativas estavam articuladas num conjunto hierarquizado de

\footnotetext{
${ }^{2}$ Entendida aqui como o poder régio, os secretários de estado e os conselheiros do Conselho Ultramarino.

${ }^{3}$ Fernando A. Novais. Portugal e Brasil na Crise do Antigo Sistema Colonial (1777-1808). 6. ed. São Paulo, 1995, p. 57.
} 
relações para atender a exploração colonial. ${ }^{4}$ Isso não impediu, todavia, que no seio dessas sociedades se desenvolvessem formas de organização políticas, econômicas e sociais, intra e intercoloniais - tanto mais fortes quanto mais se aproximava do fim do Antigo Regime - de maneira a pressionar pela desarticulação daquele sistema.

A noção de Império, também utilizada no decorrer desta tese, não entra em contradição com o conceito anterior desde que se conceba esse Império como constituído de partes ligadas assimetricamente entre si e a um centro - o reino -, onde ocorriam as decisões políticas essenciais.

A Ilha de Santa Catarina ocupou posição peculiar no sistema colonial. Sua principal função era de servir de base militar para defesa de espaços mais valorizados do ponto de vista econômico. Contudo, não se restringia a isso. Estava ela mesma diretamente vinculada aos interesses mercantis de Lisboa através do fornecimento do óleo de baleia e da arrematação dos contratos dessa pesca e do dízimo. No mercado interno, desempenhou a importante função no abastecimento de farinha de mandioca aos armazéns reais do Rio de Janeiro, do Rio Grande de São Pedro, da própria Ilha, senão também de outras praças, para sustento das tropas e da população em geral. Além disso, deve-se considerar ainda que a sociedade local constituiu, ao longo do tempo, mecanismos e estratégias no sentido de criar formas próprias de organização e desenvolvimento, subvertendo as determinações provindas da Corte.

O Governo - entendido não só como o território de jurisdição de um governador, mas também como o conjunto de pessoas que exercem o poder político e que determinam a orientação política da sociedade que governam - está associado ao Estado Moderno. Todavia, a constituição deste é mais recente que daquele. A formação de um poder de Governo remonta a uma fase histórica anterior, a formas pré-estatais de organização política e, por isso, é importante não confundir os governos que se instauram na América, mesmo no século XVIII, com uma estrutura estatal perfeitamente territorializada. $^{5}$

Sem se aprofundar no longo debate sobre a natureza do Estado Absolutista no ocidente, pode-se dizer, no entanto, que, entre os séculos XVI e XVIII, houve guardadas as particularidades de cada país - um processo crescente de centralização de

\footnotetext{
${ }^{4}$ Vera Lucia Amaral Ferlini. Prefácio, in Maria Fernanda Bicalho e Vera Lucia Amaral Ferlini (Orgs.) Modos de Governar: Idéias e Práticas Políticas no Império Português, séculos XVI a XIX. São Paulo: Alameda, 2005, p. 12.

${ }^{5}$ Cf. Lucio Levi. Governo. In: Norberto Bobbio, Nicola Matteucci e Gianfranco Pasquino. Dicionário de Política. 5 ed. Brasília: Ed. UnB, 2000, p. 553; e Michel Senellart. As Artes de Governar: do regimen medieval ao conceito de governo. São Paulo: Ed. 34, 2006, pp. 23 e 24.
} 
poder das monarquias européias. ${ }^{6}$ No caso específico de Portugal, verificam-se a partir do reinado de Dom João V (1706-1750) políticas de reforço da autoridade régia por meio de, entre outras medidas, submissão da nobreza e do clero ao rei e de reversão das capitanias hereditárias à Coroa, movimento esse que se acentuaria com o ministro plenipotenciário Sebastião José de Carvalho e Melo, o Marquês de Pombal (17501777). ${ }^{7}$ O final do Antigo Regime, assinalou José Subtil, foi uma época na qual, claramente, a imagem do príncipe como cabeça da república se sobrepôs às restantes, e em que o governo assumiu as "características de uma atividade dirigida por razões específicas (as razões do Estado), tendentes a organizar a sociedade, impondo-lhe uma ordem". 8

O trabalho está dividido em três capítulos, de maneira a tentar responder basicamente a três questões: que espaço se governa, quem governa e como se governa.

No primeiro - Da Ilha ao Continente: a organização política do espaço -, procura-se mostrar a importância que teve a Ilha de Santa Catarina na configuração das fronteiras meridionais da América.

Distintamente do limite, representação física, geográfica, concreta, que se define por uma linha, natural ou artificial, e que estabelece objetivamente onde começa a soberania de uma nação e termina a de outra, a fronteira remete a um espaço incerto, subjetivo, zona de encontros e também de confrontos, entre dois ou mais grupos. A fronteira é a sede da diferença; o limite remete para a sede da autoridade delegada, porquanto, em vez de atrair grupos distintos manifesta a capacidade de dividi-los e submetê-los ao poder e à lei. ${ }^{9}$

$\mathrm{Na}$ análise do processo de configuração territorial entre os impérios ibéricos na América Meridional não cabe, portanto, aquela representação idealizada que procurou

\footnotetext{
${ }^{6}$ Para uma introdução sobre o tema ver, entre outros, Perry Anderson. Linhagens do Estado Absolutista. São Paulo: Brasiliense, 2004; Emmanuel Le Roy Ladurie. O Estado Monárquico: França, 1460-1610. São Paulo: Companhia das Letras, 1994; Norbert Ellias. O Processo Civilizador. Rio de Janeiro: Zahar, 1993, especialmente o vol. 2 - Formação do Estado e Civilização; e Theo A. Santiago (Org.) Capitalismo: transição. Rio de Janeiro: Eldorado, 1975.

${ }^{7}$ Ver, entre outros, Jorge Couto. "D. João V" in, João Medina (Dir.) História de Portugal dos tempos préhistóricos aos nossos dias - vol. VII - Portugal Absolutista. Alfragide: Ediclube, s/d.; e Nuno Gonçalo Freitas Monteiro. "A Consolidação da Dinastia de Bragança e o Apogeu do Portugal Barroco: centros de poder e trajetórias sociais (1668-1750)" in, José Tengarrinha (org.). História de Portugal. 2 ed. Bauru, SP: EDUSC; São Paulo: UNESP; Portugal: Instituto Camões, 2001.

${ }^{8}$ José Subtil. "Os Poderes do Centro" in, António Manuel Hespanha (Coord.). O Antigo Regime (16201807). Lisboa: Ed. Estampa, 1997, p. 143. (Col. História de Portugal, Dir. José Mattoso - vol. 4)

${ }^{9}$ Cf. Jean-Pierre Roncayolo. Significados da fronteira, in Enciclopédia Einaudi. Vol. 8 - Região. Lisboa: Imprensa Nacional - Casa da Moeda, s/d., pp. 133-34. Ver também Hélio Viana. História das Fronteiras do Brasil. Rio de Janeiro: Gráfica Laemmert, 1948, p. 12; e Gervásio Neves. Fronteira Gaúcha Fronteira do Brasil com o Uruguai. Porto Alegre: UFRGS (Dissertação de Mestrado), 1976.
} 
ver a fronteira como tendo apenas um caráter excludente entre os povos. Indiferentes aos limites estabelecidos diplomaticamente pelas duas Coroas, portugueses e espanhóis, em tempos de paz ou de guerra, inter-relacionaram-se por meio dos casamentos, das transações comerciais e mesmo dos serviços militares, como mostram alguns estudos ${ }^{10}$.

Para a compreensão do que foi essa unidade político-administrativa que se implantou na Ilha de Santa Catarina, em 1738, depois expandida ao continente, recorreu-se à análise do vocabulário utilizado pelas autoridades, na documentação coeva, indagando empiricamente quando, como e por quem as denominações de "governo", "distrito", "praça militar" e "capitania" foram utilizadas. Partindo do pressuposto de que algumas palavras carregam conceitos específicos, procurou-se identificar quais os sentidos que os diferentes agentes coloniais atribuíram àquele estabelecimento. $^{11}$

Com base nas reflexões de António Manuel Hespanha sobre as relações entre poder e espaço, assim como nas de Antonio Carlos Robert Moraes sobre a formação territorial do Brasil Colonial ${ }^{12}$ pôde-se problematizar a estrutura político-geográfica do governo da Ilha de Santa Catarina e rejeitar as representações históricas que projetaram num passado remoto as atuais configurações territoriais do Estado Catarinense.

No segundo capítulo - Governadores: os homens e seus ofícios -, analisa-se, inicialmente, os perfis sociais e profissionais desses indivíduos. Nos sessenta e nove anos estudados aqui (1738-1807), quinze governadores (cinco dos quais interinos) e uma junta governativa (no ano de 1800), atuaram na governança da Ilha de Santa Catarina. As trajetórias individuais interessam na medida em que colocam problemas e contribuem para a elucidação de aspectos não só do governo para o qual foram designados, mas também da sociedade colonial, a exemplo de outros estudos realizados nesse sentido. ${ }^{13}$

\footnotetext{
${ }^{10}$ Ver Fabio Kühn. Gente da Fronteira: família, sociedade e Poder no Sul da América Portuguesa século XVIII. Niterói-RJ: UFF, PPG-História (Tese de Doutorado), 2006; Do mesmo autor: A fronteira em movimento: relações luso-castelhanas na segunda metade do século XVIII, in Estudos IberoAmericanos, PUCRS, vol. XXV, n. 2, pp. 91-112, dez. 1999; e Helga I. Landgraf Piccolo. Os confrontos nos encontros: a dinâmica do processo de colonização no Sul do Brasil, in Francisca L. Nogueira de Azevedo e John M. Monteiro (Coords.) Raízes da América Latina. São Paulo: EDUSP, 1996, pp. 343356.

${ }^{11}$ Ver Reinhart Koselleck. Uma história dos conceitos: problemas teóricos e práticos, in Estudos Históricos, Rio de Janeiro, vol. 5, n. 10, 1992, pp. 134-146.

${ }^{12}$ António Manuel Hespanha. As vésperas do Leviathan: Instituições e poder político. Portugal - séc. XVII. Coimbra: Almedina, 1994; Antonio Carlos Robert Moraes. Bases da Formação Territorial do Brasil: O Território Colonial Brasileiro no "Longo" Século XVI. São Paulo: Hucitec, 2000.

${ }^{13}$ Ver, entre outros, Dauril Alden, Royal Government in Colonial Brazil. With Special Reference to the Administration of the Marquis of Lavradio, 1769-1779. Berkeley, 1968; Heloísa Liberalli Bellotto
} 
Importantes foram também as pesquisas de Nuno Gonçalo Monteiro e Mafalda Soares da Cunha sobre os governadores e capitães-mores do Império Português. Segundo esta historiadora, as qualidades nobiliárquicas e sociais dos nomeados, a titulatura dos cargos, os soldos que recebiam e a atração social que o posto suscitava servem de indicadores da posição do território na hierarquia política dos espaços do Império. $^{14}$

Feito isso, procurou-se avançar na compreensão das atribuições e limites jurisdicionais de poder dos governadores subalternos da Ilha de Santa Catarina. Embora se trate da análise de um caso particular, acredita-se que o estudo contribua para um entendimento mais amplo sobre a formação política do Brasil Meridional, no século XVIII.

No terceiro e último capítulo - A Governança de uma capitania subalterna analisam-se aspectos da prática governativa. Quais foram as políticas traçadas pela Monarquia Portuguesa para o governo da Ilha de Santa Catarina? Como os governadores conduziram no exercício do cargo essas diretivas frente às pressões e demandas locais? Mas o tema da governança é muito amplo. Se, por um lado, o governador não tinha poderes para ingerir sobre outras áreas da administração colonial, como da Fazenda, a cargo do Provedor, ou da vila, sob a responsabilidade da Câmara, por outro, ele podia ser - e de fato era - cobrado, pelas autoridades superiores, por todos os problemas políticos, econômicos, militares e até religiosos de seu estabelecimento. Consideradas essas temáticas, as fontes disponíveis são numerosas e possibilitam outras questões e problemáticas de pesquisa que, em decorrência do tempo e dos limites deste trabalho, não foram abordadas aqui.

Entre 1738 e 1807, pode-se perceber pelo menos quatro momentos distintos na governança da Ilha de Santa Catarina: os primeiros dez anos, em que ela era um praça militar e a preocupação dos seus governadores girava em torno da montagem e administração do sistema de defesa; de 1748 a 1763, fase de consolidação do

Autoridade e Conflito no Brasil Colonial: o Governo do Morgado de Mateus em São Paulo (1765-1775). São Paulo: Conselho Estadual de Artes e Ciências Humanas, 1979; Laura de Mello e Souza. O Sol e a Sombra..., op. cit.; Francisco Carlos Cardoso Cosentino. Governadores Gerais do Estado do Brasil (séculos XVI e XVII): ofício, regimentos, governação e trajetórias. Niterói: ICHF-UFF (Tese de Doutorado), 2005; e Augusto da Silva. Rafael Pinto Bandeira: de bandoleiro a governador. Relações entre os Poderes Privado e Público em Rio Grande de São Pedro. Porto Alegre: IFCH-UFRGS (Dissertação de Mestrado), 1999.

${ }^{14}$ Mafalda Soares da Cunha. Governo e governantes do Império português do Atlântico (século XVII), in Maria Fernanda Bicalho e Vera Lucia Amaral Ferlini. Modos de Governar, op. cit., p. 72. Outros trabalhos dessa autora e de Nuno Monteiro serão citados ao longo do trabalho. 
estabelecimento colonial, com instalação da ouvidoria, da provedoria e da chegada dos casais açorianos e madeirenses; o período seguinte foi marcado pela guerra com os espanhóis. De 1763 a 1776, a barra do Rio Grande e grande parte daquele continente esteve sob o domínio castelhano e, em 1777, a própria Ilha foi por eles invadida; no último período que se analisa aqui, da restituição da Ilha aos portugueses, em 1778, até 1807, tem-se a reorganização política, militar e econômica dessa colônia.

Uma última observação: seguindo a orientação dos professores que presidiram a banca do exame de qualificação, optou-se por atualizar a ortografia das fontes citadas neste trabalho, com exceção dos documentos que vão transcritos em anexo. 


\section{Da Ilha ao Continente: A Organização Política do Espaço}

O futuro viria provar que a Ilha tinha que ser a escala protetora do continente; e que o inimigo, quando quisesse assenhorear-se do Rio Grande, era inevitavelmente forçado à conquista da Ilha.

Jaime Cortesão $^{15}$

... pois esta ilha vem a ser de maneira geral, o melhor lugar de refrescamento para nossos armadores, que se querem render ao mar do sul.

George Anson ${ }^{16}$

A partir do final do século XVII, a expansão colonial portuguesa na América inflectiu-se para o centro-sul. As descobertas de ouro nos sertões mineiros pelos paulistas, a tentativa de restabelecer o domínio comercial sobre o rio da Prata, com a fundação da Colônia do Sacramento na margem setentrional daquele rio em 1680, e a apropriação do solo e suas riquezas naturais colocaram essa extensa área do Sudeste da América Meridional como um dos centros de interesse português por todo o século XVIII. Esse movimento, no entanto, ia de encontro à expansão das colônias espanholas para o mesmo espaço, forçada pelas missões jesuíticas que faziam avançar a Província do Paraguai para leste dos rios Paraná e Uruguai e pela Província do Rio da Prata que se projetava para o norte, desencadeando um processo de disputa militar e diplomática que perduraria por aproximadamente um século e meio. Este capítulo tem por objetivo

\footnotetext{
${ }^{15}$ Jaime Cortesão. Alexandre de Gusmão e o Tratado de Madrid. (Parte I - Tomo I) Rio de Janeiro: Ministério das Relações Exteriores; Instituto Rio Branco, c. 1950, p. 305.

${ }^{16}$ George Anson. A Voyage round the world In the Years MDCCXL, I, II, III, IV... in Ilha de Santa Catarina: Relatos de viajantes estrangeiros nos Séculos XVIII e XIX. $3^{a}$ ed. Rev. Florianópolis: Ed. UFSC; Lunardelli, 1990, p. 69.
} 
analisar, em primeiro lugar, a importância que a Ilha de Santa Catarina desempenhou na configuração desse território de disputa e, em seguida, compreender, tanto quanto possível, as estratégias de organização política do espaço, a partir da formação de um governo com centro naquela Ilha e sua posterior expansão ao continente, de 1738 a 1807.

\subsection{Mais que um “Bon-port” nos mares do Sul}

Na manhã do dia $1^{\circ}$ de abril de 1712 , a expedição francesa que levava o engenheiro militar Amedée François Frézier fundeava na Ilha de Santa Catarina "à procura de um sítio apropriado para fazer aguada" e "conseguir alguns refrescos"17. Em terra, os tripulantes dirigiram-se às casas existentes nas praias, mas, para surpresa deles, encontraram-nas vazias, uma delas "abandonada há poucas horas, a julgar pelas cinzas ainda quentes". Com medo dos visitantes, os moradores haviam se refugiado nas densas matas que cobrem a Ilha e a costa continental.

Segundo Frézier, essa reação podia ser explicada por já terem eles a notícia da tomada e pilhagem da cidade do Rio de Janeiro pelo corsário francês Duguay-Trouin, no ano anterior. Esclarecido ao "governador" da Ilha, "Emanuel Mansa"18, que não buscavam outra coisa senão aprovisionamentos para prosseguir viagem (Frézier havia sido encarregado pelo Rei Católico para a construção de fortes nas colônias espanholas do Pacífico contra possíveis invasões de ingleses e holandeses ${ }^{19}$ ), os habitantes

\footnotetext{
${ }^{17}$ Amedée François Frézier. Relation du voyage de la mer du Sud aux côtes du Chily et du Perou. Fait pendant les années 1712, 1713, \& 1714 ... in Ilha de Santa Catarina, op. cit., p. 19 e 22.

${ }^{18}$ Tratava-se, na verdade, de Manoel Manso de Avelar, sargento-mor nomeado pelo governador da Capitania de São Paulo. Não se encontrou a carta-patente de sua nomeação, todavia, uma correspondência do capitão-mor de Laguna, Francisco de Brito Peixoto, de 26 de maio de 1722, revela o seu posto militar. Chegando aquele capitão na Ilha de Santa Catarina à procura de Manso de Avelar disseram-lhe os moradores que ele "tinha ido para o Rio de São Francisco a mandar fazer um bastão de Sargento-mor", AESP, Documentos Interessantes para a história e costumes de S. Paulo, vol. 32, p. 270. Manoel Joaquim d'Almeida Coelho (Major). Memória Histórica da Província de Santa Catharina. $2^{\mathrm{a}}$ ed. Desterro: Typ. J. J. Lopes, 1877, p. 11, se equivoca em dizer que o sargento-mor Manso de Avelar teria ido para a ilha de Santa Catarina com sua família, em 1714, pois, além de Frézier encontrá-lo dois anos antes nela, o próprio sargento-mor, em carta escrita a 08 de novembro de 1722, ao governador de São Paulo disse que assistia a quarenta anos naquela ilha. AESP, DI, vol 32, p. 304.

${ }^{19}$ Gregorio Weiberg. "Prólogo" in Amadeo Frezier. Relacion del Viaje por el Mar del Sur. Trad. Miguel A. Guerin. Caracas: Biblioteca Ayacucho, s/d., pp. ix-lxiii.
} 
retornaram às suas casas e, como de costume, conduziram em suas pirogas ${ }^{20}$ até ao navio estrangeiro os produtos e refrescos que possuíam, no caso, galinhas, frutos e fumo. "Em troca dos víveres que traziam a nós - observou Frézier -, não aceitavam dinheiro, dando mais importância a um pedaço de pano ou fazenda para se cobrir.",21

Assim como Frézier, muitos outros navegadores europeus, fazendo a rota do Atlântico-Pacífico, pelo Cabo Horn, ou do Atlântico-Alto Peru, via rio da Prata, na Época Moderna, arribaram à Ilha de Santa Catarina ou, pelo menos, tomaram-na como um importante ponto de referência náutica nos mares do Sul, como se pode verificar na extensa cartografia sobre o Novo Mundo produzida a partir do século XVI. ${ }^{22}$

Nas lonjuras meridionais do Atlântico, depois de viajarem por semanas, ou meses, no mar grande, já sem água potável para beber, desprovidos de alimentos frescos, com parte da tripulação enferma (eram comuns doenças como mal-de-luanda o escorbuto -, febres tropicais ou linfáticas, pleurisias, sarampo, doenças venéreas e de pele...) $)^{23}$ e ainda, muitas vezes com avarias nas embarcações (mastros danificados, velas rasgadas...), causadas pela fortuna do mar, os navegadores buscavam, antes do seu destino final, um ancoradouro seguro onde pudessem remediar a todos esses males. A Ilha de Santa Catarina foi seguramente um desses "oásis" no mar oceano.

\footnotetext{
${ }^{20}$ Aintoine Joseph Pernetty, na sua Histoire d'un Voyage aux Isles Malouines fait em 1763 \& 1764, assim descreveu a piroga observada quando de sua passagem pela ilha de Santa Catarina, em 1763: "É uma espécie de bote feito de um só tronco de árvore, côncavo, que os selvagens da América meridional tinham o costume de usar. Acrescentam na parte traseira algumas pranchas para tornar mais altas as bordas. Às vezes costumam desenhar figuras de selvagens ou coisas grotescas. Cheguei a ver até doze homens em uma só destas pirogas. Disseram que as maiores carregam até cinqüenta pessoas, com suas munições de guerra e víveres", in Ilha de Santa Catarina, op. cit., p. 80.

${ }^{21}$ Frézier, op. cit., p. 23.

${ }^{22}$ Uma relação bem completa dos viajantes europeus que passaram pela Ilha de Santa Catarina, no século XVI, com biografia dos navegadores e objetivos das viagens, encontra-se em Amilcar d'Ávila Mello. Crônicas das Origens: Santa Catarina na era dos descobrimentos geográficos. Florianópolis: Expressão, 2005. (3 vols.). No século XVII, tomando por base o livro MAPA: Imagens da Formação Territorial Brasileira, organizado por Isa Adonias, Bruno Furrer et. al. Rio de Janeiro: Fundação Emilio Odebrecht, 1993, ela foi representada, entre outros, pelos cartógrafos: Jansson, "América do Sul" (1641); Nicolas I Visscher (1618-1679), "Novo e atualizado mapa de toda a América" (s/d); Nicolas Sanson d'Abbeville (1600-1667), "América Meridional dividida em suas principais partes..." (s/d); Pieter Goos (c. 16161675), "Carta Náutica que mostra grande parte da América, a África ocidental e o sudoeste da Europa" (1629); Claes Jansz Vooght (?-1696), "Carta hidrográfica da costa que se estende do Cabo São Tomé à Ilha de Santa Catarina....”.

${ }^{23}$ Cf. Inácio Guerreiro. "Particularidades da vida no mar" in Oceanos - Navios e navegações - Portugal e o Mar. Lisboa: CNCDP, n. 38, abril/junho, 1999, pp. 149-160. Segundo o autor, "O problema da alimentação a bordo vai ser uma constante ao longo dos séculos [XVI, XVII e XVIII] porque se mantêm os mesmos defeitos de conservação dos gêneros alimentícios, a mesma cupidez dos feitores responsáveis pelo abastecimento dos navios, a mesma falta de higiene do vasilhame em que se armazena a água e o vinho. (...) A falta de escalas na viagem fazia com que os navios usassem em todo o percurso a água do primeiro abastecimento em Lisboa. (...) com navios estrangeiros, constatamos que o panorama da alimentação não era mais reconfortante".
} 
Ela efetivamente reunia condições sócio-ambientais favoráveis para essa função: oferecia um bom ancoradouro com fundura razoável, sem bancos de areias móveis, protegido dos ventos e - talvez, mais importante ainda - desde o final do século XVII, a existência de uma população que, mesmo rarefeita, interagia com os visitantes suprindoos das provisões necessárias, pois, de que adiantava encontrar um bom porto se nele não se pudessem remediar aqueles problemas?

Por outro lado, há que se considerar também que os relatos de viagem e os mapas produzidos pelos viajantes, descrevendo e assinalando as vantagens que havia em aportar neste ou naquele porto, serviam como uma espécie de guia aos navegantes vindouros, definindo bem ou mal, assim como se faz hoje em dia, rotas e escalas a serem seguidas.

Segundo Alberto Vieira, os cinco vértices insulares sobre os quais a Coroa Portuguesa assentou os pilares atlânticos de sua ação e defesa das rotas oceânicas foram: Açores, Canárias, Cabo Verde, Madeira e São Tomé. ${ }^{24}$ Do outro lado do Atlântico e no Oriente, elas também desempenhariam papel fundamental nas conquistas. Pequenas ou grandes - escreveu Fernand Braudel sobre a importância das ilhas -, elas serviam de "escalas indispensáveis nas rotas do mar, e de serem relativamente calmas e procuradas pela navegação as águas que as separam entre si ou as separam do continente". ${ }^{25}$ É o caso de Santa Catarina e das suas dezenas de pequenas ilhas e ilhotas as quais em torno dela descansam, como a do Arvoredo, da Galé (ou Gal), do Papagaio, de Anhatomirim, do Campexe e de tantas outras.

Mas teria sido essa sua única função possível aos navegadores no Atlântico Sul: servir de porto de passagem e lugar de "refresco" aos mareantes? Não era só isso. Os viajantes, sobretudo no século XVIII, vislumbraram outras potencialidades daquela Ilha e seu continente fronteiro.

De fato, ela não possuía metais preciosos nem outro produto que, de imediato, pudesse oferecer aos mercadores europeus um negócio altamente rentável, mas tornouse atraente à medida que o espaço no qual ela se situa passou, pouco a pouco, a ser valorizado estratégica e economicamente pelos conquistadores.

Frézier, por exemplo, observou que os habitantes de Santa Catarina gozavam "de um bom clima e de um ar muito saudável”; que possuíam também "muitos remédios

\footnotetext{
${ }^{24}$ Alberto Vieira. A Fortuna das Afortunadas, in Oceanos. n. 46, abr./jun., 2001, p. 57.

${ }^{25}$ Fernand Braudel. O Mediterrâneo e o Mundo Mediterrânico na Época de Filipe II. Lisboa: Martins Fontes, 1983, vol. 1, p. 172.
} 
naturais do país" e suas árvores frutíferas eram "excelentes em suas espécies”. Fez ainda minuciosa descrição do arbusto que dá o algodão. Segundo ele, viviam na Ilha e orla da terra firme 147 brancos (de portugueses e europeus fugitivos), além de alguns negros e índios, que não pagavam qualquer tributo ao rei de Portugal, embora fossem seus súditos e obedecessem ao "Governador ou Capitão (...), cujo comando não passa ordinariamente de três anos, [e] depende do Governador da Lagoa [referia-se a Santo Antônio dos Anjos da Laguna], pequena vila distante da ilha de 12 léguas ao SSO". ${ }^{26}$ George Shelvocke, comandante no navio inglês Speedwell, que passou pela Ilha em 1719, notou que o "sassafrás, tão valorizado na Europa, é tão comum ali" que cortaram uma boa quantidade dele para fogo, em vez de outras madeiras e, que existia naquela Ilha "uma grande abundância de laranjas, tanto da espécie 'China', como da 'Sevilha', limões, cidras, limas, bananas, palmitos, melões de todas as espécies e batatas". Também havia “a cana-de-açúcar muito grande e boa, mas dela não fazem nenhum ou muito pouco uso, por falta de utensílios. (...) Lá cada pedra e até mesmo as raízes das árvores à beira da água abrigam uma deliciosa espécie de ostras verdes de pequeno tamanho" e nas "savanas de Arezitiba [Araçatuba], no continente, bem em frente à parte extrema sul da Ilha de Santa Catarina, eles têm gado preto em grande número"27.

Ao longo do século XVIII, e, sobretudo depois que ela foi invadida pelos espanhóis, em 1777, constituiu-se a idéia de que a defesa do continente dependia do controle dessa Ilha; "o seu porto é de tanta importância, que da sua conservação depende a segurança desta costa, e até me atrevo a dizer de todo o Estado do Brasil", dizia o governador João Alberto de Miranda Ribeiro à rainha, em $1797 .^{28}$

A descoberta dos fenômenos da natureza, o conhecimento do planeta e dos povos exóticos, o desenvolvimento da ciência e da razão se associava ao interesse das nações à exploração de novas potencialidades expansionistas e colonizadoras. ${ }^{29}$

Nos diários de bordo e nas cartas náuticas, os viajantes informavam sobre as correntes marítimas, a força e regime dos ventos, a qualidade do clima de cada região; registravam a topografia dos lugares, profundeza das encostas, capacidade das enseadas,

\footnotetext{
${ }^{26}$ Frézier, op. cit., pp. 23 e 24.

${ }^{27}$ George Shelvocke. A Voyage round the World by the Way of the Great South Sea, Perform'd in the year 1719, 20, 21, 22...in Martim Afonso Palma de Haro (org.), op. cit., pp. 46 e 47.

${ }^{28}$ AHU-SC, cx. 6, doc. 386. Ofício do governador João Alberto de Miranda Ribeiro à rainha D. Maria I, em 16.11.1797. Daqui em diante usa-se a abreviação OMR-1797. Ver documento transcrito no Anexo 1.

${ }_{29}$ Maria Fernanda Bicalho. A Cidade e o Império: o Rio de Janeiro no século XVIII. Rio de Janeiro: Civilização Brasileira, 2003, p. 105.
} 
importância das ilhas, costumes dos povos e sistema de governo; faziam ainda inventários minuciosos descrevendo a flora e a fauna existente no Novo Mundo.

A precisão descritiva dos lugares tinha por objetivo a apreensão qualitativa do todo e posterior conquista do espaço. Conquista essa que se deve fundamentalmente, como observou Vitorino Magalhães Godinho, aos mercadores e mareantes, levados pelo desenvolvimento do comércio com outros continentes e ilhas. Precisamente por isso, tais descrições são feitas sobretudo do ponto de vista comercial: formas e cores não importam por si próprias (como devem importar na literatura de ficção), mas apenas à medida "que servem para caracterizar mercadorias, indicar regiões que vale a pena explorar economicamente". 30

Mas por que motivo somente no final da terceira década do século XVIII a Coroa Portuguesa resolveu efetivamente estabelecer na Ilha de Santa Catarina um sistema de fortificações, com um governo separado da capitania de São Paulo e vinculado ao do Rio de Janeiro, haja vista ser ela conhecida e visitada desde o século XVI? Qual a importância que a Ilha teve na configuração territorial portuguesa na América Meridional?

A historiografia, seja ela de escopo regional ou geral vem tratando direta ou indiretamente dessas questões e nos fornece algumas respostas plausíveis. Todavia, creio que tanto numa quanto noutra abordagem ainda não se obteve uma compreensão mais completa da importância e dimensão desse estabelecimento colonial no Atlântico Sul. Enquanto nas histórias sobre Santa Catarina percebe-se a valorização dessa formação específica, e a ausência das questões geopolíticas e econômicas mais amplas nas quais ela se inseria, nas histórias de perspectiva mais geral vêem-se contempladas estas questões, mas reduzida, ou até mesmo apagada, a posição que aquela colônia ocupou nesse contexto.

Destaca-se nas interpretações de corte mais regional que a formação de um governo na Ilha justificava-se não pelo seu valor em si, mas pela importância que ela desempenhou como base militar-estratégica - marítima, principalmente - na defesa das praças militares do extremo-Sul, sobretudo da Colônia do Sacramento.

Segundo Walter Piazza, as razões para a criação da "Capitania da Ilha de Santa Catarina" são "principalmente, de ordem política, tendo-se em vista a recente fundação da Colônia do Sacramento (1680) e a conseqüente necessidade de dar-lhe cobertura

\footnotetext{
${ }^{30}$ Vitorino Magalhães Godinho. Mito e mercadoria, utopia e prática de navegar, séculos XIII-XVIII. Lisboa: DIFEL, 1990, p. 88.
} 
militar-estratégica, com a implantação de um sistema defensivo litorâneo, onde se incluía" essa Ilha e "a barra do Rio Grande". ${ }^{31}$ Affonso Taunay, ao referir-se ao processo inicial de povoamento da Ilha em fins do século XVII, apontava nesse mesmo sentido: "Preparava Portugal, com o maior mistério e a maior tenacidade, o assentamento do seu domínio à margem setentrional do Prata. E para tanto constituía a Ilha de Santa Catarina excelente base de operações". ${ }^{32}$

Parece não haver dúvidas quanto a esse papel desempenhado pela Ilha na expansão portuguesa na região platina, ainda mais se considerarmos os desdobramentos históricos futuros desse estabelecimento colonial: povoamento até as primeiras décadas do século XIX restrito ao litoral e tímido desenvolvimento econômico aos padrões e exigências do Império Português. Mas há que se fazer uma distinção entre a importância e a função, que a Ilha de Santa Catarina desempenhou nesse momento para a monarquia, e o seu desenvolvimento histórico efetivo no decorrer dos séculos XVIII e XIX. Além de ser base estratégica de domínio marítimo, ela apresentava-se como possibilidade de penetração no continente, de desenvolvimento econômico e de ser o melhor porto no sul do Brasil. Algumas dessas potencialidades foram cumpridas, outras não, por motivos que se procurará apontar ao longo deste trabalho.

Marlon Salomon, em pesquisa recente, veio acentuar essa função marítima da Ilha acrescentando-lhe outra. A partir do início do século XVIII, tanto a Ilha de Santa Catarina como a Colônia do Sacramento tiveram, segundo ele, "uma função bem determinada para a soberania portuguesa: a de exílio da desordem. (...) lugar de degredo da confusão, de desterro e expatriação do desalinho", e que, apenas no final da década de 1730 vai se perceber a importância da Ilha "para a conservação e preservação de todo o domínio marítimo, este último constituído como um sistema de entrepostos dependentes formados por esta ilha, o Rio Grande de São Pedro e os pontos mercantis do rio da Prata. Além do mais, é preciso compreender que conservar e defender o território estaria relacionado com a preservação destes pontos independentes que dão acessos a portos mercantis. O território como um todo não possuiria um valor que justificasse a sua defesa: defender o território significaria então defender estes portos,

\footnotetext{
${ }^{31}$ Walter F. Piazza. Santa Catarina: sua história. Florianópolis: Ed.UFSC; Lunardelli, 1983, p. 123. Assim também entendeu Carlos Humberto Correa. História de Florianópolis - Ilustrada. Florianópolis: Insular, 2004, p. 69. “A principal razão da criação da capitania de Santa Catarina por D. João V, como se viu, foi torná-la um ponto fortificado para proteger a Colônia do Sacramento e, conseqüentemente, impedir a invasão espanhola em território português no Brasil Meridional".

32 Affonso de E. Taunay. Em Santa Catarina Colonial: capítulo da história do povoamento. São Paulo: Imprensa Official do Estado, 1936 (Separata do vol. VII da RIHGSP), p. 25.
} 
que são ou escalas para entrepostos mercantis ou pontos estratégicos para o apoio à sua conservação". 33

Em sua tese de doutorado, na qual desenvolve mais demoradamente essas questões, coloca que a atenção da "soberania portuguesa" esteve "até o início do século XIX, totalmente voltada em direção ao horizonte marítimo e a sua vigília, contra o inimigo externo que jamais adormece". ${ }^{34}$ Mesmo quando o autor destaca a importância da fortificação da Ilha para a defesa do espaço continental - "porque através dela se pode atingir por terra, em caso de invasão, necessidade de socorro ou impossibilidade de utilização dos seus portos, as povoações portuguesas que se encontram ao sul, a de Rio Grande e de Sacramento"35 -, não explica por que motivos se quer defender essas praças; o quê efetivamente as Coroas Ibéricas disputavam nesse espaço? Sua argumentação ampara-se fundamentalmente no que ele chamou de a constituição de um novo "saber do espaço", na "emergência do espaço como um problema do poder", ${ }^{36}$ no século XVIII. Fator sem dúvida importante para a compreensão da formação de todo o sistema de defesa da costa Sul, mas que por si só não explica o fenômeno; a formação de uma nova cultura científica, os novos saberes da engenharia militar e da cartografia inserem-se num conjunto de fatores políticos, econômicos e culturais próprios do século das luzes.

Quanto à Ilha ser um lugar "de exílio da desordem”, com efeito, era prática comum dos monarcas, vice-reis e governadores gerais afastar dos centros do império os desordeiros, insubordinados, vadios e criminosos realocando-os na periferia dos seus domínios. Com uma só medida atingiam dois fins: ordenava-se o espaço das grandes cidades, centros do poder político e administrativo e, ao mesmo tempo, povoava-se, bem ou mal, com vassalos do rei de Portugal, aquelas praças fronteiriças. ${ }^{37}$

\footnotetext{
${ }^{33}$ Marlon Salomon. "O exílio da desordem e a segurança da Ilha de Santa Catarina no século XVIII", in Ana Brancher, Silvia Maria Fávero Arend (Orgs.) História de Santa Catarina, Séculos XVI a XIX. Florianópolis: EdUFSC, 2004, pp. 80 e 90.

${ }^{34}$ Marlon Salomon. O saber do espaço: Ensaio sobre a geografização do espaço em Santa Catarina no século XIX. Florianópolis: CFCH-UFSC (Tese de Doutorado), 2002, pp. 14 e 35. "De repente, irá se perceber que entre o longo trajeto marítimo que separa o Rio de Janeiro do Rio da Prata, onde dever-se-á organizar e de onde deverão partir as forças de apoio contra os espanhóis, há uma ilha que oferece um porto para reabastecimento. Rapidamente, uma consciência crítica sobre sua importância para aqueles que seguem ao sul, em defesa da Colônia do Sacramento, irá se constituir, sobretudo após os problemas enfrentados pela expedição que fora enviada de Lisboa em 1736 (...).”

${ }^{35}$ Id., ibid., pp. 40 e 41.

${ }^{36}$ Id., ibid., p. 37.

${ }^{37}$ Sobre essa questão ver o estudo de Laura de Mello e Souza para o caso de Minas Gerais, Desclassificados do ouro - a pobreza mineira no século XVIII. Rio de Janeiro: Graal, 1982, sobretudo o capítulo 2, "Da utilidade dos vadios".
} 
A Ilha de Santa Catarina serviu, de fato, de ponto de apoio logístico e base sobre a qual se faziam os aprovisionamentos de guerra e de boca às praças militares no extremo-Sul. Tornava-se impraticável, em função da distância do Rio de Janeiro, manter a Colônia do Sacramento, assim como também o recém fundado presídio Jesus-MariaJosé, na barra do Rio Grande de São Pedro (1737). É verdade também que o cerco imposto pelos espanhóis àquela Colônia entre 1735 e 1737 contou favoravelmente na decisão da Corte lisboeta de, no ano de 1738, fortificar a Ilha, mas essa deve ser considerada apenas uma de suas importantes funções no contexto geral da expansão portuguesa ao Sul. Sua mais completa dimensão tem de ser apreendida na lenta e crescente valorização do espaço no qual ela não só se inseria, mas que ocupava posição fundamental.

As ilhas que ficam junto aos continentes, como a de Santa Catarina, são ilhas bifrontes, uma de suas faces volta-se ao mar, outra, à terra, exercendo dupla função aos navegadores: domínio dos mares e dos continentes. A valorização socioeconômica dos espaços insulares, assinalou Alberto Vieira, dependia da confluência de dois fatores: "primeiro, os rumos definidos para a expansão atlântica", depois, "as condições propiciadoras de cada ilha ou arquipélago em termos físicos, de habilidade ou da existência ou não de uma população autóctone". Paulatinamente, elas "ganharam a merecida posição na estratégia colonial, projetando-se nos espaços continentais próximos e longínquos. Elas abriram as portas do Atlântico e mantiveram-se até a atualidade como peças fundamentais. Foram portas abertas à descoberta do oceano, tal como foram para a afirmação e controle dos mercados continentais vizinhos". ${ }^{38}$

O espaço que se pretendia defender e ocupar com o domínio da Ilha de Santa Catarina era muito mais amplo e envolvia, como adiante se procurará mostrar, não só a Colônia de Sacramento, mas também o Continente do Rio Grande ${ }^{39}$, o território das

\footnotetext{
${ }^{38}$ Alberto Vieira. A Fortuna das Afortunadas, op. cit., p. 57.

39 A busca de uma explicação para a denominação de Continente à capitania do Rio Grande já rendeu debate historiográfico. Varnhagen defendeu a seguinte tese: passou-se a chamar de continentistas os moradores do Rio Grande em oposição aos ilhéus, moradores da ilha de Santa Catarina. Aurélio Porto, por sua vez, entendia que a denominação servia para diferenciar um espaço que está unido por um todo terra continente - não cortado de rios, ou mares, continuo, da recortada costa litorânea que se desenha em outras partes do Brasil, o que parece ser mais plausível. Cf. Francisco Adolfo de Varnhagen (e nota explicativa n. 40 de Rodolfo Garcia). História Geral do Brasil - Tomo IV. 5a. ed. São Paulo: Melhoramentos, 1956, p. 20. Contudo, há que se considerar ainda outro fator, que foi a própria incompreensão histórica do que era o Rio Grande de São Pedro. Transpôs-se anacronicamente a unidade política que se formou no século XIX a um tempo anterior, quando ela ainda não existia. Os homens de meados do século XVIII, ao se referirem a Rio Grande de São Pedro estavam denominando a barra que liga o mar à lagoa, o presídio militar e a vila que em torno deste se formou. Quando queriam se referir às vastas terras que ficavam no interior, a hinterlândia - que nesse caso adquiriram maior importância
} 
missões jesuíticas, a própria Ilha e seu sertão correspondente e - o que é praticamente ignorado pelos historiadores - a região das minas. Não se pode esquecer que a mesma carta régia de 11 de agosto de 1738, dirigida a Gomes Freire de Andrade, governador do Rio de Janeiro, mandando criar governo na Ilha de Santa Catarina, ordenava também que "as Minas dos Goiases, Cuiabá e mais descobertos deviam ter um Governador particular ficando subordinado ao das Minas Gerais". 40 Se tomarmos o quadro "Produção do ouro brasileiro no século XVIII" elaborado por Virgílio Noya Pinto percebe-se que do quadriênio 1730/34 ao de 1735/39 a produção desse metal, considerando Minas Gerais, Goiás e Mato Grosso, passou de 9.000 para $14.137 \mathrm{Kg}-$ significativo aumento de mais de $57 \% .^{41}$

Nessa extensa área - grande parte ainda incógnita -, estavam em jogo assim as minas descobertas e a descobrir, as vacarias, as madeiras, a erva-mate e tantos outros recursos naturais que aquelas terras e mares poderiam fornecer e produzir ao comércio europeu.

Por fim, há que se considerar ainda dois fatores de ordem política associados à decisão da monarquia portuguesa na criação de um governo na Ilha de Santa Catarina: a guerra de sucessão espanhola e outros conflitos diplomáticos na primeira metade do século XVIII, que colocaram Portugal e Espanha em lados opostos; e a orientação da política de $\mathrm{D}$. João $\mathrm{V}$ que, em seu reinado promoveu um reordenamento da administração monárquica com vistas ao reforço da autoridade régia - processo esse que se intensificaria no período josefino -, com políticas de submissão da nobreza e do clero ao rei, de reversão das capitanias hereditárias à $\mathrm{Coroa}^{42}$ e, no caso específico desse território em disputa, de criação de "capitanias subalternas" ou "governadorias" vinculadas diretamente ao governo do Rio de Janeiro, reduzindo assim o poder jurisdicional da capitania-geral de São Paulo.

econômica do que as do litoral, em função do gado que nela havia em abundância - podiam usar então a expressão o Continente do Rio Grande. Mais para o final do setecentos, quando se começa a definir uma unidade político-administrativa, será com tal nome que a capitania vai ser denominada.

${ }^{40}$ RIHGRGS, Ano, 1948, n. 109 a 112, "Coleção de documentos sobre o Brigadeiro José da Silva Paes", p. 132. Doravante, usa-se Col. Doc.

${ }^{41}$ Virgílio Noya Pinto. O Ouro Brasileiro e o comércio Anglo-português. Ed. Nacional: São Paulo, 1979 (Col. Brasiliana, vol. 371), p. 114.

42 Jorge Couto. "D. João V" in João Medina (Dir.). História de Portugal dos tempos pré-históricos aos nossos dias. Vol. VII - Portugal Absolutista. Alfragide: Ediclube, s/d., p. 244. 
Carta particular da Ilha de Santa Catarina - Frézier (1712)

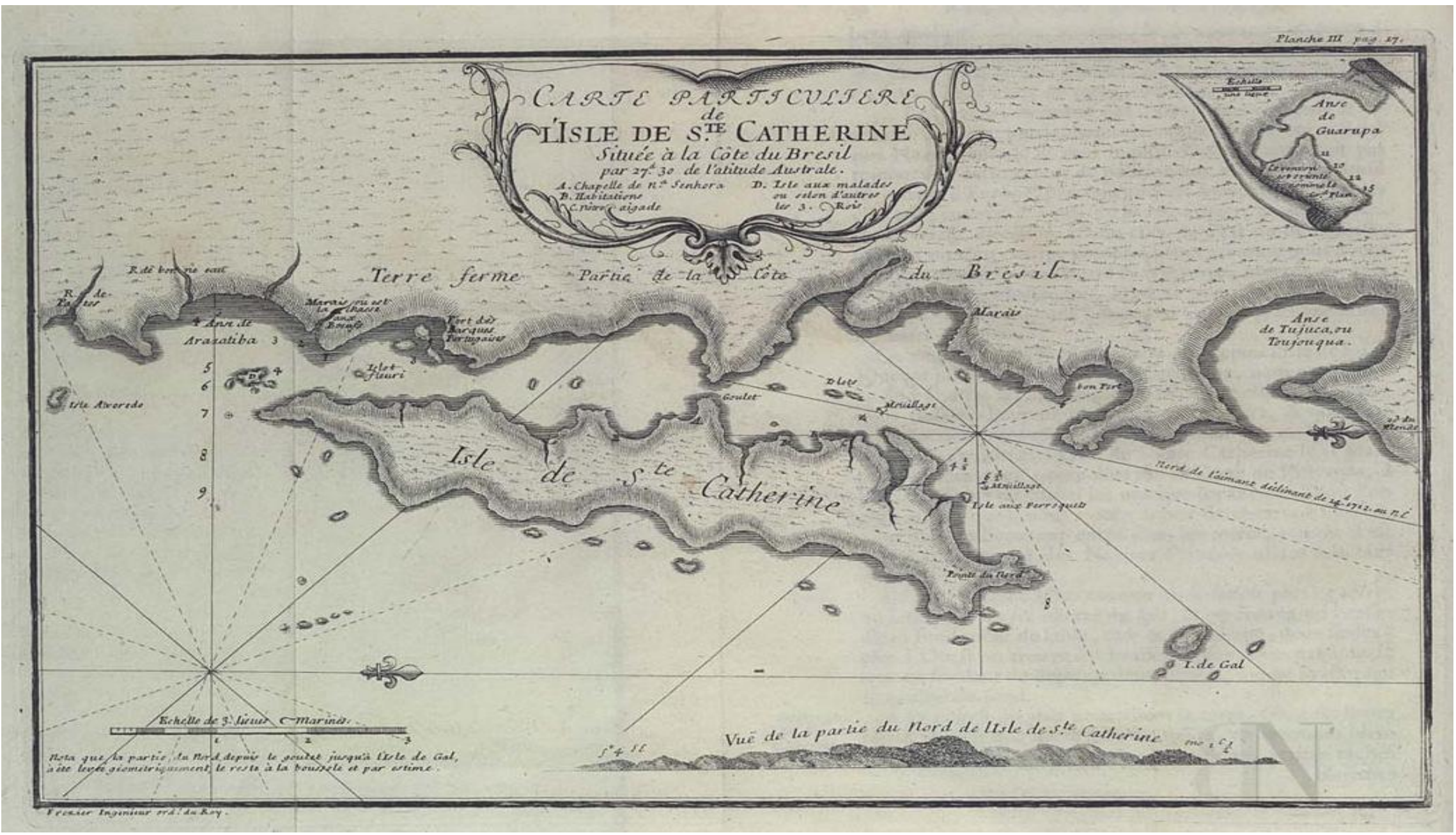

Amédée François Frezier. Carte particuliere de l'Isle de Ste. Catherine: située à la Côte du Bresil par 27.d 30 de l'atitude Australe, In: idem. Relation du Voyage de la Mer du Sud aux côtes du Chily et du Perou, fait pendant les années 1712, 1713 \& 1714. BNL, D.S. XVIII-75. 


\subsection{A valorização do espaço}

Tomando uma definição de Antônio Carlos Robert Moraes, é com base na valorização de um espaço que se deve apreender o "processo historicamente identificado de formação de um território". "O território - aponta esse geógrafo - é um espaço social, que não pode existir sem uma sociedade que o crie e qualifique, logo inexiste como realidade puramente natural, sendo construído com base na apropriação e transformação dos meios criados pela natureza. (...) O território é, portanto, uma expressão da relação sociedade/espaço, sendo impossível de ser pensado sem o recurso aos processos sociais." $" 43$

Durante todo o século XVI e grande parte do XVII, essa extensa área de solo fértil e clima subtropical, no Sudeste da América Meridional, ficou fora dos domínios coloniais ibéricos. As povoações portuguesas ao Sul, ainda em 1648, não ultrapassavam Cananéia, na capitania de São Vicente e, do lado espanhol, o único esforço sistemático de colonização nessa área foi realizado pelos padres da Companhia de Jesus vinculados à Diocese de Assunção que, entre 1610 e 1640, fundaram dezenas de missões ao oriente dos rios Paraná e Uruguai, mas que não resistiram aos ataques dos paulistas em busca do cativo indígena. Após 1680, entretanto, quando Portugal resolveu expandir seus domínios até o rio da Prata fundando a Colônia do Sacramento, na margem setentrional daquele rio, iniciava-se formalmente uma disputa diplomática e militar com a Espanha pelo domínio desse espaço, transformando-o num território de disputa. Após um século e meio de negligência, conforme a análise de Dauril Alden, essa área tornou-se as "Debatable Lands" $"$ - território litigioso.

O estabelecimento da Nova Colônia daria, como escreveu Vera Ferlini, um contorno diferente aos domínios meridionais: "Entre São Paulo, até então ponta de lança ao sul e a fronteira de Sacramento, abria-se um grande espaço a esquadrinhar, medir mapear, povoar e defender." ${ }^{45}$ A definição das fronteiras territoriais sob bases mais

\footnotetext{
43 Antonio Carlos Robert Moraes. Bases da Formação Territorial do Brasil: o território colonial brasileiro no "longo" século XVI. São Paulo: Hucitec, 2000, pp. 17 e 18. Um maior aprofundamento teórico dessa questão encontra-se em Antonio C. R. Moraes \& Wanderley Messias da Costa. Geografia crítica. A valorização do espaço. São Paulo: Hucitec, 1984.

${ }^{44}$ Dauril Alden. Royal Government in Colonial Brazil. With Special Reference to the Administration of the Marquis of Lavradio, Viceroy, 1769-1779. Berkeley: University of California Press, 1968, p. 59.

${ }^{45}$ Vera Ferlini. "São Paulo, de Fronteira a Território: uma Capitania dos Novos Tempos" in Laboratório do Mundo - Idéias e saberes do século XVIII. São Paulo: Imprensa Oficial, 2004, p. 20.
} 
estáveis só ocorreria com a independência da República Oriental do Uruguai, em $1828 .{ }^{46}$

Mapa 1.2

Parte da América Meridional - século XVIII ${ }^{47}$

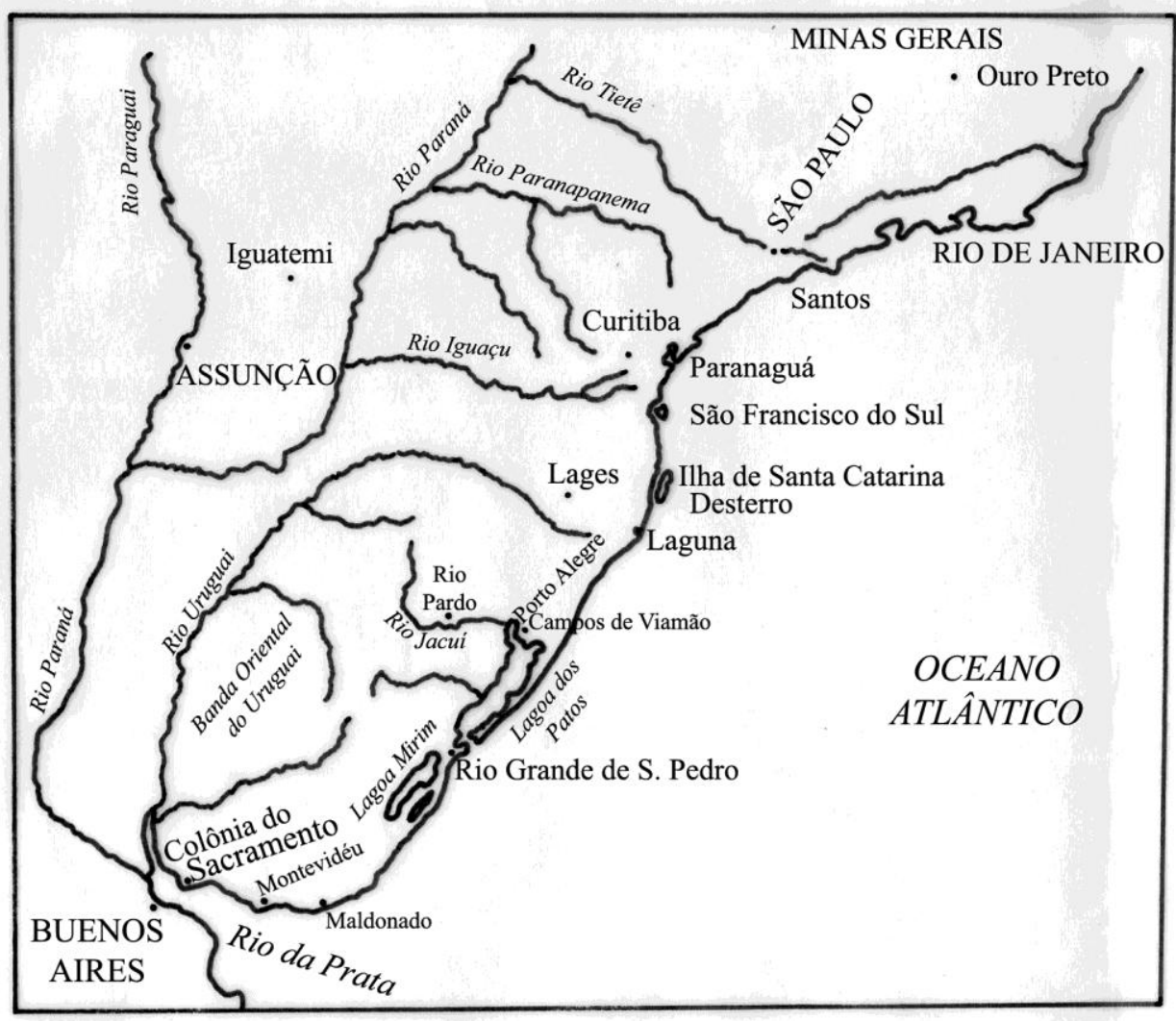

Podemos falar, como apontou Alden, numa negligência das nações ibéricas com relação à ocupação desse espaço? Segundo ele, enquanto os portugueses estavam preocupados com as capitanias tropicais, onde produziam açúcar e outros produtos altamente valiosos ao mercado europeu, os espanhóis ocupavam-se com a exploração

\footnotetext{
${ }^{46}$ Ficou remanescente um litígio entre Brasil e Argentina sobre qual seria o verdadeiro curso dos rios Pepery-Guaçu e Santo Antônio definidos no Tratado de Madri, visto que na ocasião das Partidas demarcatórias não foram devidamente assinalados. Conhecida como "Questão de Palmas" para os brasileiros e "Questão de Misiones" para os argentinos este problema só foi resolvido com o Tratado de Cleveland celebrado em 05 de fevereiro de 1895. Cf. Walter Piazza. A Colonização de Santa Catarina. Florianópolis: BRDE, 1985, p. 251.

${ }^{47}$ Adaptado do Mapa The Debatable Lands de Dauril Alden. Royal Government..., op. cit., p. 62. Agradeço a Bruno Vilagra pela digitalização do mapa.
} 
dos minérios nas montanhas andinas. ${ }^{48}$ Sandra Pesavento, sobre a "tardia integração" do Rio Grande do Sul, entendeu que "Desvinculado da agricultura colonial de exportação diretamente integrada ao mercado internacional", ele "carecia de sentido no contexto do processo de acumulação primitiva de capitais (...)". ${ }^{49}$ De fato, somente no momento em que surgiram condições para integrar essa área ao sistema econômico colonial, fosse por meio da vinculação direta ao mercado europeu, como foi o caso dos couros, fosse por meio da vinculação com o mercado interno, caso do gado em pé, do charque e dos produtos agrícolas (trigo, mandioca etc) é que fez sentido a sua colonização. ${ }^{50}$

Mas isso é válido para os projetos mais sistemáticos de ocupação. Como bem assinalou Luís Ferrand de Almeida, não faltaram projetos e tentativas de colonização nessa vasta área intermédia que permaneceu fora dos domínios efetivos dos europeus durante grande parte do século XVII. Sem falar nos empreendimentos espanhóis com a fundação das missões jesuíticas e da existência efêmera de Ontiveros, Ciudad Real e Vila Rica. $^{51}$

A um fator de ordem econômica a justificar a existência desse vácuo colonizatório por quase dois séculos, deve se acrescentar outro de natureza políticodiplomática, ou seja, como resultado da própria convergência dos impérios ibéricos ao mesmo espaço e, por conseguinte, da hesitação de ambos sobre quais seriam seus limites nele, retardando assim um processo de ocupação formal. Constituiu-se ali uma ampla zona de fronteira, não só espaço de encontros, mas também de confrontos, exigindo cautela por parte das Cortes Ibéricas nas políticas de expansão de seus domínios.

Esse parece ter sido o motivo de Dom João $\mathrm{V}$ em autorizar o povoamento de casais açorianos e madeirenses para aquela área somente em agosto de 1746, depois das insistentes argumentações do governador do Rio de Janeiro, Gomes Freire de Andrade e do Brigadeiro José da Silva Paes nesse sentido. ${ }^{52}$ Enviar os colonos antes poderia

\footnotetext{
${ }^{48}$ Dauril Alden. Royal Government..., op. cit., p. 63.

${ }^{49}$ Sandra Jatahy Pesavento. História do Rio Grande do Sul. 7 ed. Porto Alegre: Mercado Aberto, 1994, p. 7.

50 Caio Prado Júnior. Formação do Brasil Contemporâneo (Período colonial). 23 ed. São Paulo: Brasiliense, 1999.

${ }^{51}$ Luís Ferrand de Almeida. A Diplomacia Portuguesa e os Limites Meridionais do Brasil - (1493-1700) Vol I. Coimbra, 1957, p. 93.

52 Uma Consulta do Conselho Ultramarino de 26.08.1738 tratava de informações passadas pelo Brigadeiro José da Silva Paes acerca da necessidade de se enviar casais das ilhas [Açores e Madeira] para o Rio Grande de São Pedro, "porque só por este meio se poderá evitar a grande despesa, que precisamente se há de fazer com os transportes dos mantimentos do Rio de Janeiro por falta de cultivadores que naquelas vastíssimas terras os fabriquem, além de ficarem estes também igualmente servindo para a sua
} 
melindrar as difíceis negociações do Tratado de Madri com Filipe V. Segundo Jaime Cortesão, a ascensão de Fernando VI ao trono espanhol, em junho de 1746, teria criado condições mais favoráveis para o estabelecimento de relações amistosas entre as duas coroas, até porque a rainha daquele novo soberano era filha de D. João V. ${ }^{53}$ No capítulo 3 volta-se a esse ponto.

Há que se estabelecer, também, uma distinção entre os movimentos mais espontâneos dos colonizadores e o processo formal de incorporação desse espaço aos domínios imperiais ibéricos (implantação das fortalezas e dos regimentos militares, povoamento sistemático, doação de sesmarias e criação das instituições políticoadministrativas).

A expansão dos portugueses, segundo Magalhães Godinho, extrapolou o império de Portugal. ${ }^{54}$ Individualmente ou em grupos, inseriram-se em outros quadros sociais e econômicos ultrapassando os limites dos Estados, das capitanias e das feitorias. Antes da fundação da Colônia de Sacramento, ainda na primeira metade do século XVII, os preadores de indígenas paulistas e os mercadores luso-fluminenses fizeram emergir "uma nova geografia sul-atlântica". ${ }^{55}$ Os primeiros por terra; os segundos por mar.

A cidade do Rio de Janeiro, escreveu Maria Fernanda Bicalho, tornou-se, nos séculos XVII e XVIII, “um dos principais pólos de articulação da vasta região do Atlântico meridional". ${ }^{56}$ Os peruleiros, como eram chamados aqueles mercadores, constituíram, desde o período de união das coroas ibéricas (1580-1640), um intenso intercâmbio comercial com as Províncias platinas do Baixo Peru. Segundo Alice Canabrava, eles conseguiram estabelecer, por meio do comércio lícito - o Asiento (contrato entre a Coroa espanhola e um particular) - e do contrabando, "a preponderância comercial no Rio da Prata, que se transformou num verdadeiro rio

necessária defesa...”, Col. Doc., p. 62. Em carta de 18.12.1744 a Pedro de Azambuja Ribeiro, substituto de Silva Paes na comandância de Santa Catarina, Gomes Freire lamenta que, para o povoamento dessa Ilha "S. Maj. não foi servida mandar casais das Ilhas, melhor meio para uma vez" ser ela povoada. ANRJ, Códice 84, vol. 11, fl. 29.

${ }^{53}$ Jaime Cortesão. Alexandre de Gusmão e o Tratado de Madrid. (Parte I - Tomo II) Rio de Janeiro: Ministério das Relações Exteriores; Instituto Rio Branco, c. 1950, p. 245; Da mesma forma entende Jorge Couto. "D. João V" in João Medina (Dir.) História de Portugal dos tempos pré-históricos aos nossos dias - vol. VII - Portugal Absolutista. Alfragide: Ediclube, s/d., p. 251.

${ }^{54}$ Vitorino Magalhães Godinho. Mito e mercadoria..., op. cit., p. 98.

${ }^{55}$ Luiz Felipe de Alencastro. O Trato dos viventes - Formação do Brasil no Atlântico Sul, século XVI e XVII. São Paulo: Companhia das Letras, 2000, p. 199.

${ }^{56}$ Maria Fernanda Baptista Bicalho. A Cidade do Rio de Janeiro e a Articulação da Região em torno do Atlântico-Sul: Séculos XVII e XVIII. In: Revista de História Regional, vol. 3, n. 2 - inverno 1998, p. 1, http://www.rhr.uepg.br/v3n2/fernanda.htm, acesso em 04.03.2006. 
português". ${ }^{57}$ De Pernambuco, da Bahia, do Rio de Janeiro e de São Vicente um tráfico contínuo de pequenas naus levava para Buenos Aires uma diversidade de produtos como, arroz, sal, marmelo, gengibre, azeite, vinhos, tecidos diversos, enxadas, foices, cal, telhas, tijolos, madeiras e principalmente escravos e açúcar. De retorno, elas traziam farinha de trigo, carnes salgadas, sebo, algum ouro e, sobretudo, "reais de prata". ${ }^{58}$

Um dos mais proeminentes armadores nesse negócio foi Salvador Correia de Sá e Benevides (1602-86). Como Governador do Rio de Janeiro (1637, 1647-48 e 1658), restaurador e governador de Angola (1648) e um dos principais articuladores da base mercantil formada pelo triângulo Rio-Luanda-Buenos Aires, que abastecia as províncias platinas de escravos negros em troca da prata peruana, soube reconhecer e valorizar as terras situadas entre a capitania de São Vicente e o rio da Prata. ${ }^{59}$

Com a Restauração, em 1640, e o controle holandês de Angola (1641-48), o tráfico de escravos para Buenos Aires ficou prejudicado, reduzindo, em consequiência, drasticamente o ingresso da prata nas praças do Rio de Janeiro e de Lisboa. A alternativa que Salvador de Sá apontava para se restabelecer o fluxo desse metal - como ele próprio manifestou a D. João IV em uma audiência realizada em Évora - era de conquistar Buenos Aires com uma força "do Rio de Janeiro e de São Vicente em navios mercantes e que" demandassem "pouca água”, levando 500 até 600 homens, enquanto

\footnotetext{
${ }^{57}$ Alice P. Canabrava. O Comércio Português no Rio da Prata (1580-1640). Belo Horizonte: Itatiaia; São Paulo: Edusp, 1984r, p. 148. A autora explica que essa presença marcante dos mercadores portugueses na região se deve a vários fatores, entre eles: insuficiência da indústria metropolitana espanhola em abastecer suas colônias com produtos manufaturados; a proximidade da colônia portuguesa na América; e, principalmente, pelo conhecimento que os portugueses tinham do complicado acesso ao canal do Rio da Prata "de pouca profundidade, coberto de brumas e entulhado de areia; nos depósitos móveis que forram o leito do estuário" (p. 63). Somente com embarcações de pequena tonelagem e de baixo calado podia-se penetrar aquele canal, o que favorecia os portugueses, que praticavam a navegação de cabotagem no litoral do Atlântico Sul.

${ }^{58}$ Id. ibid., pp. 141-144. Fernand Braudel chama a atenção para o fato de que o papel dos mercadores portugueses no período filipino foi intenso não só na região platina, mas ainda no México, Lima, São Domingos, Cartagena de las Indias, assim como também no Pacífico e Extremo Oriente, envolvendo todo o Novo Mundo numa uma imensa rede comercial alimentada pela prata extraída clandestinamente de Potosí. Civilização Material, Economia e Capitalismo, Séculos XV-XVIII. - Vol 2 - Os Jogos das Trocas. São Paulo: Martins Fontes, 1996, pp. 135-137.

${ }^{59}$ Homem influente na vida política fluminense - seu pai e seu avô haviam sido governadores do Rio -, e da Corte Portuguesa, exercendo o cargo de conselheiro do Conselho Ultramarino, Salvador de Sá estabeleceu também fortes vínculos familiares e patrimoniais no lado espanhol. Nascido de mãe espanhola, filha de um governador de Cádiz, Salvador de Sá casou-se, em 1631 (ou 32), com Dona Catalina de Uzarte y Velasco, herdeira de grande fortuna e prestígio na Província de Tucuman, onde ele se tornou encomendero (senhor de terras e de indígenas). Na Província do Paraguai foi comandante de tropas e maestro de campo general (coronel) na luta contra os indígenas. Ver Luiz Felipe de Alencastro, O Trato dos Viventes, op. cit., p. 200 e 201; Charles R. Boxer. Salvador de Sá e a Luta pelo Brasil e Angola, 1602-1686. Trad. Olivério de Oliveira Pinto. São Paulo: Ed. Nacional, Edusp, 1973. (Brasiliana, v. 353), p. 109 e 111.
} 
os paulistas avançariam pelo sertão descendo o rio Paraguai até o estuário platino para, finalmente, se abrir uma estrada às minas de Potosi. ${ }^{60}$

Ainda que esse projeto não tenha sido levado a termo, sua estratégia antecipava em algumas décadas o plano, menos agressivo, mas ainda assim ousado, de fundação da Colônia do Sacramento, concretizada pelo governador do Rio de Janeiro, Dom Manoel Lobo, em janeiro de 1680.

Por outros meios, no entanto, Salvador de Sá buscou até o final de sua vida receber por mercê uma capitania hereditária "de 100 léguas de costa" para si e seus herdeiros, "nas terras onde chamam a Ilha de Santa Catarina, começando nela, partindo a metade para a banda do norte, e a outra metade para a banda do sul (...) para usar dela na forma referida nesta petição, e se aumentar a propagação da fé e fazenda de $\mathrm{V}$. Maj." ${ }^{\prime 61}$ Rejeitada por duas vezes, em $1646^{62}$ e 1658 , a petição foi reapresentada, em 1675, e concedida, em 1676, ${ }^{63}$ só que dessa vez em nome do seu neto, o Visconde de Asseca, e do seu filho, João Correia de Sá.

Importante observar que a consulta feita no Conselho Ultramarino, em 1658, foi favorável à doação, mas a mercê da donataria feita a um desafeto de Salvador de Sá, Agostinho Barbalho de Bezerra. ${ }^{64}$ Todavia, a criação de uma capitania da Ilha de Santa Catarina não se concretizara, pois o agraciado morrera pouco tempo depois de recebida a mercê. Os pareceristas consultados no Conselho, homens influentes na Corte, alertavam sobre a importância de colonizar aquelas terras. Marcos Corrêa de Mesquita, Provedor da Fazenda e Coroa da Índia, argumentava que,

\footnotetext{
${ }^{60}$ ABNRJ, vol. XXXIX, p. 27 e 28. "Informação de Salvador Corrêa de Sá e Benavides acerca do modo como se poderia abrir o comércio com Buenos Aires. Évora, 21 de outubro de 1643.”

${ }^{61}$ ABNRJ, Vol. XXXIX, p. 80. "Consulta do Conselho Ultramarino acerca da concessão de 100 legoas de terras que pedira Salvador Corrêa de Sá no districto da Ilha de Santa Catharina. Lisboa, 14 de março de 1658."

${ }^{62}$ Cf. Charles R. Boxer. Salvador de Sá... Op. cit., p. 308.

${ }^{63}$ ABNRJ, Vol XXXIX, p. 142. "Salvador Corrêa de Sá, como tutor de seu neto o Visconde de Asseca e procurador de seu filho o General do Estreito de Ormus João Corrêa de Sá, donatários das Capitanias de São Salvador dos Campos e Santa Catarina da Mos, no distrito da Paraíba do Sul, apresentou neste conselho um papel por ele assinado em que diz que V. A. lhes acrescentou as ditas Capitanias por serem limitadas 75 legoas da Costa na dita Repartição do Sul entre o marco do Rio da prata, onde parte esta Coroa, e os donatarios a quem V. A. tem feito mercê (...)". Consulta do Conselho Ultramarino, Lisboa, 25 de janeiro de 1677”. Ver também Charles R. Boxer. Salvador de Sá...Op. cit., p. 391.

${ }^{64}$ ABNRJ, Vol. XXXIX, p. 99. "Resolução regia pela qual se fez mercê a Agostinho Barbalho Bezzerra da doação da Ilha de Santa Catarina, em remuneração de seus serviços e dos de seu pai Luiz Barbalho Bezerra. Lisboa, 9 de outubro de 1663." As atitudes de Salvador diante da revolta ocorrida no Rio de Janeiro, em 1660, mandando executar Jerônimo Barbalho, irmão de Agostinho, parece não ter criado atmosfera favorável para ele, na corte de Lisboa. Cf. Charles R. Boxer. Salvador de Sá...op. cit., p. 335.
} 
as terras são muito boas abrindo-se e cultivando-se, darão toda a novidade de mandioca, legumes, tabaco, algodão e canas de açúcar, se lhas plantarem (...) e haverá comércio com o Rio de Janeiro e Bahia, e abrir-se-ão alfândegas, cujos direitos podem render muito, assim pela saca dos frutos da terra, como das mercadorias, que podem vir de fora a este Reino, como de Buenos Aires, de que se pode comerciar dali, por ficar muito perto e haver ocasião de se meter prata neste Reino, de que tanto carece. E querendo V. M. que Deus guarde cometer alguma facção por ali contra Castela, para se aproveitar de algum porto donde lhe possa, vir prata, tendo aqueles portos povoados, e navegáveis o pode fazer com maior facilidade. ${ }^{65}$

Na opinião do Padre Luiz Pessoa, da Companhia de Jesus,

as terras que correm de Cananéia para o sul, são muitas e muito férteis; a prova é a experiência que sendo lá mui poucos os moradores, o principal sustento da gente de guerra do Rio e ainda da Bahia, são as farinhas e legumes, que vem daquelas partes; e é certo que havendo quem as cultive serão dobrados os frutos. Depois da Cananéia está o porto da Paranaguá, após deste o Rio novo de São Francisco, Ilha de Santa Catarina e junto a ela a grande lagoa, chamada dos patos, todos portos belíssimos, e capacíssimos de muitos e grandes navios, fertilíssimos de madeiras e abundantíssimos de pescados, será coisa de grande serviço de Deus e de V. M. e aumento de sua fazenda repartirem-se aquelas partes a pessoas de porte, e timoratas, para que as façam crescer depressa e com temor de Deus, e obediência de seu Rei $(\ldots){ }^{66}$

Além de procurar restabelecer o acesso à prata peruana, Salvador de Sá, ao assenhorear-se dessa costa - parte lateral do triângulo Rio-Luanda-Buenos Aires, não um de seus vértices, mas, nem por isso desprezível, pois, se fosse, não teria ele insistido tanto para obter uma capitania com centro naquela ilha - contava com a possibilidade de alcançar aquelas minas por um caminho alternativo, ou até descobrir outras, como a da Serra das Esmeraldas ${ }^{67}$, de Paranaguá, de Sabarabuçu e de Taió, situadas em algum lugar imaginário do sertão.

Mas por que a resistência da Corte Portuguesa em conceder essa mercê ao restaurador de Angola, se interessava tanto a ela a retomada do comércio platino? Luiz Felipe de Alencastro que, diga-se, não se refere em nenhum momento sobre as insistentes petições encaminhadas por Salvador de Sá para obtenção de uma capitania

\footnotetext{
${ }^{65}$ ABNRJ, Vol. XXXIX. "Consulta... op. cit., p. 81.

${ }^{66}$ Ibid., p. 82. Os demais pareceristas nessa Consulta, o Bispo de Angola, frei Christovão de Lisboa, o frei Guardião de Santo Antonio dos Capuchos de Lisboa, Manuel de Sancta Maria e o Capitão Salvador Thomé Mealhadas foram da mesma forma favoráveis à doação da mercê.

${ }^{67}$ ABNRJ, vol. XXXIX, p. 90. "Consulta do Conselho Ultramarino acerca do requerimento de Salvador Corrêa de Sá e Benavides, em que pedia a confirmação de seu filho João Corrêa de Sá no posto de Mestre de Campo do Terço do Rio de Janeiro, com que ia ao descobrimento e entabulamento das minas da Serra das Esmeraldas. Lisboa, 18 de março de 1660.”
} 
na Ilha de Santa Catarina, afirmou, todavia, que a monarquia temia que ele "- atraído por honras, lucros e vínculos familiares - se bandeasse para o lado espanhol". ${ }^{68}$ É possível.

Interessante refletir sobre essa omissão de Alencastro. Ao enfatizar os vértices do triângulo desconsiderou outras possibilidades, ou projetos de expansão, tanto por parte dos particulares como da monarquia portuguesa. As restrições desta à concessão das donatarias revela pelo menos duas questões: a Coroa tinha os seus meios burocráticos e institucionais de barrar, ou pelo menos frear, o poder de homens como Salvador de Sá, o que de certa forma nos leva a questionar a ênfase dada pelo próprio Alencastro na relação bipolar - Brasil-Angola - dos negócios no Atlântico Sul; havia já na segunda metade do século XVII uma preocupação da monarquia portuguesa transformada em política efetiva no reinado de D. João $\mathrm{V}$ - com os destinos desse amplo território existente entre a capitania de São Vicente e o rio da Prata.

Inseridos numa economia continental e, portanto, mais distantes e independentes das redes políticas da Corte, os paulistas vão avançar, na primeira metade do século XVII, ao Oeste e ao Sul da América Meridional, primeiro priorizando a captura do cativo indígena ${ }^{69}$, depois, o descobrimento das pedras e metais preciosos.

A partir de meados do século XVII, grupos partindo de São Paulo, São Vicente e Santos - dessa vez com perspectivas de fixação à terra - deram origem aos povoados de Paranaguá (1648), Nossa Senhora das Graças do Rio de São Francisco do Sul (1658), Curitiba (1668), Santo Antônio dos Anjos da Laguna (c. 1682) ${ }^{70}$ e Nossa Senhora do Desterro, na Ilha de Santa Catarina (c. 1690). ${ }^{71}$

\footnotetext{
${ }^{68}$ Luiz Felipe de Alencastro. O Trato dos Viventes... Op. cit., p. 202.

${ }^{69} \mathrm{O}$ auge desse apresamento ocorreu entre 1628 e 1641, quando assaltaram as missões jesuíticas em Guairá e Tapes. Cf. Myriam Ellis. "As bandeiras na expansão geográfica do Brasil” In: Sérgio Buarque de Holanda (Dir.) História Geral da Civilização Brasileira. T. I, vol. 1. Rio de Janeiro: Bertrand Brasil, 1989, p. 277.

${ }^{70}$ Essas datas foram extraídas de Walter F. Piazza. Santa Catarina: sua história. Florianópolis: Ed. da UFSC, 1983, pp. 111-114; e Sérgio Buarque de Holanda. "A Colônia de Sacramento e a Expansão no Extremo Sul" In: $H G C B$, vol. 1, op. cit., p. 322. Há muitas dúvidas, em decorrência da falta de documentos, acerca das datas em que principiaram esses povoados, o que é um indício da não oficialidade desse movimento colonizatório. Existe uma carta de Domingos de Brito Peixoto em que ele expõe ao rei a sua pretensão de povoar Laguna, escrita em Santos, em 10 de fevereiro de 1688 e outra do Ouvidor Geral Thomé de Almeida e Oliveira, escrita no Rio de Janeiro, de 26 de maio de 1688, dando a seguinte informação ao rei: que estando "na vila de Santos, em correição me deu noticia o capitão Domingo de Brito, morador na dita vila, que ia povoar a Laguna, parte mais vizinha a Maldonado, porquanto queria fazer alguns descobrimentos de prata, que já tinha notícia, por ter já postos alguns currais, e eu o ajudei, com o que lhe foi necessário, e alguns casais que logo levou para a dita povoação" [o último grifo é meu]. As duas cartas encontram-se em ABNRJ, vol. XXXIX, pp. 177 e 178.

${ }^{71}$ A primeira fundação é atribuída a Francisco Dias Velho que, por volta de 1675, veio com a sua família e agregados para a ilha de Santa Catarina, onde ergueram uma capela dedicada a Nossa Senhora do Desterro. Todavia, contam os historiadores que, em 1689, esse incipiente povoado fora destruído, assim
} 
$\mathrm{Na}$ maioria dos casos, essas empresas corriam também mais por conta e risco das famílias de povoadores do que da Coroa Portuguesa, muito embora o rei, por meio das graças e mercês, pudesse regular a concessão das patentes militares, dos rendimentos e das doações de sesmarias que suplicavam. E mesmo que não recebessem essas graças e mercês, a própria expectativa de um dia virem a receber, materializadas nas petições, representava um vínculo, ainda que tênue, entre a monarquia lusitana e esses colonos.

Segundo Luiz Felipe de Alencastro, a formação desses pequenos povoados ao longo da costa litorânea, vincula-se, numa mesma estratégia para retomar o tráfico de escravos africanos e a prata de Buenos Aires, à reconquista de Angola (1648), à criação do bispado do Rio de Janeiro com jurisdição até a embocadura do Prata (1676), à donataria concedida ao visconde de Asseca, neto de Salvador de Sá, de setenta e cinco léguas de terras ao norte do Rio da Prata (1676) e, enfim, à fundação da Colônia de Sacramento (1680). ${ }^{72}$

De fato, mas não se pode desconsiderar também o crescente interesse dos colonizadores e da própria Coroa por esse território ainda inexplorado. Novas possibilidades abriam-se com a expansão das conquistas - o aproveitamento do gado, a extração das madeiras, da erva-mate e de produtos agrícolas, que o cultivo daquelas férteis terras poderia dar. Além do mais, "O esforço de territorialização da fronteira, exigiu sua defesa e efetivo domínio de novas áreas". ${ }^{73}$

Pode-se dizer que esse processo de expansão desencadeado por grupos e indivíduos em proveito de seus interesses particulares - a captura do cativo indígena, a apropriação da terra e a sempre promissora possibilidade de encontrarem metais preciosos - abriu caminho e preparou o terreno para a posterior instalação do poder político e institucional do Estado monárquico lusitano. Mas até que isso acontecesse, a probabilidade de que outra nação (não só Espanha, mas também Inglaterra, França ou Holanda) invadisse aquela "terra de ninguém" era sempre iminente.

Em verdade, assegura Charles Boxer, havia pouco risco de, no tempo de Salvador de Sá, os espanhóis precederem os portugueses nessa área, pois, os hispano-

como assassinado o seu fundador, por piratas (ingleses ou holandeses), em vingança ao saque que Dias Velho fizera nas mercadorias que eles traziam, quando, um ano antes, aportaram naquela ilha. Ver, entre outros, Oswaldo R. Cabral. Nossa Senhora do Desterro. Florianópolis: Lunardelli, 1979, pp. 18 e ss.

${ }^{72}$ Luiz Felipe de Alencastro. O Trato dos Viventes..., op. cit., p. 203.

${ }^{73}$ Vera Ferlini. “São Paulo, de Fronteira a Território...”, op. cit., p. 23. 
americanos tiveram que se manter na defensiva face à pressão que os luso-brasileiros faziam no vice-reinado do Peru. ${ }^{74}$ Ameaças maiores viriam de outros lugares.

Ainda que Portugal e Espanha detivessem os mais extensos domínios ultramarinos, o equilíbrio das relações políticas internacionais, a partir da segunda metade do século XVII, passava a se organizar em torno de outros centros. Segundo Fernando Novais, França e Inglaterra "assumiam definitivamente a dianteira no desenvolvimento econômico e no movimento das idéias, passando as monarquias ibéricas a potências de segunda ordem,"75.

Os territórios ainda pouco explorados, desguarnecidos de fortificações e regimentos militares, como estavam essas terras e mares entre a capitania de São Vicente e o Rio da Prata, despertavam também o interesse das potências marítimas e comerciais européias.

Thomas Maynard, cônsul-geral inglês em Lisboa, escreveu uma carta ao Lord Arlington, em 21 de outubro de 1670, muito reveladora a esse respeito, informando-lhe sobre a importância e vantagens econômicas para a Inglaterra desse território e incentivando-o muito a colonizá-lo.

Meu Senhor, tem sido muitas vezes intenção minha dizer a Vossa Senhoria alguma coisa a respeito daquela região que fica entre o Trópico de Capricórnio e o Estreito de Magalhães, bem como da probabilidade de mostrar-se ela vantajosa ao comércio da Inglaterra, como escoadouro de nossas manufaturas, além do proveito que o reino pode tirar da plantação de tudo quanto aquele excelente e bem situado solo é capaz de produzir, como sedas, azeite, açúcar, anil, uvas, vinhos, tabaco e muitos outros artigos que recebemos da Itália, da Espanha e da França, sem falar nos produtos nativos, como o cacau, essa canela da região, que é muito estimada na Holanda e na França, paus de tinta e couros, e tampouco no ouro e outros minerais, pois é sabido que os portugueses muitas vezes têm obtido ouro dos nativos. Verdade é que o rei de Portugal pretende ser sua toda a região em apreço até o Rio da Prata ou Buenos Aires; mas não faz nenhum comércio ao sul do Rio de Janeiro, que fica no trópico, embora existam ali pequenas povoações habitadas por portugueses, como São Vicente, $\mathrm{Pa}[$ rana]guá, Cananéia e Santos, lugares que são supridos do que precisam pela Europa, por meio de barcos que vêm do Rio de Janeiro, ao longo da costa, e que, segundo estou informado, gostariam de entreter um tráfico com quem quer que lhes trouxesse aqueles artigos; (...) $\mathrm{O}$ mundo não oferece lugar mais bem situado para quem queira se estabelecer $(. ..) .^{76}$

\footnotetext{
${ }^{74}$ Charles R. Boxer. Salvador de Sá... Op. cit., p. 392.

${ }^{75}$ Fernando A. Novais. Portugal e Brasil na Crise do Antigo Sistema Colonial (1777-1808). 6 ed. São Paulo: Hucitec, 1995 [1 ${ }^{\mathrm{a}}$. ed. 1979], p. 18.

${ }^{76}$ Apud Charles R. Boxer. Salvador de Sá..., op. cit., pp. 393 e ss.
} 
Não se sabe qual foi a reação de Lord Arlington a essas sugestões do cônsul inglês, mas servem para mostrar a visibilidade que esse território passava a ter na alta política inglesa. De qualquer forma, os históricos laços de compromissos luso-britânicos - a proteção política que estes ofereciam àqueles em troca de vantagens comerciais crescentes - davam à Inglaterra, a condição de "nação mais favorecida" nos negócios de Portugal com suas colônias. $^{77}$

No início do século XVIII, as agitações políticas causadas pela Guerra de Sucessão ao trono espanhol (1703-1712), estimularam uma atuação mais agressiva dos mercadores franceses no ultramar. A adesão de Portugal à Grande Aliança (Inglaterra, Holanda e Áustria), em 1703, contra a candidatura de Filipe V, neto de Luís XIV, ao trono de Madri acabou por animar o corso francês às colônias lusas na África, na América e no Oriente; eles saquearam as ilhas de Príncipe (1706) e São Tomé (1709), no golfo da Guiné, queimaram a cidade de Benguela, na África Ocidental (1705), e pilharam Santiago de Cabo Verde, em $1712 .^{78}$ No Rio de Janeiro, o exército, juntamente com moradores, conseguiu repelir a expedição de Jean-François Duclerc, em 1710, mas não resistiu à do famoso corsário bretão René Duguay Trouin, no ano seguinte. ${ }^{79}$ Essa cidade - escreveu Charles Boxer - "era considerada como o prêmio mais desejável, em vista da grande riqueza canalizada através de seu porto, proveniente do ouro de Minas Gerais." 80

As incursões dos corsários franceses não foram o único problema que Dom João V teve de enfrentar logo no início do seu longo reinado (1706-1750). O Império Luso sofreu também com: a depredação dos campos fronteiriços do reino pela guerra; a perda da Colônia de Sacramento para os espanhóis em 1705; maus anos agrícolas (17071750), ocasionando escassez de alimentos; agitações sociais no reino, provocadas pela grande subida do preço dos cereais e também pelo atraso do pagamento do soldo. No

\footnotetext{
${ }^{77}$ Fernando Novais. Portugal e Brasil na Crise..., op. cit., p. 22. Uma artimanha utilizada por Frézier para adentrar nos portos portugueses sem ser hostilizado pelos habitantes era de colocar no mastro principal do navio um galhardete branco sob uma bandeira inglesa. Assim ele procedeu nas ilhas de Santo Antônio (arquipélago de Cabo Verde) e de Santa Catarina. Cf. Amadeo Frezier. Relacion del Viaje..., op. cit., p. 25 e 30. "Havíamos hasteado a bandeira inglesa com o galhardete no mastro principal e anunciado com um canhonaço para que os habitantes da ilha de Santo Antônio, que só estavam a duas léguas dali viessem a nós; mas, seja porque desconfiassem de nossa artimanha ou porque a bruma os impedisse ver-nos claramente, não vieram."

${ }^{78}$ Charles R. Boxer. A Idade de Ouro do Brasil: Dores de crescimento de uma sociedade colonial. 3 ed. Rio de Janeiro: Nova Fronteira, 2000, p. 113.

${ }^{79}$ Para uma análise do contexto histórico em que ocorreram as invasões francesas, ver também Maria Fernanda Bicalho. A Cidade e o Império. O Rio de Janeiro no século XVIII. Rio de Janeiro: Civilização Brasileira, 2003.

${ }^{80}$ Charles R. Boxer. A Idade de Ouro..., op. cit., p. 113.
} 
Brasil, teve ainda a guerra dos emboabas nos sertões mineiros, entre paulistas e reinóis (1707-1709) e guerra dos mascates entre os senhores de engenho de Pernambuco, por um lado, e mercadores e oficiais mecânicos recifenses, por outro (1710-1711). Ao mesmo tempo, entretanto, começavam afluir para a Metrópole quantias significativas do ouro descoberto nas Minas Gerais, aliviando o tesouro régio dos encargos causados pela crise. $^{81}$

$\mathrm{O}$ ingresso em altas quantidade de ouro e diamantes do Brasil, na primeira metade do século XVIII, deu condições a Portugal de equilibrar sua balança comercial de pagamentos a curto prazo, mas causou o abandono das políticas mais sistemáticas de industrialização e de modernização da agricultura, com conseqüências danosas a longo prazo. $^{82}$

A exploração do ouro e dos diamantes provocou um reordenamento do espaço colonial: o centro de atração econômica deslocou-se do litoral-Norte, agrário, para o centro-Oeste do continente, mineiro; de uma sociedade formada de estabelecimentos praticamente isolados entre si (como que numa espécie de arquipélago continental) voltada quase que exclusivamente para o mar, deu-se início à construção de uma rede de caminhos internos, ligando suas unidades, e produzindo um primeiro sentido de unidade territorial para o Brasil. Promoveu-se também a ampliação e diversificação da economia de abastecimento interno por meio da constituição de lavouras e da criação pecuária. Do sertão da Bahia e dos campos do sul rasgavam-se os primeiros caminhos praticáveis, por onde se conduzia o gado de corte, as besta muares e as cavalhadas, em demanda dos mercados das Minas Gerais. ${ }^{83}$

Muito embora as Índias Orientais continuassem a ser motivo de orgulho e glória dos portugueses, o grande centro de interesses e fonte de recursos para Portugal passara a ser o Brasil e o mundo Atlântico. A importância econômica e estratégica da América no conjunto do Império "levou D. João V a prestar particular atenção à sua colonização,

\footnotetext{
${ }^{81}$ Ver Jorge Couto. "D. João V”, op. cit., pp. 244 e 245.

${ }^{82}$ Frédéric Mauro. "Portugal e o Brasil: a Estrutura Política e Econômica do Império, 1580-1750" in Leslie Bethell (Org.) História da América Latina - América Latina Colonial (Vol. I). 2 ed. São Paulo: EdUSP; Brasília, DF: Fundação Alexandre de Gusmão, 2004, p. 468; A. J. R. Russell-Wood. "O Brasil Colonial: o Ciclo do Ouro, c. 1690-1750" in Leslie Bethel (Org.). História da América Latina - América Latina Colonial (Vol. II ). São Paulo: EdUSP; Brasília, DF: Fundação Alexandre de Gusmão, 2004, p. 524. Um excelente balanço da produção de ouro brasileiro no século XVIII encontra-se em Virgílio Noya Pinto. O Ouro Brasileiro e o comércio Anglo-português. Ed. Nacional: São Paulo, 1979 (Col. Brasiliana, vol. 371), p. 114.

${ }^{83}$ Guilhermino Cesar. História do Rio Grande do Sul - Período Colonial. Porto Alegre, Globo, 1970, p. 89.
} 
desenvolvimento e defesa". ${ }^{84}$ D. Luís da Cunha, seu diplomata mais proeminente, sugeria em suas Instruções Políticas inclusive a formação de um império luso-brasileiro com a sede da corte na cidade do Rio de Janeiro, pois, segundo ele,

o dito príncipe, para poder conservar Portugal, necessita totalmente das riquezas do Brasil, e de nenhuma maneira das de Portugal, que não tem, para sustentar o Brasil; de que se segue, que é mais cômodo e mais seguro estar onde se tem o que sobeja, que onde se espera o de que se carece. ${ }^{85}$

As negociações em Utrecht, nas quais participou ativamente esse diplomata, levaram à assinatura dos tratados de paz com a França (11 de abril de 1713), e com a Espanha (6 de fevereiro de 1715). Com estes os portugueses obtiveram a restituição da Colônia do Sacramento e seu "território", 86 com aqueles, a soberania sobre a área situada entre os rios Amazonas e Oiapoque.

Mas o saldo mais positivo do conflito tirara a Inglaterra que, a partir de 1715, ampliara o seu domínio na Europa "desde o Báltico ao Levante; sobre as três Américas - a do Norte, a Antilhana e a do Sul; ao mesmo tempo que invadia progressivamente o Índico e o Pacífico". Obteve ainda da Espanha o "navio-licença" para instalar o seu comércio no Rio da Prata, "porta atlântica do Peru". ${ }^{87}$

Os franceses, embora derrotados, continuavam com seu antigo propósito de estabelecerem-se na América portuguesa, tanto que, em 1723, ocuparam a ilha de Fernando de Noronha rebatizando-a de Isle Delphine. ${ }^{88}$

Os espanhóis, por sua vez, mantinham acesas suas pretensões pelo território ao norte do Rio da Prata e difícil foi para os portugueses manter o domínio da Colônia do Sacramento. Essa praça encontrava-se isolada e exposta à invasão dos inimigos, assim como também as suas linhas de comunicação. Entre o Rio de Janeiro e o Prata, escreveu Jaime Cortesão, "os barcos podiam facilmente buscar abrigo e aguada em lugares mal

\footnotetext{
${ }^{84}$ Jorge Couto. "D. João V", op. cit., p. 246.

${ }^{85}$ D. Luís da Cunha. Instruções políticas. (introdução, estudo e edição de Abúlio Diniz Silva) Lisboa: CNCDP, 2001, pp. 363 e 371.

${ }^{86}$ A expressão "território" da Colônia, especificada no Tratado de paz, teve interpretação diversa para portugueses e espanhóis. Enquanto estes entendiam que ele se restringia à área circunscrita ao "raio de um tiro de canhão", aqueles consideravam-no como toda a Banda Oriental do Uruguai. Ver Jônathas da Costa Rego Monteiro. A Colônia do Sacramento (1680-1777). Porto Alegre: Globo, 1937 (2 vol.), p. ; e J. Capistrano de Abreu. "Sobre a Colônia do Sacramento" in Ensaios e Estudos (crítica e história) - 3" série. Rio de Janeiro: Sociedade Capistrano de Abreu, 1938, p. 75.

${ }^{87}$ Jaime Cortesão. Alexandre de Gusmão..., op. cit., p. 20 e 21.

88 Joaquim Romero Magalhães. "As Novas Fronteiras do Brasil” in Francisco Bethencourt e Kirti Chaudhuri (Dir.) História da Expansão Portuguesa - Vol. 3 - O Brasil na Balança do Império (16971808). Lisboa: Temas e Debates, s/d., p. 19.
} 
guarnecidos ou indefesos, como Porto Seguro, Cabo Frio, Ilha Grande e, mais que tudo, a Ilha de Santa Catarina, para de aí interromper o tráfico português, aprisionando navios negreiros", ou abastecendo-se e remuniciando-se com os socorros e suprimentos que do Rio seguiam para a Colônia. ${ }^{89}$

Restituída aos portugueses, em 1716, a Colônia consolidou sua posição no rio da Prata como porto da indústria ganadeira e comércio de couros. Nos próximos vinte anos, até ao cerco posto pelos espanhóis em finais de 1735, "aquelas atividades puderam desenvolver-se num vivo crescendo, malgrado todos os embargos opostos pelos governadores de Buenos Aires". 90 Enquanto os seus moradores puderam cultivar os campos em volta da praça e estabelecer relações comerciais com os espanhóis de Buenos Aires, principalmente por meio do contrabando, ela constituiu-se em apreciável fonte de lucros aos particulares e também à Coroa Portuguesa.

O secular objetivo da Coroa de alargar as fronteiras de seus domínios na América até a margem norte do Rio da Prata foi perseguido por D. João V, que deu um significativo impulso à colonização das terras ao sul de São Vicente. ${ }^{91}$ Para isso, mas também como parte de um movimento mais amplo de fortalecimento da autoridade régia e submissão da nobreza e do clero, ele adquiriu a capitania hereditária de São Vicente, em 1711, do Marquês de Cascais.

José de Gois de Morais, filho do capitão-mor governador Pedro Tacques de Almeida, cavaleiro fidalgo da casa real, intentou comprar ao Marquês de Cascaes por quarenta e quatro mil cruzados cinqüenta léguas que tinha por costa, porém, el-rei o Senhor D. João $5^{\circ}$ resolveu que o dito marquês recebesse da fazenda real, esse dinheiro, e ficassem as ditas cinqüenta léguas de terra incorporadas á coroa e patrimônio real. ${ }^{92}$

E havia sido essa a posição dada pelo Conselho Ultramarino ao rei,

Porque esta Capitania é hoje a mais importante que V.M. tem em seus reais domínios e que contém em si minas, ficando nas vizinhanças das mais preciosas e passagem para elas, sendo por este respeito tão apetecidas, e que convém que deva toda a atenção à conservação daquelas terras, se vê este Conselho obrigado a pôr na real consideração de V.M. esta matéria, para que V.M. por benefício de seu real serviço e conveniências que estão

\footnotetext{
${ }^{89}$ Jaime Cortesão. Alexandre de Gusmão..., op. cit, p. 65.

90 Ibid., p. 34; Ver também interessante análise sobre esse período em Fabrício Prado. Colônia do Sacramento: o Extremo Sul da América Portuguesa no Século XVIII. Porto Alegre, 2002, p. 19.

${ }^{91}$ Jorge Couto. “D. João V”..., op. cit., p. 247.

${ }^{92}$ Pedro Tacques de Almeida Paes Leme. História da capitania de S. Vicente. São Paulo: Melhoramentos, s/d. [1772], p. 117.
} 
assegurando o ficar a posse delas na Coroa e as consequiências que disso podem resultar, pondo-se sempre no posto de Capitão-Mor pessoa de maior suposição do que escolhem os donatários, que são uns feitores seus, sem graduação de serviços para acudirem a sua defesa, que V.M. nesta consideração deve haver por bem de que por conta de sua Real Fazenda se pague ao mesmo Donatário o preço que se lhe promete, tirando-se para a sua satisfação do rendimento dos quintos do ouro que vem para estas partes, e enquanto se lhe não entrega o dito dinheiro que se lhe satisfaçam os juros de 5 por cento. ${ }^{93}$

Segundo António Vasconcelos de Saldanha, esse processo de incorporação das capitanias hereditárias pela Coroa "constitui uma preocupação antiga da política ultramarina portuguesa, que, com o caráter de ação conjunta, remonta pelo menos ao reinado de D. João IV, sobrevivendo através de ações pontuais nos reinados dos sucessores, para atingir o seu auge no consulado de Carvalho e Melo, já na segunda metade do século XVIII". 94

Nesse momento, entretanto, quando o Brasil se torna a base fundamental de sustentação econômica do império português, o processo de extinção do sistema senhorial respondeu sobretudo à necessidade de fortalecimento e centralização do poder monárquico.

À medida que foram sendo incorporadas ao real domínio criavam-se as capitanias gerais ou governos subordinados (chamados pela historiografia de capitanias subalternas ou subcapitanias), sujeitos não mais ao controle perpétuo de donatários, e sim, da administração amovível dos governadores. ${ }^{95}$ Dessa forma, Dom João V mandou criar, em 1709, a capitania geral de São Paulo e Minas do Ouro, que ficou com extensa jurisdição territorial. Compreendia o sertão mineiro e toda a Repartição do Sul, excetuando-se a Colônia do Sacramento que, desde sua fundação, esteve vinculada ao Rio de Janeiro. Ao oeste, estendia-se por um amplo e impreciso espaço, projetando-se até ao Rio Paraná, senão além.

\footnotetext{
${ }^{93}$ Eduardo de Castro e Almeida (Org.). Inventários de Documentos Relativos ao Brasil existentes no Archivo da Marinha e Ultramar de Lisboa, organizado para a Biblioteca Nacional do Rio de Janeiro. Rio de Janeiro, 1913-1918, vol. 6, p. 323-325. Com relação a donataria dos Assecas (dois quinhões de terras situadas entre a capitania do Marquês de Cascais e o rio da Prata) doada por D. Pedro, em 1676, a reversão se processou de outra forma. Como seus donatários (filho e neto de Salvador Correia de Sá e Benevides) não chegaram a tomar posse nem se instalaram, as terras foram reincorporadas ao patrimônio régio, em 1727, por se ter negado D. João V a confirmar a doação anterior. Cf. Guilhermino César. História do Rio Grande do Sul, op. cit., pp. 48 e 49.

${ }^{94}$ António Vasconcelos de Saldanha. As capitanias do Brasil: Antecedentes, desenvolvimento e extinção de um fenómeno atlântico. Lisboa: CNCDP, 2001, p. 420.

${ }^{95}$ Houve, é certo, desde o século XVI, capitanias que sempre estiveram sob o controle direto da Coroa e não de donatários, como a Bahia, o Rio Grande (do norte), a Paraíba e o Rio de Janeiro.
} 
Depois, como parte dessa reestruturação administrativa e modo de ampliar ainda mais o controle régio sobre determinados espaços estratégicos do império português, Dom João $\mathrm{V}$ tomou uma série de medidas que reduziam o poder jurisdicional dos capitães-generais de São Paulo: na antiga "Minas de Ouro", criou a capitania geral "das Minas" (1720) $)^{96}$; anexou a esta a administração das minas de Goiás e Cuiabá (1738), transformando-as, dez anos depois, cada qual, em capitanias gerais ${ }^{97}$; transferiu para a jurisdição do Rio de Janeiro a Ilha de Santa Catarina (1738), o Rio Grande de São Pedro $(1738)^{98}$ e Laguna (1742); e, por fim, o próprio governo de São Paulo passou a ser uma dependência administrativa do Rio de Janeiro (1748).

Enquanto a conquista avançava a passos firmes para o ocidente - no sertão mineiro -, medidas eram tomadas não apenas para o conhecimento e exploração mais pormenorizada da costa litorânea e povoações meridionais, mas para seu domínio mais efetivo. As duas expedições realizadas pelo sargento-mor da praça de Santos, Manuel Gonçalves de Aguiar, por ordem dos governadores do Rio de Janeiro, tinham esse objetivo.

Na primeira, efetuada entre fevereiro e abril de 1711, ele foi de Santos à Ilha de Santa Catarina, passando por Paranaguá, São Francisco do Sul e Enseada das Garoupas.

Logo que cheguei à vila de Paranaguá fiz presente ao Capitão-mor dela João Rodrigues França e aos oficiais da câmara a diligência a que ia do serviço de S. M. e que convocassem os seus moradores mais antigos que ali houvessem e tivessem andado aquela costa e mineiros das antigas minas, para que todos dessem seus depoimentos do que soubessem assim da capacidade da Enseada das Garoupas e mais portos, como de minas de ouro e de alguns metais mais de que tivessem notícia (...). ${ }^{99}$

\footnotetext{
96 Alvará de 2 de dezembro de 1720. Somente em 1732, quando da nomeação do governador Conde de Galveias, André de Melo e Castro, é que se fixou o nome de "Minas Gerais". Ver Antônio Gilberto Costa (Org.) Cartografia da Conquista - Território das Minas. Belo Horizonte: Ed. UFMG; Lisboa: Kapa Editorial, 2004, p. 112.

97 As duas capitanias foram instituídas pela Provisão de 9 de maio de 1748. Ver F. A. Varnhagen. História Geral..., - Tomo V, op. cit., pp. 290 e 291.

${ }^{98}$ Col. Doc., p. 132. Carta régia de 11 de agosto de 1738. A preocupação com um controle mais direto sobre a marinha vinha de mais tempo. Em 12 de janeiro de 1704, o rei declarava que o governador da praça de Santos estava subordinado imediatamente ao governador do Rio de Janeiro. Cf. AESP, DI, vol XVI, pp. 30 e 31. Em 28 de outubro de 1714, em decorrência das representações feitas pelo governador de São Paulo sobre servir a esse governo a praça de Santos, D. João V em carta a Gomes Freire de Andrade ordenava que aquela praça devia "ficar debaixo da jurisdição desse Gov. ${ }^{\circ}$ do Rio de Janeiro, como está determinado, e assim deveis pôr todo o cuidado em ser bem municiada a dita praça socorrendoa de tudo quanto for necessário para qualquer ocasião que se ofereça; e ao Governador Geral de S. Paulo se avisa dessa resolução e que havendo ocasião de ser socorrida que assim ele como vós, lhe deveis acudir mutuamente como for necessário para a sua defesa e conservação (...).” AESP, DI, vol. XVIII, p. 4.

99 ABNRJ, vol XXXIX, p. 403. "Relação da diligencia que fez Manuel Gonçalves de Aguiar, sobre a capacidade da Enseada das Garoupas para nela se fundar uma cidade, e mais notícias de minas naquelas partes...”. Em 20 de abril de 1711. O governador do Rio de Janeiro era Francisco de Castro Morais.
} 
Dentre as informações que colheu constava que havia na "dita Vila de Paranaguá, distante um dia de viagem, (...) uma grandiosa mina de ouro de beta" e que na Enseada das Garoupas ele próprio constatou que não seria "capaz para povoação (...), nem para embarcações de navios ou patachos lá entrarem, e a terra quando muito" poderia "acomodar na enseada 2 moradores em razão de estarem as serras junto ao mar, e não ser terras capazes, por ser toda alagadiça". ${ }^{100}$

Sobre São Francisco, era do parecer que se devia continuar a povoação,

pela capacidade que em si tem de muitas e grandes Baías, rios e enseadas para se fazerem nelas ricas fazendas e muitas madeiras ao pé d'água para navios, com uma barra singular, capaz de toda a navegação, assim de sumacas, como de naus de alto bordo. ${ }^{101}$

E que, apesar de ser terra "muito fértil e abundante de todos os gêneros de mantimentos" não era mais povoada por causa das violências e tiranias cometidas pelo capitão-mor Domingos Francisco Francisques, de alcunha o Cabecinha, que naquela vila estava há vinte anos.

Da Ilha de Santa Catarina, achou, pelo que viu, serem as melhores terras de toda a América do Brasil "por nela se darem todos os gêneros de frutos assim deste, como de Portugal, e poder acomodar muitos mil moradores, assim da dita Ilha, como na terra firme", e que se devia informar ao rei para se continuar "as Povoações do Rio de São Francisco Xavier e principalmente desta Ilha de Santa Catarina que delas é que poderá ter o dito Senhor e seus vassalos conveniências depois de povoadas”. Quanto ao sistema de defesa da Ilha, entendia Gonçalves de Aguiar que não podia

haver fortificação, porquanto se pode botar gente em todas as partes de praias e enseadas dela sem o menor perigo; e o que me parece conveniente em serviço a S. M. e seus povos desta Costa do Sul, é mandar-se para a dita Ilha uma companhia de soldados pagos para impedirem com muita facilidade junto com os moradores as aguadas, lenhas e refresco ao inimigo que ali se vão atualmente refrescar. ${ }^{102}$

\footnotetext{
${ }^{100}$ Id., p. 404.

${ }^{101}$ Id., p. 404.

102 Id., p. 405.
} 
Na segunda expedição, realizada entre novembro de 1714 e agosto de 1715, portanto, bem mais longa que a primeira, Gonçalves de Aguiar levava consigo um sargento e seis soldados. Além de dar continuidade aos trabalhos de averiguação da costa - chegara ele desta vez até Laguna, onde obtivera também informações do Rio Grande - tinha a missão de fortalecer a soberania portuguesa naqueles povoados contra a autonomia dos loco-tenentes e protegendo aqueles portos contra as ameaças de invasão estrangeira. Vinha com ordens do governador do Rio de Janeiro, Francisco Xavier de Tavora, "para prender todos os soldados ausentes, e conduzi-los a esta praça [de Santos], e a todos os criminosos, facinorosos que alteravam com insolências e mortes todos aqueles povos". ${ }^{103}$ Segundo Afonso Taunay, uma de suas principais missões era capturar o "feroz Cabecinha", que inclusive já havia sido deposto do cargo de capitão-mor de São Francisco do Sul, sendo provido em seu lugar Agostinho Alvares Marinho, por patente do governador do Rio de Janeiro, por volta de junho de $1713 .{ }^{104}$ De passagem pela Ilha de Santa Catarina deixou três dos seus soldados, tendo em vista que os franceses continuavam "quase todos os meses" a aportar naquele porto.

Em 1717, o sargento-mor de Santos foi novamente solicitado a prestar informações sobre a costa do Sul. Uma carta régia ordenava que se examinasse a entrada do porto da Ilha de Santa Catarina, "se tem monção em algum tempo do ano assim por ventos como pela correnteza das águas (...), se há abundância de peixe e se pode haver pescaria de Baleias", e se a Ilha "é montanhosa", ou tem "campinas, a que chamam Massapês", e "se há gentio no dito Sítio apontado do rio Mandoui [Maruí] até o Rio Tramande [Tramandaí], e se ficam os Campos perto, e se neles há gado, ou o gentio faz algum resgate, se há noticia que os Castelhanos venham aquele Sertão buscar a erva Congonha ${ }^{105}$,, e, finalmente, pedia ainda para que declarasse, se povoasse aquele distrito poderia "servir para o aumento da Nova Colônia". ${ }^{106}$ Com apoio nessas

\footnotetext{
103 ABNRJ, vol. XXXIX, p. 406. "Relação da diligencia que o Governador do Rio de Janeiro e das capitanias do Sul mandou fazer ao Sargento-mor Manuel Gonçalves de Aguiar a todos os portos do sul, desde a vila de Santos até a Laguna, ultima povoação desta Costa do sul.” Em junho de 1714.

${ }^{104}$ Affonso de E. Taunay. Em Santa Catharina Colonial: Capítulo da história do povoamento. São Paulo: Imprensa Oficial do Estado, 1936, pp. 71-83. Nesta obra o autor fez uma boa pesquisa sobre a carreira de Gonçalves de Aguiar e suas expedições nas costas do Sul.

105 Também chamada pelos contemporâneos de erva do Paraguai ou erva-mate, recebeu por A. de SaintHilaire o nome científico de Ilex paraguariensis.

${ }^{106}$ AESP, Ministério da Marinha, 1611-1822 - "Avisos - Cartas régias - Provisões", CO O419, docto. 7, “Carta Régia sobre as vantagens do porto de Santa Catharina..." Lisboa, 10 de abril de 1717. Nos DI, vol. 18, pp. 9-11, há um erro de transcrição que altera de maneira significativa o teor da carta: no lugar de "Nova Colônia", que se referia indiscutivelmente à Colônia do Sacramento, colocaram "Nossa Colônia", dando a entender - e talvez fosse essa a intenção do transcritor, em 1896 - que se tratava do Brasil Colônia.
} 
questões, o governador do Rio de Janeiro, Antonio de Brito e Menezes, organizou um inquérito com vinte e uma perguntas que foram respondidas uma a uma por Gonçalves de Aguiar, em 26 de agosto de 1721. ${ }^{107}$ A última delas questionava sobre:

Em que parte se pode fazer uma Povoação conveniente assim para se aproveitar de toda a utilidade, como para o aumento da nova Colônia, e prontidão para os seus socorros, assim dentro deste Porto do Rio Grande como fora da Costa do mar, ou perto da Ilha de Santa Catarina?

Ao que ele respondeu:

(...) no Rio Grande de S. Pedro, dizem todos os que nele estiveram, e cursaram aquelas campanhas, Rios, matos, e serras, que não só se pode fazer uma cidade muito grande, mas de grandes conveniências para sua Majestade, e seus Vassalos, segundo consta das Certidões das Câmaras, e moradores das Povoações desta Costa, em que afirmam haver nele ouro e pedras de valor, achadas por vezes naquelas terras, como também abundância grande de prata, e muito maior de gado, que com facilidade se pode conduzir da campanha, e criar naqueles campos havendo moradores, que o domestique. (...) [e na] ilha de Santa Catarina pela facilidade com que se lhe pode acudir daquela Ilha por mar, e em todo o tempo, assim como madeiras que as tem excelentes, como com mantimentos que os produz de todo o gênero com abundância. Povoando-se esta Ilha poderão formar nela seus moradores alguns Engenhos de açúcar, porque as suas canas, são tão pingues e açucaradas, que de qualquer pingo delas se faz um açúcar; a sua entrada não depende de monção, de dia ou de noite a pode tomar qualquer navio, e sair dela; e para a sua defesa bastará uma única fortaleza no Estreito, e para impedir dos inimigos as lenhas, e as aguadas com uma companhia de Infantaria paga $(. . .)^{108}$

As expedições de Gonçalves de Aguiar demarcaram uma etapa do movimento da Coroa portuguesa na consolidação de seu domínio e soberania até o Rio da Prata. Ainda que algumas de suas sugestões e idéias não tenham sido seguidas - o sistema de defesa que ele entendia ser o melhor para a ilha não foi seguido por José da Silva Paes e, quanto à pesca das baleias, que ele desencorajou empreender, tornou-se uma das atividades econômicas mais rendosas realizada em Santa Catarina, na segunda metade do século XVIII - seus relatórios serviram como importantes instrumentos para se

\footnotetext{
${ }^{107}$ Affonso de E. Taunay. "Notícias Práticas da Costa e Povoação do Mar do Sul”, in Relatos Sertanistas. São Paulo: Itatiaia: EdUSP, 1981, pp. 213-225. As Notícias... foram também publicadas por A. Taunay em Em Santa Catharina Colonial..., op. cit., pp. 71-83.

${ }^{108}$ Id., ibid., p. 224.
} 
definir as estratégias de reordenamento da estrutura militar, política e administrativa das capitanias do Sul, nas décadas de 1720 e 1730 , como o futuro nos mostrou. ${ }^{109}$

Entende-se, que os relatórios elaborados por Aguiar foram não só claros e coerentes como também serviram para esclarecer e definir quais eram os pontos mais importantes naquela costa: São Francisco do Sul e, principalmente, Ilha de Santa Catarina e porto do Rio Grande de São Pedro. Na verdade, ele vinha reforçar algumas idéias já formadas sobre esse território. Das vinte e uma perguntas que lhe foram feitas na Notícia, doze pediam informações específicas da Ilha e seu entorno.

Quanto ao problema da defesa da ilha, ele tinha uma opinião diversa da que foi implantada por José da Silva Paes dezoito anos depois. ${ }^{110}$ As expedições de Gonçalves de Aguiar e os relatórios que ele produziu faziam parte do movimento mais decisivo da Corte Portuguesa na consolidação dos seus domínios no extremo-Sul.

As visitas de correição do ouvidor-geral de São Paulo, Rafael Pires Pardinho, para definir os termos das vilas de São Francisco e de Laguna, no correr do ano de 1720, faziam parte do mesmo processo.

Até 1738, a Ilha de Santa Catarina vinha sendo comandada por um sargentomor, subordinado ao capitão-mor de Laguna e, ambos, ao governador da capitania de São Paulo. Tal estrutura hierárquica de poder, estabelecida dentro dos quadros do sistema político-jurídico português da Época Moderna, não impedia, contudo, que esses homens exercessem sua autoridade de maneira relativamente autônoma sobre a sociedade local. Na verdade, a capitania de São Paulo, como já mencionado, adquiriu, em decorrência de sua formação política, social e econômica peculiar, maior independência em relação ao poder central metropolitano. Problema esse que a Coroa

\footnotetext{
${ }^{109}$ Questiona-se, portanto, a interpretação feita por Marlon Salomon para quem as respostas dadas por Aguiar na Notícia, em 1721, tenham sido totalmente obscuras. Diz esse autor que, "Em primeiro lugar, Aguiar não foi além de Laguna em sua expedição, o que o impedia de observar e definir quais eram os pontos fundamentais destas costas, sem os quais ela não poderia ser sustentada; depois, não soube definir a diferença da importância entre o porto da Ilha de Santa Catarina e a enseada das Garoupas; finalmente, considerou que fortificar a Ilha de Santa Catarina seria um 'erro', pois sua enorme quantidade de praias permitia o desembarque de naus por todos os seus lados. (...) Desse modo pode-se depreender que as conclusões do sargento-mor Manoel Gonçalves de Aguiar sobre a inviabilidade da construção de fortificações na ilha legitimarão seu abandono no início do século XVIII, mesmo com a constituição deste novo interesse e preocupação pela defesa e conservação do território." Cf. "O exílio da desordem...", op. cit., pp. 86 e 87.

${ }^{110}$ Resposta de Manoel Gonçalves de Aguiar à $14^{\mathrm{a}}$ pergunta: "Ainda que se fizessem não só uma fortaleza, mas quatro, era impossível o impedir-se a entrada de navios, e defender aquele porto, ou fossem na terra firme, ou na Ilha, principalmente na barra do Norte, que é a melhor, e a mais segura; porque [onde] os Navios dão fundo no Ratones há de ter mais de uma légua de largo; e só na paragem onde chamam o estreito, ou na terra firme, ou na Ilha, é, que se poderá fazer uma boa fortaleza para defesa da Povoação; porque de qualquer das partes a descobre, por ser um tiro de mosquete seguro de pontaria de uma, e outra parte", in Afonso de E'Taunay. Relatos Sertanistas, op. cit., p. 218. [Grifo meu]
} 
Portuguesa levaria em conta no esforço de garantir sua soberania naquele território. A própria diligência de Gonçalves de Aguiar, que vinha por ordens do governador do Rio de Janeiro, já apontava nessa direção.

Possivelmente por isso, como conseqüência dessa pressão por um maior ordenamento político daquele espaço, devassas foram abertas contra as autoridades locais acusadas de praticarem contrabando em consórcio com os mercadores estrangeiros.

Em 16 de novembro de 1721, o governador da capitania de São Paulo, Rodrigo Cezar de Menezes, emitiu uma ordem ao capitão-mor de Laguna, Francisco de Brito Peixoto, para que prendesse um tal de Pedro Jordão, “da Nação Francesa”, que se achava naquela vila, e andava fazendo "negócio com os moradores, e Índios que habitam naquela costa", e tirasse ainda uma devassa para averiguar o envolvimento de autoridades locais no contrabando com os franceses. Dizia o governador que

Manoel Glz' Ribeiro, morador na Vila de Laguna, que serve de Juiz Ordinário da dita Vila, o qual esquecido da obrigação de Juiz, e de vassalo de S. Maj. tem trato, e correspondências com os Franceses, concorrendo com o dito Manoel Manso de Avellar, para que três naus Francesas que foram a Ilha de S. Catarina, fizessem nela uma feitoria em que levantaram casas e deixaram nela alguns Franceses, que depois vieram presos para a Vila da Laguna, e outro sim me constar que o ano passado de 1720, vindo de Maldonado uma nau de França de que era Capitão Monsieur Doloso [sic], aportando na Ilha de S. Catarina, fizeram os ditos Manoel Manso de Avellar, e Manoel Gonçalves Ribeiro uma escritura de contrato, com o dito Capitão em que ambos se assinaram para ir a nau de França carregar a costa da Mina de pretos, e lhes trazer, como também certas fazendas de França dando-lhas pelo que lá custassem, e lhe fazerem pago em courama, de que resultou ir a dita Nau a França e depois indo a costa de Mina roubou uma Sumaca nossa, que vinha carregada de pretos metendo homens que nela vinham do Porão com os quais chegou a Ilha de S. Catarina, e por não achar a courama junta, prendeu ao dito Manoel Manso de Avellar, tomando-lhe tudo o que lhe achou, vindo reconhecer a terra, tomando conhecimento da nossa costa, e das forças, e defesas, que tem aquelas povoações de que, se podem recear graves danos pelas consequiências que se seguem de que as nações estrangeiras, contratem nos portos desta Capitania (...). ${ }^{111}$

Não se pode, evidentemente, tomar essas acusações como verdadeiras. Havia muitas denúncias de negócios ilícitos praticados pelas autoridades, desvios dos quintos reais, até mesmo contra o governador Rodrigo Cezar de Menezes, mas os resultados das

\footnotetext{
${ }^{111}$ AESP, DI., vol 12, p. 17 e 18. "Regimento de uma ordem que se mandou ao Capitão-mor da Laguna Francisco de Brito Peixoto, para prender Pedro Jordão e tirar um sumário de testemunhas dos confidentes."
} 
devassas tiradas nesses casos eram demasiadamente parciais, ou porque as testemunhas arroladas no processo estavam de alguma forma vinculadas ao círculo de influência dos acusados e os absolviam, ou porque estavam fora dele e os condenavam. ${ }^{112}$ Além do mais, o delito do contrabando só ganha sentido com a institucionalização política e jurídica da sociedade, o que ainda era muito precário naquelas comunidades. Em outubro de 1722, o sargento-mor da Ilha Manoel Manso de Avellar advertia ao governador de São Paulo que

aquela vila da Laguna e ilha de Santa Catarina são somente duas meras povoações pobres e limitadas, e para melhor dizer são duas pescarias aonde não houve ainda justiça nem Regimento algum, e somente agora no ano de 1719 e 1720 [foi] a elas o doutor Raphael Pires Pardinho e então somente é que ficamos com alguma luz de justiça (...). ${ }^{113}$

Nas fronteiras do império, com frágeis - ou mesmo inexistentes - instituições civis, militares e eclesiásticas e em contato freqüente com estrangeiros, esses homenslimite $^{114}$ vão estabelecer suas próprias relações sociais e econômicas. George Shelvocke deixou a seguinte impressão sobre o caráter dos portugueses da Ilha de Santa Catarina em 1719:

São uma malta de bandidos, que aqui chegam como refugiados das outras colônias mais estritamente governadas do Brasil; Emanuel Mansa [sic. Manuel Manso], que era o assim chamado Capitão da Ilha, já era o chefe deles no tempo do Sr. Frézier. Porém, de minha parte, eu lhes devo fazer a justiça de dizer que sempre negociaram honestamente comigo e foram sempre muito educados para com todos nós (...). ${ }^{115}$

\footnotetext{
${ }^{112}$ Ver no AESP, DI, vol. 32, Anexo K "Correspondência do capitão-mor da Laguna Francisco de Brito Peixoto; Anexo M - "Cartas de Manoel Manso de Avelar preso em Santos e acusado de passar contrabando em Santa Catarina", em 10.08.1722; e Anexo O, p. 304 - "Algumas peças do processo movido contra Manoel Manso de Avelar...", em junho de 1722; Em carta ao governador de São Paulo, em 13 de dezembro de 1722, Francisco de Brito Peixoto disse "que esteve preso pelo mesmo Manoel Gonçalves Ribeiro", p. 280.

Sobre o envolvimento de Rodrigo Cesar de Menezes no desaparecimento de cunhos da Casa de Fundição e Moeda de Cuiabá ver Laura de Mello e Souza. O Sol e a Sombra: Política e administração na América Portuguesa do século XVIII. São Paulo: Cia. das Letras, 2006, p. 281.

113 AESP, DI, vol. 32, p. 302. Segundo Oswaldo R. Cabral, Manoel Manso de Avelar formou a primeira oligarquia de Santa Catarina, "tornando-se, enquanto viveu, o mais poderoso potentado, cuja vontade era lei e cujas arbitrariedades não conheceriam limites”. Nossa Senhora do Desterro. vol. 1 - Notícia. Florianópolis: Lunardelli, 1979, p. 24.

${ }^{114}$ Vera Ferlini. "São Paulo, de Fronteira a Território...”, op. cit., p. 19.

115 George Shelvocke. A Voyage round the world..., op. cit., p. 47. Acusado de pirataria e desvio de fundos da coroa, Shelvocke foi preso no seu retorno à Inglaterra.
} 
De fato, era prática comum dos governadores portugueses transferir os transgressores da ordem (desertores, criminosos, insubordinados, vadios e outros desclassificados) para as áreas periféricas do império, como já foi dito anteriormente. À medida que se começa dominar o espaço, a territorializar a fronteira, impõe-se ao mesmo tempo um domínio e ordenamento da população.

Afora esse problema político-institucional, a ordem do governador de São Paulo dá visibilidade ainda a aspectos relevantes da vida social e econômica na Ilha de Santa Catarina e seu continente. O intercâmbio que os visitantes estrangeiros (no caso, os franceses) estabeleciam com a comunidade local era muito mais complexo do que o simples abastecimento de provisões de viagem. Previa a instalação de feitorias na Ilha, o trato de couros e de escravos africanos.

Contavam os primeiros povoadores - e também a Coroa Portuguesa - com a possibilidade de se encontrar outras minas de metais preciosos em algum lugar desse sertão. Os oficiais da Câmara de Laguna informaram a Manuel Gonçalves de Aguiar que, distante poucas léguas do Rio Grande, havia "muitas minas de prata e ouro (...) as quais senhoriam os padres da Companhia Castelhanos, com os gentios das aldeias, que pela distância se verifica com toda a verdade estarem nas terras de Portugal". 116

Contudo, a conquista dos territórios não se pautava apenas pela busca dos metais preciosos. Em verdade, a Coroa Portuguesa atuou "para proteger a sociedade e a economia de Portugal dos resultados potencialmente desastrosos de uma corrida do ouro desenfreada". ${ }^{117}$ Temiam que a sedução pelas minas pudesse levar à migração em massa, ocasionando abandono da agricultura e desguarnecendo a marinha. No caso específico do Sul, a descoberta de minas em território litigioso poderia ainda atrapalhar os planos expansionistas portugueses e as negociações diplomáticas de limites. Não era outra a preocupação do governador do Rio de Janeiro ao afirmar:

Se o descobrimento que estes homens prometem na vizinhança das Missões, ou divisões pretendidas pelos Castelhanos, é conveniente ao serviço de S. Maj. se não continue este descoberto, pois o divulgar-se servirá de embaraço aos nossos interesses, sobre que se trabalha nas cortes de Paris, e Madrid, e servirá de grande obstáculo ver pretendermos terras já com os tesouros a vista. $^{118}$

\footnotetext{
${ }^{116}$ ABNRJ, vol. XXXIX, p. 408. "Informação do Juiz e oficiais da câmara da Povoação da Laguna de Santo Antonio... Laguna, 6 de janeiro de 1715."

${ }_{117}^{11}$ A J. R. Russell-Wood. O Brasil Colonial: O Ciclo do Ouro, c. 1690-1750, op. cit., p. 478.

${ }^{118}$ ANRJ, Códice 84, Correspondências dos governadores do Rio de Janeiro com diversas autoridades. Vol. 12, fl. 299v. De Gomes Freire de Andrade ao governador da Ilha de Santa Catarina Manoel Escudeiro Ferreira de Souza, em 02 de maio de 1749.
} 
Uma Consulta do Conselho Ultramarino sobre carta do governador da ilha de Santa Catarina, em 26 de outubro de 1750, até mesmo desencorajava a sua procura.

Que o não se acharem minas foi o acontecimento mais feliz que podia ter esta colônia, e se persuade que se deve ordenar que se não procurem porque bastaria o desejo de as buscar para se não poderem conter uns povos que não estão ainda bem seguros, e para se perder o trato e comércio dos gêneros do país, que é sempre o mais seguro, e estimável principalmente onde há tantos e que podem ser de tanta utilidade. ${ }^{119}$

Com efeito, a valorização daquele espaço se daria por outros motivos. O gado existente nos campos do sul - as vacarias do mar (nos campos da banda oriental do Uruguai e do Viamão) e as vacarias dos pinhais (campos de cima da serra: Vacaria, Lages e Curitiba) -, como já referido, tornou-se um grande atrativo para a dinamização da economia extrativa das Minas Gerais. Os primeiros caminhos ligando essas campanhas ao centro-oeste foram abertos no início do século XVIII, servindo a vila de Laguna de base para as primeiras incursões exploratórias: a "Frota" de João de Magalhães se internou no continente, em 1725, descendo até a barra do Rio Grande de São Pedro; e, em 1727, Francisco de Sousa Faria abriu o caminho dos Conventos, ligando Laguna aos campos de Lages. Antes, em 1703, Domingos da Filgueira escrevia o "Roteiro por onde se deve governar quem sair por terra da Colônia do Sacramento para o Rio de Janeiro ou Vila de Santos". ${ }^{20}$

Produto valioso no mercado europeu, os couros saiam pela Colônia de Sacramento, sobretudo após 1716, quando sua produção e comércio tiveram um êxito prodigioso. Segundo Jaime Cortesão, de 1726 até 1734 a exportação anual para o Rio de Janeiro variou entre 400 e 500 mil peças. ${ }^{121}$ E, conforme estudo de Jean François Labourdette, um terço das exportações portuguesas feitas para a França, em 1738, consistia em couros da "Nova Colônia". ${ }^{122}$

\footnotetext{
${ }^{119}$ BNRJ, DH, vol. XCIV, p. 158.

${ }^{120}$ Cf. Guilhermino Cesar. História do Rio Grande do Sul, op. cit., pp. 88 e ss.;

121 Jaime Cortesão. Alexandre de Gusmão..., Parte I, Tomo II, op. cit., p. 39. Ver também Jônathas da Costa Rego Monteiro. A Colônia do Sacramento, 1670-1777. Porto Alegre: Globo, 1937. [2 vols.] Segundo Virgílio Noya Pinto. O Ouro Brasileiro..., op. cit., pp. 152-159, a exportação anual de couros nesse período girava em torno de 80 mil unidades.

122 Jean François Labourdette. La Nation Française à Lisbonne de 1699 à 1790. Entre Colbertisme et Liberalisme. Paris: Fundação Calouste Kulbenkian, 1988, apud Joaquim Romero Magalhães. As Novas Fronteiras do Brasil. In: Francisco Bethencourt; Kirti Chaudhuri (Dir.) História da Expansão Portuguesa. Vol. 3. Lisboa: Temas e debates, 1998, p. 10.
} 
Sacramento tornou-se ainda grande produtora e exportadora de trigo, fato esse lembrado por D. Luís da Cunha em suas Instruções: “(...) mas quanto ao trigo, é constante que em grande abundância cresce no Rio de Janeiro e Colônia do Sacramento (...)". ${ }^{123}$ Entre 1726 e 1734 a produção média anual desse cereal foi superior a 10.000 alqueires. $^{124}$

O domínio do território e dos produtos nele existentes dependia também da relação amistosa com os grupos indígenas - nas campanhas do sul, principalmente com os charruas, guaranis e os minuanos. Em troca dos animais e couros que traziam, ou mesmo por permitirem o acesso àqueles campos, davam-lhes, fumo, artigos europeus e, sobretudo, aguardente.

A erva-mate, largamente utilizada pelos indígenas e incorporada pelos hispanoamericanos das Províncias do Paraguai e do Rio da Prata foi também, em função disso, disputada pelos luso-brasileiros. ${ }^{125}$ Ela servia como moeda de troca nas negociações com os nativos. O capitão-mor de Laguna, Francisco de Brito Peixoto, em carta ao governador Rodrigo Cezar de Menezes de 18 de janeiro de 1725, dizia:

tenho lotado a minha gente para os matos desta povoação a fazer cargas de uma erva que chamam congonha, do que são muito amigos e desejosos dela o gentio chamado minuano; assim mais mando fazer aguardente de cana para também remeter um par de barris para o dito gentio (...) para os obrigar a ter pazes com os portugueses, e defenderem as campanhas de S. Maj. (...) e juntamente encher de gados estas campanhas do Rio Grande para esta parte, que são as ditas campanhas muito grandes, não para conveniência minha que nunca a tive, e só me acompanha as conveniências da fazenda Real. ${ }^{126}$

O "Grande Sítio" imposto pelos espanhóis à Colônia do Sacramento (17351737), provocado a pretexto de um conflito diplomático ocorrido na embaixada portuguesa em Madri, levou a Coroa a tomar medidas mais incisivas na consolidação do domínio luso ao norte do Rio da Prata.

No período do conflito, armadas partiram de Lisboa para o estuário platino e muitos socorros militares foram remetidos de Pernambuco, Bahia, Rio de Janeiro,

\footnotetext{
${ }^{123}$ D. Luís da Cunha. Instruções Políticas, op. cit., p. 367.

${ }^{124}$ Fabrício Prado, Colônia do Sacramento...op. cit., p. 116.

${ }^{125}$ Segundo D. Luís da Cunha, "o comércio da erva, que toma o nome do dito rio Paraguai, não lhes vale pouco, porque tem notável saída para os reinos do Peru e Chile, etc, e não sei porque aqueles bons homens [os jesuítas], que de tudo se sabem aproveitar, não introduzem a dita erva, com a do chá, na Europa, pois me lembra, que tomando eu dela em Londres com o doutor Fernandes Mendes da Costa, me disse aquele grande médico que era uma bebida sem comparação muito mais salutar que a do chá e café (...)”. Instruções Políticas, op. cit., p. 370.

${ }^{126}$ AESP, DI, vol. 32, p. 284.
} 
Minas e São Paulo para defender a Colônia e aliviar seus moradores do apertado cerco que sofriam. ${ }^{127}$ Em 1736, uma expedição comandada pelo Brigadeiro José da Silva Paes e outra pelo Capitão-de-mar-e-guerra Luís de Abreu Prego, se uniram para romper com o bloqueio da Colônia, desalojar os espanhóis de Montevidéu e fundar uma fortaleza na barra sul do Rio Grande. Por terra, Cristóvão Pereira de Abreu, à frente de uma companhia de "aventureiros" paulistas, deveria introduzir cavalhadas pelas campanhas do Rio Grande para servirem às tropas de soldados portugueses. ${ }^{128}$

Aliviada a situação da Colônia e fracassada a missão a Montevidéu, coube a Silva Paes o comando da instalação, a partir de fevereiro de 1737 , do presídio ${ }^{129}$ Jesus- $^{-}$ Maria-José no Rio Grande e de outras guardas e fortins em seu entorno, no passo do Arroio Chuí, no Saco da Mangueira, no Taim e, mais ao sul, em território hoje do Uruguai, no Cerro de São Miguel.

A Ilha de Santa Catarina assumiu a partir daí importância fundamental no sistema de defesas no Sul. Esse era o parecer do Conde das Galveas, André de Melo e Castro.

\begin{abstract}
Como hoje essa Ilha nos é de tanta importância e sem ela não podemos manter coisa nenhuma do que temos no Rio da Prata e em especial no Rio Grande de São Pedro, porque o porto não é praticável no inverno e no verão são raras as vezes que se pode entrar sem dificuldade; todos os mantimentos e socorro que forem destinadas àquelas localidades necessitam fazer escala sempre no porto da mencionada Ilha, local onde devem ficar em depósito, até encontrar oportunidade para remetê-los por terra ao Rio Grande, na eventualidade de não ser possível o transporte por via marítima (...). ${ }^{130}$
\end{abstract}

Em 11 de agosto de 1738, D. João V expedia ordem a Gomes Freire de Andrade, governador do Rio de Janeiro, reordenando o controle político e militar de toda a costa litorânea entre essa capitania e o Rio da Prata.

(...) q. o Brigadeiro José da Silva Paes passe logo a Ilha de Santa Catarina, e faça nela uma fortificação qual ele entender ser capaz para a sua defesa procurando evitar nela tudo quanto lhe for possível a maior despesa; e atendendo a que desse porto do Rio de Janeiro devem sair todos aqueles

\footnotetext{
${ }^{127}$ Jaime Cortesão. Alexandre de Gusmão..., op. cit., pp. 65 e ss.

${ }^{128}$ Col. Doc., pp. 4-29. "Documentos sobre a Colônia do Sacramento e expedição que a foi socorrer em 1736 ".

${ }^{129}$ Segundo Guilhermino Cesar, História do Rio Grande do Sul, op. cit. p. 104, "Presídio, na linguagem da época, significa praça de guerra, ou a sua guarnição”.

${ }^{130}$ Carta de André de Melo de Castro a Antônio Guedes Pereira, em 23 de maio de 1738, in Paschoal Apóstolo Pítsica. A Capitania de Santa Catarina: alguns momentos. Florianópolis: Fundação Franklin Cascaes; Lunardelli; Fundação Catarinense de Cultura, 1993.
} 
socorros, e ordens que se fizerem precisas para defesa da Nova Colônia, e ajuda do novo estabelecimento do Rio Gr. de S. Pedro do Sul sendo conveniente q. fiquem todos os portos, e lugares da marinha debaixo de um só mando: Fui outro sim servido haver por bem separar desde logo do Gov. de S. Paulo e unir ao desse do Rio de Janr. ${ }^{\circ}$ a dita Ilha e o Rio de S. Pedro (...). ${ }^{131}$

De abril de 1739, quando de sua chegada, a agosto de 1743, não uma, mas quatro fortalezas haviam sido construídas na Ilha, sob o comando do engenheiro-militar Silva Paes, como ele próprio informou ao rei, em 20 de agosto de 1743.

Pela certidão que remeto do Comissário de mostras destes Presídios n. $^{\circ} 1$ verá V. Maj. o q. tem feito de despesa as quatro Fortalezas que se acham acabadas S. Cruz em Anhatomirim, S. José na ponta grossa, S. Antonio nos ratones e N. Sr. ${ }^{a}$ da Conceição na Barra do Sul com quartos, casa para comandante e oficiais, corpos de guarda em todas e calabouços, armazéns de Pólvora a prova, de mantimentos materiais e Telheiros, menos na da Conceição que ainda lhe faltam esta oficinas e em todas as plataformas de lajedo que deve vir de Portugal e aumentarem-se os parapeitos de formigão $(\ldots) .{ }^{132}$

Todo esse investimento, a fundação de praças e fortalezas ao longo da costa meridional e, posteriormente, as vultosas despesas com o povoamento de cerca de 6.000 casais açorianos e madeirenses foi pago com o ouro do Brasil. ${ }^{133}$

A Ilha de Santa Catarina e o Rio Grande de São Pedro formaram a partir desse momento as duas bases políticas e militares sobre as quais Portugal consolidou sua soberania no extremo-Sul. Embora, sob o aspecto econômico, a Ilha (incluída a sua jurisdição no continente) tivesse tido importância menor que o Continente de São Pedro no sistema colonial, ambos faziam parte de um mesmo arranjo, de um mesmo sistema político e econômico, não podendo, pois, ser compreendidos separadamente. Sem o controle da Ilha, possivelmente os portugueses não teriam reconquistado o Rio Grande, em 1776, como se verá mais adiante. E tal era sua importância nesse espaço que os espanhóis a tomaram no ano seguinte. A epígrafe com que se abriu este capítulo sintetiza essa intrínseca relação entre os dois: "O futuro viria provar que a Ilha tinha que

\footnotetext{
${ }^{131}$ Col. Doc. p. 132. Carta régia a Gomes Freire de Andrade de 11 de agosto de 1738.

${ }^{132}$ Id., p. 142. Para uma maior compreensão do sistema defensivo montado na ilha de Santa Catarina ver, entre outros, os trabalhos de: Sara Regina Silveira de Souza. As fortificações catarinenses: notas para uma revisão histórica. Florianópolis: EdUFSC, 1991; e de Oswaldo R. Cabral. As defesas da Ilha de Santa Catarina no Brasil Colonial. [s.1.] Conselho Federal de Cultura, 1972.

${ }^{133}$ Jaime Cortesão. Alexandre de Gusmão..., (Parte I - Tomo I), op. cit., p. 67.
} 
ser a escala protetora do continente; e que o inimigo, quando quisesse assenhorear-se do Rio Grande, era inevitavelmente forçado à conquista da Ilha". ${ }^{134}$

Mas, o plano de que toda essa costa ficasse "debaixo de um só mando", recolocado pelo Marquês do Lavradio, ao defender, em seu Relatório de Governo (1779), a criação de uma capitania única no Sul e, finalmente, pelo príncipe regente, em 1807, quando da criação da capitania geral do Rio Grande, que incluía sob sua jurisdição a Ilha de Santa Catarina, não impediu que nesta e naquela se constituíssem, no decorrer da segunda metade do século XVIII, duas unidades política, administrativa, e economicamente distintas e assimétricas.

Em 20 de dezembro de 1740, George Anson, comandante de uma esquadra inglesa composta de cinco navios de guerra, antes de fundear "em uma baía do Continente, larga e cômoda, que os franceses chamam de 'Bon-port'" pôde avistar as duas fortalezas, de São José na Ponta Grossa e de Santa Cruz em Anhatomirim, ainda em construção, mas já guardando, com as bandeiras de Portugal içadas, a baía norte da Ilha de Santa Catarina. ${ }^{135}$

A seguir, analisa-se a formação dessa organização política e administrativa que se instaurou na Ilha e que o Brigadeiro José da Silva Paes foi inaugurar.

\subsection{De Praça Militar a Capitania}

A carta régia de 11 de agosto de 1738 foi considerada por alguns historiadores como a certidão de nascimento da Capitania (da Ilha) de Santa Catarina. Dessa forma compreendeu Varnhagen: "Enquanto a colonização se estendia assim, a passos gigantescos para o Ocidente, não deixavam de seguir desenvolvendo-se e crescendo muito os estabelecimentos da parte meridional, cujos territórios, por uma provisão régia de 11 de Agosto de 1738, foram desmembrados da capitania de São Paulo e anexados ao governo do Rio de Janeiro (...). Por essa ocasião foi resolvido o ocupar-se militarmente a ilha de Santa Catarina, constituindo-se aí uma capitania subalterna

\footnotetext{
${ }^{134}$ Ibid., p. 305.

135 George Anson. A Voyage round the world In the Years MDCCXL, I, II, III, IV... in Martim Afonso Palma de Haro (org.), op. cit., p. 65. A baía denominada de "Bon-port", no continente, próximo à ponta norte da ilha, aparece na Carte particuliere de L'Isle de Ste. Catherine... (1716) de Amedée François Frézier (ver reprodução à p. 29) e também na Carte de L'Isle de Ste. Catherine... de Jacques Nicolas Bellin (1764). Os dois mapas podem ser visualizados no catálogo digital da Biblioteca Nacional de Lisboa, www.bn.pt.
} 
(...)". ${ }^{136}$ Walter Piazza, no mesmo sentido, escreveu que "Várias razões levaram, evidentemente, a Coroa Portuguesa a pensar na criação da Capitania da Ilha de Santa Catarina, concretizada na Provisão Régia de 11 de agosto de $1738 " .{ }^{137}$ Em livro recente, Carlos Humberto Correa reforça esse fato: "A capitania da Ilha de Santa Catarina havia sido criada pelo Aviso Régio de 11 de agosto de ano anterior [1738], quando também a desmembrou da capitania de São Paulo e subordinou-a diretamente ao governo do Rio de Janeiro. É necessário deixar claro que a capitania criada era denominada 'da Ilha de Santa Catarina', e não 'de Santa Catarina', deixando bem definida a característica de insularidade da nova administração". ${ }^{138}$

Outros classificaram aquele ato régio como dando origem a um "governo separado"139 ou, subgovernadoria ${ }^{140}$.

A divisão entre capitanias gerais e subalternas tornou-se a classificação mais usual entre historiadores brasileiros e brasilianistas, no século XX. No final do Setecentos, tínhamos entre as primeiras: Grão-Pará, Maranhão, Pernambuco, Bahia de Todos os Santos, Minas Gerais, Goiás, Mato Grosso, Rio de Janeiro e São Paulo; entre as segundas: São José do Rio Negro, subalterna à Grão Pará; Piauí, subalterna ao Maranhão; Ceará ${ }^{141}$, Rio Grande do Norte e Paraíba, subordinadas à Pernambuco; Sergipe e Espírito Santo, subordinadas à Bahia; e Santa Catarina e Rio Grande de São Pedro, subordinadas ao Rio de Janeiro. ${ }^{142}$

Se, por um lado, essa classificação nos ajuda a compreender e exprime de fato um aspecto da estrutura hierárquica da administração colonial portuguesa na América, por outro, pouco esclarece sobre a distinção entre uma e outra, o nível dessa vinculação

\footnotetext{
${ }^{136}$ Francisco Adolfo de Varnhagen. História Geral do Brasil. 5a ed. São Paulo: Melhoramentos, 1956, (Tomo IV), p. 80.

${ }^{137}$ Walter Piazza. Santa Catarina, op. cit., p. 123.

${ }^{138}$ Carlos Humberto Correa. História de Florianópolis - ilustrada. Florianópolis: Insular, 2004, p. 52 e 53.

${ }^{139}$ São eles: Joaquim Gomes de Oliveira e Paiva (Arcipreste). "Notícia geral da Província de Santa Catarina" in Dicionário Topográfico, Histórico e Estatístico da Província de Santa Catarina. Florianópolis: Instituto Histórico e Geográfico de Santa Catarina, 2003 (Col. Catariniana, 5), p. 33. [1 $1^{\mathrm{a}}$ ed. 1868]; Manoel Joaquim d'Almeida Coelho (Major). Memória Histórica da Província de Santa Catarina. $2^{\mathrm{a}}$ ed. Desterro: Typ. J. J. Lopes, 1877, p. 25. [1 ${ }^{\mathrm{a}}$ ed. 1853]. José Feliciano Fernandes Pinheiro (Visconde de São Leopoldo). "Resumo Histórico da Província de Santa Catarina", in Anais da Província de São Pedro. Porto Alegre: Mercado Aberto, 1982 (Série Documenta, 11), p. 223. [1 ${ }^{\text {a }}$ ed. c. 1832]. Segundo este autor, em 1738, formou-se na "ilha e terra adjacente, com os mesmos limites, que ainda hoje conserva, governo separado, despachando para seu primeiro Governador o brigadeiro José da Silva Paes". ${ }^{140}$ Heirich Handelmann. História do Brasil. $4^{\mathrm{a}}$ ed. São Paulo: Itatiaia, 1982, p. 36. [1ª ed. alemã: 1860]

${ }^{141}$ Esta capitania tornou-se autônoma em 1799.

${ }^{142}$ Cf. Helio Vianna. História do Brasil Colonial. São Paulo, 1945, p. 69; Dauril Alden. Royal Government.... op. cit., p. 40; Caio Prado Jr. Formação do Brasil... op. cit., p. 305; Paulo Pedro Perides. A organização político-administrativa e o processo de regionalização do território brasileiro. In: Revista do Departamento de Geografia. São Paulo: USP-FFLCH, n. 9, pp. 77-91, 1995.
} 
e, menos ainda, a natureza e funcionamento administrativo desses estabelecimentos coloniais.

Tais questões inserem-se em discussões historiográficas mais amplas sobre a importância da administração e dos seus agentes na colonização do Brasil.

Caio Prado Jr. entendia "que a administração portuguesa estendeu ao Brasil sua organização e seu sistema, e não criou nada de original para a colônia”. Segundo ele, “O Brasil não constitui para os efeitos da administração metropolitana, uma unidade. O que havia nesta banda do oceano, aos olhos dela, eram várias colônias ou províncias, até mesmo 'países', se dizia às vezes, que, sob o nome oficial de capitanias, se integravam no conjunto da monarquia portuguesa". No que diz respeito à distinção entre "capitanias principais" e "subalternas" escreveu apenas que estas estavam mais ou menos sujeitas àquelas; "muito, como as do Rio Grande do Sul e Santa Catarina ao Rio de Janeiro, ou a do Rio Negro ao Pará; pouco, como a do Ceará e outras subalternas de Pernambuco. Mas em conjunto e de uma forma geral, os poderes dos governos" eram "os mesmos em ambas as categorias provinciais". 143

Contudo, ao verificar que havia uma distância, ou até mesmo contradição, entre aquilo que constava nos textos legais e o que efetivamente se praticava, acabou por valorizar assim, não só a existência de uma formação histórica específica, como também a necessidade de se buscar outras fontes para a compreensão da vida administrativa da colônia. $^{144}$

Como se mostrará no decorrer deste trabalho, comprova-se essa maior sujeição de Santa Catarina e do Rio Grande de São Pedro ao Rio de Janeiro, principalmente a partir de 1763, com a transferência do vice-reinado para essa cidade e da atuação da Junta da Real Fazenda criada em 1761. Tal fato, entretanto, reduzia o poder desses governadores subalternos.

O "caos imenso de leis", a "monstruosa, emperrada e ineficiente máquina burocrática", marcada pela "complexidade dos órgãos, a confusão de funções e competência”, identificada por Prado Jr. na administração colonial ${ }^{145}$, era, na verdade, uma forma de flexibilização da estrutura política e jurídica portuguesa do Antigo Regime para atender os objetivos da colonização. A complexidade, esse "caos" e

\footnotetext{
${ }^{143}$ Caio Prado Jr. Formação do Brasil..., op. cit., pp. 303 e ss.

${ }^{144}$ Caio Prado Jr. Formação do Brasil..., op. cit., p. 301. Um excelente balanço dessas discussões encontra-se em Laura de Mello e Souza. O Sol e a Sombra: política e administração na América Portuguesa do Século XVIII. São Paulo: Companhia das Letras, 2006, especialmente, o capítulo 1. "Política e administração colonial: problemas e perspectivas".

${ }^{145}$ Caio Prado Jr. Formação do Brasil..., op. cit., pp. 300 e 333.
} 
"irracionalidade" com que se nos apresenta aquela estrutura política e administrativa, vem justamente da nossa incompreensão de seu funcionamento mais completo.

Raymundo Faoro acentuou o papel centralizador do Estado português na formação do Brasil colonial. Entendia ele que "Sobre a colônia descem as sufocadoras garras da administração colonial, cortadas nos conselhos do reino, sem respeito pelas peculiaridades do trópico. A ordem pública portuguesa, imobilizada nos alvarás, regimentos e ordenações, prestigiada pelos batalhões, atravessa o oceano, incorrupta, carapaça imposta ao corpo sem que as medidas deste a reclamem. O Estado sobrepôsse, estranho, alheio, distante à sociedade, amputando todos os membros que resistissem ao domínio. [...] Ao sul e ao norte, os centros de autoridade são sucursais obedientes de Lisboa: o Estado, imposto à colônia antes que ela tivesse povo, permanece íntegro, reforçado pela espada ultramarina, quando a sociedade americana ousa romper a casca do ovo que a aprisiona". ${ }^{146}$

Não se pode negar que a participação do Estado português, através da pletora de leis, decretos, alvarás, regimentos, e da atuação das instituições e de seus agentes, foi efetiva em todos os níveis da sociedade colonial, até mesmo em questões tidas hoje como menores da vida cotidiana. Todavia, Faoro reduz excessivamente o papel das forças e conjunturas locais na formação da administração colonial. O Estado só conseguiu se impor em todos os recantos do império porque soube flexibilizar as estruturas tradicionais da administração face às demandas e pressões regionais.

António Manuel Hespanha ressaltou a necessidade de problematizarmos a historiografia que, desde o século XIX até meados do século $\mathrm{XX}$, procurou ver, na Idade Moderna, a constituição do Estado, com as características de racionalidade e de centralização do poder, próprios do nosso tempo. Segundo ele, aqueles historiadores estavam demasiadamente próximos “do advento da forma política 'Estado' para poder escapar à tentação de a aplicar à descrição e avaliação da evolução histórica das formas políticas". ${ }^{147}$ Ao considerarem cada elemento do Antigo Regime isoladamente como parte formadora do Estado contemporâneo, tal perspectiva historiográfica impediu, de acordo com esse autor, que se compreendesse "a lógica interna dos sistemas políticos passados". Tal constatação "fez surgir a consciência de que o Antigo Regime tinha de

\footnotetext{
${ }^{146}$ Raymundo Faoro. Os Donos do Poder: formação do patronato político brasileiro. Vol. 1.11 ed. Porto Alegre: Globo, 1997, p. 164 e 165. [1 ed. 1958]

${ }_{147}$ António M. Hespanha. As vésperas do Leviathan. Instituições e poder político: Portugal - séc. XVII. Coimbra: Almedina, 1994, p. 22.
} 
ser estudado com recurso a conceitos próprios, decalcados numa percepção e sensibilidade (incluindo a afetividade) diferente das relações sociais e políticas". ${ }^{148}$

De fato, Hespanha nos dá algumas chaves para a compreensão das lógicas internas da administração portuguesa moderna. A organização política do espaço, que atualmente obedece às características de unidade, monopolização e contigüidade territorial polarizados em torno de um centro único, não podem ser transpostas para a estrutura de organização dos poderes de tipo tradicional, onde ainda não existia um território unificado e os poderes jurisdicionais não eram concêntricos. ${ }^{149}$

Hespanha oferece ainda outros modelos explicativos para a compreensão da organização político-administrativa: o "paradigma jurisdicionalista", onde a função do rei era, no essencial, "a de manter as jurisdições dos restantes corpos políticos no equilíbrio estabelecido pela constituição (natural) da sociedade" e que, "aquilo que hoje designaríamos por "administração ativa" quase se limitava, à punição penal, ou à atividade de defesa da paz e aos atos de autoridade exigidos pela salvaguarda dos direitos dos particulares; e "governo poli-sinodal", que se realiza "por meio de conselhos, tribunais ou juntas". Tanto o "paradigma jurisdicionalista" quanto a "estrutura poli-sinodal" acabavam limitando "fortemente a capacidade de ação da coroa" e gerando uma "burocracia descerebrada". 150

Entretanto, há que se considerar que as análises de Hespanha concentram-se, espacialmente, no Portugal continental, no "Reino", excluindo assim da análise as dependências ultramarinas e, temporalmente, aos séculos XVI e XVII. ${ }^{151}$ Além disso, outros estudos vêm relativizar essa idéia de que a administração central no Antigo Regime encontrava-se limitada a esferas bem restritas. No reinado de D. Pedro II (1668-

\footnotetext{
${ }^{148}$ António M. Hespanha. As estruturas políticas em Portugal na Época Moderna. In: José Tengarrinha. (org.) História de Portugal. São Paulo: Edusc; Unesp; Portugal: Instituto Camões, 2001, p. 122. Ver também na mesma linha, mas respeitadas as perspectivas particulares de cada um, Ângela Barreto Xavier e António Manuel Hespanha. "A Representação da Sociedade e do Poder", in António M. Hespanha (Coord.) História de Portugal - vol. 4 - O Antigo Regime. Lisboa: Ed. Estampa, 1997; José Subtil. "Os Poderes do Centro", in idem; entre outros.

${ }^{149}$ António M. Hespanha. As vésperas..., op. cit., p. 88 e 89.

${ }^{150}$ António M. Hespanha. As vésperas..., op. cit., pp. 278, 279, 286, 287 e 288.

${ }^{151}$ Ver a esse respeito as críticas de Laura de Mello e Souza em seu livro $O$ Sol e a Sombra..., op. cit., pp. e a réplica de António Manuel Hespanha no artigo "Depois do Leviathan", in almanack braziliense, n. 02, USP, maio de 2007. Para ele, "se o policentrismo, o pluralismo jurídico-político, a confusão jurisdicional, a raquítica extensão do domínio periférico da coroa, se verificavam no Reino, um pedacinho territorial de $89.000 \mathrm{Km}^{2}$, territorial e linguisticamente integrado desde o séc. XIII, como é que isto podia deixar de acontecer num imenso território, cujas costas estavam separadas da metrópole por mais de um mês de Oceano a atravessar, cujos interiores eram, para além disso, muito pouco acessíveis a partir da costa, um território enorme, dividido por sertões, por rios, por florestas, por nativos pouco dômitos, por colonos ainda mais indômitos e senhores de si, habituados à vida política de um 'território de fronteira'?", pp. 60 e 61.
} 
1706), Nuno Monteiro pôde "identificar com clareza a existência de uma esfera bem definida de política, da disputa política e da decisão política. De forma abreviada, essa esfera pode resumir-se aos seguintes tópicos: nomeação de pessoas para os cargos e ofícios superiores, remuneração de serviços (mercês), decisão final sobre contendas judiciais especialmente relevantes, política tributária e alinhamentos políticos externos (incluindo a guerra), para além, na conjuntura estudada, do problema específico dos cristãos-novos. A todas essas dimensões dever-se-ia acrescentar mais uma: a forma e o quadro institucional onde tinham lugar os despachos régios". No reinado de D. João V (1706-1750), o alcance da administração central se ampliou mais ainda ou, como escreveu o autor, "representou uma grande mutação silenciosa". ${ }^{152}$

Criada e dirigida com a função de assegurar os domínios ultramarinos e de promover o desenvolvimento econômico dos estabelecimentos coloniais em favor da metrópole, a estrutura política e administrativa assumiu, no decurso de três séculos de colonização, sentido e caráter peculiar.

O "sentido da colonização" - explorar os recursos naturais dos territórios conquistados em proveito do comércio europeu ${ }^{153}$ - não impediu obviamente o desenvolvimento de uma economia de abastecimento interno e de subsistência nem também a acumulação endógena de capital, ainda que em um nível baixo. ${ }^{154}$ Até porque, como disse judiciosamente Fernando Novais, ao apontar as contradições desse sistema: "Não é possível explorar a colônia sem desenvolvê-la; isto significa ampliar a área ocupada, aumentar o povoamento, fazer crescer a produção. É certo que a produção se organiza de forma específica, dando lugar a uma economia tipicamente dependente, o que repercute também na formação social da colônia. Mas, de qualquer modo, o simples crescimento extensivo já complica o esquema; a ampliação das tarefas administrativas vai promovendo o aparecimento de novas camadas sociais, dando lugar aos núcleos

\footnotetext{
${ }^{152}$ Nuno Gonçalo Freitas Monteiro. "A Consolidação da Dinastia de Bragança e o Apogeu do Portugal Barroco: centros de poder e trajetórias sociais (1668-1750)" in José Tengarrinha (org.). História de Portugal, op. cit., pp. 207 e 214. Ver também do mesmo autor: "Trajetórias sociais e governo das conquistas: Notas preliminares sobre os vice-reis e governadores-gerais do Brasil e da Índia nos séculos XVII e XVIII" in João Fragoso, Maria Fernanda Bicalho e Maria de Fátima Gouvêa (Orgs.) O Antigo Regime nos Trópicos: A dinâmica imperial portuguesa (séculos XVI-XVIII). Rio de Janeiro: Civilização Brasileira, 2001; e, em parceria com Mafalda Soares da Cunha, "Governadores e capitães-mores do império atlântico português nos séculos XVII e XVIII" in Nuno Gonçalo F. Monteiro, Pedro Cardim e Mafalda Soares da Cunha (Orgs.) Optima Pars: Elites Ibero-Americanas do Antigo Regime. Lisboa: Imprensa de Ciências Sociais, 2005.

${ }^{153}$ Caio Prado Jr. Formação do Brasil..., op. cit., p. 31.

${ }^{154}$ Sobre essa questão, ver o importante artigo de José Jobson de Andrade Arruda. O Sentido da Colônia. Revisitando a Crise do Antigo Sistema Colonial no Brasil (1780-1830). In: José Tengarrinha (org.) História de Portugal. 2 ed. rev. e ampl. Bauru, SP: EDUSC; São Paulo: UNESP; Portugal: Instituto Camões, 2001, p. 245-263.
} 
urbanos etc". ${ }^{155}$ Da mesma forma, não se pode supor que todas as instituições e autoridades coloniais corresponderam plenamente aos objetivos e anseios para as quais foram criadas pela metrópole portuguesa.

Admitir esse desenvolvimento interno da colônia em todos os níveis político, econômico, social e cultural que crescia à medida que se ampliava a crise do Antigo Regime, não significa dizer que a colônia possuía autonomia suficiente para determinar os rumos da administração. Havia, por certo, um descompasso cada vez mais evidente entre as diretrizes traçadas pela Coroa e o desenvolvimento histórico efetivo nas colônias.

Deve-se, pois, evitando as interpretações extremas que viram a onipresença do Estado, ou então sua quase ausência, na formação da sociedade colonial portuguesa na América, buscar as aproximações do que foi o sistema político particular que se formou na colônia a partir, por exemplo, do que Stuart Schwartz chamou de "abrasileiramento da burocracia". Segundo ele, "o governo e a sociedade no Brasil colonial estruturaramse a partir de dois sistemas interligados de organização. Em um nível havia a administração controlada e dirigida pela metrópole, caracterizada por normas burocráticas e relações impessoais, que amarrava os indivíduos e os grupos às instituições políticas do governo formal. Paralelamente, existia uma teia de relações interpessoais primárias baseadas em interesse, parentesco ou objetivos comuns que, embora não menos formal, não contava com o reconhecimento oficial". ${ }^{156}$

Dito isso, precisa-se agora esclarecer então o que foi essa "Capitania Subalterna de Santa Catarina".

Em primeiro lugar, a delimitação espacial desse topônimo. Santa Catarina significava, no momento da criação do governo, em 1738, tão somente a ilha. ${ }^{157}$ Apenas no correr da segunda metade do século XVIII, em decorrência da ampliação dos limites jurisdicionais desse governo - e somente nesse âmbito -, é que a designação começou a significar, além da Ilha, parte do continente. Mas, como veremos adiante, esse percurso

\footnotetext{
${ }^{155}$ Fernando A. Novais. As Dimensões da Independência. In: Carlos Guilherme Mota. 1822 - Dimensões. São Paulo: Perspectiva, 1972, p. 23.

${ }^{156}$ Stuart B. Schwartz. Burocracia e Sociedade no Brasil Colonial. A Suprema Corte da Bahia e seus Juízes: 1609-1751. São Paulo: Perspectiva, 1979, pp. xi e 251.

${ }^{157}$ Há dúvidas quanto à origem da denominação de "Santa Catarina" para a ilha: ou seria uma homenagem a Santa Catarina de Alexandria, virgem e mártir festejada pela Igreja Católica, a 25 de novembro, ou, então, lembraria a figura de Catarina Medrano, esposa do navegante Sebastião Caboto, a quem alguns atribuem o batismo da ilha, mas que, ao publicar os mapas de sua viagem, em 1544, chamou-a de "porto dos Patos". O nome de Santa Catarina para a ilha e baía que a envolve aparece pela primeira vez no mapa mundi de Diego Ribeiro (c. 1529). Cf. Walter F. Piazza. Santa Catarina: sua história, op. cit., p. 85.
} 
não foi realizado de maneira unívoca. A compreensão que as autoridades metropolitanas tinham acerca da dimensão desse governo não era a mesma dos governadores que passavam a administrá-la.

A percepção dos indivíduos, que viviam sob a jurisdição daquele governo (Ilha e continente), de pertencerem a uma unidade denominada Santa Catarina e a construção de uma identidade comum que os definissem como catarinenses foram processos ulteriores. Sem aprofundar muito essas questões - que na verdade seriam importantes para uma compreensão mais abrangente do tema, mas que ultrapassam os limites desta pesquisa, por causa sobretudo do universo distinto de fontes que envolveriam -, pode-se dizer, no entanto, que o peso das identidades microrregionais das vilas (São Francisco, Laguna e Desterro) se sobrepôs à noção de conjunto ao qual pertenciam. Uma característica que, em princípio, não é muito diferente do que ocorreu nas outras capitanias - a estrutura "ganglionar" de colonização -, mas que, em Santa Catarina, adquiriu forma mais acentuada, pois, enquanto as vilas do Rio de Janeiro, de São Paulo e mesmo do Rio Grande de São Pedro serviram de centro político-administrativo e de base sobre a qual se difundiu a colonização, com a fundação de outros povoados e vilas, a Ilha de Santa Catarina não desempenhou essa função. Os povoados de Laguna e São Francisco eram mais antigos e, pelo menos até 1739, não dependiam nem econômica, nem politicamente da Ilha. A incorporação da vila de Lages, em 1820, que até então estava sob a jurisdição de São Paulo ${ }^{158}$, acrescentaria mais uma peça no mosaico de pequenas unidades distintas e separadas que formavam a capitania de Santa Catarina.

Seguindo uma classificação de Antonio Carlos Robert Moraes, toda a construção de território associa e hierarquiza três dimensões: militar, jurídica e ideológica. Em alguns casos, pode ocorrer de haver uma identidade fortemente marcada que se transforma no meio jurídico e consegue se afirmar, em algum momento, diplomática ou militarmente; em outros, a conquista do espaço se impõe por um aparato militar e uma legislação forte, com a criação da identidade a posteriori, a partir do território. ${ }^{159}$ Este parece ter sido o caso de Santa Catarina, não obstante a formação militar e jurídica ser posterior à instalação dos três primeiros povoados.

\footnotetext{
${ }^{158}$ Lages foi fundada por Antonio Correia Pinto por ordem do governador da capitania de São Paulo, Morgado de Mateus, em 1770, "para fazer testa as Missões Castelhanas, e fortificar o Rio das Pelotas, por ser o Passo mais defensível daquele Sertão". Cf. Manoel da Silva Mafra. Exposição Histórico-Jurídica. Florianópolis: IOESC, 2002, p. 141. (Ed. Fac-similar de 1899)

${ }^{159}$ Palestra proferida na FFLCH/USP, em 08 de maio de 2006.
} 
Seja como for, nesse processo estavam colocadas as idéias de domínio, de identidade, de soberania, de jurisdição e de Estado territorial. As capitanias constituíram uma dessas unidades estatais na história da conquista portuguesa no ultramar. Contudo, a noção que se tem da transformação das capitanias em províncias e destas nos estados - continuidade que em certo sentido de fato existiu -, não deve encobrir as rupturas e diferenças entre uma formação e outra.

A divisão administrativa proposta por Caio Prado Jr. pode ser válida para as capitanias gerais, mas não para as subalternas. Segundo ele, "A capitania forma pois a maior unidade administrativa da colônia. Divide-se seu território em comarcas, sempre em pequeno número. A comarca compõe-se de termos, com sede nas vilas ou cidades respectivas. Os termos, por sua vez dividem-se em freguesias, circunscrição eclesiástica que forma a paróquia, sede de uma igreja paroquial, e que servia também para a administração civil. Finalmente as freguesias ainda se dividem em bairros, circunscrição mais imprecisa, e cujo principal papel aparece na organização das ordenanças (...)". 160

Os limites de jurisdição da ouvidoria criada na Ilha não só não se enquadravam nos limites da capitania como lhes eram superiores. Além do mais, a própria noção de capitania, para esse caso, não tinha o mesmo significado para os agentes coloniais.

O termo capitania não teve o mesmo conceito nos diferentes espaços do império português e nem nos diferentes tempos decorridos entre os séculos XV e XVIII.

Instituição originária ainda no período medieval, elas difundiram-se no processo de expansão portuguesa, nos séculos XV e XVI, podendo ser tanto donatarias - sistema implantado nas ilhas de Açores, Madeira, Cabo Verde, São Tomé, no Brasil e em Angola, de caráter hereditário -, como governadorias - mais comuns nas praças, fortalezas e feitorias estabelecidas nas costas da África e do Oriente, de feição militar e amovível. ${ }^{161}$ Neste caso, as capitanias podiam estar vinculadas ao espaço de tempo que durava o comando do capitão-mor; uma divisão administrativa das fronteiras marítimas, águas territoriais, fluviais, lacustres, das ilhas e terras de além-mar que ficavam sob o comando do chamado capitão do porto. ${ }^{162}$

Segundo Diogo de Vasconcellos, o termo Capitão foi traduzido do latim Capitanus, e derivado de caput, que se empregava genericamente para designar a

\footnotetext{
${ }^{160}$ Caio Prado Jr. Formação..., op. cit., p. 306.

${ }^{161}$ Verbete "capitania" in Enciclopédia Luso-Brasileira de Cultura. Lisboa: Verbo, s/d.

${ }^{162}$ Verbete "capitania" in Grande Enciclopédia Portuguesa e Brasileira. Lisboa; Rio de Janeiro: Editorial Enciclopédia, s/d.
} 
cabeça principal de um corpo coletivo em qualquer diligência ou serviço; e, só mais tarde, para evitar ambigüidades, passou a significar apenas uma terminação militar. ${ }^{163}$ Para o Pe. Raphael Bluteau, em 1712, toma-se esta palavra "Capitam”

em diferentes sentidos. Algumas vezes significa o que manda um exército inteiro, ou uma armada grande, como Capitão General. Outras vezes significa o que manda um corpo mais pequeno, como capitão-mor. ${ }^{164}$

Assim, por extensão, chamava-se a principal nau de uma esquadra, "a que manda às outras", de "nau capitânia".

Sobre as capitanias hereditárias do Brasil diz Bluteau que

vem a ser o mesmo, que Província. São estas Capitanias quatorze. Compreende em particular cada uma delas até cinqüenta léguas de costa, \& quanto se quer alargar ao sertão. Na sua História da Guerra Brasílica, pag. 23, diz Francisco de Brito Freire, El-Rei Dom Manoel, por estar muito empenhado no Oriente, atendeu pouco ao Brasil, \& assim pela menos estimação, que se fez dele, o repartiram inconsideradamente a diversas pessoas, chamando, às terras Capitanias, \& aos Donatarios Capitães; aos quais concederão de juro, \& herdade demasiado domínio no poder, \& excessiva largueza do distrito (...) Como cada Capitania destas é uma espécie de Governo, poderás chamar-lhe Prefeitura. ${ }^{165}$

Refletindo sobre essas capitanias e, sobretudo as do Brasil, António Vasconcelos de Saldanha coloca que independentemente das vicissitudes da sua existência e das dos seus donatários, elas devem ser consideradas como sendo complexos não exclusivamente jurídico-institucionais, mas também como fenômenos sociais, políticos e econômicos inerentes à evolução da sociedade portuguesa. ${ }^{166}$ No caso dessas capitanias, "os monarcas doadores, reservando para si um domínio eminente, transferem para o Donatário um domínio útil, preenchido por direitos relativos a uma bem determinada área territorial do reino, englobada na genérica categoria dos bens da Coroa". ${ }^{167}$ Tais doações, afirma Saldanha, não se faziam por mera liberalidade do rei,

\footnotetext{
${ }^{163}$ Diogo de Vasconcellos. "Linhas Gerais da Administração Colonial. Como se exercia. O Vice-Rei, os Capitães-Generais, os Governadores, os Capitães-Mores de Capitanias e os Capitães-Mores de Ilhas e cidades", in RIHGB - Tomo especial, parte III, 1916, p. 281-298.Cf. também verbete "capitán" do Dicionário de La Lengua Española. Real Academia Espanhola. 21ª ed. Madri: Espasa, 1992.

${ }^{164}$ Raphael Bluteau. Vocabularário Portuguez e Latino... Coimbra, 1712, Vol. II. 165 Ibid.

166 António Vasconcelos de Saldanha. As capitanias do Brasil: Antecedentes, desenvolvimento e extinção de um fenómeno atlântico. Lisboa: CNCDP, 2001, p. 18.

${ }^{167}$ Id. Ibid., p. 45.
} 
mas para atingir alguns fins como, as necessidades de povoamento e colonização. Assim entendia o Procurador da Coroa, Tomé Pinheiro da Veiga, no início do século XVII:

o fim principal a que são destinadas [as capitanias] é a povoação da costa e terra firme delas com obrigação de levarem cada ano certos casais e moradores que as povoem e cultivem, e para isso se lhes concedem as terras com direitos e rendas e amplíssima jurisdição... ${ }^{168}$

Indissociável dessa finalidade de promover a povoação e a cultura estava presente a necessária evangelização das terras pagãs: "exaltação da nossa Santa Fé e proveito dos meus reinos e senhorios e dos naturais deles...” recomendava D. João III, no Regimento passado ao governador-geral Tomé de Souza, em 1548. ${ }^{169}$ Mas havia ainda uma outra causa motivadora nas doações. Os reis tinham não só o direito, mas o dever de distribuir mercês, premiando ou galardoando os vassalos e fiéis merecedores. Prerrogativa esta que se entrelaçava "sabiamente com os intentos expansionistas e colonizadores". 170

Os donatários, cavalheiros pertencentes à mais alta nobreza, recebiam amplos poderes de jurisdição fiscais, administrativas e militares. Embora a forma da capitania hereditária fosse extraída da experiência medieval portuguesa, foi adaptada, nos séculos XV, XVI e XVII, às novas necessidades da expansão colonial. Como afirmam Stuart Schwartz e James Lockhart, ainda que, "em certos aspectos, a capitania fosse uma forma arcaica que parecia ir na direção contrária à centralização real, essas concessões não eram 'feudais' nem na lei nem na prática. Eram dadas como recompensa por serviços prestados e não dependiam das costumeiras obrigações feudais dos vassalos para com os suseranos. Além disso, seu objetivo era o desenvolvimento econômico". ${ }^{171}$

Várias foram as tentativas dos portugueses em colonizar as terras ao sul de São Vicente pelo sistema de capitanias hereditárias. A primeira delas aparece na doação feita a Pero Lopes de Souza, em 1534: no quinhão de "quarenta léguas de terra começarão de doze léguas ao sul da ilha de Cananéia, e acabarão na terra de Santa

\footnotetext{
168 Apud António Vasconcelos de Saldanha. Op. cit., p. 96.

${ }^{169}$ Regimento de Tomé de Sousa in Marcos Carneiro de Mendonça. Raízes da Formação Administrativa do Brasil. Rio de Janeiro: IHGB; Conselho Federal de Cultura, 1972, vol. I, p. 31.

${ }^{170}$ António de Vasconcelos de Saldanha. Op. cit., p. 100.

${ }^{171}$ Stuart Schwartz e James Lockhart. A América Latina na época colonial. Rio de Janeiro: Civilização Brasileira, 2002, p. 222.
} 
Anna, que está em altura de vinte e oito graus e um terço" ${ }^{\text {172 }}$. Problemas como o processo sucessório - falta de herdeiros legítimos e diversa interpretação dos limites dessa donataria e da de São Vicente, doada ao irmão de Pero Lopes, Martim Afonso de Sousa, levaram, no final do século XVII, ao chamado pleito Vimieiro-Monsanto. O resultado dessa contenda veio com a carta-régia de 11 de janeiro de 1692, que confirmava a doação da Capitania de Santo Amaro e Terras de Sant'Ana a D. Luis Alvares de Tayde Castro Noronha e Souza, $7^{\circ}$ Conde de Monsanto e $2^{\circ}$ Marquês de Cascais. ${ }^{173}$

Vale lembrar também das petições que, em meados do século XVII, fez Salvador de Sá para receber por mercê uma capitania com centro na Ilha de Santa Catarina; da doação dessa donataria concedida a Agostinho Barbalho de Bezerra, em 1663; das 75 léguas de terras ao norte do rio da Prata que o Visconde de Asseca e João Correia de Sá, neto e filho, respectivamente, de Salvador de Sá, receberam em $1676^{174}$; e finalmente, da petição de Sebastião da Veiga Cabral, que pedia por mercê o "senhorio e propriedade" daquela Ilha, em 1717, "deserta e inabitada, na forma que se tem praticado com as pessoas que fazem e levantam à sua custa alguma vila". ${ }^{175}$

$\mathrm{Na}$ maioria dos casos, essas iniciativas não passaram das petições ou das cartas de doação, sem qualquer resultado mais concreto de colonização. Contudo, faltam estudos mais pontuais sobre a ação do Marquês de Cascais e seus capitães-mores no processo de povoamento de São Francisco do Sul, Desterro e Laguna a partir do último quartel do século XVII.

A falta de herdeiros legítimos, a inépcia dos donatários, ou mesmo a ausência dos capitães podiam levar à extinção das capitanias e sua conseqüente reversão à Coroa. ${ }^{176}$ Tais problemas associados a uma crescente necessidade de fortalecimento do

\footnotetext{
${ }^{172}$ Carta de Doação a Pero Lopes de Souza, in Pedro Tacques de Almeida Paes Leme. História da Capitania de S. Vicente. São Paulo: Melhoramentos, s/d., p. 77. Segundo esse autor, em 1772, ano em que escreveu a obra, havia muita dúvida se a ilha de Santa Catarina estava dentro das quarenta léguas dessa doação.

${ }^{173}$ Para uma melhor compreensão desse pleito ver, sobretudo, Pedro Tacques, op. cit, pp. 77 e ss.; Walter F. Piazza. Santa Catarina: sua história. Op. cit., pp. 99 e 100; e António Vasconcelos de Saldanha. As capitanias..., op. cit., pp. 79 e ss.

174 Segundo Jaime Cortesão. Raposo Tavares e a Formação Territorial do Brasil. Rio de Janeiro. Ministério da Educação e Cultura, 1958, p. 32, o objetivo dessa doação era de "atribuir à coroa portuguesa a posse e jurisdição direta sobre todo o espaço que medeava entre o lote meridional de Pero Lopes de Sousa [nesse momento, do seu sucessor, o Marquês de Cascais] e o estuário platino".

${ }^{175}$ AESP, DI, vol XVIII, pp. 8 e 9. Carta régia de D. João V ao governador da praça de Santos, em 11 de março de 1717.

${ }^{176}$ António Vasconcelos de Saldanha. Op. cit., p. 112. "O regime sucessório das capitanias funda-se, em princípio, na existência de descendência direta, legítima, varonil, sem admissão de transversais. A não
} 
poder Monárquico levaram ao encerramento da história das donatarias, no século XVIII. À proporção que foram sendo incorporadas ao real domínio criavam-se as capitanias gerais ou os governos subalternos, sujeitos não mais ao controle perpétuo de donatários, e sim, da administração temporária dos governadores-capitães generais, para as primeiras, e, dos governadores-coronéis ou capitães-mores, para os segundos.

Como já referido, a capitania do Marquês de Cascais foi comprada pela Coroa em 1711, e a dos Assecas reincorporada ao patrimônio real, em 1727. ${ }^{177}$

O estabelecimento que se implantou na Ilha de Santa Catarina, em 1738, foi um “governo", uma "praça militar", e assim denominavam as autoridades metropolitanas e coloniais. No decorrer das décadas de 1760 e de 1770, momento em que as jurisdições militar, judiciária e fazendária estavam já melhor delimitadas e havia também uma população considerável, tornou-se comum o uso do termo "capitania". Contudo, essa denominação foi, por todo o período que aqui se estuda, mais usual pelas autoridades e sociedade locais do que pelas autoridades metropolitanas, o que evidenciava uma certa tensão existente entre as distintas perspectivas do que era - ou deveria ser - essa unidade político-administrativa.

Na carta régia de 11 de agosto de 1738, D. João V ordenava a Gomes Freire de Andrade que o Brigadeiro José da Silva Paes fosse fortificar a ilha de Santa Catarina e que se devia "por bem separar desde logo do Governo de S. Paulo e unir ao desse do Rio de Janeiro a dita Ilha e o Rio de S. Pedro". Em resposta, escreveu Gomes Freire: "pela dita ordem fico entendendo foi V. Maj. servido anexar o Governo da dita Ilha ao do Rio de Janeiro". ${ }^{178}$

Dez anos mais tarde, outra ordem real mandava que avisasse "aos Governadores da Colônia, Santos, e Ilha de Santa Catarina; e Comandante do Rio Grande de S. Pedro" para que cumprissem tudo o que ele, Gomes Freire, lhe encarregasse, "assim em matéria de despesas como em todas as outras" que se oferecessem de seu serviço. ${ }^{179}$ Da mesma forma entendia Tomás da Costa Corte-Real, Secretário de Estado da Marinha, ao dizer:

verificação de qualquer destes requisitos tinha como pura e simples conseqüência a reversão dos bens à Coroa, segundo o dispositivo da Lei Mental."

177 Ver p. 43.

${ }^{178}$ Col. Doc., p. 132 e 133. [Grifo meu]

179 BNRJ, CEHB, Mss., 3, 4, 3 n. 103. Carta régia de D. João V a Gomes Freire de Andrade, em 11.09.1748. 
"No que pertence as praças dependentes daquele Governo [Rio de Janeiro], como são, Santos, Santa Catharina, Rio Grande, e Colônia (...)". ${ }^{180}$

Excetuando-se o Rio Grande que, de 1738 a 1760 ficou, pelo menos de direito, como uma comandância militar, essas praças militares eram, sob o aspecto político e administrativo, hierarquicamente equivalentes.

Não havia, nessa primeira metade do século XVIII, uma idéia clara e nem mesmo um projeto definido de como se organizariam politicamente aqueles domínios no Sul. Ocorreu, pode-se dizer, um aumento da jurisdição territorial da capitania do Rio de Janeiro em espaços até então pertencentes à capitania de São Paulo, contudo, eram espaços vagos e sem limites precisos a demarcar onde terminava o governo de uma e onde começava o de outra.

A transferência de toda essa costa atlântica para o Rio, proposta na carta régia de 11 de agosto de 1738, não foi realizada de uma só vez. Santos, como se viu, encontravase já em 1704, vinculado àquele governo; Laguna passaria em 1742, quatro anos depois da Ilha de Santa Catarina e Rio Grande de São Pedro, com a seguinte justificativa:

Faço saber a vós Governador e Capitão General da Capitania do Rio de Janeiro que atendendo a ficar muito distante da Capitania de S. Paulo, a vila da Laguna que é da jurisdição daquele governo, e que por distância se não pode dar providencia naquela parte em qualquer caso que peça pronto remédio. Fui Servido determinar por Resolução de 18 de Dezembro do ano próximo passado tomada em consulta do meu Conselho Ultramarino que a dita vila da Laguna se separasse do mesmo Governo de S. Paulo, e se una ao dessa Capitania do Rio de Janeiro, de que vos aviso para que assim tenhais entendido ser da vossa jurisdição a dita vila. ${ }^{181}$

De fato, podia-se alcançar esses povoados costeiros muito mais rapidamente indo do Rio de Janeiro pelo mar, do que de São Paulo por terra. Mas as longas distâncias e os difíceis caminhos nunca foram óbices para os destemidos paulistas. $\mathrm{O}$ problema central colocado nessa reconfiguração política era sobretudo de soberania, de controle mais direto, sem mediações, da Coroa Portuguesa sobre aquele território em disputa.

Em 18 de junho de 1750, era a vez da vila de São Francisco do Sul. Gomes Freire em carta ao Governador da Ilha de Santa Catarina, Manuel Escudeiro Ferreira de

\footnotetext{
${ }^{180}$ ANRJ, Secretaria do Estado do Brasil, Fundo 86, Cód. 952, vol. 39 “Cartas Régias, Provisões, Alvarás e Avisos". Carta de Tomás da Costa Corte-Real a Gomes Freire de Andrade, em 31.01.1758.

${ }^{181}$ BNRJ, CEHB, Mss., 5616 - 3, 4, 3 n. 78. Carta régia de D. João V a Gomes Freire, em 4 de janeiro de 1742.
} 
Sousa, informava, entre outras coisas, que tinha ele avisado o governador de Santos (vale lembrar aqui que a capitania de São Paulo havia sido extinta em 1748) "sobre se desmembrar a povoação de S. Francisco daquele governo [Santos] e pertencer a esse [da referida ilha]". ${ }^{182}$ Com efeito, a carta régia de 9 de maio de 1748, que extinguiu a capitania de São Paulo havia passado a administração militar de São Francisco para Santos,

por ser conveniente, que as duas comarcas de S. Paulo, e Paranaguá, que medeiam, e são mais vizinhas a esta Capitania do Rio de Janeiro dependam desta; sou servido que o Governador da Praça de Santos administre todo o militar das ditas duas Comarcas, ficando subalterno ao Capitão General dessa Capitania do Rio de Janeiro, como estava antes que se criasse o Gov. de São Paulo, e como estão os governadores da Ilha de S. ${ }^{\text {ta }}$ Catarina, do Rio de S. Pedro, e da Colônia, e os confins do mesmo Governo subalterno de Santos $(\ldots) .{ }^{183}$

A comarca de Paranaguá limitava-se ao norte com a de São Paulo por uma linha imaginária traçada leste-oeste entre Iguape, na costa, e Furnas, no sertão, e, ao sul, com o rio da Prata, incluindo, portanto, sob sua jurisdição, Curitiba, Desterro, Laguna, São Francisco do Sul e Rio Grande de São Pedro. ${ }^{184}$

Mas, junto ao esforço da Corte Portuguesa na consolidação de seu domínio no Extremo-Sul - a construção das fortalezas, a formação dos regimentos militares e, sobretudo, a transmigração de milhares de casais açorianos e madeirenses para a Ilha de Santa Catarina e seu continente fronteiro a partir de 1748 - tornava-se necessária também a aproximação dos órgãos e agentes da administração judiciária, fazendária e eclesiástica.

Em 3 de julho de 1747, D. João V ordenou ao Provedor da Capitania de São Paulo que, sobre o contrato dos dízimos do distrito onde se estabeleceriam os casais açorianos - "Ilha de Santa Catharina e na terra firme dos seus contornos, começando do Rio de S. Francisco exclusive p. a parte do Sul até o Serro de S. Miguel” - deveria, "findo o triênio do contrato dos dízimos do povoado de Santos, e S. Paulo que ultimamente se arrematou, no qual foi incluído o mesmo distrito", arrendar a parte e

\footnotetext{
${ }^{182}$ AESP, DI, vol. 47, p. 139. Interessante observar que, no título sumário aposto pelos editores ou transcritores no documento, em 1929, consta: "Carta em que o governador do Rio de Janeiro comunica ao de S. Catarina ter passado a jurisdição deste a povoação de S. Francisco, desmembrada de S. Paulo - de 18 de junho de 1750 ”. Ora, a capitania de São Paulo havia sido extinta em 1748 e, portanto, não tinha mais jurisdição sobre S. Francisco.

${ }^{183}$ BNRJ, CEHB, Mss. n. 5616 - 3, 4, 3, n. 102. De D. João V a Gomes Freire de Andrada.

${ }^{184}$ Manoel da Silva Mafra. Exposição Histórico-Jurídica, op. cit., p. 95.
} 
ficar pertencendo à Provedoria do Rio de Janeiro. ${ }^{185}$ Pouco tempo depois, para a administração desses rendimentos e despesas, seriam criadas duas novas provedorias: da Ilha de Santa Catarina e do Rio Grande de São Pedro. A primeira, com data anterior a 7 de novembro de 1750, como indica o requerimento do provedor nomeado, Félix Gomes de Figueiredo, suplicando ajuda de custo para fazer a viagem da Corte àquela Ilha; ${ }^{186}$ a segunda, pela provisão régia de 21 de novembro de $1749 .{ }^{187}$ Não se tem notícia dos limites jurisdicionais dessas duas provedorias, e é provável que não tenham sido mesmo estipulados, pois, como adiante se mostrará, tal indefinição motivou conflitos de poder entre as autoridades locais. O fato dos seus provedores receberem o mesmo ordenado $640 \$ 000$ mil réis ao ano - indica, no entanto, que estavam no mesmo grau hierárquico de poder e deviam, cada qual, subordinação ao Rio de Janeiro e à Corte em Lisboa. ${ }^{188}$

Diferentemente se procedeu com a jurisdição territorial da nova ouvidoria criada na Ilha de Santa Catarina, em 20 de junho de 1749. Seu primeiro ouvidor-geral teria

o mesmo ordenado e percalços [que tinha] o de Paranaguá, e que o distrito d'aquela nova Ouvidoria ficasse para o Norte pela barra austral do Rio S. Francisco pelo Cubatão do mesmo Rio, e pelo Rio negro que se mete no grande Rio da Curitiba, e que para o Sul acabasse nos montes, que deságuam para a Lagoa Imeri [Mirim]. ${ }^{189}$

Ou seja, com uma só comarca abrangia-se todo o território destinado ao estabelecimento dos casais açorianos e madeirenses. Distintamente das capitanias gerais, que podiam ter mais de uma comarca dentro de sua circunscrição política, a

185 AHU-SC, cx. 1, doc. 30. O grifo é meu.

${ }^{186}$ AHU-SC, cx. 1, doc. 66. Anterior a 7 de Novembro de 1750.

${ }^{187}$ AHRS, Livro de Registro Geral do Comissário de Mostras da Expedição e Fazenda - F 1197, fl. 132. "Eu El Rei faço saber aos que esta minha Provisão virem que tendo consideração ao Bacharel Manoel da Costa Morais Barba Rica me haver servido alguns anos... Hei por bem fazer-lhe mercê de o nomear Provedor de minha fazenda no Rio Grande de São Pedro por tempo de três anos em a qual ocupação haverá seis centos e quarenta mil reis de ordenado cada ano (...) pelo que mando ao meu Governador e Capitão General da Capitania do Rio de Jan. ${ }^{0}$ dê posse ao dito Bacharel (...)." Ver também, Márcia Eckert Miranda. Continente de São Pedro: Administração Pública no Período colonial. Porto Alegre: Assembléia Legislativa do Estado do RS, 2000, p. 87 - Cap. 3 "Administração Fazendária".

${ }^{188}$ AHU-SC, cx. 2, doc. 50. Ofício do provedor da Fazenda Real da ilha de Santa Catarina ao Secretário de Estado da Marinha e Ultramar, Diogo de Mendonça Corte Real, enviando as relações de ordenados, propinas e emolumentos dos funcionários da Provedoria da Fazenda, em 4 de agosto de 1756. A partir do que escreve Manoel Joaquim d'Almeida Coelho. Memória Histórica da Província de Santa Catharina. op. cit., p. 82, fica-se por supor, erroneamente, que não havia sido criada uma Provedoria em Rio Grande de São Pedro: "Por ordem régia de 8 de Maio de 1746 mandou-se informar ao Governador do Rio de Janeiro sobre a conveniência do estabelecimento de uma casa d'Administração da Fazenda no RioGrande, resultando de tal informação o efetuar-se na Ilha de Santa Catarina a Provedoria da Fazenda em $1751(\ldots) "$.

${ }^{189}$ Manoel da Silva Mafra. Exposição Histórico-Jurídica. op. cit., p. 103. De D. João V a Gomes Freire de Andrade, em 20 de junho de 1749. 
ouvidoria da Ilha de Santa Catarina abrangia sob sua jurisdição parte do governo da Ilha (São Francisco do Sul continuaria sob o controle da comarca de Paranaguá) e do Rio Grande de São Pedro.

Embora a provisão que regulasse o transporte e destino desses colonos mandasse que fossem estabelecidos ao longo de toda aquela costa "e no sertão correspondente a este distrito (com atenção porém a que se não [desse] justa razão de queixa aos espanhóis confinantes)", ${ }^{190}$ e se formassem povoados com 60 casais, na prática, a distribuição dos colonos não ocorreu dessa forma. Tirando o número dos que foram destinados para o Rio Grande de São Pedro e Laguna, a maior parte deles se adensou na Ilha de Santa Catarina e proximidades do continente, quer porque os ilhéus resistiam, depois de chegarem àquela Ilha, às agruras de uma nova transferência para lugares mais ermos, mesmo que para isso tivessem que se contentar com menores porções de terra, quer porque faltaram iniciativas mais concretas por parte dos administradores na formação de novos povoados. Ainda assim, o ulterior desenvolvimento daquelas colônias mostraria que, o propósito de incorporar aquelas terras aos domínios de Portugal, mesmo não fechando todos os espaços, havia sido cumprido.

A sede do ouvidor-geral foi, desde a sua criação, em 1749, a vila de Nossa Senhora do Desterro até que o Alvará de 16 de novembro de 1812 a fez transferir para a vila de Porto Alegre, que passou a ser a cabeça de comarca com as mesmas jurisdições que tinha a anterior. Contudo, não sendo possível que um só ministro corrigisse a tão vasta extensão, o Alvará de 12 de fevereiro de 1821 manteve a comarca de Porto Alegre e restabeleceu a da Ilha de Santa Catarina, ainda sem jurisdição sobre a vila de São Francisco do Sul. ${ }^{191}$ A anexação desta vila à ouvidoria da Ilha só ocorreria em $1832 .{ }^{192}$

A circunscrição do governo civil e militar - instância que mais nos interessa aqui - apresenta-se mais difusa, sem contornos precisos. Numa análise literal da carta régia de 11 de agosto de 1738, o governo da Ilha de Santa Catarina - cometendo aqui uma tautologia -, teria como jurisdição tão somente à Ilha. Mas, isso não fica claro e, como se verá, não corresponde à ação efetiva dos governadores.

Em perspectiva oposta, alguns historiadores tiveram o entendimento de que, desde a criação daquele governo, formou-se uma unidade política e administrativa com

\footnotetext{
190 "Provisão Régia pela qual S. M. ordenou o transporte e estabelecimento dos colonos das Ilhas dos Açores para a Ilha de Santa Catarina" (09.08.1747) in Gen. João Borges Fortes. Os Casais Açorianos: presença lusa na formação sul-rio-grandense. $3^{\mathrm{a}}$ ed. Porto Alegre: Martins Livreiro, 1999, p. 30.

${ }^{191}$ Manoel Joaquim d'Almeida Coelho. Memória Histórica da Província de Santa Catharina. Desterro: Typ. J. J. Lopes, 1877, p. 78.

${ }^{192}$ Cf. Carlos da Costa Pereira. História de São Francisco do Sul. Florianópolis: Ed. UFSC, 2004, p. 78.
} 
dimensões territoriais amplas e, em certos casos até, com configuração igual, ou próxima, do atual Estado de Santa Catarina. Para Visconde de São Leopoldo, em 1738, formou-se na "ilha e terra adjacente, com os mesmos limites, que ainda hoje conserva [1832], governo separado, despachando para seu primeiro Governador, o brigadeiro José da Silva Paes". ${ }^{193}$ Noção semelhante passa-nos Oswaldo Cabral, para quem "O Estado de Santa Catarina, no espaço político administrativo que vem ocupando desde 1916, e que foi com pequenas alterações aquele que historicamente sempre pretendeu ocupar, é dividido em toda a sua extensão de norte a sul, em duas regiões perfeita e nitidamente distintas - a região litorânea, orla marítima, de grande comprimento e pouca profundidade, e a região planaltina, de grande profundidade e menor comprimento (...). Esta divisão realiza-a a Serra Geral (...)". ${ }^{194}$ Mais recentemente, Carlos Humberto Correa, defendeu que, "Diferentemente da maioria dos demais Estados brasileiros, Santa Catarina não nasceu na plenitude de seu território geográfico mas, apesar de já tê-lo desde a origem, lutou com países estrangeiros, Províncias e estados irmãos e o próprio governo da União, para consolidar seu torrão e incorporar seus filhos a um mesmo pensamento de catarinensismo". 195

A busca pelas origens dos Estados, as disputas territoriais externas ou internas e a construção das identidades regionais foram questões que pautaram grande parte das histórias locais no século XX. Não se pode exigir daqueles historiadores problemas, conceitos e questionamentos próprios de nosso tempo.

No caso de Santa Catarina, esse problema dos limites do Estado e da definição de uma identidade regional marcou sensivelmente o pensamento historiográfico do século passado. O litígio territorial sobre o espaço geográfico situado entre os rios Iguaçu e Uruguai pelas Províncias de Santa Catarina e do Paraná, que se acirra após a Proclamação da República, ${ }^{196}$ levou alguns historiadores a transporem para um passado

\footnotetext{
193 José Feliciano Fernandes Pinheiro. (Visconde de São Leopoldo). "Resumo Histórico da Província de Santa Catarina", in Anais da Província de São Pedro. Porto Alegre: Mercado Aberto, 1982 (Série Documenta, 11), p. 223. [1 $1^{\text {a }}$ ed. c. 1832].

${ }^{194}$ Oswaldo R. Cabral. A Campanha do Contestado. $2^{\mathrm{a}}$ ed. Florianópolis: Lunardelli, 1979, p. 24. Afora a alteração do título dado na $1^{\mathrm{a}}$ ed. de 1960 - João Maria: Interpretação da Campanha do Contestado, publicado pela Companhia Editora Nacional de São Paulo, o texto não apresenta revisão ou acréscimos.

195 Carlos Humberto Correa. “"A Descoberta do Oeste Catarinense”, in RIHGB, Rio de Janeiro, 161 (408) 101-111, jul./set. 2000, p. 102. [O grifo é meu]

${ }^{196}$ A alteração do sistema de arrecadação tributária nacional com a primeira Constituição republicana (1891) provocou o acirramento dos litígios territoriais entre os Estados federativos. Enquanto o imposto de importação passava a ser arrecadado exclusivamente pelo poder central, as rendas advindas do imposto de exportação ficavam com os estados. Cf. Américo Freire e Celso Castro. "As bases republicanas dos Estados Unidos do Brasil" in Ângela de Castro Gomes, Dulce Chaves Pandolfi e Verena Alberti (Orgs.) A República no Brasil. Rio de Janeiro: Nova Fronteira, CPDOC, 2002, p. 37.
} 
remoto uma unidade jurídica, política e territorial, senão também identitária, que seguramente não existia. Isso é válido da mesma forma para o Paraná, embora a história político-administrativa dessa Província e os fundamentos que juristas e historiadores paranaenses buscaram para justificar sua defesa tenham sido outros. ${ }^{197}$

Interessante observar que a historiografia regional anterior à obra do Conselheiro Mafra, muito embora tenha concebido também Santa Catarina como uma formação política ampliada desde a sua criação, valorizando assim a existência de um território catarinense já nos séculos XVII e XVIII, não usou a forma capitania para denominar aquela unidade estatal, mas tão-somente governo. ${ }^{198}$

Outra questão colocada pela historiografia, mas que precisa ser revista e problematizada é a subordinação da comandância militar do Rio Grande de São Pedro, entre 1738 e 1760, ao governo da Ilha de Santa Catarina. ${ }^{199}$ De fato, segundo Dauril Alden, concomitante com a fundação do Rio Grande (1737), Santa Catarina era conduzida sob um controle mais direto do poder régio. ${ }^{200}$ A organização política do espaço foi realizada antes nessa do que naquele. Nossa Senhora do Desterro tinha foros de vila desde 1726, enquanto a vila de Rio Grande só se instalaria em 1751; a Ilha tornou-se cabeça de comarca, a partir de 1749, com jurisdição da barra de São Francisco do Sul até a Lagoa Mirim mantendo-se assim até 1812, quando a sede da ouvidoria passou a ser a vila de Porto Alegre ${ }^{201}$; e, dos cerca de doze anos que o Brigadeiro José da Silva Paes esteve encarregado da instalação dos presídios no Sul, mais de sete deles fez da Ilha de Santa Catarina a sua base principal de comando. Contudo, não se tem notícia de nenhuma carta régia, provisão ou instrução que estabelecesse ou

\footnotetext{
${ }^{197}$ Enquanto este Estado utilizou em seu processo de defesa o recurso jurídico do uti possidetis, valorizando assim a história de conquista e ocupação dos paulistas e paranaenses nos Campos de Guarapuava e de Palmas, o Estado catarinense fundamentou sua defesa no jus possidetis, na formação jurídico-legal da Capitania, no século XVIII. Ver Manoel da Silva Mafra. Exposição Histórico-Jurídica Por parte do Estado de Santa Catarina sobre a questão de limites com o Estado do Paraná. Florianópolis: IOESC, 2002. [ $1^{\mathrm{a}}$ ed. 1899] e; Joaquim da Costa Barradas. Memorial por parte do Paraná. Rio de Janeiro: Typ. Olympio de Campos, 1902. A solução desse litígio territorial entre os dois Estados foi celebrada pelo Acordo de 1916.

${ }^{198}$ Ver nota 125.

${ }^{199}$ De acordo com Guilhermino Cesar, "a totalidade do território de São Pedro" ficou subordinada à “"capitania subalterna' de Santa Catarina”. História do Rio Grande do Sul. op. cit., p. 118. Ver também a esse respeito: Sandra J. Pesavento. História do Rio Grande do Sul, op. cit., p. 20; José Arthur Boiteux. Santa Catharina nos tempos d'El-Rey Nosso Senhor. Florianópolis: Typ. São José, 1929. (Conferência no Centro Popular de Florianópolis, em 21 de abril de 1928), p. 9; Lucas A. Boiteux. Notas para a História Catharinense. Florianópolis: Moderna, 1912, p. 215; e Manoel da S. Mafra. Exposição..., op. cit., p. 632. ${ }^{200}$ Dauril Alden. Royal Government..., op. cit., p. 72. No original, "Concomitant with the founding of Rio Grande (1737), Santa Catarina was brought under more direct royal control".

${ }^{201}$ Porto Alegre foi também cabeça da comarca entre 1777-78, quando da ocupação espanhola da Ilha de Santa Catarina. Somente em 1821 é que foi desmembrada a Comarca de Santa Catarina da Comarca do Rio Grande de São Pedro. Cf. Márcia E. Miranda. Continente de São Pedro..., op. cit., p. 79.
} 
regulamentasse aquela subordinação. O que é mais visível nessa incipiente estrutura de poder que se começou a montar é o comando do Brigadeiro, como encarregado direto de Gomes Freire de Andrade - em alguns momentos como governador interino da capitania do Rio de Janeiro - sobre aqueles estabelecimentos no Sul e seus oficiais imediatos. No Rio Grande de São Pedro ele ficou de 1737 a 1739, deixando em seu lugar o Mestre de Campo André Ribeiro Coutinho (1739-40) e, depois, o Coronel Diogo Osório Cardoso (1741-52); ${ }^{202}$ na Ilha de Santa Catarina esteve em dois momentos: de 1739 a 1743 e de 1746 a 1749. Nesse meio tempo foi substituído pelo Capitão Patrício Manuel de Figueiredo (1743-44) e pelo Marechal de Campo Pedro de Azambuja Ribeiro (1744-46).

Quando Silva Paes saiu em diligência para a Colônia do Sacramento, em 29 de agosto de 1743, deixou uma instrução a Patrício Manuel de Figueiredo recomendando que observasse, entre outras coisas, sobre o procedimento que deveria tomar no caso de arribada de navios estrangeiros naquele porto e das obras e reparos necessários nas fortalezas daquela Ilha. Nenhuma orientação foi feita acerca do Rio Grande de São Pedro, ${ }^{203}$ e nem podia, pois, o comandante dessa praça, em 1743, era o Coronel Diogo Osório Cardoso que, obedecendo à hierarquia militar, não receberia ordens ou instruções de um oficial de graduação inferior como o do Capitão Manuel de Figueiredo.

Não se encontra registro de patente de governador para Silva Paes e é bem possível que ele nunca tenha sido investido desse caráter. Na correspondência que enviava ou recebia era mais comum aparecer tão-somente o título de Brigadeiro e/ou Comandante daqueles estabelecimentos. ${ }^{204}$ A esse respeito, é interessante uma interpretação que Oswaldo Cabral fez - em tom laudatório, é verdade - da posição e importância de Silva Paes naquela colônia: “Tornou-se o impulsionador da vida na Vila [de Desterro], iniciando um período de atividades até então desconhecidas. Fez mais: tornou Santa Catarina uma Capitania. Deu calor e organização à sua existência e tão bem se houve, que outra alternativa não encontrou o Conselho Ultramarino, senão a de reconhecer a existência de uma nova Capitania d'El Rei - e quando o Governo teve de lhe dar, a ele Silva Paes, sucessores, passou a nomeá-los com a qualidade de

\footnotetext{
${ }^{202}$ O último comandante militar do Rio Grande foi o Tenente-Coronel Pascoal de Azevedo (1752-60). A carta-patente, de 9 de setembro de 1760, passada ao Tenente-Coronel Ignacio Eloy de Madureira nomeando-o governador do Rio Grande, não se refere à subordinação que havia desse governo à Ilha de Santa Catarina. AHRS - F-1242, fls. 176v e 177.

${ }^{203}$ Col. Doc., p. 144.

204 Ver Col. Doc., pp. 3-145.
} 
governadores e não mais como simples comandantes de presídio, isto é, comandantes de praça de guerra, como até então". ${ }^{205}$

De fato, a construção de quatro fortalezas entre 1739 e 1743 com quartéis, casas de comandantes, armazéns de pólvora, paióis de mantimentos e demais construções um investimento fabuloso viabilizado com o ouro do Brasil e o trabalho escravo de negros e de índios -, e mais, o transporte e estabelecimento por conta da fazenda real de aproximadamente 6.000 colonos açorianos indicavam a relevância da Ilha de Santa Catarina no processo de expansão portuguesa na América Meridional, no segundo quartel do século XVIII. Por outro lado, a Corte demonstrava muita cautela e parcimônia com relação à estrutura política a ser montada ali.

Uma Consulta dada pelo Conselho Ultramarino, em 13 de maio de 1745, sobre a Patente e o soldo que deveria ter o substituto de Silva Paes na Ilha de Santa Catarina evidencia a perspectiva dos conselheiros sobre o que era, ou teria de ser, esse governo.

Ao Conselho parece que para se haver de prover de Governador a Ilha de S. Catarina na forma que V. Maj. tem resoluto se faz preciso que V. Maj. declare a graduação e soldo que deve ter dito Governador e entende o Conselho que pode ter a graduação, e soldo que tem o Governador da Praça de Santos, a quem se dão três mil cruzados de soldo e a patente de Mestre de Campo Governador. ${ }^{206}$

Dom João V, pouco mais de três anos depois, nomeava o Coronel Manoel Escudeiro Ferreira de Souza com o soldo não de três mil cruzados ao ano como defendiam os conselheiros, mas de cinco mil. ${ }^{207}$

A nomeação régia desse governador assim como a dos que lhe sucederam foram oficializadas com a forma: "Hei por bem nomeá-lo Governador da Ilha de $S^{\text {ta }}$. Catarina por tempo de três anos, e o mais que eu for servido em quanto lhe não mandar sucessor". ${ }^{208} \mathrm{Na}$ mesma posição se colocava o governador interino João Alberto de

\footnotetext{
205 Oswaldo R. Cabral. Nossa Senhora do Desterro. Vol. 1 - Notícia. Florianópolis: Lunardelli, 1979, p. 24.

${ }^{206}$ AHU-SC, cx. 1, d. 24.

207 AHU-SC, cx. 1, doc. 50. “Atendendo a algumas despesas extraordinárias de que senão poderá escusar o Coronel Manoel Escudeiro Ferreira de Souza no Governo da Ilha de Santa Catarina para q' o tenho nomeado, hei por bem que vença de soldo cinco mil cruzados por ano enquanto Eu não mandar o contrário. O Conselho Ultramarino o tenha entendido, e faça expedir as ordens necessárias. Lisboa a treze de setembro de 1748."

208 AHU-SC, cx. 1, doc. 48 - Decreto de nomeação de Manoel Escudeiro Ferreira de Souza, em 20.08.1748. O grifo é meu; Esta forma se repetiu, com mínimas variações gramaticais, nos Decretos e Cartas Patentes de nomeação (ou confirmação) dos seguintes governadores: José de Melo Manoel, em 20.04.1753, AHU-SC, cx. 2, doc. 85; Francisco Antonio Cardoso de Menezes, em 18.09.1761, AHU-SC,
} 
Miranda Ribeiro em ofício remetido ao Secretário de Estado da Marinha e Ultramar, em 24 de dezembro de 1793: "Fui mandado para esta Ilha, e encarregado do Governo da mesma por Ordem do $\mathrm{Il}^{\mathrm{mo}}$. e $\mathrm{Ex}^{\mathrm{mo}} \cdot \mathrm{Sn}^{\mathrm{r}}$. Conde de Rezende, Vice-Rei do Estado do Brasil". 209

No princípio do estabelecimento - o primeiro decênio pode-se dizer (1739-48) -, o que existe é uma praça militar. Em 12 de janeiro de 1744, Pedro de Azambuja Ribeiro presta juramento ao governador e Capitão General do Rio de Janeiro, Gomes Freire de Andrade, "pelo Governo da Ilha de Santa Catarina, e suas Fortalezas, tanto das que existem, como das que novamente se fizerem". 210

A expressão "Capitania" aparece excepcionalmente na Carta Patente de confirmação da nomeação do governador Pedro Antônio da Gama Freitas, em 05 de junho de 1776, mas, como se pode perceber, sem alterar as funções e poderes atribuídos a este governador que continuavam com os mesmos limites e prerrogativas jurisdicionais de seus antecessores.

Hei por bem fazer lhe mercê de o confirmar como por esta confirmo / no dito cargo de Governador da Capitania de Santa Catarina com a referida Graduação [Coronel de Infantaria] com o qual vencerá de soldo o mesmo que por ordem minha se acha estabelecido para os governadores daquela Ilha e ultimamente o estava recebendo o Governador dela Francisco de Souza de Menezes a quem foi suceder e gozava de todas as honras, jurisdições e mando de que gozavam os mais Governadores da dita Ilha. Com subordinação ao governo do Rio de Janeiro. ${ }^{211}$

Contudo, ainda que não houvesse um instrumento legal que lhe desse esse estatuto de "capitania", as autoridades locais (governadores, oficiais da câmara e outros) passaram, no decurso da segunda metade do século XVIII, a tratá-la como se capitania fosse e, como podemos perceber na documentação, o espaço de atuação jurisdicional civil e militar dos governadores de fato não se restringiu à Ilha de Santa Catarina, mas também ao território continental adjacente a ela, incluindo os termos das vilas de Laguna, primeiro, e de São Francisco do Sul, depois.

cx. 3, doc. 166; Francisco de Souza Menezes, em 30.01.1765, ANTT, Chancelaria de D. José I, Lv. 74, fl. 213v; Francisco de Barros Morais Araújo Teixeira Homem, em 23.09.1778, AHU-SC, cx. 4, d. 275; Joaquim Xavier Curado, em 29.11.1800, ANTT, Chancelaria de D. Maria I, Lv. 64, fl. 185; Luis Mauricio da Silveira, em 18.08.1804, ANTT, Chancelaria D. Maria I, Lv. 72, fl. 178.

${ }^{209}$ AHU-SC, cx. 5, doc. 355. Ofício do Governador João Alberto de Miranda Ribeiro a Martinho de Melo e Castro.

${ }^{210}$ PAPN, Vol. VII, 1907, p. 71.

${ }^{211}$ ANTT, Chancelaria de D. José I, Lv. 36, fl. 257. O grifo é meu. 


\subsection{1 "O continente dessa ilha"}

O que pode parecer um paradoxo para a Geografia não é para a História. Em determinados espaços do império português foram os continentes que gravitaram em torno das ilhas e não o contrário. A expressão "o continente dessa ilha" foi utilizada pelo vice-rei Conde de Rezende ${ }^{212}$ ao se referir a uma parte do estabelecimento de Santa Catarina.

A dimensão espacial do governo da Ilha de Santa Catarina, desde o princípio de seu estabelecimento, em 1738, pressupunha também domínio sobre certa parte do continente adjacente, pois, com ele a Ilha formava seu porto; todo o sentido militar e comercial da Ilha associava-se ao domínio do mar e do continente, como mostram as numerosas correspondências entre as autoridades e as representações cartográficas dela feitas por portugueses e estrangeiros. Mas os limites desse governo, sobretudo ao oeste, ficariam, por muito tempo ainda vagos e imprecisos.

Em 1747, portanto, poucos anos após José da Silva Paes erguer o sistema de defesa na Ilha, Gomes Freire de Andrade pedia-lhe para que ele lhe explicasse "na terra firme", por onde se dividia "esta Capitania [do Rio de Janeiro], da de S. Paulo, por que não quisera ter dúvida com o Snr. Luiz de Mascarenhas, como tem sucedido na Capitania das Minas por incúria das Secretarias". ${ }^{213}$ Não se tem a resposta de Silva Paes, mas antes que surgissem dúvidas entre os limites com São Paulo, uma resolução régia extinguia essa capitania e destituía seu capitão general, em maio de 1748, ficando assim, subordinada ao Rio de Janeiro pelos próximos 17 anos. Somente após sua restauração, em 1765, surgiriam então problemas entre os limites jurisdicionais entre a capitania de São Paulo e o governo da Ilha de Santa Catarina.

A instalação dos cerca de 6.000 colonos açorianos e madeirenses, entre 1748 e 1756, na Ilha e seu continente fronteiro é que, de fato, daria corpo e vida a esse estabelecimento colonial. De nada adiantava o domínio do espaço sem gente que o povoasse. Nos mapas demográficos e de produção econômica, como se verá no capítulo 3, pode-se perceber a dimensão espacial que tomava essa colônia. Interessante observar que nos dois Mapas populacionais apresentados pelo governador José de Melo Manoel,

\footnotetext{
${ }^{212}$ APESC, Ofícios do Vice-Rei para o Governador da Capitania, 1799-1802. Do Conde de Rezende ao governador João Alberto de Miranda Ribeiro, em 01 de fevereiro de 1800.

${ }^{213}$ ANRJ, Cód. 84, vol. 11, fl. 195v. De Gomes Freire de Andrade a José da Silva Paes, em 16 de agosto de 1747 .
} 
um em 1753, outro em 1756 (ver anexos 3 e 4), a vila de São Francisco do Sul só aparece nesse último, muito embora ela já estivesse sob a jurisdição civil e militar da Ilha desde 1750.

Nos ofícios e relatórios encaminhados aos vice-reis e à Corte, os governadores tratavam de esclarecer dos limites daquela colônia, mais ou menos precisos ao norte e ao sul e vagos ao oeste. José de Melo Manoel, em ofício ao Conselho Ultramarino, em 1753, dizia que "no continente da terra firme" compreendia "a jurisdição daquele governo mais de setenta e sete léguas, contadas desde o rio de São Francisco até a passagem de Tramandaí da parte do sul". ${ }^{214}$ Ao vice-rei Conde de Azambuja, Francisco de Sousa Meneses informava, em 1767, os mesmos limites norte-sul, mas segundo ele, a extensão da costa de terra firme passava de 80 léguas e acrescentava ainda que

os fundos destes países, ainda são incógnitos; [posto] que há grande tradição de que encerram riquíssimas Minas; mas só estão povoadas há poucos anos, e perto das praias; pelo que se pode, com muita propriedade dizer delas, o que escreveu o elegante Gen. Francisco de Brito, desta Nova lusitânia; isto é, que são uma peça de riquíssimo pano da qual até o presente só temos visto o ourelo. $^{215}$

Numa notícia dada a esse mesmo governador, de autor desconhecido e sem data (mas, provavelmente no momento em que ele assumia o cargo em 1765), colocava, no entanto, que "o extremo do dito Governo pela parte do Sul" eram "as Torres", raia limite de divisão do governo do Rio Grande de São Pedro. ${ }^{216}$ No final do século XVIII, Miranda Ribeiro colocava no Artigo $1^{\circ}$. do seu Relatório ao vice-rei, com bastante clareza e precisão, a extensão e limites do seu governo.

A Terra firme da Capitania deste Governo Confina pela parte do Norte com a Vila de Guaratuba, pertencente à Capitania de S. Paulo, no Referido Rio de Sahy. Pela parte do Sul confina com o Governo do Continente do Rio Grande no Referido Registro das Torres: Pela parte de Leste confina com o Mar, e com a mesma Ilha de Santa Catarina: E pela parte do Oeste confina com a Vila de Curitiba, e Vila das Lages, pertencentes à Capitania de S. Paulo (...).

A Serra que forma os fundos, ou Vertentes deste Sertão da Terra firme, no Lugar das Torres fica somente 5 Léguas a Oeste: porém depois se vai

\footnotetext{
${ }^{214}$ BNRJ, DH, vol. XCIV, Consultas do Conselho Ultramarino (1726-1756), p. 258.

215 BNRJ, Mss. 07, 3, 47. Ofício do governador Francisco de Souza de Meneses ao vice-rei, em 08 de dezembro de 1767.

216 AHU-SC, cx. 3, doc. 205. "Extrato da Ilha de Santa Catharina, seu continente, e mais partes dependentes daquelle Governo; cuja notícia se dá ao S. ${ }^{r}$ Governador Francisco de Souza de Menezes".
} 
alargando de forma que se supõe serem os fundos de 16 ou 17 Léguas defronte da Vila da Laguna (....). ${ }^{217}$

Contudo, como se verá no próximo tópico, a definição desses limites passou antes por uma série de conflitos e ajustes até a sua configuração definitiva.

No que diz respeito às noções do que era essa unidade política que se implantou na Ilha de Santa Catarina, percebe-se que, ao lado das denominações de "governo", “estabelecimento", “distrito”, ou “departamento" da capitania do Rio de Janeiro, tornouse também usual, a partir da década de 1760, sobretudo por parte das autoridades locais (governadores, provedores, oficiais da Câmara), a utilização do termo "capitania".

Como "Escrivão da Fazenda Real e Matrícula da Gente de Guerra nesta Capitania da Ilha de Santa Catarina", se colocava Domingos Gomes Dias; 218 "Mapa do Batalhão de Marim e de toda a Guarnição desta Capitania...” era o cabeçalho de um quadro com o número dos oficiais e soldados de Santa Catarina assinado pelo seu governador Francisco de Souza de Menezes, em 30 de novembro de $1773 ;{ }^{219}$ da mesma forma apresentava seu relatório o provedor, em 31 de dezembro de 1780: "Conta Corrente da Entrada e Saída de todo o dinheiro, que entrou nos Cofres da Provedoria da Real Fazenda da Cap. ${ }^{\text {nia }}$ de S. $^{\text {ta }}$ Catharina...",220 O vice-rei Marquês do Lavradio, em seu Relatório de 1779, também usou essa denominação. ${ }^{221}$ Em 1796, o morador Manoel de Moraes Pedrozo encaminhou requerimento ao Conselho Ultramarino suplicando a confirmação de uma data de sesmaria de "uma légua de terra nas margens do Rio Tubarão da Vila de Laguna na Capitania de Santa Catarina". 222

Esse último caso, ocorrido no final do século XVIII, demonstra a noção que algumas pessoas passavam a ter de pertencerem a uma unidade política maior que a vila, denominada de Capitania.

\footnotetext{
${ }^{217}$ RMR-1797, p. 123.

${ }^{218}$ AHU-SC, cx. 3, doc. 225. Conta da despeza da Fazenda Real Para o Real Erário, 1763.

${ }^{219}$ ANRJ, Cód. 106, vol. 2, fl. 211.

${ }^{220}$ ANRJ, Cód. 106, vol. 03 (final).

${ }^{221}$ Relatório do Marquês de Lavradio, apresentado ao Vice-Rei Luis de Vasconcelos e Sousa seu sucessor, em 19 de junho de 1779, in Visconde de Carnaxide. O Brasil na Administração Pombalina (Economia e Política Externa). Rio de Janeiro: Companhia Editora Nacional, 1940, p. 329.

${ }^{222}$ AHU-SC, cx. 5, doc. 371. Despacho do Conselho Ultramarino em 29 de janeiro de 1796. Para citar apenas mais dois exemplos, entre tantos outros que se poderia dar: no relatório que encaminhou à rainha D. Maria I, em 16 de novembro de 1797, o governador João Alberto de Miranda Ribeiro referia-se ao "Regimento, ou Regimentos porque se dirigem, e tem dirigido os Governadores desta Capitania da Ilha de Santa Catarina, na administração do Governo destes mesmos Povos de que atualmente estou encarregado" Os grifos desta citação e das anteriores são meus; "Memória Política sobre a Capitania de Santa Catarina", escrita no Rio de Janeiro, em 1816, e publicada em Lisboa, em 1829, é o título da obra de Paulo Jozé Miguel de Brito, Ajudante de Ordens que foi do Governo da mesma.
} 


\subsubsection{Conflitos de jurisdições e mando}

A constituição dessa unidade política e administrativa foi realizada por meio de uma série de ajustes e conflitos nas diferentes esferas judiciária, fazendária, militar e eclesiástica com os demais corpos políticos circunvizinhos em formação. Mas a questão das jurisdições internas - os limites entre as provedorias, ouvidorias e governos - foi um problema muito maior para as autoridades locais do que para os vice-reis e à Corte. Os insuficientes recursos destinados pela fazenda real para suprir as despesas ordinárias (principalmente os soldos das tropas) levavam os governadores a procurar ampliar as fontes de arrecadação de rendas como, por exemplo, direitos sobre as passagens dos rios, administração dos contratos dos dízimos e outros. Além disso, a ampliação de sua área de influência e mando proporcionava, por conseguinte, aumento do poder e prestígio social das autoridades na hierarquia política e social do império português.

Em 6 de novembro de 1771, o provedor da Fazenda Real do Rio Grande, Inácio Osório Vieira, mandou publicar um Edital por ordem do vice-rei Marquês do Lavradio de arrematação do contrato das passagens dos rios Tramandaí, Mampituba ${ }^{223}$ e Araranguá. Não havendo pessoa que arrematasse aqueles direitos, assentaram o governador Antônio da Veiga de Andrade e o provedor fazer a arrecadação pela própria provedoria, nomeando para recebedor dos dinheiros um tal de Domingos Vicinote, que deveria assistir no registro do rio Tramandaí e nele cobrar as passagens dos três rios

tanto da ida deste Continente para Laguna, como na volta de lá para o mesmo. A saber. De cada pessoa que passar em cada rio, quarenta réis, que respectivo aos três rios faz cento e vinte réis. De cada cavalo carregado, oitenta réis em cada rio, que faz duzentos e quarenta réis. De cada cavalo só com cangalha, quarenta réis, respectivo ao mesmo. De cada carreta carregada, oitocentos réis, que nos três, dois mil e quatrocentos réis. De cada carreta vazia, ou meia carga, quatrocentos e oitenta réis, com a mesma formalidade. Não consentirá o dito Recebedor passem bestas muares, potros, gados e couros sem lhe apresentarem guia desta Provedoria em como ficam nela pagos os direitos que se costumam fazer de semelhantes animais e feitos. ${ }^{224}$

\footnotetext{
${ }^{223}$ Este rio é, hoje, a atual divisa entre os Estados de Santa Catarina e do Rio Grande do Sul.

${ }^{224}$ AHRS, F-1244, O Registro do Edital, fl. 13v.; instrução passada pelo Provedor da Fazenda do Rio Grande a Domingos Vicinote, em 4 de janeiro de 1772, fls. 16, 16v e 17.
} 
Quase uma década depois, em 15 de junho de 1779, o governador e o provedor da Fazenda da Ilha de Santa Catarina reclamariam ao sucessor de Lavradio, Luís de Vasconcelos e Souza, para que este revisse a forma daquela arrecadação e passasse o direito sobre as passagens dos rios Araranguá e Mampituba à administração da provedoria da Ilha, pois eram "aqueles Rendimentos pertencentes ao território desta Capitania; que para ela e por ela se cobraram sempre até o anno referido [1772], que se mandaram pagar para Viamão". E observava ainda o provedor:

Que estes direitos vão para o Rio Grande, ou que venham para esta Ilha, tudo é o mesmo para S. Maj., porém não é o mesmo para aqueles que cobram aqui os seus ordenados e os seus soldos pela Folha Eclesiástica, Militar, ou Civil $(\ldots) .{ }^{225}$

Em resposta a essa representação, o vice-rei informou ao governador da Ilha que

Propondo este negócio na Junta da Real Fazenda, por ser próprio do seu conhecimento, achei depois das averiguações necessárias que n'ela se não havia tratado coisa alguma sobre esta matéria, e com efeito pelo Registro da Secretaria do Estado se verifica, que a resolução que tomou o S. Marquês do Lavradio, foi do seu próprio arbítrio.

Mas como para o Tribunal poder tomar uma nova resolução contra aquele e se poderem dar tais Providências, com que para o futuro fiquem do modo possível acauteladas semelhantes dúvidas, se faz necessária mais indagação: se assentou que logo se passasse ordem ao Rio Grande, para que a Junta d'aquele Continente informe com todas as clarezas necessárias para a vista de tudo se poder tomar uma resolução final, pondo-a ao mesmo tempo na Real Presença de S. Maj. para que a confirme. ${ }^{226}$

Mesmo não havendo encontrado nenhuma resolução régia na Junta da Real Fazenda do Rio de Janeiro que autorizasse aquela forma de arrecadação, Vasconcelos e Sousa considerava a probabilidade de que tal houvesse na Junta do Continente do Rio Grande e, para isso, contrariando uma possível atitude arbitrária e autonomista de seu antecessor, mostrava muita ponderação e cautela na resolução do caso. Problemas com os limites jurisdicionais internos das conquistas e arrecadação tributária dependiam em última instância dos desígnios régios.

\footnotetext{
${ }^{225}$ ANRJ, Secretaria do Estado do Brasil, Fundo 86, Cód. 106 - Correspondência com os Governadores da Ilha de Santa Catarina, vol 1 - 1779, d. 4, Do provedor Félix Gomes de Figueiredo ao vice-rei Luis de Vasconcelos e Sousa.

${ }^{226}$ ANRJ, Secretaria do Estado do Brasil, Fundo 86, Cód. 106 - Correspondência com os Governadores da Ilha de Santa Catarina, vol 1 - 1779, d. 14, do vice-rei Luis de Vasconcelos e Sousa ao governador Francisco de Barros Morais Araujo Teixeira Homem, em 01 de outubro de 1779.
} 
Outros conflitos dessa ordem ocorreriam ao norte e ao oeste da Ilha de Santa Catarina com a capitania de São Paulo, após sua restauração em 1765. Como já referido, se, na esfera civil e militar, a vila de São Francisco ficara, a partir de 1750, sob o comando do governador da Ilha, na esfera judiciária, continuava sob a jurisdição da comarca de Paranaguá. Inconformado com essa forma de divisão de poderes, o governador Francisco de Barros Morais apresentou ao vice-rei uma dúvida sobre quem deveria presidir a eleição de capitão-mor das ordenanças em São Francisco do Sul. Em resposta de 11 de agosto de 1780, Vasconcelos e Sousa disse-lhe que não achava

fundamento bastante, para que de aqui em diante vá o Ouvidor dessa Ilha exercitar naquela Vila ato algum de Jurisdição, mas sim o Ouvidor de Paranaguá; porque em primeiro lugar vejo que sempre sem contradição alguma exercitou nela toda a Jurisdição (...) e querendo certificar-me mais disto examinei as causas, que dela tem subido por Apelação para esta Relação [do Rio de Janeiro], e achando muitas, todas vêm do Ouvidor de Paranaguá, sem que aparecesse alguma do Ouvidor dessa Ilha; além disto o grande incômodo assim do mesmo Ouvidor dessa Ilha em ir exercer os atos de Jurisdição a uma tão grande distância, como dos habitadores da dita Vila de São Francisco em irem aí requerer os seus direitos, quanto tudo isto se evita conservando-se o antigo costume de serem aqueles Povos sujeitos ao Ouvidor de Paranaguá (...) porque ainda no caso de haver alguma Ordem positiva a este Respeito, depois do que fica ponderado, eu não devia alterar, e interromper um tal costume, sem primeiro dar conta a S. Maj. Nestes termos deve ser o Ouvidor de Paranaguá, quem resida a eleição de Capitão-Mor da Vila de São Francisco. ${ }^{227}$

Um ano depois, o mesmo governador, ao elaborar uma relação dos rendimentos de todos os empregos da fazenda real, de justiça e das câmaras do seu governo, por ordem do vice-rei, deparava-se com outra dúvida: a quem deveria pertencer o arrendamento do ofício de Escrivão da Câmara da vila de São Francisco do Sul, se à capitania do Rio de Janeiro e, nesse caso, incluiria em sua relação; se à capitania de São Paulo e, como tal, devia seguir na relação desse governador. Alertava esse problema para que não sucedesse de aquele ofício ir duplicado em duas diferentes capitanias e questionava também se neste caso não haveria "alguma usurpação de jurisdição", pois, segundo ele, se fazia "muito árduo de ver, que o provimento, e arrendamento de um oficio daquela Vila [tocasse] ao Governo de São Paulo, pertencendo a Vila ao Governo do Rio de Janeiro". Visivelmente insatisfeito com os problemas de jurisdições e mando

\footnotetext{
227 AESP, DI, vol. 47, pp. 152 e 153. Do vice-rei Luis de Vasconcelos e Sousa ao governador Francisco de Barros Morais.
} 
sobre a vila de São Francisco, o governador expunha ainda outro fato a Luís de Vasconcelos e Souza.

Logo que recebi a ordem de V. Ex. ${ }^{\text {a }}$ para a remessa dos animais quadrúpedes, ou voláteis, a participei ao Comandante da Vila de São Francisco recomendando-lhe bem aquela diligência no seu território: ele me respondeu que seria necessário esperar o tempo do inverno pra nele se fazer a diligência de apanhar alguns, e os domesticar depois, por quanto os que havia naquela Vila e vizinhanças tinham ido para São Paulo em virtude das Ordens, que o Governador daquela Capitania, tinha passado ao Ouvidor de Paranaguá.

Daqui colho, que o Governador de São Paulo manda na Vila de São Francisco pela boca do Ouvidor: passa as suas ordens ao Ouvidor para fazer uma diligência na sua Comarca; e este passa a Câmara da Vila de São Francisco como sua dependente e subordinada; e conseqüentemente vem o Governador (segundo o nosso adágio) a tirar a sardinha com a mão do gato, e a governar ali pela boca do Ouvidor de Paranaguá. ${ }^{228}$

Tais problemas de jurisdição de poder sobre essa vila se arrastaram até as primeiras décadas do século XIX. Segundo Paulo Jozé Miguel de Brito, que escreveu sua memória em 1816, "todos os rendimentos Reais da vila do Rio de S. Francisco, que mal e indevidamente" se recebiam na Junta da Fazenda de S. Paulo, deviam passar para

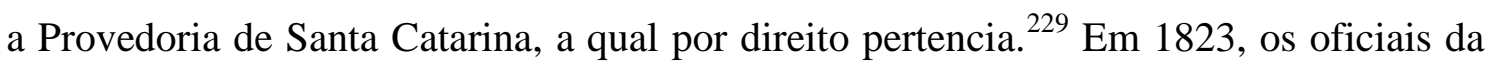
Câmara de São Francisco, em representação ao imperador D. Pedro I, solicitavam mudanças na divisão comarcã argumentando que,

A localidade e relações civis e militares que esta Vila tem com a nova Comarca de Santa Catarina, a que por lei não pertence, não obstante a persuasão dos Tribunais da Corte, nos fazem conceber o interesse que ela teria se com efeito se desmembrasse da Comarca de Paranaguá para a nova de sua capital, em benefício de S. N. e I. e da comodidade dos Povos. ${ }^{230}$

A vila de Lages, fundada em cima da serra, em 1770, por ordem do governador de São Paulo, Luís Antonio de Souza Botelho Mourão, o Morgado de Mateus, constituiria outro foco de tensões. Em 2 de maio de 1776, o governador Pedro Antônio da Gama Freitas queixava-se ao vice-rei Marquês do Lavradio que grande parte do

\footnotetext{
${ }^{228}$ AESP, DI, vol. 47, pp. 164 e ss. De Francisco de Barros Morais ao vice-rei, em 28 de julho de 1781.

${ }^{229}$ Paulo Joze Miguel de Brito. Memória Política sobre a Capitania de Santa Catarina. Lisboa, 1829, p. 91.

${ }^{230}$ Apud Carlos da Costa Pereira. História de São Francisco do Sul. Florianópolis: Ed. UFSC, 2004, p. 78. Como já referido, a ouvidoria da Ilha só passou a exercer jurisdição sobre a vila de S. Francisco em 1832.
} 
território da terra firme (referia-se a uns campos recém descobertos) pertencente à jurisdição daquela Ilha estava sendo usurpado por São Paulo.

Aquela Capitania tem lesado o Território deste Governo, quanto lhe tem sido possível, porque já pela demarcação verdadeira desta Jurisdição, ficava pertencendo a ela a sobredita Vila das Lages; porém a respeito da decisão destas terras, não pode haver questão de dúvida, pois que é muito para cá da dita Serra Geral, que naquela parte faz divisão das capitanias. O principal motivo da entrada naquele sertão foi o descoberto do Morro do Taió, que passa por tradição ser abundante de Ouro; não me consta que por ora haja mais nada, que terem-no conhecido (...). ${ }^{231}$

No governo de José Pereira Pinto, quando se começou a empreender efetivamente a abertura do caminho do sertão (da Ilha a Lages), as queixas sobre a quem pertenceria a jurisdição dessa vila continuaram. Contudo, essas disputas internas não constituíam um problema maior para os vice-reis e à Corte. Em resposta a um dos ofícios de Pereira Pinto, explicava o vice-rei:

Não duvido que os Limites desse Governo se tenham apertado com a usurpação dos Terrenos, que tem apropriado a Capitania de São Paulo, e que a Vila das Lages haja de pertencer ao Distrito dessa Ilha: mas sendo certo que, não devendo igualmente reclamar os Terrenos usurpados, por serem todos pertencentes a S. Maj., ainda que em diversos Distritos (...). ${ }^{232}$

Com a ampliação de suas jurisdições territoriais, as autoridades visavam não só a uma maior arrecadação tributária de suas alçadas, mas, principalmente, ao aumento do poder e prestígio social que isso lhes possibilitava.

Contudo, não se deve procurar nesse processo de organização política do espaço - limites territoriais, jurisdições de poder e estruturas hierárquicas da administração uma racionalidade fundamentada nas lógicas próprias do Estado contemporâneo. O que se nos apresenta hoje de maneira confusa e caótica obedecia a uma lógica específica do Estado Monárquico Absolutista. Imprecisão, vaguidade, contradição ou mesmo omissão das leis e regimentos a respeito da definição dos poderes e jurisdições acabava por fragilizar os poderes locais e fortalecer o poder régio. Como bem assinalou Maria Fernanda Bicalho, esta justaposição de funções e competências foi, até certo ponto, uma

\footnotetext{
${ }^{231}$ ANRJ, Cod. 68, vol. 01, fls. 03 a 05. De Pedro Antônio da Gama Freitas ao Marquês do Lavradio, em 02 de maio de 1776.

${ }^{232}$ AESP, DI, vol. 47, pp. 176 e 177. Do vice-rei ao governador José Pereira Pinto, em 31 de outubro de 1787.
} 
estratégia de governo, "uma política deliberada da Coroa, que chegou a incentivar um certo enfrentamento entre seus agentes justamente pelo motivo de se acharem isolados pela grande distância que os separava do Reino". ${ }^{233}$

Dessa forma começava-se a organizar nas esferas judicial, eclesiástica, fazendária, civil e militar, ainda que com circunscrições territoriais de poder não coincidentes, essa unidade político-administrativa de Santa Catarina. Somente com a anexação da vila de São Francisco à comarca da Ilha, em 1832, é que as jurisdições desses diferentes poderes encontraram-se justapostas.

Mas a organização política do espaço não se confunde com a ocupação e domínio efetivo dele. A definição diplomática de limites entre os impérios ibéricos na América, que resultou nos Tratados de Madri (1750) e de Santo Ildefonso (1777), não impediu que o vasto sertão que se abria por cima da serra ficasse por largo tempo ainda incógnito aos colonizadores. E mesmo entre os diferentes pontos de ocupação, entre uma vila e outra, persistiam espaços vazios, pouco conhecidos e às vezes de difícil circulação pelos colonizadores. No interior da própria Ilha de Santa Catarina, as pequenas freguesias formavam também espécies de "ilhas" isoladas entre si; “...vivem seus habitantes na longitude de três, sete, nove e mais léguas, sem terem quem lhes administre o Pasto Espiritual, sujeito às Contingências do Mar, ou ao longo e escabroso trânsito de terra”, colocava o governador João Alberto de Miranda Ribeiro em seu Relatório de $1797 .{ }^{234}$ No Continente do Rio Grande, a geografia era outra, e maior era a amplitude dos espaços vagos. ${ }^{235}$

Aquilo que António Manuel Hespanha chamou de a "miniaturização das circunscrições políticas" nos sistemas tradicionais de poder pode, consideradas as devidas especificidades, ser aplicado para a América Portuguesa Setecentista, ou seja, a formação de unidades políticas que não chegavam a preencher todo o espaço físico. Segundo ele, "Nos limites dos territórios não se encontravam, então, linhas de fronteira (limes), mas a extensão vazia, política e juridicamente sem significação. (...) Na periferia, existiam espaços abertos, com um estatuto jurídico e político indefinido - em

\footnotetext{
${ }^{233}$ Maria Fernanda Baptista Bicalho. Centro e periferia: pacto e negociação política na administração do Brasil colonial. In: Leituras: Revista da Biblioteca Nacional. Lisboa, n. 6, abr.-out., pp. 17-39, 2000, p. 21.

${ }^{234}$ AHU-SC, cx. 6, doc. 386, em 16 de novembro de 1797.

${ }^{235}$ BNRJ, Col. Martins - 22, 1, 28, n. 1. Segundo o parecer do engenheiro Francisco João Roscio, "Todas estas terras estão povoadas, mas todas desertas", porque ainda que muitos campos estejam despovoados, todos estão dados, e têm senhorios. "Relação de Francisco João Roscio a destinatário não mencionado sobre as condições dos caminhos de Santa Catarina ao Rio Grande de São Pedro, recursos econômicos e possibilidades estratégicas", sem local e data.
} 
rigor, eles não pertenciam ao território, mas também não estavam fora dele, constituindo, de alguma forma, zonas de expansão política legítima dum espaço político." 236

\subsubsection{Projetos de uma capitania-geral no Sul}

Com o restabelecimento do domínio português do extremo-Sul, em 1777, e da favorável conjuntura econômica que se seguiu nas duas décadas seguintes, surgiram projetos por parte do vice-rei Marquês do Lavradio e dos Secretários de Estado de se fazer da Ilha de Santa Catarina, com sua "terra firme", e do Continente do Rio Grande de São Pedro uma só capitania-geral. No Relatório que deixou ao seu sucessor, colocava o Marquês:

era o meu sistema a respeito daquela Capitania [de Santa Catarina], que ela fosse unida com a do Rio Grande de S. Pedro, e que ambas fizessem uma Capitania geral sujeita e subalterna ao Vice-Rei do Estado, ficando assim na Ilha, como nas suas duas partes do Continente do Rio Grande, isto é no Rio Pardo, e em Viamão em cada um destes lugares um Governador subalterno ao Comandante, a quem fossem dirigidas as ordens da Capitania general, e que eles fossem responsáveis da execução delas. ${ }^{237}$

Em verdade, pensar esses dois estabelecimentos coloniais como uma unidade não era idéia totalmente nova. De certa forma, já estava presente no processo de reconfiguração política empreendida, na década de 1730, especificamente, na carta régia de 11 de agosto de 1738, que mandava deixar todos esses territórios "debaixo de um só mando". Os quatorze anos de ocupação espanhola do sul (1763-1777) prejudicaram a política pombalina em dar seqüência ao processo de reestruturação administrativa daquelas colônias, principiado no reinado de D. João V. A reconquista do Rio Grande, em 1776, e da Ilha, em 1778, abria assim a possibilidade de restabelecer aqueles domínios sobre bases mais seguras e estáveis e, dessa forma, integrar definitivamente suas economias ao mercado colonial. Segundo o próprio Marquês,

Aquelas Províncias podem, não só dar toda a farinha de trigo necessária para a América, evitando-se por esta sorte que da Europa nos venha um gênero, que tanto lá necessitam; mas promovendo-se esta lavoura, e dando-se as providências necessárias para os prontos transportes dos efeitos daquele

\footnotetext{
${ }^{236}$ António M. Hespanha. As vésperas..., op. cit. pp. 90-92.

${ }^{237}$ Relatório do Marquês do Lavradio... (1779), in Visconde de Carnaxide, op. cit., p. 324.
} 
Continente, poderiam mandar ainda para a Europa uma grande porção desta mesma farinha.

Podem sair daquele Continente todos os anos para cima de duzentos mil couros, com os que vêm da Espanha (....). ${ }^{238}$

Com efeito, em meio ao "ressurgimento agrícola"239 (açúcar, algodão, fumo, anil, cacau, arroz e café), que se verificou no início dos anos 1780, o Rio Grande teve "um papel importante como espaço produtor e abastecedor de gêneros alimentícios charque e trigo - para outras regiões da América Portuguesa, secundado pela exportação de couros, dirigida ao mercado europeu"240.

Martinho de Melo e Castro, Secretário de Estado dos Negócios Estrangeiros, era também favorável à criação de uma capitania-geral no Sul.

Pelo que respeita a Ilha de Santa Catarina me persuado segundo o que vejo das Cartas Topográficas que V. Ex. ${ }^{\text {a }}$ me tem remetido, e de outras que eu tenho do Continente fronteiro a mesma Ilha, que o seu Plano poderá ser fortificar-se o referido Porto de Santa Catarina da parte da Terra firme; e formar-se de todos aqueles Distritos uma nova Capitania.

Se esta é a Idéia de V. Ex. ${ }^{a}$ a consequiência dela ao que me parece, será fazer Sua Majestade uma nova e útil aquisição nos seus próprios Domínios composta de excelentes Terras, quais são, os Campos da Vacaria, por cima do Albardão, ou da Serra Geral, e as que ficam entre o Uruguai e o Curitiba com o excelente Porto de Santa Catarina, para a exportação dos Frutos, e facilidades do comércio daquela considerável porção de continente até agora desprezada e desconhecida. ${ }^{241}$

Não se sabe por que motivo, mas o projeto não foi executado. Talvez, nesse momento, a insuficiência de rendimentos locais capazes de cobrir os soldos, salários e outros encargos que uma capitania-geral exigia. Outra questão que pode ter contribuído para isso foram as dificuldades encontradas pelo vice-rei para a execução do Tratado de Santo Ildefonso. Queixava-se ele da carência de recursos materiais e humanos para os

\footnotetext{
${ }^{238}$ Ibid., pp. 326 e 327.

${ }^{239}$ Expressão utilizada por Dauril Alden, em "O Período Final do Brasil Colônia: 1750-1808”, in Leslie Bethell. História da América Latina, América Latina Colonial, vol. II. São Paulo: Ed. USP, 2004, p. 556 e segs.

${ }^{240}$ Helen Osório. Estancieiros, Lavradores e Comerciantes na Constituição da Estremadura Portuguesa na América: Rio Grande de São Pedro, 1737-1822. Niterói: UFF-PPG-História (Tese de Doutorado), 1999, p. 165. De acordo com Maximiliano Menz, foi a partir desse momento, nos desdobramentos lusobrasileiros da crise do Antigo Sistema Colonial, que o Rio Grande se prendeu economicamente "à face americana do Império, selando a integração dos mercados coloniais brasileiros e formando uma divisão imperial do trabalho". Entre dois Impérios: Formação do Rio Grande na Crise do Antigo Sistema Colonial (1777-1822). São Paulo: USP-FFLCH (Tese de Doutorado), 2006, p. 19.

${ }^{241}$ BNRJ, Mss. CEHB, 5616 - 3, 4, 7, n. 113. De Martinho de Melo e Castro ao Marquês do Lavradio, em 31 de janeiro de 1779.
} 
trabalhos na demarcação dos limites. ${ }^{242}$ Como primeiro comissário português nas expedições fora nomeado, em 1781, Sebastião Xavier da Veiga, que já desempenhava o cargo de governador do Rio Grande (1780-1801). ${ }^{243}$

No final do século e início do seguinte, entretanto, a participação desse estabelecimento no comércio colonial tornou-se, de fato, bem mais significativa. ${ }^{244}$ No caso de Santa Catarina, destaca-se sempre a importância estratégica e militar do seu porto, mas não se pode menosprezar a participação de pelo menos dois produtos extraídos dali para os negócios coloniais: o óleo das baleias e a farinha de mandioca.

Quando, em 1796, o sucessor de Melo e Castro, Dom Rodrigo de Souza Coutinho, recolocou a necessidade de se criar a capitania geral do "Rio Grande de S. Pedro e S. ${ }^{\text {ta }}$ Catarina", indicou inclusive quem deveria ser o seu primeiro governador e capitão-general: Sebastião Xavier da Veiga. ${ }^{245}$

Segundo Maximiliano Menz, para o vice-rei, Conde de Rezende, a Ilha de Santa Catarina poderia, além de desempenhar a função de praça intermediária entre o Rio Grande e a metrópole, tomar o "lugar do Rio de Janeiro na triangulação do comércio asiático português, porque ali as Naus da Índia conseguiriam mais facilmente os alimentos para seguir a monção. Contudo, necessitava de ter uma 'praça' que trocasse as letras de Lisboa e Porto por prata e ouro, 'principal fundo das negociações d'Ásia', só que antes de mais nada era preciso receber as fazendas européias para que a praça ficasse em débito com a metrópole e, portanto, sempre trocasse as letras emitidas pelos seus credores europeus". 246

Enfim, em 1807, a Corte resolve implantar o referido projeto. Pelo menos dois fatos ocorridos no princípio desse século devem também ter contribuído para essa decisão: a anexação ao Rio Grande de São Pedro das ricas terras pastoris e agrícolas no sul - a região dos Sete Povos das Missões -, à revelia do Tratado de Badajós (1801); e a iminência da invasão francesa em Portugal e de suas colônias americanas.

A nomeação régia do seu primeiro governador e capitão general fora lavrada nos seguintes termos:

\footnotetext{
${ }^{242}$ Relatório do Marquês do Lavradio... (1779), op. cit., pp. 330 e segs.

${ }^{243}$ Em decorrência dessa comissão, ele teve de ser substituído interinamente no governo por três vezes entre 1784 e 1793.

${ }^{244}$ Helen Osório, op. cit., p. 166. Ver também Maximiliano M. Menz. Entre Dois Impérios..., op. cit. pp. 161 e segs.

245 ANRJ, Cód. 67, vol. 21, fl. 123. De Rodrigo de Souza Coutinho ao Conde de Rezente, em 9 de dezembro de 1796.

${ }^{246}$ Maximiliano M. Menz. Entre Dois Impérios..., op. cit., p. 219.
} 
Faço saber aos que esta Minha carta-Patente virem que Atendendo a já grande distância em que fica do Rio de Janeiro a Capitania do Rio Grande de São Pedro do Sul e o aumento que tem tido há anos em População, cultura, e comércio exigem pela sua importância quem me possa vigiar de perto sobre os interesses dos seus habitantes e da Minha Real Fazenda sou servido desanexar este governo da Capitania do Rio de Janeiro a que até agora era sujeito e erigi-lo em Capitania geral com a denominação de Capitania de São Pedro, o qual compreenderá todo o continente ao sul da capitania de São Paulo e as Ilhas adjacentes, e lhe ficará subordinado o governo da Ilha de $S^{\text {ta }}{ }^{\text {Catarina }}{ }^{247}$

Com essa reconfiguração, o governo da Ilha passaria a ser subalterno não mais à Capitania do Rio de Janeiro, mas à de São Pedro. Contudo, na prática, não foi o que se verificou. Seus governadores continuaram prestando contas ao vice-rei do Brasil e, a partir de 1808, com a transferência da sede do Império para o Rio de Janeiro, à própria Corte. De estatuto político indefinido e posição inferior em relação às capitanias-gerais, que se refletia numa estrutura administrativa, repasses de recursos e soldo e salários de seus oficiais reduzidos, adquiriria somente a partir de 28 de fevereiro de 1821, pelo menos juridicamente, condição de igualdade às demais unidades políticas do Brasil, quando as capitanias passaram a denominar-se províncias.

A criação da Capitania de São Pedro, em 1807, significou a consolidação da fronteira no Sul e a proeminência política e econômica que esse estabelecimento passou a exercer na região Meridional do Império Luso-Brasileiro.

\footnotetext{
${ }^{247}$ ANTT, Chancelaria de D. Maria I, Lv. 78, fl. 181v, Carta Patente de nomeação de D. Diogo de Souza, em 25.02.1807. [Grifo meu]
} 


\section{GOVERNADORES: OS HOMENS E SEUS OfÍCIOS}

Este Negócio é de tanta importância, que até se devera invocar primeiro a Graça do Espírito Santo, para que influísse no acerto da escolha dos mesmos Governadores; porque neles delega o Rei o Supremo poder de governar os Vassalos como Filhos, da mesma forma com que o Soberano Autor da Natureza lhe transferiu, e confiou a Autoridade Legislativa sobre os mesmos Vassalos, para os conservar em justiça e sociedade racional, como princípios, que fazem o seguro fundamento de uma brilhante Monarquia.

Francisco de Almeida Silva ${ }^{248}$

No decorrer do século XVIII e princípios do XIX, observam-se duas tendências, em certo sentido conflitantes, acerca da composição dos cargos políticos e administrativos do império português. Por um lado, havia a pressão tradicional de reservá-los aos indivíduos de acordo com a sua posição social, mantendo dessa forma a estrutura da sociedade de ordens do Antigo Regime. Por outro, colocava-se, cada vez com maior vigor, em sintonia com os princípios de racionalidade iluministas, a necessidade de adequá-los às imposições técnicas, profissionais e conjunturais específicas que os cargos exigiam, no reino e no ultramar. A Dissertação de Francisco de Almeida Silva, acima citada, é bom exemplo da tentativa de superar esse problema da política portuguesa com relação à escolha dos governadores das conquistas ultramarinas. $^{249}$

\footnotetext{
${ }^{248}$ Dessertação instrutiva sobre a escolha dos Governadores das Conquistas; a sua existencia nos Governos; e o seo regresso para a Corte (1780). ACL, Série Vermelha, Cód. 29, fl. 01.

${ }^{249}$ A Dissertação é destinada ao Frei Jozé Maine, com o intuito de que esse levasse às mãos do Secretário de Estado da Marinha e Ultramar, Martinho de Mello e Castro, como se pode perceber na carta em que o autor encaminha o documento (ver transcrição integral dela e da Dissertação no Anexo 2). Na Biblioteca da Ajuda, sob a cota 54-XIII-16 (136), há um excerto desse mesmo documento (6 $6^{\mathrm{a}}, 7^{\mathrm{a}}$ e $8^{\mathrm{a}}$ Máximas), porém, com algumas diferenças textuais em relação à cópia da ACL e, constando na última folha uma anotação, de outro punho, sugerindo ser ele de autoria de Rodrigo Jozé de Menezes, Governador e Capitão General da Capitania de Minas Gerais. Uma hipótese que merece ser considerada na investigação sobre a autoria do texto. É interessante destacar que essa Dissertação não foi incluída na análise de
} 
Neste capítulo, busca-se analisar quem foram os governadores nomeados para administrar a Ilha de Santa Catarina entre 1738 e 1807. Quais eram as qualidades dos nomeados - estatuto nobiliárquico, experiência militar, formação intelectual e administrativa? E quais foram os critérios de seleção e nomeação utilizados? Por fim, no conjunto mais amplo da administração portuguesa e dos estudos já realizados sobre o cargo, procura-se compreender as atribuições específicas - jurisdições de poder, níveis de subordinação e de autonomia - dos governadores aqui estudados.

\subsection{As qualidades dos governadores}

Pertencentes à alta administração colonial, os governadores (do governo geral, das capitanias principais, das subalternas ou de praças) foram figuras chave na expansão e consolidação do Império Português ultramarino no Oriente, na África, nas ilhas Atlânticas e na América. Eles representavam o braço mais forte do rei nas conquistas, a se oporem aos poderes concorrentes já fortemente vinculados à terra, como os capitãesmores, juízes ordinários, oficiais da câmara, provedores, comerciantes, padres, entre outros.

Os critérios de escolha desses homens, a análise de suas trajetórias e do exercício do cargo que ocuparam nos conduz à compreensão de aspectos fundamentais das políticas da monarquia portuguesa com relação às suas conquistas, da valorização e hierarquização dos espaços do império e, ainda, do próprio desenvolvimento da sociedade que iam governar. Foram agentes de ligação entre o reino de Portugal e os domínios ultramarinos; cada qual conduzindo de maneira específica as complexas relações de forças existentes entre, de um lado, as determinações emanadas da Corte, de que eram portadores e, de outro, as circunstâncias políticas, econômicas e socioculturais reais com que se defrontavam na sociedade colonial.

trabalhos históricos significativos que versam sobre a temática dos governadores do império português. Dauril Alden lamentou ter-se extraviado esse documento no IHGB, in Royal Government in Colonial Brazil. With Special Reference to the Administration of the Marquis of Lavradio, Viceroy, 1769-1779. Berkeley, 1968, nota 2, p. 4; Heloísa L. Bellotto fez referência a ele sem utilizá-lo, in Autoridade e Conflito no Brasil Colonial: o Governo do Morgado de Mateus em São Paulo (1765-1775). São Paulo: SEC, 1979, p. 66, nota 137; e a recente historiografia portuguesa, profícua em estudos sobre os governadores, parece desconhecê-lo. Por ora não se sabe quem era Francisco de Almeida Silva. Que cargo ocupava no governo? Qual sua posição social e que influência exercia na Corte? Pode-se depreender, no entanto, com base nesse documento, que era um homem não só bem instruído dos problemas políticos e administrativos do Império português de uma maneira geral e do cargo de governador em particular, como também ilustrado na forma de apresentá-los. 
Refletindo sobre os governadores de praças, o francês Antonio de Ville Tolozano, que teve sua obra traduzida para o português em 1708, entendia ser esse cargo um

dos mais importantes empregos de hum estado; (...) porque há algumas [Praças], de que depende uma Província inteira, ou também a maior parte de um estado; e a perda de semelhantes Praças não é menos prejudicial, do que a perda de um exército derrotado em um combate, porque este pode-se reunir, e refazer, e também segurar o país, retirando-se as Praças vizinhas; porém dificultosamente se recupera uma boa Praça depois de perdida; e portanto deve o Príncipe ter grande atenção na escolha dos Governadores de tais Praças, para depois senão achar enganado: deve os conhecer bem, e estar certo do seu talento, e mais partes que se requer para este emprego. ${ }^{250}$

Disso estava também convencido Francisco de Almeida Silva, para quem a escolha dos governadores das Conquistas era um "objeto da primeira ponderação", e ainda que "com o poder precário e restrito da sua Comissão", representavam a "Pessoa do Soberano, seu Legítimo Senhor, como Pai comum dos Vassalos da Corte, dos Reinos, e dos Limites da Capitania, que a cada um confere" ${ }^{251}$.

De fato, deles dependia, em grande parte, o sucesso da empresa colonial ultramarina para a monarquia portuguesa. Mas quais seriam as qualidades desejáveis de um governador colonial?

Deveriam ser prudentes, justos, leais vassalos à Monarquia, defensores do cristianismo e com reconhecida experiência militar. A questão da submissão vassálica dos governadores era reiteradamente colocada nos preâmbulos das cartas, requerimentos e petições que dirigiam aos seus superiores, às vezes de forma exagerada como fez o governador da Ilha Francisco de Souza de Menezes ao Secretário de Estado Francisco Xavier de Mendonça Furtado.

\footnotetext{
${ }^{250}$ BRG, XVIII - 94 (Col. Silva Paes). Antonio de Ville Tolozano. O Governador de Praças, obra muy util, e necessária não só para os governadores das Praças; mas tambem para todos os officiaes de guerra, que quizerem aprender a doutrina militar, e as suas obrigações principalmente nos presidios. Lisboa, 1708 [Tradução para o português de Manuel da Maia, do original De la charge des gouverneurs des places... Paris, 1639. (informação extraída de Marlon Salomon. O Saber do Espaço. Ensaio sobre a geografização do espaço em Santa Catarina no século XIX. Florianópolis: Tese de doutorado, PPGHistória, CFCH/UFSC, 2002, P. 23)]. Interessante destacar que essa obra fazia parte da biblioteca particular do governador da Ilha de S. Catarina José da Silva Paes, cf. Ana Cristina Araújo. Livros de uma Vida: Critérios e modalidades de constituição de uma livraria particular no Século XVIII, in Revista de História das Idéias. Vol. 20 - O Livro e a Leitura. Coimbra, 1999, p. 173. Agradeço a Profa. Iris Kantor pela indicação desse artigo.

${ }^{251}$ Dessertação instrutiva... op cit. fl. 01.
} 
Meu Amo, e meu Ex. ${ }^{\text {mo }}$ Snr. de toda a minha Veneração, e Respeito. Como o mais humilde criado de V.Ex. ${ }^{a}$ Reconhecendo a minha inutilidade, e venerando a superioridade da Pessoa de V.Ex. ${ }^{\text {; }}$ e do seu grande nascimento; e virtudes de que o altíssimo dotou a V.Ex. a, e lembrando-me da muita honra que devo a V.Ex. ${ }^{\text {a }}$; e a toda a sua Ilustre descendência; fundado nestas Razões espero que V.Ex. ${ }^{a}$ desculpe o meu atrevimento, pedindo-lhe me se ponha de joelhos aos seus pés beijando-lhe reverentemente a mão com o amor de filho e com submissões de escravo. ${ }^{252}$

Era aconselhável também que fossem homens de boa condição econômica, possuidores de propriedades ou de outros bens, como forma de evitar que buscassem no cargo interesses pessoais pecuniários. Tolozano destacou ainda, entre outras virtudes, que todo o governador devia ser valoroso,

como se se dissera, que o que quer ser soldado, deve ter espada: são estas cousas tão inseparáveis, que dizendo é Governador, se supõe ao mesmo tempo que é valoroso, e por consequiência isento dos dois vícios, que são os extremos desta virtude, a saber a temeridade, e a covardia. (...) Um Governador deve ser prudente, seguro, que se não perturbe de cousa alguma, e dê ânimo aos demais, que aonde for necessário mostre ousadia, e que saiba porém conservar a sua pessoa, como a Praça, sustentando-a em quanto puder; e se ele quer perecer, há de ser no último esforço, e na última resistência, que na Praça puder fazer. ${ }^{253}$

Na carta patente de Marechal de Campo a Pedro de Azambuja Ribeiro, futuro governador da Ilha, constava uma série de valorosas missões militares a serviço de Portugal, combatendo os mouros, socorrendo a praça de Mazagão, comboiando as naus da Índia e outras tantas honrosas ações. ${ }^{254}$

O governador Francisco Antonio Cardoso de Menezes e Souza foi promovido a Coronel de Infantaria do Rio de Janeiro por ter desempenhado, nos quatorze anos de exercício militares continuados, suas obrigações nos referidos postos "sempre com distinto procedimento, atividade e zelo...". 255

Precisavam ainda esses oficiais estar isentos de outros vícios: a impiedade; a avareza, pois, pagando mal seus soldados, seria "aborrecido do povo"; a gula: "o vício do vinho (...) por que um homem ébrio perde a razão". E mais, o governador teria de

\footnotetext{
${ }^{252}$ AHU-SC, cx. 3, doc. 77. Em 30 de novembro de 1768.

${ }^{253}$ Antonio de V. Tolozano. O Governador de Praças..., op. cit., pp. 6 e 7.

${ }^{254}$ ANTT, Chancelaria de D. João V, Lv. 82, fl. 370. Em 23 de setembro de 1733.

${ }^{255}$ ANTT, Chancelaria de D. José I, Lv. 64, fl. 276v. Em 13 de março de 1752.
} 
saber as leis militares e as civis; amar a sua Praça "mais que qualquer coisa do mundo"; e ainda, prever tudo a tempo para se evitar uma surpresa. ${ }^{256}$

Todos esses atributos, em verdade, deviam reunir-se em uma só e essencial qualidade: a nobreza de sangue. ${ }^{257}$

Segundo Nuno Monteiro, “a noção de 'qualidade', central na cultura política das elites dos séculos XVII e XVIII, reportava-se à 'qualidade do nascimento', ou seja, ao estatuto que cada um tinha antes mesmo de nascer". No final do Antigo Regime, os tratados de nobreza admitiam que a nobreza era uma dignidade derivada tanto dos pais como da concessão do Príncipe, permitindo, assim, distinguir entre uma nobreza natural, derivada da 'qualidade de nascimento', e a nobreza adquirida por outras vias. Contudo, o ideal nobiliárquico manteve-se "sempre prisioneiro desse referencial originário e fundador, em larga medida associado a funções militares". ${ }^{258}$

Em princípio, todos os cargos de governadores - assim como também dos chefes militares e dos oficiais da administração - do império português deviam ser confiados a pessoas nobres, ou, mais restritamente, como afirmam Nuno Monteiro e Mafalda Cunha, detentoras do estatuto de fidalguia. ${ }^{259}$

Na prática, essa regra mostrou-se flexível, fosse por causa da própria fluidez ou mesmo diluição - da noção de nobreza ${ }^{260}$, tanto maior quanto mais se aproximava do final do Antigo Regime, fosse porque os diferentes espaços do ultramar incorporados ao império português (a vasta extensão das conquistas a demandar um número crescente de oficiais e outros fatores ligados às circunstâncias específicas e conjunturais do lugar que iam governar como, por exemplo, a existência de conflitos militares abertos ${ }^{261} \mathrm{em}$ território de disputa) exigiam outras qualidades aos governadores nomeados. Apesar das restrições por parte da Corte de que se ocupassem os cargos de governança nas conquistas com os nacionais, o estado de guerra viva com os castelhanos no Sul exigiu

\footnotetext{
${ }^{256}$ Antonio de V. Tolozano. O Governador de Praças..., op. cit., pp. 8 e 9.

${ }^{257}$ Cf. Dauril Alden. Royal Government..., op. cit., pp. 3 e 4; e A. J. R. Russell-Wood. Governantes e Agentes, in Francisco Bethencourt e Kirti Chaudhuri (Orgs.) História da Expansão Portuguesa - vol. 3. O Brasil na Balança do Império (1697-1808). Lisboa: Temas e Debates, 1998, p. 173.

258 Nuno Gonçalo Monteiro. O 'Ethos' Nobiliárquico no final do Antigo Regime: poder simbólico, império e imaginário social, in almanack braziliense, n. 02, nov. 2005, p. 6.

${ }^{259}$ Mafalda S. da Cunha e Nuno G. Monteiro. Governadores e capitães-mores do império atlântico português nos séculos XVII e XVIII, in Nuno G. Monteiro, Pedro Cardim e Mafalda S. da Cunha (Orgs.) Optima Pars - Elites Ibero-Americanas do Antigo Regime. Lisboa: ICS, 2005, p. 216.

${ }^{260}$ Nuno G. Monteiro. Notas sobre Nobreza, Fidalguia e Titulares nos Finais do Antigo Regime. Ler História. Lisboa, n. 10, 1987, p. 21 e 23 e passim.

${ }^{261}$ Mafalda S. da Cunha. Governo e governantes do Império português do Atlântico (século XVII), in Maria Fernanda Bicalho e Vera Lúcia Amaral Ferlini (Orgs.) Modos de Governar: Idéias e Práticas Políticas no Império Português - séculos XVI a XIX. São Paulo: Alameda, 2005, p. 73.
} 
homens com reconhecida experiência militar e profundo conhecimento do espaço. Isso explica por que indivíduos como Rafael Pinto Bandeira, nascido na América e filho de pais americanos, proprietário de muitas léguas de terras e de milhares de cabeças de gado na fronteira sul, chefe de bandos e devassado no Conselho de Guerra por crime de contrabando, se tornasse governador interino do Rio Grande de São Pedro por duas vezes, entre 1784 e 1793. ${ }^{262}$ Manoel Soares Coimbra e Joaquim Xavier Curado, homens também com fortes vínculos familiares e patrimoniais na América, tornaram-se governadores efetivos da Ilha de Santa Catarina nos anos de 1791 a 1793 e de 1800 a 1805, respectivamente. Todos eles alcançariam alguma distinção honorífica no final de suas vidas pelos serviços militares prestados à monarquia.

Deve-se considerar ainda, no decurso do século XVIII, uma tendência crescente da administração portuguesa pela valorização técnica e profissional dos agentes e governantes do império.

A clássica divisão trinitária, os três estados - clero, nobreza e povo (oradores, defensores e lavradores) - não traduz as distintas hierarquias estatutárias existentes na sociedade portuguesa moderna. ${ }^{263}$ Em comparação com outras aristocracias da Europa, Nuno Monteiro constatou que Portugal era um "reino de nobreza numerosa e, em parte por isso, fortemente polarizada, diversificada e hierarquizada, ao ponto de, no final do Antigo Regime, se poder duvidar da identidade comum dos muito diversos sectores abrangidos pelos vários graus de nobreza e de fidalguia - duas coisas distintas, no caso português".

Os fidalgos (filhos d'algo) formavam uma categoria superior no interior da nobreza. Pertenciam à classe da Nobreza Titulada, com privilégios especiais e títulos específicos, ao contrário do que acontecia com os da simples nobreza. ${ }^{264}$ "Todo fidalgo era nobre. Nem todo nobre era fidalgo", explica Joaquim Romero Magalhães e, quando

\footnotetext{
${ }^{262}$ Para uma análise da trajetória desse homem e, sobretudo, do conflito entre ele e o governador José Mercelino de Figueiredo, que resultou na Devassa citada ver: Augusto da Silva. Rafael Pinto Bandeira: de Bandoleiro a Governador. Relações entre os poderes privado e público em Rio Grande de São Pedro. Porto Alegre: UFRGS, IFCH-PPG História (Dissertação de Mestrado), 1999.

${ }^{263}$ Ver, entre outros, Nuno Gonçalo Monteiro. O Crepúsculo dos Grandes: A casa e o património da aristocracia em Portugal (1750-1832). Lisboa: Imprensa Nacional-Casa da Moeda, 1996, p. 19; do mesmo autor Elites e Poder - Entre o Antigo Regime e o Liberalismo. Lisboa, ICS, 2003; Joaquim Romero Magalhães. "A Sociedade", in idem (Coord.) No Alvorecer da Modernidade. Lisboa: Editorial Estampa, 1997, pp. 399 e ss. (Col. História de Portugal, vol. 3, Dir., José Mattoso); e António Manuel Hespanha. A Nobreza nos Tratados Jurídicos dos Séculos XVI a XVIII, in Penélope - Fazer e Desfazer a História. Dossiê Nobrezas e Aristocracias. Lisboa, n. 12, pp. 27-42.

${ }^{264}$ Nuno G. Monteiro. Governadores e capitães-mores do Império Atlântico português no século XVIII, in Maria F. Bicalho e Vera Ferlini (Orgs.) Modos de Governar..., op. cit., p. 97 e passim.
} 
um homem era "designado só como nobre ficava numa zona indefinida e difusa de transição entre o plebeu e o fidalgo". ${ }^{265}$

Ao longo dos séculos XVII e XVIII, afirma Nuno Monteiro, “a base da pirâmide nobiliárquica foi-se alargando cada vez mais, enquanto o topo, pelo menos até meados de setecentos, se cristalizou progressivamente, com a constituição de uma "primeira nobreza de corte' claramente circunscrita e homogâmica". Dessa forma, "ao invés da polarização entre nobres e não nobres (ou nobres e mecânicos ${ }^{266}$ ), que só tem relevância a certos níveis, aquilo com que nos defrontamos é com uma miríade de distinções e hierarquias e com a extrema dificuldade em definir uma estratificação nobiliárquica abrangendo toda a Monarquia". ${ }^{267}$

Não obstante isso, e alertando para os limites de qualquer classificação esquemática, o autor propõe a seguinte estratificação da aristocracia portuguesa no final da Época Moderna: "Na base, uma vasta e imprecisa categoria que se estendia desde a 'nobreza simples' aos cavaleiros de hábito, a qual incluía todos os licenciados e bacharéis, os oficiais do exército de primeira linha, milícias e ordenanças, os negociantes de grosso trato, os juízes e vereadores de um número indeterminado de vilas e cidades, enfim, todos os que "viviam nobremente"". Por serem muitos, encontravam-se desqualificados socialmente, levando-os a uma intensa disputa por graças e mercês, como os hábitos das Ordens Militares (de Cristo, de Avis, e de Sant'Iago). Acima deste, um grupo intermediário formado por alguns milhares de fidalgos. 'Por fim, a 'primeira nobreza da Corte', constituída por cerca de centena e meia de senhores, comendadores e detentores de cargos palatinos, no cume da qual se encontrava a meia centena de casas dos Grandes do reino". ${ }^{268}$

E de qual desses grupos provinham os governadores nomeados para as conquistas? Isso dependia de uma série de fatores ligados à importância do território e, portanto, do cargo para a Coroa Portuguesa e, também, do interesse dos indivíduos pelos postos de comando no além-mar.

A extensão das conquistas e, conseqüentemente, dos muitos postos de governo, exigia a flexibilização dos critérios de escolha. Não havia como se restringir à fidalguia. Para Francisco de Almeida Silva, que parecia saber conciliar os princípios do Antigo

\footnotetext{
${ }^{265}$ Joaquim R. Magalhães. “A Sociedade”, op. cit., p. 416.

${ }^{266}$ Na definição de Luís da Silva Pereira de Oliveira em sua obra Privilegios da nobreza, e fidalguia de Portugal... de 1806, são "oficios mecânicos" os "que dependem mais do trabalho do corpo do que do espírito". Citado por Nuno G. Monteiro in Notas Sobre a Nobreza... op. cit., p. 21.

${ }^{267}$ Nuno G. Monteiro. Governadores e capitães-mores..., op. cit., p. 98.

${ }^{268}$ Nuno G. Monteiro. Elites e Poder, op.cit., pp. 144-45.
} 
Regime com as novas necessidades, isso não consistia em problema. Estava ele convicto de que não seria somente nas "duas classes da Nobreza Cortesã” que se achariam

as pessoas adequadas, e próprias para governar as Conquistas; porque isso seria coartar a Liberalidade com que a Destra Onipotente do Rei dos Reis, espalhou igualmente na Corte, como nas Províncias desta Monarquia, o grande número de pessoas nobres aptas, próprias, e dignas de diferentes Empregos.

Até porque, segundo ele, seria um absurdo pensar que a escolha tivesse que se restringir ao pequeno número da Nobreza da Corte

sabendo, há mais de vinte anos, que este mesmo número se reparte em diferentes destinos, proporcionados às suas propensões, e vocações: Porque os Primogênitos das Casas, que assentam praça, são mui poucos em paralelo com o número de seus Irmãos; e entre esses poucos, são mui raros os que têm gênio para governar uma Capitania: Há muitos virtuosos, instruídos, e Sábios, capazes do serviço do Paço, e do Corpo Diplomático, mas nem por isso se segue, que são próprios para Governadores; nem se devem reputar inúteis, se a Natureza os não preparou com estes princípios. Os Filhos Segundos seguem a vida das Letras, e se recolhem depois à Basílica Patriarcal, ou às Ordens Religiosas, como abrigo decente à sua Pessoa e estado; e alguns se anexam também aos Corpos Diplomático, e Jurídico, por que os seus gênios, e os seus estudos, lhe abriram aqueles caminhos: por este modo qual pode ser o resto, que fique do que é pouco, se esse pouco por esta forma se reparte? ? $^{26}$

E ia mais longe ainda Almeida Silva em sua instrução. Deviam ser "dignos da benigna reflexão do Soberano nesta importante matéria" os próprios "Nacionais daqueles dilatados continentes", visto que eles tinham a "felicidade de serem Vassalos desta Monarquia, pela Piedade, Religião, Providência, Liberalidade, e Justiça dos Soberanos”. Mas alertava que não bastava colocar os nomes em uma urna e escolher aleatoriamente os governadores para os diferentes lugares, pois podia incorrer-se no grave erro de constituir um governador para a Índia sendo-o próprio para governar o Pará ou o Mato Grosso, ou de reverso modo, querendo sortear um governador para Goiás sair outro perfeito para vice-rei do Brasil. Era preciso fazer as "combinações dos Países com os Sujeitos, e com a Conjuntura”, pois, assim como os temperamentos dos corpos não são os mesmos em um e outro, igualmente, "dentro de um mesmo Estado, e de um Reino, há nas suas Províncias diferentes costumes, opostos diametralmente do

\footnotetext{
${ }^{269}$ Francisco de A. Silva. Dessertação instrutiva..., op. cit., os dois trechos na fl. 3.
} 
Sistema político, urbano, e civil da Capital do Estado, ou da Corte do Reino". E completava ele,

Esta urgência da Conjuntura, deve ser o primeiro móvel da mesma escolha; pois não basta encontrar-se nos Escolhidos as propriedades do Governador, é igualmente necessário refletir na ocasião para escolher o mais virtuoso, se o Continente estiver em paz, e o melhor Soldado, se se achar em guerra: E ainda muito mais em tempo de algumas perturbações domésticas dos mesmos Povos, em cujas circunstâncias é trabalhosa a escolha; porque com dificuldade se descobre um homem severo sem crueldade; benigno sem frouxidão; belicoso sem cólera, e prudente com sagacidade. ${ }^{270}$

Não se sabe se essa Dissertação chegou de fato às mãos do Secretário de Estado Martinho de Melo e Castro como queria Almeida Silva. Segundo ele próprio externou na carta de apresentação do documento, mostrou "a três pessoas das mais Doutas desta Corte, e a dois homens instruídos em Governos", e que "todos o aprovaram com elogios grandes", dizendo ainda que, dois daqueles cinco encorajaram-no a que ele fosse pessoalmente entregar ao rei e ao ministro de Estado, "pelo benefício que poderia resultar às Conquistas das importantes matérias, que tratavam as mesmas Máximas". ${ }^{271}$

Seja como for, as idéias colocadas por Almeida Silva não eram nada mirabolantes para aquele tempo. Tocavam em questões específicas e representavam demandas concretas vindas do ultramar, e que os ministros tinham de lidar na montagem política daqueles governos. A flexibilização nos critérios de escolha dos governadores constituía já uma prática da monarquia. Embora, no século XVIII, identifique-se um processo de aristocratização dos critérios de recrutamento dos governadores às capitanias principais ${ }^{272}$, o universo dos candidatos habilitados à ocupação dos postos era já bastante elástico. $\mathrm{O}$ mesmo não se pode dizer de outras reflexões presentes na Dissertação. As propostas de aproveitamento dos nacionais para aqueles cargos e o aumento da autoridade e autonomia dos governadores defendidos por Almeida Silva seriam, como se verá mais adiante, pontos mais delicados e que a Monarquia não estava disposta a ceder.

O problema da conjuntura dos diferentes espaços seria, com efeito, um dos critérios que a Coroa levaria em conta para a escolha dos governadores.

\footnotetext{
${ }^{270}$ Ibid., fls. 1v. e 2.

${ }^{271}$ Ver Anexo II, fl. I.

${ }^{272}$ Mafalda S. da Cunha e Nuno G. Monteiro. Governadores e capitães-mores..., op. cit., p. 224.
} 
O império português, explica Mafalda Cunha, “era constituído por territórios de desigual valor para a Monarquia", podendo ser hierarquizado "a partir do seu peso econômico, militar e simbólico". A titulatura dos cargos de governo, os ordenados dos governantes e a atração social que suscitavam, constituem elementos de identificação dessas hierarquias. A nomeação dos governadores podia decorrer "tanto dos critérios sociais e de mérito pré-definidos pelo poder régio para cada território, quanto da construção individual da decisão de aceitar ou não o posto. E esta era influenciada pelo resultado das negociações sobre mercês que o governante indigitado iniciava antes de aceitar o cargo e pela situação concreta em que se encontrava o próprio território". ${ }^{273} \mathrm{O}$ estatuto nobiliárquico dos governadores serve, portanto, como um "bom indicador da importância atribuída pelo centro da Monarquia a cada capitania". ${ }^{274}$

Com base num extenso quadro prosopográfico dos governadores e capitãesmores do império português, fundamentado em informações colhidas em fontes primárias (principalmente em arquivos portugueses) e bibliografia específica (genealógica e historiográfica), Nuno Monteiro e Mafalda Cunha apresentam um mapeamento do perfil social dos nomeados em relação aos diferentes espaços das conquistas para os quais eram designados. ${ }^{275}$

Os governadores nomeados para Angola, por exemplo, eram todos fidalgos inequívocos. Alguns pertencendo, inclusive, à primeira nobreza de Corte, o que demonstra a importância que tinha a economia angolana nos negócios do Atlântico Sul. Outros espaços, como a Índia e o norte da África, embora não figurando mais como eixos principais do comércio ultramarino português no século XVIII, continuavam tendo seus postos de governança como representativos de alta distinção honorífica. $\mathrm{O}$ mito de heroicidade e de tradição guerreira presente no imaginário português Setecentista asseguravam àqueles lugares "uma indisputada primazia na escala de prestígio da monarquia". ${ }^{276}$ Ao contrário, Cabo Verde, Guiné e São Tomé, devido a crescente periferização econômica que sofriam nesse mesmo tempo, tinham seus governos em baixa cotação.

\footnotetext{
${ }^{273}$ Mafalda S. da Cunha. Governo e governantes..., op. cit., pp. 72 e 73.

${ }^{274}$ Nuno G. Monteiro. Governadores e capitães-mores do Império Atlântico português no século XVIII, in Maria F. Bicalho e Vera Ferlini (Orgs.) Modos de Governar..., op. cit., p. 104.

275 Projeto denominado Optima Pars, atualmente coordenado pelo Prof. Nuno G Monteiro no ICS/Universidade de Lisboa. Agradeço a ele a disponibilização desse banco de dados para esta pesquisa.

${ }^{276}$ Mafalda S. da Cunha e Nuno G. Monteiro. Vice-reis, governadores e Conselheiros de Governo do Estado da Índia (1505-1834). Recrutamento e Caracterização social, In Penélope - Fazer e Desfazer a História. Lisboa, n. 15, 1995, p. 116.
} 
Na América Portuguesa, a reorientação dos interesses econômicos no decurso do século XVIII, do norte para o centro-sul, como já tratado no capítulo anterior, explica a valorização que tiveram os governos de São Paulo (após sua restauração, em 1765), das capitanias mineiras (das Gerais, de Goiás e de Mato Grosso) e do Rio de Janeiro. Para seus governos iam, geralmente, os "fidalgos mais selecionados e politicamente significativos" 277 , que concorriam também aos cargos palatinos. Nessa posição encontravam-se, por exemplo, homens como D. Antonio Rolim de Moura Tavares, $1^{\circ}$ Conde de Azambuja, Comendador de Zamora, Presidente do Conselho da Fazenda, Governador e Cap. General do Mato Grosso (1751-62) e vice-rei do Brasil (1766-69); André José de Melo e Castro, $4^{\circ}$ Conde de Galveias, couteiro-mor da Casa de Bragança, comendador de Santiago de Lanhoso e de Santa Maria da Penha, governador e Cap. General das capitanias de Minas Gerais (1732-35) e da Bahia (1735-49), foi também diplomata na Santa Sé em Roma por duas vezes; Gomes Freire de Andrade, Conde de Bobadela, comendador de N. Senhora da Conceição de Vila Velha de Rodão e governador e capitão general, entre 1748 e 1763, de todo o centro-sul da América portuguesa (incluía sob o seu comando os governos do Rio de Janeiro, de São Paulo, de Goiás, de Cuiabá, de Mato Grosso, de Santa Catarina, de Rio Grande de S. Pedro e da Colônia de Sacramento); D. Pedro Miguel de Almeida Portugal, o Conde de Assumar, comendador de Sta. Maria da Graça do Monforte no Alentejo, membro do Conselho de Guerra, Mordomo-mor da Rainha Ana Maria de Áustria, governador da capitania de São Paulo e Minas do Ouro (1717-21) e Vice-Rei do Estado da Índia. ${ }^{278}$

Quanto à Ilha de Santa Catarina, se por um lado seu posto de governança valorizava-se por ocupar posição estratégica fundamental em território de disputa entre as duas nações ibéricas, e ela tivesse se constituído, de fato, como base política e militar aos planos expansionistas da Coroa Portuguesa nesse espaço, por outro, o governador estava juridicamente subordinado ao Rio de Janeiro, o que reduzia o status do cargo. Na mesma condição encontravam-se os postos de Rio Grande de São Pedro e da Colônia de Sacramento e a qualidade nobiliárquica dos seus governadores seguiu padrão muito semelhante: poucos fidalgos, muitos nobres de nobreza reconhecida ou duvidosa e nenhum deles pertencentes à primeira nobreza de Corte. ${ }^{279}$

\footnotetext{
${ }^{277}$ Mafalda S. da Cunha e Nuno G. Monteiro. Governadores e capitães-mores... op. cit., pp. 222 e 225.

${ }^{278}$ Banco de dados Optima Pars.

${ }^{279}$ Mafalda S. da Cunha e Nuno G. Monteiro. Governadores e capitães-mores..., op. cit., p. 225.
} 


\subsubsection{Nobres governadores na vila do Desterro}

A análise do estatuto social dos quinze governadores da Ilha de Santa Catarina entre 1739 e 1807, mostra que provinham da segunda e da terceira classe da aristocracia portuguesa. Uns poucos em posições sociais mais confortáveis - fidalgos já de nascimento -, a maioria, oriunda do grande e impreciso grupo da chamada "nobreza simples", ou até de origens mais humildes, que alcançaram ao longo de suas carreiras alguma distinção honorífica por meio dos serviços prestados nas conquistas.

Segundo a classificação do Optima Pars, que não incluiu em seu rol os governadores Patrício Manuel de Figueiredo e Pedro de Azambuja Ribeiro, três eram fidalgos, seis nobres, um mecânico, dois nascidos no Brasil e outro de estatuto ignorado. Consideraram os autores o estatuto social à data de nascimento, uma vez que buscavam "identificar percursos, e não os pontos de chegada". 280

José da Silva Paes, primeiro governador da Ilha de Santa Catarina (1739-49), nasceu na freguesia de Nossa Senhora das Mercês, em Lisboa, no ano de $1679 .{ }^{281}$ Seus pais, Roque Gomes Paes e Dona Clara Maria da Silva eram abastados, mas não nobres. Em 1705, ele requereu mudança do hábito de Santiago, que lhe chegara às mãos por via de sua mulher, D. Maxima Teresa da Silva (ou de Brito), para o de Nosso Senhor Jesus Cristo, "em consideração aos seus próprios serviços", mas lhe foi negado, visto que seu avô paterno havia sido "Piloto de Navios da Carreira do Brasil, ou seja, um ofício mecânico e, por este impedimento se julgou não estar capaz de entrar na Ordem". 282

Com efeito, das três ordens militares - Avis, Santiago e de Cristo - esta última era a que mais poder e prestígio propiciava ao nobilitado. ${ }^{283} \mathrm{Em} \mathrm{1715}$, Silva Paes reapresenta a petição obtendo dessa vez, mas “em sua vida somente", o direito àquela distinção honorífica ${ }^{284}$ e mais a Tença efetiva de $12 \$ 000$ réis, como remuneração de

\footnotetext{
${ }^{280}$ Mafalda S. da Cunha e Nuno G. Monteiro. Governadores e capitães-mores..., op. cit., especialmente o Quadro n. 8, p. 214 e 251.

${ }^{281}$ Cf. Walter Piazza. O Brigadeiro José da Silva Paes: Estruturador do Brasil Meridional. Rio Grande: Ed. FURG, 1988, p. 23.

282 Citado por Walter Piazza. O Brigadeiro... op. cit., p. 43.

${ }^{283}$ Tratava-se de fato da mais poderosa instituição religiosa e militar portuguesa. Foi fundada, em 1315, pelo rei D. Diniz ao nacionalizar os bens que possuía no Reino a Ordem dos Templários. Cf. Evaldo Cabral de Mello. O Nome e o Sangue: uma Parábola Familiar no Pernambuco Colonial. 2 ed. Rio de Janeiro: Topbooks, 2000, p. 21. Para um estudo detalhado sobre as ordens militares no Império Português ver: Fernanda Olival. As Ordens Militares e o Estado Moderno: Honra, Mercê e Venalidade em Portugal (1641-1789). Lisboa, 2001.

${ }^{284}$ Ana Cristina Araújo. Livros de uma vida..., op. cit., p. 153.
} 
bons serviços. ${ }^{285}$ Segundo Ana Cristina Araújo, “a partir de 1716 passa a gozar do mais elementar capital de prestígio social, de onde manam honras, atributos e favores sem conta. E grande gala fazia na ostentação pública desse tão sofrido merecimento, pois, para usar em ocasiões especiais, guardava numa arca um hábito de cavaleiro de Cristo em rubis e diamantes, avaliado em 180 mil réis, uma cruz de ouro, estimada em 20 mil réis, e o respectivo cordão, também em ouro, no valor de 16 mil réis". ${ }^{286}$ Após ter desempenhado diversos serviços à Monarquia como engenheiro-militar em Açores, no Rio de Janeiro, na Colônia de Sacramento, no Rio Grande de São Pedro e na Ilha de Santa Catarina, projetando e erguendo fortalezas, obras públicas, como o Aqueduto da Carioca, e fundando povoados, Silva Paes retornou ao reino na década de cinqüenta, já com idade avançada. Seu domicílio, situado próximo à bica dos Anjos na cidade de Lisboa, como consta em seu testamento e inventário, era um pequeno palacete, farto em espaço, provido de loja e andar superior, com casa de moços, cocheira, cavalariça e capoeiras, com bons móveis, pratarias e uma biblioteca composta por 437 volumes. "No estilo e na praxe - assegura Cristina Araújo - Silva Paes vivia, sem sombra de dúvida, à lei da nobreza". Nessa condição, ele morreu, em 14 de novembro de $1760{ }^{287}$

Patrício Manuel de Figueiredo e Pedro de Azambuja Ribeiro exerceram a governança interina da Ilha, em substituição a Silva Paes entre 1743 e 1746. Não obstantes as poucas informações que deles se têm, pode-se dizer que engrossavam o grupo dos que pertenciam à nobreza simples. Eram militares com larga folha de serviços prestados no reino e nas conquistas ultramarinas. Manuel de Figueiredo, com quase oitenta anos de idade, "cincoenta do Real Serviço", encontrava-se no Rio de Janeiro quando requereu licença para se recolher ao Reino, pois, por padecer de "moléstias capitais", desejava voltar aos "ares pátrios com a esperança de poder viver neles mais alguns anos". ${ }^{288}$ Levaria ainda mais dois anos para que seus serviços fossem reconhecidos e lhe concedessem a tão almejada mercê do título da Ordem de Cristo. Recebera nessa ocasião, para poder desfrutar em cada ano de sua vida que, seguramente, não se prolongaria por muito tempo mais, a tença de $18 \$ 000$ réis efetiva paga no “almoxarifado do paço da Madeira”, em Lisboa. ${ }^{289}$

\footnotetext{
${ }^{285}$ Walter Piazza. O Brigadeiro... op. cit, p. 44.

${ }^{286}$ Ana Cristina Araújo. Livros de uma vida..., op. cit., p. 153.

287 Ibid., p. 157.

${ }^{288}$ ANTT, Chancelaria de D. José I, Lv. 70, fl. 174v. Provisão a Patrício Manoel de Figueiredo vir para o reino, em 9 de novembro de 1761.

${ }^{289}$ ANTT, Chancelaria de D. José I, Lv. 50, fl. 137. Tença a Patricio Manoel de Figueiredo, em 14 de outubro de 1763.
} 
Mais escassas são as informações sobre Azambuja Ribeiro. Afora sua trajetória militar, que mais adiante se mencionará, sabe-se apenas que, em 1730, chegou a pleitear, sem sucesso, o posto de governador das Minas de Goiás ${ }^{290}$ e, segundo Pizarro Araújo, fora cavaleiro professo da mesma ordem. ${ }^{291}$

Outros governadores de nascimentos obscuros ${ }^{292}$ obtiveram também acesso às ordens militares. Manuel Escudeiro Ferreira de Souza, governador de 1749 a 1753, nasceu em Lisboa por volta de 1688. Filho de um "alfaiate de Loja aberta", mecânico portanto, e de "mulher de humilde prole", obteve mesmo assim o Hábito de Cristo em $1719 .^{293}$

José de Mello Manuel, embora sendo filho bastardo de Francisco Manuel, usava o título de dom, distinção em princípio restrita à alta nobreza. ${ }^{294}$ Recebera o foro de moço fidalgo, em $1724,{ }^{295}$ e gozava também dos privilégios daquela ordem militar, com a tença de $12 \$ 000$ réis. Seis anos após deixar o governo da Ilha, que administrara entre 1753 e 1762, ele pleiteou em remuneração dos seus serviços a mercê de uma Comenda de $400 \$ 000$ réis obtendo parecer favorável do Conselho Ultramarino. ${ }^{296}$

Mais bem nascidos parecem ter sido Francisco Antônio Cardoso de Meneses e Sousa, Francisco Antonio da Veiga Cabral da Câmara e Francisco de Barros Morais Araújo Teixeira Homem. O primeiro nasceu no bispado de Lamego, Paróquia de São Cusmado, em 1710. Era filho de Luís Cardoso de Meneses e Sousa, fidalgo da Casa Real e de Elena Teixeira Castro, também de nobre linhagem. Em 1762, ano em que fora nomeado governador da Ilha, obteve por carta padrão a tença de $12 \$ 000$ a título do Hábito da Ordem de Cristo que havia recebido por mercê em $1754 .{ }^{297}$ Segundo o viajante francês Antoine Joseph Pernety, que passou pela Ilha em 1763, Dom Francisco Cardoso era "Coronel, Cavalheiro de Cristo, e de uma ilustre família de Portugal".

${ }^{290}$ Cf. Walter Piazza. Dicionário Político Catarinense. Florianópolis: Ed. Assembléia Legislativa do Estado de Santa Catarina, 1985, p. 494.

${ }^{291}$ José de Souza Azevedo Pizarro Araújo. Memórias Históricas do Rio de Janeiro e das Províncias anexas à Jurisdição do vice-rei do Estado do Brasil. Rio de Janeiro: Imprensa Nacional, 1822, p. 303.

${ }^{292}$ Essas expressões que denotam uma escala de estima social, como nascimentos puros ou impuros, pureza de sangue ou sangue infecto, quando utilizadas, servem para dar a dimensão e o sentido que elas tinham naquele tempo.

${ }^{293}$ Cf. Walter Piazza. Dicionário Político..., op. cit. p, 551; e Banco de Dados Optima Pars.

${ }^{294}$ Cf. Raphael Bluteau. Vocabulário Português e Latino..., op. cit., vol. III, Dom - "título honorífico, que antigamente se dava só aos Reis, e seus descendentes, aos Ricos homens e a cavaleiros, que tinham privilégio Real por grandes serviços. Deriva-se esta palavra de Dommus abreviado de Dominus (...). Porém com o tempo se fez o Dom comum, que por se singularizarem nesta vulgaridade, fazem alguns cavaleiros brio de não emitir".

${ }^{295}$ Cf. Walter Piazza. Dicionário Político..., op. cit. p, 324.

${ }^{296}$ Banco de Dados Optima Pars.

${ }^{297}$ ANTT, Chancelaria da Ordem de Cristo, Lv. 270, fl. 263, mf. 2277; e Habilitações da Ordem de Cristo, Lv. F, Mç. 3, N. 11. 
Tinha ele quinze filhos, todos ilegítimos, "uma vez que nunca havia se casado". Um deles era capitão no Regimento do pai e os outros - contou o governador a Pernety "viviam em Lisboa, onde tinham segundo as leis, as mesmas honrarias e prerrogativas dos filhos nobres e legítimos". Os bastardos eram "gentis-homens natos. Uma de suas filhas havia se casado "com um dos Ministros da Corte de Portugal e um outro ocupava um dos primeiros postos do governo". 298

Francisco Antonio da Veiga Cabral da Câmara, fidalgo da Casa Real e Coronel de Infantaria, filho primogênito do General da Província de Trás-os-Montes, Francisco Xavier da Veiga Cabral, e neto do Mestre de Campo, General Sebastião da Veiga Cabral. Foi, assim como seu pai e avô, comendador das comendas de Santa Maria de Bragança, de São Lourenço de Deilão e de São Bartolomeu do Arraial, "todas três da ordem de Cristo". ${ }^{299}$ Seu tio, também com o nome de Sebastião da Veiga Cabral fora governador da Colônia de Sacramento (1699-1705) ${ }^{300}$ e seu irmão, Sebastião Xavier da Veiga Cabral da Câmara, governador do Rio Grande de São Pedro (1780-1801). Francisco Antonio da Veiga foi encarregado pelo Marquês do Lavradio para a elevada missão de receber a Ilha de Santa Catarina dos espanhóis (realizada em 31 de julho de 1778), conforme determinava o Tratado de Santo Ildefonso $(1777)^{301}$ e restabelecer aquela colônia portuguesa. Mas, antes de completar um ano de governo interino foi substituído pelo Coronel de Infantaria do Regimento de Bragança, Francisco de Barros Morais Araújo Teixeira Homem. Possivelmente, Francisco Antonio aguardava algum posto de mais alta distinção, que pouco tempo depois lhe seria oferecido. Em 1784, foi nomeado governador e capitão general da Índia, cargo que ocupou até 1807 . No ano seguinte retornou ao Rio de Janeiro junto com a família real, sendo agraciado, em 1810, com o título de visconde de Mirandela. ${ }^{302}$

Natural da Freguesia de Nossa Senhora de Samaioes, termo da vila de Chaves em Portugal, filho do cavaleiro e Governador de Lagos, João de Barros Pereira do Lago, "gente nobre", e de Dona Jerônima Morais, que vivia "de acordo com as leis da nobreza", Francisco de Barros Morais foi governar a Ilha, em 1779, já como fidalgo e cavaleiro da ordem de cristo. ${ }^{303}$ Não tinha ele a intenção de permanecer no Brasil e

\footnotetext{
298 Antoine Joseph Pernety. Histoire d'um Voyage aux isles Maouines, fait em 1763 \& $1764 \ldots$, in Relatos de viajantes estrangeiros... op. cit., p. 80 e 81.

299 ANTT, Chancelaria de D. Maria I, Lv. 84, fl. 329v.

${ }^{300}$ Sobre esse governador ver estudo de Laura de Mello e Souza. O Sol e a Sombra..., op. cit.

${ }^{301}$ AHU-SC, cx. 4, doc. 273.

${ }^{302}$ Walter Piazza. Dicionário Político..., op. cit., p. 126.

${ }^{303}$ Cf. Banco de dados Optima Pars; e Walter Piazza. Dicionário Político..., op. cit., p. 551.
} 
muito menos na Ilha de Santa Catarina, como se pode ver em carta que escreveu ao Secretário de Estado Martinho de Mello e Castro. Assim que completou o primeiro triênio no governo dela pedia para que fizesse a graça de mandar sucessor que lhe rendesse.

\begin{abstract}
Rogo humildemente a V. Ex. ${ }^{\mathrm{a}}$, e por tudo quanto lhe posso pedir, que me proteja esta súplica com S. Maj.; pois sendo eu criado, e nascido em Chaves, Província de Trás dos Montes, que é um País seco, tenho experimentado graves moléstias nesta Ilha, que não posso atribuir a outra causa, mais que a muita umidade do ar, e freqüentes chuvas do País; cuja umidade me é inteiramente oposta à constituição da minha natureza. ${ }^{304}$
\end{abstract}

Mesmo contrariado, Francisco de Barros teve de ficar no cargo por mais quatro anos. Em 1786, então com 67 anos de idade, pôde assim retornar ao reino.

É possível que a escolha desses fidalgos estivesse relacionada com as circunstâncias específicas pelas quais passava a Ilha de Santa Catarina. O primeiro foi nomeado às vésperas da Guerra dos Sete Anos (1762), que teve como desdobramentos no Sul da América Meridional a invasão por parte do governador de Buenos Aires, D. Pedro de Cevallos, da Colônia do Sacramento (1762), do Rio Grande de São Pedro (1763-76) e da própria Ilha (1777-78). Os outros dois, tiveram por missão a reorganização daquele estabelecimento colonial após ter sido reincorporado ao domínio português.

Entre 1765 e 1775, a Ilha esteve sob a governança de outro reinol: Francisco de Souza de Menezes. Nascido em 1732, na freguesia de São Martinho de Salréu, termo de Coimbra, era filho do cavaleiro professo da Ordem de Cristo, D. Gonçalo Souza de Meneses e de D. Ana Luisa Teodósia de Castro. Entre as distinções nobiliárquicas que galgou aparecem a de moço-fidalgo com 1.000 réis de moradia por mês, a de fidalgoescudeiro e o Hábito da Ordem de Cristo recebido em 1765. 305

\footnotetext{
${ }^{304}$ ANRJ, Cód. 106, vol. 13, fl. 10. De Francisco de Barros Moraes à Martinho de Mello e Castro, em 10.06.1782.

${ }^{305}$ ANTT, Ministério do Reino - Decretamentos de Serviços, Mç. 31, n. 12; Walter Piazza. Dicionário político..., op. cit., p. 349; e Banco de dados Optima Pars. Ao longo de praticamente toda a sua gestão, Francisco de Souza Menezes teve de administrar a prisão do ilustre conselheiro ultramarino, José Mascarenhas Pacheco Pereira Coelho de Melo. Enviado especial do Marquês de Pombal para expulsão da Companhia de Jesus dos domínios portugueses e um dos fundadores da Academia Brasílida dos Renascidos na cidade de Salvador, em 1759, José Mascarenhas foi preso na ilha de Anhatomirim, acusado de parceria com os franceses e de tentativa de conciliação com os jesuítas. Cf. Iris Kantor. "A Academia Brasílica dos Renascidos e o Governo Político da América Portuguesa (1759): contradições do Cosmopolitismo Acadêmico Luso-Americano". In: István Jancsó. Brasil: Formação do Estado e da Nação. São Paulo: Hucitec; Ijuí: E.UNIJUÍ, 2003, pp. 321-343.
} 
De Luís Maurício da Silveira, considerado como de estatuto social ignorado pelo projeto Optima Pars, sabe-se que nasceu na Freguesia de Santos Velho, Lisboa, por volta de 1763. Era filho de D. Antonio Ignacio da Silveira e de D. Guilhermina Joaquina Leocadia Vales Verona e neto legítimo da parte paterna do Conselheiro de Guerra, Dom Braz Baltazar da Silveira, que foi Governador e Capitão General da Capitania de São Paulo e Minas Gerais (1713-17). Dom Luiz Mauricio da Silveira, como costumava assinar, considerava-se um "homem Fidalgo pouco socorrido da fortuna". 306 Segundo Walter Piazza, requereu, assim como fizera Pedro de Azambuja Ribeiro, também sem obter sucesso, o governo da Capitania de Goiás, mas consta que fora agraciado com o Hábito da Ordem de Cristo, em $1804 .^{307}$

Manoel Soares Coimbra e Joaquim Xavier Curado nasceram no Brasil. O primeiro, no Rio de Janeiro por volta de 1737, o segundo, na Freguesia de Meia Ponte, Goiás, no ano de 1743. Os títulos e gratificações que lhes chegaram às mãos viriam depois de muitos anos de serviços militares prestados na América e concedidos em um período (virada do setecentos para o oitocentos) em que houve uma maior abertura na política de mercês. ${ }^{308}$ Soares Coimbra, logo que assentou praça no Rio, embarcou para Lisboa, em 1754, retornando em seguida ao Brasil onde faria toda sua carreira militar. Antes de ser destacado para governador da Ilha de Santa Catarina (1791-1793) servia já no Regimento de Linha dela no posto de Capitão de Infantaria (1766). O Hábito da Ordem de São Bento de Avis e mais a tença de $40 \$ 000$ réis por mês que pleiteava só lhes chegariam às mãos em 1802, aos 65 anos de idade. Faleceu na vila do Desterro cinco anos depois. ${ }^{309}$

Xavier Curado pleiteou, em 1791, a remuneração dos seus serviços com o Hábito da Ordem de Avis e a tença de $60 \$ 000$ réis, recebendo parecer favorável do Conselho Ultramarino. Em 1815, foi agraciado com o título de Barão e Conde de São João das Duas Barcas. ${ }^{310}$

\footnotetext{
${ }^{306}$ ANRJ, Cód. 106, vol. 16, fl. 199 e ss. Requerimento e memorial, em 3 de julho de 1806.

${ }^{307}$ Walter Piazza. Dicionário político..., op. cit., p. 536. Consta nessa mesma obra que Luís Henrique da Silveira, atual governador do Estado de Santa Catarina, é tataraneto de Luís Maurício da Silveira.

${ }^{308}$ Nuno G. Monteiro e Mafalda S. Cunha. Governadores e capitães-mores..., op. cit., p. 229.

${ }^{309}$ Walter Piazza. Dicionário Político..., op. cit., p. 163; Banco de Dados Optima Pars; Pizarro Araújo. Memórias Históricas..., op. cit., p. 318.

${ }^{310}$ Walter Piazza. Dicionário Político..., op. cit., p. 194; Banco de Dados Optima Pars; Pizarro Araújo. Memórias Históricas..., op. cit., p. 320.
} 
Quadro n. 2.1 - Governadores da Ilha de Santa Catarina (1738-1807)

\begin{tabular}{|c|c|c|c|c|c|c|c|c|c|c|c|}
\hline Nomes & $\begin{array}{c}\text { Classe } \\
\text { Social }^{311}\end{array}$ & Nasc. & Óbito & Nomeação & $\begin{array}{l}(+/-) \text { Id. } \\
\text { Nom. }\end{array}$ & Cargo & $\begin{array}{l}\text { Patente Milit. no } \\
\text { exerc. cargo }\end{array}$ & $\begin{array}{l}\text { Soldo por } \\
\text { ano em réis }\end{array}$ & $\begin{array}{l}\text { Posse no } \\
\text { cargo }\end{array}$ & $\begin{array}{l}\text { Deixa o } \\
\text { cargo }\end{array}$ & $\begin{array}{l}\text { Tempo no } \\
\text { Cargo (+/-) }\end{array}$ \\
\hline 1 - José da Silva Paes & mecânico & Pt. 10.1679 & Pt. 10.1760 & & 59 & Gv. & Brigadeiro & & 07.03 .1739 & 24.08 .1743 & 4 a. e $5 \mathrm{~m}$. \\
\hline 2 - Patrício Manuel de Figueiredo & & Pt. 1674 & Pt. & & 69 & Gv. Int. & Cap. de Granad. RJ & & 25.08 .1743 & 24.01 .1744 & $5 \mathrm{~m}$. \\
\hline 3 - Pedro de Azambuja Ribeiro & & Pt. (?) & - & $\begin{array}{l}\text { Gv. e Cap. } \\
\text { Gen. RJ }\end{array}$ & & Gv. Int. & $\begin{array}{l}\text { Ten. de Mestre de } \\
\text { Campo Gen. do RJ }\end{array}$ & & 25.01 .1744 & 19.03 .1746 & 1 a. e $3 \mathrm{~m}$. \\
\hline José da Silva Paes & & & & & & & & & $\begin{array}{l}\text { Reassume } \\
20.03 .1746 \\
\end{array}$ & 01.02 .1749 & $\begin{array}{l}2 \text { a. e } 11 \mathrm{~m} . \\
\text { tot } 7 \text { a. e } 4 \mathrm{~m} .\end{array}$ \\
\hline 4 - Manuel Escudeiro Ferreira de Souza & nobre & Pt. 1688 & Pt. 04.1760 & régia & 61 & Gv. & Coronel de Inf. & $2: 000 \$ 000$ & 02.02 .1749 & 24.10 .1753 & 4 a. e $8 \mathrm{~m}$. \\
\hline 5 - José de Mello Manoel ${ }^{312}$ & nobre & - & - & régia & & Gv. & & $2: 000 \$ 000$ & 25.10 .1753 & 06.03 .1762 & 8 a. e $4 \mathrm{~m}$. \\
\hline $\begin{array}{l}6 \text { - Francisco Antônio Cardoso de } \\
\text { Menezes e Souza }\end{array}$ & fidalgo & Pt. 1710 & RJ. 1771-72 & régia $^{313}$ & 52 & Gv. & Coronel de Inf./RJ & $2: 000 \$ 000^{314}$ & 07.03 .1762 & 11.07 .1765 & 3 a. e $4 \mathrm{~m}$. \\
\hline 7 - Francisco de Souza de Menezes & nobre & Pt. 1732 & - & régia & 33 & Gv. & Coronel & & 12.07 .1765 & 04.09 .1775 & 10 a. e $1 \mathrm{~m}$. \\
\hline 8 - Pedro Antônio da Gama Freitas ${ }^{315}$ & nobre & Pt. $1741-42$ & Pt. & $\begin{array}{l}\text { vice-rei e } \\
\text { conf. régia }\end{array}$ & 33 & Gv. & Coronel de Inf. & & 05.09 .1775 & 24.02 .1777 & 1 a. e $6 \mathrm{~m}$. \\
\hline \multicolumn{12}{|c|}{ Ocupada pelos espanhóis de 09.03.1777 até 30.07 .1778 (c. 1 ano e 4 meses) } \\
\hline $\begin{array}{l}9 \text { - Francisco Antônio da Veiga Cabral } \\
\text { da Câmara }\end{array}$ & fidalgo & Pt. 1734 & RJ. 06.1810 & vice-rei & 44 & Gv. Int. & Coronel & $2: 000 \$ 000$ & 30.07 .1778 & 06.06 .1779 & $11 \mathrm{~m}$. \\
\hline $\begin{array}{l}10 \text { - Francisco de Barros Morais Araújo } \\
\text { Teixeira Homem }\end{array}$ & fidalgo & Pt. 1719 & Pt. 1791-92 & régia & 60 & Gv. & $\begin{array}{l}\text { Coronel de Inf. de } \\
\text { Bragança }\end{array}$ & & 07.06 .1779 & 06.06 .1786 & 7 a. \\
\hline 11 - José Pereira Pinto & nobre & Pt. & RJ. 1794 & vice-rei & & Gv. Int. & Sargento-mor/RJ $J^{316}$ & $2: 000 \$ 000$ & 07.06 .1786 & 16.01 .1791 & 4 a. e $7 \mathrm{~m}$. \\
\hline 12 - Manoel Soares Coimbra & & RJ. 1737 & SC, 11.1807 & & 54 & Gv. & Coronel/RJ & & 17.01 .1791 & 07.07 .1793 & 2 a. e $5 \mathrm{~m}$. \\
\hline 13 - João Alberto de Miranda Ribeiro & nobre & Pt. 1744 & SC, 01.1800 & vice-rei & 49 & Gv. Int. & Tenente Coronel/RJ & $1: 200 \$ 000^{317}$ & 08.07 .1793 & 17.01 .1800 & 6 a. e $5 \mathrm{~m}$. \\
\hline Junta Governativa Provisória ${ }^{318}$ & & & & & & & & & 18.01 .1800 & 07.12 .1800 & $11 \mathrm{~m}$. \\
\hline 14 - Joaquim Xavier Curado & & Goiás, 1743 & RJ. 09.1830 & $\begin{array}{l}\text { vice-rei e } \\
\text { conf. régia }\end{array}$ & 57 & Gv. & Coronel & & 08.12 .1800 & 02.06 .1805 & 4 a. e $5 \mathrm{~m}$. \\
\hline 15 - Luiz Maurício da Silveira ${ }^{319}$ & $?$ & Pt. 1763 & RJ. 04.1824 & régia & 42 & Gv. & Tenente de Inf. & $2: 000 \$ 000^{320}$ & 03.06 .1805 & \begin{tabular}{|l|}
13.07 .1817 \\
\end{tabular} & 12 a. e $1 \mathrm{~m}$. \\
\hline
\end{tabular}

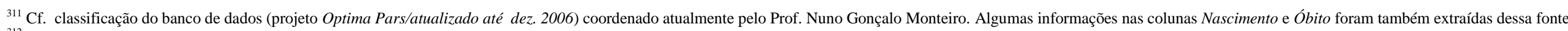
312 ANTT, Chanc. D. José I, Lv. 69, fl. 205v. Em 19.08.1760, foi nomeado para o governo de Santa Catarina João Antônio de Souza Falcão, que morreu antes de assumir o cargo.

${ }_{313}^{313}$ AHU-SC, cx. 3, d. 173, indicado ao governo pelo Conde de Bobadela (Gomes Freire de Andrade).

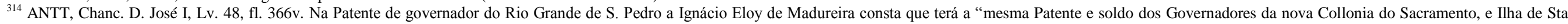

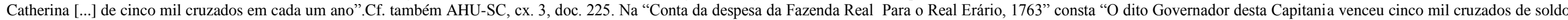
por ano...”.

${ }_{315}$ No período de fevereiro de 1775 a março de 1777 a comandância militar da Ilha ficou a cargo do Brigadeiro Antonio Carlos Furtado de Mendonça.

${ }_{316}$ AHU-SC, cx. 4, d. 329. Pede ao Rei a mercê de o promover com a Patente de Coronel de um dos Regimentos do Rio de Janeiro, em 20.3.1789.

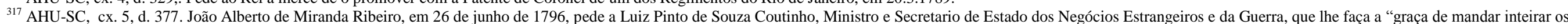

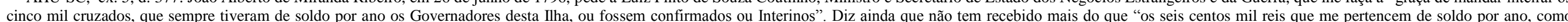

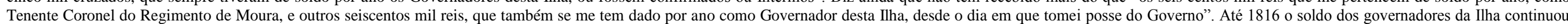
Tenente Coronel do Regimento de Moura, e outros seiscentos mil reis, que tambem se me tem dado por ano como Governador desta liha, desde o dia em que

sendo de cinco mil cruzados ao ano, cf. Paulo Joze Miguel de Brito. Memória Política sobre a Capitania de Santa Catarina. Rio de Janeiro, 1829 [1816], p. 70.
${ }_{318}$ AHU-SC, cx. 6, d. 406. Em 07.11.1799 já assinam pelo governo. Era formada pelo tenente-coronel José da Gama Lobo Coelho D’Eça, o ouvidor Aleixo Maria Caetano e o vereador José Pereira da Cunha.

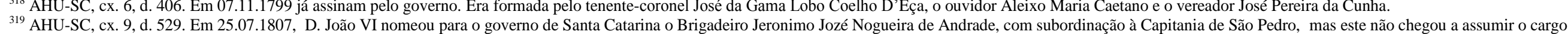
${ }^{320}$ ANTT, Chancelaria D. Maria I, Lv. 72, fl. 178. Patente de Governador a Luís Maurício da Silveira em 18.08.1804. 
Os filhos da América enfrentavam, via de regra, dificuldades maiores que os indivíduos nascidos no reino para ascender na hierarquia social portuguesa. Segundo Mafalda Cunha e Nuno Monteiro, "A distância da corte acentuava-se naturalmente na colônia, agravando de forma notória a clivagem que no território europeu se verificou ao longo de todo o século entre as elites da corte e as das províncias. Raros foram, de resto, os naturais da colônia que se aproximaram do centro da decisão política da monarquia". 321

As classificações nobiliárquicas e suas subdivisões hierárquicas, embora sirvam como índice para se avaliar a importância do posto e da capitania no conjunto do império, têm de ser relativizadas, em função da ampliação, ou mesmo banalização, do conceito de nobreza, como já assinalado. As dificuldades que os historiadores têm hoje em compreender esses diferentes estatutos sociais decorre, em parte, das distintas representações que os próprios indivíduos, naquele tempo, faziam de si mesmos e dos outros, através da busca constante por hábitos, comendas, tenças e outras mercês havendo inclusive manipulações genealógicas ${ }^{322}$ para a construção de linhagens puras como forma de agregar distinções e ter acesso às posições de poder e de prestígio.

Questão ainda mais complexa parece ser compreender a inserção dessas categorias do Antigo Regime português no Antigo Sistema Colonial. ${ }^{323}$ O que significava ser nobre nas colônias?

Maria Beatriz Nizza da Silva optou por deixar de lado o estudo da "alta administração colonial, seja ela civil (governadores, vice-reis e outros) ou eclesiástica (bispos e arecebispos)" por entender que esses indivíduos pertenciam "mais à nobreza reinol do que à colonial" e "simplesmente passavam pelo Brasil antes de se dirigir a outros pontos do império português e poucas raízes deixaram na Colônia, ao contrário dos magistrados ou dos eclesiásticos". 324

De fato, a circularidade dos governadores era maior do que a de outros oficiais como provedores, ouvidores, juízes ordinários e oficiais do exército. Todavia, a análise da trajetória dos governadores nomeados para a Ilha de Santa Catarina mostra algumas particularidades que precisam ser consideradas. Utilizando-se da terminologia de Luiz

\footnotetext{
${ }^{321}$ Mafalda S. da Cunha e Nuno G. Monteiro. Governadores e capitães-mores... op. cit., p. 197.

${ }^{322}$ Ver, por exemplo, o caso de Felipe Pais Barreto em Pernambuco, analisado por Evaldo Cabral de Mello. O Nome e o Sangue - Uma Parábola Familiar no Pernambuco Colonial. $2^{\mathrm{a}}$ ed. revista. Rio de Janeiro: Topbooks, 2000.

${ }^{323} \mathrm{Na}$ acepção que lhe dá Fernando Novais. Portugal e Brasil na Crise do Antigo Sistema Colonial (1777-1808). 6 ed. São Paulo: Hucitec, 1995, p. 58.

${ }^{324}$ Maria Beatriz Nizza da Silva. Ser Nobre na Colônia.São Paulo: UNESP, 2005, p. 8.
} 
Felipe de Alencastro, que distingue dois agentes sociais: o "homem ultramarino", que "faz sua carreira no ultramar buscando lucros, recompensas e títulos", mas que serão desfrutados no reino, e o "homem colonial", que "circula em diversas regiões do Império, mas joga todas as suas fichas na promoção social e econômica acumulada numa determinada praça, num enclave colonial que às vezes não o viu nascer mas onde possui bens, herdeiros e tumba reservada", ${ }^{325}$ pode-se dizer que os governadores da Ilha identificam-se mais com esse segundo grupo. Ainda que a maioria deles fosse reinóis de nascimento - treze dos quinze governadores nasceram em Portugal, fato que confirma o caráter imperial do cargo ${ }^{326}$-, sabe-se que sete, no mínimo, permaneceram e morreram no Brasil. E nem todos que retornaram para Portugal o fizeram por livre e espontânea vontade. Pedro Antônio da Gama Freitas, retornou ao reino preso, condenado pela "entrega" da Ilha aos espanhóis e acabou falecendo na prisão. O governador José de Melo Manoel, de quem não se tem informações dos locais de nascimento e óbito, também retornou ao reino preso. Mesmo que os três governadores que se desconhece o local de óbito tivessem também retornado para Portugal, ainda assim o número dos que permaneceram na América é bastante expressivo, sobretudo se considerarmos o período posterior à ocupação espanhola (1778-1807), em que apenas um, Francisco de Barros Morais, regressou para lá (ver quadro n. 2.1).

Outro traço significativo a considerar a respeito da trajetória desses indivíduos é que, na maioria dos casos, sua área de circulação tendia a se restringir aos territórios de jurisdição, ou de influência, do Rio de Janeiro, como mais adiante se mostrará. Dos doze governadores dos quais se sabe o local de óbito, cinco morreram no Rio e dois em Santa Catarina.

Seja como for, no esforço de centralização do poder da monarquia portuguesa, eles representavam o braço mais forte a se oporem aos poderes locais concorrentes nas conquistas.

Mas, ainda que esses governadores, e também outros indivíduos, reinóis ou não, tentassem preservar ou reproduzir as lógicas sociais e econômicas do reino no Novo Mundo (a estrutura de classes, os privilégios e o próprio estilo de vida), as condições

\footnotetext{
${ }^{325}$ Luiz Felipe de Alencastro. O Trato dos Viventes: formação do Brasil no Atlântico Sul, séculos XVI e XVII. São Paulo: Companhia das Letras, 2000, pp. 103 e 104.

${ }^{326}$ Nuno G. Monteiro. Governadores e capitães-mores..., op. cit., p. 242. "No equilíbrio local e regional de poderes que se estabelecia nos territórios atlânticos da Coroa portuguesa, os governadores representavam a parcela mais 'imperial' dos protagonistas. Por isso se foi impedindo cada vez mais as elites locais de chegarem aos governos das conquistas, deixando-lhes quando muito algumas capitanias secundárias para as quais faltavam outros candidatos."
} 
concretas com que se deparavam nos territórios que iam governar ou viver - a lógica mercantil da colonização, a ambição do lucro fácil, o trabalho escravo, a predação dos recursos naturais e humanos - conduziam inexoravelmente à formação de uma sociedade peculiar com estrutura e dinâmicas próprias. ${ }^{327}$ Eles próprios inseriam-se, querendo ou não, numa "rede relacional" complexa envolvendo-se com os grupos e indivíduos locais, até porque o novo meio cercado de ameaças (vindas dos indígenas, das epidemias, dos ambientes inóspitos, dos corsários...) e o próprio funcionamento da colônia exigia o apoio mútuo.

Segundo estudo de Laura de Mello e Souza para as Minas Gerais, "Ia-se consagrando um padrão societário específico. A sociedade continuava estratificada segundo preceitos estamentais, mas comportava grau considerável de flexibilidade e mobilidade: os mulatos herdavam, os bastardos eram reconhecidos. Entretanto, persistia o estranhamento dos nobres administradores portugueses ante um mundo improvisado, que desprezava tradições consagradas e reinventava procedimentos", 328

Há que se questionar também, em comparação com a vida na Corte portuguesa, o valor, material e simbólico, dos títulos honoríficos obtidos pelos nacionais. Os Hábitos, as comendas e outras distinções dadas pelo monarca a esses homens serviram de importante moeda de troca pelos serviços militares prestados na expansão e consolidação do Império português, mas tiveram significado peculiar no Novo Mundo. Segundo Fernanda Olival, "a economia da mercê destinava-se prioritariamente aos reinóis; era com base neles que se pretendia assegurar o Império. No entanto, ajustavase aos naturais e, em casos extremos, até aos nativos. Deste ponto de vista, terá sido até um fator de coesão do disperso império português". 329

No sul da América Meridional, a monarquia teve de contar com homenslimite $^{330}$ (limite não só do ponto de vista da geografia do império, mas também sob o aspecto de identificação social, lingüística e cultural), chefes de bandos armados habituados com a vida em sertões incivilizados, muito distantes do mundo cortesão, mas

\footnotetext{
${ }^{327}$ Arno Wehling e Maria José Wehling. O Funcionário Colonial entre a Sociedade e o Rei, in Mary Del Priore (Org.) Revisão do Paraíso: os Brasileiros e o Estado em 500 Anos de História. Rio de Janeiro, Campus, 2000, p. 142; e Laura de Mello e Souza. O Sol e a Sombra: Política e Administração na América Portuguesa do século XVIII. São Paulo: Companhia das Letras, 2006, especialmente o capítulo 4 "Nobreza de sangue e nobreza de costume...".

${ }^{328}$ Laura de M. e Souza. Id., p. 168.

${ }^{329}$ Fernanda Olival. Mercês, Serviços e Circuitos Documentais no Império Português, in Maria Emilia Madeira Santos (Coord.) O Domínio da Distância: Comunicação e Cartografia. Lisboa: Instituto de Investigação Científica Tropical, 2006, p. 70.

${ }^{330}$ Vera Ferlini. São Paulo, de Fronteira a Território... op. cit., p. 19
} 
que também seriam pagos com honras e mercês. Referindo-se a esses homens, em carta ao comandante dos exércitos do Sul, o Tenente General João Henrique de Böhm, dizia o vice-rei Marquês do Lavradio:

Não é o capricho de honra que os conduz aos perigos e as atrevidas ações, que eles [os paulistas] muitas vezes intentaram e puseram em prática: eles dão-lhes o nome de estímulos de honra, porém em quanto a mim, não foi nem será nunca, que um espírito de ambição, e creio que todas as vezes, que se repartir com eles, com mão muito larga, do que eles apreenderem, que este será o único modo, de os ter sempre contentes, e se conseguir deles algum bom serviço. (...)

O célebre Rafael Pinto, não se esqueceu das suas utilidades como costuma, porém como agora nos é necessário, não há outro remédio senão deixá-lo fartar.

O espírito de honra deste oficial é o mesmo que o dos Paulistas, porém assim mesmo na ocasião presente nos é útil e conveniente. ${ }^{331}$

Rafael Pinto Bandeira, importante militar na reconquista do Rio Grande de São Pedro aos espanhóis, em 1776, seria agraciado com o Hábito da Ordem de Cristo onze anos depois. ${ }^{332}$

Por certo, muitos dos governadores nomeados para as conquistas no ultramar não se enquadravam nesse perfil. Nascidos no reino, para lá almejavam voltar, onde desfrutariam de maior poder e prestígio. Mas, como se verá adiante para alguns dos nomeados para Santa Catarina, era na América, e inseridos nos mundos próprios que ela oferecia, que iriam fazer suas vidas.

Deve-se levar em conta algumas especificidades econômicas, sociais e políticas da Ilha de Santa Catarina. As atividades produtivas montadas nela não propiciaram a formação de oligarquias tão poderosas quanto as do norte açucareiro, do sertão mineiro, ou dos campos de criação no sul. Ao invés da grande propriedade dedicada à monocultura, prevaleceu ali a pequena e média propriedade voltada para culturas diversificadas. A própria distinção feita em outras partes do Brasil entre datas de terra para se designar os pequenos lotes, e sesmarias, para os grandes, não era feita em Santa Catarina: "na linguagem do País deste Governo são sinônimas", explicava o governador Francisco de Barros Moraes ao vice-rei. ${ }^{333}$

\footnotetext{
${ }^{331}$ BCRGEH, pp. 81 e 83. Carta do Marquês do Lavradio ao Tenente General João Henrique de Böhm, em 11 de janeiro de 1776.

${ }^{332}$ ANTT, Habilitações da Ordem de Cristo, Letra R, Mç. 6, n. 16. Em 11 de outubro de 1787.

333 ANRJ, Cód. 106, vol. 04, of. 3. De Francisco de Barros Moraes Araújo Teixeira Homem ao vice-rei Luís de Vasconcelos e Souza, em 20 de março de 1781.
} 
Os rendimentos oriundos das armações da pesca da baleia montadas em seu litoral foram vultosos por toda a segunda metade do século XVIII, mas Santa Catarina pouco se beneficiou deles: os arrematantes do Contrato não eram da Ilha, nem aplicavam nela suas rendas. Além disso, a arrematação do negócio era realizada na Fazenda Real do Rio de Janeiro, que centralizava os recursos e repassava-os de maneira coartada à Provedoria da Fazenda da Ilha, para se completar o pagamento das folhas civil, militar e eclesiástica. Santa Catarina fornecia também às praças do Rio de Janeiro e do Rio Grande de São Pedro a farinha de mandioca (chamada também de farinha de pau ou de guerra), importante alimento à escravaria, às tropas e à população em geral. Mas, como se verá melhor no capítulo terceiro, a prática política dos governadores de confiscar arbitrariamente parte do que produziam sem que houvesse o respectivo pagamento levou-os a reduzirem a produção, ou - o que é mais provável - a buscarem mercados alternativos e rentáveis, fora dos circuitos mercantis legais do sistema colonial, em prejuízo da Fazenda Real.

A transmigração de aproximadamente 6.000 açorianos em meados do século XVIII, na Ilha de Santa Catarina e seu continente inseria-se num plano audacioso da Coroa Portuguesa de ocupação e de defesa dos territórios até o rio da Prata. Além disso, buscavam ainda, com a introdução desses trabalhadores livres, a maioria dos quais agricultores, poder até prescindir da utilização da mão-de-obra escrava (ver tópico 3.2).

Mas não foi só esse fator a subverter os padrões societários tradicionais na América. $\mathrm{O}$ transplante das instituições e da estrutura burocrática do reino sofreria os efeitos do novo meio. A periferização econômica de Santa Catarina no sistema colonial refletiu-se diretamente na montagem da sua estrutura política e administrativa, bem mais precária se comparada com as capitanias gerais.

Em carta de 03 de agosto de 1779, dirigida ao vice-rei Luís de Vasconcelos e Souza, o governador da Ilha, o fidalgo Francisco de Barros Morais pintava um quadro bastante sombrio da qualidade dos oficiais da justiça na vila do Desterro e, por esse motivo, solicitava-lhe um ouvidor e ministro letrado para aquela colônia. Dizia ele:

Se no espiritual há faltas como representei a V. Exa. (...) também não pode deixar de as haver na administração da justiça: o Ouvidor da terra é um tendeiro da mesma; o Juiz ordinário mal sabe qual é a sua mão direita: em toda esta Ilha e continente fronteiro não há um letrado, nem ainda um solicitador, que tivesse alguma prática de auditórios; e enfim o mais inteligente sempre é o Escrivão, que naturalmente há de governar ao Juiz, se 
este não tiver empenho em contrário; porque por inteligência do direito são aqui leigos duas vezes. ${ }^{334}$

Apesar das precárias condições que dispunham para montar aquele estabelecimento e da inversão de alguns papéis sociais, os governadores procuravam, assim mesmo, preservar as distinções estatutárias tradicionais, que eles mesmos ambicionavam. Em 1813, o governador Luis Mauricio da Silveira queixava-se ao rei de um injurioso Edital que o juiz de fora de Desterro mandara publicar, dispensando-lhe o tratamento de "Senhoria" e assinando o documento na mesma linha do seu, o que era uma afronta, pois desconsiderava assim o grau hierárquico entre eles. Reclamava ainda que os oficiais da câmara recusavam-se a buscá-lo e levá-lo em sua casa, por ocasião das festividades, e negavam-lhe, nas procissões, o lugar de preferência que lhe era devido. Conflitos de jurisdição entre as autoridades eram comuns e podiam se manifestar de diversas formas. Os códigos sociais, as maneiras de tratamento, os gestos, a etiqueta, o lugar dos indivíduos nas procissões e festividades, importantes signos de distinção e da posição que cada indivíduo ocupava na sociedade eram ciosamente exigidos pelos governadores da subalterna capitania de Santa Catarina. A resposta de D. João VI aos reclames do governador veio na Provisão de 23 de julho de 1814 e, seguramente, não o agradou muito.

Hei por bem declarar-vos, que a Câmara não vos deve ir buscar a casa, nem acompanhar-vos para as funções em que tendes de concorrer; que quando fordes acompanhar a procissão do Corpo de Deus, tenhais sempre o lugar imediato ao pálio, seguindo-se depois a Câmara, e quanto ao tratamento de Senhoria, nem o alvará de 29 de Janeiro de 1739 vo-lo concede, em razão do vosso posto, nem vos pode ser aplicável o alvará de 2 de Maio de $1782 .{ }^{335}$

Conformados ou não com as limitadas condições de seu posto e daquele estabelecimento, os nobres governadores da Ilha de Santa Catarina tinham que adequar os padrões sociais tradicionais com a realidade do novo ambiente.

Isso aparece, por exemplo, na narrativa do naturalista Antoine Joseph Pernetty sobre um jantar em que ele, o navegador francês Louis Antoine Bougainville e outros oficiais da expedição foram, em $1^{\circ}$ de dezembro de 1763 , à casa do governador, que servia também de palácio, situada na pequena vila de Nossa Senhora do Desterro. O

\footnotetext{
${ }^{334}$ ANRJ, Cód. 106, vol. 01, d. 13.

${ }^{335}$ RTIHGSC, vol. IV, 1915, p. 35.
} 
Coronel e cavalheiro de Cristo, Dom Francisco Cardoso de Menezes e Souza, recebeuos à porta e introduziu-os em uma grande sala, onde já se encontrava "o couvert posto e a mesa servida". Além do governador e de seu filho, jantaram com eles o major da Praça, o chefe da Justiça, dois outros oficiais e um padre franciscano. Muitos outros oficiais da guarnição ficavam de pé e alguns deles tinham a função de servi-los. "Estes oficiais fazem este serviço subalterno, cortejando ao Governador; ele os convida alternadamente a jantar, servindo-se uns aos outros”. Sua impressão da comida e dos serviços era de que

os pratos estavam preparados à moda da região, mas, bem mal preparados ao gosto dos franceses. O pão, sobretudo, nos pareceu muito ruim, com a superfície um pouco dura, tendo ficado pouco no forno. Por dentro era seco, parecendo uma pasta sólida de trigo escuro, comparável ao alimento dos moradores de Limosin, chamado 'gallette'.

A refeição era composta de muitos pratos, todos preparados com açúcar, que colocavam em quase todos os molhos, assim como o açafrão, $\mathrm{O}$ serviço era de estanho, com forma antiga. Os talheres, passados da moda, mas de prata, eram pesados, assim como os pratos; algumas taças tinham a forma de um cilindro octogonal, com sete a oito polegadas de tamanho. Só gostamos mesmo nesta refeição, do vinho, que era do Porto. ${ }^{336}$

Sua tentativa em estabelecer uma conversa em latim com o padre franciscano mostrouse frustrada, pois, segundo Pernety, suspeitando de sua intenção, "tão logo terminou o jantar, ele desapareceu; o bom padre ignorava esta língua, e acredito que este defeito é comum em quase todo o clero no Brasil.” Após o jantar,

enquanto se servia o café, uns doze oficiais da guarnição entraram apresentando-nos um pequeno concerto de música instrumental. Tinham quase todas as peças de nossos melhores músicos franceses e as executavam, como Corelli ou Gaviniez.

A depender da Corte Portuguesa a estrutura política e administrativa a ser montada nas colônias seria a mais enxuta possível - gastar os mínimos recursos e extrair o máximo de rendimentos que ela pudesse dar. Francisco de Almeida Silva, na terceira de suas Máximas, defendia inclusive que os governadores não deviam levar para as conquistas nem sua família feminina nem muitos criados próprios e agregados, pois as

\footnotetext{
${ }^{336}$ Antoine Joseph Pernety. Histoire d'um Voyage aux isles Maouines, fait em 1763 \& 1764..., in Ilha de Santa Catarina... op. cit., pp. 81 e 82. O objetivo dessa expedição era fundar uma colônia francesa nas Ilhas Malvinas.
} 
nomeações para os postos no ultramar criavam uma falsa expectativa de enriquecimento muito fácil: "apenas se espalha a notícia de ir Governador para o Brasil, ou para a Índia, já todos se propõe a idéia de uma indubitável felicidade". ${ }^{337}$ Para Almeida Silva, as coisas não eram tão simples assim,

para ir, e vir de qualquer dos Governos com tão grande Família, é precisa a despesa de trinta e cinco até quarenta mil cruzados; e ainda mais: e se o empenho da Casa importar também quarenta (porque menos dessa quantia não há Cavalheiro algum, que suponha pesado o empenho da sua Casa) ambas as parcelas montam a oitenta, e já é grande. Também não sabe quem os informa, que em qualquer das Capitanias da América, ou do Oriente, a ostentação do Luxo chega a ser repreensível, porque até cobre as pessoas de uma insignificante representação.

De fato, em meio às simples e precárias instalações coloniais como a da vila de Nossa Senhora do Desterro, pareceria mesmo descabido o luxo da corte. Além do mais era muito mais fácil adaptar-se às condições que o novo ambiente oferecia - mobília, alimentação, vestuário etc. - do que procurar importar os produtos do reino, que chegavam na América a preços exorbitantes. Mais um importante argumento utilizado por Almeida Silva a favor de que os governadores deixassem no reino sua grande família.

Os víveres, e os gêneros que produz o país da primeira necessidade, são cômodos; porém os que são logo imediatamente precisos, como as Sedas, as Lãs, Azeite, Manteiga, Vinho, Vinagre etc. etc. transportados de Portugal, sobem alguns a maior preço que o de 120, e 130 por 100; e ainda muito mais conforme for a distância dos postos do Mar. Os ordenados desta numerosa Família, se se pagam, são dobrados; e enfim, os soldos de Governador são a proporção diminutos, e não podem manter, e conservar esta despesa sem grandes empenhos logo, se esta premissa do desempenho é cercada, e coberta de todas aquelas contradições, onde está o avanço, e o Lucro, que o Governador tira, se por mal informado se empenhou mais, ou, ao menos, senão desempenhou? Finalmente é mais acertado que a Família feminina fique em Portugal.

Se Almeida Silva estava correto com relação ao montante dos gastos necessários para que os governadores mantivessem um alto padrão de vida nas conquistas e, ao mesmo tempo, sustentassem suas Casas no reino, de fato, os soldos que eles auferiam no cargo eram insuficientes.

\footnotetext{
${ }^{337}$ Francisco de A. Silva. Dessertação instrutiva..., op. cit., esta citação e as seguintes às fls. 4 e 5.
} 
Mas o valor do soldo variava de uma capitania a outra. Distinção essa que serve como um importante índice, talvez mais objetivo do que o estatuto nobiliárquico dos indivíduos, da importância que a monarquia dava a cada capitania e, conseqüentemente, do grau de status e de prestígio dos diferentes postos de governança do império.

Enquanto na Ilha de Santa Catarina os governadores, desde Manoel Escudeiro Ferreira de Souza (1749-53) até a nomeação de Luís Maurício da Silveira, em 1804, auferiam 5.000 cruzados $^{338}$ (2:000\$000 réis) ao ano, no Mato Grosso, o Conde de Azambuja (1751-62) e em Minas Gerais, os governadores José Luis Meneses Abranches Castelo Branco (1768-73) e D. Antonio Noronha Beja (1775-80) recebiam, todos, 12.000 cruzados anuais. Pelo governo do Rio de Janeiro (1710-13), Antonio de Albuquerque Coelho de Carvalho ganhava a cada ano 15.000 cruzados e D. Luiz Antônio de Souza Botelho Mourão, o Morgado de Mateus, auferia pela capitania geral de São Paulo 20.000 cruzados. ${ }^{339}$

Comparando-se os governos da Ilha de Santa Catarina e do Rio Grande de São Pedro com o de outros governos subalternos percebe-se, no entanto, o significativo valor que os estabelecimentos do Sul passaram a ter para a monarquia portuguesa na América. Na década de 1720, os capitães-mores do Espírito Santo ganhavam meros 750 cruzados e, nas de 1760 e 1770, 1.250 cruzados. João Coutinho de Bragança auferia 1.000 cruzados pelo governo do Rio Grande do Norte entre 1757 e $1760 .^{340}$ Quando se criou a capitania geral do Rio Grande de São Pedro, em 1807, o soldo do seu primeiro governador, D. Diogo de Souza, ficou fixado em 15.000 cruzados. ${ }^{341}$

Mesmo os governos das capitanias gerais do norte perderam prestígio ao longo do século XVIII, em favor dos postos no centro-sul. Manuel Inácio da Cunha e Meneses governou Pernambuco (1769-74) com o soldo de 6.000 cruzados e José Serra, governador do Maranhão (1732-36), ganhava apenas 1.500 cruzados.

\footnotetext{
${ }^{338}$ AHU-SC, cx. 1, doc. 50. Os mesmos 5.000 cruzados recebia o governador do Rio Grande de São Pedro Inácio Elói Madureira, conforme a Carta Patente passada em 27.09.1760. ANTT, Chancelaria de D. José I, Lv. 48, fl. 366v. Como se pode ver no Quadro n. 2.1 não se encontrou a comprovação documental sobre o soldo de alguns governadores, entretanto, com base nas informações que trazem as notas 4 e 7 desse Quadro, é muito provável que todos eles, no período mencionado (1749-1793), recebessem os 5.000 cruzados anuais.

${ }^{339}$ Heloísa L. Bellotto. Autoridade e Conflito... op. cit., p. 67. Sobre o soldo dos governadores de Minas Gerais ver Instrução para o Governo da Capitania de Minas Gerais de José João Teixeira Coelho. Belo Horizonte: Fundação João Pinheiro, 1994, Capítulo 7.

${ }^{340}$ Todas as informações sem referência específica sobre os soldos dos governadores foram extraídas do Banco de dados Optima Pars; e de Mafalda S. da Cunha e Nuno G. Monteiro. Governadores e capitãesmores..., op. cit., p. 208.

${ }^{341}$ ANTT, Chancelaria de D. Maria I, Lv. 78, fl. 181v., mf. 1674. Carta Patente de 25 de fevereiro de 1807.
} 
Havia, contudo, grande circularidade dos oficiais, sobretudo dos governadores, pelos diferentes espaços do império, inclusive entre as capitanias principais e às subalternas. Era praxe da monarquia portuguesa, depois de eles terem cumprido seus mandatos em um estabelecimento, realocá-los em outro, conjugando as políticas de mercês, a nobilitação dos indivíduos, com as necessidades conjunturais de cada território. Os rumores de uma invasão espanhola a algum ponto da costa brasileira, em 1774-75 - calculava Pombal que o ataque seria feito mesmo à Ilha de Santa Catarina ${ }^{342}$ (fato que se confirmou no início de março de 1777) -, provocaram mudanças na distribuição dos governadores no sul. O Brigadeiro general Antônio Carlos Furtado de Mendonça, governador da capitania de Minas Gerais desde 1773, recebeu ordens, em setembro de 1774, do Secretário de Estado Martinho de Mello e Castro para comandar os regimentos militares de Santa Catarina, pois a preservação e segurança dessa Ilha, naquele momento, face àquela iminente invasão, era "um dos objetos mais importantes ao Real Serviço". ${ }^{343}$ Em seu lugar, nas Minas, assumiu interinamente o Tenente Coronel Pedro Antonio da Gama Freitas que, cinco meses depois, seria também designado para o governo da mesma Ilha. Muito embora Antonio Carlos não fosse nomeado como governador, o regime de governança que se configurava nela, como se verá no terceiro capítulo, era dual e, na hierarquia dos cargos, pelo que tudo indica, o comandante militar falava mais alto. Quanto aos soldos, sabe-se que Pedro Antonio deveria receber o mesmo que se achava "estabelecido para os governadores daquella Ilha, e ultimamente o estava recebendo o Governador della", 344 que era de 5.000 cruzados. Não se tem notícia de qual ficou sendo o soldo de Antonio Carlos como comandante militar. Antes de passar por Minas, fora ele governador de Goiás (1770-72) e auferira nesse posto 12.000 cruzados. $^{345}$ É pouco provável que para tão importante missão para a qual havia sido incumbido, tenha tido redução de seu padrão de rendimentos.

Mas os soldos não constituíam a única fonte de rendimentos dos governadores. Como já referido, muitos ganhavam também as tenças, pensões periódicas vinculadas a títulos recebidos. ${ }^{346}$ Além disso, no exercício do cargo, podiam se beneficiar das transações mercantis estabelecidas em seu território de jurisdição. A impressão que o navegador inglês George Anson, em 1740, teve do Brigadeiro José da Silva Paes não foi

\footnotetext{
342 Dauril Alden. Royal Government... op. cit., p. 138.

343 Citado por Caio Boschi. Administração e administradores no Brasil pombalino. In Tempo. Rio de Janeiro, n. 13, jul. 2002, p. 104.

${ }^{344}$ AHU-SC, cx. 4, doc. 257. Carta Patente de 18 de agosto de 1775.

${ }^{345}$ Banco de dados Optima Pars.

${ }^{346}$ Ver p. 103 e segs.
} 
nada lisonjeira a esse respeito. Comparando-o com os capitães-mores do passado, anotou em seu diário que

ele se veste melhor, vive mais magnificamente, conhece melhor o valor do dinheiro do qual os habitantes jamais sonharam, empregando meios para enriquecer que os outros também nunca tiveram a menor idéia. (...) Porque uma de suas espertezas consiste em colocar sentinelas aqui e acolá, para impedir os habitantes de nos vender alguns refrescos, a menos que os façam por um preço exorbitante, que seria loucura dar. Para justificar esta conduta, a qual excede os limites de sua autoridade, pretextava a necessidade de guardar víveres para mais de cem famílias, que deveria chegar em pouco para reforçar sua Colônia. A invenção de um pretexto tão especial, marca que não é nada inexperiente em seu emprego. Mas este aspecto, se bem que odioso, é apenas uma amostra de sua conduta indigna. Pela proximidade do rio da Prata, ele faz um bom comércio de contrabando entre os portugueses e os espanhóis. O principal ramo deste comércio consiste na troca do ouro pela prata, o que prejudica o rendimento dos dois Reis, que ficam privados do seu quinto. $^{347}$

Anson sentia na verdade os efeitos da mudança que se começara a implantar em 1739 no que diz respeito ao aumento do controle político da monarquia portuguesa sobre a Ilha de Santa Catarina e seu continente fronteiro. Se em tempos anteriores os moradores e capitães-mores tinham maior liberdade e autonomia para negociarem com os estrangeiros e estes se sentiam mais à vontade para se refrescarem na Ilha, a partir daquela data, o poder ficava, de fato, mais centralizado nas mãos do governador que, certamente, podia também tirar vantagens pessoais nas negociações. Problema esse que as autoridades metropolitanas conheciam, mas que toleravam em benefício do fortalecimento do poder régio naqueles territórios.

Outras qualidades deveriam também ser consideradas na escolha dos governadores das conquistas.

\subsubsection{Experiência militar e outras qualidades}

Raros foram os governadores não militares nomeados para as conquistas ultramarinas. Segundo Nuno G. Monteiro, na América, com exceção de alguns juristas como Luís Vasconcelos e Sousa, vice-rei do Brasil, ou Caetano Pinto de Miranda

\footnotetext{
${ }^{347}$ George Anson. A Voyage round the world in the years MDCCXL, I, II, III, IV, in Ilha de Santa Catarina..., op. cit., p. 66.
} 
Montenegro, governador de Mato Grosso e de Pernambuco, a quase totalidade dos governadores era composta de militares. ${ }^{348}$

Em se tratando de territórios de disputa, com conflitos militares abertos, como era o caso do Sul da América Meridional, essa experiência se tornava então prérequisito fundamental.

A patente militar que a maioria dos governadores da Ilha de Santa Catarina, ${ }^{349}$ do Rio Grande de São Pedro e da Colônia de Sacramento tinham, ou alcançavam, no momento de suas nomeações era de coronel de infantaria. Vale lembrar que para as capitanias gerais os nomeados eram designados como governadores e capitães generais. ${ }^{350}$ Quando ocorria de ficarem no posto com uma patente inferior, suplicavam pela promoção. Assim procedeu José Pereira Pinto. Após um triênio de governo interino da Ilha, como sargento-mor, pediu para que lhe fosse conferida a patente do posto de coronel de um dos regimentos de infantaria do Rio de Janeiro, que se encontravam vagos. ${ }^{351}$ Da mesma forma pleiteou João Alberto de Miranda Ribeiro, por mais de uma vez, enquanto exercia o cargo de governador, também interino, da Ilha. Em um dos ofícios dizia:

Tive a honra de escrever a V. Ex. ${ }^{a}$ em 17 de outubro de ano próximo passado suplicando a Proteção de V. Ex. ${ }^{a}$ para fazer valer a minha Justiça na pretensão que tinha de ser promovido a Coronel do meu Regimento por ter falecido Jozé Victorino Coimbra que o era, e ser eu o Tenente Coronel do mesmo Regimento, com os Serviços que constavam de um Memorial que tive a honra enviar na mesma ocasião a V. Ex. ${ }^{\mathrm{a}}$.

Não me passa pela imaginação, que deixarei de Ser feliz, se V.Ex. ${ }^{a}$ se dignar; de tomar debaixo da Sua Ilustre Proteção o meu Requerimento (...). ${ }^{352}$

Miranda Ribeiro exerceu o governo por seis anos e cinco meses e morreu no cargo sem ter alcançado a tão almejada promoção.

\footnotetext{
${ }^{348}$ Nuno G. Monteiro. Governadores e capitães-mores..., op. cit., p. 108.

${ }^{349}$ Ver Quadro n. 2.1.

${ }^{350}$ Não procede, portanto, para o caso de Santa Catarina, a afirmação de Paulo Pedro Perides segundo a qual, "Nas capitanias de menor importância o governador recebia o título de 'capitão-mor' ou simplesmente de 'governador'. Ficava sob a jurisdição do 'governador' e capitão general' de uma determinada 'capitania geral', sendo por isso denominada 'capitania subalterna'. In: A organização político-administrativa e o processo de regionalização do território colonial brasileiro. Op. cit., p. 85.

351 AHU-SC, cx. 4, doc. 329. Carta ao Secretário de Estado dos Negócios Ultramarinos Martinho de Mello e Castro, em 20 de março de 1789.

352 AHU-SC, cx. 5, doc. 373. Carta ao Secretário de Estado da Marinha e Ultramar Luiz Pinto de Souza Coutinho, em 24 de maio de 1796. Há um outro requerimento com o mesmo propósito dirigido a Martinho de Mello e Castro, em 11 de março de 1795, AHU, cx. 5, doc. 359.
} 
A posição militar inferior de alguns governadores explica em parte a interinidade do posto, mas isso não consistia regra rígida, pois um dos governadores interinos, Francisco Antônio da Veiga Cabral da Câmara, tinha a patente de coronel.

Experiência militar - tempo de serviço e exercício de outros postos do império português - era de fato um dos critérios importantes a ser levado em conta na escolha dos governadores. Dos doze governadores da Ilha de Santa Catarina, dos quais se conseguiu identificar a idade, apenas dois tinham menos de 40 anos no momento da nomeação. A idade média dos nomeados era de mais de 50 anos, o que significa que assumiam a governança da Ilha com considerável tempo de serviços prestados à Coroa.

Pedro de Azambuja Ribeiro, de quem não se sabe a idade, tinha, quando de sua nomeação como substituto de Silva Paes no governo da Ilha, 53 anos só de tempo de serviço! ${ }^{353}$ Começara sua carreira na vila de Abrantes, Portugal, servindo como praça de soldado, cabo de esquadra e alferes, participando de várias missões militares no reino e ultramar, como mostra sua carta-patente de Marechal de Campo:

Embarcando-se no ano de 1694 ma fragata M. Sra. do Cabo foi correr a costa e dar comboio a uma charrua carregada de Artilharia e outras Munições (...) e avistando um Navio de Mouros combateu com ele até que se fossem fugidos; [foi] com duas caravelas socorrer a Praça de Mazagão. Em 1698 comboiou as Naus da Índia, e as mais que iam para as conquistas lançando em Terra ao Governador da Ilha da Madeira (...) e avistando nas Ilhas dos Açores a Frota do Rio de Janeiro, e Naus da Índia a acompanhou até entrar neste Porto de Lisboa (...). ${ }^{354}$

Sendo promovido ao posto de sargento-mor da vila de Abrantes, foi encarregado do governo dela "em que satisfez inteiramente a tudo o que lhe tocava, sossegando aquele Povo com muita prudência e acerto em um motim que se levantou". Em 1711, com essa patente, passou para um dos terços da praça do Rio de Janeiro onde foi promovido ad honorem ao posto de Mestre de Campo, comandando ali um regimento. Em 1721, "pedindo o Governador das Minas ao do Rio de Janeiro um destacamento de 150 soldados para o sossego daquela Capitania foi [Azambuja Ribeiro] pôr cabo dele em que houve com grande vigilância, satisfazendo prontamente as suas obrigações".

\footnotetext{
353 ANTT, Chancelaria de D. João V, Lv. 82, fl. 370. Patente de Marechal de Campo a Pedro de Azambuja Ribeiro, em 23 de setembro de 1733.

${ }^{354}$ ANTT, Chancelaria de D. João V, Lv. 82, fl. 370.
} 
Seu antecessor no governo da Ilha, Patrício Manoel de Figueiredo, apresentava também comprida folha de serviços. Na carta-patente de tenente-coronel, expedida em 14 de março de 1752, constava ter

servido neste Reino e nas capitanias de Pernambuco e Rio de Janeiro por espaço de 45 anos, 8 meses, e 5 dias continuados de 6 de Abril de 1704, até 18 de Maio de 1751, em praça de soldado, Cabo de Esquadra, Sargento Supra, Alferes, Tenente Ligeiro, e de granadeiros, Capitão de Infantaria ligeiro, Capitão de Granadeiros, e sargento-mor de Infantaria de um dos regimentos da Praça do Rio de Janeiro. ${ }^{355}$

Na década de 1750, por várias vezes, assumiu nessa capitania seu governo interino. Na última vez, em 1757, teve de conter a arribada na baía de Guanabara de uma esquadra de guerra francesa armada por Luís XV e pela Companhia da Índias Orientais, cuja finalidade era combater os ingleses nos mares orientais. ${ }^{356}$

Desde o século XVI, de acordo com Fernanda Olival, “o tempo de serviço foi-se tornando num bem patrimonial em si mesmo (...), quer para quem o cumpria no Reino, quer fora dele. Passou a ser medido com grande rigor, em anos, meses e dias, se contínuo ou interpolado, se individualmente feito ou se na companhia de homens e cavalos sustentados à custa do servidor". 357

Aspecto marcante na trajetória desses homens, presente já nos dois exemplos supracitados, e que se tornará recorrente com os governadores seguintes, é que, na América, lugar onde a maioria deles permaneceria até o final de suas vidas, eram destacados para algum Regimento no Rio de Janeiro, e nele ficavam vinculados, atuando nos territórios de sua jurisdição, ou de influência. Tirando alguns poucos casos como o de Francisco Antonio da Veiga Cabral que, após sua rápida governança da Ilha foi nomeado governador geral da Índia, ou do já citado Patrício Manoel de Figueiredo que, antes de governá-la era capitão de infantaria na guarnição de Pernambuco, os espaços nos quais atuavam se restringiam aos territórios do Rio de Janeiro, de Minas Gerais, de Goiás, de São Paulo, de Santa Catarina, do Rio Grande de São Pedro e da Colônia do Sacramento. O próprio Veiga Cabral acabou retornando para o Rio de Janeiro depois de exercer a governança da Índia.

\footnotetext{
${ }^{355}$ ANTT, Chancelaria de D. José I, Lv. 64, fl. 246.

${ }^{356}$ Segundo Maria Fernanda Bicalho, ele mostrou-se inexperiente e "titubeante na administração da ameaça representada por aqueles visitantes e no apaziguamento dos ânimos temerosos e alterados dos moradores". A Cidade e o Império. O Rio de Janeiro no século XVIII. Rio de Janeiro: Civilização Brasileira, 2003, p. 61.

${ }^{357}$ Fernanda Olival. Mercês, Serviços e Circuitos Documentais no Império Português, op. cit, p. 59.
} 
Francisco Antônio Cardoso de Meneses e Souza começou sua carreira militar no reino, em 1735, como "praça de soldado de cavalo ligeiro". Por volta de 1738, foi destacado para o regimento do Rio Grande de São Pedro no posto de Ajudante de Dragões, sendo promovido a Capitão do mesmo em 1743. Em maio de 1745, teve licença para ir ao Reino, regressando para a América três anos depois, dessa vez, para a capitania de Minas Gerais, com a patente de Mestre de Campo General. Por ordem do governador e capitão general da capitania do Rio de Janeiro, Gomes Freire de Andrade, foi incumbido, em 1751, de seguir novamente ao Rio Grande levando numerário às tropas daquele Continente e, no ano seguinte, já como coronel, designado Primeiro Comissário da Primeira Partida da demarcação do Tratado de Madri. Em 1757, estava no Rio de Janeiro, onde comandou um dos regimentos de infantaria daquela praça. ${ }^{358}$ Em 14 de abril de 1762, como governador da Ilha de Santa Catarina, ele dirigiu um longo e interessante requerimento a Francisco Xavier de Mendonça Furtado suplicando piedosamente que lhe fosse garantido, após deixar aquela governança, o posto de coronel de infantaria do Rio de Janeiro a que estava vinculado. Embora Gomes Freire, que foi quem o convidou para aquele governo, houvesse assegurado que sua majestade faria a honra de o conservar em seu posto e que, acabado o tempo do seu governo podia recolher-se ao serviço do seu regimento, não estava nem um pouco seguro disso, visto que essa promessa não havia sido formalizada e, por esse motivo, requeria então ao secretário de Estado que oficializasse em carta-patente essa condição.

O documento revela que a preocupação de Meneses e Sousa era de que, enquanto estivesse desempenhando o cargo de governador da Ilha, o posto de coronel daquele regimento fosse ocupado por outra pessoa. Argumentava ao secretário que era um "dos mais antigos Coronéis de todas as tropas de Sua Maj. tendo nelas servido com a honra que justificam as certidões" que lhe tem passado o seu General; dizia ainda que serviu "a perto de vinte e cinco anos nesta América tendo marchado muitos centos de légua por asperíssimos Sertões, e dos últimos que foram os de Missões (...)". 359 Pelo que tudo indica, Meneses e Sousa não teve problemas ao findar sua gestão na Ilha de Santa Catarina em 1765. Dois anos depois, recebia o título de Brigadeiro, com exercício de Coronel de Infantaria no Rio de Janeiro. Em 21 de julho de 1766, então com seus 56

\footnotetext{
${ }^{358}$ ANTT, Chancelaria de D. José I, Lv. 64, fl. 276v. Carta-patente de coronel de infantaria a Francisco Antônio Cardoso de Meneses e Souza, em 13 de março de 1752; Walter Piazza. Dicionário político..., op. cit., p. 544; e Banco de dados Optima Pars.

${ }^{359}$ AHU-SC, cx. 3, doc. 166.
} 
anos de idade, ele foi nomeado governador da Nova Colônia do Sacramento, ${ }^{360}$ todavia, não se sabe por que motivo, ele não chegou a assumir o cargo. ${ }^{361}$ Segundo Walter Piazza, ele faleceu no Rio de Janeiro por volta de $1771 .^{362}$

Luís Maurício da Silveira demonstrava ter preocupação semelhante à de Meneses e Sousa e apontava ainda para outro problema: exercer o cargo de governador podia se tornar inclusive um entrave para a progressão na carreira militar. Em requerimento ao rei, de 3 de julho de 1806, relatava que era

Governador do Departamento da Ilha de Santa Catharina por Decreto de V. A. R. de 20 de junho de 1804, achando-se o Suplicante no mesmo posto empatado o seu adiantamento, vendo neste mesmo Governo Capitães que passarão a Tenentes Coronéis, e Alferes a Capitães por todos esses motivos recorre o Suplicante a Inata Piedade de V. A. R. seja servido Despachar ao Suplicante no posto de Sargento Mor para qualquer dos Regimentos da Cidade do Rio de Janeiro, ou para este mesmo Regimento da Ilha (...) atendendo a que o Suplicante deseja ficar servindo na América sendo V. A. R. servido graduá-lo nos postos, em contemplação ao bem que tem servido (...) atendendo também às grandes despesas e empenho em que deixou sua casa para fazer uma viagem com a sua família tão dilatada; este o motivo por que receia que findos os anos do seu Governo seja mudado e não acomodado para outro, ou em outro emprego que V. A. R. seja servido, e ver-se o Suplicante na consternação de ter que tornar a fazer uma tal viagem em que acabe de se empenhar, e arruinar o pouco que nessa cidade tem (...). ${ }^{363}$

Ele morreu no Rio de Janeiro no ano de 1824 com aproximadamente 61 anos de idade. ${ }^{364}$ Para quem não podia - ou não queria - retornar ao reino, fazer carreira militar na capital do Estado do Brasil e almejar alto posto em um de seus regimentos constituía o objetivo de muitos dos oficiais do império português na América.

A família de Francisco Antônio da Veiga Cabral da Câmara, como se pôde ver, teve significativa representação nos cargos de governança portuguesa no sul da América Meridional: seu tio, Sebastião da Veiga, fora governador da Colônia do Sacramento (1699-1705); seu irmão, Sebastião Xavier, do Rio Grande de São Pedro (1780-1801); e ele, da Ilha de Santa Catarina (1778-1779). Segundo o próprio Francisco Antônio

\footnotetext{
${ }^{360}$ AHU-CS, cx. 7, doc. 582, Decreto de D. José I.

${ }^{361}$ Cf. Dauril Alden. Royal Government..., op. cit., p. 448; e Paulo César Possamai. O Cotidiano da Guerra: a vida na Colônia do Sacramento (1715-1735). São Paulo: USP-FFLCH (Tese de Doutorado em História), 2001, p. 17. Equivoca-se, portanto, F. A. Varnhagen. História Geral..., vol. 5, op. cit., p. 306 em listar ele como governador dessa praça entre 1769 e 1775. Walter Piazza. Dicionário político..., op. cit., p. 544, colocou-o também como governador no ano de 1769.

${ }^{362}$ Dicionário político..., op. cit., p. 544.

363 ANRJ, Cód. 106, vol. 16, fl. 201.

${ }^{364}$ Walter Piazza. Dicionário político..., op. cit., p. 536.
} 
declarou em requerimento para obter comendas que seu pai e avós possuíam, ele teria assentado praça de soldado "aos primeiros anos de sua vida", em $1743 .{ }^{365}$ Seguiu sua vida militar no reino alcançando os postos de capitão e sargento-mor da cavalariça. No início da década de 1770, passou ao Rio de Janeiro, servindo nos regimentos de infantaria dessa cidade e da Bahia com a patente de Ajudante General e coronel disciplinar. Em 1776, sendo a capital do Estado ameaçada de invasão estrangeira, foi nomeado pelo Marquês do Lavradio na conformidade das reais ordens, como Comandante General da sua defesa com a graduação de Brigadeiro. Em julho de 1778, considerado Marechal de Campo, lhe foi delegada pelo sobredito marquês vice-rei a incumbência de receber a Ilha de Santa Catarina de Guilherme Waughan, Marechal designado pela corte de Madri, e ficou governando-a por aproximadamente um ano. ${ }^{366}$ Entre os governadores da Ilha, Francisco Antônio foi provavelmente aquele que alcançou maior grau de distinção nobiliárquica (obteve o título de visconde de Mirandela, em 1810) e, também, militar. Entre 1784 e 1807 foi ele governador geral da Índia. Regressando ao Rio de Janeiro junto com a família real, em 1808, cidade onde permaneceria até a sua morte, em 1810, graduou-se como Marechal do Exército, foi vogal do Supremo Conselho Militar, Conselheiro de Guerra e, finalmente, Governador das Armas da Corte dessa capitania.

Manoel Soares Coimbra tinha raízes mais profundas na América. Seu pai era natural da Ilha de Santa Catarina e ele, do Rio de Janeiro. Nessa cidade começou suas atividades militares por volta dos 15 anos de idade como soldado voluntário (1751). Em 1754, embarcou para Lisboa, retornando à América logo em seguida para servir em uma Companhia de Granadeiros no Sul, onde alcançou o posto de Alferes (1762) e capitão de infantaria da Ilha de Santa Catarina (1766). ${ }^{367}$ Em 31 de março de 1776, liderou um dos dois regimentos, sob o comando superior do tenente-general austríaco João Henrique de Böhm, que reconquistou a vila de Rio Grande dos espanhóis, ocupada desde 1763. ${ }^{368}$ Foi tenente-coronel do Regimento de Bragança destacado no Rio e,

\footnotetext{
${ }^{365}$ Se a informação que ele deu e a data que se tem do seu nascimento (1734) estão corretas, então teria ele aproximadamente nove anos de idade!

${ }^{366}$ ANTT, Chancelaria de D. Maria I, Lv. 84, fl. 329v.

${ }^{367}$ Walter Piazza. Dicionário político...op. cit., p. 163; Banco de dados Optima Pars.

368 Dauril Alden. Royal Government..., op. cit., p. 184, narra um fato pitoresco ocorrido nessa ação militar: 31 de março era o dia de aniversário de Mariana Vitória, rainha de Portugal e irmã de Carlos III, rei da Espanha e, como era costume comemorar os aniversários da família real em todos os cantos do império português, o Gen. Böhm, utilizando-se do evento, mandou disparar 21 salvos de canhão em homenagem à rainha, os quais foram respondidos em igual número pela guarnição espanhola, que observava da praia os portugueses festivos e relaxados atravessarem o canal da Lagoa dos Patos. Na
} 
quando de sua nomeação ao governo da Ilha, em 1791, foi promovido a coronel do regimento dela. Numa folha de pagamentos dessa guarnição de 30 de outubro de 1797 aparece, além de seu comandante, o coronel Manoel Soares Coimbra, um capitão de granadeiros de mesmo nome, o capitão de fuzileiros Joaquim Soares Coimbra e o alferes de granadeiros João Soares Coimbra, provavelmente, seus filhos. ${ }^{369}$

Ao assumir o governo da Ilha de Santa Catarina, em dezembro de 1800, Joaquim Xavier Curado trazia também em seu currículo larga experiência militar além de outras habilidades. Na carta-patente de tenente-coronel que lhe foi passada, em 27 de março de 1798, constava ter servido

há 32 anos o posto de Sargento Mor efetivo do Primeiro Regimento do Rio de Janeiro pela extinção do qual, ficara agregado aos de Bragança destacado na mesma cidade ocupando-se sempre no serviço da Praça e em outras muitas e diferentes Diligências tanto civis como militares, com inteira satisfação do Público, do Atual Vice Rei do Estado, e de todos seus Antecessores: fazendo a Campanha do Rio Grande no decurso de 6 anos, e sendo antecedentemente nomeado para o Destacamento de Iguatemi, distrito de São Paulo, e fora também para vir a esta Corte com a comissão e que se encarregara dar conta na Secretaria de Estado dos Negócios Ultramarinos, tendo a sorte de ficar na viagem Prisioneiro dos Franceses, padecendo os incômodos próprios daquela triste situação, e q. vencendo-a viera pronto a seguir as Minhas Reais ordens (....). ${ }^{370}$

A trajetória militar desses homens (os cargos ocupados no exército, as ações e batalhas travadas a serviço de Portugal) constituía, de fato, elemento fundamental a contar nos critérios de escolha dos governadores no sul da América Meridional, mas não era só isso. Eles traziam na bagagem outros conhecimentos e experiências: alguns eram engenheiros, cartógrafos; outros, escritores, matemáticos; todos, de alguma forma, administradores, pois, o exercício da governança, mesmo nas praças militares, compreendia também os assuntos civis. Pode-se dizer ainda que vinham influenciados uns mais, outros menos - pelas novas idéias do século das luzes.

Ao longo do reinado de D. João V (1706-1750) houve uma difusão em Portugal da cultura científica estrangeira, tanto por meio dos serviços contratados a estrangeiros (cartógrafos, astrônomos, geógrafos, engenheiros e matemáticos), como dos chamados

seqüência, eles tomara o povoado de São José do Norte, na margem setentrional da Barra do Rio G. de São Pedro.

${ }^{369}$ ANRJ, Cód. 106, vol. 13, fl. 225. “Conta de distribuição de 8:059\$820 rs. que proximamente vieram da Capital do Rio de Janeiro para pagamento de 6 meses de soldos, e despesas ordinárias desta Ilha até setembro do corrente ano...".

${ }^{370}$ ANTT, Chancelaria de D. Maria I, Lv. 56, fl. 38. 
“estrangeirados", diplomatas, médicos, políticos, homens de ciência e de letras portugueses que passaram a freqüentar as cortes européias tornando-se agentes de uma lenta transformação da mentalidade no reino. Entre esses pode-se destacar D. Luís da Cunha, o Conde da Ribeira Grande, Sebastião José de Carvalho e Melo (Marquês de Pombal), o Visconde da Vila Nova de Cerveira e o Conde de Ericeira. O próprio monarca "procurou adquirir e difundir no reino essa cultura científica e as técnicas de seu tempo como instrumento indispensável da expansão e da soberania política nas conquistas ultramarinas. ${ }^{371}$ Fundou a Academia Real de História Portuguesa; deu início às atividades astronômicas em Portugal; apoiou uma reforma do ensino baseado em métodos pedagógicos modernos, valorizando o saber experimental, investindo na conclusão da Universidade de Évora e encarregando Luís António Verney a estudar os sistemas de ensino das nações européias, de cuja missão resultou a publicação da obra Verdadeiro Método de Estudar (1746). Como engenheiro-mor do reino, nomeou Manoel de Azevedo Fortes, divulgador das teorias cartesianas e autor de várias obras, entre elas, O Engenheiro Portuguez (1728) e a Lógica Racional, Geométrica e Analítica (1744). As Academias Militares sob o impulso de Fortes tornaram-se um viveiro de engenheiros, geógrafos e cartógrafos, donde saíram os governadores do Mato Grosso, Dom Antonio Rolim de Moura e Luís Albuquerque Pereira e Cáceres, e de Santa Catarina, José da Silva Paes (que governou também o Rio Grande de São Pedro), André Ribeiro Coutinho e José Custódio de Sá e Faria.

As circunstâncias próprias do território que iam governar e as novas necessidades do império português exigiam habilidades específicas dos governadores. Quando, a partir da década de 1730, a Coroa Portuguesa resolveu consolidar seu domínio nesse amplo território entre a capitania de São Paulo e o rio da Prata, necessitou de homens com aguçado sentido do espaço, bons cartógrafos e hábeis engenheiros-militares capazes de, ao mesmo tempo, comandarem as tropas e projetarem fortalezas nos pontos estratégicos para sua defesa.

Segundo Jaime Cortesão, se a cultura portuguesa do Quatrocentos e do Quinhentos pode ser caracterizada por uma "cultura da latitude", baseada no método de navegar por alturas - a altura do Sol, da Estrela do Norte ou do Cruzeiro do Sul - que lhes permitiu assim traçar as cartas de latitude observadas e desenhar e situar os

\footnotetext{
${ }^{371}$ Jaime Cortesão. Alexandre de Gusmão e o Tratado de Madrid. Parte I, Tomo I, op. cit., p. 92. Ver também Jorge Couto. "D. João V", in João Medina (Dir.) História de Portugal, op. cit., p. 266; e Maria da Conceição Ruivo. O Iluminismo e a Cultura Científica, in Laboratório do Mundo: idéias e saberes do século XVIII. São Paulo: Imprensa Oficial, 2004, p. 32.
} 
continentes nas suas posições em relação ao Equador, o processo que se seguiu no século XVII e, sobretudo no XVIII, define-se pela "cultura da longitude", da noção espacial de profundidade. E, se à primeira fase correspondeu um tipo social - a do piloto cosmopolita, viajante de todos os mares, como João Dias de Solis, D. João de Castro e Fernão de Magalhães, agentes de um processo de colonização linear e ganglionar, que construíram "edifício de fachada imensa, mas sem profundidade" -, à segunda vai corresponder a do "matemático" e, mais especificamente, do engenheirocartógrafo que projeta a fixação e a expansão para o interior dos continentes. ${ }^{372}$

Quinze ou dez anos antes da celebração do Tratado de Madri (1750), todos os portos chaves da América portuguesa foram ocupados por engenheiros, ou por governadores que se faziam acompanhar de engenheiros ou cartógrafos. De todos esses homens, "o que se aproxima mais do ideal do engenheiro setecentista em que se fundem o técnico, o político, e o organizador, é José da Silva Paes, que constrói fortalezas, desenha mapas e funda províncias". 373

Segundo apontam seus biógrafos, as habilidades e virtudes de Silva Paes não se restringiam a isso. Mostrava ser um homem erudito para o seu tempo, com interesses em diversas áreas do conhecimento científico e literário europeu. Sua biblioteca particular composta de 437 livros recebeu a seguinte ordem em seu inventário: Religião (68), Filosofia (14), Geometria e Trigonometria (89), História e vida de príncipes (252) e Medicina e Cirurgia (14). Ao lado de obras como a Arte de Amar a Deos, Manual dos Evangelhos, Bíblia Sacra, podia-se encontrar, por exemplo, duas edições (uma em francês) de As paixoens da Alma de René Descartes, Filosofia Methodica de Victorino José da Costa e um dos dez volumes do Vocabulario Portuguez e Latino de Rafael Bluteau. Estavam bem representados nela os portugueses, clássicos e modernos, Camões, Fernão Mendes Pinto, o Padre Antônio Vieira, Francisco Rodrigues Lobo. Dentre tantas obras de engenharia e prática militar que possuía constavam dois exemplares do Engenheiro Portuguez de Manoel de Azevedo Fortes, Fortificaçam moderna de Johann F. Pfeffinger, o Methodo Lusitanico de desenhar as fortificações de Luis Serrão Pimentel, O Capitão de Infantaria Portuguez do André Ribeiro Coutinho

\footnotetext{
${ }^{372}$ Jaime Cortesão. Alexandre de Gusmão e o Tratado de Madrid. Parte I, Tomo I, op. cit., p. 292 e ss.

373 Ibid., p. 320.
} 
(Mestre de Campo que o substituiu na comandância militar do Rio Grande de São Pedro em 1739) e O Governador de Praças de Antonio de Ville Tolozano. ${ }^{374}$

Silva Paes demonstrou ainda ter participado ativamente da incipiente vida cultural do Rio de Janeiro, pois seu nome aparece como um dos trinta membros da Academia dos Felizes, instituição que reunia letrados e pessoas com expressão no meio artístico e científico, fundada no Palácio do governador daquela cidade no ano de $1736 .^{375}$

No primeiro decênio de governança da Ilha de Santa Catarina (1739-48), período em que o estabelecimento era basicamente uma praça militar, as atividades e preocupações dos governadores giravam em torno da administração da tropa e da construção das fortalezas. A partir daí, com o aumento da população civil (chegada dos casais açorianos e madeirenses), a diversificação das atividades produtivas e comerciais e a crescente institucionalização da sociedade (criação da ouvidoria, provedoria e hospital), o estabelecimento foi se tornando mais complexo, exigindo dos governadores maior habilidade no trato das questões político-administrativas. As reformas pombalinas com vistas à racionalização da administração (criação das Juntas da Fazenda, maior exigência nas prestações de conta e instauração do método das partidas dobradas na contabilidade) acentuariam esse processo.

É certo que a questão militar, o sistema de defesa da Ilha, frente ao invasor estrangeiro, continuou sendo a tônica das preocupações daquele governo, e assim foi pelo menos durante as duas primeiras décadas do século XIX, com as pretensões joaninas de formação da província cisplatina. Mas, mesmo nos momentos de guerra declarada, a Corte Portuguesa não pôde abrir mão dos encargos civis: organização da produção econômica, distribuição das sesmarias e tantos outros problemas que envolviam a vida dos povoadores. Quando, a partir de meados de 1774, intensificou-se o conflito militar no sul - o iminente ataque da esquadra de guerra espanhola montada pelo Marquês de Casa Tilly formada por mais de cem embarcações, em algum porto do sul da América Meridional e o esforço militar português na reconquista do Rio Grande de São Pedro - alterou-se a configuração da estrutura de poder dos governos desse estabelecimento e da Ilha de Santa Catarina. Os governadores que até então acumulavam no cargo as funções civis e militares tiveram que dividir o mando com um

${ }^{374}$ Ver Ana Cristina Araújo. Livros de uma vida... op. cit.; Walter Piazza. O Brigadeiro José da Silva Paes..., op. cit.; e Abeillard Barreto. A livraria de José da Silva Paes, in Província de São Pedro. Porto Alegre, 15: 178-80, 1951.

${ }^{375}$ Walter Piazza. O Brigadeiro José da Silva Paes..., op. cit, pp. 69 e 70. 
alto oficial do exército. O Coronel Pedro Antônio da Gama Freitas fora designado como governador da Ilha, em setembro de 1775 , com poderes que, talvez não de maneira explícita, mas tacitamente, eram restritos à esfera civil. Os assuntos militares estavam sob o comando superior do Brigadeiro General Antônio Carlos Furtado de Mendonça, desde fevereiro daquele ano. ${ }^{376}$

Nesses momentos críticos de guerra contava a patente e, sobretudo, a experiência reconhecida em ações militares. Furtado de Mendonça, além de ser mais graduado, trazia em seu currículo missões na Índia como Capitão e Coronel de Infantaria. Gama Freitas, por sua vez, havia sido Ajudante de Ordens do vice-rei Marquês do Lavradio, ${ }^{377}$ um ofício de cunho mais burocrático. ${ }^{378}$

A relação entre os dois não foi muito amistosa, ou pelo menos isso é o que se percebe depois de serem devassados pela perda da Ilha de Santa Catarina aos espanhóis. Em seu Auto de defesa, Furtado de Mendonça acusava o governador Gama Freitas de, além de ser jovem demais e inexperiente para o cargo, ser também intrometido, incompetente e lacaio do Marquês vice-rei. ${ }^{379}$ Tratava-se evidentemente de uma visão parcial do Brigadeiro, na tentativa de ser absolvido pelo Conselho de Guerra a que estava sendo submetido. Contudo, verdade ou não, sabe-se que os critérios subjetivos como a política de mercês com a nobilitação dos indivíduos, as relações de compromisso, amizade, ou apadrinhamento, concorriam com os fatores técnicoprofissionais na escolha dos governadores.

Com a devolução da Ilha de Santa Catarina a Portugal, em julho de 1778, conforme mandava o Tratado de Santo Ildefonso (1777), os governadores que se seguiram em seu comando, voltaram a concentrar em suas mãos os poderes civis e militares. O compromisso inicial era restabelecer aquela colônia, "refundar a capitania",

\footnotetext{
${ }^{376}$ ABNRJ, vol. 103, 1983, Carta n. 1. Ao mesmo tempo, no Rio Grande de São Pedro, enquanto o governo civil estava a cargo de José Marcelino de Figueiredo, o comando militar era exercido pelo Tenente-General João Henrique de Böhm.

${ }^{377}$ ANTT, Chancelaria de D. José I, Lv. 32, fl. 31. Patente de licença a Pedro Antônio da Gama Freitas, em 20 de agosto de 1771. Ver também a esse respeito Maria de Fátima Fontes Piazza. A Invasão Espanhola na Ilha de Santa Catarina. Brasília: UnB (Dissertação de Mestrado - Política Externa), 1978, pp. 126 e 127.

${ }^{378}$ A obra de Graça Salgado (Coord.). Fiscais e Meirinhos - A Administração no Brasil Colonial. 2a. ed. Rio de Janeiro: Nova Fronteira, 1985, não faz referência ao cargo de Ajudante de Ordens, mas pode-se depreender essa natureza mais administrativa do ofício em uma minuta expedida, em 4 de setembro de 1794, pelo secretário de estado da Marinha e Ultramar, Martinho de Mello e Castro, ao vice-rei do Estado do Brasil, o Conde de Resende (D. José Luís de Castro), ordenando que o coronel do Regimento de Dragões do Rio Grande de São Pedro, Gaspar José de Matos, que servia como ajudante de ordens do vice-rei, regressasse ao seu posto militar, atendendo à sua importância no comando e manutenção da disciplina dos soldados e ofícios a seu cargo necessários para a defesa daquele território. [grifo meu] AHU-RJ, cx. 152, doc. 11566.

${ }^{379}$ Citado por Dauril Alden. Royal Government..., op. cit., p. 231, nota 25, e p. 269.
} 
fazendo retornar os povoadores que, durante a invasão haviam se estabelecido no continente, reanimar a agricultura e restaurar o poder institucional português.

Percebe-se no período que vai de 1778 a 1807 um maior esforço dos governantes (Corte, vice-reis e governadores) com a organização política e administrativa e com o desenvolvimento econômico daquele estabelecimento, sem contudo, deixar de se preocupar com o seu sistema defensivo. A invasão de 1777 evidenciara a vulnerabilidade daquele porto e, conseqüentemente, de todo o território meridional. E, de fato, essa preocupação com a defesa justificava-se, pois a paz que se instaurou nas décadas seguintes era percebida como instável: o Tratado de Santo Ildefonso não conformava plenamente os anseios das nações ibéricas naquele espaço e, após 1789, o temor de uma invasão estrangeira recairia mais uma vez sobre os franceses.

A invasão de 1777 foi, sem dúvida, um marco para a história de Santa Catarina, não tanto sob os aspectos sociais e econômicos, pois, como se procurará mostrar no terceiro capítulo, não se verificam grandes rupturas na política pós-pombalina com relação a ela, mas por outros motivos. Primeiro, porque, num plano político, ela deve ser inscrita no conjunto de fatos que sacudiram o império luso-brasileiro nesse momento: a morte do rei D. José I (24.02.1777) e a queda do Marquês de Pombal, a celebração do Tratado de Santo Ildefonso e a própria substituição do Marquês do Lavradio dois anos depois. Embora em termos econômicos a Ilha e seu continente fronteiro representassem pouco para o império como um todo, a sua perda colocava em sério risco os territórios do Rio Grande de São Pedro, de São Paulo e até mesmo do sertão mineiro. Não foi por menos que uma das acusações dirigidas contra Pombal, após ser substituído no ministério, era de que "a Praça de Almeida, e a Ilha de Sta. Catarina foram entregues aos castelhanos por ordens particulares" dele. ${ }^{380}$

Segundo, porque, sob o aspecto cultural e simbólico, a rendição da Ilha - a "capitulação de Cubatão", ${ }^{381}$ como foi chamada -, sem que a guarnição dela oferecesse a mínima resistência, soou como uma terrível e humilhante derrota na América e no reino. Como dizia Antonio de Ville Tolozano, o governador devia estar isento de dois vícios: a temeridade e a covardia e, ressalte-se que, a entrega de uma praça militar, ou

\footnotetext{
${ }^{380}$ BNL, PBA, 695, mf. 1635. Em 2 de abril de 1777, Pombal apresentou o documento Apologias que tenho escrito sobre cada huma das calumnias, que a ingratidão, e a inveja espalharam contra mim no grande Povo de Lisboa, depois da minha auzencia. Ver Decima Quarta Apologia, fl. 177.

${ }^{381}$ Cubatão é um rio que tem nascente na Serra do Taboleiro, no continente, e corre os rumos de nordeste a leste até desaguar na Baía Sul da Ilha de Santa Catarina. Cf. Joaquim Gomes de Oliveira Paiva. Dicionário topográfico, histórico e estatístico da Província de Santa Catarina. Florianópolis, IHGSC, 2003.
} 
de um forte ao inimigo sem que o comandante oferecesse qualquer resistência era muito mais que uma desonra, consistia de fato em crime contra a monarquia, motivo pelo qual alguns militares preferiram desertar a serem submetidos ao Conselho de Guerra. O assunto era tão complicado e embaraçoso aos governadores, que Tolozano, ao dedicar a última parte de sua obra a ele - "Das Capitulações, e entrega das Praças" -, fez a seguinte consideração:

Eu estava na resolução de não escrever este Capítulo para dar a entender aos Governadores que nunca devem capitular, e que é esta matéria que menos devem saber, e estudar; porém como pode suceder que depois de uma valorosa, e competentemente dilatada defesa, o Príncipe queira que a Praça se renda por algumas considerações, que a isso o poderão mover, e por que em fim falta o lugar, e a terra para se entrincheirar, ou já não tem soldados para se defender, ou lhe faltam as munições para atirar, ou as que servem ao sustento, achando-se obrigado a capitular; direi aqui a ordem que deve ter antes, e depois da capitulação. ${ }^{382}$

Em carta ao governador da Bahia, escrita um mês após a invasão, o Marquês do Lavradio expressava todo seu sofrimento diante daquela derrota:

Veja V. Ex. qual terá sido a minha dor e a minha consternação. Eu não sei o como me não tem estalado o coração por toda a parte. Esta dor é daquelas que quanto mais se lhe procura o remédio, menos alívio se lhe encontra.

Eu conheço que é necessário revestir-me de toda a constância e desafogo, para poder obrar o que devo, para restaurar a honra e glória da nação; porém se Deus me não der forças, eu não poderei resistir. ${ }^{383}$

Podia-se questionar sobre as condições concretas da guarnição portuguesa que se encontrava na Ilha de Santa Catarina ${ }^{384}$ - do número e qualidade das tropas, dos seus armamentos e embarcações em comparação com a Armada espanhola, das fragilidades do seu sistema defensivo (o desembarque espanhol na Ponta das Canasvieiras mostrara que as barras Norte e Sul não eram as únicas portas de entrada na Ilha) -, mas não se trata de fazer aqui juízo sobre a atitude dos responsáveis pela capitulação. Refletindo mais sobre os desdobramentos do fato, sabe-se que o governador, Pedro Antônio da

\footnotetext{
382 O Governador de Praças..., op. cit, pp. 444 e 445.

${ }^{383}$ ABNRJ, vol. 32, 1914, p. 349. Ofício do vice-rei Marquês do Lavradio ao Governador da Bahia, em que lhe dá parte de ter o General Antonio Carlos Furtado de Mendonça abandonado a Ilha de Santa Catarina e várias notícias relativas a Esquadra espanhola, em 24.03.1777.

384 Para uma análise mais aprofundada dessas questões ver, entre outros, Dauril Alden. Royal Government..., op. cit., especialmente o capítulo IX - The Second Cevallos Campaign; Maria de Fátima F. Piazza. A Invasão Espanhola na Ilha..., op. cit., capítulo 2; e João Carlos Mosimann. Ilha de Santa Catarina, 1777-1778. A Invasão Espanhola. Florianópolis, Ed. do autor, 2003.
} 
Gama Freiras, o comandante da guarnição, Antônio Carlos Furtado de Mendonça e outros oficiais do exército ${ }^{385}$ foram levados ao Conselho de Guerra, presos e tiveram seus bens seqüestrados, até que, em 14 de janeiro de 1786, um decreto real mandava que os "referidos Autos, sentenças e informações" fossem "recolhidos a Secretaria de Estado da Repartição da Guerra, para nela se guardarem com o maior segredo e recato a fim de que este negócio" ficasse "em perpétuo esquecimento". ${ }^{386}$ Infelizmente, o perdão chegava tarde demais para alguns que, a essa altura, já haviam morrido na prisão.

Mas, a tentativa de apagar da memória acontecimento tão nefasto seria em vão. As autoridades, os memorialistas e, sobretudo os historiadores, tratariam de alimentar no imaginário das gerações subseqüentes, a idéia da queda "vergonhosa" da Ilha em 1777. Segundo José Arthur Boiteux, a tomada da Ilha por Ceballos constituía em "página que deslustraria os foros de bravura e heroísmo" da história catarinense. ${ }^{387}$ Em 1944, o General Vieira da Rosa proferia uma conferência no IHGSC com o título "A Vergonha de 1777", "não para verberar uma covardia coletiva que não houve, mas para causticar a memória dos chefes que cometeram um crime de lesa-pátria". ${ }^{388}$ E a culpa maior da tragédia recairia sobre o governador Pedro Antonio da Gama Freitas, que foi caracterizado como aquele que "entregou esta Ilha aos espanhóis"; 389 ou, como um homem que, não obstante "fosse dotado de excelentes qualidades careceu de energia e resolução para obstar o desembarque [deles] na Ilha, a qual entregou sem queimar uma escorva"; 390 ou ainda, como aquele que esqueceu de lembrar-se de "que era Governador da Província, quando os espanhóis" se apoderaram dela. ${ }^{391}$

Mas essa representação negativa da invasão de 1777 deixou marcas mais profundas na história de Santa Catarina. Analisando um pouco mais a historiografia regional, observa-se que praticamente toda a história política dessa colônia até aquele momento foi caracterizada como "decadente" e conduzida por governadores inábeis, ou despóticos e violentos. Afora José da Silva Paes, que aparece geralmente como o

\footnotetext{
${ }^{385}$ O Brigadeiro José Custódio de Sá e Faria, engenheiro-cartógrafo com mais de vinte anos de serviços prestados a Portugal na América, após a invasão, ficou com a guarnição espanhola. Não se sabe ao certo se como prisioneiro, ou por seu livre-arbítrio, como forma de escapar da condenação que lhe espervava no Conselho de Guerra.

${ }^{386}$ BNL, PBA, 653, fl. 267.

387 Santa Catharina nos tempos d'El-Rey Nosso Senhor. Florianópolis: Typ. São José, 1929. (Conferência no Centro Popular de Florianópolis, em 21 de abril de 1928), p. 13.

${ }^{388}$ General Vieira da Rosa. A Vergonha de 1777. In: RIHGSC, vol. XIII, $2^{\circ}$ sem., 1944, p. 25.

389 Memória Histórica da provincia de Santa Catarina, relativa as pessoas que a tem governado. (Anônima, 1821). In: RTIHGSC, Florianópolis, vol. 2, 1913, p. 5.

390 Joaquim Gomes de Oliveira Paiva. Dicionário topográfico, histórico... (1868), op. cit., p. 35.

391 Manoel Joaquim d'Almeida Coelho. Memória Histórica da Província de Santa Catharina. $2^{\mathrm{a}}$ ed. Desterro: Typ. J. J. Lopes, 1877 [1 $1^{\text {a }}$ ed. 1853], p. 64.
} 
fundador da "capitania" - governador que "prestou relevantes serviços à província, tanto a respeito da defesa do país (...) como pelo que pertence à política, comércio e lavoura"; ${ }^{392}$ homem repleto de virtudes e capacidades -, os governadores que se seguiram até Gama Freitas pouco teriam feito para o seu desenvolvimento. O governo de Manoel Escudeiro (1749-53) não zelou pelo "aumento e prosperidade dos povos e conservou-se quase em inação"; 393 o de Francisco Antonio Cardoso de Menezes (176265) "foi uma calamidade para Santa Catarina, pois o povo se viu obrigado a trabalhar nas obras públicas, e a fazer exercícios militares, não dispensando os próprios lavradores, do que resultou o atraso da lavoura e do comércio", e no governo de Francisco de Souza de Menezes (1765-75) "não foi mais feliz o povo". ${ }^{394}$ Visconde de São Leopoldo chegou inclusive a dizer que após a chegada do primeiro governador, José da Silva Paes, e dos 4.000 colonos açorianos entre 1748 e 1756 "Nada digno de memória ocorreu nos períodos intermédios, até o estrondoso feito" da invasão espanhola. $^{395}$

Bem diversa foi a avaliação que esses historiadores fizeram dos governadores nomeados pós-1777. Francisco Antonio da Veiga (1778-79) “deu provas mais evidentes da sua probidade, aptidão, liberalidade, amor das tropas e caridade. No curto espaço de seu Governo revocou os povos dispersos para se empregarem na lavoura e seus prédios, e os soldados abandonados por causa da guerra, reuniu e empregou de novo no serviço da guarnição da praça. Organizou os Tribunais e reparou os estragos que o inimigo causara". Saindo do governo, deixou "os povos submergidos em grande pesar e cheios de reconhecimento e gratidão". 396 Francisco de Barros Moraes (1779-86) foi “observante exato da lei, distribuiu justiça imparcial. Procurou os meios de reparar as ruínas da Província. (...) Prosperando o comércio e a lavoura, começaram a aparecer lojas abertas e negociantes. Construíram-se novos edifícios, levantaram-se fábricas de açúcar: cresceu a população"397; foi um governador "justiceiro e humano...". 398 José Pereira Pinto (1786-91), "Hábil militar, reparou as ruínas dos edifícios reais: fez

\footnotetext{
392 Joaquim G. O. Paiva. Dicionário topográfico..., op. cit., pp. 33 e 34; em termos muito semelhantes observou também Manoel J. d'A. Coelho. Memória Histórica..., op. cit., p. 61.

${ }^{393}$ Manoel J. d'A. Coelho. Memória Histórica..., op. cit., p. 101; reproduzido por Joaquim G. O. Paiva. Dicionário topográfico..., op. cit., p. 34.

${ }^{394}$ Joaquim G. d’O. Paiva. Dicionário topográfico..., op. cit., p. 34.

395 José Feliciano Fernandes Pinheiro (Visconde de São Leopoldo). "Resumo Histórico da Província de Santa Catarina", in Anais da Província de São Pedro. Porto Alegre: Mercado Aberto, 1982. [1 $1^{\mathrm{a}}$ ed. c. 1832] (Série Documenta 11), pp. 222 e 223.

${ }^{396}$ Manoel J. d'A. Coelho. Memória histórica..., op. cit. pp. 64 e 65.

${ }^{397}$ Id. ibid., pp. 65 e 66.

${ }^{398}$ Joaquim G. O. Paiva. Dicionário..., op. cit, p. 36.
} 
aparelhar alguns pequenos vasos para o serviço da marinha: promoveu a agricultura, a plantação de café (...). Não deu execução à ordem bárbara de mandar inutilizar os teares de que se servia a pobreza para o tecido do pano chamado da terra." ${ }^{399}$ João Alberto de Miranda Ribeiro (1793-1800) “organizou as milícias, disciplinou a tropa, e muito concorreu para dar ao povo certo grau de civilização". 400

Oswaldo Cabral, posteriormente, apresentou essa distinção cronológica de forma mais clara, mas não menos ingênua. Dividiu ele o período que vai de 1738 a 1822 em dois momentos: o primeiro, que dura até a invasão de 1777, caracterizado pela decadência progressiva da colônia; o segundo, de 1778 até a Independência, época de reflorescimento da capitania, administrada pelos governadores reconstrutores. ${ }^{401}$

Se determinados acontecimentos destacados por essa historiografia acerca das gestões dos governadores nos dão elementos e pistas objetivas sobre várias questões, o mesmo não se pode dizer do juízo que fizeram entre bons e maus governos.

Segundo as fontes disponíveis, se compararmos os perfis, tanto do que diz respeito à posição social, quanto à experiência militar, dos sete governadores nomeados para a Ilha de Santa Catarina após a ocupação espanhola (1778-1807) com os oito do período precedente (1738-1777) não se identificarão significativas alterações. Nota-se, todavia, que, por força das exigências do governo, eles se tornaram cada vez mais políticos e administradores. A carreira militar continuava sendo, e seria por muito tempo ainda, o percurso natural com que galgavam um posto de governo e constituía-se, de fato, como aquilo que com mais honra e orgulho eles apresentavam em suas folhas de serviço, ou memoriais. Mas, passados os dez anos iniciais de instalação daquela praça militar (1739-1748) e os quinze anos de conflitos no Sul (1762-1777), os governadores puderam se ocupar mais livremente da organização política e econômica daquele estabelecimento. Não se quer dizer com isso que existiram tipos sociais distintos e bem definidos entre um momento e outro, mas apenas destacar que as ações militares foram cedendo lugar, pouco a pouco, às atividades administrativas e intelectuais, o que se fez sentir na qualificação de alguns dos governadores.

O Coronel Francisco de Barros Moraes, por exemplo, que governou a Ilha entre 1779 e 1786, demonstrava ser homem culto, "Filósofo", como ele próprio se definiu ao

\footnotetext{
${ }^{399}$ Id. ibid., p. 36.

${ }^{400}$ Id. ibid., p. 37.

401 Oswaldo Cabral. Santa Catarina (História - Evolução). São Paulo: Companhia Editora Nacional, 1937, (Col. Brasiliana, vol. 80), pp. 98 e ss.
} 
vice-rei. ${ }^{402}$ Segundo La Perouse, "falava perfeitamente o francês, e seus vastos conhecimentos inspiravam a maior confiança". ${ }^{403}$ Em 1761, ano em que era Ajudante de um regimento em Chaves, fez publicar de sua autoria a obra Breve Instrucção Militar sobre a Infantaria, da qual só se encontrou a primeira parte. Não se trata de obra muito original no gênero. Como ele próprio escreveu na dedicatória a Dom Luiz da Cunha, ${ }^{404}$ consistia em um resumo para a língua portuguesa das "doutrinas mais bem recebidas" dos escritores, sobretudo os franceses, que uniram a teoria à prática; e, talvez como esses, "que consumiram seus gloriosos annos (...) com a espada", vencendo as batalhas, queria agora, com a pena, imortalizar sua fama. ${ }^{405}$ Quando, em 1780, soube que seria escolhido para ser um dos comissários da demarcação dos limites no Sul, tratou de escrever ao vice-rei externando os graves problemas de saúde que padecia: uma infecção no pé causada por um ferimento antigo feito na cidade do Rio de Janeiro, "tonteiras de cabeça"; sofria ainda de "alguns esquecimentos, porém não muitos", que ele atribuía mais aos seus 61 anos de idade do que outra coisa e, por esses motivos todos, suplicava ao vice-rei para que nomeasse outro oficial para aquela tão importante diligência. ${ }^{406}$ Embora se tratasse de uma missão de paz, Francisco de Barros Moraes preferia a tranqüilidade de suas atividades administrativas na Ilha à cansativa - e sempre perigosa - tarefa de definição dos limites meridionais da América entre as duas nações ibéricas.

Luís Maurício da Silveira, governador que mais tempo ficou no cargo (quatro triênios, de 1805 a 1817), declarou em seu memorial que, no Regimento de Vieira Telles onde fora proposto a Capitão, aplicou-se "aos diferentes Estudos assim de Matemática e Artilharia, como Desenho e Arquitetura Naval". 407

Houve, na segunda metade do século XVIII, uma preocupação da Monarquia Portuguesa com a formação de uma classe de profissionais extraídos das famílias nobres do Reino preparando as futuras elites dirigentes do Império. A fundação em Lisboa do Colégio Real dos Nobres, em 1761, por Dom José I tinha esse fim. Buscava instruir os

\footnotetext{
${ }^{402}$ ANRJ, Cód. 106, vol. 03, Of. 21. Francisco de Barros Moraes ao vice-rei Luís de Vasconcelos e Sousa, em 16 de agosto de 1780.

${ }^{403}$ Jean-François Galup De La Pérouse. Voyage de La Pérouse Autour du Monde..., in Ilha de Santa Catarina ...op. cit., p. 114.

${ }^{404}$ Tratava-se de Dom Luiz da Cunha Manuel, Secretário de Estado dos Negócios Estrangeiros e da Guerra.

${ }^{405}$ Francisco de Barros Moraes Araujo Teixeira Homem. Breve Instrução Militar sobre a Infantaria. Parte I. Lisboa: Oficina Patriarcal de Francisco Luiz Ameno, 1761. BNL, Cota - SC 33634 P.

${ }^{406}$ ANRJ, Cód. 106, vol. 03, Of. 21. De Francisco de Barros Moraes a Luís de Vasconcelos e Souza, em 16 de agosto de 1780.

${ }^{407}$ ANRJ, Cód. 106, vol. 16, fl. 200, em 3 de julho de 1806.
} 
jovens aristocratas (que deviam ingressar com a idade entre os 7 e os 13 anos) nos conhecimentos de Línguas (Latina, Grega, Francesa, Italiana e Inglesa), assim como em Retórica, Poética, Lógica, Física, História, Matemática, Arquitetura Militar e Civil e Artes de Cavalaria, Esgrima e Dança. Uma das prerrogativas do Colégio era de encaminhar os colegiais, "que nele se conduzirem regularmente (...) para os Empregos e Lugares Públicos; e tanto mais quanto maior for a distinção com que se houverem assinalado nas suas diferentes Profissões". 408

Fosse qual fosse o diploma que traziam em suas bagagens, foi na prática administrativa do governo que tiveram de demonstrar melhores habilidades. De meados do século XVIII em diante verifica-se que os governadores tiveram que, não só remeter com maior regularidade aos vice-reis relatórios e mapas com informações sobre as finanças da "capitania", a produção econômica, a condição das tropas, a população, entre outras, como também, apresentá-las com maior precisão e detalhamento. ${ }^{409}$ Em 30 de julho de 1760, o secretário de Estado Francisco Xavier de Mendonça Furtado encaminhava ofício ao governador da Ilha de Santa Catarina recomendando que ele reunisse na sua presença o provedor, oficiais da Fazenda e alguma pessoa "perita da Ciência do cálculo" para que fizesse

uma receita geral de todos, e cada um dos contratos, e partidas, de que se compõem o Rendimento atual dessa Ilha; sem que [ficasse] de fora coisa alguma; e outra Relação das partidas da despesa também anual da mesma Ilha; isto é das três Folhas Eclesiástica, Civil, e Militar; lançando-se as ditas Receitas e despesa em um livro de Contas, arrumadas por partidas dobradas de sorte, que o mesmo Senhor [pudesse] ter uma idéia clara de todas e cada uma das partidas de despesa, que com ela se faz; para a vista de tudo dar as providências necessárias a conservação dessa Ilha (....). ${ }^{410}$

Mas foi a partir de 1778 que essas prestações de conta tornaram-se mais efetivas. O melhor exemplo disso foi sem dúvida o extenso e minucioso relatório que o

\footnotetext{
${ }^{408}$ Estatuto do Colégio Real dos Nobres (7 de março de 1761). In: Antonio Delgado da Silva. Coleção da legislação portuguesa. Desde a última compilação das ordens. Lisboa, 1830-1844. Agradeço à Professora Iris Kantor pela indicação desse documento.

${ }^{409}$ A invasão espanhola de 1777 pode justificar, em parte, a escassez, ou algumas lacunas existentes na documentação do período 1739-77 nos arquivos históricos de Florianópolis, hoje em dia, pois, segundo alguns governadores (João Alberto de M. Ribeiro, por exemplo) ela teria levado à desorganização das secretarias da Ilha e a conseqüente perda dos papéis e ofícios daquele governo. Mas essa justificativa não pode ser usada para analisarmos o volume e o fluxo da coleção de correspondências enviadas pelos governadores da Ilha aos vice-reis no Rio de Janeiro, guardadas hoje no Códice 106 (16 vols.) do Arquivo Nacional dessa cidade. Enquanto as cartas do período de 1752 a 1777 estão todas em um único volume, as do intervalo 1778 a 1807 compõem os outros quinze.

${ }^{410}$ APESC, Avisos Diversos ao Governador da Capitania, 1748-1804, Of. n. 17.
} 
governador João Alberto de Miranda Ribeiro encaminhou, em novembro de 1797, ao vice-rei Conde de Resende. Compõe-se ele de 133 folhas com análises descritivas e dezenas de mapas e quadros estatísticos tratando, entre outras coisas: da qualidade dos portos, rios, lagoas, serras e morros mais notáveis da Ilha e seu continente; "Do número das Freguesias, Capelas e Oratórios"; "Dos Engenhos e Fábricas de toda a qualidade"; "Do número, e qualidade das Embarcações"; "Do Estado atual do Comércio, e da cultura das Terras"; "Das Terras Devolutas"; "Resumo geral de toda a população..." de homens e de mulheres, dos forros e dos escravos de todas as freguesias, com a discriminação por classes de idade; "Da quantidade dos Gêneros e Efeitos que se Colhem e Fabricam Anualmente"; de relações detalhadas dos animais, aves, peixes, madeiras e frutos que se podiam encontrar naquela "capitania". 411

Na mesma ocasião, Miranda Ribeiro enviou para a rainha D. Maria $\mathrm{I}^{412}$ um outro relatório de governo, igualmente minucioso, mas de natureza distinta. Apresentava nesse um balanço político e administrativo do seu governo e de todos que o sucederam na governança daquela Ilha. Enquanto o relatório enviado ao vice-rei tinha um caráter mais sócio-econômico, quantitativo, o relatório enviado para a rainha era mais político, qualitativo e crítico, apontando inclusive propostas para o melhoramento daquele governo.

\subsection{Seleção, nomeação e posse}

A forma de seleção dos governadores das capitanias incorporadas à Coroa - as capitanias gerais - desde o século XVII era feita geralmente pelo sistema de "concurso". Dos candidatos que se ofereciam ao cargo, o Conselho Ultramarino elaborava uma lista tríplice com o nome dos possíveis governadores, classificando-os em ordem de preferência para a escolha régia final. Ao longo do século XVIII a estrutura estatal portuguesa sofreu uma série de modificações que apontavam para uma maior centralização do poder monárquico. Em 1736, tem lugar a reforma das secretarias de

\footnotetext{
${ }^{411}$ AHU-SC, cx. 6, doc. 387, em 17 de novembro de 1797. O original encontra-se na BNRJ, CEHB, n. $574-3,3,17 ; 575$ e $2919-7$, 4, 5. Esse Relatório foi transcrito, publicado e comentado por Dante Laytano com o título "Corografia da Capitania de Santa Catarina", in RIHGB, Vol. 245, 1959, pp. 3-187. Nesta tese utiliza-se essa publicação, doravante com a abreviação RMR-1797.

${ }^{412}$ OMR-1797. D. Maria I havia deixado de governar desde 10 de fevereiro de 1792, mas somente em 15 de julho de 1799 um Decreto cessava o direito de serem promulgadas leis em seu nome. Ela faleceu em 20 de março de 1816. Cf. F. A. Varnhagen. História Geral do Brasil, Tomo V, op. cit., p. 242.
} 
Estado, que pouco a pouco ganhariam proeminência sobre o "governo dos conselhos e tribunais". ${ }^{413}$ À Secretaria dos Negócios da Marinha e Domínios Ultramarinos caberiam as principais funções administrativo-burocráticas referentes às colônias. Suas atribuições relativas ao Brasil eram: "nomeação dos vice-reis, governadores e capitãesgenerais; provimento de todos os postos militares, ofícios de Justiça e Fazenda, assim como das dignidades, canonicatos, paróquias e benefícios; negócios das missões e de todos os mais pertencentes à administração da Justiça, Fazenda Real, comércio e governo". ${ }^{414} \mathrm{O}$ reforço da administração monárquica seria potencializado no ministério pombalino.

Ao governo da Ilha de Santa Catarina, e também aos de Rio Grande de São Pedro e da Colônia de Sacramento, constata-se uma particularidade: o papel decisivo que desempenharam o governador do Rio de Janeiro, Gomes Freire de Andrade, e, a partir de 1763, os vice-reis do Estado do Brasil, na escolha dos governadores, evidenciando, também nesse aspecto, o controle que aquela capitania-geral tinha sobre as suas anexas no Sul. Até porque, vale lembrar, a maioria deles fazia parte de Regimentos militares daquela cidade.

Tem-se notícia de apenas um concurso para governador da Ilha, mas que acabou não tendo efeito. Possivelmente em decorrência das acusações dirigidas em agosto de 1757, pelos oficiais da Câmara de Desterro contra o governador dela D. José de Mello Manuel, acusando-o de usurpação de poder ${ }^{415}$, o Conselho Ultramarino abriu concurso, em que participaram cinco candidatos. Em lista tríplice de 18 de fevereiro de 1758, os conselheiros propuseram ao rei "em $1^{\circ}$ lugar a Patricio Manoel de Figueiredo, que já havia comandado a Ilha em substituição ao Brigadeiro José da Silva Paes nos anos de 1743 e 1744. Em 2º ${ }^{\circ}$ Joze Roquete da Silva, e em 3', Joze Soares da Silva". ${ }^{116}$ Não se sabe por que motivo, mas a substituição de D. José de Mello Manuel só aconteceria quatro anos depois (em março de 1762), e por outra pessoa que não as que prestaram o concurso. Assumiria em seu lugar o coronel Francisco Antônio Cardoso de Menezes e Souza, com larga folha de serviços ao império nas campanhas do Sul da América. Em ofício dirigido ao secretário de Estado da Marinha e Ultramar, Francisco Xavier de

${ }^{413}$ Pedro Cardim. "O Processo Político (1621-1807)", in José Mattoso (Dir.) História de Portugal. Lisboa: Estampa, 1997 (Vol. 4 - O Antigo Regime), p. 415. Ver também, Nuno G. Monteiro. Governadores e capitães-mores..., op. cit., pp. 100 e ss.

${ }^{414}$ Graça Salgado (Coord.). Fiscais e Meirinhos - A Administração no Brasil Colonial. 2a . ed. Rio de Janeiro: Nova Fronteira, 1985, p. 44.

${ }^{415}$ AHU-SC, cx. 2, doc. 142. Em 1 de agosto de 1757.

${ }^{416}$ AHU-SC, cx. 2, doc. 143. Os outros dois candidatos eram José Bernardo Galvão, que ocupava o posto de capitão de infantaria na ilha de Santa Catarina, e Leonardo Luciano de Campos. 
Mendonça Furtado, em 14 de abril de 1762, deixou claro como foi conduzido ao cargo: “O meu General o Il. ${ }^{\text {o }}$ e Ex. ${ }^{\text {mo }}$ Snr.' Conde de Bobadella [Gomes Freire de Andrade] me ofereceu em a cidade do Rio de Janeiro se eu queria vir governar a Ilha de S. Catarina". 417

Embora Gomes Freire de Andrade acumulasse amplos poderes sobre as "capitanias" do Sul, a condição de subordinação política e administrativa dessas ao Rio de Janeiro, como se verá mais adiante, se intensificou após 1763, com a transferência do vice-reinado para aquela cidade. Das nove nomeações de governadores para a Ilha entre esse ano e 1807, cinco foram feitas pelo vice-rei para posterior confirmação régia (na verdade, dos secretários de Estado), três aparecem como sendo nomeadas diretamente pelo poder régio e uma, a de Manoel Soares Coimbra, não identificada, mas como se vê a seguir, já constava em listas anteriores do vice-rei. (Ver Quadro n. 2.1)

Para o Rio Grande de São Pedro não era diferente. Em maio de 1780, Luís de Vasconcelos e Sousa, por determinação de Martinho de Mello e Castro, elaborou uma lista tríplice para o governo daquela colônia. Como mais indicado na lista, o vice-rei sugeria o Brigadeiro Sebastião Xavier da Veiga Cabral da Câmara; em segundo, o Marechal de Campo Joze Raimundo Chichorro; e em terceiro, o Tenente Coronel com exercício de Sargento-Mor, Manoel Soares Coimbra. Sobre esse último justificava seu nome por se ter portado "com valor na ocasião, que teve no mesmo Rio Grande" (foi comandante de um dos navios da reconquista dessa vila, em 1776); mas fazia a seguinte ressalva: "que este Oficial é natural d'esta cidade [Rio de Janeiro], e que pela experiência", que tinha, não achava "geralmente conveniente ocupar os filhos da América n'ela em lugares ainda de muito menos suposição". ${ }^{418}$ Martinho de Mello seguiu a sugestão do vice-rei nomeando o primeiro da lista. Onze anos depois, já como coronel, Soares Coimbra seria nomeado governador da Ilha de Santa Catarina.

A nomeação de governador era formalizada por dois atos: o decreto régio e o juramento de preito e homenagem. Este como sinal de sujeição e promessa de fidelidade, que o vassalo-governador tinha de prestar pessoalmente ao monarca ou, caso isso não fosse possível - o que era mais comum nas nomeações que aqui se estuda - a um representante desse, como o vice-rei ou mesmo um governador e capitão general. Alguns, como Francisco de Barros Moraes e Francisco de Souza de Menezes, que se

\footnotetext{
${ }^{417}$ AHU-SC, cx. 3, doc. 173.

${ }^{418}$ ANRJ, Códice 68, Correspondências do vice-reinado para a Corte, vol. 3, fl. 1. Do vice-rei Luis de Vasconcelos e Sousa ao Secretário de Estado Martinho de Melo e Castro, em 2 de maio de 1780.
} 
encontravam no reino no momento da nomeação, juraram na chancelaria real, "na forma costumada", fazendo preito e homenagem nas "Reais mãos" pelos governos que lhes foram designados. ${ }^{419}$

Como a maioria dos escolhidos já se encontrava na América tornava-se impraticável prestarem aquele juramento diante do monarca. Nesses casos, o representante real reproduzia nas conquistas, com todo rigor e cerimônia possíveis, o ritual daquela solenidade.

Assim ocorreu com o Tenente de Mestre de Campo General Pedro de Azambuja Ribeiro quando foi escolhido para substituir José da Silva Paes no governo da Ilha de Santa Catarina. Aos 12 de janeiro de 1744, compareceu na casa de residência do governador Gomes Freire de Andrade, na cidade do Rio de Janeiro, prostrou-se de joelhos diante dele e fez seu juramento:

Eu Pedro de Azambuja Ribeiro, faço preito, e homenagem a S. Maj. ${ }^{\mathrm{e}}$ em mãos de V. Ex. ${ }^{a}$ como seu Governador, e Capitão General destas Capitanias pelo Governo da Ilha de Santa Catarina, e suas Fortalezas, tanto das que existem, como das que novamente se fizerem de que V. Ex. ${ }^{a}$ me encarrega da parte do mesmo Senhor, para que aguarde e governe, ao qual acolherei na dita Ilha, e suas Fortalezas, altos, e baixos dela, de dia, ou de noite, a pé, ou cavalo, a quaisquer horas, e tempo que seja, irado, e pagado, com poucos, e com muitos, vindo em seu livre poder, e dela farei guerra, e manterei tréguas, e paz, segundo por S. Maj. ${ }^{\mathrm{e}}$, e V. Ex. ${ }^{\mathrm{a}}$ me for mandado; e a dita Ilha, e suas Fortalezas, não entregarei a pessoa alguma de qualquer Estado, grau, dignidade, ou preeminência que seja, senão a S. Maj. ${ }^{e}$, como meu Rei, e Senhor natural, a V. Ex. ${ }^{a}$ como seu Governador, e Capitão General (...) e me obrigo, que tenha, e mantenha, cumpra, e guarde inteiramente, este preito, e homenagem, o que tudo juro, aos Santos Evangelhos, em que ponho as mãos, de bem, e verdadeiramente, guardar o serviço de S. Maj. ${ }^{\text {e }}(. ..) .{ }^{420}$

Selecionados e nomeados aqui, esses governadores assumiam o posto na condição de interinos e assim ficavam até que chegasse o decreto de confirmação régia, o que às vezes, a exemplo do caso acima, não acontecia (ver Quadro n. 2.1). E podia não vir por diversos motivos: ou por se tratar de uma nomeação de fato provisória até que o governador efetivo retornasse ao cargo, ou pessoa mais habilitada fosse escolhida para ele, ou porque a Corte não queria dar a promoção da patente militar e respectivo aumento de soldo, que o decreto de confirmação implicava, ou até mesmo pela

\footnotetext{
419 ANTT, Chancelaria de D. José I, Lv. 74, fl. 213v. Patente de Governador a Francisco de Souza Menezes, em 30 de janeiro de 1765; e Chancelaria de D. Maria I, Lv. 12, fl. 153. Patente de Governador a Francisco de Barros Moraes Araujo Teixeira Homem, em 5 de dezembro de 1778.

${ }^{420}$ PAPN, vol. VII, 1907, p. 70.
} 
assincrônica e morosa correlação das decisões político-administrativas tomadas na América com os despachos e confirmações vindos da Corte. O governador Pedro Antônio da Gama Freitas, por exemplo, tomou posse da Ilha, em 05 de setembro de 1775, por ordem do Marquês do Lavradio e só teve a confirmação régia nove meses depois, em 05 de junho de $1776 .^{421}$

Chegando ao local para o qual eram designados, os governadores deviam tomar posse na Câmara de Vereadores da vila capital, no caso da Ilha de Santa Catarina, Câmara da Vila de Nossa Senhora do Desterro. Mas houve quem descumprisse com essa obrigação. Uma representação dos oficiais dela dirigida à Corte, em 7 de agosto de 1751, colocava, entre outras graves acusações contra o seu governador que,

sendo estilo praticado em todo o Brasil, mandarem os governadores, e Capitães Generais assim que chegam as Capitanias, que vem governar, registrar suas patentes nas Câmaras, e estas darem-lhe posse, ou ao menos assistirem a ela, o Governador atual Manoel Escudeiro Ferreira de Souza o fez tanto pelo contrário, que indo já com três anos de governo até o presente não cumpriu com esta obrigação pelo que nem sabemos, que poderes tem, nem de que proeminências goza, e só o conhecemos por governador em razão de que com a sua chegada a esta Ilha se retirou o Brigadeiro José da Silva Paes, e pelo que põem, e dispõem mais segundo a sua vontade, que conforme as Leis de Deus e de V. ${ }^{\mathrm{a}}$ Maj. ${ }^{\text {de }}$, por que não é possível as haja tais, que todos vivemos vexados nesta Colônia de tantas conseqüências e que requer no princípio de seu estabelecmento mais amor, que rigor para bem se estabelecer. $^{422}$

A Câmara de Desterro existia desde 1726 e era composta por indivíduos que, se não eram antigos moradores, acabavam representando os interesses de grupos tradicionais. A figura do governador como representante do rei, a partir de 1739, redimensionou a estrutura de poder na Ilha. Nesse princípio de estabelecimento, momento de instauração do governo e dos órgãos da administração judiciária e fazendária e, portanto, de maior imposição do poder monárquico, o governador Manoel Escudeiro parece mesmo ter tiranizado aquela instituição camarária, mas isso não permaneceria assim nos governos seguintes. Embora a relação entre governo e Câmara, por todo o período que aqui se estuda, fosse sempre um pouco tensa, apresentando volta e meia situações de conflito, pode-se dizer que esses poderes encontraram um certo equilíbrio e reconhecimento mútuo do lugar e função de cada um deles na estrutura

\footnotetext{
${ }^{421}$ ANTT, Chancelaria de D. José I, Lv. 36, fl. 257.

${ }^{422}$ AHU-SC, cx. 1, doc. 74.
} 
político-institucional da "capitania". E o primeiro gesto nesse sentido era o respeito dos governadores àquele ato formal e simbólico de posse na vila.

Assim fez, por exemplo, Francisco de Souza de Menezes quando, aos doze dias do mês de julho de 1765, ele e o governador em exercício, Francisco Antônio Cardoso de Menezes e Souza, dirigiram-se para o ato solene à Câmara de Desterro. Na presença de todos, Juiz Ordinário e vereadores, o escrivão leu a patente real que nomeava ao dito Francisco de Souza de Menezes para "governador desta Ilha e seus continentes", e lavrou o referido termo de posse do dito governo. ${ }^{423} \mathrm{E}$, segundo narraram os oficiais à Corte, tudo foi feito com "grande solenidade, porque foi geral o gosto de todo este Povo com a sua vinda, que se celebrou com três dias de Luminárias", e beijavam "a mão a V. Maj., por lhes dar "um Governador de tão Ilustre qualidade e que pelo seu bom modo", lhes parecia que era "dotado de um Coração pio e justo, virtudes tão raras, como precisas em semelhante emprego". 424

A substituição de um governador por outro poderia causar sentimentos distintos entre os indivíduos ou grupos sociais; temor para alguns, alívio para outros. Ocorreram casos como o do citado Manoel Escudeiro. Cinco meses antes de findar seu mandato trienal, os oficiais da Câmara de Desterro dirigiram uma representação ao rei denunciando que

todo o governo deste governador é um desgoverno, e uma desordem; e quando se entendeu que com a chegada do ouvidor que V. ${ }^{a}$ Maj. foi servido mandar-nos para esta Ilha, tomassem as coisas diferente caminho tudo está no mesmo estado, por que o Ministro em nada lhe vai a mão, e diz que se não quer embaraçar com o Governador e que faça ele o que quiser, o que conhecido pelo mesmo Governo continua em vexar os povos que não ousam a falar com medo das violências, das descomposturas, e dos calabouços aos quais certamente iremos parar sabendo que pusemos na presença de V. ${ }^{\mathrm{a}}$ Maj. estas tão certas como indubitáveis queixas. ${ }^{425}$

Pelo jeito essa denúncia fez eco no Conselho Ultramarino, somando-se a outras já encaminhadas contra ele. ${ }^{426}$ Menos de um mês depois, os conselheiros expediam

\footnotetext{
${ }^{423}$ RTIHGSC, vol. VII, $1^{\text {o }}$ trim., 1918, pp. 44 e 45. Encontram-se também nessa Revista os termos de posse de Pedro Antônio da Gama Freitas e Francisco de Barros Moraes Araujo Teixeira Homem.

${ }^{424}$ AHU-SC, cx. 3, doc. 194. Oficiais da Câmara da Vila de Desterro para a Corte, em 27 de julho de 1765.

${ }^{425}$ AHU-SC, cx. 1, doc. 74. Em 7 de agosto de 1751.

${ }^{426}$ Ele havia mandado criar por portaria sua, três cargos de juízes e outros tantos de escrivães, todos sem juramento na Câmara, mas que "usavam da vara" e estavam fazendo atos de jurisdição. Tão logo a Corte soube desses atos arbitrários tratou de repreender o sobredito governador com os seguintes termos: "Ouvido o procurador de minha Coroa, advertimo-vos da nulidade das referidas nomeações. Ordenamos
} 
parecer ao rei recomendando "a grande necessidade que há de se mandar sucessor ao atual Governador da Ilha de Santa Catarina (...) pelas muitas queixas que há contra ele". 427

Em 26 de julho de 1799, moradores da Ilha, que se denominavam "O Povo de Santa Catarina da América", enviaram uma representação à rainha "desesperados do jugo das violências do modo com que lhe usurpam os seus efeitos o tirano governador", o tenente-coronel João Alberto de Miranda Ribeiro. ${ }^{428}$

Houve casos, porém, em que se suplicava para que os governadores fossem mantidos no seu cargo, como ocorreu com Luís Maurício da Silveira, por dar "provas de sua prudência, retidão, inteireza e moderação (...)"; ${ }^{429}$ e Joaquim Xavier Curado, por ter "servido a Sua Alteza Real desde que tomou posse do Governo até o presente com muita honra, desinteresse e zelo do Real serviço (...)". 430

O governador que saía devia, em tese, passar ao que chegava todas as instruções por escrito e verbais sobre aquele governo. Assim ocorreu quando assumiu o Sargentomor José Pereira Pinto em junho de 1786. Em ofício ao vice-rei dizia ele que

O Brigadeiro Francisco de Barros, meu Antecessor, me entregou os papéis que constituem a Secretaria deste Governo, e assim mesmo me comunicou verbalmente, e por escrito as instruções necessárias das pessoas e coisas principais dele; e tem sido para comigo tão complacente, que fez com que esteja perfeitamente satisfeito da sua recepção. ${ }^{431}$

Mas isso nem sempre ocorria. Saídas intempestivas dos governadores, como Pedro Antônio da Gama Freitas, na invasão espanhola de 1777, ou Manoel Soares Coimbra, afastado, em 1791, por Devassa aberta contra sua administração, deixaram seus sucessores sem as devidas informações. As ordens reais, alvarás, leis, decretos, livros e mais papéis pertencentes ao governo da Ilha, que Gama Freitas levou consigo

ao Ouvidor-Geral dessa Ilha que suspenda esses intrusos de cargos oficiais, nomeando a Câmara os que forem necessários, prestando-se juramento e regulando-se a jurisdição na forma do que a Lei do Reino determina”. Provisão de 24.09.1754, in Pascoal Apóstolo Pítsica. A Capitania de Santa Catarina: alguns momentos. Florianópolis: Fundação Franklin Cascaes; Lunardelli, 1993, p. 127. Há, no entanto, incoerência na data dessa Provisão, pois Manoel Escudeiro deixou o governo, em 24.10.1753.

${ }^{427}$ AHU-SC, cx. 1, doc. 75. Em 2 de setembro de 1751.

${ }^{428}$ AHU-SC, cx. 8, doc. 458.

${ }^{429}$ AHU-SC, cx. 9, doc. 524. Oficiais da Câmara de Desterro ao secretário de Estado, Visconde de Anadia, em 10 de junho de 1807.

${ }^{430}$ AHU-SC, cx. 8, doc. 448. Oficiais da Câmara de Desterro ao secretário de Estado, Visconde de Anadia, em 22 de outubro de 1803.

${ }^{431}$ ANRJ, Cód. 106, vol. 9. De José Pereira Pinto a Luís de Vasconcelos e Souza, em 17 de junho de 1786. 
para o Rio de Janeiro, o vice-rei faria retornar ao governador Francisco de Barros, em julho de $1779 .{ }^{432}$ Na maioria dos casos havia também pouco tempo para a transmissão do cargo, pois a embarcação que trazia o governador que entrava era a mesma que levava o que saía.

\subsection{As atribuições do cargo}

As atribuições e limites de jurisdições de poder dos donatários das capitanias hereditárias eram regulados pelas cartas de doação e pelos forais. As primeiras estabeleciam as dimensões de cada uma das capitanias concedidas pela Coroa; os segundos, regulamentavam os direitos fiscais e os privilégios dos donatários, além de estabelecer os tributos régios. ${ }^{433} \mathrm{O}$ primeiro governador-geral, Tomé de Souza (15491553), teve suas atribuições e competências reguladas pelo regimento de 17 de dezembro de 1548. Segundo Salgado, "Os regimentos baixados aos governadores-gerais proporcionariam a partir de então a mais importante base legal para o funcionamento da organização administrativa da Colônia”. Esse representante maior do rei na América “dispunha de poderes administrativos não só no centro do governo, como também nas demais capitanias, embora sua ação ficasse, por um lado, limitada pelo alto grau de ingerência (pelo menos no plano legal) do poder da Coroa em todas as esferas da administração colonial e, por outro, pelas grandes dimensões territoriais que reduziam o seu alcance". ${ }^{434}$ Além disso, os governadores das capitanias mantinham uma relativa independência político-administrativa com relação ao governador-geral, estabelecendo um vínculo direto de subordinação com a Corte.

De maneira sumária, pode-se dizer que as atribuições dos governadores-gerais dividiam-se em três grandes áreas: a militar - talvez, a de maior relevância (eles próprios, com raras exceções, eram militares de ofício) -, com autoridade máxima na área de defesa colonial, tanto no plano interno como no externo; a fazendária - o sentido da colônia era de promover o desenvolvimento do comércio em proveito da metrópole, com organização do sistema de fisco e da arrecadação de tributos, atividades essas que ficavam a cargo do Provedor-Mor, responsável pela administração geral da Fazenda; a

\footnotetext{
${ }^{432}$ ANRJ, Cód. 106, vol. 01. De Luís de Vasconcelos e Souza a Francisco de Barros Morais, em 19 de julho de 1779 .

${ }_{433}$ Graça Salgado. Fiscais e Meirinhos..., op. cit., p. 50.

${ }^{434}$ Ibid., p. 52.
} 
judiciária - como a anterior, o governador tinha a atribuição mais de fiscalizar o cumprimento da lei do que sua efetiva aplicação, que ficava sob a responsabilidade do Ouvidor-Geral.

Não se deve, no entanto, confundir tal distribuição de poderes com a estrutura de organização administrativa do Estado contemporâneo, com as jurisdições e hierarquias de seus órgãos e autoridades bem delimitadas. Os governadores-gerais e, depois os vice-reis, tinham amplas competências sobre os demais setores da administração estatal, tanto na sede do governo quanto nas capitanias, mas se tratava de uma ascendência de caráter mais formal do que efetiva. Os regimentos passados aos demais funcionários (provedores, ouvidores, governadores das capitanias...) deixavam margem a ambigüidades, lacunas e mesmo contradições entre cada área de ação, o que tendia a fragilizar o poder dos agentes e fortalecer o poder régio, pois, em última instância, era dele que vinha a decisão final.

O regimento passado ao governador-geral Roque da Costa Barreto, em 1677, serviu como norteador das ações dos governadores e vice-reis, seus sucessores, até pelo menos o ano de 1806, quando D. Fernando José de Portugal e Castro o comentou. ${ }^{435}$ Segundo Marcos Carneiro de Mendonça, “A extensão do prazo de validade desta Lei geral, aumentou sua importância histórica e serviu para inspirar praxes administrativas persistentes no Brasil." Organizada em 61 capítulos, o regimento impunha, como primeira obrigação, a visita que o governador devia fazer pessoalmente às fortalezas da cidade, armazéns, e tercenas, ordenando que se fizesse inventário pelo escrivão da Fazenda Real de todas as coisas que a ela pertenciam; em seguida tratava da conversão dos gentios à Santa Fé Católica; determinava sobre a provisão dos ofícios de Guerra, Justiça e Fazenda; deliberava que se apurasse as rendas da Coroa, fiscalizando os Provedores para que cumprissem o seu Regimento. $\mathrm{O}$ documento recomendava a fiscalização dos portos de todas as Capitanias, determinando ainda o cumprimento do Regimento das Ordenanças, os alardos para a apresentação de armas, a realização dos exercícios pelas Companhias, além de tratar sobre a divisão de terras e sua doação em sesmarias para cultivo e povoamento do solo, entre outras tantas atribuições concernentes aos assuntos administrativos e econômicos. Esse "diploma legal" deixava

\footnotetext{
${ }^{435}$ Regimento do Governo Geral do Estado do Brasil dado ao Mestre de Campo Roque da Costa Barreto, em 1677, reproduzido em Marcos Carneiro de Mendonça. Raízes da Formação Administrativa do Brasil - Tomo II. Rio de Janeiro: IHGB, 1972, pp. 739-871.
} 
clara a devida subordinação que deviam os governadores das capitanias ao governadorgeral.

Quatorze anos antes, em $1^{\circ}$ de outubro de 1663, havia sido passado aos governadores capitães-mores (a maioria dos quais, donatários) um regimento geral, o único que se tem notícia dessa natureza, pelo então governador do Estado do Brasil. ${ }^{436}$ Em consonância com o Regimento de Costa Barreto, as principais atribuições daqueles oficiais deviam ser:

- Visitar as fortalezas e armazéns existentes na capitania, com o provedor da Fazenda e o escrivão, bem como fazer um levantamento sobre o estado das instalações, equipamentos e reparos necessários, dando de tudo notícia ao governador-geral.

- Passar em revista os habitantes da capitania, obrigando os que forem aptos a servir militarmente assim o façam.

- Fazer alardos anuais para o adestramento militar dos moradores.

- Subordinar-se diretamente ao governador-geral do Estado do Brasil.

- Responsabilizar-se pela defesa e segurança da capitania.

- Mandar aviso ao governador-geral quando vagar algum ofício de Justiça ou Fazenda, para o provimento do cargo.

- Não tomar parte na administração da Fazenda Real da capitania.

- Evitar que haja suborno nos dízimos.

- Advertir os oficiais da Fazenda e da Justiça quando não cumprirem suas obrigações e, em caso de reincidência, avisar o governador-geral das culpas e erros destes oficiais para que o mesmo tome a resolução mais conveniente.

- Favorecer os oficiais das Câmaras no que for benefício para a administração, respeitando a sua autonomia.

- Não doar terras em sesmarias nas capitanias reais. ${ }^{437}$

Reproduzia-se, assim, no âmbito das capitanias, o mesmo esquema político e administrativo do governo-geral. Esses regimentos serviram de base norteadora à prática governativa dos governadores futuros, pelo menos enquanto perdurou o sistema das capitanias hereditárias. Com a reversão dessas para a Coroa, alterou-se o caráter de domínio político das capitanias. De uma estrutura marcada pelo domínio senhorial, passava-se para unidades políticas de controle direto do Estado Monárquico Português.

\footnotetext{
${ }^{436}$ Graça Salgado. Fiscais e Meirinhos..., op. cit., p. 68.

${ }^{437}$ Ibid., p. 243-44.
} 
Entretanto, a reorganização da colônia em capitanias gerais significou, conforme Dauril Alden, a diminuição efetiva da autoridade dos governadores-gerais. ${ }^{438}$

Aos novos governadores e capitães-generais não se baixou mais regimento único. Para cada um eram passadas normas e instruções específicas de acordo com as particularidades e conjunturas próprias do território que iam governar.

Continuaram ocupando, em tese, o mais alto posto na estrutura administrativa das capitanias - "o chefe supremo é o governador", afirmou Caio Prado Jr. ${ }^{439}$ De fato, em comparação com os outros funcionários, possuíam status mais elevado, soldos mais altos e usufruíam de maior grau de comunicação com a Corte. Além disso, eram os que mais personificavam o rei nos domínios ultramarinos. Com o nome de "Palácio... chamam a morada do Governador, diziam os oficiais da Câmara de Desterro em representação à Corte. ${ }^{440}$ De acordo com Caio Prado Jr., "Nas cerimônias públicas e homenagens ao trono, como por ocasião de acontecimentos notáveis na dinastia reinante - nascimentos, casamentos, aniversários, etc. - o governador recebia o beija-mão como se fora o próprio rei" ${ }^{441}$ Contudo, não se deve confundir essa posição superior que ocupavam na estrutura da administração local com um poder irrestrito, como percebeu o viajante francês Auguste de Saint-Hilaire. Segundo ele, os governadores

cuja autoridade, quase ilimitada, era ao mesmo tempo civil e militar. (...) Livres de qualquer vigilância, saudosos dos prazeres de uma grande capital, cheios de desprezo pela região que governavam, devorados de tédio, não tendo mais iguais com que tratar, rodeados de aduladores e de escravos, esses capitães generais entregavam-se frequientemente a todos os caprichos do despotismo. ${ }^{442}$

Alguns, de fato, exerciam o poder de forma arbitrária e violenta, mas não possuíam poder ilimitado, pois uma ordem régia podia alterar, ou reorientar para cada casos específico, ampliando ou reduzindo as suas jurisdições, poderes e atribuições. Na já citada Dissertação instrutiva de Francisco de Almeida Silva (1780), com que se abriu este capítulo, evidenciam-se alguns dos limites de poder que lhes eram impostos. Em sua $6^{\text {a }}$ Máxima defendia ele,

\footnotetext{
${ }^{438}$ Royal Government..., op. cit., p. 40.

${ }^{439}$ Caio Prado Jr. Formação do Brasil Contemporâneo - Colônia. 23 ed. São Paulo: Brasiliense, 1999, p. 306.

${ }^{440}$ AHU-SC, cx. 1, doc. 73, em 24.01.1753.

${ }^{441}$ Caio Prado Jr. Formação do Brasil..., op. cit., p. 309, nota 13.

${ }^{442}$ Viagem à Província do Rio de Janeiro e Minas Gerais. São Paulo; Belo Horizonte: Ed. USP, Itatiaia, 1978 , p. 154.
} 
Que a todos os Governadores das Conquistas se concedam mais amplos poderes sobre a pena de morte. E que ao Vice Rei do Brasil, Capitães Generais da Índia, da Capitania da Bahia, das Minas Gerais, e de São Paulo se conceda também o privilégio, e regalia de darem em nome de S. Maj. um certo número de Hábitos das Três Ordens Militares em cada um ano; e alguns Alvarás de Foros de Fidalgos contempladas as Hierarquias, como for do Agrado de S. Maj. ${ }^{443}$

$\mathrm{Na} 7^{\mathrm{a}}$. Máxima,

Que os Governadores, nos casos, e circunstâncias urgentíssimas, possam apartar-se das Leis, Ordens, e Regimentos, convocando Juntas próprias para se resolver nelas o que for mais proporcionado, e conveniente ao Real Serviço, nas ocasiões em que os mesmos casos necessitem de uma imediata providência. ${ }^{444}$

Reivindicações essas que a Corte não estava disposta a ceder. Restringir o limite de poder de seus agentes coloniais colocava-se como uma forma de ampliar o controle régio nas conquistas.

Segundo Caio Prado Jr., “O 'governador' é uma figura híbrida, em que se reuniram as funções do 'Governador das Armas' das províncias metropolitanas; um pouco das de outros órgãos, como do 'Governador da Justiça', do próprio rei. Contudo, nunca se caracterizou nitidamente, e sua competência e jurisdição variaram sempre com o tempo, de um governador para outro, de uma para outra capitania; variaram sobretudo em função da personalidade, caráter e tendências dos indivíduos revestidos do cargo". ${ }^{445}$

As demais autoridades da colônia (provedores, ouvidores, juízes ordinários, e vereadores), "embora de categoria inferior, funcionavam como contrapesos muito sensíveis à autoridade do governador." Não formavam "propriamente degraus inferiores da escala administrativa, no sentido que hoje damos a esta noção"; nem se subordinavam "inteiramente à autoridade superior do governador como simples cumpridores de ordens". 446

Portanto, no exercício do cargo, longe de possuírem um poder absoluto na capitania, os governadores viam-se obrigados a reconhecer e a conviver, amistosamente ou não, com os poderes da Câmara, da Fazenda, da Ouvidoria, assim como também, dos

\footnotetext{
${ }^{443}$ Dessertação instrutiva...op. cit., fl. 9.

${ }^{444}$ Ibid., fl. 11.

${ }^{445}$ Caio Prado. Formação... op. cit., p. 301.

${ }^{446}$ Ibid., p. 308.
} 
grupos sociais organizados. Se alguns impuseram suas políticas de maneira arbitrária e até violenta, sobretudo no momento inicial de montagem do estabelecimento colonial, a tendência futura, na relação entre esses diversos poderes, apontava para um equilíbrio de forças, em que uns e outros, em comunicação direta com a Corte, se fiscalizavam e se denunciavam mutuamente, tendo o rei, em última instância, como fiel da balança. ${ }^{447}$

\subsubsection{Governo subalterno}

Todos os governadores capitães-generais, em princípio, deviam subordinação aos governadores-gerais ou, vice-reis do Estado do Brasil. Na prática, não era isso que ocorria. O grau de comunicação direta que aqueles oficiais podiam estabelecer com a Corte lhes conferia considerável independência político-administrativa, sobretudo em algumas capitanias como São Paulo, Bahia (depois de 1763), Minas Gerais e Pernambuco. Em verdade, a autoridade dos vice-reis do Brasil restringia-se a sua própria capitania, exceto em ocasiões extraordinárias. ${ }^{448}$

A subordinação do governo da Ilha de Santa Catarina, assim como também do Rio Grande de São Pedro e da Colônia do Sacramento, ao Rio de Janeiro era não só formal, mas efetiva. Vínculo esse que foi maior após a transferência dos vice-reis para o Rio de Janeiro, em 1763, do que na administração do governador e capitão-general Gomes Freire de Andrade (1738-1763). ${ }^{449}$

Essa era uma das reclamações que fazia o governador da Ilha, João Alberto de Miranda Ribeiro à rainha, em novembro de 1797. Segundo ele, o primeiro governador, o Brigadeiro José da Silva Paes, e seus sucessores

\footnotetext{
${ }^{447}$ Ver também a esse respeito João Paulo Aparício. Governar no Brasil Colonial na segunda metade de Setecentos: o caso de Minas Gerais, in Maria Emilia Madeira Santos (Coord.) O Domínio da Distância: comunicação e cartografia. Lisboa: Instituto de Investigação Científica Tropical, 2006, p. 83.

${ }^{448}$ Dauril Alden. Royal Government..., op. cit., p. 42.

${ }^{449}$ Segundo Paulo Joze Miguel de Brito. Memória Política sobre a Capitania de Santa Catarina. Lisboa, 1829 [1816], p. 68, "Depois que os Vice-Reis do Brasil passaram a residir nesta Cidade do Rio de Janeiro, o Governador e mais autoridades em tudo, e igualmente o ficaram à Junta da Fazenda e às Repartições fiscais: todas as arrematações das rendas do Estado eram feitas perante aquela Junta, e a mesma recebia todos os rendimentos da Capitania, e as poucas que ali se cobravam, remetiam-se para esta Cidade à mesma Junta, a qual por omissão sua ou dos Vice-Reis, ou talvez por um zelo mal entendido destes e daquela, nunca mandava em tempo, nem por inteiro, para a Capitania as somas precisas para as suas despesas; sistema bárbaro, que deu ocasião a uma dívida enorme da Fazenda Real, com indizível prejuízo da agricultura, e sacrifício de numerosas pessoas e famílias, que por aquele motivo ficaram reduzidas à miséria e indigência".
} 
sempre dirigiram as suas contas diretamente para a Corte, nos casos ocorrentes, tendentes a este tão interessante estabelecimento; a bem do qual, e dos seus novos habitantes, obtiveram algumas amplitudes, atendida a necessidade e circunstâncias atuais dos mesmos Colonos, seus filhos e Agregados, como especificam as mesmas Provisões. Esta direta correspondência cessou no Governo de D. Jozé de Melo Manoel, em conseqüência da Provisão n. 17, cujo Governo acabou em sete de março de 1762.

De fato, se observarmos as correspondências emitidas pelos governadores de Santa Catarina entre 1739 e 1762 a maior parte delas destina-se ao rei ou aos secretários de Estado, ${ }^{450}$ contrariando, pois, a afirmação de Dauril Alden de que os governadores subordinados não se comunicavam diretamente com a Corte, mas tão somente por meio do vice-rei. ${ }^{451}$ No entanto, continua Miranda Ribeiro, a partir de 1763,

e até ao presente os Governadores meus Predecessores, se tem dirigido em conformidade daquelas Ordenações primárias, das Justas, e Providentes Leis de V. Maj. naqueles objetos Militares, e Políticos, que eram, e são relativos a autoridade dos Governadores, e finalmente pelas repetidas ordens, que os excelentíssimos Vice Reis do Estado sucessivamente sobre diferentes objetos lhes dirigem, nas quais, caçando-lhes insensivelmente tudo quanto são autoridades, e Regalias, vem a ficar o Governador de uma tão considerável Capitania um homem, a quem a necessidade obriga a empregar todos os seus talentos, em descobrir alguns meios necessários para punir e castigar os delinqüentes, e nenhum para premiar e animar os beneméritos é natural que todos olhem com horror para um homem, de quem só esperam os Castigos, e nada daquelas graças e mercês, com que a Real Grandeza, e Generosa Liberalidade de V. Maj. costuma remunerar o merecimento dos que com obediência, gosto, e fidelidade se empregam no seu Real Serviço, Este é o modo, porque se tem dirigido os Governadores desta Ilha. ${ }^{452}$

A mudança no ano de 1763 relacionava-se, no plano político, à transferência do vice-reinado da Bahia para o Rio de Janeiro, fortalecendo o poder monárquico de toda a região sul do Brasil; no plano econômico-financeiro, inseria-se já no esforço de Sebastião José de Carvalho e Melo na uniformização dos procedimentos contábeis com vistas à ampliação das rendas da Fazenda Real. Sua mais importante medida nesse sentido foi a Lei de 22 de dezembro de 1761, que instituiu, em Lisboa, o Erário Régio ou Tesouro, centro de contabilidade de todos os dinheiros públicos do império. ${ }^{453}$ No

\footnotetext{
${ }^{450}$ Ver ANRJ, Cód. 106, vol. 2, que guarda as correspondências do período de 1752 e 1774; e outras citadas ao longo deste trabalho.

${ }^{451}$ Dauril Alden. Royal Government..., op. cit., p. 449.

${ }^{452}$ AHU-SC, cx. 6, doc. 386. Grifos meus.

453 Antônio de Sousa Pedroso Carnaxide (Visconde de). O Brasil na Administração Pombalina (Economia e Política Externa). São Paulo: Companhia Editora Nacional, 1940, p. 108.
} 
Brasil, os provedores das capitanias deviam, a partir de 1766, enviar suas contas de receita e despesa à Contadoria Geral da Junta da Fazenda Real do Rio de Janeiro. ${ }^{454}$

Outros governadores da Ilha demonstravam-se também inconformados com essa condição de subalternidade. José da Silva Paes argumentava ao rei D. João V, em ofício de 20 de junho de 1739, que

a experiência tem mostrado que as subordinações dos Governos uns aos outros não só são prejudiciais aos Povos, senão também ao serviço de V. Maj.; (...) Ordinariamente parece mal aos Governadores subordinados que os seus superiores derroguem e emendem os seus despachos, e contradigam as suas resoluções e em algumas matérias que parece que de justiça o não deviam fazer e da mesma sorte se lisonjeiam aqueles do recurso que se lhe interpõem (principalmente se lhe são menos afetos) e estimam achar algum caminho para mostrarem não só a sua jurisdição, senão também que só eles entendem as matérias, e fazem justiça, e por esta razão são menos atendidos dos Povos os Governadores com restrições; porque vendo que deles não dependem dos seus requisitos e os subalternos os seus melhoramentos só procuram lisonjear e respeitar ao Governo superior. (...)

Pelo que toca ao Governo das costas do mar do Sul me parece deve V. Maj. neste Porto e nesta Ilha, formar um novo Governo e que este seja independente dos mais, para poder acudir a qualquer incidente que possa sobrevir em toda a costa desde o Rio de S. Francisco, inclusive até o Rio da Prata. (...) E caso V. Maj. assim o determine parece-me deve ser esta Capitania desde o dito Rio de S. Francisco até o Rio Grande da parte do Norte e com a subordinação ordinária ao Vice Rei do Estado. ${ }^{455}$

Desejava Silva Paes que o estabelecimento que se começava a montar na Ilha de Santa Catarina se subordinasse apenas ao vice-rei (naquele momento residente na Bahia), como estavam todos os capitães-generais do Brasil. Um vínculo que, como já se disse, era mais formal do que efetivo.

De fato, as restrições ao poder desses governadores subalternos deixavam-nos numa posição bastante incômoda, pois, no jogo de forças locais, isso acabava por fortalecer os poderes concorrentes (provedores, ouvidores e oficiais da Câmara). Darlhes maior autonomia, ou uma estrutura de governo que se equiparasse às capitaniasgerais, segundo eles, seria o melhor meio de aquela colônia atingir os seus fins. Não se pode esquecer, todavia, que nessas reivindicações estavam em jogo, também, a elevação do status social dos governadores.

Pouco tempo depois de assumir a governança da Ilha, Manoel Escudeiro Ferreira de Souza dirigiu requerimento à Corte solicitando aumento de seu soldo e também um

\footnotetext{
${ }^{454}$ Márcia Eckert Miranda. Continente de São Pedro: Administração Pública no Período Colonial. Porto Alegre: Assembléia Legislativa do Estado do RS, 2000, p. 92.

${ }^{455}$ Col. Doc., pp. 135-36.
} 
Oficial de Sala (também chamado de Pluma), para a Secretaria do seu governo, assim como havia nas capitanias gerais. Marco Antônio de Azevedo Coutinho, Secretário dos Negócios Estrangeiros e Guerra, indeferiu os pedidos recolocando de maneira muito incisiva a condição daquele governo e de seu governador:

Quanto ao que V. M. ${ }^{\mathrm{e}}$ expõe a Respeito do seu soldo deve lembrar-se, que sendo de três mil cruzados: Foi S. Maj. servido acrescentar-lhe a cinco que é o mesmo que tem o Governador da Colônia [do Sacramento] atendendo as mesmas despesas que V. M. ${ }^{\mathrm{e}}$ representa; pelo que não tem o dito Snr. por conveniente inovar neste particular coisa alguma: A criação de Secretário e de Oficiais de Sala para esse Governo além de ser um grande acréscimo de despesa para o princípio de um estabelecimento, que já por outras coisas custa tanto, parece a S. Maj. por ora menos necessária, atendendo as poucas ocasiões que ainda há para empregar os ditos oficiais, podendo facilmente suprir-se por outros modos (...). ${ }^{456}$

Assim se procedeu por quase todo o século XVIII. Como registrou Miranda Ribeiro em 1797, a mesma Secretaria vinha sendo "servida por um Oficial subalterno tirado do Regimento da Guarnição para este exercício" que não levava salário algum além do soldo de seu posto "pago com o mesmo atraso, que a todos os mais indivíduos do Regimento". ${ }^{457}$ Da mesma forma, era tirado um capitão para servir de Expediente das Ordens do Governador, o qual servia também "debaixo do correspondente soldo de sua patente, e pago da mesma forma que os outros". Houve um período apenas em que esse cargo foi exercido por um "secretário de propriedade". Quando o Brigadeiro Francisco de Barros Moraes entrou no governo da Ilha, em junho de 1779, trouxe consigo um Ajudante de Ordens com a patente de capitão. Mas quando esse faleceu nenhum outro foi provido em seu lugar, voltando aquele cargo a ser desempenhado por um oficial desviado da guarnição. ${ }^{458}$

Outro caso que ajuda a elucidar a hierarquia político-administrativa dos estabelecimentos do Sul, em meados do século XVIII, ocorreu com o governador da praça de Santos. Logo após extinta a capitania de São Paulo (1748), ele obrigou os Oficiais de Sala dela a trabalharem a seu serviço. Contrariados com aquela situação, os oficiais dirigiram uma representação a Gomes Freire de Andrade que, prontamente

\footnotetext{
${ }^{456}$ BNRJ, Mss. CEHB n. 5616 - 3, 4, 3 n. 113. Ofício de Marco Antonio de Azevedo Coutinho a Manoel Escudeiro Ferreira de Souza, em 20 de novembro de 1749.

${ }^{457}$ OMR-1797, fl. 04.

${ }^{458}$ Ibid., fl. 04.
} 
esclareceu a questão: "Parece-me justo o seu requerimento, pois os oficiais de ordens do General não fazem sala aos Governadores de Praças". 459

Entre as restrições ao poder dos governadores subalternos estava o direito de conceder cartas de sesmarias, como concediam os governadores e capitães-generais, ${ }^{460}$ muito embora, a Provisão de 9 de agosto de 1747, autorizasse o governador da Ilha de Santa Catarina, que na época era José da Silva Paes, a fazer concessões de um quarto de légua em quadro aos casais açorianos, "nas terras que ainda não estivessem dadas de sesmarias". ${ }^{461}$ Essa disposição legal acabou por provocar algumas confusões pelos governadores seguintes, que doavam os pequenos lotes (as datas de terras) com o nome de sesmarias. ${ }^{462}$ Em 9 de junho de 1780, o governador Francisco de Barros Moraes pedia esclarecimentos ao vice-rei acerca desse assunto:

a primeira coisa que me lembrou foi que talvez não pertencia aos Governadores desta Ilha a concessão de datas de terras por sesmarias: e não obstante que a minha Patente diz que usarei da mesma jurisdição que usavam os meus antecessores (...). Pelos registros dos Livros da Câmara achei que o primeiro Governador o Brigadeiro José da Silva Paes passava as cartas de sesmarias em Nome de S. Maj. com a cláusula de as confirmarem as partes pela Secretaria do Governo do Rio de Janeiro. ${ }^{463}$

Ao que respondeu o vice-rei:

Devo dizer a V. S. ${ }^{\text {a }}$ que os Seus Antecessores procederam nessa parte com equivocação, talvez por não terem notícia das Ordens Reais que há a este respeito, ou por não fazerem a verdadeira distinção das mesmas Sesmarias às datas de terra, que só lhes tocava dar e repartir pelos Casais Colonos de um quarto de légua em quadra (...) [Aos] Governadores dessa Ilha só pertence dar as sobreditas Datas de terra unicamente àqueles Casais, que forem matriculados, e tudo o mais, que determina a mencionada ordem, e que os mais moradores, que não forem dessa qualidade devem pedir aos Vice-Reis

\footnotetext{
459 ANRJ, Cód. 84, vol. 11, fl. 303v. De Gomes Freire de Andrade ao Governador de Santos, em 6 de maio de 1749.

${ }^{460}$ Ruy Cirne Lima. Pequena história territorial do Brasil: sesmarias e terras devolutas. 5 ed. Goiânia: Ed. UFG, 2002, p. 44.

${ }^{461}$ In, Walter Piazza. A Epopéia Açórico-Madeirense..., op. cit, p. 122. Esse direito foi extensivo aos governadores do Rio Grande de São Pedro. Ver Helen Osório. Estancieiros, Lavradores e Comerciantes na Constituição da Estremadura Portuguesa na América: Rio Grande de São Pedro, 1737-1822. Niterói: PPG-História UFF (Tese de Doutorado), 1999, p. 74.

${ }^{462}$ Ver p. 113.

463 ANRJ, Cód. 106, vol. 03, of. 14. De Francisco de Barros Moraes Araujo Teixeira Homem ao vice-rei Luis de Vasconcelos e Souza. Em outra carta de 20 de março de 1781, Francisco de Barros informava ao vice-rei que o governador Manoel Escudeiro também havia passado cartas de sesmarias aos colonos, Cód, 106, vol. 04, of. 3 .
} 
as porções de terra, que lhes forem necessárias por Sesmarias para estes lhas concederem em nome de S. Maj. ${ }^{464}$

Para todos os casos, as concessões deviam ser confirmadas pelo rei, no tempo de dois anos, na forma da Lei das Sesmarias. ${ }^{465}$

A condição de subalternidade do governo da Ilha de Santa Catarina não deve ser vista, simplesmente, como representativa de um espaço de menor importância no império. De fato, havia territórios de desigual valor para a Monarquia Portuguesa, podendo ser eles hierarquizados a partir do seu peso econômico, militar e simbólico. Mas, como já se mostrou no capítulo 1, ao longo do século XVIII, houve um redirecionamento dos interesses portugueses do norte para o centro-sul da América, impulsionado pela exploração do sertão mineiro e da agropecuária nos campos sulinos. A transferência do vice-reinado para o Rio de Janeiro, em 1763, representou, com um certo atraso, o deslocamento do centro de poder para essa cidade, frente à valorização desse amplo espaço que se abria entre a região das minas e o rio da Prata. A subordinação do governo de São Paulo, em 1748, ao Rio de Janeiro, auge da produção mineira, pode ser pensada não como desvalorização do território ocupado por ele, mas, ao contrário, como sua valorização: naquele mesmo ano retirava-se o seu governador capitão-general e criava-se dois outros postos com esse título, um em Goiás, outro em Cuiabá. Em Laguna e na Ilha de Santa Catarina, os respectivos capitão-mor e sargentomor, subordinados a São Paulo, davam lugar a um governador na Ilha, com título de Coronel e subalterno ao Rio de Janeiro. Todas essas mudanças faziam parte de um mesmo processo de reestruturação dos centros de poder na região como estratégias de melhor domínio do espaço.

A decisão de se instaurar capitania-geral ou governo subalterno passava pela análise de vários fatores, entre os quais pode-se destacar, o valor econômico do território, a sua importância estratégica e militar para o Império, a existência de poderes locais fortemente constituídos e, também, a distância-tempo dos respectivos lugares ao centro de poder.

Como tantas vezes já se disse, a Ilha de Santa Catarina foi uma importante base política e militar na consolidação das conquistas portuguesas no sul da América Meridional; economicamente, ela não tinha o peso de outras regiões como o sertão

\footnotetext{
${ }^{464}$ ANRJ, Cód. 106, vol. 03, n. XXI, em 13 de dezembro de 1780.

${ }^{465}$ Cf. doc. anterior. Segundo Ruy Cirne Lima. Pequena história territorial..., op. cit., p. 45, o prazo era de um ano.
} 
mineiro, o norte açucareiro ou mesmo os campos de criação no sul, muito embora a inserção de seus dois principais produtos de exportação - a farinha de mandioca e o óleo de baleia -, no sistema colonial, não devam ser menosprezados. No terceiro capítulo volta-se a esse ponto. Além disso, Santa Catarina - pelo menos no período que aqui se estuda - não houve poderes locais tão ameaçadores quanto naquelas regiões mencionadas, que ameaçasse e colocasse em risco o poder monárquico lusitano. Quanto à questão da distância-tempo do centro de poder, é interessante o parecer que deu o Brigadeiro José da Silva Paes sobre a criação dos novos governos no sertão mineiro.

Primeiramente não me acomodo nem nunca votarei na união dos Governos das Minas dos Goiazes, e Cuiabá ao das Gerais, e não somente me parece deve qualquer destes ser separado e independente do das Gerais, senão ainda do de S. Paulo, porque a grande distância em que se acham uns dos outros faz com que seriam mui prejudiciais ao serviço de V. Mag. e aos Povos, as morosas resoluções que se houvessem de tomar em incidentes donde são precisas determinações prontas.

Da cidade de S. Paulo aos Goiazes (pelas informações que tirei de pessoas fidedignas) são quarenta dias de viagem de gente escoteira que fazem mais de duzentas léguas, e de S. Paulo ao Cuiabá, ainda é muito mais distante pois se gastam meses e por inumeráveis perigos e incômodos; desta Capitania do Cuiabá aos Goiazes ainda que se tenha descoberto picada gastam os viageiros, dois meses (...).

Por este cálculo se percebe bem as grandes distâncias em que se acham aquelas Capitanias umas das outras; e quando em as Gerais houvesse superioridade devia só ser como a que tem o V. Rei deste Estado sobre os mais Governos do Brasil, ou na forma da Capitação e contribuição dos quintos e em tudo o mais independentes (...). ${ }^{466}$

Bem menor era o tempo que se gastava para se ir do Rio de Janeiro à Ilha de Santa Catarina: aproximadamente 7 dias de viagem pelo mar.

Com efeito, o governo da Ilha sempre esteve mais sob o controle direto do poder régio do que os de São Paulo, do Rio Grande de São Pedro ou da Colônia de Sacramento. ${ }^{467}$ Em se tratando dos territórios sob a jurisdição do Rio de Janeiro, quanto menor a autoridade dos governadores locais, tanto maior era a atuação vice-reis naqueles governos.

\subsection{2 "Algumas Régias Ordens vagas"}

\footnotetext{
${ }^{466}$ RIHGRGS, n. 109 a 112, 1948, p. 135. De José da Silva Paes ao rei, em 20 de junho de 1739.

${ }^{467}$ Ver p. 75.
} 
Em 30 de julho de 1796, conselheiros ultramarinos, em nome da rainha, ordenavam ao governador interino da Ilha de Santa Catarina, João Alberto de Miranda Ribeiro, que remetesse àquele órgão

uma cópia do Regimento, ou Regimentos [dessa] capitania, com todas as ordens que os tenham alterado, ampliado, ou restringido, praticando-o assim, com uma circunstanciada informação, e parecer sobre cada um dos seus artigos presentemente praticáveis, ou impraticáveis, em benefício do Real Serviço e dos Povos de sorte que por ele à vista das ordens, e do mais que ocorrer, se possam formalizar de novo, analisar e corrigir os antigos Regimentos, que existem nessa Capitania, procedendo-se a outros, que se acomodem, e tenham uso segundo a vicissitude dos tempos; cuja remessa farei com toda a possível brevidade, por Eu haver assim Resoluto, em 20 de junho do presente ano, ordenado uma Geral reforma de todos os sobreditos Regimentos; E por que nessa Capitania pode suceder não haja Regimento, no caso que assim se verifique, remetais por cópias todas as Ordens que respeitarem a este fim, e objeto, para se vos dar de novo particular Regimento, para o Governo dela (...). ${ }^{468}$

Observa-se nessa provisão régia que não havia por parte da Corte um controle das instruções, ordens e regimentos emitidos por suas secretarias e conselhos às conquistas ultramarinas - ou, pelo menos, ao governo da Ilha de Santa Catarina. O documento revela ainda que era prática da política monárquica portuguesa com relação a algumas capitanias a administração por meio de ordens circunstanciais e específicas, "segundo a vicissitude dos tempos". Nem todos os governadores levavam Regimentos. No final do século XVIII, uma nova conjuntura política e econômica - mas também uma nova mentalidade sobre a administração, com princípios mais racionais e padronizados - colocava a necessidade de uma "Geral reforma de todos os sobreditos Regimentos".

Miranda Ribeiro levou cerca de um ano e meio para responder ao Conselho Ultramarino, e se desculpou por isso, justificando que precisava recolher e averiguar todos os documentos e informações para apresentar seu Relatório de governo. Com efeito, são dele os mapas e quadros estatísticos mais completos e minuciosos sobre a administração da capitania de Santa Catarina que se têm notícia. No preâmbulo do documento que enviou à Corte, em 16 de novembro de 1797, dizia:

\footnotetext{
${ }^{468}$ ANRJ, Cód. 106, vol. 13, fl. 147 (cópia). Assinado por José Xavier Cunha d’Eça Telles de Menezes Carvalho e Silva e Francisco da Silva Corte Real. Vale lembrar que a rainha D. Maria I deixara de governar desde 10.02.1792. Ver nota 412 à p. 139.
} 
posso assegurar a V. Maj.: que na Secretaria deste Governo se não acha Regimento em forma de Regularidade, que sirva de Guia, ou ditame para os Governadores o seguirem e só sim se encontram algumas Régias Ordens vagas, que para diferentes objetos, foram aos mesmos Governadores remetidas (...), e portanto sou obrigado a confessar, que eu me estabeleço (como Governador) em algumas das Referidas Provisões Régias, que (por Casualidade) apesar da referida confusão [invasão espanhola de 1777] apareceram: assim como no que me parece mais acertado, conforme o costume e prática dos meus Antecessores (....). ${ }^{469}$

Não houve, portanto, para o governo da Ilha de Santa Catarina, nenhum regimento único que servisse de base legal e regulamentasse as atribuições dos seus governadores, entre 1738 e 1807. Para cada um eram expedidas ordens e instruções específicas, além daquelas que lhes deveriam passar os governadores que deixavam o cargo, a exemplo da transmissão de cargo de Francisco de Barros Moraes a José Pereira Pinto, em 1786. Ao que saía, orientava o vice-rei:

Desejarei que V. S. ${ }^{a}$ dê por escrito todas as instruções precisas ao referido seu sucessor, que juntas à boa capacidade, e conhecimento que tem, não deixarão de ser-lhe convenientes para se saber dirigir nesse Governo, e muito indispensáveis para se não afastar das regras mais seguras com que V. $\mathrm{S}^{\mathrm{a}}$ procurou sempre empregar-se no Serviço de S. Maj. ${ }^{470}$

Ao que entrava, dirigia um ofício instruindo-o das principais atribuições do seu governo. ${ }^{471}$ Primeiramente, alertava-o de que

o Governo da Ilha de Santa Catarina é inteiramente dependente da Resolução dos Vice-Reis deste Estado, e que em qualquer caso, que se não ache já decidido, e que admita demora, se deve esperar a mesma Resolução, depois de se ter participado com todas as suas circunstâncias, e provas sumárias, que admitir, para a Resolução ser acertada, mas quando acontecem casos que tem identidade, ou muita semelhança com outros, que estão resolvidos, é escusado procurar novas Resoluções, que só servem de confundir umas com outras ordens, ou de as haver repetidas por diversos termos, ou de se contradizerem em alguma parte, quando nada é mais prejudicial do que a variedade de Resoluções no mesmo Distrito, e entre os mesmos habitantes em casos idênticos (...).

\footnotetext{
${ }^{469}$ AHU-SC, cx. 6, doc. 386.

${ }^{470}$ ANRJ, Cód. 106, vol. 9, of. IV. Do vice-rei Luis de Vasconcelos e Souza ao governador Francisco de Barros Moraes Araujo Teixeira Homem.

${ }^{471}$ ANRJ, Cód. 106, vol. 9, of. X. Do vice-rei Luis de Vasconcelos e Souza ao governador José Pereira Pinto, em 22 de maio de 1786.
} 
Recolocava o vice-rei, de maneira muito clara, a subordinação daquele governo ao Rio de Janeiro, mandando, porém, que levasse sempre em consideração as instruções passadas anteriormente de forma a não haver redundância de leis sobre os mesmos objetos e, nem procurasse inovar sobre aquilo que já estava decidido.

Sobre a relação com as demais autoridades naquela capitania salientava:

Tem V. M. naquela Ilha um Ministro Eclesiástico, e um Ministro da Coroa, com os quais deve conservar a melhor harmonia, que for possível, e ainda quando V. M. ${ }^{\text {ce }}$ tenha com o tempo motivos de menor estimação, ou ainda de lhes fazer alguma advertência, deve conservar-lhes no exterior a mesma decência, para que os Povos conservem sempre o mesmo Respeito à Jurisdição, que exercitam, que toda dimana do poder Real.

Mais do que uma definição rígida de hierarquias, a boa harmonia entre as autoridades, defendida pelo vice-rei, apontava para o necessário respeito das jurisdições de cada um e o favorável equilíbrio entre os poderes.

A última orientação tratava do desenvolvimento do comércio e da agricultura daquele estabelecimento.

Tudo o que se opõe aos progressos destas duas fontes de opulência se deve rejeitar como prejudicial ao Estado: tudo por consequiência que possa concorrer para o seu aumento, as deve promover, e merece toda a vigilância, atividade, e auxílio de quem governa. A qualidade do Terreno para uma abundante produção, e a grandeza do Porto para uma exportação fácil, e desembaraçada devia excitar mais indústria, e mais ambição nos Habitantes do Distrito que V. M. ${ }^{\text {ce }}$ vai governar, mas eles tem a fraqueza de contentar-se com a cultura de gêneros de pouco valor (...).

Em meio ao "ressurgimento agrícola" do Brasil, ${ }^{472}$ nas duas últimas décadas do Setecentos, sobretudo do açúcar e do algodão, as autoridades metropolitanas buscavam uma melhor inserção econômica daquele distrito nos negócios coloniais, mesmo que fosse para suprir o mercado interno, como ocorria com o Rio Grande de São Pedro na produção do charque. Essa última instrução aponta também para uma questão que se analisará no próximo capítulo: o que o vice-rei chama de "fraqueza" dos habitantes em contentarem-se "com a cultura de gêneros de pouco valor" pode ser visto como uma resistência deles às formas de organização das atividades econômicas coloniais.

${ }^{472}$ Ver p. 89. 
Com efeito, entre os planos contidos nas instruções, regimentos e ordens reais e o desenvolvimento da sociedade local havia uma distância muito grande, distância essa que cabia aos governadores dirimir, equacionar ou, pelo menos, justificar aos seus superiores.

Bem distintas foram as instruções passadas ao Brigadeiro José da Silva Paes em sua governança (1738-49). Pode-se considerar que a primeira delas foi a já tão citada carta régia de 11 de agosto de 1738, que lhe ordenava fortificar a Ilha e estabelecer nela um governo. Outras ordens e instruções viriam do rei, do Conselho Ultramarino ou do governador do Rio de Janeiro orientando-o, sobretudo, acerca do sistema de defesa e do controle dos navios estrangeiros que chegavam àquela costa. Quase no final de sua gestão teve a incumbência de recepcionar e acomodar, conforme regulava a Provisão Régia de 9 de agosto de 1747, os primeiros casais açorianos que chegavam na Ilha de Santa Catarina. Curiosamente, o governador João Alberto de Miranda Ribeiro, em 1797, considerou essa Provisão como o Regimento do governo de Silva Paes. ${ }^{473}$

Entre 1738 e 1807 conjunturas políticas e econômicas distintas, externas ou internas, demarcaram as formas específicas pelas quais a Ilha de Santa Catarina devia ser governada.

${ }^{473}$ OMR-1797, fl. 02. 


\section{A Governança de Uma Capitania Subalterna}

É incontestável, que os dois Pólos sobre que se estriba a boa Ordem do Governo, são o da Justiça, e da Equiidade: e que destes se deduzem os dois atributos do Castigo, e do Prêmio: o primeiro para reprimir, e conter os maus nos seus deveres; e o segundo para animar, e premiar os beneméritos. Mas o primeiro é um tristíssimo poder, para quem governa, quando lhe falta a autoridade para Lançar mão ao segundo, a fim de fazer ver aos súditos o equilíbrio da mesma Justiça: e esta é a triste situação, em que se acha o Governador da Ilha de Santa Catarina.

Governador João Alberto de Miranda Ribeiro ${ }^{474}$

Pode-se dividir o período de 1738 a 1807 no que diz respeito às orientações político-administrativas centrais do governo da Ilha de Santa Catarina, em pelo menos quatro momentos distintos. O primeiro, que vai até 1748 , corresponde à instalação da praça militar, ou seja, construção de todo o sistema de defesa da Ilha (fortes, fortalezas, guarnição etc). Essa questão, em verdade - "vocação" maior da Ilha de Santa Catarina para o Império Português - por todo o período restante, esteve na pauta entre as principais atribuições dos governadores; o segundo, de 1748 a 1763, caracterizou-se pela consolidação do estabelecimento colonial do ponto de vista político, com a criação da ouvidoria e provedoria na Ilha, social-demográfica, com a recepção e acomodação dos casais açorianos e madeirenses, e também econômico, pela maior inserção das atividades produtivas da Ilha nos negócios coloniais do Atlântico Sul; o terceiro, de 1763 a 1777, embora não cessassem as preocupações com as atividades produtivas, caracterizou-se pela importância estratégica e militar que a Ilha desempenhou no tempo de guerra com os espanhóis. Em 1763, eles invadiram a vila de Rio Grande de São Pedro, bloqueando o acesso português àquele porto. A partir daí, a Ilha de Santa Catarina e a vila de Laguna tornaram-se as principais ligações entre o Rio de Janeiro e os povoados de Viamão e de Porto Alegre, servindo de bases de comunicação e de

${ }^{474}$ OMR-1797, fl. 19. 
abastecimento dos exércitos no Sul, até o ano de 1777, quando os espanhóis invadiram a Ilha; o quarto e último, que vai de 1778, ano de restituição da Ilha aos portugueses, a 1807, pode ser caracterizado como um período de "refundação da capitania". Apesar da ameaça de invasão francesa, a estabilidade política e a favorável conjuntura econômica do Brasil contribuíram para uma melhor organização das atividades produtivas do estabelecimento. A prática governativa nesses quatro momentos constitui o objeto de análise deste capítulo.

\subsection{O governo da praça militar}

A decisão em se criar um governo na Ilha de Santa Catarina, em 1738, desencadeou um conjunto de mudanças profundas na vida política, social e econômica desse estabelecimento colonial. Com a chegada do Brigadeiro José da Silva Paes, em março de 1739, a Ilha tornava-se a principal base de apoio político e militar português ao sul do Rio de Janeiro e de São Paulo ou, pelo menos a mais estável, visto que a Colônia de Sacramento, situada na margem norte do rio da Prata, demonstrara ser uma praça frágil, pois, desde a sua fundação, em 1680, já havia sido invadida três vezes pelos espanhóis, ${ }^{475}$ e o presídio Jesus-Maria-José, que o Brigadeiro mandara levantar na barra sul do Rio Grande de São Pedro, em 1737, seria também alvo de acirrados conflitos entre as nações ibéricas.

Aquela "pobre e limitada... pescaria”, onde não havia "justiça nem Regimento algum" - dizia Manoel Manso de Avelar, em 1722, ${ }^{476}$ sobre a Ilha de Santa Catarina, na qual era o sargento-mor -, subordinada ao capitão-mor de Laguna, e ambas à capitania de São Paulo, passava agora a ter um governador com submissão direta ao Rio de Janeiro. A autoridade que trazia o primeiro deles, não se restringia ao campo políticoinstitucional. Silva Paes era homem letrado; possuía formação de engenheiro, título de Brigadeiro das Armas do rei de Portugal, além de outras honrarias militares. Um status que o colocava inequivocamente em posição bem superior aos homens principais das vilas de Desterro, de Laguna e de São Francisco do Sul, muito embora, nesse momento

\footnotetext{
${ }^{475}$ Em 1680, 1704 e 1735. E seria também, em 1762 e, finalmente, em 1777, quando essa Colônia passou em definitivo para o domínio espanhol.

476 Ver p. 51
} 
inicial, essas duas últimas vilas continuassem sob a jurisdição da capitania de São Paulo. Silva Paes assumia, em verdade, a comandância (ou o governo) de três praças militares do sul: Ilha de Santa Catarina, Rio Grande de São Pedro e Colônia de Sacramento, antes que houvesse qualquer unidade política-estatal estruturada entre elas (ver tópico 1.3). Segundo Michel Senellart, "Historicamente - no plano das representações que modelaram o pensamento político - o governo precedeu o Estado. $\mathrm{O}$ ato de reger, em outros termos, foi definido, analisado e codificado antes que fosse concebível uma res publica compreendida nos limites de um território. Por isso é essencial não ligar muito intimamente a problematização da atividade governamental à existência de uma estrutura estatal". 477

Segundo um antigo manual militar francês de 1639, mas publicado em Portugal, em 1708, havia

duas sortes de governadores; a saber, os de Províncias, e os de Praças: os Governadores de Províncias são como Vice-Reis, e o seu poder é grande, pois se estende não somente sobre todas as Praças do seu governo, ou Província, mas também sobre todo o país: os Governadores de Praças são de duas sortes, fora da França; a saber, Governadores de Praças, Vilas, ou Cidades; e Governadores de Castelos, ou Cidadelas. ${ }^{478}$

A Ilha de Santa Catarina foi uma praça militar, e assim a denominavam muitas das autoridades portuguesas em meados do século XVIII. Entre as fortalezas construídas nas extremidades norte e sul da ilha, no centro dela, encontrava-se a vila de Nossa Senhora do Desterro, tudo sob o comando do Brigadeiro.

Quase que apartada dos centros de poder monárquico lusitano, com lógicas próprias de funcionamento, a Ilha passou a exercer um papel fundamental nos planos da Monarquia na consolidação dos seus domínios no Brasil Meridional, alterando a estrutura tradicional daquela comunidade, assim como também sua relação com outros espaços coloniais.

Aos antigos moradores - pequenos agricultores e pescadores -, agregava-se uma nova camada de habitantes, distinta daqueles pelas funções que exerciam e pelas posições que ocupavam. ${ }^{479}$ Desde 1737 , militares, oficiais e soldados, começaram a ser

\footnotetext{
477 Michel Senellart. As Artes de Governar: Do regime medieval ao conceito de governo. [trad. Paulo Neves] São Paulo: Ed. 34, 2006, pp. 23 e 24.

478 Antonio de Ville Tolozano. O Governador de Praças..., op. cit., pp. 12 e 13.

${ }^{479}$ Ver Fernando Henrique Cardoso. "O Negro e Desenvolvimento Econômico e Social de Florianópolis", in Fernando Henrique Cardoso e Otávio Ianni. Cor e Mobilidade Social em Florianópolis: aspectos das
} 
transferidos para a Ilha de Santa Catarina onde deveriam compor a primeira guarnição de infantaria paga. Em maio daquele ano, o governador de Santos João dos Santos Ala, por ordem real, enviou para ela 63 homens (o capitão Antonio de Oliveira Bastos, um alferes, dois sargentos, cinqüenta e dois soldados e sete artilheiros). ${ }^{480}$

Fernando Henrique Cardoso superdimensionou o impacto que teria causado a transferência dos militares para essa Ilha, nesse momento e, subdimensionou a capacidade produtiva da comunidade que nela vivia. Segundo ele "a fixação da tropa e das famílias dos oficiais acarretou um aumento da população improdutiva. A população local, reduzida e pobre, tinha escassas possibilidades de produzir o suficiente para suportar essa sobrecarga demográfica. O desequilíbrio econômico resultante só encontraria correção ou no abastecimento da população com recursos importados de outras partes da Colônia, ou pela intensificação da produção interna. Ora, nos quadros da economia colonial dificilmente haveria condições para o abastecimento contínuo e regular da tropa e da população da Ilha com recursos importados. É sabido que a produção de mantimentos, na época colonial, organizava-se nos moldes de uma economia de subsistência, visando diretamente o consumo local, de modo que o comércio de gêneros tendia a desenvolver-se apenas nas áreas que podiam garantir preços realmente compensadores àquelas utilidades, como se poderia exemplificar com o tráfico nas minas. Por sua vez, o sistema de transportes era muito deficiente". ${ }^{481}$

Como se mostrará mais a frente, não houve, nesse primeiro momento, a introdução de um contingente militar na Ilha tão numeroso a ponto de provocar uma crise de abastecimento. O regimento foi sendo montado aos poucos ao longo das três décadas seguintes. Além do mais, aquele bom-porto constituíra-se como local de abastecimento de víveres aos navegadores estrangeiros, levando seus moradores, tradicionalmente, a produzirem além do necessário para sua subsistência. Não se pode dizer também que o sistema de transporte para a Ilha de Santa Catarina era deficiente. Por terra, sim, era complicado ir até mesmo a Laguna ou a São Francisco. Porém, isso não constituiu grande obstáculo para o intercâmbio entre as diferentes vilas e povoados situados na costa litorânea. É justamente a facilidade de acesso à Ilha de Santa Catarina

relações entre negros e brancos numa comunidade do Brasil Meridional. São Paulo: Companhia Editora Nacional, 1960, p. 15.

${ }^{480}$ Documento transcrito em Manoel Joaquim d'Almeida Coelho. Memória Histórica da Província de Santa Catarina.Desterro: Typ. J.J. Lopes, 1877, p. 14.

${ }^{481}$ Fernando Henrique Cardoso. O Negro e o desenvolvimento..., op. cit., pp. 17 e 18. 
no Atlântico Sul que deu a ela esse lugar de importante base estratégica e militar naquele espaço.

Em abril de 1739, Silva Paes comunicava que se achavam na "Ilha mais de 900 pessoas" e não havia nela nem "médico, nem cirurgião, nem botica" e, por esse motivo solicitava que lhe enviasse tais especialistas. ${ }^{482}$ Alguns meses depois, dando notícia ao rei sobre a chegada de um navio estrangeiro no lugar de Itapocoróia, 18 léguas ao norte da Ilha, que andava "descarregando fazendas em terra", ele informava que se encontrava sem "forças competentes" pela pouca gente que tinha, pois não chegavam a "cento e cinqüenta pessoas, entre soldados, Pedreiros, carpinteiros, Ferreiros, Índios e escravos". ${ }^{483}$ Em outra missiva ao monarca em abril de 1741, dizia ter 140 soldados em toda a Ilha, espalhados entre as fortalezas e em vários postos, guardas e nos 3 redutos da vila de Desterro. ${ }^{484}$ Cinco anos depois, um mapa da guarnição, artilharia e mais munições de guerra, que se achavam nas fortalezas e postos da Ilha de Santa Catarina apresentava: 4 capitães, 7 alferes, 2 sargentos, 3 tambores, 175 soldados, 68 índios e negros, perfazendo um total de 259 militares. ${ }^{485}$

De acordo com Tolozano,

a obrigação de Governador de uma Praça propriamente consiste no cuidado de a conservar, e defender, e a estes dois pontos se reduz tudo o que devem saber: destes pontos nascem outros muitos, a saber, o que toca ao governo civil, que consiste em dar boa ordem entre os moradores, e no governo militar, que consiste na boa disposição, e ordem com que devem viver, e tratar os soldados para com os seus Cabos, uns com outros, e para com os paisanos: logo se seguem as instruções, ou exercícios militares, que constam de ensinar, ou fazer ensinar aos soldados o que devem fazer, e o que lhes é proibido, tanto na paz, como na ocasião de guerra, ou de sítio. ${ }^{486}$

Com efeito, observando as correspondências trocadas entre Silva Paes e o governador do Rio de Janeiro, Gomes Freire de Andrade, ou daquele com a Corte,

\footnotetext{
${ }^{482}$ Col. Doc., p. 101. Carta de José da Silva Paes ao Mestre de Campo Mathias Coelho de Souza, em 30 de abril de 1739 .

${ }^{483}$ Ibid., p. 94. De José da Silva Paes ao rei, em 16 de outubro de 1739.

${ }^{484}$ Ibid.., p. 119. De José da Silva Paes ao rei, em 5 de abril de 1741.

${ }^{485}$ ABNRJ, Vol. 50, 1928, p. 117. Em 21 de março de 1746.

${ }^{486}$ Antonio de Ville Tolozano. O Governador de praças..., op. cit, p. 13. A obra apresentava ainda uma série de outros pontos a serem observados, entre os quais: "Cap. III - Do que o Governador de uma praça deve fazer entrando nela"; "Cap. IV - Das ordens que o governador deve dar na sua praça pertencentes ao governo civil"; "Cap. V - Em que exercícios deve o Governador instruir os soldados da sua guarnição"; "Cap. VI - Da cautela de que deve usar o governador com os seus soldados, e oficiais"; "Cap. VII - Que número de soldados deve haver em uma praça"; "Cap. VIII - Das armas necessárias em uma praça"; "Cap. XI - Das munições de boca necessárias em uma praça"; "Cap. XXXIII - Como o Governador deve prevenir, e remediar os motins"; e o último, "Cap XLIX - Das capitulações, e entrega das Praças".
} 
observa-se que, entre as principais preocupações do governo da Ilha de Santa Catarina, na primeira década, estavam: a construção do seu sistema de defesa, o controle das arribadas de navios estrangeiros naquela costa, a necessidade de se formar um Regimento militar e de se povoar a Ilha e seu continente. ${ }^{487}$ Em carta ao rei, ponderava o Brigadeiro que a conservação da Ilha era conveniente também para a escala de navegação portuguesa com a Colônia, o Rio Grande e até mesmo com a Índia. ${ }^{488}$

Entre 1739 e 1743, o Brigadeiro projetou e comandou a construção das quatro principais fortalezas de Santa Catarina: três na Barra Norte e uma na Barra Sul. ${ }^{489}$ Obras monumentais feitas com o trabalho de muitos homens, entre os quais, como já se pôde ver, de índios e de escravos. Logo que ele chegou à Ilha, soube que tinham presos ali alguns levantados, havendo entre eles, onze escravos negros. Como "eram de bom corpo" e se necessitava de gente para esta obra, os mandou entregar ao "Almoxarife da Fazenda Real para por ela serem assistidos e trabalharem nas fortificações". 490

Quando, em agosto de 1743, Silva Paes saiu em diligência para a Colônia do Sacramento deixou uma instrução de governo ao seu substituto na Ilha, o Capitão Patrício Manoel de Figueiredo, recomendando-lhe, primeiramente, que, caso entrasse naquele porto embarcações que não fossem da Coroa e vassalos de Sua Majestade devia então tomar todas as providências necessárias para esses casos; em se tratando de inimigos ou piratas, "além de os bater das Fortalezas", devia puxar para dentro delas "alguns paisanos ou índio da terra" e ainda mandar vir de São Francisco e de Laguna outros paisanos para aumentar sua guarnição naquela Ilha. As demais instruções dirigiam-se basicamente para a execução das obras que ainda estavam por fazer nas ditas fortalezas. ${ }^{491}$

O intercâmbio direto que antes os moradores da Ilha mantinham com os navegadores estrangeiros, ou mesmo luso-brasileiros, negociando os gêneros da terra por fazendas européias e outros produtos de que careciam interrompeu-se, ou pelo menos tornou-se proibido, com a instituição dos governadores. É certo que esses, agora, estavam em posição privilegiada para tirar vantagens pessoais naqueles negócios e,

\footnotetext{
${ }^{487}$ Ver AHU-SC, cx. 1; Col. Doc., pp. 94-145; e DH, vol. XCIV pp. 79-87, 101-163.

${ }^{488}$ DH, Vol. XCIV, 1951, p. 84. Consulta do Conselho Ultramarino de 9.04.1742.

${ }^{489}$ Esses projetos foram examinados e aprovados pelo engenheiro-mor do reino, Manoel de Azevedo Fortes, Col. Doc., p. 123. De Manoel de Azevedo Fortes ao rei, em 15 de dezembro de 1741.

${ }^{490}$ Col. Doc., p. 133. De José da Silva Paes à Gomes Freire, em 30 de abril de 1739.

${ }^{491}$ Col. Doc., pp. 144-45. De José da Silva Paes a Patrício Manoel de Figueiredo, em 28 de agosto de 1743. Silva Paes reassumiu o governo da Ilha, em 20 de março de 1746.
} 
segundo o navegador George Anson, assim procedia o Brigadeiro Silva Paes. ${ }^{492}$ Seja como for, essa reconfiguração política vinha fortalecer o poder do Estado Monárquico Português naquele território.

Segundo informação passada por Gomes Freire de Andrade, a idéia de Silva Paes de como deveria ser organizado o sistema de defesa no Sul era:

haver nas ditas fortalezas do Rio Grande 700 homens e inclusos neste número os de que se formam as 6 companhias de dragões e estão naquele estabelecimento (...), cuja importância faz soma de 67:839\$520 rs.; e a guarnição da Ilha de Santa Catarina achamos ser precisa de 150 homens, na forma que o seu cálculo mostra e soma 8:928\$160 rs.; e a Colônia sendo a sua guarnição de um batalhão de Infantaria e 2 companhias de dragões, que atualmente tem, com as mais despesas incluídas no seu cálculo, importa $44: 938 \$ 892$ rs., e as três parcelas $120: 938 \$ 872$ [sic por $121: 706 \$ 572]^{493}$

Uma proposta de distribuição dos investimentos militares que deixa evidente o peso diferenciado que tinham esses distintos espaços coloniais para Portugal ou, vendo por outro ângulo, do aparato militar necessário para a defesa de cada uma daquelas praças. Não se deve esquecer, elas têm de ser compreendidas como parte de um mesmo sistema de defesa e ocupação dos territórios, cada qual desempenhando a sua função específica. Quanto mais ao sul maior o grau de tensão e risco de guerra viva com os espanhóis. No entanto, a comprovada instabilidade da Colônia, sobretudo após o Grande Sítio (1735-37) imposto pelos espanhóis, colocava o Rio Grande como a nova alternativa para o comércio de couros e trigo que se fazia pelo rio da Prata e que vinham do interior do continente. De acordo com Jaime Cortesão, “A três grandes chefes, a ele, Gomes Freire, a José da Silva Paes e a André Ribeiro Coutinho, se devem os sólidos alicerces do Rio de São Pedro. (...) Todos eles compreenderam também que a ilha de Santa Catarina fazia parte integrante do sistema defensivo daquele novo Domínio, que se estendia na direção do Rio da Prata."494

A Ilha encontrava-se fora do palco principal dos confrontos e, por isso, era o porto mais seguro, sede do governo de Silva Paes e, pode-se dizer, limite dos domínios políticos e institucionais mais consolidados e estáveis do Império Português no Sul da

\footnotetext{
${ }^{492}$ Ver p. 120.

493 ABNRJ, vol. 46, 1934, p. 361. "Informação do Governador Gomes Freire de Andrade... em 8 de julho de 1739".

494 Jaime Cortesão. Alexandre de Gusmão e o Tratado de Madrid. Rio de Janeiro: Ministério das Relações Exteriores; Instituto Rio Branco, c. 1950, (Parte II), p. 245. André Ribeiro Coutinho foi o substituto de Silva Paes na comandância do Rio Grande entre 1737 e 1740.
} 
América Meridional. A invasão dela pelos espanhóis em 1777-1778 foi uma exceção que confirma a regra de quase 150 anos de conflitos militares não contínuos no sul. Quando o Rio Grande foi reconquistado, em 1776, e se consolidou como fronteira política e econômica, no final do século (a elevação desse governo em capitania geral, em 1807, foi o coroamento desse processo), a Ilha deixou de desempenhar aquela função.

Mas todo o investimento material e humano de que se necessitava para povoar e defender aqueles territórios tardaria a chegar. Em carta de 23 de agosto de 1742, o Brigadeiro escrevia ao rei dizendo que "todas essas prevenções e obras sem gente que as guarneça eram corpos sem alma" e já apontava para uma alternativa de povoamento que ganharia força na Corte até ser efetivamente implementada em 1748: a transmigração dos casais açorianos e madeirenses. Defendia ele que, se dessas ilhas

se pudessem remeter alguns casais seria utilíssimo, e ainda alguns recrutas porque assim se aumentaria a cultura daquelas terras que eram próprias não só para todos os frutos da América, senão também da Europa, e que dos filhos dos mesmos casais se recrutaria o terço ou tropas que ali assistirem, e que seriam mais permanentes do que os de fora. ${ }^{495}$

Gomes Freire entendia ser também essa a melhor solução, pois, segundo ele, sua capitania estava impossibilitada de poder suprir "a formatura das guarnições do Rio Grande e ilha de Santa Catarina", tendo em vista o reduzido número de soldados que dispunha em seu Regimento, que era de quatrocentos homens. ${ }^{496}$ Em outra missiva concordava que "nem as fortalezas se podiam aumentar com vantagem nem a ilha cultivar, e pôr em abundância sem povoadores”. Mas que, habitantes do Brasil,

só com ordem de Vossa Majestade e obrigados por ela se transportarem famílias àquela ilha, sendo impossível, por discurso fazê-los entrar em mudança para fora do continente, (...) que só havendo povoadores sem ciência da licenciosa vida do Brasil poderão ser úteis e conservarem-se (....). ${ }^{497}$

Apesar dos reiterados pedidos de Silva Paes e de Gomes Freire e das consultas favoráveis emitidas pelo Conselho Ultramarino para se povoar o sul do Brasil com os ilhéus, D. João V protelou a aprovação desse projeto a agosto de 1746. Segundo Jaime

\footnotetext{
${ }^{495}$ DH, vol. XCIV, 1951, p. 107.

${ }^{496}$ DH, vol. XCIV, 1951, p. 85. De Gomes Freire de Andrade ao rei D. João V, em 29 de maio de 1741.

${ }^{497} \mathrm{DH}$, vol. XCIV, 1951, p. 115. De Gomes Freire de Andrade ao rei D. João V, em 20 de maio de 1744.
} 
Cortesão, a morte do rei da Espanha, Filipe V, um mês antes e a subida ao trono de Fernando VI e Bárbara de Bragança teria aberto o caminho para se negociar o tratado de limites entre as duas nações. "Enviar os colonos antes poderia melindrar as difíceis negociações do Tratado com Filipe V., ${ }^{498}$

Até a chegada da primeira leva de casais, no princípio de 1748, e sem ainda um Regimento militar compatível com as fortalezas que havia construído, Silva Paes tinha de administrar a Ilha segundo as condições disponíveis. Em agosto 1747, informava ao rei que havia colocado parte dos ordenanças

para guarnecer medianamente [as fortalezas], pela falta com que se acham de soldados pagos (...), [e] que seria justo mandar-lhes dar o soldo (...) dos dias que assistiram com as suas armas e fardamentos, pois todos o fizeram a sua custa, (...) e deixaram esses pobres de trabalhar nas suas roças. ${ }^{499}$

Problema esse recorrente na governança daquela Ilha por todo o período que aqui se estuda. Outra questão que preocupava o Brigadeiro era a falta de sacerdotes nas fortalezas,

pois estavam aquelas guarnições vivendo como gentios, sem em todo o ano ouvirem uma missa mais que pela desobriga e no perigo de poderem em algum incidente morrer sem confissão nem sacramentos por estarem aqueles presídios distantes da vila algumas seis léguas. ${ }^{500}$

Embora a gestão de Silva Paes tenha se caracterizado mais por questões de ordem política e militar, não quer dizer que ele não tenha se preocupado com os problemas econômicos. Muito pelo contrário, a função principal de todo aquele sistema defensivo era justamente dar suporte e proteção ao perfeito funcionamento dos empreendimentos mercantis que se faziam naqueles territórios como, a doação de sesmarias nos campos de Viamão às famílias lagunenses, o transporte do gado pelo caminho das tropas desses campos até o sertão mineiro, o comércio de couros e trigo via rio da Prata e Rio Grande, o abastecimento das tropas e, não menos importante, a pesca das baleias na Ilha de Santa Catarina. O próprio Silva Paes foi quem deu despacho favorável no requerimento do pleiteante Tomé Gomes Moreira, comerciante português,

\footnotetext{
${ }^{498}$ Jaime Cortesão. Alexandre de Gusmão..., (parte II), op. cit., p. 245.

${ }^{499}$ AHU-SC, cx. 1, doc. 38. De José da Silva Paes ao rei D. João V, em 20 de agosto de 1747.

${ }^{500} \mathrm{DH}$, Vol. XCIV, 1951, p. 144. Consulta do Conselho Ultramarino, em 10 de julho de 1748.
} 
para arrematação do contrato dessa pescaria, em 16 de setembro de $1738 .{ }^{501}$ Como se mostrará, a Armação montada por esse arrematante na entrada da Barra Norte da Ilha de Santa Catarina estava ativa, desde 1743. Mas, os governadores pouco se ocupavam com esse negócio, pois o direito à sua exploração era concedido pela Coroa Portuguesa diretamente a particulares por meio de um contrato, cabendo a esses a montagem da fábrica e sua administração.

Ao lado dessa atividade econômica, a Ilha já se constituíra como abastecedora de alimentos aos viajantes estrangeiros e ao comércio de cabotagem na costa brasileira, fornecendo feijão, frutos, fumo, aguardente, peixe seco e, sobretudo, farinha de mandioca. Mas uma participação mais expressiva dessas produções, no mercado colonial, só seria levada a efeito com a chegada dos imigrantes açorianos.

\subsection{O Governo das gentes: economia e sociedade}

No dia 6 de janeiro de 1748, depois de quase três meses de viagem, entravam no porto da Ilha de Santa Catarina duas galeras vindas da Ilha Terceira, trazendo o primeiro carregamento com 85 casais açorianos ${ }^{502}$, dos 4.000 que haviam sido autorizados pela Coroa para serem transportados (esclareça-se: um casal podia compreender o marido, a mulher, os filhos e muitas vezes alguns parentes próximos ou agregados). Quem os recebeu foi o governador José da Silva Paes, e a ele competia dar destino certo àqueles colonos provendo-lhes de alojamentos, rações alimentares, sementes, ajuda de custo, animais, utensílios, ferramentas, terras, bem como estabelecer a forma de organização das povoações, traçado urbano, localização das suas igrejas, a estruturação das Companhias de Ordenanças e as medidas fiscais a serem empregadas, tudo conforme ordenava a Provisão Régia de 9 de agosto de $1747 .{ }^{503}$ Da mesma forma deveriam proceder os governadores subseqüentes à medida que ingressavam as novas levas de

\footnotetext{
${ }^{501}$ Cf. Walter Piazza. Santa Catarina: sua História. Florianópolis: Ed. UFSC; Lunardelli, 1983, p. 196.

${ }^{502}$ Walter Piazza. Santa Catarina..., op. cit., 1983, p. 144; e do mesmo autor A Epopéia AçóricoMadeirense, 1748-1756. Florianópolis: Ed. UFSC; Lunardelli, 1992, p. 368.

${ }^{503}$ Walter Piazza. Santa Catarina..., op. cit., p. 142.
} 
imigrantes. Entre 1748 e 1756, segundo Walter Piazza, 6.000 ${ }^{504}$ colonos (5.941 açorianos e 59 madeirenses) entraram na Ilha de Santa Catarina.

Todavia, os resultados dessa colonização não saíram exatamente como o planejado. Nas palavras do governador Miranda Ribeiro:

\begin{abstract}
A Real Ordem de 9.08 .1747 (...) não foi com toda a sua extensão executada: tanto a respeito da mesma distribuição das terras aos novos Colonos, como daqueles socorros, com que Vossa Majestade tão providentemente os mandava fornecer, quais eram, as ferramentas necessárias, as Vacas e as Éguas para o seu Laboratório fabril, de cujos gêneros, a alguns se completaram as ferramentas, a outros parte delas, aliás havendo-as; e a nenhuns os Animais Cavalares e Vacuns, sem que a mim me seja possível presentemente averiguar, qual fosse a Causa de uma tão considerável falta, que incontestavelmente foi uma das Causas porque ainda hoje se fazem pouco sensíveis os seus desejados progressos. ${ }^{505}$
\end{abstract}

Nem os governadores dispunham de todos os recursos materiais, humanos e financeiros para fazer cumprir as promessas do Edital de convocação e da Provisão citada, nem os casais se submeteram a todas as determinações que lhes foram dirigidas.

A primeira delas mandava que fossem assentados "na mesma Ilha como na terra firme adjacente desde o Rio de São Francisco do Sul até o Serro de São Miguel, e no sertão correspondente a este distrito", 506 mas sempre sem provocar queixa dos espanhóis. Não se tratava agora de fundar novas praças fortes, nem permitir a ocupação desordenada de bandos erradios, mas de espalhar por um vasto território - do ponto de vista do conquistador "vazio" -, uma série de núcleos de colonos estrategicamente colocados, com mais ou menos 60 casais cada um. Na prática não foi bem isso que aconteceu. Tirando aqueles casais que foram para Laguna e Rio Grande, a grande maioria adensou-se na Ilha de Santa Catarina e seu continente próximo. Os que deveriam ser conduzidos para as missões jesuíticas acabaram povoando a região de Viamão, em decorrência da Guerra Guaranítica (1753-1756) e da própria indefinição posterior sobre a soberania daqueles territórios.

\footnotetext{
${ }^{504}$ Walter Piazza. A Epopéia Açórico-Madeirense (1748-1756). Florianópolis: Lunardelli; Ed. UFSC, 1992, pp. 345-55. Segundo esse autor, 520 madeirenses que vinham para a Ilha de Santa Catarina naufragaram no litoral da Bahia, em 1756.

${ }^{505}$ AHU-SC, cx. 6, doc. 386, fl. 05. De João Alberto de Miranda Ribeiro à rainha D. Maria I, em 16.11.1797.

${ }^{506}$ Provisão Régia de 9 de agosto de 1747, transcrita em Walter Piazza. A Epopéia Açórico-Madeirense..., op. cit., pp. 120-25; e em Gen. João Borges Fortes. Os Casais Açorianos..., op. cit., pp. 28-32. Serro de São Miguel situa-se, hoje no litoral norte da República do Uruguai.
} 
Determinava também a Provisão que no contorno de cada povoado estabelecido, nas terras que ainda não estivessem dadas de sesmarias, se assinalaria "um quarto de légua em quadro a cada um dos cabeças de casal". O que se verificou em Santa Catarina foram propriedades com dimensões bem inferiores a essas, como se pode constatar no livro de registro das datas de terras concedidas aos casais no período de 1753 a $1806 .{ }^{507}$ Das 138 concessões lançadas ali, apenas 15 (10,8\%) possuíam um quarto de légua em quadro, ou 750 braças quadradas; outras 15 com dimensões superiores a essa medida; uma sem registro das dimensões; e as 107 (77,5\%) restantes com dimensões inferiores a ela. Fazendo uma média aritmética do tamanho das propriedades desse último grupo chega-se a uma área de 230, 17 braças quadradas.

A explicação que José da Silva Paes deu ao rei, em carta de 24 de fevereiro de 1748, parece plausível.

\begin{abstract}
A maior parte destes que vieram se contentam com muito menos, por quererem ficar mais perto uns dos outros, o que não conseguiriam se o tivessem de o tomar cada um o que V. Majestade lhe manda dar, havendo tal que se contenta com duzentas braças de terra e ainda menos, por ficarem juntos dos Patrões que lhes dei de quem senão querem separar, e por dizerem que com aquela porção de terra tem as que lhe bastam para poderem lavrar (...) [e] se houver de dar-se-lhe o $4^{\circ}$ de Légua ficarão mui dispersos e distantes uns dos outros o que eles repugnam, e da Missa que é o que não querem perder. $^{508}$
\end{abstract}

Com efeito, a vila de Nossa Senhora do Desterro proporcionou, ainda que de forma precária, uma acolhida material e espiritual aos imigrantes. Chegados ali, depois da longa e penosa travessia do mar-oceano, era compreensível que resistissem a uma nova transferência para locais incertos, isolados, e onde estava tudo por fazer. Se a falta de estrutura e recursos para acomodá-los em Desterro era uma realidade, mais difícil seria ainda para os novos estabelecimentos. Como explicava o governador Manoel Escudeiro,

Os casais se vão acomodando como pode ser, e não em a formalidade que quisera, por conta de virem tantos a um mesmo tempo e não haver quem os

\footnotetext{
507 "Livro que há de servir na Ilha de Sta. Catarina, para nele se lançarem as datas de terras que Sua Majestade manda dar aos casais que passam das Ilhas dos Açores...", transcrito em forma de quadro com as informações de ano, mês, dia, $\mathrm{n}^{\circ}$. de braças, nomes dos concessionários e lugar por Walter Piazza. $A$ Epopéia Açórico-Madeirense..., op. cit., pp. 385-391.

${ }^{508}$ Transcrito em Walter Piazza. A Epopéia Açórico-Madeirense..., op. cit., p. 381. Grifo meu.
} 
possa e saiba arrumar: pois não tenho oficiais nem engenheiro mais que um Capitão, que quase sempre está enfermo e para nada tem servido (...). ${ }^{509}$

Em fevereiro de 1751, o mesmo governador mandou fundar uma nova povoação quatro léguas ao sul de Laguna, no lugar chamado de Magalhães, com o fim de que servisse de disposição para outras povoações que facilitassem a comunicação com o Rio Grande. Porém, quando contava já certo de se haver executado aquela diligência, recebeu a notícia do capitão a quem havia encarregado a tarefa de que

os novos Povoadores não quiseram trabalhar na sua acomodação, voltandose unânimes para a Laguna, com o descontento de não acharem logo Barro para barrearem os Ranchos, ou casas para viverem; dizendo: que queriam situar-se ou no Rocio da própria Vila, ou nos Campos de Una, e do Xavier, que ficam para o seu Norte. ${ }^{510}$

Outros problemas ocorreram com o fornecimento das éguas, vacas e provisões prometidas aos colonos no Edital. Havia uma determinação régia para que o governador do Rio Grande, que na época era Diogo Osório Cardoso, despachasse para a Ilha de Santa Catarina aqueles animais, assim como tudo o mais que fosse preciso para o abastecimento dos casais, o que não foi realizado. Em 9 de janeiro de 1750, Manoel Escudeiro deu conta disso ao Conselho Ultramarino, que logo tratou de repreender a atitude daquele governador.

Se deve ordenar ao coronel Diogo Osório que prontamente cumpra as respectivas ordens que há a este respeito, dando todo o socorro e ajuda que lhe pedir o governador da dita ilha e estranhando-se-lhe com a maior severidade a falta que tem tido na sua obrigação com tanto prejuízo da Fazenda Real e daquele estabelecimento, e como este oficial não tem o governo mais que interinamente e enquanto se não nomeia governador, parece que logo se devia propor a Vossa Majestade pessoa que fosse governar o Rio Grande, e por este modo se pode socorrer a esta desordem sem alterar os limites das demarcações dos governos. ${ }^{511}$

Entre os planos traçados pela Coroa e os desdobramentos históricos daquelas colônias haveria, por certo, inevitáveis distanciamentos. A suposta subordinação do

\footnotetext{
${ }^{509}$ ABNRJ, vol. 50, 1928, p. 106. Carta do governador Manoel Escudeiro Ferreira de Souza (destinatário não identificado), em 20.02.1750.

${ }^{510}$ AHU-SC, cx. 1, doc. 72. Carta do governador Manoel Escudeiro Ferreira de Souza ao rei D. José I, em 24.04.1751.

${ }^{511} \mathrm{DH}$, vol. XCIV, 1951, p. 156. Consulta do Conselho Ultramarino de 26.10.1750.
} 
comandante do Rio Grande ao governador da Ilha de Santa Catarina entre 1738 e 1760 parece não ter se confirmado na prática. ${ }^{512}$ Esses dois estabelecimentos constituíram-se, cada vez mais, como unidades políticas distintas e relativamente autônomas. Certas arbitrariedades, no entanto, podiam ser, e eram mesmo, corrigidas pelo poder régio, mediante advertências ou, nos casos mais graves, pela própria substituição dos governadores.

3.2.1 "Casais das ilhas", "filhos da terra" e outras almas

Sem a pretensão de apresentar novos quadros conclusivos sobre a demografia da capitania, no século XVIII - isso ultrapassaria os limites e objetivos desta tese -, buscase neste tópico, entretanto, obter uma noção razoável, com base da historiografia sobre o tema e dos documentos aqui consultados, dos números e da condição social da população que estava sob o governo da Ilha de Santa Catarina.

Não se pode aferir com precisão e segurança a população do Brasil na primeira metade do século XVIII. O que se tem são meras estimativas - às vezes grosseiras feitas por militares portugueses ou viajantes estrangeiros. Mas até mesmo depois, quando as autoridades promovem os primeiros levantamentos populacionais, os dados oferecidos são sempre imprecisos e pouco confiáveis. ${ }^{513}$ Questão essa, ainda em 1816, identificada como um problema de governo pelo memorialista e ex-Ajudante de Ordens da capitania de Santa Catarina, Paulo José Miguel de Brito:

nem a Capitania de Santa Catarina, nem outras muitas do Brasil, fornecem os precisos elementos para se tratar esta matéria com a exatidão e miudeza, que ela merece. Se os cálculos da população são sempre incertos, em razão das dificuldades que há em a avaliar com precisão, se isto mesmo acontece entre as nações mais ilustradas da Europa (...) Com muito maior razão se encontrarão inexatidões na avaliação da população de uma Capitania do Brasil, onde este ramo de Estatística (bem como outros) está ainda tão atrasado. Uma prova desta verdade se encontra nos ridículos mapas de população, que de algumas Capitanias se remetem anualmente ao Ministério. ${ }^{514}$

\footnotetext{
${ }^{512}$ Ver p. 75.

${ }^{513}$ Fabio Kühn apresenta e analisa alguns quadros populacionais das vilas sulinas, no século XVIII, em sua tese de doutorado. Gente da Fronteira: família, sociedade e Poder no Sul da América Portuguesaséculo XVIII. Niterói-RJ: UFF, PPG-História, 2006, pp. 54, 64, 111 e 130.

${ }^{514}$ Paulo José Miguel de Brito. Memória Política sobre a Capitania de Santa Catharina. Lisboa, 1829 [1816], p. 48.
} 
Não obstante todas essas dificuldades, no confronto das fontes disponíveis, é possível trabalhar com algumas aproximações. Nos primeiros mapas populacionais do governo da Ilha, especificamente os de 1753 e 1756 apresentados por José de Melo Manoel, constava a distinção entre os imigrantes açorianos e madeirenses, classificados como casais e filhos das ilhas, e os antigos moradores, classificados como casais da terra (ou naturais) e filhos da terra. Mostrou-se antes que, no meio desses, encontravam-se pessoas de origens e condições sociais diversas. Em 1712, o engenheiro e militar francês Frézier observara que a Ilha de Santa Catarina era ocupada por "portugueses, uma parte de europeus fugitivos e alguns negros; vê-se também índios, alguns servindo voluntariamente (...), outros que são aprisionados em guerra". 515

Com a criação do governo na Ilha, militares começaram aos poucos a ser transferidos para ela, formando uma nova categoria social de status superior aos demais grupos ali estabelecidos. Em termos numéricos, todavia, a população da Ilha e dos demais povoados do sul permaneceu inexpressiva até a introdução dos casais das ilhas.

Os autores que se debruçaram sobre a questão não são concordes quanto ao número de açorianos e madeirenses que desembarcaram na Ilha de Santa Catarina, em meados do século XVIII, o que é perfeitamente justificável, pois, no confronto das esparsas fontes existentes, a contabilidade dos indivíduos alistados naquelas ilhas, embarcados efetivamente, mortos na travessia do Atlântico, desembarcados na América e, ainda, mortos logo após terem chegado não fecha. Listas que incluíam os "inocentes" (crianças abaixo de 7 anos), outras que não, além dos erros nem sempre involuntários que todos esses inventários podiam trazer, impossibilitam um conhecimento preciso do número dos indivíduos que chegaram. O melhor levantamento a esse respeito parece ser ainda o de Walter Piazza. A partir de pesquisas feitas em diversos arquivos, sobretudo em Portugal e nas ilhas Atlânticas, ele chegou a cifra de 6.000 pessoas, a maior de todas até então apontada. ${ }^{516}$ Não menos difícil é saber quantos dos que chegaram na Ilha foram destinados a outros lugares como Laguna, Rio Grande e Viamão.

O quadro que segue abaixo - diga-se, de um documento não mencionado por Walter Piazza na obra citada - sugere, no entanto, que o número de imigrantes pode ter sido ainda superior aos 6.000 considerado por esse historiador, já que pelo menos outro carregamento teria sido feito nos quatro anos seguintes. Trata-se de uma Relação

\footnotetext{
${ }^{515}$ Frézier, Relation du Voyage..., op. cit., p. 23.

${ }^{516}$ Um quadro comparativo com as estimativas apresentadas por diversos autores encontra-se em Walter Piazza. A Epopéia Açórico-Madeirense..., op. cit., p. 354.
} 
enviada pelo governador Manoel Escudeiro ao vice-rei, em 26 de agosto de 1752, que se transcreve da forma como foi apresentada.

Quadro n. 3.1

Relação de todos os casais e pessoas que têm vindo das Ilhas dos Açores e Madeira para esta de S. Catarina do ano de 1748 até $1752^{517}$

\begin{tabular}{|c|c|c|c|}
\hline & casais & pessoas maiores & menores \\
\hline Ano de 1748 & 85 & 451 & 43 \\
\hline 1749 & 98 & 509 & 81 \\
\hline 1750 & 326 & 1.555 & 204 \\
\hline 1751 & 279 & 1.312 & 198 \\
\hline 1752 & 269 & 1.377 & 151 \\
\hline \multirow[t]{2}{*}{$\begin{array}{l}\text { Casais da Madeira vindos pelo Rio de } \\
\text { Janeiro em } 1749\end{array}$} & 21 & 99 & 10 \\
\hline & 1.078 & 5.303 (a) & 687 (b) \\
\hline $\begin{array}{l}\text { Casais que foram desta Ilha para a Vila de } \\
\text { Laguna }\end{array}$ & 80 & 395 (c) & \\
\hline $\begin{array}{l}\text { Casais que foram desta Ilha para o Rio } \\
\text { Grande até o último de julho de } 1752\end{array}$ & 278 & 798 (d) & \\
\hline $\begin{array}{l}\text { Casais que se acham nesta Ilha e Povoações } \\
\text { do seu continente }\end{array}$ & 720 & 4.442 (e) & \\
\hline $\begin{array}{l}\text { Pessoas que têm falecido nas viagens e em } \\
\text { terra até o último de junho de } 1752\end{array}$ & & 355 (f) & \\
\hline Somam todas & & $5.990(\mathrm{~g})$ & \\
\hline
\end{tabular}

Até julho de 1752, portanto, 5.990 pessoas entre adultos e crianças $(\mathrm{g}=\mathrm{a}+\mathrm{b})$ teriam chegado à Ilha de Santa Catarina. Segundo Piazza, em fevereiro e março de 1754 desembarcaram nesse porto outros 1.187 imigrantes, o que elevaria o número total a mais de 7.000 .

Assim também com relação específica ao número dos madeirenses imigrados. A confiarmos no quadro de Manoel Escudeiro, no ano de 1749 teriam entrado 109 e não os 59 que aquele historiador registrou para todo o período de 1748 a 1756.

O número de 4.442 dos "Casais que se acham nesta Ilha e Povoações do seu continente" ( $\mathrm{e}=\mathrm{g}-\mathrm{c}-\mathrm{d}-\mathrm{f})$ ganha credibilidade se compararmos com os 4.223 que o

${ }^{517}$ ANRJ, Cód. 106, vol. 2, fl. 14. 
governador José de Melo Manoel registrou em seu Mapa, um ano depois, dos casais das ilhas e filhos existentes nas freguesias de Desterro, Lagoa da Conceição, São José, Enseada de Brito e São Miguel. ${ }^{518}$ Mas, como já se disse, é preciso tomar cuidado com esses números. Ao analisarmos os relatórios apresentados por outros governadores, encontraremos resultados distintos. José da Silva Paes, por exemplo, registrou que, no ano de 1748 , chegaram ao todo àquele porto 461 pessoas $^{519}$ e não as 494 apontadas por Manoel Escudeiro.

Fato que parece consensual entre os historiadores é o impacto demográfico que a imigração açoriana significou para as vilas e povoados no sul do Brasil, em meados do século XVIII, trazendo profundas alterações na organização política, econômica e sociocultural dessas regiões. Segundo Fábio Kühn, verifica-se um acréscimo considerável na curva populacional da vila de Laguna a partir de 1750 e, na freguesia de Viamão, o número de batizados entre 1752 e 1754 triplicou em decorrência dessa imigração. ${ }^{520}$ Notável foi também o crescimento demográfico da vila de Rio Grande nesse mesmo período, como assinalou Maria Luiza Bertuline Queiroz. ${ }^{521}$

Grupo populacional que cresceria nas vilas e povoados do sul, no decorrer da segunda metade do século XVIII, sobretudo após a invasão espanhola do Rio Grande, em 1763, foi o dos militares.

As forças militares do governo da Ilha de Santa Catarina - obedecendo à organização dos exércitos do Império Português na Época Moderna de uma maneira geral - estruturavam-se em três grupos: a tropa regular de primeira linha (ou primeira Plana), formada por oficiais e soldados pagos; a tropa auxiliar de milicianos, chamada também de Terço (em função da forma como era organizada) ou de Legião de Auxiliares, não remunerada, que tinha a função de prestar apoio às tropas regulares na defesa das conquistas. Essa tropa de segunda linha era formada por homens recrutados entre a população civil e alistados em categorias: brancos, pardos e pretos; e as Companhias de Ordenanças (tropas de terceira linha), composta também pela população local, não recebiam pagamento pelo desempenho da função, mas, distintamente do

\footnotetext{
${ }^{518}$ AHU-SC, cx. 2, doc. 92. "Mapa das Freguesias que tem a Ilha de Santa Catarina, e seu Continente com distinção de uns e outros casais e Companhias de Ordenanças, e número de Almas que contém, ano de 1753". (Ver Anexo 3)

${ }^{519}$ Walter Piazza. Santa Catarina..., op. cit., p. 144. Pode-se inferir também pelas informações dadas por Manoel Escudeiro que cada casal representava em média 5,5 pessoas.

${ }^{520}$ Fábio Kühn. Gente da Fronteira..., op. cit., pp. 64 e 108.

${ }^{521}$ Maria Luiza Bertuline Queiroz. A vila do Rio Grande de São Pedro (1737-1822). Rio Grande: FURG, 1987, p. 91.
} 
corpo auxiliar, em princípio, não podiam ser deslocados da sua base territorial. ${ }^{522}$ Havia ainda distinções quanto ao uso da farda, dos tipos de armamentos utilizados e, sobretudo, do regime disciplinar que competia a cada um desses corpos militares. Àqueles que exerciam atividades de ordenanças exigia-se menos exercícios que os demais, contudo, como se verá adiante, em Santa Catarina, assim como também no Rio Grande, eles foram mais exigidos a esse respeito do que em outras parte do Brasil, em função da belicosa condição desses territórios.

Nas gestões de governo de Manoel Escudeiro (1749-53) e de José de Melo Manoel (1753-62) a falta de um Regimento militar de primeira linha, que completasse as fortalezas continuou sendo um problema. Em 1752, o rei Dom José I mandou criar na ilha da Madeira um Batalhão de 6 companhias de infantaria, de 60 homens cada uma, para servirem em Santa Catarina, todavia, pelo menos até junho de 1757, essas tropas não haviam chegado. Em 30 de novembro de 1753, Melo Manoel encaminhou uma extensa carta ao rei relatando que no seu governo se achavam

alistados 18 companhias de ordenança com mil e trezentos paisanos, todos armados de espingardas, e destinados aos lugares a que hão de acudir em casos de necessidade. (...) [e] que para a guarnição destas quatro fortalezas e de vários guardas que se põem desde a passagem da Laguna à de Tramandaí, além do corpo de infantaria que é necessário assistir na vila de Nossa Senhora do Desterro, em cujo presídio é a residência dos governadores, se não acham até ao presente naquela ilha mais que cento e trinta e oito soldados dos destacados da praça do Rio de Janeiro, e alguns oficiais pertencentes ao mesmo corpo. ${ }^{523}$

Num documento anexo com os ordenados e soldos que aquela provedoria teria de gastar em um ano, informava o governador os postos militares ainda vagos, a espera daquela nova companhia criada, e os que se encontravam já ocupados. Entre esses últimos, contabilizava as "Férias de Índios Recrutas" que estavam no serviço dessa Praça e Presídio no valor de 1:487\$600 ao ano. ${ }^{524}$ Em outra missiva de 14 de junho de 1757, dessa vez ao secretário de Estado, a situação militar da Ilha continuava na mesma. Dizia que se achava, naquele momento,

\footnotetext{
${ }^{522}$ Ver Graça Salgado (Coord.). Fiscais e Meirinhos..., op. cit., pp. 97 e 98; e Caio Prado Jr. Formação do Brasil Contemporâneo..., op. cit., pp. 310-313.

${ }_{523}$ BNRJ, $D H$, Vol. XCIV, 1951. Consultas do Conselho Ultramarino (1726-1756), p. 258. Grifo meu.

${ }^{524}$ AHU-SC, cx. 2, doc. 92. "Resumo da Despesa que se faz nesta Provedoria e Presídio da Ilha de Santa Catarina em tempo de um ano". Em 30 de novembro de 1753.
} 
com 130 soldados somente destacados da Praça do Rio de Janeiro que são a escória daqueles Regimentos, em préstimo e procedimento e muitos deles velhos e incapazes de todo o serviço, havendo aqui quatro fortalezas que guarnecer. ${ }^{525}$

Antes de entrar no governo da Ilha de Santa Catarina, em 12 de maio de 1765, Francisco de Sousa de Meneses recebeu um longo documento dando notícias sobre a extensão da colônia que ia governar, suas freguesias, qualidade dos portos, número e predicados dos eclesiásticos e dos oficiais civis e militares. Desses últimos, o informante dizia que

Não têm mais Tropas aquele Governo que seis Companhias de Infantaria, que suposto fossem criadas com (...) 60 homens cada uma, ainda não puderam chegar, depois que se formaram, ao número de 40, por não haver aonde se faça esta redução, nem até agora se ter dado a ela providência alguma, nem se poder tirar soldados dos Moradores da Ilha, e Terra firme, estando os Ilhéus dispensados desse ônus, pelo Alvará de criação do dito Governo, em que S. Majestade os isenta dele; e dos Paisanos, que não tem este Privilégio, menos se poder fazer esta recondução, por serem poucas as Famílias. ${ }^{526}$

De fato, segundo o Edital de alistamento dos casais "os homens que passarem por conta de Sua Majestade, ficaram isentos de servir nas tropas pagas no caso de se estabelecerem no termo de dois anos nos sítios que se lhes destinarem". ${ }^{527}$ Todavia, foi com esses, ou melhor, com os filhos desses que o governador completaria o seu Regimento, possivelmente com a orientação - ou, pelo menos, com a aprovação - da Corte, pois, não se tem notícia de que ele tenha sido advertido por isso. Talvez, observando melhor a letra da lei, e seguindo uma política já orientada pelo Brigadeiro José da Silva Paes, em 1748, convocava-se então sem problemas os "filhos dos mesmos casais". ${ }^{528}$ De qualquer maneira, essa medida foi vista posteriormente como uma das causas da "decadência" ou do "atraso" da capitania. Segundo João Alberto de Miranda Ribeiro, Sousa de Meneses recrutou "mais de quinhentos homens filhos dos Lavradores" para completar a guarnição daquele governo. Um expediente que, na sua avaliação,

\footnotetext{
${ }_{525}$ ANRJ, Cód. 106, vol. 2, fl. 43. De José de Melo Manoel a Tomé Joaquim da Costa Corte Real.

${ }^{526}$ AHU-SC, cx. 3, doc. 205. "Extrato da Ilha de Santa Catharina, seu Continente, e mais partes dependentes daquele Governo, cuja notícia se dá ao Sr. Governador Francisco de Sousa de Meneses." Sem data e sem remetente.

${ }_{527}$ Transcrito em Walter Piazza. A Epopéia açórico-madeirense..., op. cit., p. 88.

${ }^{528}$ Ver p. 169.
} 
à primeira vista, não deixa de parecer um bom Militar, por ver o Regimento Completo de bons Recrutas, contudo, ele foi um mal político, e de gravíssimas conseqüências, porque tantos foram os Recrutados, quantos os braços que se desviaram do trabalho da Cultura, e por conseqüência ela foi em diminuição. ${ }^{529}$

Nesse mesmo tempo - é provável que com parte desses novos recrutas -, foi criado o Terço ou Legião de Auxiliares composto de Companhias de Infantaria e Cavalaria por toda a extensão da capitania. ${ }^{530}$

Em ofício ao Conde de Azambuja de 8 de dezembro de 1767, Sousa de Meneses informava que o Batalhão de 6 companhias, entre oficiais e soldados, tinha 490 homens, com soldo igual ao Regimento de Artilharia dessa Corte", e que havia também mais um destacamento vindo de Pernambuco,

todas as tropas de ambos os Batalhões, com os oficiais inclusive não passam de 679 homens, na verdade menos do que necessita só a Fortaleza de Santa Cruz de Anhatomirim. (...) Os Paisanos, capazes de tomarem Armas espalhados por toda a extensão do meu governo, são quase 3.000 homens, dos quais a $3^{\text {a }}$ parte são pretos, e pardos. Estão alistados em Companhias das Ordenanças, com três Capitães-mores. Um nesta vila, e dois na de S. Francisco e Laguna. ${ }^{531}$

Tirando os oficiais do exército - grupo que se manteria no topo da hierarquia social da capitania -, a distinção inicial existente entre militares de carreira e lavradores tenderia a se desfazer, fosse por causa dos casamentos entre aqueles e as filhas desses, fosse por causa das práticas políticas utilizadas na administração dessa colônia, que acabou por forçar a mobilidade social desses grupos. Em tempos de maior necessidade bélica, a carência de militares na guarnição fez com que os governadores obrigassem os lavradores a servirem como soldados; em tempos de paz, a falta prolongada no pagamento dos soldos impeliu os soldados a trabalharem como lavradores ou pescadores.

A instabilidade militar na disputa pelos territórios no sul, forçou não só um aumento no contingente de tropas regulares na região, mas também um tratamento

\footnotetext{
${ }^{529}$ OMR-1797, fls. 07 e 08.

${ }^{530}$ Id. fl. 08.

531 BNRJ, Mss. 07, 3, 47. Ofício de Francisco de Souza de Menezes ao vice-rei Conde de Azambuja, em 08.12.1767.
} 
diferenciado às companhias de ordenanças. Os governadores obrigavam os civis a fazerem exercícios militares semanalmente e não apenas duas vezes ao ano como se praticava em outras partes do Brasil. Em 27 de julho de 1765, momento de substituição do governador Francisco Antônio Cardoso por Francisco de Sousa de Meneses, os oficiais da Câmara de Desterro dirigiram uma representação ao rei denunciando essa prática como abusiva. Informavam que o governador que deixava o cargo obrigava

todos os moradores a contínuos exercícios militares como se fossem Tropas pagas (...) [e] que pondo-se as ditas ordenanças tão práticas nas evoluções militares, que todos os oficiais peritos confessam não as executarem melhor as Tropas pagas, e isto porque todos estes Vassalos desejavam no tempo da

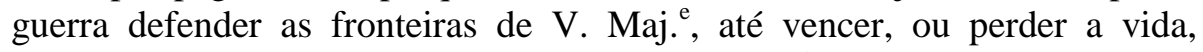
contudo sem embargo da gloriosa paz que V. Maj. ${ }^{\mathrm{e}}$ mandou publicar a mais de dois anos tem continuado (...) os exercícios todas as semanas, não obstante que o Regimento de V. Maj. ${ }^{\text {e }}$ ordena que no tempo da paz só estes se façam duas vezes cada ano, e assim se perdem totalmente as Lavouras e os negócios dos habitantes, sem distinção alguma dos que servem, e tem servido nesta Câmara porque a cada passo os descompõe e espanca qualquer Cabo de Esquadra pago que o Governador nomeava para os Exercícios, e algumas vezes é um homem Pardo, guardando-se para estas ocasiões as vinganças particulares, e sendo só escusos aqueles que lhe podem fazer alguma conveniência. ${ }^{532}$

De fato, o Tratado de Paris (1763) punha fim à Guerra dos Sete Anos em que Portugal e Espanha estiveram em lados opostos. Contudo, no sul da América Meridional, as hostilidades entre essas nações continuaram. O General D. Pedro de Ceballos, governador de Buenos Aires, devolveu a Colônia de Sacramento aos portugueses, mas não desocupou a vila do Rio Grande. Por esse motivo mantinha-se o estado de beligerância não só em Viamão e Rio Pardo, fronteira-sul dos domínios portugueses nesse momento, mas também na Ilha de Santa Catarina.

Em resposta à representação da Câmara, o Secretário da Marinha, Francisco Xavier de Mendonça Furtado, ordenava ao governador seguinte, que continuasse com as ordenanças bem disciplinadas, pois, alegava ele:

Sendo essa praça fronteiriça e tão próxima a qualquer agressão dos inimigos, por mar ou por terra, é indispensável que todos os moradores se conservem

532 AHU-SC, cx. 3, doc. 194. Representação dos oficiais da Câmara da vila de Desterro ao rei, em 27.07.1765. Grifo meu. Esse momento de substituição de um governador por outro era propício para essas representações, pois os oficiais da câmara sentiam-se mais livres tanto para denunciar o governador que deixava o cargo, escapando assim das possíveis represálias que poderiam vir, como para propor mudanças ao governador que entrava. 
em condições de tomarem as armas conscientemente de que podem reprimir o orgulho dos inimigos.

Certamente, assim não se sucederá, deixando esses moradores na ignorância em que se encontram a maioria dos que habitam os centros de toda a América.

Os dois exercícios por ano servem apenas para que os capitães-mores vejam se os moradores dos seus distritos possuem as armas que são obrigados a terem, na conformidade do regimento. ${ }^{533}$

A partir de meados da década de 1770, intensificam-se as tensões na fronteirasul da América. O esforço na reconquista do Rio Grande e a iminência de uma nova invasão espanhola, dessa vez por mar, exigiram da Coroa portuguesa redobrados investimentos militares naqueles territórios. Calculava-se, já desde 1774, que a armada de guerra que se montava nos portos da Espanha destinava-se a atacar a Ilha de Santa Catarina. ${ }^{534}$ Com efeito, mais de 100 embarcações e cerca de 15.000 homens, ${ }^{535}$ sob o comando do General D. Pedro de Ceballos chegaram na Ilha no final de fevereiro de 1777 levando o governador e o comandante dos exércitos portugueses dela à capitulação.

Em 1776, o quadro geral de forças militares de Santa Catarina era de 1.552 homens da tropa paga (773 do Regimento de Infantaria da mesma Ilha e 779 do Regimento da Capitania de Pernambuco), 1.452 das tropas auxiliares, um destacamento de Artilharia de que se não diz a força e mais 1.674 praças das cinco embarcações que se encontravam sob o controle do "Coronel de Mar" Robert Mac Douall. ${ }^{536}$

\footnotetext{
${ }^{533}$ Carta de Francisco Xavier de Mendonça Furtado à Câmara do Desterro, em 18.04.1766, in Paschoal Apóstolo Pítsica. A Capitania de Santa Catarina..., op. cit., pp. 150-51.

${ }^{534}$ Em carta de 18 de setembro de 1774, Marquês de Pombal dizia ao vice-rei Marquês do Lavradio que "a conquista da importante Ilha de Santa Catarina tem feito um dos principais objetos das Expedições da Corte de Madrid. Para que V. Exa. haja de dobrar as cautelas, e as forças necessárias para a conservação da referida Ilha: fazendo executar tudo o que a este respeito lhe preveni na minha Instrução de 9 de julho próximo precedente (...)", in Carlos Silveira Carneiro (Almirante). Enciclopédia de Santa Catarina. s.n.t., vol. 2, n. 34. O Marechal de Campo Antônio Carlos Furtado de Mendonça, comandante das tropas de Santa Catarina, em carta ao General João Henrique de Böhm, de 2 de setembro de 1775, estava também convencido disso: "a notícia de que os castelhanos se acham com toda a força armando navios em todos os seus portos com o destino de passarem ao nosso Brasil, e como esta Ilha é, que embaraçada, pode cortar todo o socorro, que é preciso para esse Continente, julga-se que será o primeiro lugar, que eles possam atacar (...)". "Correspondência passiva do General Böhm", in ABNRJ, vol. 103, 1983, carta n. 48, p. 59.

${ }_{535}^{5}$ Walter Piazza. Santa Catarina..., op. cit., pp. 182-83.

${ }^{536}$ Carlos Silveira Carneiro (Almirante). Enciclopédia de Santa Catarina. s.n.t. vol. 3, pp. 185-193. "Quadro das forças de mar e terra existentes nas Capitanias do Rio de Janeiro, Santa Catarina, Rio Grande, Minas Gerais e na Praça da Colônia disponíveis para a defesa da Fronteira do Sul, em 1776." As forças de terra do Rio de Janeiro eram de 11.270 homens, as do Rio Grande de 6.717 e as da Colônia de 699. Segundo Antonio Carlos Furtado de Mendonça havia também chegado na Ilha, em 1775, duas companhias de Santos que, talvez, já estivessem computadas entre os Auxiliares acima referidos. Cf. ABNRJ, vol. 103, 1983, cartas n. 48 e 50.
} 
A invasão espanhola desestruturou todo esse sistema de defesa. Grande parte das tropas se desfez, muitos soldados desertaram, regressando aos seus locais de origem, refugiando-se em povoados próximos, ou mesmo fugindo para o sertão adentro. ${ }^{537}$ Muitos foram também parar no Rio Grande de São Pedro. José Marcelino de Figueiredo, governador daquele Continente, em carta ao vice-rei, dizia que havia recolhido nas imediações de Laguna alguns desertores da Ilha e juntado com outros, que já passavam de 400 homens. $^{538}$ As tropas que permaneceram fixaram-se nas proximidades do rio Cubatão, no continente, e a elas se agregariam mais 219 praças da cavalaria auxiliar enviado por terra pelo governador de São Paulo, Martim Lopes Lobo de Saldanha, para fazer "a mais vigorosa barreira aos inimigos". 539

Depois de restituída a Ilha aos portugueses, em julho de 1778, o seu novo governador, Francisco Antonio da Veiga Cabral, fez juntar o resto do Regimento da Guarnição que havia se espalhado mas, pelo menos até as campanhas militares de D. João VI e de D. Pedro I no território cisplatino, as tropas regulares não teriam mais tantos praças como nas vésperas daquela Invasão. De qualquer forma, os militares continuaram representando um percentual significativo da população geral da capitania de Santa Catarina. No quadro populacional apresentado pelo governador Miranda Ribeiro para janeiro de 1796, os militares da tropa paga, 1.027 praças (excluindo, pois, os soldados dos Terços Auxiliares), representavam 4,1\% da população total, que era de 24.892 pessoas. $^{540}$

Mas, se por um lado, a invasão espanhola provocou uma desestruturação da vida política, administrativa e militar na Ilha de Santa Catarina e marcou como um fato "vergonhoso" a heróica história do Império Português - "vergonha" essa reproduzida pelos memorialistas e historiadores futuros -, por outro, os investimentos e a mobilização militar na montagem do seu sistema de defesa imprimiram nela maior dinamismo econômico e social. Nunca antes havia ocorrido tanto movimento de barcos

\footnotetext{
${ }^{537}$ No meio da expedição que, em 1787, fazia o Alferes Antonio José da Costa de abertura do caminho do sertão (da vila de Desterro à vila de Lages) ele "encontrou um quilombo com um Negro e uma Negra, que havia 18 anos estavam vivendo naqueles desertos; no seu rancho se acharam alguns restos de Fardamentos, e outros fragmentos, com 46\$280 réis pertencentes aos soldados que desertaram no tempo da Invasão entre os quais ia também um Sargento de Artilharia, Marcelino Amador dos Santos, sobrinho do Coronel do mesmo Regimento, que junto com os outros morreram naqueles bosques cansados, faltos de sustento e de caminho que os conduzisse a povoado (...)". ANRJ, Cód. 106, vol. 10, of. 02. Do governador José Pereira Pinto ao vice-rei Luis de Vasconcelos e Sousa, em 24.05.1787.

${ }_{538}$ Devo essa informação a Fábio Kühn que, segundo ele, consta em BNL, Códice 10854.

539 AESP, DI, vol. 79, p. 80. Carta do governador de São Paulo ao Capitão Manuel Gonçalo Leyte de Barros, em 9.08.1777.

${ }^{540}$ RMR-1797, "Rezumo Geral de toda a população pertencente ao governo da Ilha..." e "Mapa das Pessoas que não andam incluídas nas listas da População por serem militares".
} 
e gentes no seu porto; nunca antes tinha se visto tanta circulação de mercadorias e dinheiro naquele povoado.

Entre os povoadores da Ilha de Santa Catarina e seu continente havia também, como já destacado em alguns documentos acima, índios, negros e mulatos. Em que proporção? E quantos eram escravos? Impossível saber. Somente no final do século XVIII, os mapas populacionais apresentam a distinção entre livres, libertos e escravos. É provável que a escravaria indígena, na primeira metade do século XVIII, tenha desempenhado um papel mais importante do que a africana, em decorrência da tradição dos seus primeiros colonizadores - paulistas, santistas e vicentistas - na utilização dos gentios. ${ }^{541}$ Segundo o memorialista Paulo José Miguel de Brito, Francisco Dias Velho, quando se deslocou com sua família de São Paulo para a Ilha de Santa Catarina, na segunda metade do século XVII, teria levado consigo, além de dois frades, "quinhentos índios domesticados". 542

A partir de meados do século XVIII, a escravidão negra passou a ocupar posição cada vez mais significativa na organização social e produtiva daquela colônia. Como bem mostrou Beatriz Mamigonian, não só os povoadores, em suas pequenas e médias propriedades agrícolas, voltadas para o abastecimento interno da colônia, empregavam crescentemente a mão-de-obra escrava. As armações baleeiras, fundadas nos territórios de jurisdição da Ilha, foram grandes unidades escravistas. Assim como os engenhos de açúcar, "as armações contavam, da mesma forma, com uma mobilização de mão-deobra livre para funções especializadas, tanto do mar (timoneiro, arpoador) quanto de terra (oficiais mecânicos, mestre do azeite), e de grande número de escravos para todas

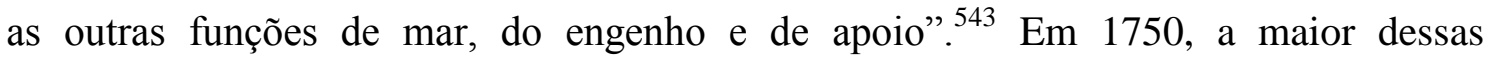
armações, a da Piedade, tinha em 1750, 107 escravos, todos africanos. Quando, em 1801, as seis armações de Santa Catarina passaram a ser administradas pela Fazenda Real, havia nelas 525 escravos. ${ }^{544}$

Em 1796, a população de escravos da capitania de Santa Catarina, 5.191 pessoas, entre "pardos" (676) e "pretos" (4.515), representava 20\% da população total,

\footnotetext{
${ }^{541}$ Cf. Fernando Henrique Cardoso. "O negro e o desenvolvimento...”, op. cit., pp. 10 e segs.

${ }^{542}$ Paulo José Miguel de Brito. Memória Política..., op. cit., p. 14.

543 Beatriz Gallotti Mamigonian. "Africanos em Santa Catarina: escravidão e identidade étnica (17501850)", in João Fragoso, Manolo Florentino et. al. (Orgs.) Nas rotas do Império: eixos mercantis, tráfico e relações sociais no mundo português. Ilha de Vitória, ES: Edufes, 2006, pp. 619 e 620.

${ }^{544}$ Id. ibid., pp. 618 e 619.
} 
que era de 24.892 habitantes. ${ }^{545}$ Segundo estimativa de Miguel de Brito, em 1816, a relação entre a população cativa e livre era de um terço. ${ }^{546}$

Expressiva parece ter sido a participação desses cativos e dos libertos nas companhias de ordenanças. Conforme informação do governador Francisco de Sousa de Meneses, dos 3.000 homens capazes de tomarem armas, em 1767, uma terça parte era formada de "pretos" e "pardos". 547

Feita essa discussão sobre os diferentes grupos étnicos e sociais que formaram esse estabelecimento colonial, com alguns números esparsos de uns e outros, monta-se a seguir dois quadro demográficos com os totais da população da capitania de Santa Catarina. O primeiro, com números oferecidos por dois historiadores; o segundo, com base nos Mapas populacionais apresentados pelos governadores.

Quadro 3.2

População da Capitania de Santa Catarina segundo Walter Piazza e Dauril Alden

\begin{tabular}{ccccccccccc}
\hline & 1749 & 1753 & 1774 & 1775 & 1787 & 1788 & 1796 & 1800 & 1803 & 1805 \\
Piazza $^{548}$ & 4.197 & - & 9.058 & 9.000 & 16.177 & - & 21.013 & 21.068 & 17.843 & 18.132 \\
Alden $^{549}$ & - & 7.180 & - & $\mathrm{c} .10 .000$ & - & 20.916 & 23.865 & - & - & - \\
\hline
\end{tabular}

Segundo Alden, considerando o período 1772-82, a população da capitania de Santa Catarina (c. 10.000 habitantes) representava no quadro total da população do Brasil, aproximadamente 0,6 \%, enquanto a capitania de Minas Gerais ocupava 21,2 \%, a de Pernambuco 15,9 \%, a do Rio de Janeiro 11,3 \%, a de São Paulo 7,7 \% e a do Rio Grande de São Pedro 1,1\%. ${ }^{550}$ De acordo com Piazza, o índice seria ainda menor.

O quadro seguinte, muito embora não traga informações para esse período, sugere, no entanto, que a população total naquela década fosse superior aos 10.000 habitantes.

\footnotetext{
${ }^{545}$ RMR-1797, "Rezumo geral...”, op. cit.

${ }^{546}$ Paulo José Miguel de Brito. Memória política..., op. cit., p. 55.

${ }^{547}$ Ver p. 181.

${ }^{548}$ Walter F. Piazza. A Escravidão Negra Numa Província Periférica. Guarapuvu, 1999, p. 12. O autor coloca que extraiu os dados das "Falas e Relatórios de Governadores e Presidentes da Província de Santa Catarina", mas, infelizmente, não especificou as fontes.

${ }^{549}$ Dauril Alden. The Population of Brazil in the Late Eighteenth Century: A Preliminary Study. Hispanic American Historical Review, Vol. XLIII, n. 2, May., 1963, p. 187. Para o ano de 1753, o autor utilizou o "Mapa das Freguezias que tem a Ilha de Santa Catarina, e seu continente..." elaborado no governo de José de Melo Manoel, AHU-SC, cx. 2; para $1775 \mathrm{fez}$ uma estimativa a partir de várias fontes não referenciadas. Como ele argumentou, "too extensive to cite here"; para 1788, "Ilha de S.ta. Caterina, 1788-89-90”, AHU-SC, cx. 2 (não localizada); e, para 1796, "Dados estatísticos sobre... Santa Catarina, 1797”, BNRJ, II-35, 30, 3, n. 2.

550 Ibid., p. 191.
} 
Quadro n. 3.3

Levantamentos populacionais do governo da Ilha de Santa Catarina (1739-1806)

\begin{tabular}{|c|c|c|c|c|c|c|c|}
\hline & $1739^{551}$ & $1753^{552}$ & $\begin{array}{l}\text { c. } 1756 \\
553\end{array}$ & $1796^{554}$ & $1803^{555}$ & $1805^{556}$ & $1806^{557}$ \\
\hline Ilha de Santa Catarina & $>900$ & 4.820 & 4.584 & 9.160 & 11.144 & 10.599 & 11.016 \\
\hline N. S. do Desterro & & 4.317 & 2.649 & 3.757 & 4.613 & 5.694 & 4.223 \\
\hline N. S. da Conceição da Lagoa & & 503 & 565 & 1.916 & 2.499 & 2.456 & 2.496 \\
\hline N. S. das Necessidades de S. Antônio & & - & 1.370 & 2.447 & 2.901 & 2.449 & 2.914 \\
\hline N. S. da Lapa do Ribeirão & & - & - & 1.040 & 1.131 & $?$ & 1.383 \\
\hline $\begin{array}{l}\text { N.S. do Rosário da Enseada de } \\
\text { Brito }\end{array}$ & & 172 & 212 & 1.091 & 1.315 & 1.379 & 1.393 \\
\hline São José & & 503 & 533 & 2.091 & 2.192 & 2.656 & 2.833 \\
\hline São Miguel (e Ganchos) & & 441 & 481 & 2.758 & 3.475 & 3.498 & 3.339 \\
\hline $\begin{array}{l}\text { Soma das } 7 \text { freguesias/distritos } \\
\text { pertencentes a vila do Desterro }\end{array}$ & & 5.936 & 5.810 & 15.100 & 18.126 & 18.132 & 18.581 \\
\hline $\begin{array}{l}\text { Vila de N. S. da Graça do Rio de } \\
\text { S. Francisco }\end{array}$ & $?$ & $?$ & 2.299 & 4.453 & $?$ & 5.293 & 5.485 \\
\hline Sant'Ana (Vila Nova) & & 312 & 382 & 1.109 & $?$ & $?$ & 1.617 \\
\hline Vila de S. A. dos Anjos da Laguna & $?$ & 234 & 557 & 3.203 & $?$ & 5.684 & 4.479 \\
\hline Soma & & 6.482 & 9.048 & 23.865 & $?$ & 29.109 & 30.162 \\
\hline Militares da tropa paga & $?$ & 138 & $?$ & 1.027 & $?$ & $?$ & $?$ \\
\hline Total & $?$ & 6.620 & $?$ & 24.892 & $?$ & $?$ & ? \\
\hline
\end{tabular}

Em 1756, José de Melo Manoel registrava um total de 9.048 "almas", com a provável exclusão dos militares de primeira linha (o Mapa incluía as companhias de ordenanças, ver Anexo 04). A exemplo de João Alberto de Miranda Ribeiro, no seu

${ }^{551}$ Col. Doc., p. 101. Projeção de José da Silva Paes, em 30.04.1739, quando chega à ilha de Santa Catarina.

${ }^{552}$ AHU-SC, Cx. 2, doc. 92. "Mapa das Freg. ${ }^{\text {as }}$ q. tem a Ilha de S. ${ }^{\text {ta }}$ Cathr. ${ }^{\text {a }}$, e seu Contin. ${ }^{\text {te }}$ com distinção do $n .^{\circ}$ de huns e outros cazaes e Comp. ${ }^{\text {as }}$ de Ordenansa, e n. ${ }^{\circ}$ das Almas q. contem, anno de 1753" encaminhado pelo governador José de Melo Manoel ao Conselho Ultramarino, em 30 de novembro de 1753. Agradeço a colaboração de Fábio Kühn na interpretação desse Mapa.

${ }^{553}$ AHU-SC, Cx. 1, doc. 67. "Mapa das Freg. ${ }^{\text {s }}$ q. tem a Ilha de S. ${ }^{\text {ta }}$ Cathr. ${ }^{\text {a }}$, e seu Contin. ${ }^{\text {te }} . . . "$ encaminhado pelo governador José de Melo Manoel para o Conselho Ultramarino. Na catalogação feita por Maria Bernardete Ramos Flores e Élio Serpa, no Projeto Resgate, consta "c. 1750". Contudo, a data que aparece no documento de 05.09.1756, anotação de outro punho, parece mais correta, não só por mostrar o aumento que teve a população em comparação ao quadro anterior, decorrente dos novos ingressos dos casais das ilhas, mas também por incluir nesse a Freguesia de Nossa Senhora das Necessidades de Santo Antônio que, segundo W. Piazza, teve princípio em 1755.

${ }_{554}$ RMR-1797, p. 166. "Rezumo Geral de Toda a População pertencente ao Governo da Ilha de Santa Catarina...".

${ }^{555}$ AHU-SC, cx. 8, doc. 454. "Resumo da População em particular dos sete Destritos q'. pertencem a Vila de Nossa Senhora do Desterro da Ilha de Santa Catarina extraido do Mapa geral que derão os Comandantes dos mesmos Destritos no anno de 1803."

${ }_{556}$ AHU-SC, Cx. 9, doc. 501. Mapas encaminhados pelo Gov. Luiz Mauricio da Silveira ao Visconde de Anadia, Ministro e Secretário de Estado dos Negócios da Marinha e Domínios Ultramarinos, em 02.06.1806.

${ }^{557}$ AHU-SC, Cx. 12, doc. 14. Mapas encaminhados pelo Gov. Luiz Mauricio da Silveira ao Visconde de Anadia, em 08.06.1807. Consta na Enseada do Brito a população do povoado de Garopaba. 
"Resumo Geral de toda a população..." de 1796, acredita-se que era comum aos governadores registrar em separado o efetivo das tropas regulares, até mesmo pela importância que isso tinha, com informações pormenorizadas dos oficiais superiores e inferiores, dos soldados, dos doentes, dos licenciados e dos que haviam sido destacados para outros regimentos.

Considerando os contingentes militares de primeira e de segunda linha transferidos para a Ilha nas décadas de 1760 e 1770, do ingresso de escravos africanos (evento sobre o qual poucas informações se dispõe), e do crescimento natural da população, pode-se justificar melhor o significativo aumento demográfico da capitania de mais de $160 \%$ entre 1756 e 1796.

\subsection{2 - Economia e finanças}

Esperava-se com a colonização açoriana que os povoados que com eles se formariam no sul do Brasil fossem não só auto-sustentáveis economicamente, mas que também pudessem, num futuro próximo, trazer benefícios mercantis à Coroa, até porque não faltavam relatos de autoridades portuguesas e de viajantes estrangeiros sobre a fertilidade do solo desses territórios para a agricultura - próprio "para todos os frutos da América, senão também da Europa”, dizia José da Silva Paes ao rei, em 23 de agosto de $1742 .{ }^{558}$

Constata-se, porém, que, se por um lado essa colonização cumpriu seu principal papel, que era de povoamento e defesa desse vasto território ao Império Português, por outro, no caso específico de Santa Catarina, os mecanismos impostos para o seu funcionamento - as formas de organização da produção e do trabalho, assim como a prática de recrutar os lavradores para completar o Regimento militar, acabaram, paradoxalmente, por frustrar a expectativa da Coroa com os negócios mercantis que dela poderia extrair. O fato é que, ao fim e ao cabo, as orientações governativas, frente às adversidades que se colocavam na sua administração, sempre priorizavam a função militar do seu porto. Isso não impediu que se estabelecessem redes informais de

${ }^{558}$ DH, vol. XCIV, 1951, p. 107. 
comércio e se ampliasse ao longo do período colonial, a capacidade produtiva da capitania, ainda que em nível baixo.

Por todo o período que aqui se estuda, muitas foram as iniciativas e os esforços das autoridades portuguesas com a introdução ou ampliação das culturas em Santa Catarina. A primeira delas foi com o trigo. A citada Provisão de 9 de agosto de 1747 de assentamento dos açorianos mandava dar "a cada casal no tempo oportuno (...) dois alqueires de sementes," mostrado a experiência se não logra depois de bem criado (...) motivo por que se tem abandonado esta sementeira", informava D. José de Melo Manoel a Diogo de Mendonça Corte Real, em novembro de $1753 .{ }^{560}$ Mas, dizia também o governador:

\begin{abstract}
A terra tanto nesta Ilha como no continente em que é firme, produz todos os frutos com muita suficiência, e com especialidade mais excessiva Canas de Açúcar, Arroz e Mandioca: Do $1^{\circ}$ gênero há vários Engenhos de Aguardente de que já anualmente se tiram bastantes pipas delas; A Mandioca não responde com menos fertilidade e em forma tal que não só se sustentam com ela seus moradores e se provêem os Armazéns destes presídios, mas carece de que se extraiam os sobejos para fora, e assim o tenho já requerido ao mesmo general [Gomes Freire] para que a Corte ordene que o provimento deste gênero que se manda fazer no Rio de Janeiro para o Rio Grande, para sustento daquelas tropas, o venham aqui buscar, a este Porto (...) onde a farinha de pau é muito mais barata que na dita cidade do Rio de Janeiro, o ajudando por este modo o viver estes Povos, pois de outra sorte senão animam a fazer maiores plantações da dita Mandioca.
\end{abstract}

Melo Manoel constatava, e tornaria a partir daí uma política econômica de governo, o que, na verdade, já vinha sendo feito pelos antigos moradores da Ilha e, sobretudo, de São Francisco do Sul, que era o abastecimento de farinha de mandioca para os mercados do Atlântico Sul. Segundo registram alguns historiadores, dessa última vila saíam, desde o final do século XVII, carregamentos desse produto para Paranágua e também para a Colônia do Sacramento. ${ }^{561}$ E essa tradição podia ter raízes ainda mais remotas. Paulo Jozé Miguel de Brito relata em sua memória que os índios carijós que habitavam essa região já forneciam, desde o século XVI, a farinha de

\footnotetext{
${ }^{559}$ In Walter Piazza. A Epopéia Açórico-Madeirense..., op. cit., p. 123.

${ }^{560}$ ANRJ, Cód. 106, vol. 2, n. 3. Do governador José de Melo Manoel ao secretário de Estado, Diogo de Mendonça Corte Real, em 30 de novembro de 1753.

${ }^{561}$ Cf. Carlos da Costa Pereira. História de São Francisco do Sul. Florianópolis: Ed. UFSC, 2004, p. 98; e Lucas Alexandre Boiteux. Notas para a História Catharinense. Florianópolis: Moderna, 1912, pp. 163 e segs.
} 
mandioca e outros víveres aos navegadores que passavam pela Ilha de Santa Catarina. ${ }^{562}$ Em 1719, o capitão inglês George Shelvocke relatou ter suprido nela seu navio dos seguintes mantimentos: diversos porcos, a 4 dólares cada, 200 peixes salgados, a 10 dólares o cento, 160 arrobas de trigo, algumas das quais pagou em dinheiro, outras, trocou por sal, arroba por arroba, um bom estoque de fumo e 150 arrobas de farinha de pau. ${ }^{563}$

A idéia do governador, de ser a Ilha a fornecedora de farinha para as tropas do Rio Grande, foi autorizada por Provisão régia de 31 de dezembro de $1754{ }^{564} \mathrm{Com}$ o aumento da produção, periodicamente, paquetes e sumacas levavam carregamentos de farinha da Ilha de Santa Catarina e de São Francisco para aquela vila do sul e aos armazéns reais do Rio de Janeiro. Em transações particulares, como se verá oportunamente, a farinha produzida nessas duas vilas chegava até aos portos da Bahia e de Pernambuco. Infelizmente, só se encontraram documentos com as quantidades de produção e de exportação desse produto, assim como de outros gêneros, para o final do século XVIII e princípio do século XIX.

Outra atividade que os imigrantes açorianos se não introduziram, com toda a certeza incrementaram e aperfeiçoaram foi a da tecelagem. José de Melo Manoel informava ao secretário de Estado, no final de 1753 que

As produções de maior conveniência e utilidade que têm este País, são o Linho e o Algodão, os quais nele se dão admiravelmente e a cuja cultura se vão aplicando seus moradores, tecendo já bastantes panos em um e outro gênero em que cada dia se vão aperfeiçoando mais, e ele governador cuidando muito em fomentar estas pequenas fábricas na esperança que aumentando-se o seu progresso possam ser de grande benefício àqueles povos, não só tendo panos para outras partes sem necessidade dos estranhos, melhorando neste tráfico a suma pobreza em que vivem. ${ }^{565}$

Em abril do ano seguinte, o governador despachava um ato ordenando que todos os moradores da Ilha e do seu continente deveriam plantar 100 árvores de algodão para cada porção de 50 braças de terras lavradas e cultivadas, e quem descumprisse ou

\footnotetext{
${ }^{562}$ Paulo Jozé Miguel de Brito. Memória Política sobre a Capitania de Santa Catharina. Lisboa, 1829, p. 7.

${ }^{563}$ George Shelvocke. A Voyage round the World..., op. cit., p. 45. E complementava: “... que é a farinha da raiz de mandioca, tão fina como a nossa farinha de aveia; trata-se de comida muito substanciosa e é preparada sem grande trabalho, bastando para isso ferver água e derramar uma quantidade dessa farinha nela, o que vem a formar uma espécie de pirão imediatamente".

${ }^{564}$ In Pascoal Apóstolo Pítsica. A Capitania..., op. cit., p. 134.

565 ANRJ, Cód. 106, vol. 2, n. 3. Do governador Jozé de Melo Manoel a Diogo de Mendonça Corte Real, em 30.11.1753; e DH, vol. XCIV, 1951, p. 257, Consulta do Conselho Ultramarino de 30.12.1754.
} 
contrariasse essa ordem, que seria fiscalizada de seis em seis meses pelo juiz de cada freguesia, teria como pena a reversão de suas terras à Fazenda de Sua Majestade. ${ }^{566} \mathrm{~A}$ medida foi aprovada pelo rei por Provisão de 10 de outubro de 1754 , com duas ressalvas: com relação à aplicação das penas, ordenava que na primeira transgressão deviam os colonos pagar 10 tostões por árvore não plantada, pela segunda transgressão, a pena seria cobrada em dobro e, só na terceira, eles perderiam as terras; advertia também que a plantação do algodão não deveria comprometer outras culturas, devendose, pois, sempre deixar espaço para se semear outras sementes. ${ }^{567}$

Desde o princípio, as autoridades portuguesas já pensavam a organização desse estabelecimento calcadas em outra lógica econômica de integração colonial, ou seja, fundada na produção diversificada de gêneros e não na tradicional monocultura aplicada no norte. Em parte isso se justificava pela imperiosa necessidade de abastecimento das tropas militares.

Os teares se multiplicaram pelos sítios da Ilha e seu continente, porém, a não ser pelos dízimos arrecadados, a Coroa pouco deve ter se beneficiado com essa protoindústria. A forma de organização da produção em pequenas unidades, domésticas se poderia dizer, dirigidas sobretudo pelas mulheres, contribuiu para o fortalecimento das trocas, entre os próprios fregueses, num âmbito regional ou, no máximo, num comércio de cabotagem. Sabe-se da participação ativa das mulheres nessa atividade pelos processos de eleição dos juízes de ofícios realizados pela Câmara de vereadores da vila. Cabia a essa casa regulamentar e fiscalizar os ofícios mecânicos como de alfaiate, de sapateiro, de serralheiro, de ferreiro, de carpinteiro, da tecedeira, entre outros. Nos termos de vereança que se lavraram em janeiro de 1757 , constata-se que a fabricação dos tecidos era um ofício organizado pelas mulheres. No dia 12 desse mês,

apareceram as tecedeiras do tear desta vila [de Desterro] para votarem em uma que houvesse de ser Juíza do dito ofício em que saiu a mais votos (...) Mariana Inácia mulher de Manoel Antônio a qual por estar presente lhe deu o Juiz presidente o juramento dos Santos evangelhos sobre o cargo do qual the encarregou (...) guardando em tudo o serviço de Deus e de Sua Majestade. ${ }^{568}$

\footnotetext{
${ }^{566}$ RIHGSC, vol. II, 1913, p. 41. Ato do Governador regulamentando a plantação de pés de algodão, em 01.04.1754.

${ }^{567}$ RIHGSC, vol. II, 1913, p. 78.

${ }^{568}$ RTIHGSC, vol. VI, 1917, p. 195. Lavrou-se também, no mesmo mês, os termos de eleição das mulheres juízas do ofício de tecedeira das freguesias de São Miguel, Enceada de Brito, São José e Santo Antônio.
} 
A quantidade de teares e de tecidos produzidos era, de fato, significativa, como mostra o quadro abaixo enviado pelo Governador Melo Manoel à Corte.

Quadro n. 3.4

Relação dos teares e dos tecidos produzidos na Ilha de Santa Catarina e freguesias da terra firme $(1755)^{569}$

\begin{tabular}{|c|c|c|c|c|}
\hline Freguesias & Sítios & Teares & $\begin{array}{l}\text { Panos de Linho } \\
\text { tecido com algodão } \\
\text { (varas) }\end{array}$ & $\begin{array}{c}\text { De algodão Puro } \\
\text { (varas) }\end{array}$ \\
\hline N. Sr. ${ }^{a}$ do Desterro & 200 & 50 & 5.439 & 631 \\
\hline N. Sra . da Conceição da Lagoa & 150 & 52 & 6.283 & 202 \\
\hline N. Sra ${ }^{\mathrm{a}}$ das Necessidades (Sto. & & & & \\
\hline Antônio) & 190 & 32 & 592 & 5.180 \\
\hline São Miguel (na terra firme) & 143 & 27 & 1.188 & 1.710 \\
\hline São José (na terra firme) & 182 & 51 & 6.020 & 2.080 \\
\hline N. Sr ${ }^{a}$ do Rosário da Enseada de & & & & \\
\hline Brito (na terra firme) & 148 & 24 & 291 & 1.717 \\
\hline Santa Ana (na terra firme) & 123 & 30 & 4.264 & 661 \\
\hline Soma & 1.136 & 266 & 24.077 & 12.181 \\
\hline
\end{tabular}

Como já observou Walter Piazza a respeito dessa relação, percebe-se, além de uma distribuição equilibrada dos teares por todas as freguesias que se formaram pelos casais ao longo do litoral, o potencial de tecelagem dessas pequenas fábricas ${ }^{570}$ que, girava em torno de 136 varas de tecidos produzidos por tear. Se tomarmos o número total de panos (36.258 varas) pelo número da população dessas freguesias para o ano de 1755, que era de aproximadamente 6.200 pessoas, temos uma média anual de mais de 5 varas (5,5 metros) per capita. Contudo, ainda que essa indústria tenha crescido ao longo do século XVIII, como se demonstrará em momento oportuno, as insistentes e frustradas tentativas da Corte em animar a cultura do linho cânhamo e as diminutas quantias que dele e do algodão se exportaram no final desse século mostram que aquela produção de tecidos destinava-se, sobretudo, a um abastecimento doméstico ou mercado interno.

Independentemente do valor que esses intercâmbios possam ter representado no quadro mais amplo do comércio colonial, pode-se afirmar que a economia e a sociedade de Santa Catarina organizaram-se, por todo o século XVIII, na sua relação com o

\footnotetext{
569 AHU-SC, cx. 2, doc. 97. "Relação dos Panos de Linho, e algodão que se teceram na Ilha de Santa Catarina e Freguezias de terra firme anexas no ano de 1755 e dos cítios que há nas ditas Freguezias"

${ }^{570}$ Walter Piazza. Santa Catarina..., op. cit., p. 154.
} 
mundo externo, com a vida marítima. Essa organização tornou-se perceptível com as pequenas propriedades agrícolas, fabris ou pesqueiras que produziam gêneros diversificados - farinha, arroz, milho, feijão, favas, trigo, cevada, aguardente, melado, açúcar, cebola, algodão, linho, café, fumo, tabuados, peixes, entre outros - tanto para o auto-abastecimento, como para os intercâmbios com os mareantes. E isso explica, em parte, a insistente fixação das populações de Santa Catarina na costa litorânea. Era preferível acomodar-se ao modus vivendi local a buscar uma nova, arriscada e incerta atividade econômica serra acima, sertão adentro. Junto àquela interpretação psicológica e sociocultural de Silva Paes, a respeito dos açorianos "quererem ficar mais perto uns dos outros" e não perderem a missa - fatores sem dúvida relevantes naquele contexto -, deve-se acrescentar esse outro, de ordem econômica. Os novos colonos que chegavam eram incorporados e absorvidos pelos sistemas de produção e de comercialização já constituídos.

Embora não se tenham dados para avaliar o valor dessas produções nesse período, é possível fazer uma estimativa de seu montante ou, pelo menos, uma análise comparativa com o de outros espaços coloniais, tendo como parâmetro o valor arrematado nos contratos do dízimo.

Antigo tributo eclesiástico correspondente à décima parte de tudo aquilo que se produzia, o dízimo foi cedido pela Igreja, nas conquistas portuguesas, à Ordem de Cristo. Como o monarca era o grão-mestre da Ordem, esse tributo passou a ser arrecadado pela Coroa. ${ }^{571} \mathrm{Na}$ maioria das vezes, ela transferia o direito da coleta do tributo, por meio de um "contrato" firmado, geralmente por três anos, ao arrematante que oferecesse o maior lance. Segundo Stuart Schwartz, “Os contratos do dízimo são antes uma estimativa, feita por alguém bem informado, do valor da produção. $O$ contratador tinha uma idéia aproximada da produtividade da região, mas não podia prever secas, inundações ou guerras. Ele tinha provavelmente uma capacidade muito melhor de estimar o preço dos principais gêneros produzidos. (...) Portanto, embora o dízimo não seja uma medida substituta da produção, é uma indicação do valor provável desta última, baseado na melhor estimativa de um observador interessado e, como tal, é um índice razoavelmente bom da situação econômica". ${ }^{572}$ Contudo, há que se considerar

\footnotetext{
${ }^{571}$ Caio Prado Jr. Formação do Brasil Contemporâneo..., op. cit., p. 321.

572 Stuart B. Schwartz. Segredos Internos: Engenhos e escravos na sociedade colonial. São Paulo: Companhia das Letras, 1988, p. 154.
} 
a possibilidade de favorecimentos por parte da Coroa a determinados indivíduos ou grupos mercantis, assegurando-lhes contratos subavaliados e lucros exorbitantes.

$\mathrm{Na}$ arrematação do contrato dos dízimos que se fez em 1750, no valor total de 10:815\$000 réis anuais, correspondiam ao Rio Grande e Santa Catarina 3:200\$000, e a São Paulo e Paranaguá 7:615\$000. ${ }^{573}$ Para o triênio seguinte, Pedro Gomes Moreira arrematou no Conselho Ultramarino, em 1753, os rendimentos desse tributo dos povoados de Santos, São Paulo, Ilha de Santa Catarina e Rio Grande pelo preço de 10:820\$000 réis anuais, mas sem a informação de quanto cabia a cada um dos estabelecimentos. ${ }^{574}$

Segundo Helen Osório, as arrematações trienais subsequientes para os povoados do sul tiveram pequenos acréscimos, chegando no ano de 1769 ao valor de 11:000\$000. Considerando que os mesmos arrematantes desse contrato, José Alves de Mira, Manuel Inácio Ferreira e José de Souza e Abreu, negociantes da praça de Lisboa, arremataram nesse ano também os dízimos do Rio de Janeiro por 28:460\$000, se percebe os pesos diferenciados que tinham essas economias no mercado colonial. ${ }^{575}$ A recente ocupação daquele espaço meridional pelos portugueses, com uma produção incipiente, a guerra e a ocupação de parte dos territórios pelos espanhóis entre 1763 e 1776 e do deslocamento de parte da população ativa para a composição das tropas explicaria, segundo essa historiadora, os poucos rendimentos do sul.

À provedoria da Ilha de Santa Catarina couberam os seguintes rendimentos. No triênio 1756-1758, segundo informações do governador José de Melo Manoel, a parcela era de 1:600\$000 réis anuais. ${ }^{576}$ No contrato seguinte (1759-1760), um extrato das despesas e das receitas do governo da Ilha registrava o valor do rendimento dos dízimos em 1:665\$000 réis anuais ${ }^{577}$. Em junho de 1761, José Alves Mira - que, segundo Jorge

\footnotetext{
${ }^{573}$ Helen Osório. Estancieiros, Lavradores e Comerciantes na Constituição da Estremadura Portuguesa na América: Rio Grande de SãoPedro, 1737-1822. Niterói: UFF-PPG História (Tese de doutorado), 1999, p. 200; e da mesma autora, "As elites econômicas e a arrematação dos contratos reais: o exemplo do Rio Grande do sul (século XVIII)", in João Fragoso, Maria Fernanda Bicalho e Maria de Fátima Gouvêa (Orgs.) O Antigo Regime nos Trópicos..., op. cit., p. 111.

574 Provisão de 18.05.1753 sobre arrematação do dízimo, in Paschoal Apóstolo Pítsica. A Capitania de Santa Catarina..., op. cit., p. 125. Helen Osório na obra Estancieiros, Lavradores... acima citada se refere a Pedro Gomes Pereira como arrematante do contrato de 1747 dos dízimos de Santos, São Paulo e Rio Grande, no valor de 10:600\$000. Provavelmente trata-se da mesma pessoa.

${ }^{575}$ Helen Osório. "As elites econômicas...", op. cit., p. 112.

${ }^{576}$ ANRJ, Cód. 106, vol. 2, fl. 43. Do governador José de Melo Manoel ao secretário de Estado Tomé Joaquim da Costa Corte Real, em 14 de junho de 1757.

577 ANRJ, Cód. 106, vol. 2, fl. 62. "Extrato das despesas que tem hoje o Governo da Ilha de Santa Catarina" para o ano de 1959. O valor especificado da renda dos dízimos é de 1:650\$000 réis, contudo, a soma total dos Rendimentos fecha com 1:665\$000 réis.
} 
Pedreira, estava entre os cem grandes negociantes do período pombalino ${ }^{578}$ - havia rematado os contratos do sul pelo triênio de 1761-1764, com obrigação de pagar todos os anos a essa Provedoria a mesma quantia de 1:665\$000 réis. ${ }^{579}$

Os rendimentos permaneceram nessa faixa pelo menos até 1767. Em dezembro desse ano, entretanto, o governador Francisco de Sousa de Meneses mostrava ao vicerei, Conde de Azambuja, que os dízimos de sua capitania rendiam na verdade muito mais que isso. Afirmava ele que o contrato que ordinariamente se arrematava em Lisboa, por pouco mais de 1:600\$000 réis cada ano, ele agora fez "arrematar somente por onze meses", por 2:800\$000 réis. ${ }^{580}$

O governador alertava para a defasagem existente entre o volume real da produção da capitania e o contrato dos dízimos, em prejuízo da fazenda real e benefício dos contratadores que, dessa forma, estavam arrematando a partir de uma produção subestimada e recolhendo quantias superiores com base na produção efetiva. De fato, o contrato arrematado na Junta da Real Fazenda do Rio de Janeiro para o período de três anos e meio (de julho de 1771 a dezembro de 1774) por Francisco José da Fonseca, negociante fluminense e caixa e sócio do contrato da pesca da baleia, teve por base uma estimativa de produção bem superior: 16:100\$000 réis (4:600\$000 réis ao ano), que deviam ser pagos "aos quartéis de três em três meses". No mesmo momento, arrematouse o contrato dos dízimos do Rio Grande de São Pedro, pelo mesmo período, à quantia total de 23:333\$335 réis (6.666\$667 réis ao ano). ${ }^{581}$ Estimava-se, pois, nesse período, a produção desse estabelecimento como algo em torno de $45 \%$ superior àquele.

De qualquer forma, Santa Catarina registrava um aumento significativo nos dízimos e, portanto, na produção, em relação aos anos anteriores. Francisco de Sousa de Meneses procurou valorizar isso atribuindo o resultado a seu mérito pessoal na administração daquele governo. Em carta a Martinho de Melo e Castro de 25 de setembro de 1771, dizia que tinha achado aquela capitania na maior decadência, e parecia-lhe agora a havia "restabelecido em todas as suas partes com incansável

\footnotetext{
578 Jorge Miguel de Melo Viana Pedreira. Os Homens de Negócio da Praça de Lisboa de Pombal ao Vintismo (1755-1822): diferenciação, reprodução e identificação de um grupo social. Lisboa: Universidade Nova de Lisboa - FCSH (Dissertação de doutoramento em Sociologia), 1995, pp. 164-167. 579 ANRJ, Cód. 109, vol. 1, fl. 2. "Ilha de Santa Catarina - Conta da Receita da Fazenda Real Para o Erário Régio - 1763"

${ }^{580}$ BNRJ, Mss. 07, 3, 47. "Ofício de Francisco de Sousa de Meneses ao Vice-rei Conde de Azambuja, em 08.12.1767."

${ }^{581}$ Ambos contratos em AHU-SC, cx. 3, doc. 237.
} 
trabalho. Os Dízimos reais rendem o triplo do que rendiam antes. A arrecadação da Fazenda Real só agora teve método...". 582

Os arrematantes do ramo dos dízimos de Santa Catarina eram da praça de Lisboa ou do Rio de Janeiro, e os arremates feitos nesta ou naquela cidade. No entanto, como bem assinalou Márcia Eckert Miranda, "a análise dos contratos dos dízimos exige uma observação mais acurada". Nos primeiros anos, eles eram arrematados em Lisboa, mas revendidos em ramos a rendeiros locais. Fosse por causa da distância em relação a Portugal, fosse pela instabilidade da guerra com os espanhóis naquela fronteira, "parece que para alguns comerciantes do reino ou de outras localidades da colônia, o negócio atrativo era simplesmente a revenda desses contratos". ${ }^{583}$ Percebe-se isso, por exemplo, no modo de cobrança dos dízimos de Santa Catarina contratado pelo lisboeta José Alves de Mira, em 1761. Segundo relato do provedor da Fazenda da Ilha, foi feito da seguinte forma:

O procurador do arrematante, que era José de Couto Pereira, vendeu o ramo dos Dízimos dos Lavradores desta Ilha ao Rendeiro João Gonçalves Ferreira reservando para si, como procurador bastante, que era do contratador Francisco Peres de Sousa, os que pertenciam à pesca das baleias, e o dito José de Couto fez no cofre desta Provedoria os pagamentos (...). ${ }^{584}$

Existiam intrincadas redes de relacionamentos entre comerciantes de diferentes praças e distintos ramos de negócios. O fato de os contratantes não serem da Ilha e nem fazerem nela os arremates refletia-se, por certo, de maneira negativa na economia local, pois os tributos arrecadados não retornavam em forma de investimentos. Como se verá, isso seria apontado como uma das causas para o fraco desenvolvimento econômico da capitania de Santa Catarina. O contrato dos dízimos de seis anos do período de 1797 a 1802 foi arrematado por Antonio José Ferreira, também negociante da praça de Lisboa, pelo valor total de 30:400\$000 réis. ${ }^{585}$

\footnotetext{
${ }^{582}$ AHU-SC, cx. 3, doc. 238. Do governador Francisco de Sousa de Meneses ao secretário de Estado Martinho de Melo e Castro, em 25.9.1771.

${ }^{583}$ Márcia Eckert Miranda. A Estalagem e o Império: Crise do Antigo Regime, fiscalidade e fronteira na Província de São Pedro (1808-1831). Campinas: UNICAMP - Instituto de Economia (Tese de Doutorado), 2006, p. 60.

${ }^{584}$ ANRJ, Cód. 109, vol. 1, fl. 2. "Ilha de Santa Catarina - Conta da Receita da Fazenda Real Para o Erário Régio - 1763”. Encontrou-se um João Gonçalves Ferreira como capitão e mestre da corveta N. Sra. do Monte Carmo e São Pedro, que fazia carregamentos de mercadorias entre os portos do sul do Brasil e o reino, cf. AHU-RJ, cx. 98, doc. 8439.

${ }_{585}$ APESC, "Provisões do Conselho Ultramarino", n. 89. Rio de Janeiro, 26.11.1798.
} 
Mediante os dados referidos acima pode-se então apresentar o seguinte quadro da evolução dos dízimos da capitania de Santa Catarina.

Quadro n. 3.5

Rendimentos anuais dos dízimos na Provedoria da Ilha de Santa Catarina $(1756-1802)^{586}$

\begin{tabular}{|c|c|c|c|c|c|c|c|c|c|c|}
\hline $\begin{array}{c}\text { Anos } \\
\text { Dízimos }\end{array}$ & $\begin{array}{c}1756 \\
1 \cdot 600 \$\end{array}$ & $\begin{array}{c}1759 \\
1 \cdot 665 \$\end{array}$ & $\begin{array}{c}1762 \\
1 \cdot 665 \$\end{array}$ & $\begin{array}{l}1768^{587} \\
2 \cdot 800 \$\end{array}$ & $\begin{array}{c}1772 \\
4 \cdot 600 \$\end{array}$ & $\begin{array}{c}1780 \\
4 \cdot 720 \$\end{array}$ & $\begin{array}{c}1786 \\
4 \cdot 786 \$\end{array}$ & $\begin{array}{c}1789 \\
4.920 \$\end{array}$ & $\begin{array}{c}1795 \\
5 \cdot 066 \$\end{array}$ & $\begin{array}{c}1802 \\
5 \cdot 066 \$\end{array}$ \\
\hline
\end{tabular}

Multiplicando esses números por dez obtêm-se, portanto - ressalvando todos os desvios que esse cálculo possa oferecer -, as estimativas da produção da capitania. Todavia, a estabilidade no valor dos arremates, apresentando uma curva levemente ascendente, aponta para um negócio seguro e rentável, ou seja, a produção não deve ter sido em nenhum momento subestimada, pois, caso contrário não se renovariam os contratos por preços superiores.

Analisando a evolução dos dízimos, percebe-se, no período de 1756 a 1762, um tímido crescimento da produção, mantendo-se quase que estagnada. Depois, nos dez anos seguintes, registra-se um aumento significativo de cerca de $176 \%$ e, no período subseqüiente, de 1772 a 1802, ela volta a apresentar-se praticamente estacionária. Ao aumento expressivo registrado entre 1762 e 1772 correspondeu também um crescimento da população, já analisado anteriormente (ver Quadro n. 3.3). A ocupação espanhola do Rio Grande entre 1763 e 1776, que desorganizou a estrutura produtiva daquela fronteira nesse período, refletiu de maneira positiva para a economia de Santa Catarina.

De maneira distinta dos dízimos, em que os arrematantes contratavam a captação do tributo, no contrato da pesca das baleias arrendava-se todo o processo produtivo. $\mathrm{O}$ negócio rendeu fabulosos lucros aos comerciantes portugueses, mas pouco benefício trazia aos habitantes da Ilha que, segundo observação do navegador francês Conde de La Pérouse, não passavam de "meros espectadores dessa pesca". ${ }^{588}$ De fato, o arremate da licitação era feito em Lisboa e os arrematantes do negócio não eram da Ilha nem

\footnotetext{
${ }^{586}$ Para os anos de 1780 a 1802 utilizou-se dos relatórios de conta corrente dos cofres da Provedoria da Real Fazenda da Ilha de Santa Catarina existentes no ANRJ, Cód. 106, vol. 03 (1780); vol. 9 (1786); vol. 12 (1789); vol. 13 (1795); e vol. 15 (1802).

${ }^{587}$ Valor da arrematação por 11 meses.

588 Jean-François Galaup de La Pérouse. Voyage de La Pérouse Autour du Monde..., in Ilha de Santa Catarina, op. cit., p. 113.
} 
aplicavam nela os lucros que obtinham com a empresa. Todavia, as armações acabavam movimentando a sociedade local, sobretudo pelo abastecimento de alimentos dessas grandes pescarias. Por meio das embarcações do Contrato, que levavam periodicamente o azeite para o Rio de Janeiro, era feita boa parte dos transportes de cargas e das correspondências entre essa cidade e a Ilha de Santa Catarina.

Tomé Gomes Moreira arrematou o Contrato pelo período de 1742 e 1753, e se comprometeu em estabelecer à sua custa "com todos os apetrechos necessários: embarcações, casas, armazéns, fornalhas, tanques, caldeiras de cobre, além de terras, escravos e tudo mais que fosse preciso". ${ }^{589}$ Situada no continente, defronte à barra Norte da Ilha, a “Armação Grande”, também chamada de Nossa Senhora da Piedade, em função da capela aí erguida, em 1746, foi, pelo tamanho das instalações e fartura da pesca, uma das mais importantes armações da costa brasileira, no século XVIII.

O principal produto extraído desse cetáceo para o comércio colonial português era o azeite, muito utilizado na iluminação, mas também empregado na calafetagem dos barcos e no refino do enxofre. Podia-se ainda aproveitar a carne da baleia que, embora não muito apreciada, depois de salgada, servia para alimento dos escravos negros; o âmbar-gris, empregado na fixação dos perfumes; as barbatanas e tendões, para a cordoaria; o espermacete, substância gordurosa extraída da cabeça dos cachalotes, servia para a fabricação de velas; entre outros derivados. ${ }^{590}$

Uma relação apresentada pelo governador Manoel Escudeiro Ferreira de Souza, em 1752, mostra que entre 1743 e 1751, 1326 baleias foram mortas nessa Armação, além de 443 "encostadas", das quais "só se lhes aproveita a barba". 591

Findo o assento de Gomes Moreira, novo contrato foi assinado, dessa vez com Francisco Peres de Souza que, associado com João do Couto Pereira, João Carneiro da Silva e outros, arrematou por um período de seis anos (1755 a 1760) pelo preço de 48.000 cruzados e $100 \$ 000$ réis, devendo pagar 28.000 cruzados e $100 \$ 000$ réis pela pesca do Rio de Janeiro, 10.000 cruzados pela da Ilha de Santa Catarina e 10.000 pela

\footnotetext{
${ }^{589}$ Cf. Myriam Ellis. Aspectos da Pesca..., op. cit., p. 37. Segundo Lucas A. Boiteux. A pesca da Baleia, in RTIHGSC, vol. III, $1^{\circ}$ e $2^{\circ}$ Trim., 1914, p. 5, além de Tomé Gomes Moreira mais sete comerciantes lisboetas participaram do negócio.

${ }_{590}$ Myriam Ellis. Aspectos da Pesca da Baleia no Brasil Colonial. São Paulo (Col. da Revista de História), 1958, p. 8.

${ }^{591}$ ANRJ, Cód. 106, vol. 2, fl. 5. "Relação das Baleias que se têm mortas na Armação da Ilha de Santa Catarina desde o seu princípio no ano de 1743 até o de 1751 inclusive". Ao vice-rei, em abril de 1752. No ano de 1743 foram mortas 83; em 1744, 116; em 1745, 80; em 1746, 218; em 1747, 155; em 1748, 156; em 1749, 223; em 1750, 156; e em 1751, 136.
} 
de São Sebastião, Santos e São Paulo. ${ }^{592}$ Segundo informação do provedor da Fazenda da Ilha de Santa Catarina, o direito à exploração desse negócio na Armação da Piedade até o ano de 1765 continuou nas mãos de Peres de Souza com a obrigação de pagar os mesmos 10.000 cruzados (4:000\$000 réis) em cada um ano nessa Provedoria, "sem que se obrigasse a outro algum encargo, ou propina". 593

De 1765 a 1801, a pesca da baleia no litoral brasileiro ficou sob o controle da família Quintela. Em abril de 1765, Inácio Pedro Quintela, José Alvarez Bandeira Domingos Dias da Silva, Baltazar dos Reis, Antonio dos Santos Pinto, Francisco José da Fonseca, João Fernandes de Oliveira e o já conhecido Francisco Peres de Souza arremataram o contrato dessa pesca, pelo prazo de doze anos, compreendendo as armações de toda a costa do Brasil e suas ilhas adjacentes, pela quantia de 80.000 cruzados anuais, dos quais seriam pagos 20.000 na Bahia, 40.000 no Rio de Janeiro, 10.000 em São Paulo e 10.000 na Ilha de Santa Catarina. ${ }^{594}$ Os três primeiros nomes desse grupo integravam também a lista dos 100 grandes negociantes do período pombalino. ${ }^{595}$ Inácio Pedro Quintela, "um dos principais Comerciantes da Praça de Lisboa", além do contrato da pescaria das baleias adquiriu ainda os monopólios do sal e do tabaco. Domingos Dias da Silva estava também ligado à arrematação dos direitos dos escravos de Angola. ${ }^{596}$

Investiram esses arrematantes grandes capitais em escravos, embarcações, ampliação das fábricas e criação de novas armações. A fartura da pesca em Santa Catarina fez com que, em 1772, erguessem a armação da Lagoinha, na costa oriental sul da Ilha. De acordo com Myriam Ellis, o incremento dessa empresa foi de tal magnitude, que após findo o contrato, em 1777, a sociedade contabilizava um lucro de 4.000.000 cruzados. Só na Armação da Piedade foram pescadas mais de 500 baleias. ${ }^{597}$

Tal êxito fez com que o contrato fosse renovado por mais doze anos (1777-1789) não por 80.000 , mas por 100.000 cruzados ao ano. Dessa vez o arrematante era Joaquim Pedro Quintela (sobrinho do outro Quintela) e demais sócios. Com a ocupação da Ilha pelos espanhóis, paralisou-se momentaneamente (1777-1778) a atividade nas armações da Piedade e da Lagoinha, levando os contratadores, em 1778, a erguer uma outra mais

\footnotetext{
${ }^{592}$ Myriam Ellis. Aspectos da Pesca..., op. cit., pp. 39 e 40.

593 ANRJ, Cód. 109, vol. 1, fl. 3. Informação sobre a receita da Provedoria da Ilha de Santa Catarina no ano de 1763, assinada pelo provedor Felix Gomes de Figueiredo, em 22.6.1768.

${ }^{594}$ Myriam Ellis. Aspectos da pesca..., op. cit., p. 41.

595 Jorge Miguel de Melo Viana Pedreira. Os Homens de Negócio da Praça de Lisboa..., op. cit., pp. 164167.

${ }^{596}$ Id. ibid., pp. 163 e 234.

${ }^{597}$ Myriam Ellis. Aspectos da pesca..., op. cit., p. 48.
} 
ao norte, na enseada de Itapocoróia. Os lucros obtidos nesse contrato ultrapassaram os 4.000.000 de cruzados, o que valeu a sua renovação por Joaquim Pedro Quintela, associado a João Ferreira Solis, por mais doze anos (1789-1801), na base de 120.000 cruzados anuais, pertencendo 50.000 à Bahia, 50.000 ao Rio de Janeiro, 10.000 a São Paulo e 10.000 à Ilha de Santa Catarina. ${ }^{598}$ Em 1795, foi erguida, ao sul da Ilha de Santa Catarina, a armação de Garopaba, com um prolongamento em Imbituba. Contudo, dessa vez, os rendimentos auferidos não seriam tão lucrativos quanto no passado. A escassez dos mamíferos nos mares do sul e outros fatores como a concorrência externa, levaram à decadência dessa pesca e à extinção dos contratos para a exploração dessa atividade por alvará do Príncipe Regente de 24 de abril de 1801. O viajante suíço-alemão Carl Seidler, que passou por Santa Catarina, em 1825, relatou que antigamente, na Armação da Piedade, pescava-se entre 400 a 500 baleias por ano, rendendo a soma de 400.000 piastras espanholas e agora pescava-se de 6 a 8 delas. ${ }^{599}$

Sabe-se que, embora a produção e os rendimentos dessa atividade econômica tenham sido crescentes por quase todo o século XVIII, sobretudo nos territórios da Ilha de Santa Catarina, como se pôde constatar pelas novas armações ali instaladas, a cotaparte destinada à provedoria da Ilha manteve-se sempre a mesma por todo o período de 1765 a 1801, ou seja, 10.000 cruzados anuais. ${ }^{600}$ Em contrapartida, a Provedoria da Bahia continuou recebendo até o ano de 1801 o quíntuplo desse valor, não obstante, segundo Ellis, suas armações estivessem quase inoperantes desde meados do século XVIII. A pesca da baleia era tão diminuta ali que se tornara necessário suprir essa capitania, assim como também a de Pernambuco, com o azeite fabricado no Rio de Janeiro. $^{601}$

Considerando os três últimos contratos, constata-se a decrescente participação da Fazenda Real da Ilha em relação aos valores totais arrematados:

\footnotetext{
598 ANRJ, Cód. 109, vol. 1, fl. 98. "Conta Geral dos Rendimentos Reais que se cobrão anualmente na Capitania da Ilha de Santa Catarina... dos anos de 1794 a 1796."

${ }^{599}$ Carl Friedrich Gustav Seidler. Zehn Jahre in Brasilien Während der Regie-rung Dom Pedro..., in Ilha de Santa Catarina..., op. cit., p. 285.

${ }^{600}$ Ver relatórios de "Conta corrente dos Cofres da Provedoria a Real Fazenda" in ANRJ, Cód. 106, vol. 4 para o ano de 1781; vol. 5 para 1782; vol. 6 para 1783; vol. 14 para 1798 e 1799; entre outros.

${ }^{601}$ Myriam Ellis. Aspectos da pesca..., op. cit., p. 57.
} 
Quadro n. 3.6

Rendimentos do contrato da pesca da baleia para a Ilha de Santa Catarina (1765-1801)

\begin{tabular}{cccc}
\hline $\begin{array}{c}\text { Período do } \\
\text { Contrato }\end{array}$ & $\begin{array}{c}\text { Valor total arrematado para a } \\
\text { exploração em toda a costa } \\
\text { brasileira por ano (réis) }\end{array}$ & $\begin{array}{c}\text { Parcela que coube à Provedoria } \\
\text { da Ilha de Santa Catarina por }\end{array}$ & $\%$ \\
$1765-1777$ & $32: 000 \$ 000$ & ano (réis) & \\
$1777-1789$ & $40: 000 \$ 000$ & $4: 000 \$ 000$ & 12,5 \\
$1789-1801$ & $48: 000 \$ 000$ & $4: 000 \$ 000$ & 10,0 \\
\hline
\end{tabular}

Não se tem uma relação pormenorizada do número de baleias mortas nas armações da Ilha e seu continente ao longo do século XVIII, entretanto, é bem provável que a participação delas na produção total das armações da costa brasileira apresentasse uma curva ascendente. O quadro abaixo enviado em ofício pelo conselheiro da Junta da Fazenda, Luís Beltrão de Gouveia de Almeida, a D. Rodrigo de Souza Coutinho, sobre a condição da pesca da baleia no ano de 1801, momento em que a atividade já se encontrava em franca decadência, mostra o quão significativa era participação das armações da Ilha.

\section{Quadro n. 3.7}

Lista das Baleias que se pescaram por conta da Real Fazenda na repartição do Rio de Janeiro no presente ano de $1801^{602}$

\begin{tabular}{lcc}
\hline \multicolumn{1}{c}{ Armações } & Baleias & Gibartes \\
São Sebastião & 12 & 3 \\
Bertioga & 14 & \\
& & \\
Itapocoróia & 20 & \\
Santa Catarina (Piedade) & 46 & \\
Lagoinha & 26 & \\
Garopaba e Imbituba & 42 & \\
Totais & 160 & 3 \\
\hline
\end{tabular}

${ }^{602}$ In Myriam Ellis. Aspectos da pesca.., op. cit., p. 83. Constava também no ofício: "160 Baleias produzem 2.400 pipas de azeite, que dão pelo preço de 320 a medida a quantia de 153:600\$000 rs. de que extraída a Despesa, pela importância de uma conta aproximada a dos anos anteriores, deve restar o lucro de 100:000\$000 rs." 
Ou seja, das 160 baleias pescadas nesse ano, 134 (83,7\%) foram realizadas nas armações sob a jurisdição da Ilha de Santa Catarina, e sua Provedoria era a que menos se beneficiava com o negócio.

Assim mesmo, os dois maiores rendimentos auferidos anualmente pela Fazenda Real da Ilha de Santa Catarina - para não dizer os únicos, pois, outras receitas como as oriundas das passagens dos rios, dos donativos e do guindaste eram insignificantes provinham do contrato dos dízimos e do contrato da pesca das baleias. A forma de administração dessas rendas não foi a mesma por todo o período colonial. Como já referido, entre 1738 e 1763 houve maior autonomia por parte dos governadores da Ilha de Santa Catarina na relação com o governo do Rio de Janeiro, como se pode constatar no fluxo direto de correspondências que aqueles governadores mantinham com a Corte. Quanto à arrecadação das rendas, o governador José de Melo Manoel parece ter sido o mais beneficiado de todos. Em 31 de dezembro de 1754, uma provisão régia ordenava que tanto os rendimentos dos dízimos quanto os da pesca das baleias, que pertenciam ao distrito daquela Ilha, deviam ser recebidos diretamente na provedoria dela. ${ }^{603}$ Recebia também esse governador, para as despesas do seu governo, a consignação da renda da pesca das baleias do Rio de Janeiro no valor de 11:200\$000 réis anuais.

Porém, tudo isso se alterou em decorrência da transferência do vice-reinado para o Rio de Janeiro, em 1763, e da criação da Junta da Real Fazenda nessa cidade, em $1760 .^{604}$ Antes de assumir seu cargo no governo da Ilha, em 1765, Francisco de Sousa de Meneses fora informado dessa mudança e prevenido das dificuldades que dela resultariam:

depois que se criou a Junta, e Mesa da Fazenda no Rio de Janeiro, a cujos Cofres vão todas as Rendas daquela Capital, e por Resolução da mesma Junta, se fazem todos os pagamentos, dependendo dela a própria consignação, ou o que quiserem mandar por conta dela para aquela Ilha, e destas faltas há de V. S. ${ }^{\text {a }}$ experimentar muitas. ${ }^{605}$

Os repasses complementares continuaram vindo do Rio de Janeiro - até porque as despesas com o pagamento das três folhas, civil, militar e eclesiástica, cresceram muito nos anos seguintes -, mas sempre em parcelas "coartadas e tardonhas". No último

\footnotetext{
${ }^{603}$ ABNRJ, Vol. 71, 1951, p. 47. Provisão régia de 31 de dezembro de 1754.

${ }^{604}$ Graça Salgado. Fiscais e Meirinhos..., op. cit., p. 94.

${ }^{605}$ AHU-SC, cx. 3, doc. 205, fl. 10. "Extrato da Ilha de Santa Catarina, seu Continente, e mais partes dependentes daquele Governo, cuja notícia se dá ao Sr. Governador Francisco de Sousa de Meneses" [1765]
} 
quartel do século, as remessas diminuíram ainda mais elevando sobremaneira a dívida da Fazenda Real com os "filhos da Folha" e, como veremos adiante, com os lavradores, da farinha de mandioca que lhes confiscava.

Em 1763, a receita anual da Provedoria da Fazenda da Ilha era de aproximadamente 16:865\$000 réis (1:665\$000 dos dízimos, 4:000\$000 da pesca das baleias e 11:200\$000 da remessa feita do Rio de Janeiro), enquanto as despesas ultrapassavam a casa do 24:000\$000 réis, isso sem contar os gastos extraordinários, ${ }^{606}$ resultando num déficit a cada ano de 7:135\$000 réis.

\subsection{3 - Apropriação compulsória da força de trabalho de homens livres}

Como bem assinalou Stuart Schwartz, "O Brasil-colônia foi uma sociedade escravista não meramente devido ao óbvio fato de sua força de trabalho ser predominantemente cativa, mas principalmente devido às distinções jurídicas entre escravos e livres, aos princípios hierárquicos baseados na escravidão e na raça, às atitudes senhoriais dos proprietários e à deferência dos socialmente inferiores. Através da difusão desses ideais, o escravismo criou os fatos fundamentais da vida brasileira" ${ }^{607}$

O transplante das instituições tradicionais portuguesas, a sociedade de ordens, moldou-se ao contexto americano. As distinções entre fidalgos e plebeus em Portugal tendiam a se nivelar no Brasil, pois a possibilidade de os colonizadores poderem dispor de escravos, índios ou africanos, tornava-os gentis-homens em potencial. Mas isso era uma expectativa, nem sempre realizada. A possível mobilidade social no Brasil podia conduzi-los, tendo em vista as condições em que vinham, tanto para posições hierárquicas superiores, quanto para inferiores.

Embora em condição social e jurídica bem distinta dos escravos, alguns indivíduos livres viveram em situações econômicas e de trabalho tão ou mais degradantes que aqueles. Se, por um lado, havia escravos no Brasil que podiam cultivar o seu próprio alimento, vender os excedentes, exercer funções especializadas e até de mando e podiam acumular dinheiro para comprar sua alforria, por outro, havia no Brasil indivíduos livres sujeitos a coerção, a discriminação e recebendo pouquíssima - ou mesmo nenhuma - remuneração pelo seu trabalho. ${ }^{608}$

\footnotetext{
${ }^{606}$ Id., fl. 10

${ }^{607}$ Stuart Schwartz. Segredos Internos ..., op. cit., p. 209.

${ }^{608}$ Id. ibid., p. 214.
} 
Segundo Schwartz, não só nas relações de trabalho, "as distinções raciais e a escravidão penetraram em toda a sociedade, atingindo os aspectos mais corriqueiros da vida e afetando as ações e percepções de cada um, escravo, livre, branco, negro, índio ou mestiço". 609

Na política de povoamento do sul do Brasil com os imigrantes açorianos e madeirenses, em meados do século XVIII, procurou-se imprimir um sistema de colonização distinto do que até então vinha se fazendo no norte, ou seja, em vez de um sistema produtivo baseado exclusivamente na mão-de-obra escrava africana, utilizar-se ali do trabalho de homens livres brancos.

A utilização de casais das ilhas no Brasil não era idéia totalmente original. Entre 1675 e 1677, algumas centenas de açorianos foram enviadas para o Estado do Maranhão à custa da Fazenda Real, mas é só no reinado de D. João V que a política dos casais alcançaria seu pleno desenvolvimento. ${ }^{610}$ Além de procurar consolidar a política do uti possidetis naquele amplo espaço entre a capitania de São Paulo e o Rio da Prata, projeto arquitetado pelo diplomata português Alexandre de Gusmão como estratégia nas negociações do Tratado de Madri, atribuindo-lhes a dupla - e, para alguns, naqueles tempos, incompatível - função de defensores e trabalhadores, havia ainda por parte da Coroa Portuguesa a intenção de com essa mão-de-obra livre poder até prescindir do trabalho escravo africano, projetando um novo padrão de colonização. Por um lado, imprimiu-se, de fato, uma organização social e econômica singular, mas não sem que houvesse resistências e conflitos por parte desses colonos, pois, muitos deles esperavam encontrar na América a possibilidade concreta de ascenderem socialmente - alguns, inclusive, de poder gozar dos privilégios da condição de nobreza que alegavam possuir -, ao invés de se submeterem às "degradantes" atividades mecânicas. Por outro lado, como já assinalamos oportunamente, a participação da mão-de-obra escrava africana foi não só expressiva nessa sociedade, mas determinante no desenvolvimento de todas as suas atividades produtivas.

Em carta dirigida ao rei, de 19 de fevereiro de 1750, o governador Manoel Escudeiro colocava o problema da difícil condição em que se encontravam os colonos "nobres" vindos das ilhas atlânticas.

\footnotetext{
${ }^{609}$ Id. ibid., p. 215.

${ }^{610}$ Jaime Cortesão. Alexandre de Gusmão e o Tratado de Madrid. Op. cit., Tomo II, Parte II, p. 249.
} 
Para esta Ilha tem vindo muitas famílias nobres e como estes não sabem, nem podem trabalhar e pela sua muita pobreza menos tem com que comprem escravos ou paguem, a trabalhadores, que rocem e rompam as terras, que $\mathrm{V}$. M. lhes dá: pelo que todos os da referida natureza se pasmam e justamente se consideram perdidos n'este país; que presentemente só é útil para os que se criaram com foice e machado nas mãos. E porque a base fundamental das Repúblicas é a nobreza, a quem a grandeza de V. M. costuma conservar e favorecer se me oferece representar, que só mandando-se vir de Angola por conta da Real Fazenda um transporte de escravos capazes de trabalhar para se distribuírem a crédito pelos homens de bem, e famílias graves que se acharem n'este estabelecimento e vierem para ele, debaixo da obrigação de satisfazerem o seu valor a todo o tempo que se lhes determinar (...) sendo este o único meio que me ocorre para se não perder aqui semelhante qualidade de famílias, que procurando o remédio de suas necessidades, vêm experimentar as que nunca padecerão (....). ${ }^{611}$

Fundamentava-se o governador naquilo que entendia ser - e de fato era, pelo menos no plano teórico - os valores tradicionais da nobreza; princípios intangíveis ligados a honra, o prestígio, o poder, as regalias e também ao ócio (qualquer atividade mecânica era incompatível com a condição de nobreza), todos, elementos duradouros, calcados na tradição, na hereditariedade. ${ }^{612}$ Contudo, a súplica do governador nos remete a outras questões. O estatuto de nobre que alguns colonos alegavam possuir, e que possivelmente possuíam no microcosmo de suas aldeias nas ilhas atlânticas, ganhavam outra dimensão ao serem eles deslocados para o sul do Brasil e inscritos na dinâmica mais ampla do sistema colonial. Como já assinalado no capítulo 2, segundo estudos de Nuno Monteiro, Portugal era um reino de nobreza numerosa e, por isso, fortemente polarizada, diversificada e hierarquizada. No decorrer do século XVIII, a noção de nobreza ampliou-se ainda mais. A distância que se colocava entre um fidalgo da primeira nobreza de Corte e o mais simples nobre do campo era tão grande que a distinção nobre perdia mesmo o sentido. Houve, por parte dos grupos mais dinâmicos da nobreza a absorção de valores ligados ao mérito e também dos novos empreendimentos econômicos. A fusão entre setores da aristocracia com os membros mais ricos do terceiro estado verificou-se também em Portugal, embora não de forma tão evidente como na Inglaterra. Ao mesmo tempo, marginalizava-se a chamada aristocracia pobre, que não tinha condições econômicas de manter a sua posição. ${ }^{613}$

\footnotetext{
${ }^{611}$ ABNRJ, vol. 50, 1928, p. 105.

${ }^{612}$ Pierre Serna. "O Nobre", in Michel Vovelle (Dir.) O Homem do Iluminismo. Lisboa: Editorial Presença, 1997, pp. 32-34.

${ }^{613}$ Id. ibid., p. 40.
} 
Antonio Francisco Moniz Barreto, alegando ser "pessoa muito nobre da Ilha de São Miguel” dirigiu à Corte várias petições solicitando escravos para o servir na Ilha de Santa Catarina, onde residia, mas teve seus pedidos indeferidos pelo Conselho Ultramarino,

\begin{abstract}
Por não ser conveniente quando se trata do estabelecimento dessa Ilha, e de ser habitada pelos casais das Ilhas dos Açores, porque no projeto deste estabelecimento se considerou logo, que alguns não poderiam servir, em os ministérios trabalhosos, para que se destinavam os povoadores, mas atendendo-se a que não era justo acostumar esta Nova Colônia ao prejudicial abuso de não trabalharem os brancos, que nas outras vivem em prejudicialíssima ociosidade, por ocasião deste mau costume. Nesta consideração se assentou, que se dificultasse a introdução dos escravos nessa Ilha, e que as pessoas nobres fossem servidas pelas de inferior qualidade, que os serviriam sem violência na sua pátria. ${ }^{614}$
\end{abstract}

Os escravos chegariam, não na mesma proporção que em outros lugares da América, nem da maneira como queria o governador Manuel Escudeiro, mas por iniciativa dos particulares - comerciantes, armadores, lavradores, tecedeiras, entre outros - para a montagem e funcionamento de suas pequenas e médias unidades produtivas.

A idéia de que a colonização daquele estabelecimento deveria se dar em outros parâmetros estava presente também nas instruções do secretário de Estado Martinho de Mello e Castro. Em 04 de novembro de 1778, escrevia ele ao vice-rei, Marquês do Lavradio, dizendo que era preciso introduzir nos habitantes daquela Ilha e território contíguo a ela "o amor do trabalho entre os brancos, sem recair todo nos miseráveis escravos, como é vicio transcendente em todas as partes do Brasil". 615

Pouco a pouco vai se corporizando, "no discurso crítico do Iluminismo, a imagem de um nobre ocioso, inútil para a economia do país, libertino nos seus costumes, desdenhoso e altivo quando é rico, um parasita para todos quando é demasiado pobre". 616

\footnotetext{
${ }^{614}$ AHU-SC, cx. 2, doc. 112. Carta dirigida ao governador da Capitania de Santa Catarina D. José de Melo Manoel por funcionário régio, em 02.02.1756. Em consulta do Conselho Ultramarino de 26.10.1750, sobre carta do governador Manoel Escudeiro, os conselheiros recomendavam "no que respeita aos vadios e pelo que toca ao serviço dos oficiais mecânicos da ilha de Santa Catarina, e mais misteres, se devem estes fazer pelos moradores que foram das ilhas ali estabelecerem-se na mesma forma que fariam nas suas pátrias, e que não convém porem-se na desordem que comumente se pratica no Brasil de não quererem os brancos servir os ofícios mecânicos pelo que não devem os índios ser tirados de suas aldeias para virem servir na ilha de Santa Catarina (...)”, DH, Vol. XCIV, 1951, pp. 158 e 159.

${ }^{615}$ BNRJ, Mss. CEHB, 5616 - 3, 4, 7, n. 111.

${ }^{616}$ Pierre Serna. "O Nobre", op. cit., p. 53.
} 
Incentivava-se assim na administração daquela colônia, na construção das obras públicas, nas prestações de serviços e na produção de víveres para abastecimento das tropas reais, o uso da mão-de-obra de indivíduos livres, no caso, dos casais das ilhas, principalmente. Desse expediente serviram-se os governadores Manoel Escudeiro Ferreira de Sousa (1749-53), José de Melo Manoel (1753-62), Francisco Antonio Cardoso de Meneses e Sousa (1762-65) e Francisco de Sousa de Meneses (1765-75).

As resistências dos povoadores a essas práticas, manifestas nas representações dirigidas à Corte, e a própria dívida crescente na Fazenda Real com os jornais que se lhes deviam podem ter forçado, a partir desse período, o maior ingresso de escravos africanos na Ilha de Santa Catarina, mas essa é uma hipótese que merece maiores investigações empíricas. Segundo informação do governador Francisco de Barros Moraes, no início da década de 1780, o pagamento de algumas parcelas atrasadas dos soldos dos militares colocou aquele país em

outra figura: os paisanos que não queriam plantar para fazer farinha, porque lhas tomavam e não pagavam (...) entravam a plantar, compravam-se muitos escravos e se adiantou a cultura, de sorte que o ano passado foram para fora do País alguns 24.000 alqueires de farinha ou mais. ${ }^{617}$

A primeira denúncia que se encontrou data de primeiro de agosto de 1757 e foi dirigida contra os abusos de poder do governador Melo Manoel. Diziam os oficiais da Câmara de Desterro que,

em nome de V. Maj. ${ }^{\text {e }}$ tem entrado a fazer a igreja Matriz desta Vila obrigando os Povoadores a trabalharem por faxinas com penas de prisões dilatadas, tirando-os de suas lavouras em que faz uma perda considerável, não só aos ditos casais que $\mathrm{V}$. Maj. ${ }^{\mathrm{e}}$ tem privilegiado e isentado por suas Reais ordens, ordenando se lhe pague o que o dito governador não tem feito, nem quer, mas à Fazenda Real dos direitos dominiais ou dízimos que deixa de perceber na falta das lavouras da terra. ${ }^{618}$

\footnotetext{
${ }^{617}$ ANRJ, Cód. 106, vol. 6, of. 6. Do governador Francisco de Barros Moraes Araujo Teixeira Homem ao vice-rei Luis de Vasconcelos e Souza, em 21.03.1783.

618 AHU-SC, cx. 2, doc. 142. Representação dos moradores da ilha de Santa Catarina ao rei D. José pedindo uma devassa contra o governador D. José de Melo Manoel, em 1.08.1757. No “Auto de perguntas e exames..." que segue a esse documento, feito pelo ouvidor-geral da Ilha de Santa Catarina, os oficiais da Câmara negaram ter elaborado e assinado a referida representação. Era comum, em função das represálias que podiam vir, os autores da denúncia não assinarem os documentos ou mesmo negarem como suas as assinaturas. No caso acima, o governador encontrava-se ainda no exercício do cargo, o que se tornava mais perigoso para os denunciantes. Contudo, mais importa aqui a existência e o conteúdo da denúncia, não tanto seus autores. Outra representação dos oficiais da Câmara de Desterro encaminhada ao Conselho Ultramarino, dessa vez no momento de substituição de um governador por outro, em 1765 , dizia "Igualmente é certo não ser da Régia intenção de incomparável piedade de V. Maj. ${ }^{\text {e }}$ terem os
} 
Em sete de janeiro de 1780, o governador Francisco de Barros Moraes remetia ao vice-rei uma conta geral das dívidas de sua Provedoria em salários, soldos, côngruas e outros compromissos no valor total de 91:430\$308 réis. Incluída nessa quantia computava a dívida com os jornais dos oficiais de pedreiros, carpinteiros de obra branca e ribeira, serradores, falquejadores, ferreiros, calafates, serventes e remeiros, que trabalharam nas obras que se fizeram nos fortes e fortalezas, igrejas, casas para estabelecimento dos casais e faturas das lenhas para a Colônia do Sacramento, tudo por conta da Fazenda Real, no valor de 13:162\$280 réis. O quadro abaixo mostra as quantias a saldar em cada ano.

Quadro n. 3.8

Jornais que se devem aos trabalhadores livres no ano de $1780^{619}$

\begin{tabular}{cr}
\hline $\begin{array}{c}\text { Pelo importe dos jornais } \\
\text { do ano de: }\end{array}$ & Valor em réis \\
1750 & \\
1751 & $41 \$ 680$ \\
1759 & $28 \$ 860$ \\
1760 & $861 \$ 700$ \\
1761 & $2: 738 \$ 515$ \\
1762 & $933 \$ 760$ \\
1763 & $18 \$ 240$ \\
1764 & $192 \$ 040$ \\
1765 & $170 \$ 280$ \\
1766 & $147 \$ 860$ \\
1767 & $3: 786 \$ 490$ \\
1769 & $1: 734 \$ 080$ \\
1770 & $660 \$ 130$ \\
1771 & $144 \$ 900$ \\
1772 & $241 \$ 385$ \\
1773 & $64 \$ 640$ \\
total & $1: 397 \$ 720$ \\
\hline
\end{tabular}

Governadores antecedentes obrigado todo este Povo, sem distinção de pessoa, a trabalharem em contínuas faxinas sem um só instante de alívio prometendo-lhe salário, do qual há muitos anos que se não paga coisa alguma, de sorte que estas novas Povoações, em lugar de se aumentarem como V. Maj. ${ }^{e}$ tanto deseja, se vão reduzindo a mais deplorável miséria, não tendo já os Lavradores que comer, porque nos anos antecedentes nem para plantar se lhe deu tempo, tanto assim que costumando desta Ilha sair muita Farinha de mandioca, e também Trigo, Feijões, Arroz e Algodão, presentemente até para as Tropas de V. Maj. está vindo a farinha em sumacas de fora com grande prejuízo da Real Fazenda, diminuição dos Dízimos e ruína do Povo". AHU-SC, cx. 3, doc. 194. Representação dos oficiais da Câmara de Desterro ao rei D. José, em 27.07.1765.

${ }^{619}$ ANRJ, Cód. 106, vol. 03, of. n. 01. Ofício de Francisco de Barros Moraes Araujo Teixeira Homem ao vice-rei Luis de Vasconcelos e Sousa, em 07.01.1780. 
Embora não se possa tomar esses valores como mensuração dos serviços prestados em cada ano - ainda que de maneira irrisória, se pagavam algumas parcelas -, o quadro revela que o sistema dos jornais e das faxinas foi largamente utilizado na década de 1760 .

Em 1797, fazendo um balanço crítico dos governos anteriores, João Alberto de Miranda Ribeiro colocava essa prática como uma das causas do "atraso desta tão interessante Colônia”. Explicava ele que além dos muitos artífices de uma e de outra classe que se havia empregado naquelas tarefas,

\begin{abstract}
os seus trabalhadores ou Jornaleiros eram os Lavradores nomeados por semana de todas as Freguesias, ou Distritos. A uns se distribuía este Serviço (sem paga) por modo de faxina, a outros se lhes apontava o seu vencimento, para em ocasião de féria se lhes pagar; a alguns se lhes pagou uma pequena parte do que ganharam, e a todos finalmente se lhes estão devendo não só os seus jornais, como também alguns gêneros, que se lhes tomaram; e a razão foi porque os dinheiros para estes pagamentos vinham do Rio de Janeiro; as remessas eram morosas e coartadas; e o que tudo concorreu para o empenho da Real Fazenda, e penalidade dos Povos, que sempre humildes e obedientes, gemiam debaixo do mais ativo e laborioso trabalho sem o seu correspondente prêmio. ${ }^{620}$
\end{abstract}

Nesse momento, entretanto, sabe-se graças a esse mesmo governador, que havia na capitania uma expressiva população de "pretos" e de "pardos", tanto de forros (455) como de escravos (5.191), representando esses dois grupos mais de $22 \%$ da população total, que era de 24.892 habitantes. ${ }^{621}$ É provável que essa população de escravos e forros tenha aliviado os lavradores daqueles encargos.

\footnotetext{
${ }^{620}$ OMR-1797, fls. 06 e 07.

${ }^{621}$ RMR-1797, "Resumo geral de toda a população..."
} 
Mapa 3.1 - Plano Hidrográfico da Ilha de Santa Catarina (1814)

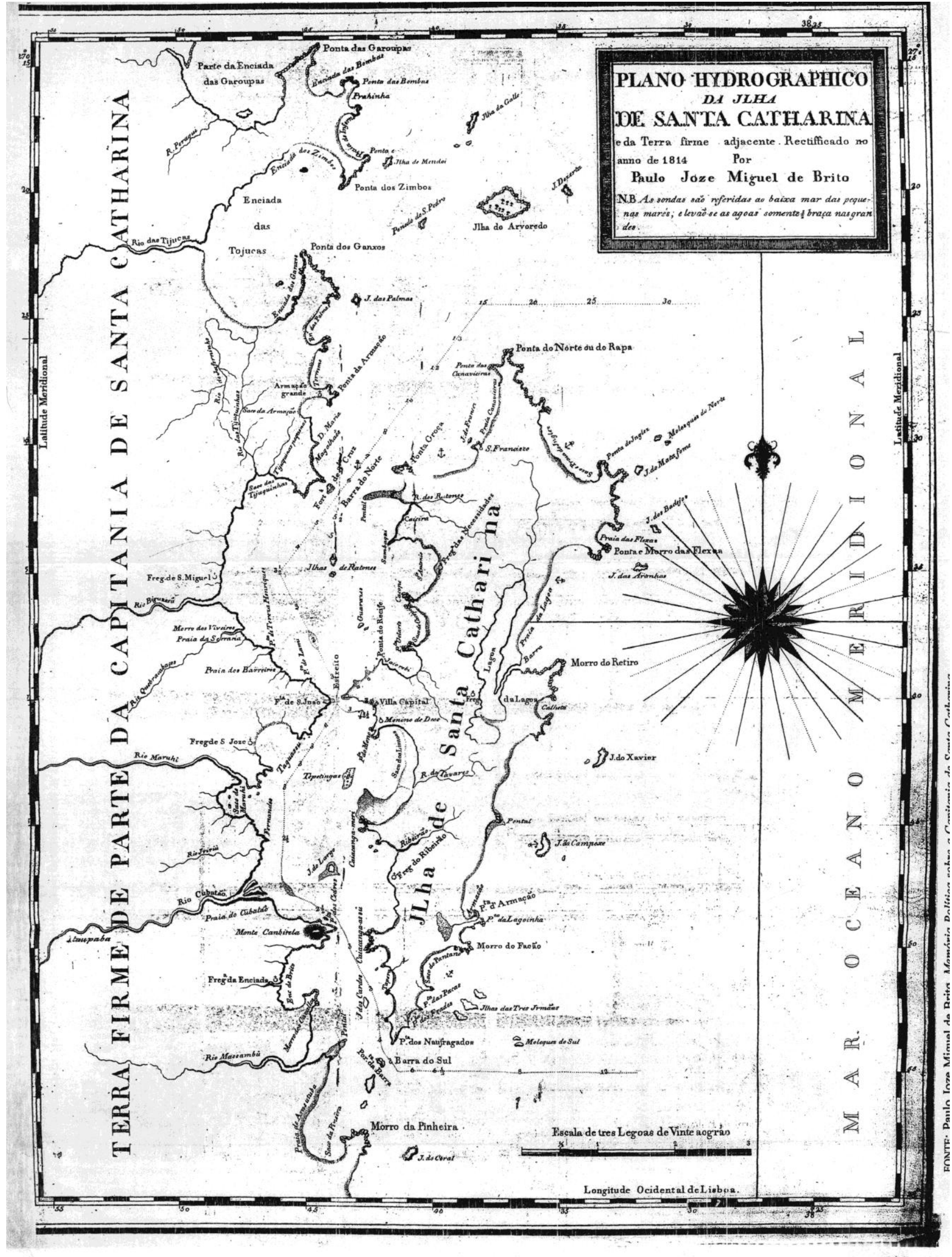

FONTE: Paulo Joze Miguel de Brito. Memória Política sobre a Capitania de Santa Catharina. Lisboa, 1829. 


\section{3 - Administração em tempo de guerra}

Em princípios de maio de 1763, o General D. Pedro de Ceballos, governador de Buenos Aires, entrava com sua tropa na vila do Rio Grande de São Pedro, dando início a uma ocupação, estendida também pelo Continente, que se prolongaria pelos próximos 13 anos. Seu objetivo era avançar mais para o norte, dilatando o império espanhol até a Ilha de Santa Catarina, senão mais além. Todavia, as tropas portuguesas se organizaram ao norte do rio Jacuí e na estreita faixa de terra que separa a lagoa dos Patos e o mar, resguardando assim Viamão, o novo centro político-administrativo do governo, nesse momento, bem mais povoado com os colonos açorianos, que tiveram de deixar a vila do Rio Grande. ${ }^{622}$ A defesa do Continente de São Pedro passou a ser uma das prioridades da Coroa Portuguesa, que tomava esse espaço já como parte de seu território imperial. Economicamente, a produção pecuária e tritícola estavam inseridas no sistema colonial.

A obstrução da barra do Rio Grande pelos espanhóis fez com que, do ponto de vista estratégico, a Ilha de Santa Catarina e a Vila de Laguna se tornassem ainda mais importantes para o Império Português. Praticamente toda a ligação entre a capital do vice-reinado e a fronteira-sul tinha de ser feita por meio desse dois pontos, pois dali até o Rio Grande a retilínea costa litorânea não oferecia nenhum ancoradouro seguro para as embarcações. Os carregamentos, cartas, dinheiros, fardamentos, munições de boca e de guerra vinham do Rio de Janeiro à Ilha, por mar, para depois seguirem de Laguna a Viamão, a Porto Alegre, ou a Rio Pardo, por terra. ${ }^{623}$

Como já referido, o clima de tensão luso-espanhol se acirrou na década de 1770, levando a Corte Portuguesa não só reforçar as suas guarnições no sul, mas reordenar a estrutura de poder daqueles governos. O tenente-general João Henrique de Böhm, nomeado em 1767, para organizar e uniformizar as forças militares do Brasil segundo os

\footnotetext{
${ }^{622}$ Para uma melhor compreensão desse processo histórico ver, entre outros, Dauril Alden. Royal Government..., op. cit., Part Two: The Debatable Lands, pp. 59-275; e Jônathas da Costa Rego Monteiro. “A Dominação Espanhola no Rio Grande do Sul” (1763-1777), in Anais do Simpósio Comemorativo do Bicentenário da Restauração do Rio Grande. - IV Vol. Rio de Janeiro, 1979. Segundo esse autor, "Depois que os espanhóis tomaram conta da vila do Rio Grande, anexaram os Governadores de Buenos Aires aos seus títulos, o de Governador do Rio Grande de S. Pedro e ao governador português do Rio Grande davam o título de Governador de Viamão, de Rio Pardo, etc." Uma distinção, segundo ele, aceita pelos próprios governantes portugueses, como José Custódio de Sá e Faria (p. 207).

${ }^{623}$ Ver ANRJ, Cód. 84, vol. 12, Correspondências dos governadores do Rio de Janeiro com diversas autoridades, ano de 1763; e "Correspondência passiva do General Böhm”, in ABNRJ, vol. 103, 1983.
} 
modernos padrões do exército, fora designado, em 1774, com amplos poderes para comandar todas as tropas no sul. ${ }^{624}$ No "comandamento militar das Praças, Portos, Guarnição e mais Forças" da Ilha de Santa Catarina, nomeava-se, em 19 de setembro de 1774, o então governador e capitão-general da capitania de Minas Gerais, o Brigadeiro Antônio Carlos Furtado de Mendonça. Conservava-se Francisco de Sousa de Meneses no cargo de governador com "toda a economia da mesma Ilha". ${ }^{625}$

Instituía-se, pois, nessa administração, uma espécie de governo dual: a administração civil, a cargo do governador e os assuntos militares, de responsabilidade daquele comandante que, em alguns documentos, aparece também denominado de governador. ${ }^{626}$

Ao General Böhm, entretanto, parece que se delegavam mais amplos poderes. De qualquer forma, os limites e jurisdições dessas autoridades não ficavam muito bem delimitados. Tratando dessa questão e, sobretudo da autoridade que passava a ter o governador do Rio Grande, o vice-rei Marquês de Lavradio dizia àquele general que

Ele [José Marcelino de Figueiredo] é verdade, que é o Governador daquele Continente, mas é para governar naquela parte que V. Exa. lhe permitir assim lhe determinam as minhas ordens, porque ele só enquanto $\mathrm{V}$. Exa. não passou ao Continente é que o seu Comando era geral em todas aquelas Províncias, só com o recurso a mim; porém, depois que V. Exa. em General em Chefe passou a comandar o Exército que guarnece as mesmas Províncias, e a ser V. Exa. a quem eu em virtude das Reais ordens de El-Rei meu Snr., fiz responsável da defesa daquelas Províncias, e de todo aquele Continente foi sustada àquele toda a sua Jurisdição, e tão somente lhe pertence aquele que V. Exa. lhe quiser permitir; e em V. Exa. o chamando, ou lhe declarando esta verdade, pode V. Exa. estar certo, que ele se há de sujeitar como deve, às ordens de $\mathrm{V}$. Exa., e se o não fizer, ainda a minha botica terá remédio com que possa livra a V. Exa. daqueles incômodos. ${ }^{627}$

Sabendo-se com certeza, em maio de 1775, que aquela monumental armada que os espanhóis montavam nos portos do Ferrol e de Cadiz destinava-se à conquista da Ilha

\footnotetext{
${ }^{624}$ Jônathas da Costa Rego Monteiro. “A dominação espanhola...”, op. cit., p. 240.

${ }^{625}$ Carlos Silveira Carneiro (Almirante). Enciclopédia de Santa Catarina. s.n.t., vol. 2, of. n. 36. De Martinho de Melo e Castro a Antônio Carlos Furtado de Mendonça, em 19.09.1774.

${ }^{626}$ AHU-SC, cx. 4, doc. 282. Diz o Visconde de Vila Nova de Cerveira ao Secretário de Estado Martinho

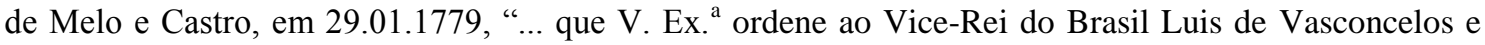
Sousa, remeta presos a este Reino ao Governador da ilha de Santa Catarina, Antônio Carlos Furtado, e aos mais réus acusados da perda daquela Ilha". Da mesma forma se refere Marinho de Melo e Castro ao Marquês do Lavradio, em 22.12.1777. AHU-SC, cx. 4, doc. 269. [Grifo meu]

627 BCRGEH, op. cit., p. 83, Do Marquês do Lavradio ao General João Henrique de Böhm, em 11.01.1776.
} 
de Santa Catarina e de todo o sul do Brasil, ${ }^{628}$ entendia Pombal que era preciso colocar no governo da Ilha alguém mais preparado para a ocasião:

Eu conheço bem, que a bondade, e honra do atual Governador da Ilha de Santa Catarina [Francisco de Souza de Menezes] não basta para que ele sem alguns talentos militares possa reger aquele Governo em uma conjuntura tão crítica. E nesta consideração é Sua Maj. servido que ele se recolha a essa Capital honrado com a Patente de Coronel, para ter o exercício que pelo dito Senhor lhe for determinado. E que V. Ex. ${ }^{a}$ nomeie para o dito Governo aquele oficial que lhe parecer mais próprio da ocasião: Levando o referido posto de Coronel (...). Se ele puder levar consigo mais alguns oficiais, nada será demasiado em uma semelhante ocasião, em que se sabe que os Castelhanos tem a referida Ilha por primeiro objeto da sua expedição para nos cortar a correspondência entre essa Capital e o Rio Grande de São Pedro, e Territórios a ele adjacentes. ${ }^{629}$

Francisco de Sousa de Meneses encontrava-se há mais de dez anos no cargo, tendo sido nomeado por decreto régio. O conceito que dele fazia o Marquês do Lavradio não era nada abonador. Dizia que esse oficial não executava as suas ordens e que, seu "gênio frouxo" e "seus poucos talentos" faziam com que, até o presente, aquela colônia ficasse com pouca diferença e no mesmo estado e desordem em que se conservava desde o seu princípio. ${ }^{630}$ Para substituir Sousa de Meneses, o vice-rei nomeou, em 18 de agosto de 1775, um oficial "digno de confiança", seu ex-Ajudante de Ordens, o Tenente-Coronel Pedro Antônio da Gama Freitas, conferindo-lhe na mesma carta a patente de Coronel.

Embora a nomeação deixasse expressa que Gama Freitas assumia a posse daquele governo "na mesma conformidade que o praticou o governador Francisco de Sousa de Meneses", a quem ia suceder, e "responsável igualmente do que ele o era, na honra, exação e fidelidade", ${ }^{631}$ com que devia proceder na segurança e defesa da mesma capitania, na verdade, ele assumia o cargo com poderes bem mais restritos que seus antecessores, pois todo o mando sobre os assuntos militares estava a cargo do brigadeiro Antônio Carlos Furtado de Mendonça.

\footnotetext{
${ }^{628}$ Carlos Silveira Carneiro (Almirante). Enciclopédia de Santa Catarina. s.n.t., vol. 2, n. 10. Do Marquês de Pombal ao Marquês do Lavradio, em 9.05.1775.

${ }^{629}$ Id. ibid. vol. 2, n. 10.

${ }^{630}$ ANRJ, Cód. 68, vol. 1, fl. 3. Do Marquês do Lavradio ao Secretário de Estado Martinho de Melo e Castro, em 14.06.1776.

${ }^{631}$ AHU-SC, cx. 4, doc. 257. Nomeação ao cargo de governador da Ilha de Santa Catarina, em 18.08.1775.
} 
Percebe-se, no entanto, que esse governo dual não se traduzia numa simples divisão de poderes civis e militares. O general Furtado de Mendonça além de ocupar posto mais alto na hierarquia militar, estava mesmo investido de maiores poderes do que o Coronel Gama Freitas, podendo intervir em questões civis e econômicas daquele governo. Lavradio, numa das instruções que lhe passou, recomendava:

\begin{abstract}
Devo porém lembrar a V. Ex. ${ }^{\mathrm{a}}$ o quanto se faz necessário nessa Ilha, e nas terras que lhe são adjacentes, aumentar-se a lavoura, e a população, e que estes dois objetos satisfeitos são as maiores defesas que têm situações semelhantes: nesta importantíssima matéria só a iluminada Corte cuidou: deu sempre para isso as mais sábias providências, com a infelicidade de não ter nunca, um fiel executor daquelas ordens; tudo talvez tenha sido mistério da providência, para que agora seja mais glorioso o Governo de V. Ex. ${ }^{\text {a }}{ }^{32}$
\end{abstract}

$\mathrm{Na}$ correspondência do Brigadeiro Furtado de Mendonça com o Gen. Böhm tratava-se, sobrretudo, dos assuntos militares. Enquanto o Brigadeiro esteve ocupado com a organização do sistema defensivo da Ilha (recebimento e aquartelamento das tropas, provimento das munições de boca e de guerra das guarnições e demais atividades militares), Gama Freitas dedicava-se ao desenvolvimento da agricultura e à abertura de caminhos terrestres entre as vilas da "capitania de Santa Catarina". No seu governo, segundo ele próprio informou ao Marquês do Lavradio, dedicou-se à produção do anil, da cochonilha e das amoreiras. ${ }^{633}$ De acordo com avaliação do governador José Pereira Pinto dez anos depois, foi com Gama Freitas que o objeto da cochonilha teve o seu maior aumento, isso porque teria tido ele recomendações do Marquês para "usar de meios fortes para obrigar aquela plantação". ${ }^{634}$

Com a iminente invasão da Ilha e do conseqüente bloqueio do seu porto, urgia que se abrissem, ou melhorassem, as passagens por terra entre as vilas de Laguna, São Francisco, Desterro e dessas com São Paulo, pois só através dessa comunicação se poderia formar uma defesa competente daqueles territórios. Em 2 de maio de 1776, Gama Freitas escreve ao vice-rei informando que estava já há mais de cinqüenta dias ocupado com o caminho "mais durável" que mandara abrir de Embaú até a Vila da

\footnotetext{
${ }^{632}$ Do Marquês do Lavradio ao General Antônio Carlos Furtado de Mendonça, em 25.03.1775, in Marquês do Lavradio. Cartas do Rio de Janeiro, 1769-1776. Rio de Janeiro: Publicações do Arquivo Nacional, 1978, carta 527.

${ }^{633}$ ANRJ, Cód. 106, vol. 13, fl. 06. Do governador Pedro Antônio da Gama Freitas ao vice-rei Marquês do Lavradio, em 06.07.1776.

${ }^{634}$ ANRJ, Cód. 106, vol. 9, n. 3. Do governador José Pereira Pinto ao vice-rei Luís de Vasconcelos e Souza, em 31.07.1786.
} 
Laguna, "porque não é crível o estado em que se achava, sendo a única passagem por terra para o Rio Grande". ${ }^{635}$ Cinco meses depois esteve ele encarregado de uma diligência na vila de São Francisco, conforme relatou ao General Böhm:

fiz esta viagem em 14 dias, tendo-os sempre de marcha, e que apesar de alguns de chuva, do mau estado, em que se acham aqueles caminhos feitos de novo por lugares asperíssimos, e com passagens de muitos rios caudalosos; porém, contudo, tenho estimado haver feito aquela diligência pessoalmente; porque só por este modo poderia conseguir com menos defeitos o estabelecimento daqueles casais; providenciar o melhor estado daquela estrada, e passagens de rios; e ultimamente animar com a minha presença aqueles miseráveis povos, que só conheciam os seus governadores pelo nome. ${ }^{636}$

A partir desse momento, a ligação continental entre os povoados e a própria unidade política-territorial da capitania colocam-se como prioridades de governo.

Quanto à relação entre o governador Gama Freitas e o comandante Furtado de Mendonça, diz a historiografia regional que foi, desde o início, muito conflituosa ${ }^{637}$, sendo inclusive colocada como uma das causas que concorreu para o "vergonhoso insucesso" da invasão. ${ }^{638}$ É possível mesmo que tenha havido problemas na jurisdição dos poderes entre um e outro. Na documentação compulsada aqui, a animosidade entre os dois grandes chefes aparece no Auto de defesa de Furtado de Mendonça, quando devassado pela perda da Ilha. Entre outras críticas que fez ao Marquês do Lavradio e a Gama Freitas, dizia ele:

que conheceu bem desde o princípio que contraste ia experimentar na sua comandância. O Marquês vice-rei na Carta de 18 de agosto lhe diz entre palavras afetadas e sonoras, que ele seria o primeiro móvel; o Governador o eco por onde se devia mover tudo - Que importava a voz, se o eco lhe não respondesse? Que importava o primeiro móvel se a mola por onde tudo devia mover-se obstruísse os movimentos? ${ }^{639}$

\footnotetext{
635 ANRJ, Cód. 68, vol. 1, fl. 05. Do governador Pedro Antônio da Gama Freitas ao vice-rei Marquês do Lavradio, em 02.05.1776.

636 ABNRJ, vol. 103, 1983, p. 131. Do governador Pedro Antônio da Gama Freitas ao General João Henrique de Böhm, em 11.10.1776.

${ }^{637}$ Manoel Joaquim d'Almeida Coelho. Memória Histórica da Província de Santa Catarina, op. cit., p. 31; Walter Piazza. Santa Catarina..., op. cit., p. 183; Carlos Humberto Corrêa. História de Florianópolis..., op. cit., p. 102; entre outros.

${ }^{638}$ Joaquim Gomes de Oliveira e Paiva. Dicionário Topográfico, Histórico e Estatístico..., op. cit., p. 237.

${ }^{639}$ Carlos Silveira Carneiro (Almirante). Enciclopédia de Santa Catarina. s.n.t., vol. 9, "Defesa de Antônio Carlos Furtado de Mendonça, respeito à entrega da Ilha de S. Catarina” [cópia].
} 
A invasão espanhola desestruturou a organização política, administrativa e militar da Ilha de Santa Catarina. Além disso, as atividades pesqueiras das duas armações, a da Piedade e a da Lagoinha, foram interrompidas no tempo da ocupação, e alguns lavradores refugiaram-se em povoados do continente. Mas deve-se relativizar essa idéia de desorganização total e inutilização de todos os trabalhos feitos até ali naquele estabelecimento, um discurso colocado pelas autoridades portuguesas e reproduzido pela historiografia. Assim como houve soldados e povoadores que fugiram com a invasão, houve também aqueles que ficaram, desenvolvendo suas habituais atividades. Além do mais, há que se considerar ainda que, toda a preparação para a defesa - o aumento demográfico em decorrência da transferência de tropas para a Ilha e os investimentos da Coroa com o pagamento dos soldos, construção de novas casas e quartéis - provocou certo desenvolvimento da "capitania". Segundo a avaliação do governador Miranda Ribeiro, em 1797,

Em todo o tempo deste Governo [Pedro Antônio da Gama Freitas (177577)], se viu esta Ilha muito abundante de fornecimentos e de dinheiro: se bem que nunca este foi em tanta quantidade, que se pudessem satisfazer algumas dívidas das atrasadas, porque apenas chegava para o diário pagamento das Tropas (...). Neste brevíssimo Governo se Construíram alguns edifícios particulares, e a proporção se aumentou o Comércio: Consequiência e natural produção do giro da moeda no País. ${ }^{640}$

A 31 de julho de 1778, o Coronel e Marechal de Campo Francisco Antônio da Veiga Cabral da Câmara, por ordem do Marquês do Lavradio, recebia a Ilha de Santa Catarina do Marechal de Campo espanhol Guilherme Vaughan. Do ponto de vista das autoridades portuguesas, entrava-se nela "assim como em uma nova Conquista" ${ }^{641}$

\subsection{A refundação da Capitania}

Embora a invasão espanhola da Ilha de Santa Catarina tivesse causado grande susto e manchado os brios lusitanos, não se verificou por parte da Coroa portuguesa nenhuma alteração profunda com relação aos investimentos daquela colônia, no período

\footnotetext{
${ }^{640}$ OMR-1797, fl. 09.

${ }^{641}$ Id., fl. 09.
} 
subseqüente. Os sete governadores que passaram pela Ilha entre 1778 e 1807, enfrentaram inclusive maiores dificuldades na condução de seus governos tendo em vista a tensão cada vez maior entre as exigências do Império, as condições concretas da colônia para executá-las e as demandas locais.

Veiga Cabral da Câmara governou a Ilha por menos de um ano e, segundo relato de Miranda Ribeiro, pôde apenas

revocar e arranjar os povoadores dispersos às possessões dos seus prédios, juntar o resto do Regimento da Guarnição, que se tinha debandado depois da infeliz entrega, restituir os Magistrados Civis à prática das suas competentes jurisdições, e finalmente, em reparar passivamente alguns danos, que tinham feito os Inimigos. Este mesmo Governador viu com bastante mágoa sua, que os soldados andavam descalços e desfardados, fazendo o serviço; que a mesma Tropa não tinha Quartéis, nem Hospital, (...) A Marinha sem os precisos Vasos para o serviço diário de navegar por Longas e desabridas Baías, que medeiam entre a Ilha, as Fortalezas e Terra Firme. As fortificações e os mais edifícios Reais, ameaçando ruína, e finalmente tudo dependente de uma pronta e imediata providência: e como lha poderia dar o Governador, se nenhumas possibilidades tinha para isso, e as suas Representações eram inatendíveis por aquele mesmo, que lhe devia fornecer os meios? ? $^{64}$

A crítica de Miranda Ribeiro recaía, como sempre, àqueles a quem os governadores, contrariados, deviam inteira submissão: os vice-reis. Mas a falta de recursos para a Ilha não era culpa da inépcia ou da má vontade desses administradores. Havia por certo distribuição desigual de recursos aos diferentes territórios coloniais face às prioridades da Coroa. Tratava-se, na verdade, de problemas estruturais de Portugal com a manutenção de suas conquistas na América. As transformações do mundo europeu no último quartel do século XVIII - Revolução Industrial inglesa e a Revolução Francesa (1789-93) - e o desenvolvimento político (demarcado, sobretudo, pela independência dos Estados Unidos da América em 1776) e econômico das colônias, exacerbavam as contradições do Antigo Sistema Colonial.

Segundo Fernando Novais, a crise surge no interior do sistema colonial assim como também os fatores de sua superação. Apesar de a sociedade escravista colonial possibilitar a ascensão da burguesia européia ela não deixa de se antepor a ela. "No conjunto, tal configuração do mundo colonial responde ao funcionamento do sistema, enquanto as economias centrais se desenvolvem apenas no nível artesanal, ou mesmo manufatureiro. Quando porém essa etapa é ultrapassada, e a mecanização da produção

${ }^{642}$ OMR-1797, fls. 09 e 10. 
com a Revolução Industrial, potenciando a produtividade de uma forma rápida e intensa, leva a um crescimento da produção capitalista num volume e ritmo que passam a exigir no ultramar mais amplas faixas de consumo, consumo não só de camadas superiores da sociedade, mas agora da sociedade como um todo, o que se torna imprescindível é a generalização das relações mercantis. Então o sistema se compromete, e entra em crise". ${ }^{643} \mathrm{O}$ atraso na agricultura e indústria portuguesas fez com que Portugal buscasse um fortalecimento do exclusivo-colonial aumentando ainda mais as tensões que levaram ao fim do sistema. ${ }^{644}$

Santa Catarina insere-se de maneira peculiar nesse processo, pois, embora a escravidão tenha desempenhado um papel significativo nessa sociedade, como se mostrou, a organização de grande parte das atividades produtivas pautou-se pelo trabalho assalariado e pela formação de pequenas e médias propriedades privadas, dando origem a núcleos de povoamento inclinados para uma economia de subsistência e de abastecimento interno de outras praças coloniais.

A função primordial da Ilha para o Império Português foi, por todo o período que aqui se estuda, a defesa do território, sobretudo do Continente do Rio Grande, que se valorizara mais em função da criação do gado e das plantações de trigo. Mas, a expectativa das autoridades metropolitanas era de que todo o investimento feito na Ilha, com o povoamento dos casais, fizesse dela não só um estabelecimento auto-sustentável economicamente, mas também fornecedora de produtos para o mercado europeu, o que não se realizou plenamente. As armações baleeiras montadas nos moldes das grandes empresas escravistas cumpriram seu papel e proporcionaram fabulosos lucros aos comerciantes de Lisboa por toda a segunda metade do século XVIII; a produção da farinha de mandioca desempenhou também papel importante nos negócios coloniais, embora, seus produtores, pouco a pouco buscassem mercados alternativos para sua comercialização; e todas as iniciativas da Coroa Portuguesa com a implantação de culturas vantajosas ao comércio colonial, como o algodão, o linho cânhamo e a cochonilha, foram de modo geral frustradas.

Grande problema para os governadores na administração da capitania seria o déficit orçamentário da Provedoria da Real Fazenda da Ilha de Santa Catarina, crescente

\footnotetext{
${ }^{643}$ Fernando A. Novais. Portugal e Brasil na Crise..., op. cit., pp. 106 e 112.

${ }^{644}$ Id. ibid., Capítulo III - "Os Problemas da Colonização Portuguesa". Sobre o conceito de "exclusivocolonial" ver à p. 72: "O chamado 'monopólio colonial', ou mais corretamente e usando um termo da própria época, o regime do 'exclusivo metropolitano' constituía-se pois no mecanismo por excelência do sistema, através do qual se processava o ajustamento da expansão colonizadora aos processos da economia e da sociedade européias em transição para o capitalismo integral."
} 
no final do século XVIII, como mostra o quadro abaixo. As remessas trimestrais que vinham da capitania do Rio de Janeiro para cobrir parte desse déficit tornaram-se cada vez menores, elevando a dívida com o pagamento dos militares, dos civis e dos eclesiásticos.

Quadro n. 3.9

Receitas principais da Provedoria da Real Fazenda da Ilha de Santa Catarina e dívida acumulada em mil réis $(1774-1789)^{645}$

\begin{tabular}{|c|c|c|c|c|c|c|}
\hline \multirow{2}{*}{ Ano } & \multicolumn{4}{|c|}{ Receitas } & \multirow{2}{*}{$\begin{array}{c}\text { Despesa } \\
\text { orçada }\end{array}$} & \multirow{2}{*}{$\begin{array}{l}\text { Dívida } \\
\text { acumulada } \\
\text { c/as } 3 \text { folhas } \\
\text { de pagto. }\end{array}$} \\
\hline & $\begin{array}{l}\text { Contrato } \\
\text { dos } \\
\text { Dízimos }\end{array}$ & $\begin{array}{l}\text { Contrato da } \\
\text { pesca das } \\
\text { baleias }\end{array}$ & $\begin{array}{l}\text { Remessas } \\
\text { da Prov. da } \\
\text { Faz. do Rio } \\
\text { de Janeiro }\end{array}$ & Total & & \\
\hline 1774 & $4: 600 \$$ & 4:000\$ & & & & $477 \$$ \\
\hline 1775 & & $4: 000 \$$ & & & & $1: 011 \$$ \\
\hline 1776 & & 4:000\$ & & & & $7: 395 \$$ \\
\hline 1777 & & 4:000\$ & & & & $11: 297 \$$ \\
\hline 1778 & & 4:000\$ & & & & $14: 402 \$$ \\
\hline 1779 & $4: 720 \$$ & 4:000\$ & $24: 000 \$$ & $32: 720 \$$ & $38: 845 \$$ & 20:096\$ \\
\hline 1780 & 4:720\$ & 4:000\$ & $24: 000 \$$ & $32: 720 \$$ & & \\
\hline 1781 & $4: 720 \$$ & 4:000\$ & $18 \$ 000 \$$ & $26: 720 \$$ & & \\
\hline 1782 & 4:720\$ & 4:000\$ & $12: 000 \$$ & $20: 720 \$$ & & \\
\hline 1783 & $4: 720 \$$ & 4:000\$ & $0 \$$ & $8: 720 \$$ & & $20: 520 \$$ \\
\hline 1784 & 4:720\$ & 4:000\$ & $12: 000 \$$ & $20: 720 \$$ & & $19: 208 \$$ \\
\hline 1785 & $4: 720 \$$ & 4:000\$ & $6: 000 \$$ & $14: 720 \$$ & & $26: 648 \$$ \\
\hline 1786 & $4: 786 \$$ & 4:000\$ & $6: 000 \$$ & $14: 786 \$$ & & 29:294\$ \\
\hline 1787 & $4: 786 \$$ & 4:000\$ & $6: 000 \$$ & $14: 786 \$$ & & $34: 402 \$$ \\
\hline 1788 & $4: 786 \$$ & $4: 000 \$$ & $0 \$$ & $8: 786 \$$ & & $45: 916 \$$ \\
\hline 1789 & 4:920\$ & $4: 000 \$$ & $0 \$$ & $8: 920 \$$ & & $60: 372 \$$ \\
\hline 1790 & 4:920\$ & $4: 000 \$$ & $6: 000 \$$ & $14: 920 \$$ & & \\
\hline 1794 & $5: 066 \$$ & $4: 000 \$$ & $16: 119 \$$ & $25: 185 \$$ & $40: 712 \$$ & \\
\hline
\end{tabular}

Embora o quadro não apresente a contabilidade completa desses anos (utilizouse dos dados disponíveis nas contas correntes da Provedoria da Ilha), não sendo incluídas receitas menores como os rendimentos das passagens dos rios, dos foros da marinha, da chancelaria, entre outros, e, consideradas somente as despesas orçadas em dois anos (maior parcela dessas quantias referentes às folhas civil, militar e eclesiástica),

${ }^{645}$ ANRJ, Cód. 106, “Conta Corrente dos Cofres da Provedoria da Real Fazenda...”: vol. 01 (1774-1779), vol. 03 (1780), vol. 04 (1781), vol. 05 (1782), vol. 06 (1783), vol. 07 (1784), vol. 08 (1785), vol. 09; (1786), vol. 10 (1787), vol. 11 (1788), vol. 12 (1789); Cód. 109, vol. 01 (1790 e 1794) "Conta Geral dos Rendimentos Reais que se cobram anualmente..."; e "Conta Geral da Despesa que faz anualmente a Real Fazenda...". Para se ter uma noção do percentual de cada uma das folhas na dívida acumulada, tomandose o ano de 1779, do total de 20:096\$000 réis, $70 \%$ corresponde aos militares, $23 \%$ aos civis e $7 \%$ aos eclesiásticos. 
pode-se concluir que o orçamento da capitania por todo esse período foi sempre deficitário. Não se têm os valores da dívida nos anos de 1780 a 1782, entretanto, percebe-se que entre 1779 e 1783 ela ficou praticamente estacionária, evidenciando que houve pagamento das folhas naquele período. No restante da década, todavia, a dívida cresceu em ritmo acelerado, em decorrência da diminuição - ou mesmo ausência nos anos de 1783, 1788 e 1789 - das remessas de numerários enviadas pela Provedoria do Rio de Janeiro. A dívida pública não era só com os “filhos da folha”, incluía também os lavradores, pescadores, boticário do hospital e outros profissionais. Segundo Paulo Joze Miguel de Brito, esse estado de coisas melhorou no vice-reinado de D. Fernando José de Portugal e Castro, o Marquês de Aguiar (1801-1806), quando se restabeleceu a consignação anual para a Provedoria da Ilha de 24:000\$000 de réis anuais para satisfazer as despesas do Regimento de Linha e começou a liquidar-se e a pagar-se a dívida atrasada da Fazenda Real, mediante a Junta da Revisão que se estabeleceu nesta cidade [Rio de Janeiro]; em conseqüência, muitos dos credores do Estado, tanto lavradores, como comerciantes, e militares cobraram o que se lhes devia e por isso principiou a girar mais dinheiro na Capitania, e a prosperar a fortuna de várias classes dos habitantes." 646

A falta de recursos não era um problema específico da Ilha de Santa Catarina. Déficits orçamentários eram enfrentados via de regra por todos os governadores coloniais. Em 1779, o governador Francisco de Barros Moraes reclamava ao vice-rei: “Tudo aqui são dívidas, e tudo é pedir dinheiro..." $" 647$; ao que esse lhe respondeu: "O mesmo sucede nesta cidade sem ter atualmente meios com que possa mandar satisfazer a infinitas pessoas miseráveis que estão clamando pelo pagamento do que se lhes deve". ${ }^{648}$ Contudo, as baixas receitas fixas e a manutenção de grande número de tropas tornavam a situação mais complexa na administração de Santa Catarina. Na mesma carta informava aquele governador que o comandante da Vila de Laguna estava há 18 meses sem receber pagamento para sua guarnição e que para a subsistência dos soldados estava constrangendo os pescadores para que fornecessem peixe a eles. Constrangimento esse que, depois de tantos meses de opressão, podia "arrebentar com alguma má conseqüência”.

\footnotetext{
${ }^{646}$ Paulo Joze Miguel de Brito. Memória Política sobre a Capitania de Santa Catarina. Rio de Janeiro, [1816], pp. 69-70.

${ }^{647}$ ANRJ, Cód. 106, vol. 01, of. n. 3. Do governador Francisco de Barros Moraes ao vice-rei Luis de Vasconcelos e Souza, em 07.07.1779.

${ }^{648}$ ANRJ, Cód. 106, vol. 01, of. XIII. Do vice-rei Luis de Vasconcelos e Souza ao governador Francisco de Barros Moraes, em 01.10.1779.
} 
Via de regra, as remessas da provedoria da Fazenda do Rio de Janeiro para o pagamento das tropas do Rio Grande eram o dobro das que iam para a Ilha de Santa Catarina. Ocorreu, no entanto, algumas vezes um fato que, quando publicizado, provocou consternação entre os moradores da Ilha. Nos momentos de maior crise financeira, quando praticamente se deixara de pagar qualquer soldo aos militares, salário aos funcionários e côngruas aos párocos, registravam-se entradas de numerário na provedoria de Santa Catarina, de remessas enviadas do Rio de Janeiro, mas que se destinavam integralmente para o pagamento da guarnição do Rio Grande. ${ }^{649}$

Em 21 de março de 1783, em outra missiva ao vice-rei, Francisco de Barros Moraes expõe esse grave problema:

\begin{abstract}
Quando chegaram os oficiais com o Coronel [Francisco João] Roscio, não se descuidaram os desta Ilha, sabendo que vinha um pagador com dinheiro, de lhes perguntar se vinha também para esta Tropa: conhecendo então pela resposta que não vinha, que lá não havia para o remeter (...) foi e tem sido uma geral consternação; têm falado ou murmurado em particular uns com outros (sem que até ao presente, contudo, seja por modo criminoso) pela quase extrema necessidade em que se acham (...) Não têm eles que comer, que vender ou empenhar, salvo se for o uniforme e as camisas; nem ache quem lhes fie, porque como a experiência mostra que não têm soldos nem por onde paguem, ninguém lhes quer emprestar (...): a necessidade vai crescendo de forma que os oficiais se têm metido a pescadores (até agora por modo descente) para terem eles e suas famílias alguma coisa que comer, mas brevemente lhes será necessário fazê-lo por ofício (...). ${ }^{650}$
\end{abstract}

Se, no passado, nos momentos críticos de guerra com os espanhóis, os lavradores foram recrutados para servir no exército, agora ocorria um movimento contrário, a falta prolongada no pagamento dos soldos obrigava os soldados a fazeremse lavradores ou pescadores, e tiveram eles, como se pôde ver, a permissão do governador para isso. Nem podia ser diferente. As circunstâncias exigiam mesmo um afrouxamento das regras sociais. Francisco de Barros Moraes, sem se embaraçar com o regulamento passou a conceder licenças aos soldados e oficiais inferiores, mesmo nos meses em que essas eram proibidas.

Procurando sensibilizar ainda mais o vice-rei para as nefastas consequiências que poderiam advir daquela situação em que se encontrava a Ilha de Santa Catarina, o

\footnotetext{
${ }^{649}$ ANRJ, Cód. 106, vol. 09, "Conta corrente dos cofres da Provedoria... janeiro de 1786"; vol. 10, idem, março de 1787; vol. 11, idem, julho de 1788; vol. 12, idem, fevereiro de 1789.

${ }^{650}$ ANRJ, Cód. 106, vol. 06, of. 6. Do governador Francisco de Barros Moraes Araújo Teixeira Homem ao vice-rei Luis de Vasconcelos e Souza, em 21.03.1783.
} 
governador tocou num dos pontos talvez mais delicados na governança das conquistas: a falta de fidelidade dos súditos para com o soberano. Nada podia ser mais agressivo e desonroso para o vice-rei, nesse contexto em que as feridas da invasão de 1777 encontravam-se ainda abertas, do que a ameaça de ter seus vassalos em harmonia com a nação invasora. No mesmo ofício anterior, dizia Francisco de Barros:

quando vim para esta Ilha e dentro dos primeiros seis meses, nas ocasiões em que os paisanos me visitavam, se na prática se vinha a falar nos Espanhóis (o que nos Paisanos era freqüente) tudo era gabá-los de boa gente, carregando no ponto de que pagavam tudo prontamente, e por grande preço, que não tomavam coisa alguma, que girava muito dinheiro, e que alguns Ilhéus se enriqueceram com o que lhes venderam: eles não diziam mais, porém, via eu, que no fundo do seu coração, amavam o Governo Espanhol, pela freqüência com que dele falavam, e por quê.

Se em outras ocasiões se falava nos meus antecessores, e na Fazenda Real, tudo era lastimarem-se que nada ou pouco se pagava, que se tomavam as farinhas aos lavradores, e que se estavam devendo de há muitos anos, motivo porque se não cuidava como devia na sua cultura, que se deviam muitos jornais, muita cal, madeiras, fazendas etc., e que por estas expressões percebia eu neles uma aversão a este modo de Governar.

Talvez, mais do que o problema da infidelidade dos súditos, a grande preocupação do governador fosse justamente a redução do seu poder naquela administração em decorrência da falta de recursos. Os governadores, de uma maneira geral, deviam também ter "aversão a este modo de Governar". De qualquer forma, seu interessante relato nos leva a relativizar o impacto da invasão espanhola na Ilha. É possível que alguns povoadores, senão também militares, tenham não só permanecido na Ilha - ou regressado para ela - após a invasão, mas levado suas vidas de maneira habitual, desenvolvendo suas atividades profissionais como antes, ou até com maior sucesso no período da ocupação. Mas tudo isso são hipóteses que necessitam de pesquisas empíricas para apuração, o que não é tarefa fácil, pois faltam documentos sobre esse tempo histórico.

Pelo menos até o início do século XIX, a dívida da Fazenda Real com os militares continuou sendo volumosa. Em 1797, João Alberto de Miranda Ribeiro registrou em seu Relatório de governo que se deviam 82 meses de soldos ${ }^{651}$; em 1801 ,

${ }^{651}$ RMR-1797, p. 159. 
Joaquim Xavier Curado registrava que se deviam 31 meses à tropa, "sem contar a dívida atrasada"! ${ }^{652}$

À vista de todas essas questões referidas, dizia Miranda Ribeiro à rainha,

claro está que todos geralmente vivem, e têm vivido em uma profunda consternação de maneira que o Corpo Militar, da mesma sorte que os Paisanos, formam um Exército de descontentes, que para não chegarem ao último ponto de exasperação, não custa poucos direitos, fadigas, trabalho, e ainda susto, a quem imediatamente os Governa! Mas que fiéis e Leais Vassalos têm Vossa Majestade nesta Conquista! Eles na verdade são dignos da Real atenção e Piedade de Vossa Majestade. ${ }^{63}$

Tratava-se evidentemente da perspectiva particular dos governadores. O nãopagamento dos soldos e salários, de fato, causava descontentamento entre os povoadores, mas isso também os impelia a buscarem alternativas de sobrevivência. Além do mais, servir nas tropas de primeira linha era quase sempre um pesado sacrifício para os homens naqueles tempos, em decorrência do austero regime disciplinar que lhes eram impostos nos regimentos. Logo, o afrouxamento da disciplina militar que aquela situação causava e a liberação para desenvolverem outras atividades pode até mesmo ter agradado aqueles "pobres" soldados.

\subsubsection{Frutos e produções da terra}

Desde o princípio do governo da Ilha de Santa Catarina com José da Silva Paes houve por parte da Coroa Portuguesa a preocupação com o desenvolvimento das culturas próprias da terra e das que podiam ser implementadas. Com a transmigração dos casais das ilhas, em meados do século XVIII, projeto audacioso e caro aos cofres reais, a monarquia esperava atingir mais do que o povoamento e a defesa daqueles territórios, queria também o seu desenvolvimento econômico em favor do comércio português. Como já se mostrou ao longo desse trabalho, boa parte desses objetivos foi cumprida. Contudo, do ponto de vista da monarquia, as produções que se extraía da Ilha e seu continente nunca foram plenamente satisfatórias.

\footnotetext{
${ }^{652}$ ANRJ, Cód. 106, vol. 15, of. 27. Do governador Joaquim Xavier Curado ao vice-rei Conde de Rezende, em 15.08.1801.

${ }^{653}$ OMR-1797, fl. 20.
} 
O peso da economia de Santa Catarina nos negócios coloniais era, de fato, menor que o das capitanias-gerais e também do Rio Grande de São Pedro. Entretanto, faltam estudos específicos que avaliem melhor a participação daquelas produções, sobretudo da farinha de mandioca, no comércio intercolonial.

A consciência das autoridades e da intelligentsia portuguesas, no reinado de D. Maria I e do Príncipe Regente, de que a economia de Portugal encontrava-se defasada em relação a outras nações européias levou a Corte a tomar uma série de medidas a serem implantadas nas conquistas, no sentido de tentar superar a crise, entre elas, a preservação do exclusivo-colonial, o combate ao contrabando, o fim dos monopólios comerciais, a abertura para o comércio intercolonial, o incentivo à produção e a proibição das manufaturas têxteis. ${ }^{654}$

Da fase autoritária do pombalismo - fortalecimento do Estado e imposição de reformas econômicas - passa-se, a partir de 1777, para uma etapa de maior abertura para o pensamento ilustrado, mas sem abrir mão das práticas mercantilistas. ${ }^{655}$

Controlar as arribadas de navios estrangeiros no porto da Ilha de Santa Catarina, ou em outros pontos da costa litorânea de sua jurisdição, sempre esteve entre as responsabilidades dos seus governadores. No final do período colonial, entretanto, o contrabando passou a exercer um papel maior na distensão do exclusivo-colonial. A emergência da Revolução Industrial inglesa dava a essa nação "uma posição competitiva de outra natureza, dado o barateamento dos custos de produção advindos da mudança tecnológica". ${ }^{656}$ Após o Alvará de 5 de janeiro de $1785^{657}$, instrumento legislativo fundamental no combate ao contrabando nesse período, multiplicam-se os ofícios e ordens aos governadores da Ilha no sentido de impedir a prática desse comércio ilícito. ${ }^{658}$ Em 28 de novembro de 1797, uma ordem real mandava que todas as embarcações que saíssem dos portos do Rio Grande, Ilha de Santa Catarina e Santos se incorporassem no porto do Rio de Janeiro para que dali fossem escoltadas para o reino por uma esquadra de guerra. ${ }^{659}$ Em junho de 1804, o vice-rei mandou inclusive que um

\footnotetext{
${ }^{654}$ Ver. Fernando A. Novais. Portugal e Brasil na Crise..., op. cit., pp. 213-298.

${ }^{655}$ Id. ibid., p. 224.

${ }^{656}$ Id. ibid., p. 242.

${ }^{657}$ Transcrito em AESP, DI, vol. 25, p. 94.

${ }^{658}$ Ver APESC, “Ofícios do Vice-rei para o Governador da Capitania (1782-1789)", vol. 1 e vol. 2; idem (1790-1792), idem (1793-1798), idem (1799-1802).

659 APESC, "Ofícios do vice-rei para o Governador da Capitania (1793-1798)", n. 456. Do Conde de Rezende a João Alberto de Miranda Ribeiro, em 28.11.1797.
} 
bergantim fizesse o controle periódico em pequenos cruzeiros (de 12 ou de 15 em 15 dias) entre o porto da Ilha e a barra de Santos, para evitar neles os contrabandos. ${ }^{660}$

A extinção das companhias de comércio a partir de 1778 visava a aumentar a concorrência entre os negociantes portugueses e, dessa forma, elevar o comércio colonial. Nesse sentido, o Alvará de 18 de maio de 1798 facultava a todo comerciante português, individualmente, ou em sociedade, preparar e armar navios destinados a pesca da baleia no alto mar. ${ }^{661}$ Ao findar o contrato dos Quintela, em 1801, o Príncipe Regente aboliu definitivamente esse monopólio, pelo Alvará de 24 de abril daquele ano. Contudo, a concorrência nesse negócio viria de fora: a penetração dos baleeiros estrangeiros, sobretudo de ingleses e de norte-americanos, desde o final do século XVIII, foi um dos fatores a contribuir para a decadência dessa indústria portuguesa. ${ }^{662}$

Outra medida adotada para tentar tirar Portugal do atraso econômico foi a abertura do comércio entre as colônias. A Provisão de 17 de março de 1791 permitia ao Rio de Janeiro que os gêneros produzidos no continente pudessem girar de um para outro porto, livre de todos os direitos. Como observou Novais, uma posição intermediária entre o mercantilismo tradicional e as novas teorias econômicas liberais. ${ }^{663}$

No último quartel do século XVIII e princípios do século seguinte intensificaram-se as instruções da Corte para o aumento e melhoria da qualidade da produção em todas as colônias de uma maneira geral. Incentivava-se o plantio do arroz, de diferentes tipos de linho, da cochonilha, do anil, da amoreira, do trigo, entre outros produtos, mas os resultados nem sempre foram compensadores. Muitos livros e impressos vinham nos navios portugueses "destinados a instruir os habitantes do Brasil em vários artigos de Agricultura, e outros objetos". 664

\footnotetext{
${ }^{660}$ APESC, "Ofícios do vice-rei para o Governador da Capitania (1802-1808)", n. 603. De D. Fernando José Portugal a Joaquim Xavier Curado, em 11.06.1804.

${ }^{661}$ Myriam Ellis. A Baleia no Brasil Colonial. São Paulo: Melhoramentos, 1969, p. 160.

${ }^{662}$ Id. ibid., pp. 166-184.

${ }^{663}$ Fernando A. Novais. Portugal e Brasil na Crise..., op. cit., p. 250.

${ }^{664}$ APESC, "Avisos diversos ao governador da Capitania, 1748-1804", of. 41 de Rodrigo de Souza Coutinho ao governador João Alberto de Miranda Ribeiro, em 01.04.1799. Entre tantos outros títulos que entraram no porto da Ilha de Santa Catarina, aparecem registrados no mesmo códice: of. 42, de Souza Coutinho à Miranda Ribeiro, em 6.05.1799 - 50 vols. de Cultura do Linho Cânhamo a $\$ 320$ réis o vol.; 5 vols. de Artes da Língua Geral do Brazil a \$600; 15 vols. de Dicionários da mesma Língua a \$600; 12 vols. de Discurso Sobre o melhoramento do Arado (grátis); of. 49 - de Souza Coutinho à Miranda Ribeiro, em 23.12.1799 - 3 vols. de Architetura Naval a 1\$200; 6 vols. de Mineralogia de Bergman a \$960; 40 vols. de Cultura do Cânhamo por Mercandier a \$240; 40 vols. de Coleção Ingleza sobre a Cultura do Cânhamo a \$320; 50 vols. de Memória sobre os queijos Roquefort a \$100; 25 vols. de Cultura do Tabaco nos Estados Unidos da América (sem valor); 50 vols. de Memória Sobre a Cultura da Urumbeba a $\$ 120$ etc.
} 
Em 4 de novembro de 1778, Martinho de Mello e Castro escrevia ao vice-rei Marquês do Lavradio dizendo-lhe que o "importante artigo do Anil” já fazia um ramo do "Comércio Nacional e que nas diferentes fábricas deste Reino se não gasta de outro". ${ }^{665}$ O Brasil deveria fornecer as matérias-primas para o desenvolvimento das fábricas têxteis no reino.

Depois de que escrevi a V. Ex. ${ }^{a}$ sobre as tintas, se têm feito diferentes experiências no Laboratório Químico das Madeiras, e cascas que V. Ex. ${ }^{a}$ me remeteu, das quais se extraíram ao todo setenta e tantas cores, muitas delas excelentes; e se fica tirando uma relação das melhores, para que dessa Capitania se remetam, e vão remetendo quantidades suficientes para se formarem as Fábricas.

E dizia mais o secretário:

O grande objeto presentemente é o da cochonilha: Da pequena porção desta preciosa Droga que V. Ex. ${ }^{a}$ me remeteu se fez a experiência com a Espanhola, com iguais porções (...) e o que dela resultou é (...) que não há a menor diferença entre uma e outra; e que somente resta animar os cultivadores (...).

Ao governador da Ilha, Francisco de Barros Moraes, o vice-rei Luís de Vasconcelos e Souza recomendava o cultivo desse produto enviando inclusive, junto à carta de 10 de novembro de 1779, uma "Instrução do modo com que se deve apanhar e preparar a cochonilha...". 666 O Marquês do Lavradio já havia dado instruções aos governadores anteriores, Francisco de Souza de Meneses e Pedro Antônio da Gama Freitas, a esse respeito. Com esse último, a cultura da cochonilha encontrou certo desenvolvimento, ${ }^{667}$ mas, segundo declaração de José Pereira Pinto, em 31 de julho de 1786, foi "desprezada inteiramente no tempo da invasão" espanhola, e nesse estado ela ainda se achava. ${ }^{668}$ Francisco de Barros entendia que a causa principal de não se ter alcançado sucesso nessa produção advinha do fato de que o lavrador cuidava da árvore e dos bichos com "grande repugnância" e que preferia

\footnotetext{
${ }^{665}$ BNRJ, Mss. CEHB 5616 - 3, 4, 7, n. 111.

${ }^{666}$ ANRJ, Cód. 106, vol. 01, n. XXI.

${ }^{667}$ Ver p. 214.

${ }^{668}$ ANRJ, Cód. 106, vol. 09, of. 3. Do governador José Pereira Pinto ao vice-rei Luís de Vasconcelos e Souza.
} 
cuidar naquilo que para logo ajuda a sustentá-lo, a ele e sua família; e como via que a conveniência que lhe podiam dar estes arbustos era muito para 0 futuro, queria aplicar o seu cuidado à cultura da farinha, milho, arroz, e outros gêneros que para logo podiam remediar as suas necessidades. ${ }^{669}$

O governador dava a entender aí que ocorria uma não-sintonia entre as diretrizes traçadas pela Corte para aquela colônia e seu efetivo processo histórico. Fato esse que tenderia a se agravar no futuro.

Experiência semelhante parece ter ocorrido com a cultura do linho cânhamo em Santa Catarina, no mesmo período. Reiterados ofícios, cartas e instruções dos vice-reis, com a remessa das sementes do linho, também nas qualidades, "galego", “donzela" e de "riga", para ver qual se adaptava mais àquele país, foram enviados aos seus governadores, mas os resultados, pelo menos para a expectativa das autoridades portuguesas, mostraram-se medíocres. Algumas plantas cultivadas na Ilha foram enviadas pelo vice-rei para Real Cordoaria de Lisboa que, após o exame constatou ser elas da "mesma força e rigidez que tem o Linho Cânhamo de Riga, que entre todos é o que (...) tem uma geral preferência". Por esse motivo recomendava S. Maj. "novamente o estabelecimento deste importantíssimo objeto", ${ }^{670}$

Francisco de Barros encontrava nos fatores climáticos - "os frios e os ventos", "a seca", ou ainda, o plantio em estação errada - a explicação para os repetidos fracassos no desenvolvimento dessa cultura na Ilha e seu continente. ${ }^{671}$ Para o vice-rei, todavia, o motivo era outro. Dizia ele:

vejo assaz provada a grande eficácia com que V. S. ${ }^{\text {a }}$ tem procurado promover esta tão útil e importante sementeira, sendo certo que, se ela se não tem adiantado mais a proporção dos esforços de V. S. ${ }^{a}$ é mais pela indolência, e desmazelo dos Lavradores do que pela irregularidade da estação, com que sempre tem argumentado. ${ }^{672}$

Não se tratava de indolência ou desmazelo dos lavradores, mas sim desinteresse deles em se dedicarem a atividades pelas quais já sabiam de antemão dos baixos

\footnotetext{
${ }^{669}$ ANRJ, Cód. 106, vol. 03, of. 6. Do governador Francisco de Barros Moraes Araújo Teixeira Homem ao vice-rei Luís de Vasconcelos e Souza, em 21.03.1780.

${ }^{670}$ ANRJ, Cód. 106, vol. 08, of. VII. Do vice-rei Luís de Vasconcelos e Souza ao governador Francisco de Barros Moraes Araújo Teixeira Homem, em 10.03.1785.

${ }^{671}$ ANRJ, Cód. 106, vol. 05, of. 10, Do governador Francisco de Barros Moraes ao vice-rei Luís de Vasconcelos e Souza, em 1782; vol. 08, of. 20, Do governador Francisco de Barros Moraes ao vice-rei Luís de Vasconcelos e Souza, em 31.10.1785.

${ }^{672}$ ANRJ, Cód. 106, vol. 09, of. VI. Do vice-rei Luís de Vasconcelos e Souza ao governador Francisco de Barros Moraes, em 08.05.1786.
} 
retornos financeiros que teriam. Como homens livres tinham suas estratégias para contornar essa situação. Produziu-se linho em Santa Catarina, mas que servia sobretudo para abastecer os teares locais que, como se verá logo em seguida, não eram poucos. Quando se usou da violência, como o fez o governador Pedro Antônio da Gama Freitas, extraiu-se maior excedente dessa produção. No tempo de Francisco de Barros Moraes, segundo relatou José Pereira Pinto, pouco se produziu, "talvez por lhe faltar amplos poderes para os obrigar, até com alguma pequena violência; ou por não ser do seu sistema empreender estes e outros semelhantes objetos, que o podiam de alguma forma comprometê-lo com estes Povos". 673

Pereira Pinto estava convencido de que o "verdadeiro Sistema de Política de um homem público [era] preencher as suas obrigações com imparcialidade e desinteresse, escolhendo contudo um meio termo entre a violência e a frouxidão.”

\section{Quadro 3.10}

Mapa da quantidade de Gêneros e efeitos que se colhem e fabricam anualmente na Ilha de S. Catarina e nos mais distritos da sua jurisdição, feito pelas memórias e observações do que aconteceu no ano de $1796^{674}$

\begin{tabular}{|c|c|c|c|c|c|c|c|c|c|c|c|}
\hline Produt & Freguesias & $\begin{array}{l}\text { Desterro } \\
\text { e } \\
\text { Ribeirão }\end{array}$ & Lagoa & $\begin{array}{l}\text { Necessi- } \\
\text { dades }\end{array}$ & $\begin{array}{l}\text { São } \\
\text { Miguel }\end{array}$ & São José & $\begin{array}{l}\text { Enseada } \\
\text { de Brito }\end{array}$ & Laguna & $\begin{array}{l}\text { Vila } \\
\text { Nova }\end{array}$ & $\begin{array}{l}\text { São } \\
\text { Francisco }\end{array}$ & $\begin{array}{l}\text { Soma } \\
\text { total }\end{array}$ \\
\hline \multirow{7}{*}{ 总 } & $\begin{array}{l}\text { Farinha de } \\
\text { Mandioca }\end{array}$ & 20.000 & 25.000 & 20.000 & 20.000 & 20.000 & 6.000 & 20.000 & 13.000 & 60.000 & 204.000 \\
\hline & Arroz & $1.412 \mathrm{1} / 2$ & 664 & 2.372 & 2.037 & 6.919 & 1.277 & 145 & 180 & 800 & $15.8061 / 2$ \\
\hline & Milho & $1.6651 / 2$ & $2.6181 / 4$ & $1.8823 / 4$ & 1.216 & 2.749 & 1.153 & 1.175 & 56 & - & $12.515 \mathrm{1} / 2$ \\
\hline & Feijão & 1.216 & $1.0083 / 4$ & 1.676 & 1.098 & 1.005 & 577 & 589 & 57 & 100 & $7.3263 / 4$ \\
\hline & Favas & $821 / 2$ & $541 / 2$ & 4 & 1 & 83 & 6 & 36 & - & - & 267 \\
\hline & Trigo & $188^{1 / 4}$ & $4213 / 4$ & $563 / 4$ & 24 & 121 & 150 & 255 & 295 & - & $1.5113 / 4$ \\
\hline & Cevada & $123 / 4$ & $71 / 4$ & 10 & - & 1 & - & 4 & - & - & 35 \\
\hline \multirow{3}{*}{$\frac{\pi}{: 0}$} & $\begin{array}{l}\text { Aguarden- } \\
\text { te de cana }\end{array}$ & $8.2511 / 2$ & 7.582 & 6.115 & 3.570 & 578 & 4.443 & 2.102 & 930 & 4.140 & $37.711^{1 / 2}$ \\
\hline & Cachaça & 1.601 & $1.5831 / 2$ & 120 & - & - & - & - & - & - & $3.3041 / 2$ \\
\hline & Melado & 3.742 & 16 & 308 & 446 & 480 & 390 & 100 & 10 & - & 5.492 \\
\hline \multirow{5}{*}{$\begin{array}{l}0 \\
0 \\
0 \\
0 \\
0 \\
Z\end{array}$} & Açúcar & $1.1421 / 2$ & $1.2291 / 2$ & $1201 / 2$ & 486 & 101 & 457 & - & 62 & - & $3.5981 / 2$ \\
\hline & Algodão & $4691 / 2$ & $4401 / 2$ & $7261 / 2$ & 254 & 271 & 184 & $921 / 2$ & - & - & 2.438 \\
\hline & Café & 36 & 20 & $51 / 2$ & 9 & 6.2 & 3 & - & - & - & $1351 / 2$ \\
\hline & Fumo & 125 & 84 & - & - & - & - & - & - & - & 209 \\
\hline & Gravatá & - & - & - & - & - & - & - & - & 70 & 70 \\
\hline \multicolumn{2}{|c|}{ Dúzias Taboado } & 127 & - & - & - & - & - & - & - & 96 & 223 \\
\hline \multicolumn{2}{|c|}{ Betas Grandes } & - & - & - & - & - & - & - & - & 1.000 & 1.000 \\
\hline \multicolumn{2}{|c|}{ Imbé Pequenas } & - & - & - & - & - & - & - & - & 800 & 800 \\
\hline \multirow{3}{*}{ 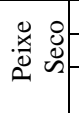 } & Contos & - & - & - & - & - & - & 4 & - & - & 4 \\
\hline & Milheiros & - & - & - & - & - & - & 100 & 455 & 30 & 585 \\
\hline & Centos & - & - & - & - & - & - & - & 7 & - & 7 \\
\hline \multicolumn{2}{|c|}{ Pedras de Linho } & $5281 / 2$ & 834 & $601 / 2$ & 172 & 381 & 119 & $2391 / 2$ & 114 & - & $2.4481 / 2$ \\
\hline \multicolumn{2}{|c|}{ Réstias Cebolas } & 200 & 200 & - & - & - & - & - & 200 & - & 600 \\
\hline
\end{tabular}

${ }^{673}$ ANRJ, Cód. 106, vol. 09, of. 03. Do governador José Pereira Pinto ao vice-rei Luís de Vasconcelos e Souza, em 31.07.1786.

${ }^{674}$ RMR-1797, p. 173. 
A despeito daquelas políticas e dos sistemas opressivos impostos por alguns governadores, os povoadores montaram uma economia bastante diversificada, como mostra o quadro acima apresentado por João Alberto de Miranda Ribeiro para o ano de 1796. Essas produções visavam à subsistência daquelas pequenas comunidades e, também, o comércio intercolonial.

A farinha de mandioca constituía-se no principal produto daquele estabelecimento, sendo produzida em grandes quantidades em todas as freguesias dele. Importante foi também a produção de aguardente.

Em outro quadro, Miranda Ribeiro apresenta o que desses gêneros foi exportado. ${ }^{675}$ Dos totais produzidos, exportaram-se, entre outros: $52.135(25,5 \%)$ alqueires de farinha de mandioca; 4.661 (29,4\%) alqueires de arroz; 2.476 (19,7\%) alqueires de milho; $1.864(25,4 \%)$ de alqueires de feijão; 35 pipas de aguardente; e $100 \%$ do peixe seco produzido em Laguna, Vila Nova e São Francisco. Embora o linho fosse produzido em quase todas as freguesias, com exceção apenas de São Francisco, não consta nenhuma exportação dele, evidenciando que se destinava exclusivamente ao consumo local.

No final do século, houve uma crise de abastecimento da farinha de mandioca nos armazéns reais da praça do Rio de Janeiro e também para os moradores da vila do Desterro. Os paquetes enviados pelo vice-rei regularmente àquela Ilha com o fim de carregarem a farinha, retornavam para o Rio com menos da metade da carga encomendada. Em resposta aos reiterados apelos e determinações do vice-rei, Conde de Rezende, para que esse problema fosse resolvido e se encontrasse uma forma de desenvolver aquele tão importante produto, o governador João Alberto de Miranda Ribeiro explicava, em 4 de junho de 1798, que,

Para promover e aumentar a Plantação das mandiocas, como V. Ex. ${ }^{a}$ me recomenda, não há outro meio mais seguro, que o de se pagarem prontamente as farinhas que pela Fazenda Real se tomam aos Povoadores: deixando-lhes contudo a Liberdade, de eles poderem dispor de alguma ao seu arbítrio. (...) A irregularidade dos pagamentos tem sido a causa da decadência da agricultura, de maneira que se faz bastantemente sensível a diminuição que se experimenta nas farinhas, não obstante as vivas e repetidas persuasões que eu faço, e tenho feito aos Lavradores (...).

\footnotetext{
${ }^{675}$ Id., p. 174. "Mapa da quantidade de gêneros e efeitos que se exportam anualmente da Ilha de Santa Catarina e mais distritos da sua jurisdição, ano de 1796"
} 
E dizia ainda:

Apesar de todos os cálculos que eu faço (...) eu mesmo não posso saber dizer a V. Ex. ${ }^{a}$ com certeza o $\mathrm{N}^{\mathrm{o}}$ de alqueires de farinha, que desta Ilha podem ser transportados para os Armazéns Reais dessa cidade, mas se V. Ex. ${ }^{a}$ confiar em mim, e me fizer a honra de mandar algum dinheiro destinado para este objeto! Queira V. Ex. ${ }^{a}$ persuadir-se, de que (...) hei de aprontar toda a quantia que for possível; (...) sem que com tudo faça a menor tortura, ou violência a estes Povos. ${ }^{676}$

A questão já vinha sendo colocada por governadores anteriores, mas não com a franqueza de Miranda Ribeiro, talvez porque não mais resolvessem práticas coercitivas com os lavradores para o cumprimento daquelas determinações. Era preferível a um colono deixar de produzir a ver os oficiais do governo confiscarem seus estoques sem receber nada em troca.

Mas possibilidades mercadológicas não faltavam na Ilha de Santa Catarina. Em agosto de 1786, o saco de farinha que a Fazenda Real na vila do Desterro fixava entre $\$ 400$ e $\$ 480$ réis, os lavradores conseguiam vender certo por até $\$ 960$ réis aos particulares. $^{677}$ Só na vila de São Francisco do Sul, no ano de 1801, segundo informações passadas pelo seu comandante ao governador da Ilha, 29.012 alqueires de farinha foram exportadas para a Bahia, Pernambuco, Rio Grande e Santos, em diversas embarcações, e que só uma se dirigiu ao Rio de Janeiro, além dos dois Paquetes para os Reais Armazéns da Ilha de Santa Catarina para subsistência das tropas. ${ }^{678}$

A crise de produção - se é que de fato havia - relacionava-se ao movimento de resistência dos lavradores às práticas tradicionais do governo na apropriação de suas forças de trabalho. Na virada do século XVIII para o XIX, isso não podia mais ser desconsiderado nas políticas de governo daquela capitania.

No mesmo dia 05 de janeiro de 1785, em que se emitiu o Alvará anticontrabando, emitiu-se também o Alvará de proibição das manufaturas têxteis no Brasil. Ambos faziam parte de um mesmo esforço da Corte na tentativa de superar uma conjuntura desfavorável do comércio português: decréscimo das exportações para as

\footnotetext{
${ }^{676}$ ANRJ, Cód. 106, vol, 14, fl. 54. Do governador João Alberto de Miranda Ribeiro ao vice-rei Conde de Rezende.

${ }^{677}$ ANRJ, Códice 106, vol. 9, of. n. 4. Do governador José Pereira Pinto ao vice-rei Luís de Vasconcelos e Sousa, em 01 de agosto de 1786.

${ }^{678}$ ANRJ, Códice 106, vol. 15, fl. 100. Do governador Joaquim Xavier Curado ao vice-rei D. Fernando Jozé de Portugal, em 31 de janeiro de 1802.
} 
suas colônias. ${ }^{679} \mathrm{O}$ documento começa apontando o problema: "o grande número de Fábricas, e Manufaturas", que nos últimos tempos se tem difundido nas "diferentes capitanias do Brasil, com grave prejuízo da Cultura, e da Lavoura, e da exploração das Terras daquele vasto Continente", sendo "que quanto mais se multiplicar o número dos Fabricantes, mais diminuirá o dos Cultivadores". ${ }^{680}$ A fabricação de manufaturas têxteis desviaria os colonos das atividades agrícolas, "fundo, e a base" do comércio português. Proibiam-se, assim:

todas as Fábricas, Manufaturas, ou Teares de Galões, de Tecidos, ou de Bordados de Ouro, e Prata: De Veludos, Brilhantes, Cetins, Tafetás, ou de qualquer outra qualidade de Seda: De Belbutes, Chitas, Bombazinas, Fustões, ou de outra qualquer qualidade de Fazenda de Algodão, ou de Linho, branca, ou de cores: E de Panos, Baetas, Droguetes, Saetas, ou de outra qualquer qualidade de Tecidos de Lã, ou os ditos Tecidos sejam fabricados de um só dos referidos Gêneros, ou misturados, e tecidos uns com os outros; excetuando tão somente aqueles dos ditos Teares, e Manufaturas, em que se tecem, ou manufaturam Fazendas grossas de Algodão, que servem para o uso, e vestuário dos Negros, para enfardar, e empacotar Fazendas, e para outros Ministérios semelhantes; todas as mais sejam extintas, e abolidas em qualquer parte onde se acharem nos Meus Domínios do Brasil, debaixo da Pena do perdimento, em tresdobro, do valor de cada uma das ditas Manufaturas, ou Teares, e das Fazendas que nelas, ou neles houver (...).

Tão logo o Alvará chegou ao Brasil, transmitiu o vice-rei a ordem a todas as capitanias gerais e governos subalternos. Em Santa Catarina, a notícia deve ter causado preocupações ao governador e aos povoadores, pois, desde pelo menos 1755 registravase um considerável número de teares na Ilha e suas freguesias da terra firme (ver Quadro 3.4), e, até o ano de 1786, essas pequenas unidades manufatureiras haviam mais que duplicado, como mostra o quadro apresentado pelo governador José Pereira Pinto.

\footnotetext{
${ }^{679}$ Cf. Fernando A. Novais. A proibição das manufaturas no Brasil e a política econômica portuguesa do fim do século XVIII, in idem. Aproximações: estudos de história e historiografia. São Paulo: Cosac Naify, 2005, pp. 61-82.

${ }^{680}$ Alvará de 5 de janeiro de 1785, transcrito em id, ibid., pp. 81-82.
} 
Quadro 3.11

Resumo do Número de teares que há nas seis Freguesias desta Ilha $[1786]^{681}$

\begin{tabular}{lr}
\hline Vila Capital de N. Sra. de Desterro & 105 \\
N. Sra. das Necessidades & 150 \\
N. Sra. da Conceição da Lagoa & 88 \\
São Miguel & 102 \\
São José & 109 \\
N. Sra. do Rosário da Enseada de Brito & 29 \\
Total de teares & 583 \\
\hline
\end{tabular}

Dizia ainda o governador que devia haver mais teares e tecedeiras, "que pela cautela e segredo com que se fez esta diligência se não pôde indagar o total número de todas as Freguesias". Além disso, não informou no quadro os teares do povoado de Santa Ana, freguesia pertencente à vila de Laguna que, em 1755, já registrava 30 deles.

No mesmo ofício seguia também uma relação dos tipos de tecidos produzidos pelas tecedeiras com os respectivos valores que os vendiam.

Quadro 3.12

Qualidade e preços dos tecidos produzidos nas freguesias da Ilha, em $1786^{682}$

\begin{tabular}{lr}
\hline Tecidos & $\begin{array}{r}\text { Pelo que se } \\
\text { vende a vara }\end{array}$ \\
Pano de linho ordinário & $\$ 320$ \\
Pano de linho mais fino & $\$ 400$ \\
Estopa grossa & $\$ 200$ \\
Estopinha & $\$ 240$ \\
Estopinha com algodão & $\$ 240$ \\
Toalhas de favo de linho e algodão & $\$ 800$ \\
Toalhas ditas mais grossas & $\$ 640$ \\
Riscados grossos de linho e algodão & $\$ 400$ \\
Riscados mais finos & $\$ 480$ \\
Fustão fino & $\$ 640$ \\
Fustão grosso & $\$ 400$ \\
Picote & $\$ 280$ \\
Colchas de algodão e estopa & $4 \$ 000$ \\
Colchas de algodão fino & $5 \$ 000$ \\
Colchas de fios de bata & $6 \$ 400$ \\
\hline
\end{tabular}

${ }^{681}$ ANRJ, Cód. 106, vol. 09, of. 12. Do governador José Pereira Pinto ao vice-rei Luís de Vasconcelos e Sousa, em 24.12.1786. Junto a esse quadro enviava também uma "Relação dos nomes dos moradores da Vila Capital de N. Sra. do Desterro que em suas casas têm teares, donde suas mulheres, e filhas tecem toda a qualidade de tecidos".

${ }^{682}$ Idem. 
A respeito dos preços, informava o governador que se tratava de valores ordinários, porque as tecedeiras podiam fazer "por mais ou menos conforme se ajustam, e as qualidades dos fiados", havendo também colchas que algumas pediam sete e oito mil réis por elas.

Como se pode observar, eram na sua maioria tecidos proibidos pelo supracitado Alvará. Mesmo assim, José Pereira Pinto procurou sensibilizar o vice-rei para que permitisse àqueles povoadores manterem seus teares, pois, segundo ele,

quase todos os ditos tecidos são para o próprio uso destes Povos, assim como o praticam algumas das nossas Províncias em Portugal, e apenas extraem para fora algumas colchas, toalhas, ou varas de pano do supérfluo, para procurarem algum necessário, o que tudo se reduz a uma insignificante exportação, e seria a maior vexação que se pode imaginar para estes Povos, se por qualquer forma se lhes embaraçasse este recurso de cobrir a sua desnudez (...). ${ }^{683}$

Não se tem notícia de teares apreendidos e de tecedeiras penalizadas nas freguesias de Santa Catarina. É muito provável que essas fabriquetas tenham mantido suas atividades regulares a despeito do Alvará.

Mesmo que as exportações fossem insignificantes, como alegou o governador em defesa dos povoadores, a produção de tecidos nessa escala, capaz de vestir a população local, ia de encontro às políticas mercantilistas da Coroa Portuguesa de valorização da indústria têxtil do reino e preservação incondicional do mercado consumidor dessa produção nas colônias.

Constata-se, portanto, que, determinadas políticas vindas de cima, da Corte ou do Rio de Janeiro, como o incentivo à produção da cochonilha e do linho cânhamo, a proibição das fábricas e manufaturas têxteis na colônia e o fornecimento de farinha de mandioca para os armazéns da Fazenda Real, foram subvertidas ou boicotadas pelos povoadores de Santa Catarina, num claro movimento de autonomização daquela sociedade.

Os governadores ficaram numa posição intermediária difícil, às vezes até ambígua, ora procurando impor as ordens de forma autoritária, e em alguns casos mesmo violenta, ora acolhendo como legítimas as demandas dos povoadores.

${ }^{683}$ Idem. 


\subsubsection{O discurso da decadência}

É nesse contexto de crise do sistema colonial que se forma a idéia de "decadência" econômica da Ilha de Santa Catarina e seu continente. Em 22 de agosto de 1795, o Conde de Rezende, considerando que “o aumento das Repúblicas dependia do aumento da sua população, dos progressos da Agricultura, da Indústria, da agitação, e influência do Comércio, favorecidos e animados por um método seguro", inquiria os oficiais da Câmara de Desterro para que lhe dessem uma "explicação sólida e assaz circunstanciada das origens, e motivos da decadência" daquele distrito, propondo-lhes "logo, os meios mais sérios, e adaptáveis" que podiam se estabelecer em benefício público e interesse de S. Maj. ${ }^{684}$ Em resposta de 9 de novembro do mesmo ano, os oficiais colocavam a falta no pagamento dos soldos à tropa como o principal motivo a impedir o florescimento daquela Ilha, "pois é bem certo que o dinheiro da Tropa se espalha pelo comércio e ainda pelos Lavradores". ${ }^{685}$ A esse fator acrescentavam outros dois: o confisco das farinhas dos colonos para os armazéns reais e a falta que faziam para o desenvolvimento do comércio as freguesias que se projetaram instalar no caminho do sertão, entre a Ilha de Santa Catarina e a vila de Lages.

Explanação bem mais completa das causas da decadência, e os meios para se promover aquele estabelecimento foi oferecido dois anos depois por João Alberto de Miranda Ribeiro no seu Relatório de governo. ${ }^{686}$ Os treze itens listados por ele podem ser sintetizados nos seis pontos abaixo:

$1^{\circ}$. a falta do pagamento de soldos à tropa (82 meses de atraso) fez com que ela se visse oprimida de dívidas que não podia saldar com os mercadores, e esses, por consequiência, adotaram o sistema de não quererem fiar coisa alguma aos militares para não contraírem maiores dívidas com os seus credores, o que fez com que uns se vissem cercados de maiores necessidades, e os outros se não podiam adiantar como sucederia se girasse aquele dinheiro;

$2^{\circ}$. quanto ao contrato dos dízimos, se fosse arrematado na Ilha, também contribuiria para o aumento do comércio, até porque alguns dos seus moradores já rematavam "parcialmente aos contratadores gerais, que têm suas residências fora dela; o lucro que

\footnotetext{
${ }^{684}$ APESC, "Cartas do vice-rei para a Câmara Municipal”, fl. 79.

${ }^{685}$ ANRJ, Cód. 110, vol. 01, Dos oficiais da Câmara de Desterro ao vice-rei Conde de Rezende.

${ }^{686}$ RMR-1797, pp. 159-163, “Artigo 12 - Da causa da sua decadência, e o meio de a promover".
} 
estes percebem passaria para aqueles, e os iria fazendo cada vez mais opulentos no seu comércio";

$3^{\circ}$. a respeito do contrato da pesca da baleia entendia ele que os comerciantes da Ilha não tinham ainda forças para rematá-lo, contudo, ponderava que o local de onde os contratantes tiravam seu maior rendimento provinha das cinco armações que havia na Ilha e distritos da sua jurisdição e, portanto, lhe parecia justo "meter nos Cofres Reais desta Provedoria o dinheiro necessário para o pagamento da Tropa";

$4^{\circ}$. uma das principais causas da decadência das culturas da Ilha era a falta de dinheiros da Fazenda Real para se pagarem prontamente aos lavradores as farinhas que se lhes tomavam todos os anos para o sustento da tropa. "Eles estão geralmente tão possuídos deste receio, pela experiência (...) que já vão plantando muito pouco, além daquela que lhes é necessária para o seu gasto". Esta diminuição faz com que "se não exportem francamente para fora da Terra, a fim de que não fiquem os povos sem sustento". Se os pagamentos fossem prontos, "haveria talvez o dobro da farinha que hoje há", e a afluência das embarcações para aquele porto, proporcionada pela opulência dos lavradores, iria gradualmente conduzir ao adiantamento de outras plantações, tais como o café, o anil, o algodão e a cana-de-açúcar;

$5^{\circ}$. para se fundar as duas freguesias no caminho do sertão que vai para a vila de Lages era necessário um investimento da Fazenda Real de pelo menos 10.000 cruzados, "mas então se veria um aumento considerável na população, na cultura, no comércio, nos Reais Dízimos", além da estratégica segurança que aqueles povoados proporcionariam ao país;

$6^{\circ}$. para se promover a cultura das terras na vila de São Francisco seria necessário meter naquele país 100 ou 150 casais dos Açores, “os quais sendo naturalmente acostumados ao trabalho das sementeiras, fariam com o seu exemplo mudar os Nacionais aquele costume em que estão de viverem mais da Caça e da Pesca do que da Lavoura". Para a vila de Laguna recomendava o mesmo recurso.

Um fator que Miranda Ribeiro não destacou aí para o vice-rei, mas sim à Corte, na mesma ocasião, foi o de recrutarem-se os lavradores para completarem a guarnição da Ilha, prejudicando dessa forma a agricultura. ${ }^{687}$

Todas essas questões contribuíram, de fato, para o lento e reservado desenvolvimento da economia de Santa Catarina, mas têm de ser inscritos como partes

${ }^{687}$ OMR-1797, fls. 07 e 08. 
de problemas mais amplos do império português. Elas evidenciavam as próprias contradições do sistema: "não é possível explorar a colônia sem desenvolvê-la". ${ }^{688}$ As alternativas encontradas pelo governador para adiantar a economia da Ilha, em benefício dos interesses reais - e ele podia estar mesmo convencido disso - apontavam, entretanto, para o fortalecimento do poder dos comerciantes locais, aumento do giro de dinheiro na colônia e a existência ali de mercados mais francos e desimpedidos em contraposição à lógica mercantilista sustentada ainda pela Coroa Portuguesa.

Desde a sua fundação (1738), até a invasão espanhola (1777), os governadores tiveram de priorizar na governança da Ilha de Santa Catarina o sistema de defesa - sua principal função naqueles territórios - em detrimento da produção colonial. No período subseqüente (1778-1807), quando a Corte passou a exigir maior inserção de seus produtos no mercado colonial, a economia dela encontrava-se já organizada em outros parâmetros e destinada a atender distintas necessidades.

Pelo menos dois autores no século XX incorporaram em suas obras (publicadas na Coleção Brasiliana) a noção de "decadência" da economia de Santa Catarina, presente no discurso dessas autoridades portuguesas do final do Setecentos. Primeiro, Oswaldo Cabral, no livro Santa Catarina (História - Evolução). Como referido no segundo capítulo, ele caracterizou o período de meados do século XVIII até a invasão espanhola de 1777 como de decadência progressiva da colônia. ${ }^{689}$ O motivo fundamental desse processo seria a incapacidade dos colonos açorianos para a agricultura. "Não eram eles, em verdade, lavradores, acostumados no trato diário da terra. Eram mais fugitivos às misérias das ilhas em que nasceram do que propriamente homens aptos para o trabalho agrícola. ${ }^{, 690}$ Quatro anos depois, aprofundando essa tese em estudo específico, acrescentaria que a colonização portuguesa no Brasil em bases rurais só foi possível pela adoção do braço escravo e, como em Santa Catarina "faltou este elemento", a agricultura tendia desde o princípio a fracassar. Não negava que a ação abusiva de alguns governadores tivesse contribuído para isso. Todavia, entendia que "mesmo sem ela, o fracasso seria igual, porque o fator principal que o provocou não esteve em qualquer ação excessiva como não esteve em qualquer dificuldade inicial desanimadora, mas no próprio imigrante, na sua própria índole, na sua própria

\footnotetext{
${ }^{688}$ Ver p. 62.

${ }^{689}$ Oswaldo R. Cabral. Santa Catarina (História - Evolução). São Paulo: Companhia Editora Nacional, 1937. (Col. Brasiliana, vol. 80), p. 98.

${ }^{690}$ Id. ibid. p. 95.
} 
formação". ${ }^{691}$ Como já referido, a escravidão, fosse de indígenas, fosse de negros africanos, sempre esteve presente na formação histórica de Santa Catarina.

O segundo autor é Fernando Henrique Cardoso no livro Cor e Mobilidade Social em Florianópolis. Embora compreendesse que as causas fundamentais da "desorganização da economia catarinense" fossem de ordem estrutural, fruto do que chamou de "estatuto colonial", entendeu ele que "o recrutamento intensivo dos agricultores veio a tornar-se (...) uma das causas da decadência econômica da ilha de Santa Catarina". 692

Tomando emprestado o raciocínio feito por Maria Luiza Marcílio para o caso da capitania de São Paulo, no século XVIII, é impróprio também para o caso de Santa Catarina o uso do conceito de "decadência". Decadência pressupõe a idéia de que houve em tempos passados momentos de prosperidade e de riqueza. Ou seja, só há decadência se houve crescimento ou desenvolvimento anterior. ${ }^{693}$ Não se verifica isso na história de Santa Catarina. As análises feitas até aqui mostram que em nenhum momento houve, quer na esfera econômica, quer na social, período que se possa considerar de "apogeu" ou de pronunciado crescimento, seguido de recuos e decaídas. Verifica-se, sim, um lento, reservado e progressivo desenvolvimento tanto na população, quanto nas atividades econômicas, como se pôde verificar nos quadros de evolução demográfica e dos contratos dos dízimos para a Ilha. Paulo Joze Miguel de Brito, crítico severo do sistema de governo dirigido à Ilha desde 1753, informava que "a agricultura tem tido um progressivo aumento, porém vagaroso, e este mesmo aumento se deve quase todo à natureza, bem pouco à arte, e nada à administração". 694

Poder-se-ia falar em "atraso" econômico da Ilha (como aquilo que ainda não foi), se o parâmetro de comparação forem as capitanias melhor inseridas à dinâmica econômica do sistema colonial. Todavia, se analisa-se o tema do ponto de vista da

\footnotetext{
${ }^{691}$ Oswaldo R. Cabral. A vitória da colonização Açoriana em Santa Catarina. Florianópolis: Imprensa Oficial, 1941, pp. 19-47. O autor, todavia, procurou mostrar, como sugere o título da obra, que apesar da inaptidão para a agricultura, o açoriano "recebeu e conservou a religião, a língua, o sentimento pátrio, os costumes dos antepassados, firmando-se como fator principal da evolução histórico-político-social de Santa Catarina".

${ }^{692}$ Fernando Henrique Cardoso. "O Negro e o Desenvolvimento Econômico e Social de Florianópolis", in Fernando H. Cardoso e Otávio Ianni. Cor e Mobilidade Social em Florianópolis: aspectos das relações entre negros e brancos numa comunidade do Brasil Meridional. São Paulo: Companhia Editora Nacional, 1960 (Col. Brasiliana, vol. 307), pp. 9 e 37. Grifo meu.

${ }^{693}$ Maria Luiza Marcílio. Crescimento Demográfico e Evolução Agrária Paulista, 1700-1836. São Paulo: Hucitec, 2000, pp. 190 e 191.

${ }^{694}$ Paulo Joze Miguel de Brito. Memória Política..., op. cit., p. 59.
} 
sociedade, dos lavradores, dos comerciantes, dos pescadores e das tecedeiras, bem diversa podia ser a leitura sobre o desenvolvimento produtivo daquela colônia. 


\section{CONSIDERAÇõES FinAIS}

Desde o século XVII, a Ilha de Santa Catarina aparece nas cartas náuticas e nos diários de viagens como importante porto de escala ou de referência para os navegadores no Atlântico Sul, sobretudo aos peruleiros fluminenses na rota mercantil que estabeleceram com o Rio da Prata. A partir do século seguinte, a valorização crescente do espaço continental, do sertão mineiro à Colônia do Sacramento, incluindo as ricas terras com os milhares de cabeças de gado controlados pelos padres da Companhia de Jesus, faria daquela Ilha um dos pontos estratégicos para conquista, defesa e domínio desses territórios. Entre 1738 e 1807, essa foi a função primordial dela aos planos da Monarquia Portuguesa na consolidação de seu Império no sul da América Meridional, mesmo que o vasto sertão que se abria por cima da serra ficasse, por todo esse tempo, praticamente inexplorado.

Se da perspectiva dos Estados Monárquicos a expansão das conquistas se fazia mais pelo signo da divisão, da demarcação dos limites jurisdicionais de soberania, para os coloniais, essa expansão representava a aproximação e o contato com o outro, na maioria das vezes de maneira amistosa. As imponentes fortalezas erigidas na Ilha sob o comando do Brigadeiro José da Silva Paes, balizando a conquista lusitana, exerciam, de fato, seu papel de controle, de vigilância, mas não impediam que os viajantes estrangeiros continuassem a arribar naquele porto.

Com base na análise documental, pôde-se problematizar o que foi essa unidade política chamada posteriormente pelos historiadores e memorialistas de capitania de Santa Catarina. Ao vulgarizar o termo capitania para todos os estabelecimentos criados no século XVIII, que se transformaram em províncias, no século XIX, a historiografia acabou por não perceber o peculiar estatuto político-jurídico de algumas colônias, projetando num passado distante uma unidade estatal, territorial e mesmo identitária que não existia. Em 1738, criou-se na Ilha um governo militar, e com essa denominação, 
preferencialmente, ela seria denominada pelas autoridades metropolitanas e coloniais, da mesma forma que o Rio Grande de São Pedro, a partir de 1760. Do ponto de vista do controle político sobre a Ilha, 1738 representou, com efeito, uma ruptura entre o tempo dos sargentos e capitães-mores, sob o domínio de São Paulo, e dos governadores, vinculados ao Rio de Janeiro. Mudança essa que se inscrevia no amplo conjunto de reformas implementadas por Dom João V com vistas ao reforço da autoridade régia sobre espaços estratégicos do Império.

Nos primeiros dez anos, montou-se na Ilha uma praça militar que, na estrutura política do vice-reinado, era hierarquicamente equivalente aos já existentes governos de Santos e da Colônia do Sacramento. Em meados do século XVIII, com a incorporação das vilas de Laguna e de São Francisco, da criação da Ouvidoria e da Provedoria e do ingresso dos casais açorianos, o governo da Ilha passou a significar, de fato e de direito, uma unidade colonial ampliada e expandida ao continente. A partir da década de 1760, torna-se comum o uso, sobretudo pelas autoridades coloniais, da forma capitania da Ilha de Santa Catarina. Todavia, a construção dessa unidade foi marcada por um longo processo de conflitos de jurisdições entre os diferentes corpos políticos circunvizinhos em formação. Somente na terceira década do século XIX é que se pode visualizar mais claramente a coincidência nas circunscrições dos poderes civil, fazendário, judiciário e eclesiástico daquele governo.

$\mathrm{Na}$ análise do estatuto desse governo e da atuação dos seus governadores, pôdese ultrapassar aquela perspectiva monolítica e homogeneizante sobre a estrutura estatal da "capitania de Santa Catarina" e perceber o longo processo de construção dessa unidade colonial entre 1738 e 1807 . Observou-se, no entanto, que no início do século XIX persistia uma indefinição sobre a natureza estatutária dessa unidade. Para as autoridades metropolitanas prevalecia, pelo menos até 1807, quando os territórios de jurisdição da Ilha passaram, oficialmente, para os domínios de São Paulo e do Rio Grande de São Pedro, o estatuto menor de "governo subalterno"; para os coloniais, entre os quais podem-se incluir alguns governadores, reforçava-se a idéia de "capitania".

Caberia numa investigação futura, analisar a reconfiguração política que se processou após a chegada da família real, em 1808, e as condições que possibilitaram a elevação da Ilha e sua Terra Firme em Província no ano de 1821.

Investigar as trajetórias e as qualidades nobiliárquicas e profissionais dos indivíduos nomeados para governar a Ilha de Santa Catarina auxiliou também na compreensão do que era, ou melhor, de como devia ser esse estabelecimento colonial. 
Nos primeiros tempos, a montagem de todo o sistema defensivo exigiu homens com amplo conhecimento do espaço, engenheiros-cartógrafos, como José da Silva Paes. A condição política subalterna da Ilha reduziu o status do seu cargo, se comparado às capitanias-gerais. Seus governadores não provinham da primeira fidalguia da Corte, mas da nobreza simples, alcançando ao longo de suas vidas alguma distinção honorífica (tenças e hábitos militares) em troca dos serviços prestados à Monarquia.

Quanto ao perfil militar desses oficiais, pode-se dizer que, no momento da nomeação tinham longa carreira no exército. Vinculavam-se a um regimento do Rio de Janeiro, desempenhando outros postos e funções nos territórios desse governo. Além disso, possuíam - ou alcançavam no momento da nomeação -, no máximo, a patente de coronéis. Entretanto, em momentos críticos, como o da iminente invasão espanhola da Ilha, em 1775, ou nos momentos em que era preciso restabelecer a soberana dignidade lusitana, como da restituição dela aos domínios de Portugal, em 1778, brigadeiros e fidalgos foram chamados para exercer sua governança.

Viu-se ainda que as atribuições dos governadores da Ilha se assemelhavam muito às dos capitães-generais, contudo, os limites de poder daqueles eram bem mais restritos do que desses. A partir de 1763, os vice-reis exerceram um controle sobre suas dependências no Sul, de fato, muito mais efetivo do que sobre as capitanias-gerais. Tal condição era vista pelos governadores subalternos, quase sempre, como opressora, indesejável e prejudicial ao perfeito funcionamento da colônia que governavam.

$\mathrm{Na}$ prática governativa, os governadores depararam-se com um problema comum nas administrações das conquistas ultramarinas: a constante falta de recursos para o pagamento das tropas e de outras despesas necessárias para o funcionamento da colônia. A imperiosa função de manter a guarnição da Ilha em estado completo e em condições mínimas levou alguns deles a tomarem medidas drásticas, às vezes até mesmo violentas, com os povoadores civis. Se, por um lado, o recrutamento dos lavradores para composição das tropas ou para a construção das obras públicas e o confisco da produção de farinha de mandioca responderam àquelas necessidades, por outro, trouxeram não só prejuízo da agricultura, mas também resistência por parte da sociedade civil às políticas imperiais portuguesas.

Observou-se ainda que, muito embora as relações estabelecidas pelos governadores com as demais autoridades fossem marcadas por conflitos, eles tiveram de se adequar a uma convivência articulada entre os diferentes poderes, mesmo que com vagos e imprecisos limites de competência e de jurisdição de uns e outros. Da mesma 
forma, não era possível àqueles oficiais, na condução das políticas da monarquia, desprezar as demandas e pressões vindas da sociedade, sobretudo no final do período colonial, quando a economia estava mais desenvolvida e diversificada, as relações sociais e políticas mais complexas e os grupos locais mais organizados e independentes. 


\section{FONTES E BIBLIOGRAFIA}

\section{Fontes}

Arquivo Histórico Ultramarino

Grupo de Arquivos - Administração Central - ACL

Fundo - Conselho Ultramarino

Série - Brasil - Santa Catarina - 021

Cx. 1

doc. 24 - Parecer do Conselho Ultramarino sobre se declarar a patente e soldo que deve ter o governador e brigadeiro da ilha de Santa Catarina, 13.05.1745.

doc. 30 - Provisão de D. João V ao governador da capitania de S. Paulo ordenando que a arrematação dos dízimos da Alfândega, pertencentes às despesas dos casais açoreanos que foram para a ilha de $\mathrm{S}$. Catarina sejam propriedade da Provedoria do Rio de Janeiro, 03, 07, 1747.

doc. 48 - Decreto de D. João V nomeando, por tempo de três anos, coronel Manuel Escudeiro Ferreira de Souza para o governo da ilha de Santa Catarina, 20.08.1748

doc. 50 - Decreto de D. João V ordenando que o governador nomeado, o coronel Manuel Escudeiro Ferreira de Souza, tenha o soldo de cinco mil cruzados por ano, 13, 09, 1748.

doc. 74 - Representação dos oficiais da Câmara de Desterro solicitando providências dos abusos cometidos pelo governador Manuel Escudeiro Ferreira de Sousa, 07.08.1751.

Cx. 2

doc. 85 - Decreto de D. João V nomeando D. José de Melo Manuel governador da ilha de Santa Catarina, por três anos, 20.04.1753.

doc. 112 - Carta anexa dirigida ao governador D. José de Melo Manoel por autoridade da corte, 02.02.1756.

doc. 142 - Representação dos oficiais da Câmara da vila de Desterro solicitando uma devassa contra o governador da ilha de Santa Catarina José de Melo Manoel, 01.08.1757.

doc. 143 - Parecer do Conselho Ultramarino sobre a nomeação de pessoas para o Cx. 3 posto de governador da ilha de Santa Catarina, 18.02.1758.

doc. 166 - Decreto de D. José I nomeando o coronel Francisco Antônio Cardoso de Meneses e Sousa para governador da ilha de Santa Catarina, por três anos, 18.09.1761.

doc. 173 - Ofício do governador Francisco Antônio C. de Meneses e Sousa ao secretário de Estado Francisco Xavier de Mendonça Furtado solicitando que seja conservado no posto de coronel do Regimento da ilha de Santa Catarina, 14.04.1762.

doc. 194 - Carta dos oficiais da Câmara de Desterro ao rei sobre a solenidade de Cx. 4 posse do governador nomeado Francisco de Sousa de Meneses, 27.07.1765.

doc. 257 - Carta patente de confirmação a Pedro Antônio da Gama Freitas como governador da ilha de Santa Catarina, 18.08.1775. 
doc. 275 - Decreto de D. Maria I nomeando o coronel Francisco de Barros Moraes Araújo Teixeira Homem governador da ilha de Santa Catarina, por tempo de três anos, 23.09.1778.

doc. 329 - Ofício do governador José Pereira Pinto ao secretário de Estado Martinho de Melo e Castro sobre seus relevantes serviços prestados no governo da ilha de Santa Catarina, 20.03.1789.

Cx. 5

doc. 355 - Ofício do governador João Alberto de Miranda Ribeiro ao secretário de Estado da Marinha e Ultramar, Martinho de Melo e Castro comunicando a sua nomeação como governador da ilha de Santa Catarina, 24.12.1793.

doc. 359 - Ofício de João Alberto de Miranda Ribeiro ao secretário de Estado Martinho de Melo e Castro sobre sua experiência e seus serviços na carreira militar, solicitando promoção no posto de coronel do Regimento de Infantaria, 11.03.1795.

doc. 373 - Ofício do governador João Alberto de Miranda Ribeiro ao secretário de Estado Luís Pinto de Sousa Coutinho sobre um requerimento em que solicitava o posto de coronel do seu regimento, 24.05.1796.

doc. 377 - Ofício do governador João Alberto de Miranda Ribeiro ao secretário de Estado Luís Pinto de Sousa Coutinho solicitando o pagamento da diferença de Cx. 6 soldo que lhe é devido, 26.06.1796.

doc. 386 - Ofício do governador João Alberto de Miranda Ribeiro à D. Maria I (Balanço político-administrativo do governo), 16.11.1797.

doc. 387 - Relatório do governador João Alberto de Miranda Ribeiro ao vice-rei, o conde de Rezende, 17.11.1797.

Registo de Consultas do Rio Grande do Sul

Cód. 422, fl. 01 - Alvará de Regimento de q.' deve usar provizoriamente o governador nomeado para a nova Capitania de S. Pedro, e Seus Successores, em 1807.

Cód. 330, fl. 01 - Alvará de Regimento Provisional, para o Governo de S. Pedro, novamente erecto em Capitania Geral. Palácio da Ajuda, 24 de outubro de 1807

Série - Brasil - Rio de Janeiro - 017

Cx. 152

doc. 11566 - Ofício do secretário de Estado Martinho de Melo e Castro ao vicerei, conde de Rezende, 04.09.1794.

Arquivo Nacional da Torre do Tombo

Chancelaria de Dom João V (próprios e comuns)

Lv. 116, fl. 378v. Patente a Manuel Escudeiro Ferreira de Souza

Lv. 116, fl. 378v. Provisão a Manuel Escudeiro Ferreira de Souza

Lv. 76, fl. 270. Licença a Patrício Manoel de Figueiredo ir a Corte

Lv. 122, fl. 171v. Provisão de prorrogação de Licença a Patrício Manoel de Figueiredo

Lv. 107, fl. 353. Patente de Capitão de Granadeiros do Rio de Janeiro a Patrício Manoel de Figueiredo 
Lv. 111 fl. 387v. Patente de Sarg.to mor a Patrício M.el de Figueiredo

Lv. 90, fl. 242. Patente do posto de Capitão de infantaria do $3^{\circ}$. do Rio de Janeiro

Lv. 45, fl. 198. Mercê de oficio a Joseph Rabello, enteado de Pedro de Azambuja Ribeiro

Lv. 79, fl. 176. Patente de Mestre de Campo ad honorem a Pedro de Azambuja

Ribeiro

Lv. 82, fl. 370. Patente de Marechal de Campo a Pedro de Azambuja Ribeiro

Lv. 105, fl. 232. Patente Capitão de Dragoens a Francisco Antonio de Cardozo de Menezes

Chancelaria de D. José I (próprios e comuns)

Lv. 3, fl. 385. Carta Padrão a Francisco Xavier da Veiga Cabral

Lv. 74, fl. 213v. Patente a Francisco de Souza Menezes, Governador da Ilha de Santa Catharina

Lv. 64 fl. 276v. Patente a Francisco Antonio Cardozo de Menezes Souza, Coronel de Infantaria do Rio de Janeiro

Lv. 32 fl. 31. Patente de licença a Pedro Antonio da Gama Freitas

Lv. 36, fl. 257. Patente de Governador a Pedro Antonio da Gama e Freitas

Lv. 10, fl. 105. Provisão para o Regimento. De Francisco de Barros de Moraes Araújo Teixeira Homem ter açougue próprio.

Lv. 6, fl. 256. Patente a Manuel Soares Coimbra

Lv. 48, fl. 366v. Patente de Governador a Ignácio Eloy de Madureira

Lv. 69, fl. 205v., mf. 1300. Patente de Governador a João Antonio de Souza Falcão

Lv. 64, fl. 246. Patente de Tenente Coronel do Rio de Janeiro a Patrício Manoel de Figueiredo

Lv. 48, fl. 245v. Patente de Coronel Reformado a Patrício Manoel de Figueiredo

Lv. 70, fl. 174v. Provisão a Patricio Manoel de Figueiredo para vir para o reino

Lv. 50, fl. 137. Tença de $18 \$ 000$ no Paço da Madeira a Patrício Manoel de Figueiredo

Chancelaria de D. Maria I, Lv. 64 (próprios e comuns)

Lv. 84, fl. 329v. Carta Padrão a Francisco Antonio da Veiga Cabral

Lv. 70, fl. 53v, mf. 2503. Padrão de $400 \$ 000$ de Tença efetiva cada ano em vida a

Francisco Antonio da Veiga Cabral

Lv. 14, fl. 179v. Carta de confirmação da patente de sargto. Mor do regto. De

Artilharia da Pça. Do RJ. 5.08.1779 a Jozé Pereira Pinto.

Lv. 22, fl. 222v. Carta de cirurgia.7.10.1784 a Joze Pereira Pinto.

Lv. 44, fl. 76v. Patente a Joze Pereira Pinto

Lv. 56, fl. 38. Carta-patente a Joaquim Xavier Curado

Lv. 1, fl. 308v. Provizão de licença de um ano para vir a Corte a Joze Pereira Pinto

Lv. 65, fl. 82. Patente Cap. de Granadeiros a Manuel Sorares Coimbra

Lv. 65, fl. 308v. Patente a Joaquim Soares Coimbra

Lv. 65, fl. 308v. Patente a Francisco da Gama Lobo

Lv. 65, fl. 309. Patente a Manuel Soares Coimbra

Lv. 23, fl. 34v. Patente de confirmação do posto de sargento-Mor João Alberto de

Miranda Ribeiro 11.09.1783

Lv. 72, fl. 178. Patente a Luis Mauricio da Silveira

Lv. 71, fl. 217. Patente de vencimento a D. Luis Mauricio da Silveira

Lv. 81, fl. 146v. Patente a Alexandre Jozé de Azevedo Leão Coutinho, gov. 
Lv. 66, fl. 125. Patente de Gov. a Manuel Soares Coimbra

Lv. 66, fl. 197v. Patente de Gov. a Paulo Joze da Silva Gama

Lv. 12, fl. 149v., mf. 491. Patente a Joze Bernardo Galvão

Lv. 12, fl. 153, mf. 491. Patente de Governador a Francisco de Barros Moraes Araujo

Teixeira Homem

Lv. 78, fl. 181v., mf. 1674. Patente de Governador a D. Diogo de Souza

\section{Chancelaria de Dom João VI (próprios e comuns)}

Lv. 16, fl. 305v. Carta a Manoel Cypriano de Seixas Braga de confirmação da doação de bens que João Alberto de Miranda e sua Molher fizeram. 18.05.1816.

Lv. 7, fl. 257v. Patente de Governador da Índia a Francisco Antonio da Veiga Cabral

\section{Chancelaria da Ordem de Cristo}

Lv. 264, fl. 107v. e Lv. 277 fl. 389v. - Habito a Francisco de Souza de Menezes

Lv. 277 fl. 390 - Alvará de Cavaleiro a Francisco de Souza Menezes

Lv. 310 fl. 126v. - Padrão de $12 \$ 000$ r. de tença com o hábito.

Lv. 270, fl. 263, mf. 2277 - Padrão de $12 \$ 000$ a Francisco Antonio Cardozo de Menezes e Souza

\section{Habilitações da Ordem de Cristo}

\section{F, Mç. 3, N. 11 - Francisco Antonio Cardozo de Menezes e Souza}

Ministério do Reino - Decretamentos de Serviço

Mç. 23, n. 59, fls. 01, 02 e 03 - Francisco de Souza de Menezes "P. a V. Mag. de seja servido attender ao Supp. ${ }^{\mathrm{e}}$ remunerando-lhe os seus serviços com o hab. ${ }^{\circ}$ de Christo e

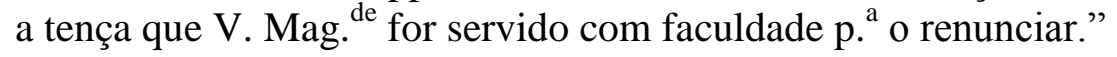

Mç. 32, n. 62 - Joze Pereira Pinto "P. a V. Magestade do habito da Ordem do Christo com a tença q. for servido em remoneração dos ditos serviços e faculdade de poder renunciar"

Ministério do Reino

Decretamentos de Serviços, Mç. 31, n. 12

\section{Biblioteca Nacional de Lisboa}

Coleção Pombalina - PBA 642 / mf. 1631

fl. 98 - Sobre servir ao Governo do Rio de Janeiro a Ilha de $S^{\text {ta }}$ Catharina e Rio de São Pedro do Sul

fl. 149 - Cópia - Sobre se separar desta Capitania a Villa da Laguna e servir ao Gov. ${ }^{\circ}$ do Rio de Janeiro

fl. 372 - Alvará em que se declaração as Pessoas q' devem suceder no cazo de falecerem, ou se auzentarem alguns dos Governadores e Capitaens Generaes, ou 
Governadores dos Estados do Brasil, e Pará, do Reino de Angola, e Ilhas adjacentes a estes Reinos, tudo na forma abaixo declarada.

PBA 653

fl. 267 - Decreto de D. Maria I de perdão aos sentenciados pela perda da Ilha de Santa Catarina aos espanhóis, em 14.01.1786.

PBA 695 / mf. 1635

fl. 4v. - Apologias que [Marquês de Pombal] tenho escrito sobre cada huma das calumnias, que a ingratidão, e a inveja espalharam contra mim no grande Povo de Lisboa, depois da minha auzencia. Em 2.04.1777

Academia de Ciências de Lisboa

Série Vermelha, Cód. 29 - Francisco de Almeida Silva. Dessertação instrutiva sobre a escolha dos Governadores das Conquistas; a sua existencia nos Governos; e o seo regresso para a Corte (1780).

Biblioteca da Ajuda (Lisboa)

Cota 54-XIII-16 (136) - excerto da Dessertação instrutiva sobre a escolha dos Governadores das Conquistas; a sua existencia nos Governos; e o seo regresso para a Corte (1780) de Francisco de Almeida Silva

Biblioteca Nacional do Rio de Janeiro

Mss. CEHB, 3, 4, 3 n. 103. Carta régia de D. João V a Gomes Freire de Andrade em 11.09.1748.

Mss. CEHB, 5616 - 3, 4, 3, n. 78. d. João manda que a vila de Laguna passe para a jurisdição do Rio de Janeiro

Mss. CEHB, 5616 - 3, 4, 3, n. 102. D. João considera desnecessário que haja governador em S. Paulo...

Mss. CEHB, 5616 - 3, 4, 3, n. 108. D. João diz que fez novo assentamento de casais na ilha.

Mss. CEHB, 5616 - 3, 4, 3, n. 109. Ofício de Marcos Antonio de A. Coutinho sobre envio da semente do cânhamo para a ilha de SC.

Mss. CEHB, 5616 - 3, 4, 3, n. 113. Marco Antonio de A. Coutinho adverte ao governador da ilha de SC que não precisa instalar os colonos todos na Ilha, mas que os acomodem desde o Rio de S. Francisco até o forte de S. Miguel.

Mss. CEHB, 5616 - 3, 4, 5, n. 56 Ofício do Secretário de Estado ao Governador do RJ sobre o modo como se deve controlar e vigiar as arribadas de navios estrangeiros nos portos do Rio de Janeiro e de Santa Catarina.

Mss. CEHB, 5616 - 3, 4, 7, n. 111. De Martinho de Melo e Castro ao Marquês de Lavradio sobre a ilha de SC e o território contíguo a ela poder formar uma nova capitania.

Mss. CEHB, 5616 - 3, 4, 7, n. 113. De Martinho de Melo e Castro ao Marquês de Lavradio sobre o formar-se em todos os distritos do sul uma nova capitania 
Mss. 7, 3, 47. Ofício de Francisco de Souza de Menezes ao Vice-Rei Conde de Azambuja dando informações sobre o governo da ilha.

Col. Martins I-28, 26, 3 - Última instrução sobre a Ilha de S. C. do Marquês de Pombal.

Col. Martins - 22, 1, 28, n. 1. "Relação de Francisco João Roscio a destinatário não mencionado sobre as condições dos caminhos de Santa Catarina ao Rio Grande de São Pedro, recursos econômicos e possibilidades estratégicas", sem local e data.

Arquivo Nacional do Rio de Janeiro

Códice 67 - Secretaria do Estado do Brasil (SEB), Fundo 86 - Correspondência da Corte de Portugal com os Vice-Reis do Brasil

Códice 68 - Negócios de Portugal, Fundo 59 - Correspondências do vice-rei para a Corte

Códice 84 - SEB, Fundo 86 - Correspondências emitidas pelo governador do Rio de Janeiro, Gomes Freire de Andrade

Códice 952 - SEB, Fundo 86, vol. 39 - "Cartas Régias, Provisões, Alvarás e Avisos"

Códice 106 - SEB, Fundo 86, Correspondência com os governadores da Ilha de Santa Catarina (1752-1807): vol. 01 (1779); vol. 02 (1752-1774); vol. 03 (1780), vol. 04

(1781); vol. 05 (1782); vol. 06 (1783); vol. 07 (1784); vol. 08 (1785); vol. 09 (1786); vol. 10 (1787); vol. 11 (1788); vol. 12 (1789). vol. 13 (1776 e outros); vol. 14 (17981799); vol. 15 (1801-1802); e vol. 16 (1804-1807). Microfilmados em quatro rolos: 001-0-78; 001-1-78; 001-2-78; e 001-3-78.

Códice 109 - SEB, Fundo 86 - Correspondência sobre contas e receitas da Provedoria da Fazenda de Santa Catarina para o Real Erário, 1 vol. (1763-1806), mf. 025-0-78

Códice 110 - SEB, Fundo 86 - Correspondência de Santa Catarina - Câmaras, 1 vol. (1752-1806), mf. 026-0-78

Arquivo do Estado de São Paulo

Ministério da Marinha, 1611-1822

CO 0419 - Avisos - Cartas régias - Provisões

Documentos Interessantes [ver documentos impressos]

Arquivo Público do Estado de Santa Catarina

Avisos diversos ao Governador da Capitania, 1748-1804

Cartas régias imperiais, 1703-1830

Ofícios dos Secretários de Estado aos Governadores

Ofícios do Vice-Rei para o Governador da Capitania

Registro Geral do Governador da Capitania

Avisos do Vice-Rei para o Governador da Capitania

Cartas do vice-rei para a Câmara Municipal

Arquivo Histórico do Rio Grande do Sul

Fundo Fazenda

F-1242 (1753-1765) 
F-1244 (1771-1780)

Fontes impressas

ALMEIDA, Eduardo de Castro e (Org.). Inventários de Documentos Relativos ao Brasil existentes no Archivo da Marinha e Ultramar de Lisboa, organizado para a Biblioteca Nacional do Rio de Janeiro. Rio de Janeiro, 1913-1918.

Anais da Biblioteca Nacional do Rio de Janeiro, Biblioteca Nacional do Rio de Janeiro.. Vols. 32, 39, 44, 46, 50, 71 e 103 (Consultas do Conselho Ultramarino)

ARAÚJO, José de Souza Azevedo Pizarro. Memórias Históricas do Rio de Janeiro e das Províncias anexas à Jurisdição do vice-rei do Estado do Brasil. Rio de Janeiro: Imprensa Nacional, 1822.

BARRADAS, Joaquim da Costa. Memorial por parte do Paraná. Rio de Janeiro: Typ. Olympio de Campos, 1902.

BRITO, Paulo José Miguel de. Memória Política sobre a Capitania de Santa Catarina. Lisboa: Academia de Sciencias de Lisboa, 1829.

CASAL, Manuel Aires de. Corografia Brasílica ou Relação Histórico-Geográfica do Reino do Brasil. Belo Horizonte: Itatiaia; São Paulo: EDUSP, 1976. (1ª . ed. 1817)

CHAVES, Antônio José Gonçalves. Memórias Ecônomo-Políticas sobre a administração pública do Brasil. Porto Alegre: ERUS, 1978.

COELHO, José João Teixeira. Instrução para o Governo da Capitania de Minas Gerais. Belo Horizonte: Fundação João Pinheiro, 1994.

COELHO, Manoel Joaquim d'Almeida (Major). Memória Histórica da Província de Santa Catharina. $2^{\mathrm{a}}$ ed. Desterro: Typ. J. J. Lopes, 1877 [1ª ed. 1853].

Coleção de documentos sobre o Brigadeiro José da Silva Paes in Revista do Instituto Histórico e Geográfico do Rio Grande do Sul, Ano 1948, n. 109 a 112.

Correspondência passiva do Tenente-General João Henrique de Böhm, in Boletim do Centro Rio-Grandense de Estudos Históricos. Rio Grande, Ano I, 1939.

COUTINHO, André Ribeiro. O Capitão de Infantaria Português com a theorica, $e$ pratica das suas funções... Lisboa: Officina Sylviana e Academia Real, 1751. (Tomo I) [Biblioteca Rio-Grandense]

CUNHA, D. Luís da. Instruções políticas. (introdução, estudo e edição de Abílio Diniz Silva) Lisboa: CNCDP, 2001.

Documentos diversos (editais, provisões, cartas régias etc.) relacionados à emigração açoriana e madeirense em Santa Catarina, in Walter Piazza. A epopéia açóricomadeirense (1747-1756). Florianópolis: Ed. UFSC, Lunardelli, 1992.

Documentos Históricos, in Paschoal Apóstolo Pítsica. A Capitania de Santa Catarina: alguns momentos. Florianópolis: Fundação Franklin Cascaes; Lunardelli; Fundação Catarinense de Cultura, 1993.

Documentos Históricos, Biblioteca Nacional do Rio de Janeiro, vol. XCIV, XCV. (Consultas do Conselho Ultramarino)

Documentos Interessantes para a história e costumes de S. Paulo, Arquivo do Estado de São Paulo. 
Vols. 11 a 27; 32, 42, 47 e 72.

Estatuto Colégio Real dos Nobres (1761). In: Antonio Delgado da Silva. Coleção da legislação portuguesa. Desde a última compilação das ordens. Lisboa, 1830-1844.

FERNANDES, Domingos José Marques. Descrição Corográfica, Política, Civil e Militar da Capitania do Rio Grande de São Pedro do Sul.. In: Pesquisas. A Primeira História Gaúcha. Porto Alegre: Instituto Anchietano de Pesquisas, História n. 15, Ano $5,1961$.

HOMEM, Francisco de Barros Moraes Araujo Teixeira. Breve Instrução Militar sobre a Infantaria. Parte I. Lisboa: Oficina Patriarcal de Francisco Luiz Ameno, 1761. BNL, Cota - SC 33634 P.

Ilha de Santa Catarina: Relatos de viajantes estrangeiros nos Séculos XVIII e XIX. $3^{\mathrm{a}}$ ed. Rev. Florianópolis: Ed. UFSC; Lunardelli, 1990. (Organizada por Martim Afonso Palma de Haro)

LAYTANO, Dante. "Corografia da Capitania de Santa Catarina", in RIHGB, Vol. 245, 1959, pp. 3-187.

LAVRADIO, Marquês do. Cartas do Rio de Janeiro, 1769-1776. Rio de Janeiro: Publicações do Arquivo Nacional, 1978.

Memória Histórica da provincia de Santa Catarina, relativa as pessoas que a tem governado. (Anônima, 1821). In: RTIHGSC, Florianópolis, vol. 2, 1913.

MENDONÇA, Marcos Carneiro de (Org.). Raízes da Formação Administrativa do Brasil. Vol. I. Rio de Janeiro: IHGB; Conselho Federal de Cultura, 1972.

"Notícias Práticas da Costa e Povoação do Mar do Sul” realizadas por Manoel Gonçalves de Aguiar, in Affonso de E. Taunay. Relatos Sertanistas. São Paulo: Itatiaia: EdUSP, 1981.

PAES LEME, Pedro Tacques de Almeida. "História da capitania de S. Vicente desde a sua fundação por Martim Afonso de Souza em 1531...", in Revista do Instituto Histórico e Geográfico Brasileiro, n. 6 - 2º Trimestre de 1847.

PAIVA, Joaquim Gomes de Oliveira e (Arcipreste). "Notícia geral da Província de Santa Catarina" in Dicionário Topográfico, Histórico e Estatístico da Província de Santa Catarina. Florianópolis: Instituto Histórico e Geográfico de Santa Catarina, 2003 (Col. Catariniana, 5) [1 ${ }^{\mathrm{a}}$ ed. 1868].

PINHEIRO, José Feliciano Fernandes (Visconde de São Leopoldo). "Resumo Histórico da Província de Santa Catarina", in Anais da Província de São Pedro. Porto Alegre: Mercado Aberto, 1982 (Série Documenta, 11) [1 $1^{a}$ ed. c. 1832].

Publicações do Arquivo Público Nacional do Rio de Janeiro, vol. VII.

Relatório do Marquês de Lavradio, apresentado ao Vice-Rei Luis de Vasconcelos e Sousa seu sucessor, em 19 de junho de 1779, in Visconde de Carnaxide. O Brasil na Administração Pombalina (Economia e Política Externa). Rio de Janeiro: Companhia Editora Nacional, 1940.

Revista Trimestral do Instituto Histórico e Geográfico de Santa Catarina. vol. III, $1^{\circ}$ e 2 ${ }^{\circ}$ Trim., 1914; vol. IV, 1915; e VI, 1917.

SAINT-HILAIRE, Auguste de. Viagem a Curitiba e Província de Santa Catarina. Belo Horizonte: Itatiaia; São Paulo: EDUSP, 1978. 
. Viagem à Província do Rio de Janeiro e Minas Gerais. São Paulo; Belo

Horizonte: Ed. USP, Itatiaia, 1978.

TOLOZANO, Antônio de Ville Tolozano. O governador de praças, obra muyto útil, e necessária não só para os governadores de praças, que quizerem aprender a doutrina militar, e as suas obrigações principalmente nos presídios. Lisboa, 1708. Biblioteca Rio-Grandense, XVIII - 94 (Col. Silva Paes).

\section{Obras de referência}

ALMEIDA, Eduardo de Castro e (Org.). Inventários de Documentos Relativos ao Brasil existentes no Archivo da Marinha e Ultramar de Lisboa, organizado para a Biblioteca Nacional do Rio de Janeiro. Rio de Janeiro, 1913-1918.

ARQUIVO HISTÓRICO ULTRAMARINO. Elementos Informativos. Brasil. Diversos. I. Lisboa, AHU, 1960. (ex. datilo).

BARRETO, Abeillard. Bibliografia Sul-riograndense (A contribuição portuguesa e estrangeira para o conhecimento e a integração do Rio Grande do Sul). Vol I. Rio de Janeiro: Conselho Federal da Cultura, 1973-1976.

BLUTEAU, Raphael. Vocabularário Portuguez e Latino... Coimbra, 1712.

BOBBIO, Norberto; MATTEUCCI, Nicola; PASQUINO, Gianfranco. Dicionário de Política. 5 ed. Brasília: Ed. UnB, 2000.

BOLETIM DO ARQUIVO HISTÓRICO COLONIAL. Lisboa: Arquivo Histórico Colonial, 1950. $521 \mathrm{p}$.

CARNEIRO, Carlos Silveira (Almirante). Enciclopédia de Santa Catarina. 68 vols. s.n.t.

Dicionário de La Lengua Española. Real Academia Espanhola. 21 a ed. Madri: Espasa, 1992.

Enciclopédia Luso-Brasileira de Cultura. Lisboa: Verbo, s/d.

FERREIRA, Carlos Alberto. Relação dos maços de ofícios dos governadores das capitanias do Ultramar que se remetem para o Rio de Janeiro em 1807 com D. João. [s.n.t.]. 4 fls.

GOUVEIA, Alfredo Mendes de. Relação abreviadíssima de alguns documentos de século XVIII existentes no Arquivo Histórico Ultramarino com interesse para a história do Rio Grande de São Pedro do Sul e cujos microfilmes foram solicitados pelo professor da Faculdade de Filosofia daquele estado, Sr. Dr. Dante de Laytano. Lisboa: Arquivo Histórico Ultramarino, 1962. 18 p. (ex. datilo.).

Grande Enciclopédia Portuguesa e Brasileira. Lisboa; Rio de Janeiro: Editorial Enciclopédia, s/d.

IRIA, Alberto. Inventário da iconografia brasileira existente no Arquivo Histórico Ultramarino: subsídios para o dicionário de Iconografia do Brasil. Lisboa: Centro de Estudos Históricos Ultramarinos. Separata de Studia, n. 16, Nov. 1965. 
Inventário geral da cartografia brasileira existente no Arquivo Histórico Ultramarino: elementos para a publicação da Brasiliae Monumenta Cartographica. Lisboa: Centro de Estudos Históricos Ultramarinos. Separata de Studia, n. 17, Abr. 1966.

Inventário geral dos códices do Arquivo Histórico Ultramarino apenas referentes ao Brasil. Lisboa: Centro de Estudos Históricos Ultramarinos. Separata de Studia, n. 28, Ago. 1966.

MAFRA, Manoel da Silva. Exposição Histórico-Jurídica. Florianópolis: IOESC, 2002. (Ed. Fac-similar de 1899).

SERPA, Élio; FLORES, Maria Bernardete Ramos (Orgs.). Catálogo de documentos avulsos manuscritos referentes à Capitania de Santa Catarina - 1717-1827.

Florianópolis: Ed. UFSC, 2000, p. 92. (Projeto Resgate)

SERRÃO, Joel (Dir.) Dicionário de História de Portugal. Porto: Livraria Figueirinhas, s/d.

SOUZA, Suzana Bleil e OSÓRIO, Hélen (Orgs.). Catálogo de documentos avulsos manuscritos referentes à Capitania de Rio Grande de São Pedro. Porto Alegre: Corag, 2001. (Projeto Resgate)

\section{Bibliografia}

ABREU, J. Capistrano de. "Sobre a Colônia do Sacramento" in Ensaios e Estudos (crítica e história) - 3a série. Rio de Janeiro: Sociedade Capistrano de Abreu, 1938.

ADONIAS, Isa Adonias; FURRER, Bruno Furrer et al (Orgs.). MAPA: Imagens da Formação Territorial Brasileira. Rio de Janeiro: Fundação Emilio Odebrecht, 1993.

ALDEN, Dauril. Royal Government in Colonial Brazil. With Special Reference to the Administration of the Marquis of Lavradio, Viceroy, 1769-1779. Berkeley: University of California Press, 1968.

. "O Período Final do Brasil Colônia: 1750-1808”, in Leslie Bethell. História da América Latina, América Latina Colonial, vol. II. São Paulo: Ed. USP, 2004.

The Population of Brazil in the Late Eighteenth Century: A Preliminary Study. Hispanic American Historical Review, Vol. XLIII, n. 2, May., 1963.

ALENCASTRO, Luiz Felipe de Alencastro. O Trato dos viventes - Formação do Brasil no Atlântico Sul, século XVI e XVII. São Paulo: Companhia das Letras, 2000.

ALEXANDRE, Valentim. Os Sentidos do Império - Questão Nacional e Questão Colonial na Crise do Antigo Regime Português. Porto: Afrontamento, 1993.

ALMEIDA, André Ferrand de. A formação do espaço brasileiro e o projeto do Novo Atlas da América Portuguesa (1713-1748). Lisboa: CNPCDP, 2001.

ALMEIDA, Luís Ferrand de. A Diplomacia Portuguesa e os Limites Meridionais do Brasil-(1493-1700), vol I. Coimbra, 1957.

ANDERSON, Perry. Linhagens do Estado Absolutista. 3 ed. São Paulo: Brasiliense, 2004. 
APARÍCIO, João Paulo. Governar no Brasil Colonial na segunda metade de Setecentos: o caso de Minas Gerais, in Maria Emilia Madeira Santos (Coord.) O Domínio da Distância: comunicação e cartografia. Lisboa: Instituto de Investigação Científica Tropical, 2006.

ARAÚJO, Ana Cristina. Livros de uma Vida: Critérios e modalidades de constituição de uma livraria particular no Século XVIII, in Revista de História das Idéias. Vol. 20 O Livro e a Leitura. Coimbra, 1999.

ARRUDA, José Jobson de Andrade Arruda. O Sentido da Colônia. Revisitando a Crise do Antigo Sistema Colonial no Brasil (1780-1830). In: José Tengarrinha (org.) História de Portugal. 2 ed. rev. e ampl. Bauru, SP: EDUSC; São Paulo: UNESP; Portugal: Instituto Camões, 2001.

A Produção Econômica. In: SERRÃO, J, OLIVEIRA MARQUES, A.H. (Dir.) Nova história da expansão portuguesa. Lisboa: Estampa, 1986.

O Brasil no Comércio Colonial. São Paulo: Ática, 1980.

AZEVEDO, João Lúcio de. O Marquês de Pombal e a sua época. São Paulo: Alameda, 2004.

BARRETO, Abeillard. A livraria de José da Silva Paes, in Província de São Pedro. Porto Alegre, 15: 178-80, 1951.

BELlotTO, Heloisa L. Autoridade e Conflito no Brasil Colonial: o governo Morgado de Mateus em São Paulo, 1765-1775. São Paulo: Secretaria de Estado da Cultura, Conselho Estadual de Artes e Ciências Humanas, 1979.

O Estado português no Brasil: sistema administrativo e fiscal. In: SERRÃO, J, OLIVEIRA MARQUES, A. H. (Dir.) Nova história da expansão portuguesa. Lisboa: Estampa, 1986.

BETHENCOURT, Francisco. A América Portuguesa. In: idem; CHAUDHURI, Kirti. (Dir.) História da Expansão Portuguesa. Lisboa, Temas e Debates, 1998. (vol. 3)

BICALHO, Maria Fernanda. A Cidade e o Império: o Rio de Janeiro no século XVIII. Rio de Janeiro: Civilização Brasileira, 2003.

Centro e Periferia: pacto e negociação política na administração do Brasil Colonial. Leituras: Revista da Biblioteca Nacional. Lisboa, n. 6, abr.-out., pp. 17-39, 2000.

A Cidade do Rio de Janeiro e a Articulação da Região em torno do Atlântico-Sul: Séculos XVII e XVIII, in Revista de História Regional, vol. 3, n. 2, inverno 1998, http://www.rhr.uepg.br/v3n2/fernanda.htm, acesso em 4 de março de 2006.

Conquista, Mercê e Poder Local: a nobreza da terra na América portuguesa e a cultura política do Antigo Regime. In: almanack braziliense, n, 02, nov. 2005, pp. 2134.

; FERLINI, Vera Lucia Amaral. Modos de Governar: Idéias e Práticas Políticas no Império Português, séculos XVI a XIX. São Paulo: Alameda, 2005.

BOITEUX, José Arthur. Santa Catharina nos tempos d'El-Rey Nosso Senhor. Florianópolis: Typ. São José, 1929. (Conferência no Centro Popular de Florianópolis, em 21 de abril de 1928).

BOITEUX, Lucas A. Notas para a História Catharinense. Florianópolis: Moderna, 1912. 
A pesca da Baleia, in RTIHGSC, vol. III, $1^{\circ}$ e $2^{\circ}$ Trim., 1914.

BOSCHI, Caio. Administração e administradores no Brasil pombalino. In Tempo. Rio de Janeiro, n. 13, jul. 2002.

BOXER, Charles R. Salvador de Sá e a Luta pelo Brasil e Angola, 1602-1686. Trad. Olivério de Oliveira Pinto. São Paulo: Ed. Nacional, Edusp, 1973. (Brasiliana, v. 353).

. A Idade de Ouro do Brasil: Dores de crescimento de uma sociedade colonial. 3 ed. Rio de Janeiro: Nova Fronteira, 2000. 2002.

O império marítimo português, 1415-1825. São Paulo: Companhia das Letras,

BRAUDEL, Fernand. O Mediterrâneo e o Mundo Mediterrânico na Época de Filipe II. Lisboa: Martins Fontes, 1983.

Civilização Material, Economia e Capitalismo, Séculos XV-XVIII. - Vol 2 - Os Jogos das Trocas. São Paulo: Martins Fontes, 1996.

BUENO, Beatriz Siqueira. Desenho e desígnio - o Brasil dos engenheiros militares. In: Oceano. Lisboa: CNPCDP, n. 41, jan.-mar., 2000, pp. 41-58.

BURCHBINDER, Pablo. La historiografía rioplatense y el problema de los orígenes de la nación. In: Cuadernos del claeh, n. 69. Montevideo, 2a ${ }^{\text {. }}$ série, año 19, 1994/1.

CABRAL, Oswaldo R.. Santa Catarina (História - Evolução). São Paulo: Companhia Editora Nacional, 1937, (Col. Brasiliana, vol. 80)

. Nossa Senhora do Desterro. Florianópolis: Lunardelli, 1979. (2 vols.)

As defesas da Ilha de Santa Catarina no Brasil Colonial. [s.1.] Conselho Federal de Cultura, 1972.

História de Santa Catarina. 2 ed. Florianópolis: Lunardelli, 1970.

A Campanha do Contestado. $2^{\mathrm{a}}$ ed. Florianópolis: Lunardelli, 1979.

João Maria: Interpretação da Campanha do Contestado, publicado pela Companhia Editora Nacional de São Paulo, 1960.

A vitória da colonização Açoriana em Santa Catarina. Florianópolis: Imprensa Oficial, 1941. 1939.

Laguna e outros ensaios. Florianópolis: IHGSC e Academia Catarinense de Letras,

CANABRAVA, Alice P. O Comércio Português no Rio da Prata (1580-1640). Belo Horizonte: Itatiaia; São Paulo: Edusp, 1984.

CARDIM, Pedro. “O Processo Político (1621-1807)”, in José Mattoso (Dir.) História de Portugal. Lisboa: Estampa, 1997. (Vol. 4 - O Antigo Regime)

CARDOSO, Fernando Henrique. Capitalismo e Escravidão no Brasil Meridional: O negro na sociedade escravocrata do Rio Grande do Sul. Rio de Janeiro: Paz e Terra, 1977.

Rio Grande do Sul e Santa Catarina. In: HOLANDA, Sérgio Buarque. (org. e dir.) História Geral da Civilização Brasileira. Tomo II - O Brasil Monárquico, $2^{\circ}$ vol Dispersão e Unidade. Livro 5 - As Províncias do Sul. 2 ed. São Paulo: DIFEL, 1967. 
. "O Negro e o Desenvolvimento Econômico e Social de Florianópolis", in Fernando

H. Cardoso e Otávio Ianni. Cor e Mobilidade Social em Florianópolis: aspectos das relações entre negros e brancos numa comunidade do Brasil Meridional. São Paulo: Companhia Editora Nacional, 1960. (Col. Brasiliana, vol. 307)

CARNAXIDE, Antonio de Souza Pedroso. O Brasil na Administração Pombalina (Economia e política externa). São Paulo: Ed. Nacional, 1940.

CESAR, Guilhermino. História do Rio Grande do Sul - Período Colonial. Porto Alegre, Globo, 1970.

CONCEIÇÃO, Margarida Tavares. A Praça da Guerra - Aprendizagens entre a Aula do Paço e a Aula de Fortificação. In: Oceanos. Lisboa: CNPCDP, n. 41, jan.-mar., 2000, pp. 25-39.

CORREA, Carlos Humberto. História de Florianópolis - Ilustrada. Florianópolis: Insular, 2004. 1983.

Os governantes de Santa Catarina de 1739 a 1982. Florianópolis: Ed. UFSC,

"A Descoberta do Oeste Catarinense", in RIHGB, Rio de Janeiro, 161 (408) 101111, jul./set. 2000.

CORTESÃO, Jaime. Alexandre de Gusmão e o Tratado de Madrid. Rio de Janeiro: Ministério das Relações Exteriores; Instituto Rio Branco, c. 1950.

Raposo Tavares e a Formação Territorial do Brasil. Rio de Janeiro. Ministério da Educação e Cultura, 1958.

COSENTINO, Francisco Carlos Cardoso. Governadores Gerais do Estado do Brasil (séculos XVI e XVII): ofício, regimentos, governação e trajetórias. Niterói: ICHF-UFF (Tese de Doutorado), 2005.

COSTA, Antônio Gilberto (Org.) Cartografia da Conquista - Território das Minas. Belo Horizonte: Ed. UFMG; Lisboa: Kapa Editorial, 2004.

COUTO, Jorge. "D. João V" in João Medina (Dir.). História de Portugal dos tempos pré-históricos aos nossos dias. Vol. VII - Portugal Absolutista. Alfragide: Ediclube, s/d.

CUNHA, Mafalda S. da. Governo e governantes do Império português do Atlântico (século XVII), in Maria Fernanda Bicalho e Vera Lúcia Amaral Ferlini (Orgs.) Modos de Governar: Idéias e Práticas Políticas no Império Português - séculos XVI a XIX. São Paulo: Alameda, 2005

ELIAS, Norbert. A Sociedade de Corte: investigação sobre a sociologia da realeza e da aristocracia de corte. Rio de Janeiro: Zahar, 2001.

O Processo Civilizador. Rio de Janeiro: Zahar, 1993. (2 vols.)

ELLIS, Myriam. "As bandeiras na expansão geográfica do Brasil” In: Sérgio Buarque de Holanda (Dir.) História Geral da Civilização Brasileira. T. I, vol. 1. Rio de Janeiro: Bertrand Brasil, 1989.

. A Baleia no Brasil Colonial. São Paulo: Melhoramentos, 1969.

. Aspectos da Pesca da Baleia no Brasil Colonial. São Paulo, 1958. 
FALCON, Francisco José Calazans. A Época Pombalina (Política econômica e monarquia ilustrada). São Paulo: Ática, 1982.

A Cidade Colonial: Algumas questões a propósito de sua importância políticoadministrativa (séculos XVII/XVIII). In: ANAIS - I Colóquio de Estudos Históricos Brasil/Portugal. Belo Horizonte: PUCMG, Universidade Portucalense Infante D. Henrique, 1994.

FAORO, Raymundo. Os Donos do Poder: formação do patronato político brasileiro. Vol. 1.11 ed. Porto Alegre: Globo, 1997.

FERLINI, Vera Lucia Amaral. Terra, trabalho e poder: o mundo dos engenhos no nordeste colonial. São Paulo: Brasiliense, 1988.

. "São Paulo, de Fronteira a Território: uma Capitania dos Novos Tempos" in Laboratório do Mundo - Idéias e saberes do século XVIII. São Paulo: Imprensa Oficial, 2004.

FERREIRA, Mário Clemente. O Tratado de Madrid e o Brasil Meridional. Lisboa: CNPCDP, 2001.

FLEIUSS, Max. História Administrativa do Brasil. 2 ed. São Paulo: Melhoramentos, 1922.

FORTES, João Borges. Os Casais Açorianos: presença lusa na formação sul-riograndense. 3 ed. Porto Alegre, Martins Livreiro, 1999.

FRAGOSO, João. Homens de Grossa Aventura. Rio de Janeiro, Arquivo Nacional, 1992.

FRAGOSO, João; BICALHO, Maria Fernanda; GOUVÊA, Maria de Fátima (Orgs.) $O$ Antigo Regime nos Trópicos: A Dinâmica Imperial Portuguesa (Séculos XVI-XVIII). Rio de Janeiro: Civilização Brasileira, 2001.

FREIRE, Américo; CASTRO, Celso. "As bases republicanas dos Estados Unidos do Brasil" in Ângela de Castro Gomes, Dulce Chaves Pandolfi e Verena Alberti (Orgs.) A República no Brasil. Rio de Janeiro: Nova Fronteira, CPDOC, 2002.

GARCIA, Rodolfo Augusto de Amorim. Ensaio sobre a história política $e$ administrativa do Brasil: 1500-1810. 2 ed. Rio de Janeiro: José Olympio, Brasília: INL, 1975.

GODINHO, Vitorino Magalhães. Mito e mercadoria, utopia e prática de navegar, séculos XIII-XVIII. Lisboa: DIFEL, 1990.

GOUVÊA, Maria de Fátima Silva. Administração. In: VAINFAS, Ronaldo (Dir.) Dicionário do Brasil Colonial (1500-1808). Rio de Janeiro: Objetiva, 2000.

GUEDES, Max Justo. A Cartografia da Delimitação das Fronteiras do Brasil no Século XVIII. In, HESPANHA, António Manuel (Dir.). Cartografia e Diplomacia no Brasil do Século XVIII. Lisboa: CNPCDP, 1997.

GUERREIRO, Inácio. "Particularidades da vida no mar" in Oceanos - Navios e navegações - Portugal e o Mar. Lisboa: CNCDP, n. 38, abril/junho, 1999.

HANDELMANN, Heirich. História do Brasil. $4^{\mathrm{a}}$ ed. São Paulo: Itatiaia, 1982. [1 $1^{\mathrm{a}} \mathrm{ed}$. alemã: 1860].

HESPANHA, António M. As vésperas do Leviathan. Instituições e poder político: Portugal - séc. XVII. Coimbra: Almedina, 1994. 
. As estruturas políticas em Portugal na Época Moderna. In: José Tengarrinha. (org.) História de Portugal. São Paulo: Edusc; Unesp; Portugal: Instituto Camões, 2001.

. (Coord.) - O Antigo Regime - vol. 4, in MATTOSO, José (Dir.) História de Portugal. Lisboa: Estampa, 1992.

- A Nobreza nos Tratados Jurídicos dos Séculos XVI a XVIII, in Penélope - Fazere Desfazer a História. Dossiê Nobrezas e Aristocracias. Lisboa, n. 12, pp. 27-42.

"Depois do Leviathan", in almanack braziliense, n. 02, USP, maio de 2007.

HOBSBAWM, Eric. Nações e Nacionalismo desde 1780. Rio de Janeiro: Paz e Terra, 1991.

HOLANDA, Sérgio Buarque de. "A Colônia de Sacramento e a Expansão no Extremo Sul” In: idem (Org.). História Geral da Civilização Brasileira. T. I, vol. 1. Rio de Janeiro: Bertrand Brasil, 1989.

JANNONI, Lucas. Presença dos homens livres pobres na sociedade colonial da América Portuguesa - São Paulo (1765-1775). São Paulo: FFLCH-USP (Dissertação de Mestrado), 2005.

JULLIARD, Jacques. A Política. In: LE GOFF, Jacques; NORA, Pierre. História: novas abordagens. Rio de Janeiro: Francisco Alves, 1988.

KANTOR, Iris. "A Academia Brasílica dos Renascidos e o Governo Político da América Portuguesa (1759): contradições do Cosmopolitismo Acadêmico LusoAmericano". In: István Jancsó. Brasil: Formação do Estado e da Nação. São Paulo: Hucitec; Ijuí: E.UNIJUÍ, 2003, pp. 321-343.

KOSELLECK, Reinhart. Uma História dos Conceitos: problemas teóricos e práticos. In: Estudos Históricos. Rio de Janeiro, vol. 5, n. 10, 1992, p. 134-146.

KÜHN, Fabio. Gente da Fronteira: família, sociedade e Poder no Sul da América Portuguesa - século XVIII. Niterói-RJ: UFF, PPG-História (Tese de Doutorado), 2006.

. A fronteira em movimento: relações luso-castelhanas na segunda metade do século XVIII, in Estudos Ibero-Americanos, PUCRS, vol. XXV, n. 2, pp. 91-112, dez. 1999.

LADURIE, Emmanuel Le Roy. O Estado Monárquico: França, 1460-1610. São Paulo: Companhia das Letras, 1994.

LIMA, Ruy Cirne. Pequena história territorial do Brasil: sesmarias e terras devolutas. 5 ed. Goiânia: Ed. UFG, 2002.

MACHADO, Lourival G. Política e administração sob os últimos Vice-reis. In: HOLANDA, Sérgio B. História Geral da Civilização Brasileira. São Paulo: DIFEL, 1960, p. 360. T. 1, V. 2: A Época Colonial.

MAGALHÃES, Joaquim Romero. "As Novas Fronteiras do Brasil" in Francisco Bethencourt e Kirti Chaudhuri (Dir.) História da Expansão Portuguesa - Vol. 3 - O Brasil na Balança do Império (1697-1808). Lisboa: Temas e Debates, s/d.

"A Sociedade", in idem (Coord.). No Alvorecer da Modernidade - vol. 3, in MATTOSO, José (Dir.) História de Portugal. Lisboa: Estampa, 1992.

MAMIGONIAN, Beatriz Gallotti. "Africanos em Santa Catarina: escravidão e identidade étnica (1750-1850)", in João Fragoso, Manolo Florentino et. al. (Orgs.) Nas rotas do Império: eixos mercantis, tráfico e relações sociais no mundo português. Ilha de Vitória, ES: Edufes, 2006. 
MARCÍlIO, Maria Luiza. Crescimento Demográfico e Evolução Agrária Paulista, 1700-1836. São Paulo: Hucitec, 2000.

MAXWELL, Kenneth; SILVA, Maria Beatriz Nizza. A Política. In: SERRÃO, J, OLIVEIRA MARQUES, A.H. (Dir.) Nova história da expansão portuguesa. Lisboa: Estampa, 1986.

MAXWELL, Kenneth. Marquês de Pombal. Paradoxo do Iluminismo. São Paulo: Paz e Terra, 1996.

MAURO, Frédéric. "Portugal e o Brasil: a Estrutura Política e Econômica do Império, 1580-1750" in Leslie Bethell (Org.) História da América Latina - América Latina Colonial (Vol. I). 2 ed. São Paulo: EdUSP; Brasília, DF: Fundação Alexandre de Gusmão, 2004.

Portugal, o Brasil e o Atlântico (1570-1670) - vol I. Lisboa: Estampa, 1988.

MELLO, Amilcar d'Ávila. Crônicas das Origens: Santa Catarina na era dos descobrimentos geográficos. Florianópolis: Expressão, 2005. (3 vols.).

MELlO, Evaldo Cabral de. O Nome e o Sangue: uma Parábola Familiar no Pernambuco Colonial. 2 ed. Rio de Janeiro: Topbooks, 2000.

MENDONÇA, Marcos Carneiro de. A rendição da Ilha de Santa Catarina. In: RIHGB, vol. 321, out.-dez., pp. 5-35, 1978.

MENEZES, Mozart Vergetti de. Colonialismo em ação: fiscalismo, economia e sociedade na capitania da Paraíba (1647-1755). São Paulo, FFLCH/USP (Tese de Doutorado, Programa História Econômica), 2005.

MENZ, Maximiliano. Entre dois Impérios: Formação do Rio Grande na Crise do Antigo Sistema Colonial (1777-1822). São Paulo: USP-FFLCH (Tese de Doutorado), 2006.

MIRANDA, Marcia Eckert. Continente de São Pedro: Administração Pública no Período Colonial. Porto Alegre: Assembléia Legislativa do Estado do RS/Ministério Público do Estado do RS/CORAG, 2000.

A Estalagem e o Império: Crise do Antigo Regime, fiscalidade e fronteira na Província de São Pedro (1808-1831). Campinas: UNICAMP - Instituto de Economia (Tese de Doutorado), 2006.

MONTEIRO, Jônathas da Costa Rego Monteiro. A Colônia do Sacramento (16801777). Porto Alegre: Globo, 1937 (2 vol.).

. “A Dominação Espanhola no Rio Grande do Sul” (1763-1777), in Anais do Simpósio Comemorativo do Bicentenário da Restauração do Rio Grande (1776-1976). Rio de Janeiro: IHGB, 1979.

MONTEIRO, Nuno Gonçalo F. Trajetórias sociais e governo das conquistas: notas preliminares sobre vice-reis e governadores-gerais do Brasil e da Índia nos séculos XVII e XVIII. In: FRAGOSO, João; BICALHO, Maria Fernanda; GOUVÊA, Maria de Fátima (Orgs). O Antigo Regime nos Trópicos: a dinâmica imperial portuguesa (séculos XVI-XVIII). Rio de Janeiro: Civilização Brasileira, 2001.

Notas sobre nobreza, fidalguia e titulares nos finais do Antigo Regime. In: Ler História, n. 10. Lisboa, 1987. 
Poder Senhorial, estatuto nobiliárquico e aristocracia. In: Hespanha, A. M. (Coord.). História de Portugal. O Antigo Regime. Lisboa: Estampa, 1993 (vol.4).

O Crepúsculo dos Grandes. A casa e o patrimônio da aristocracia em Portugal (1750-1832). Lisboa: Imprensa Nacional-Casa da Moeda, 1998.

. "A Consolidação da Dinastia de Bragança e o Apogeu do Portugal Barroco: centros de poder e trajetórias sociais (1668-1750)" in TENGARRINHA, José (org.). História de Portugal, . São Paulo: Edusc; Unesp; Portugal: Instituto Camões, 2001.

Elites e Poder - Entre o Antigo Regime e o Liberalismo. Lisboa, ICS, 2003.

O 'Ethos' Nobiliárquico no final do Antigo Regime: poder simbólico, império e imaginário social. In: almanack braziliense, n. 02, nov. 2005, pp. 4-19.

; CUNHA, Mafalda Soares da. "Governadores e capitães-mores do império atlântico português nos séculos XVII e XVIII" in MONTEIRO, Nuno Gonçalo F.; CARDIM, Pedro; CUNHA, Mafalda Soares da (Orgs.). Optima Pars: Elites Ibero-Americanas do Antigo Regime. Lisboa: Imprensa de Ciências Sociais, 2005.

. Vice-reis, governadores e Conselheiros de Governo do Estado da Índia (15051834). Recrutamento e Caracterização social, In Penélope - Fazer e Desfazer a História. Lisboa, n. 15, 1995.

MORAES, Antonio Carlos Robert. Bases da Formação Territorial do Brasil: o território colonial brasileiro no "longo" século XVI. São Paulo: Hucitec, 2000.

; COSTA, Wanderley Messias da. Geografia crítica. A valorização do espaço. São Paulo: Hucitec, 1984.

MOSIMANN, João Carlos. Ilha de Santa Catarina, 1777-1778. A Invasão Espanhola. Florianópolis, Ed. do autor, 2003.

NEVES, Gervásio. Fronteira Gaúcha - Fronteira do Brasil com o Uruguai. Porto Alegre: UFRGS (Dissertação de Mestrado), 1976.

NOVAIS, Fernando A. Portugal e Brasil na Crise do Antigo Sistema Colonial (17771808). 6 ed. São Paulo: Hucitec, 1995.

As Dimensões da Independência. In: Carlos Guilherme Mota. 1822 - Dimensões. São Paulo: Perspectiva, 1972.

. Condições da Privacidade na Colônia. In: Novais, Fernando A., Souza, Laura de M. História da Vida Privada no Brasil - Cotidiano e vida privada na América portuguesa. São Paulo: Cia. das Letras, 1997.

A proibição das manufaturas no Brasil e a política econômica portuguesa do fim do século XVIII, in idem. Aproximações: estudos de história e historiografia. São Paulo: Cosac Naify, 2005.

OLIVAL, Fernanda. As Ordens Militares e o Estado Moderno: Honra, Mercê e Venalidade em Portugal (1641-1789). Lisboa, 2001.

Mercês, Serviços e Circuitos Documentais no Império Português, in Maria Emilia Madeira Santos (Coord.) O Domínio da Distância: Comunicação e Cartografia. Lisboa: Instituto de Investigação Científica Tropical, 2006.

OSÓRIO, Helen. Apropriação da Terra no Rio Grande de São Pedro e a Formação do Espaço Platino. Dissertação de Mestrado, UFRGS, 1990. 
. "Estancieiros" e "lavradores": Rio Grande do Sul, século XVIII. Anos 90. Porto Alegre, n. 4, p. 31-43, dez. 1995.

O espaço platino: fronteira colonial no século XVIII. In: CASTELLO, Iára Regina (orgs.) ... et alli. Práticas de integração nas fronteiras, temas para o mercosul. Porto Alegre: EDUFRGS/Instituto Goethe/ICBA, 1995.

Conflitos e apropriação da terra: região platina, século XVIII. In: AZEVEDO, Francisca Nogueira de, MONTEIRO, John Manuel (Orgs.). Raízes da América Latina. São Paulo: EDUSP, 1996, p. 335-342.

Estancieiros, lavradores e comerciantes na constituição da extremadura portuguesa na América. Porto Alegre: UFRGS (Tese de Doutorado) IFCH-História, 1999.

PEDREIRA, Jorge Miguel de Melo Viana. Os Homens de Negócio da Praça de Lisboa de Pombal ao Vintismo (1755-1822): diferenciação, reprodução e identificação de um grupo social. Lisboa: Universidade Nova de Lisboa - FCSH (Dissertação de doutoramento em Sociologia), 1995.

PEREIRA, Carlos da Costa. História de São Francisco do Sul. Florianópolis: Ed. UFSC, 2004.

Acerca da Invasão Espanhola. In: RIHGSC, $1^{\circ}$ sem., 1943.

PERIDES, Paulo Pedro. A organização político-administrativa e o processo de regionalização do território brasileiro. In: Revista do Departamento de Geografia. São Paulo: USP-FFLCH, n. 9, pp. 77-91, 1995.

PESAVENTO, Sandra Jatahy. História do Rio Grande do Sul. 7 ed. Porto Alegre: Mercado Aberto, 1994.

PIAZZA, Maria de Fátima Fontes. A Invasão Espanhola na Ilha de Santa Catarina. Brasília: UnB (Dissertação de Mestrado - Política Externa), 1978.

PIAZZA, Walter F. Santa Catarina: sua história. Florianópolis: Ed.UFSC; Lunardelli, 1983.

A Colonização de Santa Catarina. Florianópolis: BRDE, 1985.

. O Brigadeiro José da Silva Paes: estruturador do Brasil Meridional. Rio Grande: Fund. URG; Florianópolis: EdUFSC, 1988. 1992.

A epopéia açórico-madeirense (1747-1756). Florianópolis: Ed. UFSC, Lunardelli,

Dicionário Político Catarinense. Florianópolis: Ed. Assembléia Legislativa do Estado de Santa Catarina, 1985.

. A Escravidão Negra Numa Província Periférica. Guarapuvu, 1999.

A Ilha de Santa Catarina e o seu continente na luta pela hegemonia portuguesa e na fixação da cultura lusitana no Brasil Meridional, in As Ilhas e o Brasil. Madeira: Centro de Estudos de História do Atlântico, 2000.

Introdução à história da propriedade rural em Santa Catarina. In: Separata dos Anais do VIII Simpósio Nacional dos Professores Univesitários de História (Aracaju, setembro de 1975). São Paulo, 1976. 
Pombal e a entrega da Ilha de Santa Catarina aos Espanhóis, em 1777. In: RIHGSC, $3^{\text {a }}$ fase, n. 4, pp. 115-129, 1982-83.

PICCOLO, Helga I. Landgraf. Os Confrontos nos Encontros: A Dinâmica do Processo de Colonização no Sul do Brasil. In: AZEVEDO, Francisca L. Nogueira de, MONTEIRO, John Manuel. Raízes da América Latina. São Paulo: EDUSP, 1996, p. 343-356.

PIMENTA, João Paulo Garrido. Estado e Nação no fim dos Impérios ibéricos no Prata: 1808-1828. São Paulo: Hucitec; FAPESP, 2002.

O Brasil e a América Espanhola (1808-1822). São Paulo, (Tese de Doutorado) FFLCH/USP, 2003.

PINTO, Virgílio Noya. O Ouro Brasileiro e o comércio Anglo-português. Ed. Nacional: São Paulo, 1979 (Col. Brasiliana, vol. 371).

POSSAMAI, Paulo César. O Cotidiano da Guerra: a vida na Colônia do Sacramento (1715-1735). São Paulo: USP-FFLCH (Tese de Doutorado em História), 2001

PRADO, Fabrício. Colônia do Sacramento: o Extremo Sul da América Portuguesa no Século XVIII. Porto Alegre, 2002.

PRADO Jr., Caio. Formação do Brasil Contemporâneo. 23 ed. São Paulo: Brasiliense, 1999.

História econômica do Brasil. 16a. ed. São Paulo, Brasiliense, 1973.

Evolução Política do Brasil. São Paulo: Ver. Tribunais, 1933.

PROENÇA, João Justino de. O Melhor Porto ao Sul do Brasil. Rio de Janeiro: Typ. Lombaerts e Comp., 1884.

PUNTONI, Pedro Luís. A guerra dos bárbaros: povos indígenas e a colonização do sertão do nordeste do Brasil, 1650-1720. São Paulo: Hucitec, Edusp, 2002.

QUEIROZ, Maria Luiza Bertuline. A vila do Rio Grande de São Pedro (1737-1822). Rio Grande: FURG, 1987.

RÉMOND, René. Por que a História Política? In: Estudos Históricos. Rio de Janeiro, vol. 7, n. 13, 1994, p. 7-19.

Por Uma História Política. Rio de Janeiro: Ed. UFRJ, FGV, 1996.

RONCAYOLO, Jean-Pierre. Significados da fronteira, in Enciclopédia Einaudi. Vol. 8 - Região. Lisboa: Imprensa Nacional - Casa da Moeda, s/d.

ROSA, Vieira da (Gen.). A Vergonha de 1777. In: RIHGSC, vol. XIII, $2^{\circ}$ sem., 1944.

ROSANVALlON, Pierre. Por Uma História Conceitual do Político (nota de trabalho). In: Revista Brasileira de História. São Paulo: v. 15, n. 30, 1995, p. 9-22.

RUIVO, Maria da Conceição. O Iluminismo e a Cultura Científica, in Laboratório do Mundo: idéias e saberes do século XVIII. São Paulo: Imprensa Oficial, 2004.

RUSSEL-WOOD, A. J. R. "O Brasil Colonial: o Ciclo do Ouro, c. 1690-1750” in Leslie Bethel (Org.). História da América Latina - América Latina Colonial (Vol. II ). São Paulo: EdUSP; Brasília, DF: Fundação Alexandre de Gusmão, 2004.

. "Governantes e Agentes", in Francisco Bethencourt e Kirti Chaudhuri (Orgs.) História da Expansão Portuguesa - vol. 3. O Brasil na Balança do Império (16971808). Lisboa: Temas e Debates, 1998 
SALDANHA, António Vasconcelos de. As capitanias do Brasil: Antecedentes, desenvolvimento e extinção de um fenómeno atlântico. Lisboa: CNCDP, 2001.

SALGADO, Graça (Coord.). Fiscais e Meirinhos: a administração no Brasil colonial. 2 ed. Rio de Janeiro: Nova Fronteira, 1985.

SALOMON, Marlon. "O exílio da desordem e a segurança da Ilha de Santa Catarina no século XVIII", in Ana Brancher, Silvia Maria Fávero Arend (Orgs.) História de Santa Catarina, Séculos XVI a XIX. Florianópolis: EdUFSC, 2004.

O saber do espaço: Ensaio sobre a geografização do espaço em Santa Catarina no século XIX. Florianópolis: CFCH-UFSC (Tese de Doutorado), 2002.

SANTIAGO, Theo A. (Org.) Capitalismo: transição. Rio de Janeiro: Eldorado, 1975.

SANTOS, Corcino de Medeiros. Economia e Sociedade do Rio Grande do Sul: século XVIII. São Paulo: Nacional, 1984.

SCHWARTZ, Stuart B. Burocracia e Sociedade no Brasil Colonial. A Suprema Corte da Bahia e seus Juízes: 1609-1751. São Paulo: Perspectiva, 1979.

Segredos Internos: Engenhos e escravos na sociedade colonial. São Paulo: Companhia das Letras, 1988.

; LOCKHART, James. A América Latina na época colonial. Rio de Janeiro: Civilização Brasileira, 2002.

SENELLART, Michel. As Artes de Governar: Do regime medieval ao conceito de governo. [trad. Paulo Neves] São Paulo: Ed. 34, 2006.

SERNA, Pierre. "O Nobre”, in Michel Vovelle (Dir.) O Homem do Iluminismo. Lisboa: Editorial Presença, 1997.

SILVA, Augusto da. Rafael Pinto Bandeira: de Bandoleiro a Governador. Relações entre os Poderes Privado e Público em Rio Grande de São Pedro. Porto Alegre, 1999. Dissertação (Mestrado em História), PPG em História/IFCH/UFRGS.

Fragilidades do Absolutismo Português do século XVIII na América Meridional. In: RAMOS, Maria Bernardete; SERPA, Élio; PAULO, Heloisa (Orgs.). O Beijo Através do Atlântico: o lugar do Brasil no Panlusitanismo. Chapecó, Argos, 2001.

SILVA, Maria Beatriz Nizza da. Ser Nobre na Colônia. São Paulo: UNESP, 2005.

SILVA, Célia Maria e. Ganchos/SC: Ascensão e decadência da pequena produção mercantil pesqueira. Florianópolis: Célia Maria e Silva, 1992.

SOUZA, Laura de Mello e. Os nobres governadores de Minas. Mitologias e histórias familiares. In: Norma e Conflito - Aspectos da História de Minas no século XVIII. Belo Horizonte: Ed. UFMG, 1999.

Administração Colonial e Promoção Social: a atividade de Luís Diogo Lobo da Silva como Capitão-General de Pernambuco e Minas Gerais (1756-1768). In: SILVA, Maria Beatriz Nizza da. (Org). De Cabral a Pedro I: aspectos da colonização portuguesa no Brasil. Lisboa: Universidade Portucalense Infante D. Henrique, maio de 2001.

Desclassificados do ouro - a pobreza mineira no século XVIII. Rio de Janeiro: Graal, 1982. 
O Sol e a Sombra: Política e Administração na América Portuguesa do século XVIII. São Paulo: Companhia das Letras, 2006.

SOUZA, Sara Regina Silveira de. As fortificações catarinenses: notas para uma revisão histórica. Florianópolis: EdUFSC, 1991.

SUBTIL, José. "Os Poderes do Centro" in, António Manuel Hespanha (Coord.). $O$ Antigo Regime (1620-1807). Lisboa: Ed. Estampa, 1997. (Col. História de Portugal, Dir. José Mattoso - vol. 4)

TAUNAY, Affonso de E. Em Santa Catarina Colonial: capítulo da história do povoamento. São Paulo: Imprensa Official do Estado, 1936 (Separata do vol. VII da RIHGSP).

Santa Catarina nos annos primevos. São Paulo: Typ. Diário Official, 1931.

VARNHAGEN, Francisco Adolfo de. História Geral do Brasil 5a. ed. São Paulo: Melhoramentos, 1956. (5 Vols.)

VASCONCELLOS, Diogo de. "Linhas Gerais da Administração Colonial. Como se exercia. O Vice-Rei, os Capitães-Generais, os Governadores, os Capitães-Mores de Capitanias e os Capitães-Mores de Ilhas e cidades", in RIHGB - Tomo especial, parte III, 1916, p. 281-298.

VIANNA, Helio. História do Brasil Colonial. São Paulo, 1945.

História das Fronteiras do Brasil. Rio de Janeiro: Gráfica Laemmert, 1948.

VIEIRA, Alberto. A Fortuna das Afortunadas, in Oceanos. n. 46, abr./jun., 2001.

WEHLING, Arno. Administração Portuguesa no Brasil de Pombal a D. João (vol. 6). TAPAJÓS, Vicente (Dir.) História Administrativa do Brasil. Brasília: Fundação Centro de Formação do Servidor Público, 1986.

WEHLING, Arno, WEHLING, Maria José. Cultura jurídica e julgados do tribunal da Relação do Rio de Janeiro: a invocação da boa razão e o uso da doutrina. Uma amostragem. In: SILVA, Maria Beatriz Nizza da (Coord). Cultura Portuguesa na Terra de Santa Cruz. Lisboa: Ed. Estampa, 1995.

. "O Funcionário Colonial entre a Sociedade e o Rei”, in Mary Del Priore (Org.) Revisão do Paraíso: os Brasileiros e o Estado em 500 Anos de História. Rio de Janeiro, Campus, 2000.

WEIBERG, Gregorio. "Prólogo" in Amadeo Frezier. Relacion del Viaje por el Mar del Sur. Trad. Miguel A. Guerin. Caracas: Biblioteca Ayacucho, s/d., pp. ix-lxiii. 


\section{Anexo $1^{695}$}

\section{[fl. 01] Senhora}

Foi Vossa Magestade servida ordenarme na Regia Provizão de trinta de Julho de mil sette centos noventa e seis, que me foi dirigida pelo Seu Conselho Ultramarino, que pelo mesmo fizese chegar á Real Prezensa de Vossa Magestade o Regimento, ou Regimentos porque se dirigem, e tem dirigido os Governadores desta Capitania da Ilha de Santa Catharina, na administrasão do Governo destes mesmos Povos de que actualmente estou encarregado: | a Cujo respeito posso segurar a Vossa Magestade: que na Secretaria deste Governo se não acha Regimento em forma de Regularidade, que sirva de Guia, ou dictame para os Governadores o seguirem e só sim se encontrão algumas Regias Ordens vagas, que para diferentes objectos, forão aos mesmos Governadores remetidas. Estas mesmas, que no anno de mil sette centos setenta e sette se acharão depois de perdidas, pelos diferentes lugares, a onde a lastimoza confuzão disgraçadamente sacrificou tudo, poderião talvez ser com maior numero se não tivessem levado o mesmo descaminho que levarão a maior parte dos papeis de todos os Cartórios Públicos, e por tanto sou obrigado a confesar, que eu me estabeleso (como Governador) em algumas das Referidas Provizoens Regias, que (por Cazualidade) apezar da referida confuzão aparecerão: assim como no que me parece mais acertado, conforme o costume e pratica dos meus Antecessores; e como Vossa Magestade na mesma Regia Provizão é Servida, não só ordenarme que lhe dê aminha informasão; mas [fl. 02] também o meo parecer, a fim de mandar formar hum novo Regimento que sirva de Ordenasão aos Governadores desta Capitania; que seja praticável nas circunstancias actuaes do tempo, com utilidade do seu Real serviso e beneficio destes Povos, que pela sua Louvável fidelidade se fazem dignos da Real Contemplasão de Vossa Magestade eu me proponho (sem perder estes esenciaes pontos da minha vista) dizer ingenuamente tudo quanto tenho alcansado, e quanto tenho discorrido sobre este importantíssimo objecto, descrevendo abreviadamente o que se tem praticado neste Governo, desde o seu primeiro estabelecimento até ao prezente, segundo a Ordem succesiva dos tempos.

Foi Vossa Magestade servida mandar publicar nas Ilhas dos Assores o Edital $\mathrm{N}^{\circ}$. $1^{\circ}$, em consequencia do qual, e das mais Ordens, que então se expedirão, se transportarão para esta Capitania quatro centas Pessoas, para fundarem o seo primeiro estabelecimento na Ilha, e Terra firme adjacente: Cuja diligencia foi incumbida ao Brigadeiro Jozé da Silva Paes, seo primeiro Governador, como se evidenscia da Real Ordem de nove de Agosto de mil sette centos quarenta e sete $\mathrm{N}^{\circ} .2$, que a elle lhe sérvio de Regimento, assim como tem servido aos Seos successores para o arranjamento daqueles Colonos. He muito provável que este mesmo official não sahise dessa Corte, sem vir monido de varias Ordens, e Instruçoens, não só verbais, mas ainda por escripto relativas ao mesmo interesante objecto: mas também he certo, que ellas não aparecem, e nem ainda por tradisão existe huma noticia certa de que as ouvésse.

Pelas Provizoens $N^{\circ} .3$ até 16 se verifica que [fl. 03] o mencionado Brigadeiro Jozé da Silva Paes entrou nesta Ilha em mil sette centos trinta e nove encarregado do seo estabelecimento, Rio Grande, e Colônia do Sacramento, cituada ao

\footnotetext{
${ }^{695}$ AHU-SC, cx. 6, doc. 386. Ofício o governador João Alberto de Miranda Ribeiro à rainha Dona Maria I, em 16.11.1797.
} 
Ocidente de Monte Vedio; e tanto elle, como os seus successores sempre dirigirão as suas contas directamente para a Corte, nos cazos ocurrentes, tendentes a este tão interessante estabelecimento; a bem do qual, e dos seus novos abitante, obtiverão algumas amplitudes, atendida a necessidade e circunstancias actuaes dos mesmos Colonos, seus filhos e Agregados, como expecificão as mesmas Provizões. Esta directa correspondência cessou no Governo de D. Jozé de Melo Manoel, em consequiência da Provizão $N^{\circ}$. 17, cujo Governo acabou em sette de Marso de mil sete centos secenta e dous, e até ao prezente os Governadores meus Predecessores, se tem dirigido em conformidade daquelas Ordenasoens primarias, das Justas, e Providentes Leis de Vossa Magestade naqueles objectos Militares, e Politicos, que erão, e são relativos a authoridade dos Governadores, e finalmente pelas repetidas ordens, que os Excelentíssimos Vice Reys do Estado successivamente sobre diferentes objectos lhes dirigem, nas quais, cassandolhe incenssivelmente tudo quanto são authoridades, e Regalias, vem a ficar o Governador de huma tão considerável Capitania hum homem, a quem a necessidade obriga a empregar todos os seus talentos, em descobrir alguns meios de se não fazer geralmente aborrecido: por que conservando só os poderes necessários para punir e castigar os delinqüentes, e nenhuns para premiar e animar os beneméritos he natural que todos olhem com orror para hum omem, de quem só esperão os Castigos, e nada daquelas grasas e mercês, com que a Real Grandeza, e Generoza Liberalidade de Vossa Magestade costuma remunerar o merecimento dos que com obediensia, gosto, e fidelidade se empregão [fl. 04] no seo Real Serviso. Este he o modo, porque se tem dirigido os Governadores desta Ilha, que passando ao Domínio de Sua Magestade Catholica, pelos infelizes acontecimentos de nove de Marso de mil sette centos settenta e sette levarão descaminho (por conseqüência de huma tal dezordem) muitas Leys, Decretos, Alvarás, e Provizoens, que constituião o fundo da Secretaria deste Governo, como já dise.

A mesma Secretaria he servida por hum Official subalterno tirado do Regimento da Guarnisão para este exercício: (visto que tendo se Reprezentado a Vossa Magestade ser necessário hum Secretario de propriedade, a Reprezentasão do Governador não foi deferida, como se colige da Provizão $N^{\circ}$. 18) pratica observada desde sette de Março de mil sette centos, secenta e dous, que entrou neste Governo o Brigadeiro Francisco Antonio Cardozo de Menezes, Cujo Secretário passando por grandicimo trabalho, não tem mais sallario algum, que o correspondente soldo do seu Pôsto, pago com o mesmo atrazo, que a todos os mais indivíduos do Regimento.

Da mesma forma he tirado hum Capitão do Regimento para servir de Expediente das Ordens do Governador, o qual serve também debaixo do correspondente soldo da sua Pattente, e pago da mesma forma que os outros: e não obstante que o Brigadeiro Francisco de Barros, quando veio para este Governo, trouxe Ajudante de Ordens de propriedade com a Pattente de Cap. ${ }^{\mathrm{m}}$ de Granadeiros, este faleceo, e jamais foi provido hum tão necessário, como indispensável Pôsto.

Tendo demonstrado a Vossa Magestade no modo possível o methodo do Governo político desta Ilha, deduzido pela subseqüente pratica de huns a outros Governadores, [fl. 05] e na Conformidade das Leys e Ordenasoens, como asima dise, he precizo outro sim demonstrar os motivos, que poderozamente tem concorrido para o atrazo desta tão interessante Colônia, huma das mais bem povoadas, com famílias tiradas das suas habitaçoens nas Ilhas dos Assores, omens sóbrios, e aferrados ao trabalho.

Deixando á parte aqueles erros, que erão susceptíveis da escabrozidade, e falta de conhecimento Local do Paiz, para a destribuisão, e organizasão das dattas de terras; a irregularidade, que nestas se cometeo, tem pelo decurso do tempo suscitado até 
agora, questoens entre os mesmos colonos, que pendentes da solusão do Governador; he este hum dos objectos políticos, que mais o sobre carrega nas deliberaçoens dos seus recursos; e esta tortura logo feita no principio do seo estabelecimento, assim como outras muitas, que seccessivamente se lhes forão acumulando, são conhecidamente a cauza do seo grandíssimo atrazo.

A Real Ordem de nove de Agosto de mil sete centos quarenta e sette №. 2, de que asima falei, não foi com toda a sua extensão executada: tanto a respeito da mesma distribuisão das terras aos novos Colónos, como daqueles soccorros, com que Vossa Magestade tão providentemente os mandava fornecer, quais erão as feramentas necessárias, as Vacas e as Egoas para o seu Laboratório fabril, de cujos generos, a alguns se completarão as ferramentas, a outros parte dellas, alias avendo as: e a nenhuns os Animaes Cavalares e Vacuns, sem que a mim me seja possível prezentemente averiguar, qual fose a Cauza de huma tão concideravel falta, que incontestavelmente foi huma das Cauzas, porque ainda hoje se fazem pouco sensíveis os seus [fl. 06] dezejados progressos. Mas estes forão tão inconseqüentes, como he fácil de prezumir: pois que principiando a entrar nesta Ilha os sobreditos colonos em mil sette centos quarenta e oitto, elles vierão vindo gradualmente até aofim do anno de mil sette centos cincoenta e dous, e já se sabe que neste brevíssimo tempo, a Cultura estava tanto na sua infansia, como o estabelecimento dos mesmos Colonos, em hum Paíz (então) agreste, e para elles inteiramente desconhecido pela diferensa do seu Clima.

Seguio-se o Governo de Dom Jozé de Melo Manoel, que entrou nesta Ilha em vinte e cinco de Outubro de mil sette centos cincoenta e três, e Governou até sette de Marso de mil sette centos secenta e dous. No espaso de quazi nove annos do seo Governo, foi construída a Igreja Matriz de Nossa Senhora do Desterro, na Villa Capital deste Governo, a Caza da Rezidensia dos Governadores, e a Igreja da Freguezia de Nossa Senhora das Necessidades.

O methodo que se adoptou na factura destes tão neccessarios Edifícios, foi o peor que se podia imaginar: por que alem dos muitos Artífices de huma e outra Classe, que nelles forão empregados; os seus trabalhadores ou Jornaleiros, erão os Lavradores nomeados por semana de todas as Freguezias, ou Destrictos. A huns se distribuía este Serviço (sem paga) por modo de faxina, a outros se lhes apontava o seu vencimento, para em ocazião de feria se lhes pagar: a alguns se lhes pagou huma pequena parte do que ganharão, e a todos finalmente se lhes estão devendo não só os seus jornaes, como também alguns generos, que se lhes tomárão; e a razão foi, porque os dinheiros para estes pagamentos vinhão do Rio de Janeiro; as remessas erão morozas, e quartadas; e o que tudo concorreo para o empenho da Real Fazenda, e penalidade dos Póvos, que [fl. 07] sempre humildes e obedientes, gemião debaixo do mais activo e laboriozo trabalho, sem o seo correspondente premio. As consequiências de tudo isto, forão, o desamparo da Lavoira, e por tanto a falta de vibres ainda dos da primeira necessidade para o diário sustento, que por algum tempo foi percizo que entrassem de fóra, naquele mesmo fertilíssimo Paiz, que podia com grande fartura soccorrer aos seus vizinhos.

Seguio se o Governo de Francisco Antonio Cardozo de Menezes, que durou por espaso de tres annos desde sette de Marso de mil sette centos cessenta e dous, até doze de Julho de mil sette centos cessenta e cinco; em cujo tempo foi edificado o Forte de Santa Anna do Estreito: e nesta Obra, a sim como em mais algumas de pouca conciderasão que fêz, seguio o mesmo perniciozo methodo, que o seu Antecessor.

Sucedeo-lhe Francisco de Souza de Menezes, que Governou pouco mais de déz annos até cinco de setembro de mil sette centos settenta, e cinco em cujo tempo forão da mesma sorte construídos os Fortes de Santa Bárbara e Sam Luiz e o de 
São Caetano na Fortaleza da Ponta Grossa; e por conseqüência aumentada a divida da Real Fazenda, e a pobreza, e indigência dos Póvos, por falta das remessas, que devião vir, e nunca chegarão do Rio de Janeiro.

Quando neste mesmo tempo mal podião ainda os Póvos respirar de tantas fadigas e trabalhos, e que apenas se divizavão escassamente os fructos da Lavoira, ella padeceo outro atrazo não menos sensível, que os antecedentes; como foi o recrutarem se mais de quinhentos homens filhos dos Lavradores para completar o Regimento: este expediente que á primeira vista não deixa de parecer hum bom Militar, por ver o Regimento [fl. 08] Completo de bons Recrutas; com tudo elle foi hum mal político, e de gravíssimas consequiências; porque tantos forão os Recrutados, quantos os braços que se desviarão do trabalho da Cultura, e por consequiência ella foi em diminuisão. Os Pais Lamentarão a falta dos Filhos, e estes a falta dos soldos, por que erão quartados e tardonhos. A mesma falta se experimentava com todos os gêneros relativos aos Fardamentos: de maneira que sempre até agora se ficou olhando com horror para o serviso Militar, sem que os Governadores lhe possão dar remédio por mais Reprezentasoens, que fasão aos Excelentíssimos Vice Reys do Estado: este mal tem sido tão contagiozo, que ainda até hoje se padese, e só a Poderoza Mão de Vossa Magestade o poderá remediar. Neste mesmo tempo foi creado o Terso ou Legião de Auxiliares composta de Companhias de Infantaria e Cavalaria, que se extende até aos Limites, em que pelo Norte comfina com a Capitania de São Paulo, e pelo Sul com a do Rio Grande de São Pedro; de baixo do Comando e diresão do mesmo Governador, que he o seu Mestre de Campo, com hum Sargento Mór e dous Ajudantes.

Áquele Governador sucedeo Pedro Antonio da Gama e Freitas, que entrou a Governar em cinco de Setembro de mil sette centos settenta e cinco, trazendo Instruçoens, e tudo quanto era necessário para os preparativos de huma vigoroza defensa, por estar ameassada esta Ilha pelos Espanhóes, por quem foi invadida no infeliz abandono de mil sette centos settenta, e sette, ficando por consequencia innutilizados todos os trabalhos, e fadigas, com que estes Póvos tinhão fielmente emcorrido para a sua defensa, passando Lastimozamente á sugeisão e domínio do Principe Estrangeiro. Em [fl. 09] todo o tempo deste Governo, se vio esta Ilha muito abundante de fornecimentos e de dinheiro: se bem que nunca este foi em tanta quantidade, que se pudessem satisfazer algumas dividas das atrazadas, porque apenas chegava para o diário pagamento das Tropas, que a guarnessião, e tal qual despeza extravagante; segundo a Critica ocorrensia de hum bem prezumido attaque. Neste brevíssimo Governo se Construirão alguns edifícios particulares, e a proporsão se aumentou o Comercio: Consequencia e natural produsão do giro da moeda no Paiz.

Esteve a Ilha debaixo do Domínio de Espanha desde nove de Marso de mil sette centos settenta e sette, até trinta de Julho de mil sette centos settenta, e oitto, dia em que nos foi restituída: mas em que estado? Vossa Magestade o póde julgar: figurando na idéia os estragos, que poderia experimentar hum Paiz invadido por Inimigos, e abandonado por huma grande parte dos Nascionais! Nos entrámos nella, assim como em huma nova Conquista.

Francisco Antonio da Veiga Cabral (hoje Tenente General e Governador de Gôa) emcarregado da recepsão, e Governo da mesma Ilha, na qual existio desde trinta de Julho de mil settecentos, e oitto, até sette de Junho de mil sette centos settenta, e nove, neste brevissimo tempo, apenas pôde revocar, e arranjar os Povoadores dispersos ás possesoens dos seus Predios; juntar o resto do Regimento da Guarnisão, que se tinha debandado depois da infeliz entrega; restituir os Magistrados Civiz á pratica das suas competentes Jurisdiçoens; e finalmente em reparar pasivamente alguns dânos, que tinhão feito os Inimigos. Este mesmo Governador vio com bastante 
magoa sua, que os soldados [fl. 10] andavão descalsos e desfardados, fazendo o serviço; que a mesma Tropa não tinha Quartéis, nem Hospital, eos Enfermos sem os úteis necessarios (como hoje mesmo acontece) para fraternalmente serem agazalhados. A Marinha sem os percizos Vazos para o serviso diário de navegar por Longas e desabridas Bahias, que medeião entre a Ilha; as Fortalezas, e Terra firme. As Fortificaçoens e os mais edifícios Reaes, ameasando Ruína, e finalmente tudo dependente de huma pronta, e imediata providencia: e como lha poderia dar o Governador, se nenhumas possibilidades tinha para isso, e as suas Reprezentaçoens erão inatendíveis por aquele mesmo, que lhe devia fornecer os meios? O Terso, ou Legião de Auxiliares desorganizada, desfardada, e desarmada, e neste mesmo estado se conservou até ao governo do Brigadeiro Francisco de Barros, que entrou nesta Ilha em sette de Junho de mil sette centos settenta, e nove, e nela existio até sette de Junho de mil sette centos outtenta e seis.

Este governador não pôde deixar de vêr com bastante desprazer seu, o mizeravel estado do Paiz, que vinha governar; a falta de meios para prover de remédio, e a dependência que para isso tinha do Vice Rey do Estado; com tudo olhando para o actual estado dos negócios naquele tempo, combinados com a feliz páz, de que gozávamos; em consequencia desta se dirigio, moldando se, quanto estava da sua parte, ás sabias Leys, e Pias Intensoens de Vossa Magestade, metendo em pratica aquelas providensias, que lhe parecerão mais razonaveis, acomodandose aos meios, que lhe oferecia a triste cituasão, em que se achava.

Organizou e disciplinou o mais que pôde o Regimento da Guarnisão, que então se achava ainda por menos da metade [fl. 11] da sua lotasão: e deste mesmo numero efectivamente licenciáva huma tersa parte, vendose na indespensavel necesidade deo fazer assim, para (nomodo possível) acudir á queles indespensaveis e urgentes artigos, que asima ficão referidos, e que carecião de huma imediata providencia; com alguns módicos reziduos das escasas, e tardonhas remessas, que vinhão do Rio de Janeiro, destinadas sómente para o pagamento das três folhas Militar; Civil, e Eclesiástica; sem que para tudo o mais ouvesse remessa, ou Consinasão alguma, como o exigia a extrema necessidade, em que tudo se achava. Da mesma forma foi com a moderasão necessária arranjando a Legião dos Auxiliares, distribuindo lhe os Armamentos que pôde; mas este Artigo ficou muito incompleto pelas infinitas dificuldades, que encontrava por toda a parte, alem de pedir este objecto pela sua natureza, tempo, prudência, e modificasão. Este foi, com mais ou menos alterasão em alguns cazos occurrentes, o seu Governo, no espaso de sette annos, dentro dos quaes a Lavoira teve algum inpulso. Obteve finalmente Licensa de Vossa Magestade, para se retirar para a Corte; e succedeo-lhe interinamente Jozé Pereira Pinto, que governou por espaso de cinco annos, principiados de sette de Junho de mil sette centos outtenta e seis, até dezaseis de Janeiro de mil sette centos noventa e hum.

Este interino Governador foi conservando as couzas com pouca diferensa, no mesmo estado, em que as achou: promovendo quanto pôde a agricultura: fez abrir a Estrada do Certão na terra firme a Oeste da Ilha, que se dirige pelo interior do Paiz á Villa das Lages, Capitania de São Paulo; mas como sobre o mesmo terreno se não edificarão (pelo menos) duas Freguezias, ella se vai outra vêz fexando, de maneira que sedo ficará sendo inútil, a pezar [fl. 12] de ter custado muito trabalho, e mais de vinte mil cruzados, que dispendeo a Câmara desta Villa em perjuizo de tantas precizoens publicas, e da primeira necessidade, a que por este motivo tem faltado, e actualmente está faltando.

Fêz algumas pequenas Embarcaçoens para o serviço da Marinha; reparou algumas ruínas nas fortificasoens, e mais Edifícios Reaes; e ainda que meteo em pratica 
todas as possíveis economias com utilidade da Real Fazenda, com tudo aumentou muito a divida Civil, e muito mais a Militar; porque no tempo do seu Governo, foi o em que se experimentou mais demóra nas remessas, que devião vir da Capital do Estado. Ao exemplo do seu Antecessor foi conservando o Regimento da Guarnisão, por menos da metade do seo Estado completo, contra a Ley e sistema Militar: mas como a origem desta desordem, era a falta dos pagamentos, bem claro está, que não era elle o culpado.

Em dezasete de Janeiro de mil sette centos noventa e hum, lhe succedeo no Governo Manoel Soares Coimbra com a Patente de Coronel do Regimento, que guarnece a mesma Ilha: e como tal, vendo o desarranjo do seu Regimento, de que elle por todos os títulos era responsável; lhe foi necessário recrutar perto de quatro centos omens para o completar; tanto pela diminuisão, com que se achava, como por ser necessário dimitir do serviso alguns soldados por moléstias, velhos, e incapazes. Este procedimento deve ser comparado com o que asima digo, praticado por Francisco de Souza de Menezes, visto que os Recrutas forão igualmente tirados aos Lavradores; pois ainda que este expediente foi praticado com a moderasão possível, com tudo [fl. 13] sempre refletio muito na Lavoira, diminuindo-lhe consideravelmente as suas forsas. $\mathrm{He}$ certo que elle não havia outro recurso, mas também he certo que estes males se devião acautelar na sua origem, não deixando chegar o Regimento a hum tal estado de diminuisão, podendo guarnecer-se immediatamente de Recrutas á proporsão dos que hião saindo: o que os meus Predecessores nunca fizerão, dando a Razão de não quererem aumentar o numero dos infelices, com a falta que sempre se experimentou de pagamentos. Em tudo o mais seguio este Governador a pratica dos seus Antecessores: fêz construir hum Quartel para o Regimento, que sendo alias percizo, e da ultima necessidade; com tudo, nenhuma razão houve, para que as suas dimensoens fosem tão extraordinariamente grandes; por que ao meo parecer, se devia contentar com muito menos, sugeitando-se ás circunstancias do tempo, e á nimia pobreza da Capitania que governava. He verdade que elle meteo em pratica tudo quanto forão economias; e que o seo infatigável zello para o Real Serviço, foi unicamente quem o dirigio a emprender tão grande obra, cujas consequencias forão disgrasadas, até por que o dito Quartel ao depois de ter grandíssimos adiantamentos ficou pasmado, e por tanto sem oferecer ao Regimento nenhumas das comodidades percizas; elle vai experimentando gravíssimas ruínas, e se chegará a perder de todo o grande trabalho, que está feito, se o Ex. ${ }^{\text {mo }}$ Vice Rey do Estado, a quem há muito tempo dei conta disto mesmo, não administrar as providencias necessarias, ao menos para se retelhar, e se lhe meterem portas, e janélas, a fim de que a imensidade das mais percizas madeiras, que ali estão empregadas totalmente se não arruinem.

[fl. 14] Neste estado se achava tudo em oito de Julho de mil sette centos noventa e tres, em que interinamente tomei posse deste Governo, por ser chamado ao Rio de Janeiro pelo Excelentíssimo Vice Rey o sobredito Manoel Soares Coimbra.

A Fragata Minerva foi a que me transportou para esta Ilha, por ser ella a que devia trazer o Avizo, para que se fortificasse este importantíssimo Pôrto, de que vim pozitivamente encarregado: e Lansando as minhas vistas sobre os diferentes objectos, que para hum tão importantíssimo fim me erão absolutamente necessarios, me instrui com a brevidade possível, não só do Local do Paiz compreendido em toda a Extensão deste Governo; mas no modo mais seguro de me acautelar; e de me servir das diminutas forsas existentes, com que me acho, para rebater vigorozamente qualquer ataque, que possão intentar os Inimigos; os quais pódem em grande numero de toda a qualidade de Embarcaçoens de Guerra ancorar neste Porto, sem receberem das Fortalezas o menor dâno, assim como fazerem o seo desembarque em qualquer parte da Ilha, ou Terra firme, sem que este se lhes possa disputar, pela razão de serem muitos, e muitos os 
lugares, em que os pódem empreender; as distancias excessivamente grandes; e a Tropa existente nimiamente pouca, e que portanto se deve conservar unida; mas apezar de tudo isto, eu me confio com bastante firmeza no plano de defeza, que me tenho proposto; tanto pelas providencias que tenho dado, e pelas Ordens, que para o mesmo fim tenho distribuído; como por que o Local do Paiz he assas escabrozo, e as suas vantagens, tenho toda a esperansa que favoreção os meos desígnios. As partes da Ilha e Terra firme, que tenho feito fortificar, e [fl. 15] atrincheirar vão demonstradas no Plano Letra A. que tenho ahonra de fazer sobir á Real Prezensa de Vossa Magestade.

Mandei continuar com todo o vigor no Ensino e Disciplina do Regimento desta Guarnisão, por ser amaior parte delle recrutado pelo meo Antecessor, como já dise, e lhe mandei também ensinar o Exercício d'Artilelheria. Da mesma forma tenho cuidado tudo quanto me he possível no Corpo dos Auxiliares, por ser este o único recurso, que achei para suprir afalta, que tenho da Tropa de Linha: E tendo asin tido o Excelentíssimo Vice Rey do Estado á Representasão que eu lhe fiz para acrescentar o numero das Companhias; não me premitio com tudo, que o devidise em mais Tersos, pela razão de que os Majores, e Ajudantes devião vencer soldos. O Estado effectivo do referido corpo he o que eu tenho a honra de aprezentar a Vossa Magestade debaixo da Letra B., animando-me a certificar que eu o tenho completamente fardado, e quazi todo Armado, e que debaixo das Armas, nenhuma diferensa fáz da mesma Tropa Regulada; e tenho toda a comfiansa, de que em qualquer critica occurrencia, me será tão util para a defensa da Ilha, como a mesma referida Tropa de Linha; por ser a sobredita Legião Auxiliar composta de excelentes omens, fortes, constantes, robustos e desembaraçados.

O reforso de Tropa que me tem vindo por duas vezes do Rio de Janeiro, consiste em quatro Companhias do Regimento de Estremôz, somente com as praças que constão do Mappa que tenho a honra de remeter a Vossa Magestade Letra C. asignado pelo seo comandante o Sargento Mór do mesmo Regimento Francisco Joze Silvano; e hum pequeno corpo de cento e vinte [fl. 16] soldados tirados dos Regimentos da Guarnisão do Rio de Janeiro, como mostra o Mappa Letra D., que ponho na Real Prezensa de Vossa Magestade asignado pelo Capitão Comandante do mesmo Destacamento.

Pelo que respeita a diferentes Armas, como Espingardas, Pistollas, Espadas, nada tenho de sobreceltente, apezar de ter pedido tudo isto por muitas vezes, assim como me acontece com todos os mais gêneros, que para o serviço da Marinha, e para outros diferentes uzos são pozitivamente necessários, e de que em todo, e qualquer tempo se devem conservar os Armazéns Reaes providos: de maneira que nem huma Aderisa havia para issar huma Bandeira, se agora me não chegase hum pequeno e insignificante socorro de alguns generos, quando a Esquadra Real chegou a este Pôrtto. $\mathrm{Na}$ mesma ocazião recebi quatro pequenas Péssas de bronze do calibre tres, que por tantas vezes tinha requerido, as quais na verdade me serão de huma grandissima utilidade apezar de serem poucas; porque o que eu pedi, os que de necessidade careso, são oitto das referidas Péssas de Parque no seu estado completo. Com as mesmas quatro que recebi, tenho feito ensinar o Exercicio de Parque a toda a Tropa de Linha, assim como já lhes ensinei o de Bataria em que estão prontos, e por tanto se me fáz menos sensível, não se meter mandado (ao menos) huma Companhia de Artilharia.

Em hum dos Armazens antigos, fiz hum hospital, por que o não havia: pois hum dos velhos Quarteis em que se recolhião (muito mal acondicionados) os mizeraveis soldados doentes, era na verdade huma situasão mais propria para hirem adquirir novas molestias, do que para serem curados das enfermidades que ali os conduzia, e foi esta huma providencia [fl. 17] tomada tanto atempo, que poucos dias depois de os passar para o novo Hospital, cahio redondamente o Quartel Velho, donde 
por felicidade já tinhão sahido. Todos os mais ameasavão a mesma ruina, de maneira que a necessidade me fêz recolher a Tropa com o novo Aquartelamento, de que já falei, apezar de ficarem muito mal acondisionados, pelos motivos que asima dise; e levantei o Quartel cahido, reedifiquei os outros todos, que não obstante serem de pau a pique, e barro, não deixou esta obra de me cauzar grande trabalho, pela falta de todos os meios, que para isto mesmo havia.

Pasei á Freguesia das Necessidades, aonde me era necessario alguma Tropa, que com mais pontualidade pudese acodir á Barra, quando algum acontecimento assim pedise: fiz construir hum novo Quartel de pau a pique, em que muito bem se acomodão quatro Companhias, e aonde effectivamente se acha hum Destacamento de trezentos e vinte e seis prasas, com mandado pelo Sargento Mor do Regimento de Estremôz Francisco Jozé Silvano: Official de muito merecimento, e de quem eu tudo confio.

Este hé o Estado actual, em que prezentemente se acha esta Capitania: cujos adiantamentos serião muito interessantes a Vossa Magestade, se não fosem os poderosos obstaculos, que se lhe tem oposto, e que ingenuamente tenho referido, alem de outros que estes mesmos em progresão arrastão apóz de sí, e que a sua narrasão seria fastidioza, passando quazi ao infifito. Ella he huma vasta Provincia, que compreende a extensão, e as Freguezias, que constão do Mappa Letra E, que tenho a honra de Levar á Real Prezensa de Vossa Magestade: o seo Pôrto he de tanta inportancia, que da sua conservasão depende a seguransa desta costa, e até me atrevo a dizer de todo o Estado do Brazil; o qual pode ser ostilizado de qualquer [fl. 18] Nasão Inimiga, que se apodére, por ser tão franco, que admite a entrada e a existencia de huma poderoza Armada, sem que recebão o menor insulto das Fortalezas; que tal he a situasão, e o modo por que ellas forão construidas. A sua Populasão he a que consta do Mappa Letra F., aonde não só se vê o tottal das Pessoas, mas quantas pertensem a cada huma das Freguezias, declarando os seus diferentes sexos, Estados, e Condiçoens. O Paiz he fertilissimo: produz com abundancia tudo quanto he necessario para o diario alimento das gentes, que o habitão: como a Mandióca, o Arrôz, o Milho, o Feijão, o Trigo; cujos generos se exportão em grande quantidade para fóra; assim como o algodão belisimo, o excelente café, e até o mesmo asucar, [?] que havia humas pequenas Engenhocas, quando aqui cheguei, e hoje passão algumas a ser Engenhos, que não só fabricão o necessario para o consumo destes Póvos, mas para se exportar para o Rio Grande, e ainda para outros diferentes Pórtos. $\mathrm{O}$ Anil nasce com porfuzão pelo Campo sem cultura, e ainda não houve um omem, que [?]lançase a cultualo, e a fazer huma Fabrica, de que certamente traria grandes utilidades, e desta forma abriria o caminho aos outros. O mesmo sucéde com a baunilha, que alguma se colhe muito boa, e que a natureza a produz igualmente pelo campo sem a menor cultura. Abunda tambem este fertilisimo terreno em preciozas Madeiras de diferentes qualidades: assim como em varias qualidades de peixes de bem comer, que aqui se vendem muito baratos, e que não deixão de fazer hum pequeno ramo de comercio, exportandose para o Rio de Janeiro, para o Rio Grande e outros Pórtos. Produz a terra muito saborozas todas as ortalisas que há na Europa, só com a diferensa, que lá custão muito trabalho, e aqui basta Lansar humas poucas de sementes para a terra. Finalmente, Senhora: o que falta nesta [fl. 19] Capitania para ser huma das mais florecentes colonias, que Vossa Magestade possue! he em primeiro lugar a circulasão do dinheiro: segundo premiar com equidade aos que se fazem dignos pelo amor e pronptidão, com que de boa vontade se empregão no Real Serviço; terceiro, favorecer aos Lavradores e animar a industria.

He incontestavel, que os dois Póllos, sobre que se estriba a boa Ordem do Governo, são o das Justisa, e da Equidade: e que destes se deduzem os dois atributos do 
Castigo, e do Premio: o primeiro para reprimir, e conter os maus nos seus deveres; e o segundo para animar; e premiar os benemeritos. Mas o primeiro he hum tristissimo poder, para quem governa, quando lhe falta a authoridade para Lansar mão ao segundo; a fim de fazer ver aos subditos o equilibrio da mesma Justisa: e esta he a triste situasão, em que se acha o Governador da Ilha de Santa Catarina.

Que importa ser Governador, e que este cheio de fadigas afabelize o Comercio, instrua, e promova a Agricultura, e discipline as Tropas, se huns e outros conhecem por experiencia, que nas mâos do Governador não existe a authoridade necessaria! que produçoens se pódem esperar? O comerciante clama, que se lhe paguem os generos, que se lhes tomárão, e tomão segundo a necessidade's exige: Os Lavradores pela paga das farinhas, que indespensavelmente se lhes toma para o monicio da Tropa: e o mizeravel estado desta não se póde dizer, nem cabalmente expressar. A Officialidade, em quem deve brilhar aquele espirito de gravidade, e de independencia, que Vossa Magestade tanto recomenda; se vê indescentemente vestida, cheia de fomes, e de mizerias, assim como as suas pobres familias; já sem terem que empenhar, nem que vender; abandonados, e sem credito para com o comercio, que os soccorre com dinheiros de emprestimo, e fazendas para escassamente se cubrirem, e manterem as necessidades da vida pelo [fl. 20] atrazo, e grande atrazo dos pagamentos.

Nas outras Repartisoens do Serviso de Vossa Magestade acontece o mesmo, com mais ou menos gravidade, e tudo isto vai refletir na Agricultura, e no comercio, que desanimado se afugenta do Paiz, ou emfraquéce; e por natural consequencia vão estas desordens fazer huma grandissima tortura sobre os interesses Reaes, que não prospérão.

Á vista de tudo quanto fica referido, claro está que todos geralmente vivem, e tem vivido em huma profunda consternasão de maneira que o Corpo Militar, da mesma sorte que os Paizanos, formão hum Exercito de descontentes, que para não chegarem ao ultimo ponto de exesperasão, não custa poucos direitos, fadigas, trabalho, e ainda susto, a quem immediatamente os Governa! mas que fieis e Leaes Vassalos tem Vossa Magestade nesta Conquista! elles na verdade são dignos da Real attensão e Piedade de Vossa Magestade.

Queira Vossa Magestade persuadirse de que esta pintura não he demaziadamente colorida: ella precizava de outros trasos mais illuminados, que demonstrasem a Vossa Magestade o seo mizerabilissimo estado, para que dignandose lansar os olhos em todas as verdades que ficão expostas, possa tambem conhecer, quais são as perniciozas consequencias, que em qualquer critica [?], e pódem prudentemente [xeccar], tanto Militares como Politicas: porque tudo se deve tomar de hum universal descontentamento.

E como então poderá o Governador dar as providencias necessarias, se as suas faculdades lhe não permitem! por que os Excelentissimos Vice-Reis ambiciozos de Regalias, todas (como já dise) chamando así, ligando as mâos do Governador [por] maneira, que tudo quanto obra, he só por huma servil obediencia? [fl. 21] Com tanto porem, que assim na Páz como na Guerra, o Governador he que hade ser responsavel de qualquer péssimo, ou desordenado acontecimento.

Que importa que os Governadores reclamem, e pugnem pelos Direitos dos subditos, que servem debaixo das suas ordens, se as suas reprezentasoens são indeferidas pelos Excelentissimos Vice Reys do Estado? Acazo á sua prezensa deixão de sobir os recursos destes Póvos, e desta disgrasada Tropa? Por ventura elles tem por isso tido algum melhoramento, ou as suas suplicas tem sido atendidas? Sertamente que não. 
Para Vossa Magestade se capacitar do mizeravel estado desta Capitania, e do motivo entre todos o mais poderozo que tem, em todos os tempos, concorrido para o seo atrazo; basta ver o empenho, em que se acha a Fazenda Real, relativo ás tres folhas, Militar, Civil, e Ecleziastica; assim como em tudo o mais, que com toda a clareza consta da conta corrente Letra G. extrahida dos assentos que se achão na Provedoria da Real Fazenda deste Governo, alem de muitas que se não pódem justificar, pelo descaminho que levarão os papeis da mesma Provedoria no anno de mil sette centos settenta e sette; assim como no Mapa do Regimento, que guarnece esta Capitania, que faso sobir á Prezensa de Vossa Magestade asignado pelo seu Tenente Coronel Comandante, Letra $\mathrm{H}$.

Á vista de tão consideravel empenho, que tanto tem concorrido para o aniquilamento desta importantissima colonia, só me resta prostrado aos Pés do Real Throno, suplicar a Vossa Magestade que se digne fazer dar aquelas Paternaes providencias, que são susceptiveis do seu Alto Poder, derramando sobre estes fieis, e obedientes Póvos os admiraveis effeitos da sua tão Grande, como incomparavel Piedade.

Pelo modo mais claro ou menos confuzo, [fl. 22] que me foi possivel, tenho feito ver a Vossa Magestade o que deixo referido, por me parecer da ultima necessidade, e muito da minha obrigasão informar a Vossa Magestade de tudo quanto se tem passado succesivamente desde o principio ou Criasão deste Governo de que hoje me acho encarregado, sem que por pretexto, ou respeito algum me seja Licito omitir, nenhuma daquelas circunstancias, que por todos os titulos devem chegar á Sua Real Prezensa, e por tanto influirem não só na felicidade deste Póvos, mas no melhoramento de todos os diferentes ramos desta Capitania, (que aplicandose lhe os meios competentes) pode fazer avultar muitisimo os Reaes interesses de Vossa Magestade; agora passo a dizer os meios, que me parecem mais proporcionados, para se conseguirem os justos fins, que Vossa Magestade quer meter em pratica, dando hum Regimento para diresão dos Governadores desta Capitania, que se possa combinar com os interesses do Seu Real Serviço e a felicidade destes Póvos, aonde Vossa Magestade tem muitos Leaes, umildes, e fieis Vassalos.

$1^{\circ}$. Seria bom que o Governo desta Capitania não tivesse dependencia da do Rio de Janeiro, tornando os Governadores a dirigirem as suas contas diretamente para a Côrte, como se praticou até ao tempo, em que governou Dom Joze de Mello Manoel (como já dise) por que acho que de nenhuma sorte convem ao Serviço de Vossa Magestade, nem ao socego e felicidade dos Póvos, nem á administrasão da Justisa, que elles estejão sugeitos aos caprixos dos Excelentissimos Vice Reis do Estado.

$2^{\circ}$. Que Vossa Magestade se digne Criar hum Secretario com o seu official de Pluma para a Secretaria deste Governo: assim como hum Ajudante de Ordens de propriedade: por que o primeiro [fl. 23] á proporsão que a Populasão se aumenta, se lhe multiplica o trabalho, a que sem o dito official de Pluma he inpraticavel dar vencimento, alem da concideravel falta, que o official da Tropa, que exercita este emprego, faz na sua respectiva Companhia, e Regimento; e o segundo, por que hé diariamente empregado não só na distribuisão das ordens para servir da Guarnisão, mas para todas as Villas, Destrictos, Freguezias, Destacamentos, e Guardas dos Registos de huma tão extensa Capitania.

$3^{\circ}$. Que os Rendimentos Reaes relativos a esta Capitania entrem nos Cofres da Provedoria respectiva, e que por esta se proceda a arrecadasão do Donativo, que lhe 
corresponde da Pesca das Baleas feita na mesma Jurisdisão deste Governo, aonde o Contracto tem o maior numero, e as melhores Armasoens, e por consequencia da onde tira os mais avultados interesses, deixando de entrar com vinte contos de reis, na cidade do Rio de Janeiro, aonde já á muitos ânos que se não pesca, e da onde segundo a Consignasão já establecida no tempo dos Excelentissimos Marquez do Lavradio, e Luis de Vasconcelos e Souza, devem vir vinte e quatro contos annuaes para os pagamentos das tres folhas, Militar, Civil e Ecleziastica desta Ilha, correndo vossa Magestade o risco da sua condução por Már; quazi sempre nas mesmas pequenas Embarcaçoens do referido contracto, que navegão para este Porto: assim como entrando nos cofres desta mesma Provedoria outros vinte contos, com que o mesmo Contracto entra na cidade da Bahia, aonde talvêz, algum dia serião necessarios, naquele tempo em que os seus proprios rendimentos não excedesem as Despezas, como he provavel que hoje acontese.

$4^{\circ}$. Que os Reaes Dizimos fosem rematados pelos Comerciantes desta mesma Capitania, assim como elles são os que rematão os [fl. 24] diferentes rámos ao Rematante Geral; porque deste arbitrio se seguião duas vantages aos Reaes Interesses de Vossa Magestade, sendo o primeiro a concideravel soma a que esta rematasão [hiria] sobir, sendo ella feita nesta mesma Provedoria, e por estes mesmos Omens, que diariamente vão conhecendo o aumento, que progressivamente vão adquirindo os diferentes ramos da Agricultura; e o segundo, que entrando este dinheiro nos Cofres da mesma Provedoria, com o mais que já fica dito, e com o que passo a dizer, não só haverá a soma conveniente para todas as Despezas da Capitania; mas dos reziduos (que cada vêz irião em maior aumento) se irião pagando as dividas atrazadas, até ao ponto de ficarem de todo extinctas, e então Vossa Magestade poderia mandar fazer diversa aplicasão deste dinheiro.

$5^{\circ}$. Que as serventias dos officiaes de Justisa fosem rematados perante o Provedor da Real Fazenda desta Capitania, e da mesma forma recolhidos os seus respectivos Donativos aos Cofres Reaes da mesma Provedoria.

$6^{\circ}$. Que todas as Embarcasoens, que vierem a este Pôrto carregar Farinhas, Trigos, Arrozes, Milhos, e Feijoens, pagacem os carregadores por cada alqueire, que embarcarem para comerciar, hum vintem para a Real Fazenda de Vossa Magestade; cuja suave impozisão de nenhuma fórma póde ser pezada aos comerciantes, pelo avanso que tirão do seu comercio.

$7^{\circ}$. Que todas as Embarcasoens, que entrarem no mesmo Porto, paguem pelo menos seis mil reis (assim como o fazem no Rio Grande de S. Pedro) para a conservação da Ponte e Guindaste, que aqui existe, aonde francamente se lhes devem deixar carregar, e descarregar os seos efeitos. [fl. 25]

$8^{\circ}$. Que todas as Pessoas, que conduzem gado do Continente do Rio Grande de São Pedro, ou da villa das Lages, para comerciarem nesta Ilha, pagacem hum vintem por cabesa, podendo conservalo o tempo, que lhes for necessario para dispor delle, nos campos de Arassatuba, que se achão debaixo da administrasão Real, ou nos pástos de Maruí que se conservão pela mesma Fazenda Real para as Bestas, que transportão os generos necessarios ás duas guardas dos Registos do Caminho do Certão.

$9^{\circ}$. Que se estabelesão cinco Freguezias, visto a pozitiva necessidade que dellas há: pagos os seus Parrocos pela Congrua annual de secenta mil reis, e fornecidos de quinze 
mil reis para guizamento, na forma que até agora com os outros que existem se tem praticado em virtude da Real Ordem de nove de Agosto de mil sette centos quarenta e sette $\mathrm{N}^{\circ}$. 2., de que asima tenho falado; pois que Vossa Magestade nella expressamente determina que para o numero de secenta cazaes se estabelesa Freguezia. As primeiras duas no caminho do Certão, que se dirige (pela Estrada de que já tratei) para a Villa das Lages na Capitania de São Paulo; cujo Plâno tenho a incomparavel honra de levar á Real Prezensa de Vossa Magestade debaixo da Letra I, mostrando o lugar que me pareceo mais proprio para a sua edificasão: assim como o Plano Letra L que aprezenta o modo porque ellas devem ser construidas, e calculando pouco mais ou menos a despeza, que cada huma dellas pode fazer á Real Fazenda de Vossa Magestade, metendo em pratica algumas economias de que há mais de dois annos dei conta ao Excelentissimo Vice Rey do Estado, quando lhe remeti estes mesmos Plânos, informando-o não só do muito, que as sobreditas Freguezias serião uteis aos Reaes interesses de Vossa Magestade fundados no mesmo [fl. 26] melhoramento dos diferentes ramos desta capitania, mas da pozitiva necessidade que dellas há para a sua propria defensa em qualquer cazo occurrente por mais adverso que elle fose; acho que com vinte mil cruzados se podem ambas construir; desempenhando o que cada huma dellas no referido Plano Letra L. reprezenta. A referida Villa das Lages por todas as razoens deve ficar pertencendo a esta Capitania; tanto por que só para ella pode exportar, como exporta com facilidade os seus effeitos, recebido igualmente os soccorros de que carece; como pela pronpta e brevissima expedisão dos seus recursos; os quais de São Paulo, ou lhe não chegão, ou chegão tarde, porque he percizo vencer com infinito trabalho quazi duzentas legoas de máo caminho pelo Sertão. Para se Povoar huma das referidas Freguezias no sobredito caminho do Sertão, me parece que devem vir pelo menos secenta cazaes das Ilhas dos Assores; por que para a outra se podem mudar alguns dos que por aqui se achão escassamente arranjados, assim como alguns soldados antigos, e cazados com numeroza familia a quem se déve baixa, uma datta de terra, e tudo o mais com que os que vierem das Ilhas devem ser soccorridos na conformidade da Real Ordem de Agosto de mil sette centos quarenta e sette, o que elles de muito boa vontade aceitarião, como huma grasa concedida em remunerasão dos seus servisos.

10. As outras tres são da maior necessidade pelo desamparo, em que vivem os seus habitantes na longitude de tres, sette, nove e mais legoas, sem terem quem lhes administre o Pasto Espiritual, sugeito ás Contingencias do Mar, ou ao longo, e escabrozo tranzito de terra.

Primeira no Destricto do Ribeirão, aonde existem tantos ou mais cazaes conforme a Ordem de Vossa Magestade. Segunda na Ensiada das Garoupas; e a Terceira no Destricto das Canavieiras, por que tanto huma, como outra, se achão em iguaes circunstancias. [fl. 27] Todas estas familias dezejão tanto as referidas Freguezias, que se oferecem para concorrer na construsão dellas com tudo quanto lhes for posivel, com tanto que Vossa Magestade os favoresa, e que lhe mande pagar pela Sua Real Fazenda aos competentes Vigarios na forma que asima vai declarada.

11. Como o Regimento desta Ilha álem do serviso diario da Guarnisão da Prassa tem que guarnecer de necessidade tantos Póstos, e Destacamentos, em huma tão Longa Capitania, como constão do Mapa Letra M, que ponho na Real Prezensa de Vossa Magestade, me parece necessario ser organizado a dés Companhias, como os de todo o Exercito, e ainda os das Capitanias da Bahia e Rio de Janeiro, conforme o Plâno, e Decreto do primeiro de Agosto de mil sette centos noventa, e seis, dignandose Vossa Magestade crear de novo mais tres, ou quatro Companhias de Artilharia adisionadas ao 
mesmo Regimento, e sendo a sua compozisão numeraria na forma do mesmo Plano do primeiro de Agosto de mil sette centos noventa e seis, porque pelos motivos referidos ellas se fazem absolutamente necessarias, assim como o seu competente Parque, e que pelo menos hum, ou dois dos seus respectivos officiaes sejão Engenheiros: Bem entendido, que os Recrutas para as ditas companhias devem vir das Ilhas dos Assores, para que se não caia no mesmo erro, que já por duas vezes fica expressado.

He da ultima necessidade para o adiantamento da Lavoira, que em cada huma das Freguezias haja hum omem inteligente munido de Jurisdisão, que vigie sobre a conducta dos Lavadores, para que se não entreguem á ociozidade; que obrigue a trabalhar os preguiçózos; que os persuada, e lhes fasa ver os grandes interesses, que podem tirar das plantaçoens da Cana, Mandioca, Feijão, Arrôz, Milho, Café, Algodão e Anil, das quais elles mesmos não conhecem ainda a utilidade. He percizo porem, que os que forem em carregados desta [fl. 28] Inspesão, não sejão daqueles omens matriaes vaidozos e de espirito venal, que alem de olharem só para os seus interesses, influidos com a jurisdisão de mandar, se desvanecem tanto, que sem consultarem a razão e a humanidade, tudo querem levar por violensia; mas sim que sejão omens de probidade, e desinteresse, para que não só animem com suavidade na persuasão, mas também que metendo com pratica tudo quanto dizem aos outros lhes sirva a elles mesmos de modello, e mais que tudo de exemplo; por que he sem duvida que o rigor, e a violencia desespera, assim como a humanidade e a brandura consilia afecto, e leva felizmente o omem ao fim dos seus dezejos. Hum omem que possua estas qualidades não será muito dificultozo acharse em cada huma das Freguezias; com tanto porem que a penetrasão de quem o escolher, deve primeiro meter em pratica algumas experiencias. Sobre todos estes deve haver hum Inspector Geral: mas eu me não posso lembrar de outro, que não seja o proprio Governador; o qual por todos os titulos, inseçantemente deve vigiar sobre o augmento do bem Publico. Que de tempos em tempos vizite todas as Villas, Freguezias da sua Capitania; vendo e examinando particularmente os establecimentos de cada hum dos Lavradores; a fim de providensiar as suas necessidades, Louvar e agradecer aos industriozos, e inteligentes o seo zelo, repreender (e sendo necessario) castigar com moderasão os preguiçozos, fazendo lhes ver a huns e a outros por calculos certos e infaliveis, os grandes interesses que podem tirar das diferentes e ricas plantasoens, que podem fazer, cuja utilidade até ao prezente ignorão: porque se lhes não tem aplicado com toda a eficacia necessaria estes conducentes, e infaliveis meios. Só os Governadores pódem nesta parte fazer a Vossa Magestade um tão util, e relevante serviso: por que sendo elles, de quem os Póvos tem, ou devem ter toda a sua dependencia, pela grande Authoridade que Vossa Magestade lhes confia, por isto mesmo elles são os que mais influem sobre o espirito dos mesmos Póvos. Que grande impresão [fl. 29] fará nos seus corasoens vendo entrar nas suas Fazendas o seu Governador com o designio de os felicitar, e de lhes proporcionar os meios para o seo adiantamento? a sua benigna prezensa os encherá de gosto: elles serão conduzidos com suavidade a satisfazer com prontidão os seus deveres: elles não pouparão trabalho, industria, nem fadiga, com os dezejos de agradarem ao seu bemfeitor: e desta forma vivirão sempre ocupados na Lavoira, e se livrarão e, (animados com a esperansa do beneficio) d'aquela inacção e abatimento de espirito, com que até agora tem vivido aterrados. Por este modo os Governadores verão de muito perto todas as necessidades dos seus Póvos, para as providensiarem, e afastarem delles todos aquels abuzos, que tem sido a cauza do seu atrazo; e então estes mesmos Póvos mais que tudo agradecidos aos Paternaes beneficios, que o Alto Poder, e Real Grandeza de Vossa Magestade se dignar derramar sobre elles, conhecerão que só a Vossa Magestade devem tudo, por que só 
Vossa Magestade os pode tirar da nimia indigensia, e cruel abatimento, em que se achão e fazelos felices, para viverem com gosto, e satisfasão no meio das suas familias. Isto he tudo de quanto eu me posso lembrar; sem me ter poupado a trabalho, ou diligencia alguma, que possa favorecer os meos dezejos, a fim de obedecer, pelo melhor modo que me he possivel, ao que Vossa Magestade me ordenou na Sua Regia Provizão, que me foi remetida pelo seu Real Concelho Ultramarino.

Deos Guarde a Vossa Magestade. Villa de Nossa Senhora do Desterro da Ilha de Santa Catharina a dezaseis de Novembro de mil sette centos noventa e sette.

[Ass.] João Alberto de Mir. ${ }^{\text {da }}$ Ribr. ${ }^{\text {o }}$ 


\begin{abstract}
Anexo $2^{696}$
[fl. ${ }^{697}$ ]

$\mathrm{R}^{\mathrm{mo}} \mathrm{S}{ }^{\mathrm{r}}$
\end{abstract}

Remeto a V. S. ria o Papel, que se tem retardado, por que pertendia ser eu mesmo o portador, aparecendo em Salvaterra onde, sem a confuzão dos Pertend. ${ }^{\text {es }}$ na Corte, pudesse falar ao Ministro de Estado para ver se por este modo se lhe imprimiam melhor as especies do sugeito; mas a minha desconsolação me tem feito tão flexivel, que chegou a capacitarme, que em Salvaterra, ou em Lisboa sempre farei o mesmo papel de infeliz; e por esta razão mudei de acordo, hindo o P. ${ }^{e}$ Luiz Ribeiro, que o entregará a V. S. ria em mão própria, pois hé o mais que eu lá poderia fazer.

O imprudente escrupulo, que teve João Gomes de $\mathrm{Ar}^{\circ}{ }^{\circ}$, de que o mesmo Papel era huma Instruç̧ão formal ao Ministério, ao qual senão deve ensinar nunca, (e do que me tenho rido muitas vezes) me obrigou a mostralo a tres pessoas das mais Doutas desta Corte, e a dous homens instruidos em Governos, affectando ser meu aquelle escrupulo ${ }^{\text {a }}{ }^{\text {o }}$ os ouvir: todos o aprováram com elogios grandes, (do que Louvo a Deos, e me não desvaneço) acrescentando dous daquelles sinco, que até em conciencia o devia eu entregar a El Rey e ao Ministro de Estado, pelo beneficio que poderia rezultar ás Conquistas das importantes materias, que tratavam as mesmas Maximas e eu o fizera pessoalm. ${ }^{\text {te }}$, se a razão de Suplicante me não acovardára, temendo [fl. Iv.] parecer Lisonjeiro o discurso da primr. ${ }^{a}$ Maxima em que, com a mais honrada sinceridade, digo o que entendo a respeito do Ministerio Ultramarino. João Gomes de Ar. ${ }^{\circ}$ hé honrado, verdadeiro, bom homem, e o melhor Off. ${ }^{\text {al }}$ de Secretaria de Estado, que tem todo o Reino; mas se elle tivera o estudo de Bellas Letras, que lhe falta, havia de saber, que em quaesquer Reinos do Mundo civilizado, todos os dias se estão offerecendo aos Reys expressam. ${ }^{\text {te }}$, Artes, e Instruçoens de governar os Vassallos em diferentes cazos; e o mais hé, que algumas com o desembaraço de falarem aos mesmos Reys por estes termos positivos $=$ Vos, Snr. deveis fazer isto $=$ Vos não podeis, não deveis fazer estoutro $=\mathrm{E}$ para provar isto mesmo, não hé precizo sahir do Reino, nem revolver Livros, cançando os Literatos com huma erudição superflua, e fastidioza, nem p. ${ }^{a}$ persuadir ao mesmo João Gomes, que sabe, como sabem todos, que huma Instrucção, ou hum Arbitrio, são synonimos, que nascêram ambos de hum só parto; e que todos os dias se estão aprezentando ao Rey sobre a Tropa, sobre o Comercio, Fabricas, Economía, Agricultura etc.; do que rezultam muitas providencias, ou ficam impraticaveis, sem que por isso se offenda o Rey, nem o seo Ministério: Pelo que esta preocupação de João Gomes hé tão rançoza como superficial; e ainda fazendo justiça á sua sinceridade, não posso deixar de refletir, que pedindo elle efficazm. ${ }^{\text {te }} \mathrm{o}$ Papel para sy, (que lho hei de dar amanhãa) não queira mostralo da sua mão ao S. ${ }^{\mathrm{r}}$ Martinho de Mello ${ }^{698}$.

\footnotetext{
${ }^{696}$ ACL, Série Vermelha, Cód. 29. As palavras ou expressões em que há dúvida quanto a real transcrição são seguidas de um ponto de interrogação.

${ }^{697}$ As duas primeiras folhas (carta em que o autor encaminha o documento) não são numeradas no original.

${ }^{698}$ Martinho de Melo e Castro, Secretário de Estado da Marinha e Ultramar (1771-1796).
} 
Por estas razoens, vou pedir a V. S. ria, queira, como que lhe faz alguma [fl. II] recordação do seo Afilhado, introduzirlhe o Papel, pedindo a restituição, sem instancia, de sorte que o mesmo Ministro se persuada, que foi feito por ordem de V.S.ria, sem a idea de que elle o visse; segurando-lhe somente, que estima a ocazião de mostrar a S. Ex. ${ }^{a}$, que o seo Afilhado não hé destituido de merecim. ${ }^{\text {to }}$; e que está nas circunstancias da sua protecção, pela qual o espera ver atendido.

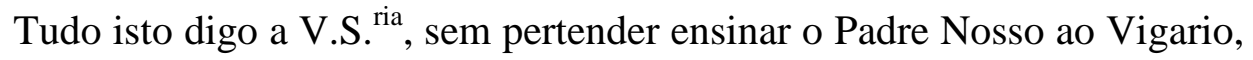
que sabe muito melhor do que eu, quantas são as Pessoas da SS. ${ }^{\text {ma }}$ Trindade. E se desta Conferencia rezultar favoravel recepção, hirei a Salvaterra, se V.S. ${ }^{\text {ria }}$ entender, que hé necessaria esta diligencia, pois não quero dar hum só passo sem a sua aprovação.

Recomendo-me m. ${ }^{\text {to }}$ ao S. ${ }^{\mathrm{r}}$ Fr. Antonio Bap. ${ }^{\text {ta }}$, porque me deve verdadeira amizade pelas suas estimaveis circunstancias; e a V.S. ${ }^{\text {ria }}$ seguro a fiel recordação dos seos favores, e o gosto com que dezejo acreditar o meu agradecim. ${ }^{\text {to }}$, servindo-o sempre como

R. ${ }^{\text {mo }}$ S. ${ }^{\mathrm{r}}$ Fr. Jozé Maine

obrig. ${ }^{\text {mo }}$ Am. ${ }^{\circ}$, e fidelis. ${ }^{\text {mo }}$ Cr. ${ }^{o}$ de V.S. ${ }^{\text {ria }}$

Junqr. $^{\text {a }} 14$ de Fevr. ${ }^{\circ}$ de 1780

Francisco de Almeida Silva 
[fl. 1]

Dessertação instructiva sobre a escolha dos Governadores das Conquistas; a sua existencia nos Governos; e o seo regresso para a Corte. ${ }^{699}$

A escolha dos Governadores das Conquistas deste Reino, hé hum objecto da primeira ponderação, sobre que escrevo o prezente Papel, sendo o importante ponto de vista reflectirse, que os mesmo Govr. ${ }^{\text {es }}$, ainda com o poder precario, e restricto da sua Comissão, reprezentam a Pessoa do Soberano, seo Legitimo Senhor, como Pai comum dos Vassallos da Corte, dos Reinos e dos Limites da Capitania, que a cada hum confere; A Elles entrega as chaves dos Dominios, e da inteligencia das Leys, e das Ordens, para aplicar estes remedios aos muitos Cazos, que tem prevenido, e providenciado; rezervando outros para os que a novidade dos Sucessos, ou a mudança dos Tempos descobre, mostrando as diversas circumstancias, que os transforma, e os fazem aparecer revestidos de diferente figura: por esta razão hé necessario muitas vezes alterar as providencias, ou mudar totalmente os mesmos remedios; não só para reprimir o vicio, e desterrar o abuzo dos Costumes, como para aumentar os Interesses da Coroa, e a felicidade dos Povos, promovendo a Agricultura, o Comercio, a Industria, e as Artes, e por consequencia a conservação do Imperio, de que o Altissimo o fez chefe independente.

Este Negocio hé de tanta importancia, que até se devera invocar primeiro a Graça do Espirito Santo, para que influisse no acerto da escolha dos mesmos Governr. $^{\text {es }}$; porque nelles delega o Rey o Supremo poder de governar os Vassallos como Filhos, da mesma forma com que o Soberano Autor da Natureza lhe transferio, e confiou a Autoridade Legislativa sobre os mesmos Vassallos, para os conservar em justiça e sociedade racional, como principios, que fazem o seguro fundamento de huma brilhante Monarquia.

A distante situação em que se acham as Conquistas, e Dominios Ultramarinos descobertos há mais de duzentos annos na America, Africa, e Azia, parece que fazem dependente este Papel das noticias particulares de cada hum dos Paizes, mostrando-se nelle a sua posição geographica, as produçoens [fl. 1v.] do Continente, o Caracter dos Incolas nascionaes, o seo espirito, genio, disposição, e Comercio; porem como me propuz somente escrever da eleição, existencia, e regresso dos Governr. ${ }^{\text {es }}$ em comum, e não huma Dessertação historica de Comercio ou de Geographia, tudo o mais que for necessario p. ${ }^{\text {a }}$ contemplar aqueles objectos no Corpo da Historia das Conquistas, se achará na Secretr. ${ }^{a}$ de Estado desta Repartição, pois me persuado, que nella se conservam as bem instruidas Cartas dos Terrenos, e as reiteradas Contas dos respectivos Vice Reys, e Governr. $^{\text {es }}$, desde o principio das Colonias, até a prezente Epoca.

Para melhor inteligencia destas Proposiçoens, que absórvem, e compreendem muitas, e diferentes circumstancias, farei huma divizão de Maximas, para que sejam perceptiveis os pontos, que devo tratar na mesma

\footnotetext{
${ }^{699}$ Parte desse documento (a partir da $6^{\mathrm{a}}$ Máxima) encontra-se na BA sob a Referência COR 1817 e cota 54-XIII-16 (136) apresentando algumas diferenças com o da ACL, que se assinalará ao longo da transcrição. Uma anotação feita posteriormente na última folha daquele sugere ser de autoria de D. Rodrigo Joze de Menezes, Governador Capitão General da Capitania de Minas Gerais.
} 
materia, na qual ensopadas [?] as minhas experiencias, me deixáram bastantem. ${ }^{\text {te }}$ instruido.

\section{$1^{\text {a }}$. Maxima: A escolha do Gov. ${ }^{\text {or }}$ proporcionado, e proprio p. ${ }^{\text {a }}$ o Governo onde for precizo.}

Todos sabem que os temperamentos dos Corpos, não são os mesmos em hum como no outro, e que as diversas constituiçoens dos Individuos, pelos seos humores, e pelos seos talentos, fazem a grande diferença de genios, e capacidades, que notamos em cada hum, até entre os Irmãos filhos dos mesmos Pays. Igualm. ${ }^{\text {te }}$ sabem todos, que ainda dentro de hum mesmo Estado, e de hum Reino, há nas suas Provincias diferentes costumes, opostos diametralm. ${ }^{\text {te }}$ do Systema politico, urbano, e civil da Capital do Estado, ou da Corte do Reino. Estas duas propriedades da natureza racional, e dos Paizes, são incompativeis e paresem dificultozas de unir, e governar por hum homem, que não foi creado em cada hum delles; mas não hé assim: Porque a mesma diferença, que observamos nos temperamentos, e nas capacidades dos Sugeitos, nos abre a porta e nos facilita a escolha de hum, e muitos proporcionados ao Governo, e à Conjuntura que o fez precizo. Esta urgencia da Conjuntura, deve ser o primeiro movel da mesma escolha; pois não basta encontrarse nos Escolhidos as propriedades do Governador, hé igualmente necessario refletir na ocazião para escolher o mais [fl. 2] virtuoso, se o Continente estiver em paz, e o melhor Soldado, se se achar em guerra: E ainda muito mais em tempo de algumas perturbaçoens domesticas dos mesmos Povos, em cujas circunstancias hé trabalhoza a escolha; porque com dificuldade se descobre hum homem severo sem crueldade; benigno sem froxidão; belicoso sem colera, e prudente com sagacidade; condições proprias para castigar os sublevados, abater os orgulhozos, sofrer os indiferentes, e conservar os Pacíficos; e de outra forma vem a ser o mesmo, que escrever, e lançar os nomes das pessoas da primeira classe em huma Urna, e quando parece necessario nomear Vice Rey p. ${ }^{\mathrm{a}}$ a India, tirar hum por sorte da mesma Urna, e constituilo Vice Rey, sendo proprio para Governador do Pará, ou Mato Grôsso; ou de reverso modo, volver os nomes na Urna querendo sortear hum Gov. ${ }^{\text {or }}$ para Goyazes, e sahir outro com qualidades perfeitas p. ${ }^{\text {a }}$ Vice Rey do Brazil; ficando assim lezada a eleição, por se controverter as propensoens, os prestimos, as experiencias, e a madureza dos Sugeitos; não só trocando-lhes o destino das suas capacidades, como atropelando a reflexão da conjuntura, que estiver pendente; e por consequencia exposta a escolha ao infeliz acazo de sahir da Urna para Governador, algum daquelles, que nem sabem governar a sua Caza. Desta idéa, que se figura, tem alguma semelhança a outra escolha, qual hé a de se promover aos Governos alguns patrocinados, e Parentes das Pessoas da primeira reprezentação no corpo politico, ou por se enganarem com o merecimento do mesmo a quem abonam, ou porque totalmente ignóram as qualidades do paiz para donde os providos devem hir.

Estas incoerencias, que podem acontecer, tambem se devem prevenir, e emendar com o remedio, que hé facil. Das Pessoas que se acham na Corte empregnadas no Gabinete, e que não viram as Conquistas, só ao Ministro de Estado da Repartição Ultramarina deve pertencer privativam. ${ }^{\text {te }}$ o conhecimento, e a Proposta dos Govern. ${ }^{\text {es }}$ das Conquistas; e não por modo vulgar, ou como regalia, mas como meyo adequado; proprio, e interessante ao Serviço de Deos, e do Rey, e á utilidade publica dos Vassallos dos Dominios, e do Comercio de toda 
a Monarquia; por muitas razoens: Primr. ${ }^{a}$ : Porque, não só naquelle Arquivo se conservam as exactas noticias dos Governos, com as Cartas [fl. 2v.] dos seos Limites, dos Povos domesticos, e civilizados pela polícia do trato, e pelas Luzes da verdadeira Religião, como pelo infinito numero de Barbaros ainda cégos, e enlodados no xárco e nas trevas do Paganismo. Segunda: Por que o mesmo Ministro todos os dias está observando, vendo e ouvindo os Requerim. ${ }^{\text {tos }}$ dos Suplicantes das diversas Capitanias de que se compôem aquelles dilatados Continentes. Terceira: Porque com esta singular ventajem, só o referido Ministro pode e déve escolher os Governadores para os Territorios da Sua Repartição; pois conhecendo tambem as Pessoas da primr. ${ }^{\mathrm{a}}$, e da segunda classe da Corte, lança os olhos, e toma proporcionadas medidas aos sugeitos de ambas as ordens, de sorte que os vá preparando na sua mente para os Governos quando forem necessarios; e por isto deve prevenir de Longe as suas observaçoens, ainda quando os mesmos governos estiverem providos, porque então lhe sobeja o tempo para escolher entre os desocupados p. ${ }^{\mathrm{a}}$ a primr. $^{\mathrm{a}}$ entrancia; e dos que estiverem em exercicio nos Governos, para serem promovidos a outros de mayor graduação: e esta inteligencia hé a outra balança, que só tem, e conserva em sy mesmo o referido Ministro de Estado, para pezar os talentos dos Individuos. Quarta: Porque os primeiros, que elége para entrar de novo, ficam como afiançados pelas informaçoens, ou exames, que houver feito das suas boas qualidades, e circumstancias; e os que se acharem empregados, e forem capazes de promossão, já tem dado outras provas do seo comportamento pelos officios, que ao mesmo Ministro vem dirigidos de cada hum dos Governos. Quinta, e ultima: Porque não hé necessaria huma intimativa sublime para persuadir, que esta hé a fonte, que o Rey destinou expressamente aos Ultramarinos, para aplacar a sede da sua justiça: e esta a Estrada, que mandou abrir pela qual, os mesmo Ultramarinos somente sobissem, e descessem dos Pes do Trono, fazendo-se larga, e espaçoza com hum Tribunal de Ministros, e Adjuntos da primr. ${ }^{a}$ excepção, e hum Prezidente da primer. $^{\text {a }}$ grandeza da Corte.

Ponderadas estas premissas, dá logo nos olhos, que só o referido Ministro deve fazer as combinaçoens dos Paîzes com os Sugeitos, e com a Conjuntura, [fl. 3] tirando consequencias bem purificadas p. ${ }^{a}$ a Proposta electiva, que há de aprezentar ao Soberano, na qual declare os nomes, e o numero dos que escolher, para que o Mesmo S'nor. a confirme, altere, ou repróve a seo arbitrio. Oh' que feliz Época para estabelecer este Systema, se S. Mag. ${ }^{\text {de }}$ fosse servida mandalo praticar!

\section{$2^{\mathrm{a}}$. Maxima, ampliando a $1^{\mathrm{a}}$.}

Não pertendo persuadir, que som. ${ }^{\text {te }}$ nas duas classes da Nobreza Cortezãa, se acham as pessoas adequadas, e proprias para governar as Conquistas; porq.' isso seria coarctar a Liberalidade com que a Dextra Omnipotente do Rey dos Reys, espalhou igualm. ${ }^{\text {te }}$ na Corte, como nas Provincias desta Monarquia, o grande numero de pessoas nobres aptas, proprias, e dignas de diferentes Empregos; humas ocupadas nas Tropas pagas destes Reinos, (cujas Aulas politicas se devem numerar pelos Regimentos) e outras nos Domiciliarios das mesmas Provincias e Reinos: Tanto assim, que seria hum absurdo repreensivel da minha imaginação, se pensara, que a escolha fosse restricta, e limitada ao pequeno numero da Nobreza da Corte, sabendo, há mais de vinte annos, que este mesmo numero se reparte em diferentes destinos, proporcionados às suas propensoens, e vocaçoens: 
Porque os Primogenitos das Cazas, que assentam praça, são mui poucos em paralello com o numero de seos Irmãos; e entre esses poucos; são mui raros os que tem genio para governar huma Capitania: Há muitos virtuozos, instruidos, e Sabios, capazes do serviço do Paço, e do Corpo Diplomatico, mas nem por isso se segue, que são proprios para Governadores; nem se devem reputar inuteis, se a Natureza os não preparou com estes principios. Os Filhos Segundos seguem a vida das Letras, e se recolhem depois à Basilica Patriarcal, ou às Ordens Religiozas, como abrigo decente à sua Pessoa e estado; e alguns se anéxam tambem aos Corpos Diplomatico, e Jurídico, por que os seos genios, e os seos estudos, lhe abriram aquelles caminhos: por este modo qual pode ser o resto, que fique do que hé pouco, se esse pouco por esta forma se reparte?

[fl. 3v.] Não se devem tambem escolher os Validos do Rey, nem os Parentes proximos dos Ministros de Estado, para Governr. ${ }^{\text {es }}$ das Conquistas, sem grandes próvas da sua capacidade, e prudencia; porque com esta virtude, fica afiançada, e segura a moderação do Gov. ${ }^{\text {or }}$, que há de empregar os seos officios em beneficiar o Continente do seu Governo; e do contrario rezultará infalivelmente a sua propria ruina, e a decadencia do mesmo Governo, se elle arrogar ao seo poder os excessos de huma Jurisdição dispotica, por abuzar do favor do Rey, ou do Ministro Parente, que está ao Lado do Mesmo S'nor., a cujos ouvidos não podem chegar os clamores dos Povos consternados pela ambição, ou pela crueldade do Gov. ${ }^{\text {or }}$, senão quando as Lagrimas, principiadas a chorar na Conquista, chegam a derramarse desesperadas aos Pes do Trono.

Os Nascionaes daquelles dilatados continentes, são dignos da benigna reflexão do Soberano nesta importante materia: Elles tem a felicidade de serem Vassallos desta Monarquia, pela Piedade, Religião, Providencia, Liberalidade, e Justiça dos Soberanos; mas tambem os mesmos Soberanos tem a singularidade de possuir os Dominios, onde se acha o amor, a obediencia, a fidelidade, e o respeito vinculados em gráo tão sublime, que parece huma segunda natureza, a qual só por sy mesma, hé digna de reputarse a primr. ${ }^{a}$ delicia do mayor Imperio do Mundo; sendo bem sabido em qualquer parte delle, que a veneração, que aquelles Vassallos professam ao seo Soberano, às vezes parece idolatria: E como as provas são muitas, e eu sou Patricio, não quero repetilas, porq'. não fique duvidoza a verdade: todos o sabem; e isto basta.

\section{$3^{\mathrm{a}}$. Maxima: Que os Govr. ${ }^{\mathrm{es}}$ não levem mais Criados p. ${ }^{\mathrm{a}}$ as \\ Conquistas, que os que lhe forem muito necessarios; \\ e que deixem ficar em Portugal a sua Familia Femenina.}

O mayor erro de politica dos Govr. ${ }^{\text {es }}$ hé, levarem para as Capitanias do seo destino, [fl. 4] hum illimitado numero de Criados proprios, e dos Agregados favorecidos pelas pessoas da sua amizade, outras de respeito, e muitas de dependencia, o que se facilita; porque apenas se espalha a noticia de hir Gov. ${ }^{\text {or }}$ p. ${ }^{\text {a }}$ o Brazil, ou p. ${ }^{a}$ a India, já todos se propôem a idéa de huma indubitavel felicidade; e sem disputar o preço, que não fazem, (porque as suas esperanças lhes reprezenta os premios futuros) vão offerecerse voluntarios ao serviço do Gov. ${ }^{\text {ro }}$; mas como sabem de sy mesmos, que sendo destituidos de prestimo, e de circumstancias esta falta fará dificultoza a recepção: estes desamparados da Natureza, e da Fortuna, são os que descóbrem os empenhos mais fortes, para obrigar ao Gov. ${ }^{\text {or }}$, que os aceite; e estes os que o Gov. ${ }^{\text {or }}$ recebe, porque não tem outro remedio, persuadido, que hé obzequio recíproco da Nobreza, serem 
flexiveis a aquelles rogos, e que devem assentir nos mesmos empenhos: Destes se faz o primeiro, e avultado numero de Criados; ainda quando o Gov. ${ }^{\text {or }}$ não tem escolhido os que lhe são necessarios; mas Logo, que os aceita, já huns, e outros (isto hé: os buscados, e os introduzidos) principiam a propôr a necessidade de huma ajuda de custo para se prepararem com decencia, e o Gov. ${ }^{\text {or }}$ consternado a exibe, acrescentando, com este prejuizo, o primeiro erro, que hé a origem dos outros, que se seguem. Os Agregados entram já prontos, por ser esta a primeira cor com que vem revestidos pelos seos Patronos, protestando logo, ou pretextando, que não querem para os seos Afilhados mais, que o transporte na viagem, e que depois, que elle Gov. ${ }^{\mathrm{r}}$ chegar á Jurisdição da sua Capital, o patrocine, e acomode com algum meyo de agenciar a sua vida. Não há facilidade mais imprudente!

Juntas estas tres Turmas, fica immediata a consequencia, de ser necessario ao Gov. ${ }^{\text {r }}$ entrar nas despezas da passagem, ou ajustala por oito, podendo-a fazer por quatro; e cada hum dos Protectores fica reputando por beneficio de pouca entidade (?) este prejuizo, que fez com a sua violencia; talvez

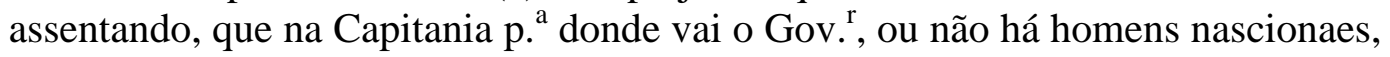
que sirvam á Republica, ou a esses devem preterir os seos Afilhados: este hé o outro erro, que nascendo do (?) Patrono, o Gov. ${ }^{\text {or }}$ tem nelle a mayor parte. Precindamos da confuzão, e dos enredos, que produzem estas tres especies de Familiares na viagem; por que até aqui está repetido de historia o que baste p. ${ }^{a}$ reflexionarse, que as consequencias, [fl. 4v.] que rezultem daquelles erros do Gov. $^{\text {or }}$, são os prejuizos, que depois vem a experimentar o Serviço de El Rey, e os Individuos nascionaes: Porque o Governador, não descobrindo Logo que chega, alguns meyos de diminuir aquella numeroza Familia, manda assentar praça a huns para verse livre dos inuteis, havendo escolhido já os melhores para seos Criados; e a alguns dos mesmos escolhidos, faz tambem assentar praça, ficando ocupados em sua Caza, de cujo exercicio, sem hirem nunca aos do Regimento, vão entrando nas Promossoens, até se habilitarem para grandes officiaes; ficando prejudicada a Fazenda Real nos soldos, que pagou, e há de pagar com o excesso proporcionado aos postos a que os promover, sem que aquelles homens tenham de soldados mais que as Fardas, que trazem, os Soldos que cobram, e as Patentes com que se desvanecem: Deste erro nasce a injustiça de preterição aos Vassallos nascionaes, a quem Legitimam. ${ }^{\text {te }}$ pertencem os póstos, como frutos do trabalho, e da honra com que tem servido a S. Mag. ${ }^{\text {de }}$ em defeza da mesma Patria e ainda que as desordens não fossem outras, esta só por sy mesma hé digna de reflexão, e de remedio. O outro erro em prejuizo da Real Fazenda hé, que vagando alguns officios de Justiça, se fazem rematar por donativos aos Criados, e agregados, sem se afrontarem os Lançadores, ou estes senão atrevem, porque tem já inteleigencia de que o Rematante hé hum Criado, ou Favorecido do Gov. ${ }^{\text {or }}$. Ainda hé mayor a outra injustiça nos officios das Aduanas, cazas de Moeda e das fundiçoens, que não pagam donativos a El Rey, e por serem reputados officios da Fazenda Real, della recebem os respectivos ordenados, que lhe tocam; estas data são Livres dos Govr. $^{\text {es }}$, os quaes se servem dellas somente para remuneração dos serviços particulares dos seos Criados, sendo proprios para manter, e conservar a viuvez, e a orfandade da molher, e dos filhos daquelles, que serviram na Patria com honra, que por lhes faltarem com estes socorros, se acham cobertos de pobreza, e de indigencia, e assim se arruinam, e morrem de mizeria, porque a distancia, que há das Conquistas á Corte, lhe faz perder com o recurso, até a memoria dos mesmos Serviços dos Pays, em que tinham todo o direito para requerer. Por outra parte 
negocêam os Criados publica, ou particularm. ${ }^{\text {te }}$ por sy, ou por outrem, conforme a privança, que tem com o Gov. ${ }^{\text {or }}$, seja em negocio do Expediente do Governo, ou seja em generos de Comercio comum, e também de [fl. 5] contrabandos, aplicando toda a industria, que podem para fartar a sua cobiça. Estas famintas Rapinas vendem por consequencia a autoridade, e a reputação do Governador, alguns dos quaes muitas vezes ignóram estes procedimentos, e outros os consentem, porque com esta permissão tácita, ou expressa, lhes paga o Povo muito mais caro o serviço, que só recebe o Gov. ${ }^{\text {or }}$; e isto sófrem, porque naquella Caza todos querem ter hum Auxiliante, ou ao menos querem evitar hum inimigo, onde lhes pode ser fatal.

Pelas mesmas razoens, e por outras muitas se deve proibir infalivelmente aos Governadr. ${ }^{\text {es }}$, que levem para os Governos as Familias femeninas, sem embargo de pertenderem esta permissão com o justo motivo do desempenho das suas Cazas; porque esses mesmos Govr. ${ }^{\text {es }}$ se enganam, pela falta das verdadeiras noticias, dos continentes, que vão governar, devendo ser persuadidos, de que o governo não hé o mesmo, que a sua Quinta para donde se retiram, na qual podem coarctar os gastos, escuzando a pompa da Corte, e até o seo decente tratamento: Quem os informa, ou persuade, ou os Lizonjêa, ou não sabe, que em se preparar para hir, e vir de qualquer dos Governos com tão grande Familia, hé preciza a despeza de trinta e sinco até quarenta mil cruzados; e ainda mais: e se o empenho da Caza importar tambem quarenta (porque menos dessa quantia não há Cavalheiro algum, que suponha pezado o empenho da sua Caza) ambas as parcelas montam a oitenta, e já hé grande. Tambem não sabe quem os informa, que em qualquer das Capitanias da America, ou do Oriente, a obstentação do Lúxo chega a ser repreensivel, porque até cobre as pessoas de huma insignificante reprezentação; pelo que a do Gov. ${ }^{\text {or }}$, e da sua nobre Familia, hé precizo que exceda p. ${ }^{\mathrm{a}}$ conservar tambem no tratamento, o equilibrio da distinção, e da autoridade. Os viveres, e os generos que produz o paiz da primeira necessidade, são comodos; porem os que são logo immediatamente precizos, como as Sêdas, as Lãas, Azeite, Manteiga, Vinho, Vinagre etc. etc. transportados de Portugal, sóbem alguns a mayor preço que o de 120 , e 130 por 100; e ainda m. ${ }^{\text {to }}$ mais conforme for a distancia dos postos do Mar. Os ordenados desta numerosa Familia, se se págam, são dobrados; e emfim, os soldos de Gov. ${ }^{\text {or }}$ são á proporção diminutos, e não podem manter, e conservar esta despeza sem grandes empenhos [fl. 5v.] logo, se esta premissa do desempenho hé cercada, e coberta de todas aquellas contradisoens, onde está o avanço, e o Lucro, que o Gov. ${ }^{\text {or }}$ tira, se por mal informado se empenhou mais, ou, ao menos, senão desempenhou? Finalmente hé mais acertado que a Familia feminina fique em Portugal; e que arbitradas as mezadas correspondentes á sua mediana subsistencia, todo o mais remanescente, que ficar das rendas da Caza se reparta em Consignaçoens para as dividas della; pois me atrevo a segurar, que por este modo, e satisfeitas as Condiçoens, que passo a escrever, pode o mesmo Gov. ${ }^{\text {or }}$ remeter $\mathrm{p} .{ }^{\mathrm{a}}$ Portugal a tersa parte dos seos soldos, sem que a economia envileça o seo caracter; Lembrando-se, que o Governo não hé Bispado, e que nem esmollas pode dar quem deve o alhêo, e tem molher, e filhos a quem sustenta: Mas como pode haver algum motivo urgentissimo, o Rey hé Legislador, e poderá dispensalo.

$1^{\mathrm{a}}$. Condição: Que o Gov. ${ }^{\text {or }}$ não Leve p. ${ }^{\mathrm{a}}$ o Governo mais que dous Criados graves, hum dos quaes escreva bem e certo; que não tenha vicios notaveis, nem mais predicados, que o da honra, e segredo; porque sendo instruido, e Sabio, parece que abáfa, e escurece o merecimento do Gov. ${ }^{\text {or }}$, entendendo-se, 
que hé seo influente, e que as disposiçoens do Governo são partes (?) da capacidade do Secretr. ${ }^{\circ}$ particular, quando são acertadas e se acontecem quaesquer desconcertos, sempre se atribue ao Gov. ${ }^{\text {or }}$ a origem expressa delles: de sorte que se se obra bem, o Secretr. ${ }^{\circ}$ hé o movel e se sucede o mal, o Gov. ${ }^{\text {or }}$ tem a culpa: Por esta razão contemplei as qualid. ${ }^{\text {es }}$ da escolha do mesmo Gov. ${ }^{\text {or }}$, para se confiar, e supor delle immediatam. ${ }^{\text {te }}$ a prudencia dos acertos; e para que o Ministerio saiba, pelos seos officios, que se lhe vão aumentando as Luzes do proprio discernimento.

$2^{\mathrm{a}}$. - Que póssa levar mais hum só Guarda-rôpa: Hum copeiro com seo Ajudante: Hum Cozinhr. ${ }^{\circ}$ o melhor, e hum Ajudante, que não seja máo Cozinheiro. E se na Capital do seo Governo rodárem Carruagens, que leve dous Bolieiros, os quaes sirvam alternativam. ${ }^{\text {te }}$ na Bolêa, e na Taboa, ficando sempre suprido o lugar com a falta de hum dos dous, nos cazos de doença, fuga, ou morte [fl. 6]. E para tudo o mais, seja bem entendido, que não há Cidade na América, Africa, ou Azia tão esteril, que deixe de ter todos os officios, e Artes, que forem necessarios ao Gov. ${ }^{\text {or }}$

$3^{\text {a }}$. - Que o Gov. ${ }^{\text {or }}$, antes de sahir da Corte, ajuste por preço certo todos os Individuos da sua Familia por mez, ou por anno, que lhe pagará infalivelmente; anticipando aos mesmos a advertencia, de não esperarem do seo Governo outro algum beneficio mais, que o que puder fazerlhe da sua propria fazenda.

$4^{\mathrm{a}}$. - Que o Gov. ${ }^{\text {or }}$ na Caza da sua rezidencia da Capital, não dê meza franca a pessoas de ceremonia, ou de confiança, com as excepçoens seguintes $=\mathrm{A}$ hospedagem de algum parente: ao Official de mayor Patente das suas ordens: ao Arcebispo, Bispo, ou pessoa constituida na primr. $^{\text {a }}$ Dignidade Eclesiastica, Militar, ou Juridica: a alguns Estrangeiros, que aportarem á sua Capital por arribada, tormenta, refugio, ou qualquer outro acazo, sendo pessoas com as quaes póssa tratar toda a civilidade, e generoza franqueza, que lhe parecer; mas nunca diariam. ${ }^{\text {te }}$ : E fora da sua Caza, no Campo, ou em jornadas, que se lhe permita toda a Libertade, que elle quizer, contemplado sempre o seo decóro; ficando-lhe voluntaria a acção de usar destas excepçoens, p. $^{\text {a }}$ poder somente restringilas, mas não para amplialas.

$5^{\text {a }}$. - Que o Gov. ${ }^{\text {or }}$ dê a toda a Tropa o exemplo de trazer vestida a sua farda annualm. $^{\text {te }}$, para que os Officiaes mayores, e por consequencia os Subalternos, e Soldados, reputem pela sua mais decente galla, e adorne o habito demonstrativo da sua profissão, qual hé o honrado Serviço de El Rey. Todas estas condiçoens, e ordens, se devem reduzir a hum Formulario instructivo assignado por S. Mag. ${ }^{\text {de }}$, para se entregar ao Gov. ${ }^{\text {or }}$ no mesmo dia, ou no seguinte da sua nomeação; e não de outro modo; porque sendo por advertencia, insinuação, ou conselho, o tempo as hirá relaxando infalivelmente, e ficarão impraticaveis: propriedade infeliz do vicio tolerado a primeira vez, [fl. 6v.] que se propaga logo que se consente, e depois fica irremediavel.

$$
\begin{gathered}
4^{\text {a }} \text {. Maxima: Que os Govr. }{ }^{\text {es }} \text { não sejam succedidos por outros } \\
\text { quando findar o tempo da Patente com que foram } \\
\text { p. }^{\text {a }} \text { o Governo; só nos cazos em que S. Mag. }{ }^{\text {de }} \text { os queira empregar, } \\
\text { ou promover a diferente Capitania, ou exercicio. }
\end{gathered}
$$

São nomeados, e providos os Govr. ${ }^{\text {es }}$ por huma Patente Limitada ao prazo de tres annos, que ordinariam. ${ }^{\text {te }}$ se excedem, em quanto S. Mag. ${ }^{\text {de }}$ não hé servida 
mandarlhes Successor, ou para que se retirem para suas Cazas, ou para que passem a outro diferente Governo. O primeiro cazo de se retirarem para a Corte, deve ter suas precizas excepçoens, sendo as principaes: o desagrado do Rey por mal servido: a necessidade do seo prestimo para diverso emprego: e os requerimentos do Gov. ${ }^{\text {or }}$ com justas cauzas, . $^{\text {a }}$ se retirar: por outro qualquer modo, hé prejudicialissimo ao Serviço do Rey, e á utilidade publica da Capitania, que estiver governando: Porque se o Gov. ${ }^{\text {or }}$ está no Governo da primr. ${ }^{\text {a }}$ entrancia, e tem dado boas provas do seo genio, e capacidade para governar, está claro, que só conservado no Lugar hé que pode aprender; pois bem sabem os que tem estudado muito esta Arte com o exercicio, que não sendo comum o Systema de hum p. ${ }^{\text {a }}$ outro Continente, ao menos do primeiro Governo, e de todo o triennio, tira humas regras geraes de prudentes combinaçoens, que o habilitam para governar depois do triennio, não só a mesma Capitania em que se acha, como qualquer outra de mayor graduação: já então os mesmos principios vão roborados com a experiencia, e com os annos; pois sem estes mestres da madureza, os acertos serão prodigios do acazo.

Entra hum Gov. ${ }^{\text {or }}$ experimentado na Capital do Governo a que foi promovido, illuminado pela pratica, que adquirio em outro: hé nella bem recebido, e festejado pelos Povos, sempre amantes da novidade. Os Infelices, e descontentes esperam melhorar de fortuna: os Contentes no governo passado, em conservar a sua sorte: e os Indiferentes, (ordinariamente infames) em observar os primeiros [fl. 7] movimentos para segurar depois o seo partido: de sorte que sendo este vicio comum em todos os Dominios do Mundo, o modo de o praticar hé diferente em cada huma das Partes. Huns logo querem sobornar os Familiares dos Govenr. $^{\text {es }}$ com prezentes, e offertas, examinando primeiro, qual the hé mais agradavel: outros com festas públicas na sua entrada, influidas no Senado, ou feitas á sua custa, ou tambem convocados os Cidadoens por huma derrama voluntaria: outros abrindo os Cofres do que grangeou talvez a sua uzura, e facilitando a exportação dos dinheiros p. ${ }^{\text {a }}$ as urgencias do Gov. ${ }^{\text {or }}$ : muitos outros cavilozos, e Lizongeiros, murmurando dos procedimentos do Antecessor, que acaba, e prognosticando felices progressos das virtudes do Successor, que ainda não conhecem; e emfim, por estes, e por outros muitos modos, ennovelados todos em hum Labyrimpto de orgulhoza confuzão, se disvelam em illudir o novo Gov. ${ }^{\text {or }}$, de sorte que o tenham proprio aos seos interesses particulares: Por esta razão no primeiro anno, o Gov. ${ }^{\text {or }}$ prudente, e instruido na Arte de governar, não pode fazer mais, que observar bem a todos, experimentalos, e conhecelos; e não faz pouco: No segundo anno, entrar com as forças da sua delegação a escolher os benemeritos para servirse delles, apartando os máos por qualquer modo, até com extraminios proporcionados á sua malicia, para que não perturbem o socego comum da Republica, que há de governar; e então faz muito: No terseiro anno hé que sabe com formalidade, quaes são as Rendas da Faz. ${ }^{\text {da }}$ Real, se se cobram, e como se distribuem; o Comercio do paiz; o caracter dos habitantes; as forças da Tropa, e das Fortalezas, se as tem; a abundancia, ou carestia dos viveres, e o excesso ou comodidade dos seos preços, para evitar os monopolios dos generos da primeira necessidade: e então hé que sabe o que perguntou, e quis saber desde o dia em que tomou posse e o não pode conseguir senão depois de passado aquelle tempo com muito trabalho. Pois se hum Gov. ${ }^{\text {or }}$ já sciente em governar os Povos, se vê obrigado a perder o tempo para reger, e pôr em ordem a outros de diferente paiz, como poderá governar o que entra de novo, e acabado o tempo porque foi provido, volta para sua Caza? 
Em consequencia do referido, hé muito necessario, que depois de conhecida a capacidade do Gov. ${ }^{\text {or }}$, se conserve na Capitania, ao menos, seis até nove annos; e que della se promôva para outras, sendo precizo, e conforme a Conjuntura [fl. 7v.] dos Negocios do Real Serviço, que occorrerem; porque por este modo, o mesmo Real Serviço será bem regulado, e a tranquilidade dos Dominios será segura, e feliz.

Não hé tambem conveniente ao Real Serviço, que se conserve o Gov. ${ }^{\text {or }}$ em hum só governo mais tempo, que o de seis até nove annos; porque como os Domiciliarios da Capital estimam as honras, que recebem dos Govr. ${ }^{\text {es }}$, tem descoberto, que o meyo mais proprio de as conseguir hé, o de convidalos p. ${ }^{\text {a }}$ Padrinhos dos baptizados de seos filhos, e para as suas Festas de Igreja: (que então por isso as fazem pompozas) esta maxima, que não hé repreensivel ao Gov. ${ }^{\text {or }}$ o vai corrompendo, e dominando a inclinação, até o ponto de o reduzir frôxo, e paizano, pela insensivel inadvertencia de se familiarizar muito com os Subtitos, sendo necessario conservarse nos Limites de huma respeitada benevolencia, pois esta hé a baze, que somente conserva a autoridade de Pai, que pelo Rey reprezenta.

Finalm. ${ }^{\text {te }}$, hé tambem precizo o systema desta Maxima, para senão amontoarem na Corte os Crédores á Corôa, os quaes não sendo despachados logo, como querem, clamam descontentes, até reputando injustiça a demora, ainda que os entretenham com boas esperanças; do que rezulta o séquito dos Parentes, a imulação, e o ódio a outros despachados, que esperáram; por se persuadirem alguns daquelles, que os seos serviços são muito mais relevantes, e que o seo nascimento até os produzio superiores á boa razão.

\section{5 . Maxima: A escolha dos Secretr. ${ }^{\text {os }}$ dos Governos, o seo exercicio, o tempo dos seos provimentos trocado com o dos Govr. ${ }^{\text {es: }}$ : Off. ${ }^{\text {al }}$ mayor das Secretarias, a necessidade de os haver.}

A escolha do Secretario de hum Governo, parece identica com a do Gov. ${ }^{\text {or }}$; porque senão hé Colega nas disposiçoens do Lugar, deve ser substituto immediato das suas inteligencias. Este hé o braço direito do Gov. ${ }^{\text {or }}$, para o ajudar a conservar em equilibrio o pezo do Governo, unindo as suas virtudes, as suas forças e o seo prestimo, ao poder do mesmo Gov. ${ }^{\text {or }}$, de sorte que elle possa manear (?) o acordo das [fl. 8] suas providencias, e o Secretr. ${ }^{\circ}$ ajudalas com a expedição, com o segredo, e com a efficacia dellas: em suma: este hé o único Confidente, e a chavemestra do Arquivo do Governo, cujas portas ninguem pode abrir, se elle mesmo não facilitar a entrada; pelo que, sendo a primeira das suas necessarias circumstancias o segredo infalivel, deve ser tambem admoestado, que o trabalhozo exercicio desta virtude, não consiste só em callar; hé muito mais precizo revestir o aspecto, e os olhos de hum ar de ignorancia do facto, que esconde, procedendo advertilo, que no concurso de muitos homens em huma pratica, e fora della, as observaçoens, e as conjecturas descóbrem muitas vezes a verdade, que se calla: e antes que a penna se remonte em materia tão vasta, e que o episódio me aparte totalmente do Assumpto, repetirei com propriedade no prezente cazo, o que ouvi em Lição particular a hum dos mayores Vassallos desta Monarquia, e até me parece, que por palavras formaes $=$ Quando ouço espalharse a noticia de alguma verdade, que só eu sei, castigo sem cólera a q. ${ }^{\mathrm{m}}$ ma repete, escarnecendo da sua credulidade; e depois passo a fazer pratica de rizo do mesmo 
que ouvi, para os conservar desvanecidos, ou, ao menos, vacilantes, em quanto se não effectúa, ou publíca a verdade = Mas saiba o Secretario, que aquelle grande homem se revestia de sorte das Limitaçoens desta regra geral, que já mais foi descoberto o que por elle foi escondido: Saiba, finalm. ${ }^{\text {te }}$, que humas vezes se deve rir, em outras enfadarse, reputando fatuidade a pratica, e em muitas callarse com gravidade, para que com esta variedade de accidentes, senão chegue a penetrar o segredo, sabendo todos, que o rizo no Secretario hé systema: Muitas vezes lhe será necessario tomar a contraria, transformando o semblante, mas em defendela com argumentos está todo o risco; porq.' então são precizas muitas razoens fortes para sustentar huma contrariedade em sy mesmo, e chegar com ellas a persuadir, e convencer: Em poucas palavras: esta instrucção será inutil, se o Secretr. ${ }^{0}$ não tiver capacidade para a entender, e para a praticar.

Depois de reflectirse, que hé infalivelm. ${ }^{\text {te }}$ necessaria esta principal circumstancia de segredo no Secretario, hé tambem precizo, que ella tenha instrucção, desembaraço, e capacidade para o expediente do Governo, no qual diariamente occorrem successos extraordinarios, sobre que o Gov. ${ }^{\text {or }}$ lhe manda escrever [fl. 8v.] Ordens, Portarias, ou Cartas; e sendo nova, ou alterada a materia de que se trata, e por isso sem conexão com as providencias já estabelecidas pelas Leys, ou pelos Costumes do Governo: hé inquestionavel, que o Secretr. ${ }^{\circ}$ deve primeiro escrever as Minutas, p. ${ }^{\mathrm{a}}$ que o Gov. ${ }^{\text {or }}$ as aprove, ou reforme, diminuindo, ou acrescentando o que lhe parecer melhor; porque desta concordancia se tira já substanciada a inteligencia de ambos, para a perfeição do Serviço de El Rey, e para a utilidade publica dos Vassallos; pois seria doutrina extravagante, entenderse, que o Gov. ${ }^{\text {or }}$ estava obrigado a sofrer todo o pezo de ambos os Lugares, embolçando o Secretario os frutos de hum pelo expediente ordinario da Secretaria.

Hé prejudicial ao Serviço do Soberano, que ao mesmo tempo sejam providos os Governr. ${ }^{\text {es }}$, e os Secretarios; porque ambos entram na Capital ás cegas, sendo mui poucas as Luzes, que lhes deixam os dous Antecessores; (sem enbargo das Ordens credenciaes) ou porque maliciozam. ${ }^{\text {te }}$ as regatêam, com a politica de fazer saudoza a sua falta, ou porque o pouco tempo, que resta desde o dia da posse, que transfere, ao em que se apartam, faz impraticavel a completa instrucção, que os dous Successores necessitam; pelo que será bem prevenido, que o Gov. ${ }^{\text {or }}$, e o Secretario entrem nos Governos em tempos deferentes, de sorte que sempre se despacha hum quando estiver o outro no Governo. Mas como o Gov. ${ }^{\text {or }}$ não está obrigado a instruir o novo Secretario, dando-lhe as primeiras noçoens do despacho ordinario, das Provizoens, Patentes, Cesmarias etc; hé igualmente necessario, que na Secretaria haja sempre Officiaes em numero proporcionado aos Negocios do Governo, ou infalivelmente hum, o qual informe, e ensine ao novo Secretario, e seja tambem capaz de servir nos seos empedimentos: (assim como nos Cartorios publicos os Escreventes ordinarios, e alguns de exercicio mais Laboriozo com Escreventes juramentados) escuzando-se por este modo, que o Gov. ${ }^{\mathrm{r}}$ se veja necessitado a servir do seo Secretario particular nas dependencias do Governo, por inhabilidade do Secretario delle. Estes Officiaes, ou Official da Secretaria deve ser pago pela Fazenda Real; porque sendo Official de El Rey, se conserva na Secretaria sempre o Instructor do Secretario, e do Gov. ${ }^{\mathrm{r}}$ para a pratica dos Negocios do Expediente comum; e sendo mercenario do Secretario, ficará duvidoza a subsistencia deste Official, se o Secretario a [fl. 9] seo arbitrio o quizer despedir, pretextando o acordo com algum motivo aparente p. ${ }^{\text {a }}$ admitir outro, sem a mesma pratica, sem o mesmo 
merecimento, e sem a reflexão de jacturar (?) o Real Serviço com esta novidade: E sendo Official de El Rey, independ. ${ }^{\mathrm{e}}$ da subordinação familiar ao Secretario, fica pertencndo ao Gov. ${ }^{\text {or }}$ somente a suspensão, logo que se lhe prove erro de Officio: E a outra razão de ser pago pela Real Fazenda hé, porque vem a ficar na Secretaria hum homem condecorado com o ordenado de El Rey, e com a denominação de Official mayor, p. ${ }^{\text {a }}$ que sirva ao lado do Gov. ${ }^{\text {or }}$ nos impedimentos do Secretario: Bem entendido, que no mesmo Secretario, ou no Off. ${ }^{\text {al }}$ mayor, ou entre ambos, deve haver a inteligencia das Lingoas Ingleza, e Franceza, muito precizas nos postos da America, e Africa, e principalm. ${ }^{\text {te }}$ no Rio de Janeiro, pelas arribadas a que os obrigam os motivos com que nelle entram as referidas Nascçoens; e isto para se examinar com delicadeza, se os mesmos motivos das arribadas são verdadeiros, ou cavilozos: Em cazo de faltar nos dous aquellas circumstancias, deve-se nomear hum Lingoa pago por S. Mag. ${ }^{\text {de }}$ como há em Gôa; e que este mesmo Lingoa sirva na Secretaria como Official de Registo, ou de Porteiro, sem outro algum ordenado, nem emolumentos mais, que os que receber como Lingoa do Estado.

6 ${ }^{\text {a }}$ Maxima: Que a todos os Govr. ${ }^{\text {es }}$ das Conquistas se concedam mais amplos poderes sobre a pena de morte. E que ao Vice Rey do

Brazil, Capitaens Generaes da India, da Capitania da Bahia, das

Minas Geraes, e de São Paulo se conceda tambem o privilegio, e regalía de darem em nome de $\mathrm{S}$. Mag. ${ }^{\text {de }}$ hum certo numero de

Habitos das Tres Ordens Militares em cada hum anno; e alguns

Alvarás de Foros de Fidalgos contempladas as Jerarquias, como for do Real Agrado de S. Mag. ${ }^{\text {de }}$

Quando S. Mag. ${ }^{\text {de }}$ hé servida nomear, e prover os Vice Reys, e Capitaens Generaes das Capitanias, delega nelles todo o poder da Sua Regia, e Suprema autoridade para castigar os Delinquentes até morte inclusiva; prezidindo e desempatando [fl. 9v.] os vótos de vida, e morte, quando não há pluralidade nos Conferentes, que faça mayor pezo em hum dos braços da balança: hum só Adjunto basta para fazer esta pluralidade, com a qual o Gov. ${ }^{\text {or }}$ infalivelmente concorda: só este Adjunto salva, ou tira a vida de hum homem; e o Gov. ${ }^{\text {or }}$ não pode beneficiar o Reo com a vida, senão quando desempata os votos: então parece Pai, e Bemfeitor, nos outros cazos, conformando-se com as Leys, deve ser por força Gov. ${ }^{\text {or }}$, e Juiz: ex aqui (?) restricto, e Limitado o poder do Gov. ${ }^{\text {or }}$ pela inteligencia da Justiça, que reprezenta o Corpo da Ley. Os Soberanos escrevem as Leys como regras certas da regularidade dos Povos, p. ${ }^{a}$ os conservar em disciplina, estabelecendo as penas para os transgressores das mesmas Leys; e se lhes fosse possivel prevenir todos os cazos, que pudessem alterar os pontos fixos das mesmas Leys, seriam infinitas as excepçoens das Leys, que determinam a pena de morte, antes de se fazer conduzir o reo para o Patibulo, há muitas, estradas Largas p. $^{\mathrm{a}}$ salvar a vida de hum homem, castigando o seo delicto, senão hé reincidente. Nos degredos de Benguella, Caconda, e Cabo-verde, de Angola, e da India, se acham innumeraveis homens, que estando em pena ordinaria por culpas puniveis, foram mandados para aquelles extraminios, onde, depois mudando de vida, e de costumes, parece que a Natureza os produzio de novo, emendando o primeiro erro com que os havia formado. Destes mesmos homens se compôem a Tropa com Officiaes Militares daquelles Prezidios, cheyos de honra, esforço, prudencia, e capacidade: Estes são os que servem os Officios publicos, e 
os que fazem respeitavel o Corpo, e o decóro da Justiça: Estes os mesmos em cujas mãos gyra o Comercio, e que promovem os interesses do Continente com a mesma verdade, e credito vulgar em qualquer outro paiz: Com estes Conversos, finalmente, se organiza a Republica socegada, temente a Deos, e ao Rey, desejando arrancar da memoria dos Homens o delicto, que os fez repreensiveis. Em consequencia do referido seria justo, que S. Mag. ${ }^{\text {de }}$ por hum Alvará de Ley ampliasse a todos os Vice Reys, e governadores a faculdade de perdoar a pena de morte, logo que o Reo tivesse a seo favor a tersa parte dos votos do Congresso, contemplando-se a satisfação das Leys com os referidos extraminios: Com a excepção, porem, de ficarem com toda a sua força, e vigor, as penas estabelecidas para os Profanadores dos Templos, e dos Vazos Sagrados; para os Regulos; para os chefes de qualquer Levantamento; [fl. 10] para Cabeças e Socios de huma Conjuração; para Salteadores, que matam; para a Leivizias circumstanciadas, e em suma, para todos os Crimes de Leza Magestade Divina, e Humana da primeira, e da segunda cabeça.

Nesta ampliação de poder a todos os Govr. es, a Coroa hé a mais interessada, pela conservação das vidas, que lhe podem ser uteis, como tenho ponderado; tambem porque os dilatados Dominios de S. Mag. ${ }^{\text {de }}$ nas Conquistas, huns são povoados de Gentios indomitos; outros são dezertos sem cultura, nem estradas; e outros nunca foram habitados, nem vistos, porque as faltas de Gente, e as distancias os conserva ainda incognitos, e impenetraveis.

Da mesma ampliação tambem se segue, que será o Gov. ${ }^{\text {or }}$ bem-quisto daqueles Povos, sabendo, que a Regia Mão, que lhe transferio o poder para castigar os seos delictos, igualmente lhe franqueou a graça de perdoalos para os reconciliar esperando a sua emenda.

E porque de todos, e quaesquer crimes há muitos Agressores Escravos, dos quaes seos Senhores perdem o dominio direito desde o instante em que a Justiça os apreende; e sendo pretos de Angola, de Benguella, da Costa da Mina, de Cabo-verde, e de Moçambique não lhes será consideravel o trabalho do degredo, antes o reputarão feliz: neste cazo, qualquer preto criminozo, e ainda Criôlo do paiz, que escapar da morte no Maranhão, seja condenado a galés por toda a vida, e remetido p. ${ }^{a}$ as Minas: os da Bahia p. ${ }^{a}$ Maranhão: e os do Rio p. ${ }^{a}$ Pernambuco; e por este modo trocados sempre os Continentes da culpa com os da pena, ficará a Justiça satisfeita, e o Reo punido com a mudança do domicilio, e com as galés a que deve ser Sentenciado; Levando Guias em que se declarem os motivos da Sentença.

E como não basta somente aquella ampliação de poder para que os Gov. ${ }^{\text {es }}$ uzem da Piedade dos soberanos com os Criminozos, devendo tambem praticar justiça com os Benemeritos; he igualmente necessario, que S. Mag. ${ }^{\text {de }}$ permita, e conceda ao Vice Rey do Estado do Brazil, Capitaens Generaes da India, e dos Governos da Bahia, das Minas Geraes, e de São Paulo, a faculdade de darem no Seo Real Nome todos os annos, hum certo numero de Habitos das [fl. 10v.] Tres Ordens Militares, e alguns Foros de Fidalgos das Classes, que S. Mag. ${ }^{\text {de }}$ for servida: E somente naquelles Governos; porque a sua população, civilidade, e Comercio, fazem os primeiros fundos dos Interesses da Monarquia; devendo por consequencia ficar as mesmas Capitanias habilitadas da primeira graduação, $p .{ }^{a}$ se contemplar a escolha, e a promossão dos Governadr. ${ }^{\text {es }}$ quando forem precizos. Declarando-se aos mesmos Vice Rey, e Govr. ${ }^{\text {es }}$, que aquellas graças, honras, e privilegios, são para repartir unicamente com os Nascionaes Paizanos da sua Capitania; aquelles que (álem da sua distinção, ou do seo tratamento, regulado 
pela Ley da Nobreza) tem servido, ou servirem a S. Mag. ${ }^{\text {de }}$, descobrindo terras de Ouro, ou quaesquer preciozidades: Com os outros, que abrirem caminhos, e estradas seguras aos Viandantes com a utilidade de diminuir as distancias, e Livralos dos frequentes insultos dos Gentios: Com aquelles, que facilitarem o passo de algum dos Ricos caudalozos, fazendo-lhe pontes a beneficio dos Passageiros: E emfim com outros muitos, aos quaes os Govr. ${ }^{\text {es }}$ ocupam em diligencias do Real Serviço, e elles desampáram contentes as suas Cazas, Familias, e Fazendas, sahindo a executar as mesmas ordens em $\mathrm{m}^{\text {tas }}$ distancias á sua custa, acompanhados dos seos Escravos, cujos serviços tambem perdem.

Estes somente devem ser os contemplados; proibindo-se aos Govr. ${ }^{\text {es }}$, que repartam com os seos Criados, nem com a Tropa paga as mesmas graças, e honras; só no cazo de algum serviço distinto, e extraordinario, que fizer qualquer Individuo militar; porque, álem do acrescentamento do posto, ou póstos, que lhe forem immediatos, a natureza relevante do mesmo serviço, lhe adquirio júz a mayor premio; e já então senão offende o direito positivo, que tem aos mesmos despachos os referidos Nacionaes Paizanos, por aquella cauza, e nunca por outra qualquer; pela justa reflexão de que a Tropa paga, não só recebe os soldos, que crescem com as promossoens dos póstos, como porque os seos serviços, são mandados contemplar pela tarifa das Remuneraçoens com a qual argumentam quando requerem: Sendo indubitavelm. ${ }^{\text {te }}$ certo, que por outro modo ficará o Gov. ${ }^{\text {r }}$ sendo Pai da Tropa, com a qual tem a comissão de repartir, e Liberalizar os beneficios, mas com os Paizanos parecerá somente Juiz para os punir, porque não cabe no seo poder a contemplação dos premios, e do perdão, tendo só autoridade para os castigar.

[fl. 11] qualquer pessoa de hum mediano raciocinio, que conhece os Povos dos Continentes da America, sabe muito bem, que os frutos desta Maxima serão infaliveis; e tambem sabe, que os mesmos Póvos animados por este modo, são capazes de empreender mayores progressos em beneficio comum da Patria, e do Serviço de S. Mag. ${ }^{\text {de }}$, pelo seo vulgar axiôma, de que os Vassallos contentes hé que fazem o importante objecto da riqueza do Estado, e da opulencia da Monarquia.

$7^{\mathrm{a}}$. Maxima: Que os Govr. ${ }^{\mathrm{es}}$, nos cazos, e circumstancias urgentissimas, póssam apartarse das Leys, Ordens, e Regimentos, convocando Juntas proprias para se rezolver nellas o que for mais proporcionado, e conven. ${ }^{\text {te }}$ ao Real Serviço, nas ocaziões em que os mesmos cazos necessitem de huma immediata provid. ${ }^{\text {a }}$

Os Dominios de S. Mag. ${ }^{\text {de }}$ em qualquer das Partes do Mundo, dilatados, e grandes em sy mesmos, são igualmente distantes da Corte do Seo Regio Domicilio; mas como o Soberano Braço da Sua Real Autoridade chega ao Continente mais remoto dos Seos Limites, pode tambem nelles abrir as Mãos das Suas Maternaes providencias, e espalhar sobre os Filhos, que não vê as mercez, e os beneficios de que elles necessitam.

A Ley da Graça, Mestra da Religião, que professamos hé a única Ley, que senão pode alterar acrescentando, nem diminuindo; porque o Omnipotente Legislador a fez acomodada aos Seculos passados, prezente, e aos futuros: Mysterios a que não chega a Humana compreenção! Todas as mais Leys com que se governam os Imperios, e os Estados do Mundo, estão sugeitos á variedade dos 
Tempos, e á diversidade dos Suscessos; e por esta razão muitas vezes se refórmam, ou totalmente se anniquilam.

[fl. 11v.] Com estes principios indubitaveis, temos outro fundamento para nos persuadirmos, que as Leys, os Regimentos, e as Ordens, podendo ser os mesmos na Corte, e nas Provincias do Reino, serão impraticaveis em cada huma das Conquistas; porque se os Govr. ${ }^{\text {es }}$ (como fica ponderado na primr. ${ }^{a}$ Maxima) devem ser proporcionados aos Continentes onde forem precizos, tambem a Legislação deve ser acomodada ao caracter dos Povos de cada hum dos Governos. São muitas vezes necessarios o jeito, a força, e a docilidade para equilibar no tempo, e nas circumstancias a Piedade; e a Justiça, e se a Ley não pode prevenir todos os cazos, e as suas circumstancias accidentaes, ainda quando trata dos mesmos cazos, como podem ser constantes, e inviolaveis as Leys nos diferentes Paizes das Conquistas? O remedio que algumas vezes fez beneficio ao Enfermo, por ser proprio ao seo temperamento, lhe pode ser tão nocivo, que o mate, ou porque os humores mudaram de especie, ou porque o diferente tempo em que se lhe aplique pode fazer arriscada, e funesta a cura: E se isto hé factivel em hum mesmo Enfermo com o mesmo remedio, quanto mais notavel hé a diferença nos diversos governos em que podem ser victimas de hum erro muitas vidas?

Pelo que, não só hé justo, como infalivelm. ${ }^{\text {te }}$ necessario, que S. Mag. ${ }^{\text {de }}$ conceda amplos poderes aos Governadr. ${ }^{\text {es }}$ para convocar as Juntas, que lhe parecerem precizas, das quaes elle seja sempre o Prezidente; propondo-se, e rezolvendo-se nellas todos os Cazos, que acontecerem; ou sejam daquelles com que as Leys pela novidade dos Successos, não tenham conexão; ou sejam dos mesmos, que tendo sido tratados pelas Leys, a Conjuntura, e outros motivos as podem fazer impraticaveis; principalm. ${ }^{\text {te }}$ se for concebida a execução dellas na sua substancia expressa e positiva, quando o exito pode ser arriscado. E como esta providencia pode degenerar em vicio sendo mal entendida pelo Gov. ${ }^{\text {or }}$ imprudente servindo-se della para hum desenfreyado dispotismo se lhe deve conceder som. ${ }^{\text {te }}$ a regalia de convocar, prezidir, votar, e aprovar a pluralid. ${ }^{\mathrm{e}}$ da mesma Junta, respeitando decorozamente o Serviço de Deos, do Rey, e o beneficio dos Povos: E pela Secretaria de Estado se devem passar as Ordens circulares, para que todos os Adjuntos, sem disputar o Lugar do Congresso, a percam onde o Gov. ${ }^{\text {or }}$ determinar.

Esta faculdade não seria estranha; porque aqui mesmo na Corte, e no Senado [fl. 12] da Suplicação se estão Lavrando muitos Assentos sobre as Leys, quando há justos motivos, que as altere nos Cazos do Foro: Com o que se prova, que o Rey quer a Justiça bem ordenada, para que seja distributiva; e por isso permite, conforme os Cazos, as diversas inteligencias dos mesmos Assentos. Todos temos lido e visto, não só na vida de hum, e muitos Reys, reformadas, e obliteradas algumas Leys, e Rezoluçoens dos Seos Regios Predecessores, como tambem na vida do mesmo Monarca ampliadas, restringidas, e declaradas as suas proprias Leys; porque as diferentes Epocas do Seo Passado, lhe descobriram urgentissimas razoens, que o obrigaram a reformalas. Este Exemplo persuade tambem os motivos, que o Gov. ${ }^{\text {or }}$ pode ter para convocar as Juntas nos cazos occorrentes já ponderados: E a Regia Delegação ao referido Senado, faz o Exemplo da necessid. ${ }^{\mathrm{e}}$, que pode haver nas Conquistas, sendo tão distantes.

A mesma faculdade não pode ser cõmua a todas as Capitaes dos Governos; porque som. ${ }^{\text {te }}$ no Rio de Janeiro, na Bahia, e na Cidade de Gôa, se acham as Relaçoens, cujos Corpos de Literatura devem ser chamados para os 
cazos do Foro; não só da mesma Capitania do seo domicilio, como de todas, e quaesquer outras de que as mesmas Relaçoens fazem cabeça de districto p. $^{\text {a }}$ as Apelaçoens, Agravos, Recursos, e Sentenças de Reos com a remessa das suas culpas. Nos Cazos Politicos poderá o Gov. ${ }^{\text {or }}$ convocar o chanceler, o Proc. ${ }^{\text {or }}$ da Coroa, e quatro Ministros mais da Relação, onde sempre há pessoas instruidas em Bellas Letras, e nos Interesses de Estado; sendo tambem prezente o Secretr. ${ }^{\circ}$ do Governo com o seo voto, e como Secretario, que deve escrever o acordo da mesma junta todas as vezes, que for convocada. Nas dependencias Militares: os Officiaes de Patente de Coronel p. ${ }^{\text {a }}$ cima; os Auditores, o Vedor da Fazenda, o Proc. ${ }^{\text {or }}$ della, e o da Coroa; conforme os Cazos em que forem precizos estes Ministros, com a excepção dos pontos declarados, ou não escritos no Regulamento das Tropas. Para os Negocios da Economia do Governo: o Senado da Camara, o Chanceler, o Procurador da Fazenda. Nos Cazos dos Ecleziasticos Seculares, ou Religiosos: o Bispo, o seo Vigario geral, as duas primeiras Dignidades da Sé, o Chanceler e o Proc. ${ }^{r}$ da Coroa: [fl. 12v.] Ficando sempre ao arbitrio do Gov. ${ }^{\text {or }}$ trocar estas duas vocaçoens de Seculares, e Religiosos conforme lhe parecer mais conveniente; porque tambem lhes poderão ser necessarios os Prelados das Religioens: Com a condição, porem, que jámais a concordancia deste Congresso fique superior aos Concilios da Igreja, nem aos Decretos Pontificios, só no cazo de haver Ordem positiva de S. Mag. ${ }^{\text {de }}$ : Nem o Gov. ${ }^{\text {or }}$ poderá convocar as referidas Juntas, p. ${ }^{\mathrm{a}}$ proceder em conformidade do Assento dellas, senão quando pela demora da Conta, (que depois deve dar a S. Mag. ${ }^{\text {de }}$ ) se fizer impratical ${ }^{700}$ [sic] a providencia, que for precizo immediatamente: E logo que S. Mag. ${ }^{\text {de }}$ aprovar as Rezoluçoens tomadas na Junta, ficando na Secretaria do Governo o Original do Seo Regio Beneplacito, deve registarse na Relação, ou no Senado da Camara ou onde pertencer, conforme foi o procedimento da Junta respectiva; para que seja constante o Exemplo, que roborado com o Real Nome, ficou desde então com natureza de Ley para os mesmos cazos.

8a. Maxima: Que os governadores entreguem aos seos Sucessores todas as Ordens de El Rey, que houverem recebido no tempo do seo Governo, pelas suas respectivas Reparticoens.

Por dous modos cõmuns se expedem as Ordens aos Governadores das Conquistas; ou pela Secretaria de Estado dos Negocios Ultramarinos, ou pelo Conselho respectivo dos mesmos Negocios: Estas Ordens, depois de vistas pelo Gov. ${ }^{\text {or }}$, devem passar immediatam. ${ }^{\text {te }}$ á Secretaria do Governo, para se extrairem dellas os Officios, e as providencias, que o Soberano determina pró, ou contra algum terseiro; e também porque sendo consequencia de algumas Contas dos Governdr. ${ }^{\text {es }}$, Rezoluçoens, ou Arbitrios Regios cõmuns ao Governo, ou a sucessos particulares, se devem [fl. 13] conservar naquelle Arquivo, para servirem humas como Leys positivas do Continente, e outras, não só como Exemplos decididos, mas como memorias interessantes para o futuro.

Algumas Ordens há sobre factos recomendados, que os Govr. ${ }^{\text {es }}$ prudentes guardam em seo poder, p. $^{\text {a }}$ as fazer executar com cautella, e para responder ao Soberano em segredo, sem que estes procedimentos cheguem á noticia do Secretario, nem de outra alguma pessoa: Porem esta Liberdade, que deve ser

${ }^{700}$ Na cópia da BA consta "impraticavel". 
Limitada, e restricta a certos cazos, tem sido adulterada por alguns Govr. ${ }^{\text {es }}$ de tal sorte, que findo o tempo da Comissão, se retiram para suas Cazas, trazendo com as referidas Ordens, outras muitas, que sempre são necessarias nos Governos, que deixam: Esta rezolução não involve malicia; porque a idéa do Gov. ${ }^{\text {or }}$ (pelo que pertence ás recomendaveis) hé conservar o segredo, que lhe foi encarregado pelo Rey, o qual lhe não ordenou expressamente, que depois de entregues as Credenciaes, e transferida a posse do Governo ao Successor, immediatamente passassem todos os Officios, que o Gov. ${ }^{\text {or }}$ houvesse recebido, e guardasse em sy de mão particular. As outras Ordens do Conselho Ultramarino, e os Officios do Ministerio da mesma Repartição, expedidos por motivo publico, ou particular, devem ficar na Secretaria infalivelmente logo que se fizer a passagem de hum para outro Gov. ${ }^{\text {or }}$; porque a mente do Soberano he, que no Governo se conservem as Suas Resoluçoens, como regimen, e não como regras accidentaes, que acabam com o Gov. ${ }^{\text {or }}$, pois isto seria o mesmo, que reduzir huma Capital de opulenta População aos preliminares da infancia de qualquer Colonia.

Desta mal entendida resolução do Gov. ${ }^{\text {or }}$, nasce a desordem de faltarem no Governo as Instrucçoens necessarias, quando acontecem cazos semelhantes a outros, que já estavam decididos, e providenciados pelo Rey: e sendo tão sensível esta falta, a outra consequencia ainda hé mais notavel, e terrivel: Porque recolhido o Gov. ${ }^{\text {or }}$ á sua Caza, ou mudado para outro Governo, levando, ou trazendo com sigo os Officios, conserva em sua vida o segredo, que com elles lhe foi recomendado, pois esta vigilancia não pode passar álem da morte; e se acazo algum Confidente familiar do seo Cartorio os não lêo, tendo o trato ordinario de manear ${ }^{701}$ huns, e outros Papeis, infalivelmente depois da sua morte os Herdeiros, o Amanoense da Caza, e o Procurador della, querendo pôr em ordem os Titulos dos Morgados, os [fl. 13v.] os serviços do falecido; e emfim as contas dos Devedores, e Credores, para se regular a mesma Caza; huns e outros ficam instruidos do segredo, e das maximas com que os mesmos Officios se puzeram em prática, ainda tendo aquelle exame diferente destino.

As Maximas, e as Resoluçoens do Gabinete de hum Rey, em todo o tempo são de segredo, até depois de executadas; porque tratando-se nelle os Negocios da primeira importancia, que depois de exitados ${ }^{702}$ por força hão de ser publicos; nem por isso se pode revelar a idéa com que se tratáram, as diligencias que se fizeram, e os embaraços que se venceram até se conseguirem, antes se devem reputar como mysterios, para os esconder da penetração dos Homens; por tal modo, que a verdade do facto fique sempre em conjecturas vacilantes no conceito dos mesmos Homens. A Guerra, a Paz, a Aliança, a Cessão de Dominios, e as Convensoens de Estado, e do Comercio entre as Potencias, são factos publicos ao nosso conhecimento; mas a polytica com que se tratáram, poucos a sabem, pois não hé vulgar a todos.

Em consequencia das referidas ponderaçoens, hé necessario, que o Gov. $^{\text {or }}$, que acaba, entregue a seo Successor todas as Ordens, Officios, Documentos e mais papeis com as primr. ${ }^{\text {as }}$, e segundas vias, que lhe foram expedidas no tempo do seo Governo, (se ainda não houverem passado para a Secretaria delle) com a obrigação de declarar sinceramente, até por escrito, o estado em que se acha cada hum dos Negocios conteudos nos referidos Officios, e o segredo com que S. Mag. ${ }^{\text {de }}$ os mandou recomendar, para que o mesmo Successor assim os conserve; e para que faça concluir todos aquelles Negocios,

${ }_{702}^{701}$ Id., "manejar".

702 Id., "praticados". 
que estiverem pendentes. E parecendo conveniente ao Serviço de S. Mag. ${ }^{\text {de }}$, que dos Negocios já concluidos, e de facto particular, que não tem dependencia com as disposiçoens ordinarias da Capitania, não hé necessidade de participarse ao novo Gov. ${ }^{\text {or }}$, neste cazo se deve ordenar ao Antecessor expressamente, que os Officios, que se lhe passáram naquella materia os traga ou remeta, para serem entregues na Secretaria de Estado dos Negocios Ultramarinos as urgente de donde emanáram, e para donde voltam, como voltam, como Depozito mais seguro: E para que esta entrega tenha formalidade coerente, deve ser feita ao Official mayor da mesma Secretaria, para que este passe hum Recibo [fl. 14] de defeza ao Gov. ${ }^{\text {or }}$, sem mais individuaçoens, que a de haver entregado aquelle, todos os Officios pertencentes a tal, ou taes Negocios.

Todas estas Maximas, dignas de reflexão, se encaminham a huma completa regularidade do Serviço de Deos, do Rey, ao credito do Gov. ${ }^{\text {or }}$, e beneficio dos Povos daquelle dilatado Imperio da America Meridional, e dos Dominios da S. Mag. ${ }^{\text {de }}$ nos Continentes d'Africa, e Azia; para que também a Chronologia dos Tempos, e dos Successos, dando as mãos huns aos outros, se vão ligando successivamente com as Épocas dos Governos, e se conserve por este modo a memoria da Nasção, tanto mais respeitada ao longe pelos Vassallos proprios, quanto conhecida pelos Estranhos: E emfim para que estes confessem admirados, que Portugal ainda que recintado na Europa parece diminuto p. ${ }^{\text {a }}$ Reino, o Reino todo hé a Corte dos Seos Augustissimos Monarcas, porque os dilatados Dominios da Sua Coroa, fazem o grande Imperio invejado de todo o Mundo.

\section{Declaração Apologetica.}

Não pertendo persuadir em alguns lugares das Oito Maximas acima escritas, que os Gov. ${ }^{\text {es }}$ que tem governado as Conquistas de S. Mag. ${ }^{\text {de }}$, foram todos incursos nos mesmos erros; e que estes se relaxáram [Fl. 14v.] de sorte, que passáram successivamente de huns a outros, para existirem nos que agora governam as mesmas Conquistas. Não sou ímpio; o meu coração, e a minha inteligencia, sempre flexiveis á honra, e á verdade, me conservam ainda firme no conceito das virtuozas circumstancias, que conhecí em alguns; os quaes são dignos de huma distinta excepção das regras geraes: Elles merecem, que os seos nomes tenham huma honrada comemoração no Catalogo dos mayores Servidores do Rey, e dos Pays da Patria, para que as mesmas virtudes sirvam de Exemplares aos seos Descendentes, e aos Vassallos de qualquer Monarquia: ${ }^{703} \mathrm{E}$ ainda que fallo em alguns abúzos como erros, que necessitam de reforma, os discursos que faço, não tem outro objecto mais, que sustentar a autoridade, e a regalía do Gov. ${ }^{\text {or }}$, o qual deve fazer huma completa reprezentação de Emissario do Rey, que lhe confiou o governo do Seo Dominio para conservar os Vassallos delle em paz, e justiça.

Aquelles erros, e abuzos tem sido praticados até o prezente por muitos Governadr. ${ }^{\text {es }}$, mas não por todos; e porque fallo dos bons, e dos máos, sem idéa positiva, vem a ser o conteudo das referidas Maximas, como huma officina de manufacturas ricas, onde não há que escolher por medidas differentes, porque as

${ }^{703}$ Id., foi suprimida esta frase, desde "Elles merecem...". 
mesmas vitolas para todos estão certas; Os Bons ficam conhecendo o vicio dos Máos, para se fortificarem no seo systema, fazendo-se melhores: E os Máos, reformando os seos erros, se vão persuadidos, que os que governam os seos passos pela estrada direita da Razão, não mancham a planta no lôdo dos vicios, nem podem chegar ás barreiras do despenho. ${ }^{704}$ Pelo que espero, que [fl. 15] huns, e outros façam justiça á sinceridade destes discursos, que escrevi somente para satisfazer a hum Amigo, sem a esperança, nem o desvanecimento de os ver praticados; porque o respeitavel Ministerio desta Repartição, não necessita de influxo estranho, nem a minha presumpção tem a cegueira de reputarse influente: ${ }^{705}$ Esta verdade, emfim todos os dias a confesso, conhecendo, que o Seo grande merecimento, e as suas relevantes virtudes são muito superiores á minha inteligencia.

[Ass.] Francisco de Almeida Silva

\footnotetext{
${ }^{704}$ Id., foi suprimido o texto desde o início do parágrafo até esse ponto.

${ }^{705}$ Id., finaliza nesse ponto, apresenta como local e data: "Lisboa 4 de Janeiro de 1780 " e não traz assinatura.
} 


\section{Anexo 3}

Mapa das Freguesias que têm a Ilha de Santa Catarina, e seu Continente com distinção do número de uns e outros casais, Companhias de Ordenanças, e número de Almas que contêm, ano de 1753

\begin{tabular}{|c|c|c|c|c|c|c|c|c|c|c|c|c|c|c|c|c|c|}
\hline Freguesias & 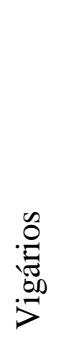 & 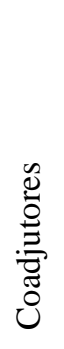 & 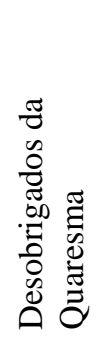 & 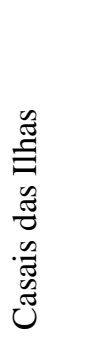 & 总 & 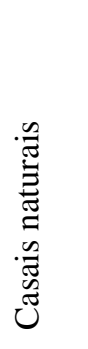 & 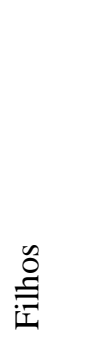 & $\frac{\mathscr{\Xi}}{\Xi}$ & 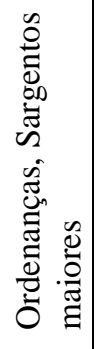 & 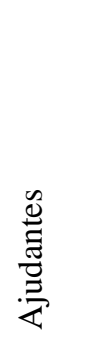 & 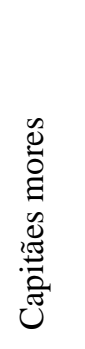 & 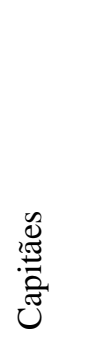 & 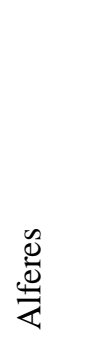 & $\begin{array}{l}\tilde{0} \\
\stackrel{0}{0} \\
\stackrel{0}{ \pm} \\
\tilde{\omega}\end{array}$ & 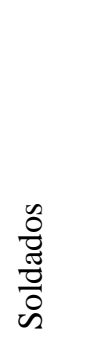 & 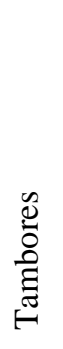 & 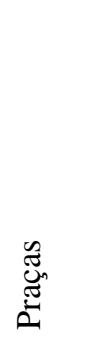 \\
\hline N. Sra. do Desterro, Vila Capital, na Ilha & 1 & 1 & 3.161 & 550 & 2.333 & 109 & 1.325 & 4.317 & 1 & 1 & - & 3 & 6 & 4 & 392 & - & 407 \\
\hline N. Sra. da Conceição da Lagoa, na Ilha & 1 & - & 508 & 92 & 350 & 11 & 50 & 503 & - & - & - & 2 & 2 & 4 & 151 & - & 159 \\
\hline São José, Terra firme & 1 & - & 905 & 183 & 230 & 20 & 70 & 503 & - & - & - & 2 & 2 & 6 & 215 & - & 225 \\
\hline N. Sra. do Rosário, Terra firme & 1 & - & 423 & 87 & 67 & 6 & 12 & 172 & - & - & - & - & - & 3 & 103 & - & 106 \\
\hline São Miguel, Terra firme & 1 & - & 677 & 140 & 191 & 25 & 85 & 441 & - & - & - & - & 1 & 4 & 145 & - & 150 \\
\hline Santa Ana, Terra firme & 1 & - & 298 & 63 & 192 & 29 & 28 & 312 & - & - & - & - & - & - & - & - & - \\
\hline S. A. dos Anjos, vila da Laguna, Terra firme & 1 & - & 364 & 19 & 20 & 108 & 87 & 234 & - & - & 1 & 3 & 3 & 6 & 146 & - & 159 \\
\hline Soma Geral & 7 & 1 & 6.336 & 1.134 & 3.383 & 308 & 1.657 & 6.482 & 1 & 1 & 1 & 10 & 14 & 27 & 1.152 & - & 1.206 \\
\hline
\end{tabular}

Fonte: AHU-SC, cx. 2, doc. 92. Tanto nesse Mapa como no que se apresenta no Anexo 04 corrigiu-se os erros de soma existentes nos documento originais. 


\section{Anexo 4}

Mapa das Freguesias que têm a Ilha de Santa Catarina, e seu Continente com distinção do número de uns e outros casais, Companhias de Ordenanças, e número de Almas que contêm

\begin{tabular}{|c|c|c|c|c|c|c|c|c|c|c|c|c|c|c|c|c|c|}
\hline Freguesias & 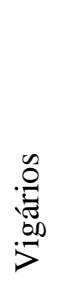 & $\begin{array}{l}\stackrel{0}{0} \\
\stackrel{0}{0} \\
\stackrel{\Xi}{0} \\
0 \\
0\end{array}$ & 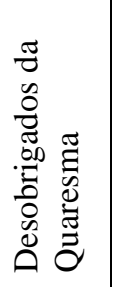 & 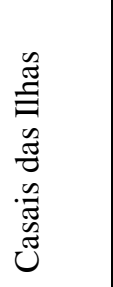 & 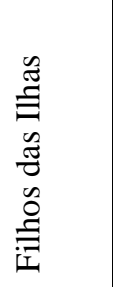 & 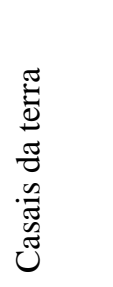 & 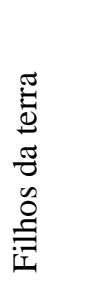 & 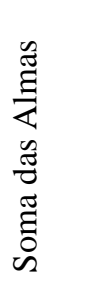 & 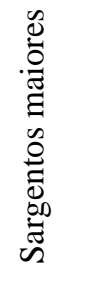 & 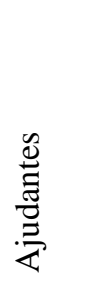 & 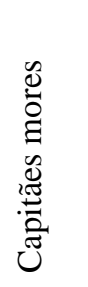 & 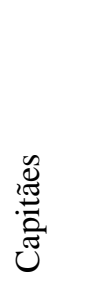 & 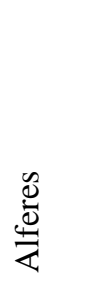 & 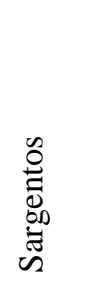 & $\begin{array}{l}\text { o } \\
\frac{0}{0} \\
\frac{\pi}{0} \\
0 \\
\text { is }\end{array}$ & 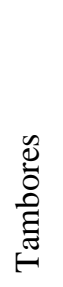 & 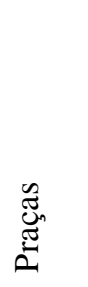 \\
\hline N. Sra. do Desterro, Vila Capital, na Ilha & 1 & 1 & 1.596 & 250 & 1.300 & 99 & 1.000 & 2.649 & 1 & 1 & - & 3 & 6 & 4 & 390 & - & 405 \\
\hline N. Sra. da Conceição da Lagoa, na Ilha & 1 & - & 500 & 108 & 365 & 22 & 70 & 565 & - & - & - & 2 & 2 & 4 & 151 & - & 159 \\
\hline N. Sra. das Necessidades, na Ilha & 1 & - & 803 & 200 & 1.010 & 60 & 100 & 1.370 & - & - & - & - & - & - & - & - & - \\
\hline $\begin{array}{l}\text { N. Sra. da Graça da Vila do Rio de S. } \\
\text { Francisco de Xavier }\end{array}$ & 1 & - & 2000 & - & - & 600 & 1.699 & 2.299 & 1 & - & - & 3 & 3 & 6 & 300 & - & 313 \\
\hline São José, Terra firme & 1 & - & 710 & 193 & 230 & 30 & 80 & 533 & - & - & - & 2 & 2 & 6 & 210 & - & 220 \\
\hline N. Sra. do Rosário, Terra firme & 1 & - & 374 & 97 & 77 & 16 & 22 & 212 & - & - & - & - & - & 3 & 103 & - & 106 \\
\hline São Miguel, Terra firme & 1 & - & 919 & 150 & 201 & 35 & 95 & 481 & - & - & - & - & 1 & 4 & 145 & - & 150 \\
\hline Santa Ana, Terra firme & 1 & - & 308 & 66 & 190 & 36 & 90 & 382 & - & - & - & - & - & - & - & - & - \\
\hline S. A. dos Anjos, vila da Laguna, Terra firme & 1 & - & 460 & 20 & 48 & 199 & 290 & 557 & 1 & 1 & 1 & 3 & 3 & 6 & 143 & - & 158 \\
\hline Soma Geral & 9 & 1 & 7.670 & 1.084 & 3.421 & 1.097 & 3.446 & 9.048 & 3 & 2 & 1 & 13 & 17 & 33 & 1.442 & - & 1.511 \\
\hline
\end{tabular}

FONTE: AHU-SC, cx. 1, doc. 67. Em anotação de outro punho consta a data de 05.09.1756, que foi a que se considerou nesse trabalho. 